UNIVERSIDADE DE SÃO PAULO

FACULDADE DE FILOSOFIA, LETRAS E CIÊNCIAS HUMANAS

DEPARTAMENTO DE LETRAS MODERNAS

PROGRAMA DE ESTUDOS LINGUÍSTICOS, LITERÁRIOS E TRADUTOLÓGICOS EM FRANCÊS

ROBERTO DE ABREU

\title{
Traduzir Les Fleurs bleues, de Raymond Queneau: o jogo do significante e o humor
}

versão corrigida

São Paulo

2011 


\section{Traduzir Les Fleurs bleues, de Raymond Queneau: o jogo do significante e o humor}

versão corrigida

Roberto de Abreu

Dissertação apresentada ao Programa de PósGraduação em Estudos Linguísticos, Literários e Tradutológicos em Francês do Departamento de Letras Modernas da Faculdade de Filosofia, Letras e Ciências Humanas da Universidade de São Paulo, para obtenção do título de Mestre.

Orientador: Prof. Dr. Alain Marcel Mouzat

De acordo

$\overline{\text { Prof. Dr. Alain Marcel Mouzat }}$ 
Roberto de Abreu

Traduzir Les Fleurs bleues, de Raymond Queneau: o jogo do significante e o humor

Dissertação apresentada ao Programa de Pós-Graduação em Língua e Literatura Francesa do Departamento de Letras Modernas da Faculdade de Filosofia, Letras e Ciências Humanas da Universidade de São Paulo, para obtenção do título de Mestre.

Área de concentração: Estudos Linguísticos Literários e Tradutológicos em Francês

Aprovado em: $/ 2011$

\section{Banca Examinadora}

Prof. Dr. Alain Marcel Mouzat (orientador)

Instituição: FFLCH/USP Assinatura:

Profa. Dra. Tokiko Ishihara

Instituição: FFLCH/USP Assinatura:

(suplente)

Instituição: FFLCH/USP

Assinatura:

Profa. Dra. Lúcia Peixoto Cherem

Instituição: UFPR

Assinatura:

(suplente)

Instituição:

Assinatura: 
A meus pais, Orlando e Elisa, saudade A minha mulher Sueli A meus filhos Fabrício, Juliano, Leandro e Rafael 


\section{AGRADECIMENTOS}

Ao Professor Dr. Alain Marcel Mouzat, orientador e amigo, pela colaboração e pelo tempo dedicado a nossas longas conversas.

À Professora Dra. Cristina Casadei Pietraróia, pelo apoio e incentivo constantes.

Às professoras Dra. Adriana Zavagli e Dra. Véronique Dahlet, componentes da banca de qualificação, pelos preciosos comentários e orientações.

Aos colegas do Curso de Francês para Iniciantes da Poli, Daniela Hirakawa, Lisiere Dantas, Marco Leite Fernandes, Wiliam M. Pereira, Ana Paula Inácio e especialmente a Vinícius Pacheco, pela compreensão quando minha participação teve que ser reduzida em função deste trabalho.

Ao amigo Marco Leite Fernandes, pela paciência e boa vontade na leitura do trabalho e pelas valiosas observações.

À Edite, pela atenção e esclarecimentos. 


\section{RESUMO}

ABREU, R. Traduzir Les Fleurs bleues, de Raymond Queneau: o jogo do significante e o humor 377 p. Dissertação (Mestrado). Faculdade de Filosofia Letras e Ciências Humanas, Universidade de São Paulo, São Paulo, 2011.

A proposta deste trabalho é a tradução para o português do romance Les Fleurs bleues, de Raymond Queneau. Trata-se de um romance que oferece resistência à tradução em função do trabalho do autor sobre a língua francesa. Para chegar ao objetivo proposto procedemos a uma historicização da obra de Queneau, de modo a compreendermos seu projeto de inclusão da língua falada na literatura e em todos os campos do conhecimento. A escrita de Queneau é caracterizada por seu estilo impregnado de humor e repleto de elementos de oralidade, em que o significante ganha autonomia: jogos de palavras, trocadilhos, provérbios, rimas, aliterações, o autor lança mão de todos os recursos para sublinhar, com humor, a "crise do signo". Procuramos analisar os procedimentos adotados por Queneau e o modo como se manifesta sua escrita em Les Fleurs bleues visando ao estabelecimento de parâmetros que possibilitassem oferecer ao leitor brasileiro uma tradução que lhe permitisse, apesar dos diferentes contextos linguísticos e culturais, uma leitura prazerosa em que ele tenha acesso ao texto de Queneau e acompanhar a narrativa, conservando o jogo de significantes e o humor. Levantamos marcas de oralidade presentes nos sistemas linguísticos francês e português, para chegarmos, finalmente à realização do trabalho tradutório, do qual comentamos as manifestações de oralidade no original e as soluções adotadas para sua restituição em português.

Palavras-chave: Tradução literária; As Flores Azuis; Raymond Queneau; Língua falada e literatura; Oralidade 


\begin{abstract}
ABREU, R. Translate Les Fleurs bleues, by Raymond Queneau: the play of the signifier and the humor 377 p. Dissertation (Masters in Arts). Faculdade de Filosofia Letras e Ciências Humanas, Universidade de São Paulo, São Paulo, 2011.

The purpose of this work is the Portuguese translation of the novel Les Fleurs bleues, by Raymond Queneau. It is a novel that offers resistance to translation as a function of author's work on the French language. To reach the proposed goal, we proceeded to a historicizing of Queneau's production, in order to understand his project for inclusion of the spoken language in literature and in all fields of knowledge. Queneau's writing is characterized by his style imbued with humor and filled with elements of orality, where significant gains autonomy: wordplay, puns, proverbs, rhymes, alliterations, the author uses all resources to emphasize with humor, the "crisis of the sign." We have analyzed the procedures adopted by Queneau and how his writing manifests in Les Fleurs bleues in order to establish parameters that offers to Brazilian readers a translation that would enables him, despite the different linguistic and cultural contexts, to have an enjoyable read and to access the text of Queneau and follow the narrative, keeping the work of signifiers and the humor. We studied the marks of orality present in French and Portuguese language systems, to arrive finally to perform the work of translation, which we commented on the manifestations of orality in the original and the adopted solutions for restitution in Portuguese.
\end{abstract}

Keywords: Literary translation; The Blue Flowers, Raymond Queneau; Spoken language; Marks of spoken language 


\section{RÉSUMÉ}

ABREU, R. Traduire Les Fleurs bleues, de Raymond Queneau: le jeu du signifiant et l'humour. 377 p. Dissertation (Master). Faculdade de Filosofia Letras e Ciências Humanas, Universidade de São Paulo, São Paulo, 2011.

Le but de ce travail est la traduction en portugais du roman Les Fleurs bleues, de Raymond Queneau. C'est un roman qui offre résistance à la traduction en fonction du travail de l'auteur sur la langue française. Pour atteindre l'objectif proposé, nous avons cherché à historiciser l'œuvre de Queneau, afin de comprendre son projet d'inclusion de la langue parlée dans la littérature et dans tous les domaines de la connaissance.. L'écriture de Queneau se caractérise par son style empreint d'humour et rempli d'éléments d'oralité, où le signifiant gagne autonomie: jeux de mots, calembours, proverbes, rimes, allitérations, l'auteur se sert de toutes les ressources pour souligner, avec humour, la "crise du signe”. Nous avons analysé les procédures adoptées par Queneau et la façon dont son écriture est manifestée dans Les Fleurs bleues afin d'établir des paramètres qui permetraient d'offrir au lecteur brésilien une traduction qui lui permettrait, en dépit des différents contextes linguistiques et culturels, une lecture agréable par laquelle il peut accéder au texte de Queneau et suivre le récit, en gardant le jeu des signifiants et l'humour. Nous avons relevé des marques d'oralité qui sont présentes dans les systèmes français et portugais, pour arriver enfin à effectuer le travail de traduction, dont nous commentons les manifestations d'oralité de l'original et les solutions adoptées pour leur restitution en portugais.

Keywords: Traduction littéraire; Les Fleurs bleues; Raymond Queneau; Langue parlée; Oralité. 
O objetivo de toda arte não é algo impossível? O poeta exprime (ou quer exprimir) o inexprimível, o pintor reproduz o irreproduzível, o estatuário fixa o infixável. Não é surpreendente, pois, que o tradutor se empenhe em traduzir o intraduzível.

Paulo Rónai 


\section{ÍNDICE}

INTRODUÇÃO .......................................................................................................11

1. O PROJETO LITERÁRIO DE QUENEAU ................................................17

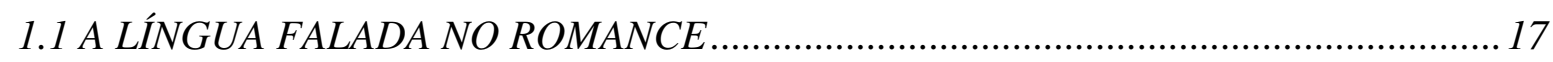

1.2 QUENEAU E A LÍNGUA FALADA ................................................................2 21

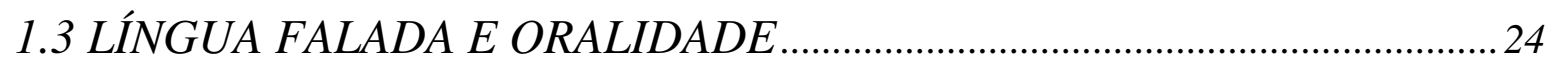

2. ENTRE HISTÓRIA E FICÇÃO _..........................................................29

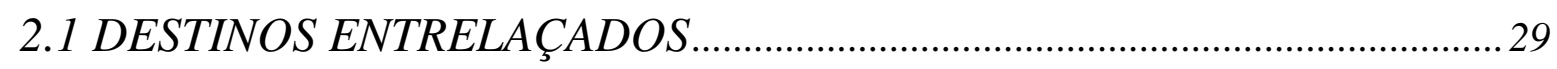

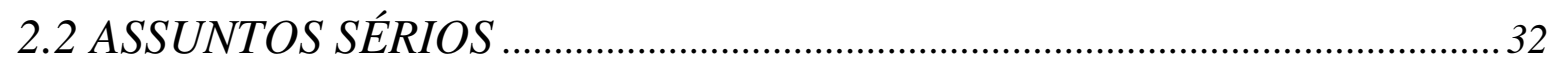

2.3 O HUMOR

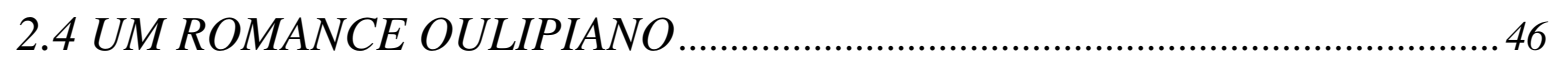

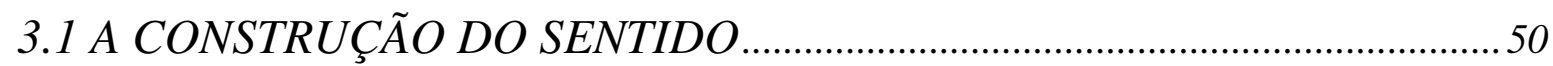

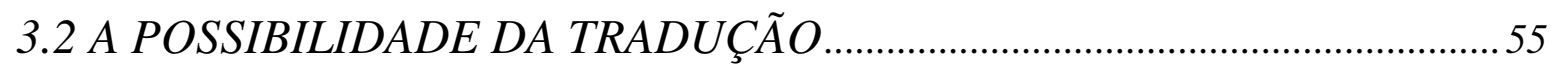

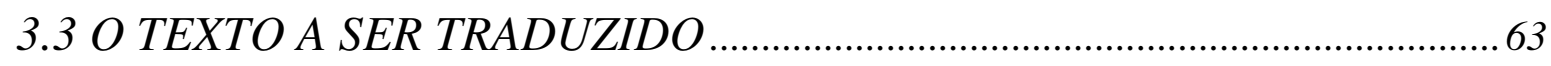

3.4 OS SISTEMAS FRANCÊS E BRASILEIRO………………..............................66

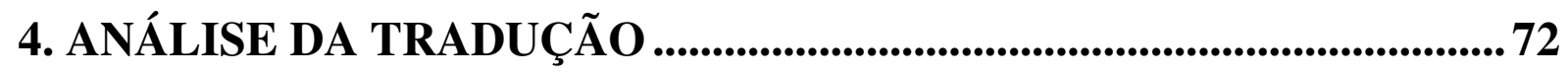

4.1 A QUESTÃO DOS NOMES PRÓPRIOS ……................................................. 72

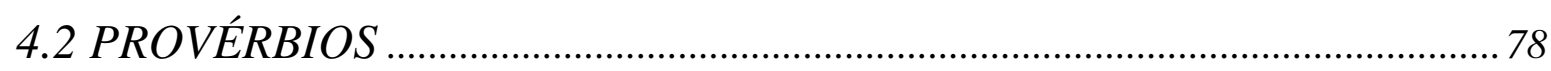

4.3 TROCADILHOS

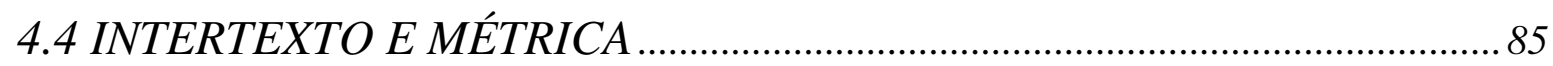

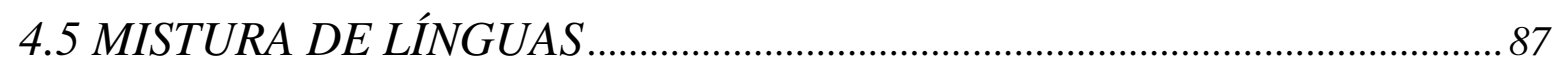

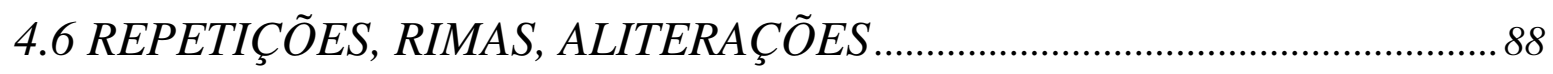

4.7 MUDANÇAS ORTOGRÁFICAS E ORTOGRAF FONÉTIK .......................... 90

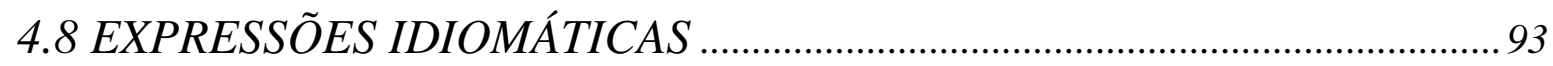

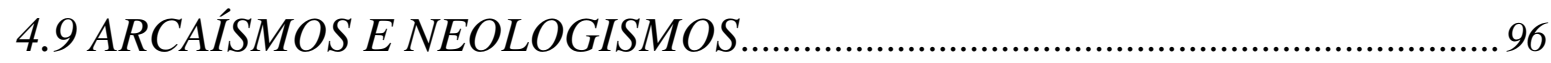

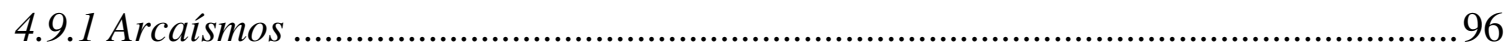

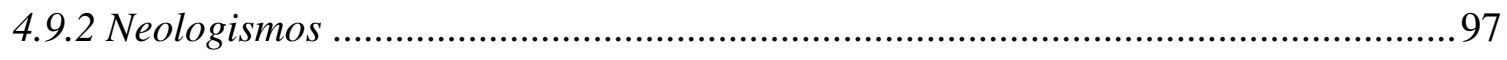

4.10 OUTRAS MANIFESTAÇÕES DE ORALIDADE ........................................101

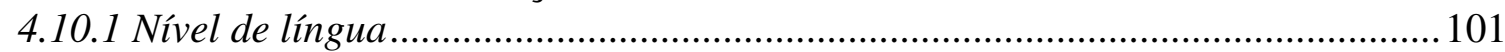

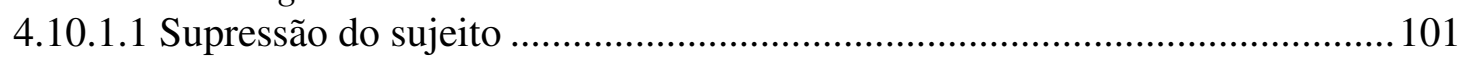

4.10.1.2 Supressão do "ne" da negação..................................................................... 102

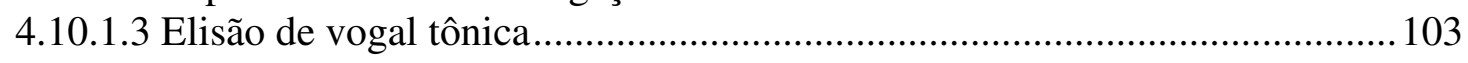

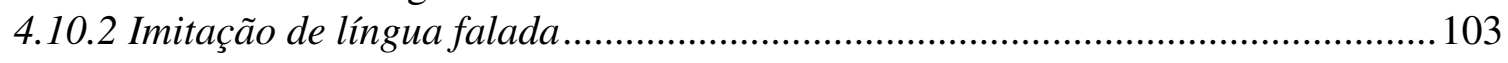




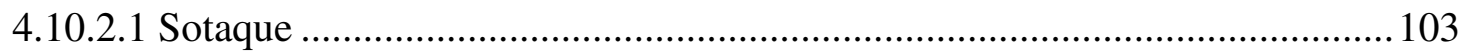

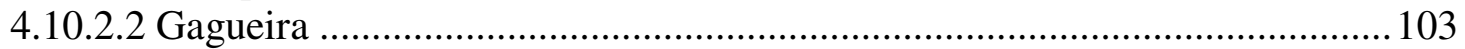

4.10.2.3 Sobreposição de turnos conversacionais ......................................................... 104

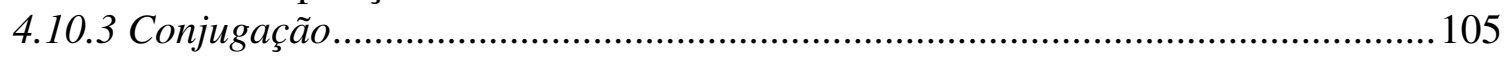

CONSIDERAÇÕES FINAIS ............................................................................106

REFERÊNCIAS BIBLIOGRÁFICAS...........................................................109

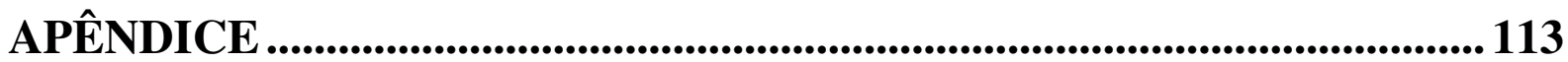




\section{INTRODUÇÃ $O^{1}$}

Ao ler o romance Les Fleurs bleues, de Raymond Queneau, sob o impacto causado pelo trabalho do autor com a linguagem - o grande número de jogos de palavras, trocadilhos, aliterações, rimas e outros elementos de oralidade - meu primeiro pensamento foi de que seria impossível traduzi-lo. Esta também foi a impressão que teve Italo Calvino quando começou a ler o romance: "Mas é intraduzível!"². Foi esse pensamento em especial que me motivou a traduzi-lo e a estudar mais profundamente o conceito de "intraduzível" e a tradução literária como "recriação", uma vez que esta resulta da interpretação do original para depois apresentá-lo em outra língua para outra cultura. “... uma tradução não diz respeito apenas a uma passagem entre duas línguas, mas entre duas culturas, ou duas enciclopédias". 3

Procuramos, então, entender o porque dessa impressão de que o texto resiste à tradução. Logo na primeira leitura do romance, percebemos que o importante não é a mensagem, pois ali a linguagem não está sendo utilizada apenas para transmitir um conteúdo, como na comunicação do dia-a-dia. Na comunicação cotidiana, quando ouvimos uma cadeia sonora temos a impressão de ouvir um sentido, assim como quando falamos emitimos sentido: o importante é a mensagem enquanto sentido, sendo, pois, o significante apenas um meio para sua transmissão. ${ }^{4}$ Já em Les Fleurs bleues, percebemos uma multiplicação de sentidos e de equívocos. Queneau, desde o primeiro capítulo, está nos alertando de que há um deslocamento do sentido e de que o significante passa a ter um valor em si mesmo. A separação entre significante e significado é colocada em questão, assim como a arbitrariedade do signo, já que o significante passa a ser essencial na construção do sentido do texto. É justamente a abundância de trabalho sobre o significante, isto é, sobre palavras da língua francesa, que faz com que o texto resista à tradução e leva a pensar em sua impossibilidade. É possível fazer em outra língua o que Queneau faz com a língua francesa?

Esse trabalho com o significante, o excesso de jogos de palavra e de trocadilhos atrai o leitor pelo lado humorístico. Mas logo ele se dá conta de que esse humor não é o objetivo do romance e não tem um fim em si mesmo. Como observa Chabanne, "os verdadeiros leitores de Queneau não se contentam em reduzir o humor a simples jogos sobre

\footnotetext{
1 Sempre que for citada uma obra em língua estrangeira, se não houver a indicação do tradutor, trata-se de "tradução nossa"

2 "È intraducibile!" (R. Queneau, I fiori blù, tradução de Italo Calvino, p. 265)

Umberto Eco, Quase a mesma coisa - experiências de tradução. Tradução de Eliana Aguiar. Rio de Janeiro: Record, 2007, p. 190

Cf. CHISS, J.L; FILLIOLET, J \& MAINGUENEAU, D. Introduction à la linguistique française. Paris: Hachette, 2001, p. 118.
} 
o material verbal e a um efeito de divertimento sem consequência para o leitor" 5 . Em seguida, citando Jacques Bens, acrescenta que "Raymond Queneau é objeto de um estranho contra-senso: tomam-no por um autor cômico, por um humorista, por alguém que faz rir. Ora, ele não é nada disso tudo. É simplesmente um escritor verdadeiro, isto é, completo". 6

Essa contradição sublinhada por Bens persegue o escritor. De fato, ele ocupa um lugar especial dentro do panorama literário francês da primeira metade do século XX. Nascido na cidade de Le Havre em 21 de fevereiro de 1903 e morto em Paris em 25 de outubro de 1976, Queneau participou ativamente da vida literária da França nesse período. Por um lado, participa da máquina da produção literária, como secretário-geral da editora Gallimard, tendo sido assim um observador privilegiado da vida intelectual e um leitor infatigável. Por outro lado, foi escritor, mas também filósofo e matemático. Talvez seja essa formação tão eclética que explique a posição ocupada por Raymond Queneau: ele não é conhecido como romancista, apesar de ter publicado 17 romances, não é considerado poeta, apesar de ter publicado 12 livros de poesia, além de ter escrito ensaios, diários e contos. De uma obra tão vasta, são citados normalmente apenas o romance Zazie dans le métro, os Exercices de style ${ }^{7}$ e alguns poucos poemas.

Para entendermos algumas características da escrita de Queneau, não podemos deixar de considerar a influência da matemática sobre ela. Desde cedo interessado por essa disciplina, tanto que entrou para a Société Mathématique de France em 1948, o escritor sempre defendeu a escrita sob regras, dizendo mesmo que o romance deve seguir regras tão estritas quanto as do soneto, e estabelecia para a construção de seus romances, regras baseadas na matemática. O Queneau matemático tem, pois, uma grande influência sobre o Queneau escritor e sobre sua relação com a linguagem e com o signo. Se na linguagem há contradições e ambiguidades, se há uma crise da significação e não se pode mais confiar nos discursos racionais e positivistas, desmentidos no início do século, principalmente pela guerra

\footnotetext{
5 "les vrais lecteurs de Queneau ne se contentent pas de réduire l'humour à de simples jeux sur le matériau verbal et à un effet d'amusement sans conséquence pour le lecteur" (CHABANNE, J-C. En lisant les lecteurs de Queneau. p. 4-5)

"Raymond Queneau est l'objet d'un étrange contresens: on le prend pour un auteur comique, pour un humoriste, pour un rigolo. Or il n'est rien de tout cela. C'est tout simplement un écrivain véritable, c'est-à-dire complet." (BENS, J. Raymond Queneau en verve: Mots, propos aphorismes, apud CHABANNE, J-C. En lisant les lecteurs de Queneau. p. 6)

7 São as únicas obras de Queneau publicadas em português: Exercices de style, de 1947, tem uma tradução de Luiz Rezende, Exercícios de Estilo, publicada. pela editora Imago em 1995; Zazie dans le métro, de 1959, tem duas traduções brasileiras, ambas com o título Zazie no Metrô, a primeira feita por Irène Monique Harlek Cubric e publicada pela editora Rocco em 1985 e a segunda, de Paulo Werneck, publicada pela editora Cosacnaify em 2009, em comemoração aos 50 anos da publicação do original.
} 
de 1914, na matemática encontra-se a verdade, representada num sistema de signos claro e unívoco.

A escrita sob regras (contraintes) é característica de toda a obra de Queneau, desde o seu primeiro romance Le Chiendent, de 1933, em cuja estrutura já se nota a aplicação de regras aritméticas. Esse tipo de escrita foi finalmente explicitada em 1960, quando, juntamente com o matemático François Le Lionnais, fundou o Oulipo, um grupo de pesquisa literária e científica, cujas regras estabelecidas para a criação das obras literárias obrigam definitivamente ao trabalho com o significante, pois é sobre eles que incidem. OULIPO, Ouvroir de Littérature Potentielle (Oficina de Literatura Potencial), é, na definição de Magali Espinasse:

Oficina porque a função do OuLiPo é produzir obras: aliás, Queneau explicita 'o trabalho oulipiano é artesanal'. Literatura potencial pois o texto escrito deve poder ser lido de várias maneiras, cada texto gera vários outros ocultos no interior do primeiro: 'uma obra potencial é uma obra que não se limita às suas aparências, que contém riquezas secretas, que se presta de bom grado à exploração' (...) Uma tal escrita não obedece mais a uma força misteriosa de inspiração mas a regras (contraintes) escolhidas, predefinidas pelo autor. ${ }^{8}$

François Le Lionnais, no primeiro manifesto sobre a Literatura Potencial, justifica a necessidade da escrita sob regras:

toda obra literária é construída a partir de uma inspiração que deve se acomodar bem ou mal a uma série de regras e de procedimentos que entram uns nos outros como bonecas russas. (...) O que certos escritores introduziram a seu modo, com talento, mas alguns ocasionalmente, outros com predileção, outros com insistência, mas numa só direção, o OuLiPo pretende fazer sistemática e cientificamente. ${ }^{9}$

Ao criar suas obras dentro do contexto oulipiano, o escritor torna-se consciente de que o importante não é o que é dito, mas sim, o dizer. Numa obra oulipiana, "é mais

8 “Ouvroir parce que la fonction de l'OuLiPo est de produire des œuvres : d'ailleurs Queneau précise 'le travail oulipien est artisanal'. Littérature potentielle car le texte écrit doit pouvoir se lire de plusieurs manières, chaque texte en engendre plusieurs autres cachés à l'intérieur du premier : 'une œuvre potentielle est une œuvre qui ne se limite pas à ses apparences, qui contient des richesses secrètes, qui se prête volontiers à l'exploration' (...) Une telle écriture n'obéit donc plus à une mystérieuse force d'inspiration mais à des contraintes choisies, prédéfinies par l'auteur." (ESPINASSE, Magali. Étude sur Les Fleurs bleues. Paris: Ellipses, 1999. pp. 16-17).

9 "Toute œuvre littéraire se construit à partir d'une inspiration qui est tenue à s'accommoder tant bien que mal d'une série de contraintes et de procédures qui rentrent les unes dans les autres comme des poupées russes» (...) «Ce que certains écrivains ont introduit dans leur manière, avec talent mais les uns occasionnellement, d'autres avec prédilection, d'autres avec insistance mais dans une seule direction, l'Ouvroir de Littérature Potentielle (OuLiPo) entend le faire systématiquement et scientifiquement" (OULIPO. La Littérature potentielle. Paris: Gallimard, 1973, pp. 16-17). 
importante para o autor o processo de criação do romance do que escrever o romance em si”" ${ }^{\prime \prime}$. Apesar dessa afirmação, apesar das regras e restrições que o escritor oulipiano se impõe para estruturar sua obra, a escrita não se torna, como se poderia pensar, um simples jogo: "Essa suposição [escrever é um jogo] é desmentida imediatamente com a leitura das principais obras oulipianas. Mesmo que tenham sido concebidas a partir de uma fórmula matemática ou de um jogo, elas emocionam e produzem algum tipo de ressignificação do mundo, ou seja, um impacto literário". ${ }^{11}$

A relação de Queneau com o signo, que em sua escrita passa a ser motivado no uso que o escritor faz das palavras para a criação de seu humor característico, faz com que, mais do que das obras, fale-se do "estilo de Queneau". Jean-Charles Chabanne, num artigo sobre o riso e a filosofia na obra de Queneau, afirma:

O que o estilo de Queneau introduz na sua obra, é uma incerteza irredutível sobre a posição do sujeito e sobre o modo enunciativo. Entre o pólo do lúdico, no qual o sujeito renuncia a dar importância ao que diz (é a fatrasia, a brincadeira, os jogos de palavras, nada pesa, nada é grave), e o pólo do sério (em que cada palavra conta, em que cada tirada tem significado, em que tudo o que é dito é importante), o texto trabalhado pelo estilo humorístico está em movimento. ${ }^{12}$

Se, como vimos, Queneau ocupa um lugar especial na literatura, Les Fleurs bleues ocupa um lugar peculiar em sua obra romanesca. Publicado em 1965, é o primeiro romance escrito depois da criação do Oulipo e o penúltimo na carreira de Queneau (antes de Vol d'Icare de 1968). O escritor já era conhecido pelo sucesso de Zazie dans le métro, de 1959, romance em que havia utilizado bastante a sua "ortograf fonétik". Em Les Fleurs bleues, encontramos todas as características que o autor procurava e aperfeiçoava desde seu primeiro romance, sobretudo no que concerne à linguagem, como observa Jaton:

Já em Le Chiendent, publicado em 1933, Queneau elabora uma receita pessoal de romance, caracterizada em primeiro lugar por uma construção rigorosa, baseada no princípio (pitagórico, platônico e joyciano, antes de ser oulipiano) da estrutura numérica, uma espantosa mistura de humorismo e de extrema seriedade, a leveza e o convite à reflexão profunda e um trabalho prodigioso sobre a linguagem. O que

\footnotetext{
10 PINO, Claudia Amigo. A ressignificação do mundo, Cult 52, novembro de 2001. p. 48.

11 Ibid. pp, 48-49.

12 "Ce qu'introduit le style de Queneau dans son œuvre, c'est une incertitude irréductible sur la position du sujet et sur le mode énonciatif. Entre le pôle du ludique, dans lequel le sujet renonce à donner toute importance à ce qu'il dit (c'est la fatrasie, la plaisanterie, le jeu de mots, rien ne pèse, rien n'est grave), et le pôle du sérieux (où chaque mot compte, où chaque coup porte, où tout ce qui est dit est important), le texte travaillé par le style humoristique est en mouvement." (CHABANNE, Jean-Charles. Rire et philosophie dans l'œuvre de Raymond Queneau. p.5)
} 
Godard chamou 'a opção pelo riso e pelo jogo', próprio ao conjunto da produção romanesca do escritor, associa-se, em Les Fleurs bleues, a uma reflexão, não raro indireta e lúdica, sobre a História e o tempo, a identidade, o sonho, as religiões (entre cristianismo militante e sabedoria oriental), a psicanálise e a linguagem, dos quais Queneau desmonta todos os mecanismos. ${ }^{13}$

Neste trabalho, procuraremos estudar os elementos que constituem a escrita de Queneau e entender os procedimentos adotados por ele, para podermos oferecer ao leitor brasileiro um texto que lhe permita, apesar dos diferentes contextos sociolinguísticos e de tratar-se de um romance "alimentado por cenas da História da França e da vida cotidiana francesa e impregnado do espírito nacional francês", ${ }^{14}$ uma leitura prazerosa em que ele tenha acesso ao texto de Queneau e possa acompanhar a narrativa, conservando o jogo de significantes e o humor.

Primeiramente, enfocaremos a preocupação de Raymond Queneau com a inclusão da língua falada no romance, gênero que passara por uma crise no início do século como consequência da crise do signo e do discurso, para podermos compreender as particularidades de sua escrita. Em seguida, abordaremos o romance Les Fleurs bleues e sua história, pois, nele, ao contrário do que ocorre com o citado Exercices de style, apesar do trabalho realizado com o significante, o processo de significação continua e vários temas são nele abordados, temas que analisaremos, com ênfase no do humor. Levantaremos ainda alguns elementos teóricos sobre tradução, leitura e construção de sentido, oralidade e manifestações de língua falada nos sistemas francês e brasileiro, para estabelecermos parâmetros que possibilitem um tipo de tradução que possa dar conta das dificuldades próprias desse texto.

Esse percurso visa, com certeza, a apresentar um produto final, pois a tradução, como o nome indica, é ao mesmo tempo processo e produto. Apresentaremos então as soluções adotadas em nossa tradução para o português, enfocando especialmente os elementos

\footnotetext{
13 "Dès Le Chiendent, paru en 1933, Queneau élabore une recette personnelle de roman, caractérisée en premier lieu par une construction rigoureuse, fondée sur le principe (pythagoricien, platonicien et joycien, avant d'être oulipien) de la structure numérique, un mélange étonnant de drôlerie et d'extrême sérieux, la légèreté et l'invitation à la réflexion profonde et un travail prodigieux sur le langage. Ce qu'Henri Godard a appelé « le parti pris du rire et du jeu », propre à l'ensemble de la production romanesque de l'écrivain, s'associe, dans Les Fleurs bleues, à une réflexion, souvent indirecte et ludique, sur l'histoire et le temps, l'ídentité, le rêve, les religions (entre christianisme militant et sagesse orientale), la psychanalyse et le langage, dont Queneau démonte tous les mécanismes." (JATON, Anne Marie. Les Fleurs Bleues - Bilan Provisoire. In : Europe - revue littéraire mensuelle - avril 2003 , p. 48).

14 "nourri de scènes de l'Histoire de France comme de la vie quotidienne française, imprégné du génie national français" (DURAND, André. «Les Fleurs bleues - roman de Raymond Queneau» In: Comptoir Littéraire.. p. 65)
} 
de oralidade ou de língua falada, cuja inclusão na literatura é, como veremos, o projeto literário de Queneau. 


\section{O PROJETO LITERÁRIO DE QUENEAU}

\subsection{A LÍNGUA FALADA NO ROMANCE}

Numa viagem à Grécia, em 1932, Queneau observa a existência de duas línguas gregas, a demótica, língua falada pelo povo, e a catarévussa, língua escrita, considerada a língua oficial, status que se manteria até 1976. Essa coexistência de duas variedades linguísticas com usos distintos, é o que os linguistas denominam diglossia, segundo o conceito formulado por Ferguson em 1959 e citado por Antonio Martins Araújo "uma situação relativamente estável de língua na qual, em acréscimo aos dialetos primários da língua (que podem incluir um padrão ou padrões regionais), há uma variedade superposta, uma de mais prestígio". 15

A observação das duas línguas gregas foi como uma revelação para Queneau e o levou a pensar que na França também coabitavam duas línguas, o francês escrito, considerada a correta e com maior prestígio, e o francês falado, popular, que ele posteriormente chamaria de neo-francês.

Queneau, no entanto, falará de bilinguismo, palavra que atualmente não seria aplicável à situação linguística mencionada, pois, segundo a definição formulada em 1973 por Bernard Pottier, "em sentido estrito, bilingüismo designa a situação de um indivíduo ser capaz de manejar duas línguas de status idêntico com igual facilidade". ${ }^{16}$ A propósito da diferença entre os dois conceitos, Araújo conclui que "Em síntese, enquanto o bilingüismo caracteriza um comportamento individual em relação a línguas de status idêntico, a diglossia caracteriza um comportamento lingüístico coletivo, com suas implicações sociais, psicológicas, políticas e culturais." 17

Queneau, em seu ensaio "Langage académique", dirá sobre o francês: "Nós falamos duas línguas assim como os gregos; a catarévussa (língua pura) é utilizada pelos jornalistas e os funcionários; a demótica (popular) pelos poetas." 18

\footnotetext{
15 ARAÚJO, A. M. Bilingüismo e crioulização nos países lusófonos. Palestra proferida em 27/06/2000 e publicada no site da Academia Brasileira de Letras.

16 Ibid.

17 Ibid.

18 "Nous parlons deux langues, tout comme les Grecs: la 'catharevousa' (langue pure) est utilisée par les journalistes et les fonctionnaires ; la 'démotique' (populaire) par les poètes.” (QUENEAU, Raymond. Bâtons, chiffres et lettres. Ed. revue et augmentée. Paris: Gallimard, 1965, p. 51).
} 
É durante essa viagem à Grécia que Queneau escreve seu primeiro romance, Le Chiendent, em que já utiliza elementos da língua falada, o neo-francês, cuja inclusão no romance passa a ser seu projeto literário.

Queneau reivindica, para essa nova língua francesa, o estatuto de língua a ser utilizada em todos os campos do conhecimento, como observa Fourcaut, ao desenvolver sua análise do romance Zazie no metrô:

Queneau reivindicou o direito, para o romance e, além, para todos os escritos
'sérios', de renunciar ao 'francês esclerosado' ou 'estático' legado pela tradição,
para adotar 'uma língua nova', uma 'linguagem verdadeira': o néo-français (neo-
francês), isto é, a língua efetivamente utilizada na vida de hoje, 'o francês falado
contemporâneo', ou ainda 'a língua francesa verdadeira, a língua falada'. ${ }^{19}$

Essa inovação na escrita faz parte de um processo que se desenvolvia na França, desde o início do século XX, quando o romance, como gênero, passava por uma crise em que todos os seus elementos eram questionados.

Durante todo o século XIX, o romance teve por objeto os conflitos sociais que retratava: burguesia e aristocracia, pobreza e riqueza, capital e trabalho, todos vividos pelo herói romanesco. Principalmente na segunda metade do século, a literatura sofre a influência do positivismo, corrente filosófica que surgiu na França no começo do século XIX, com Auguste Comte, segundo a qual a única forma de conhecimento verdadeiro é o conhecimento científico. Essa filosofia ganhou força na Europa na segunda metade do século e influenciou a literatura realista que buscava retratar a realidade social da época interessando-se por grupos sociais cujos atores eram mostrados da forma mais próxima possível da realidade. No Realismo, o romancista procura aplicar na literatura os métodos das ciências experimentais e da filosofia positivista para estudar com distanciamento os meios sociais e sua influência sobre os indivíduos. Esse procedimento cientificista abre caminho para o Naturalismo em que, sob a influência da medicina e das ciências experimentais, o escritor verifica experimentalmente nos romances o papel dos determinismos sociais e biológicos sobre o indivíduo ou o grupo, propondo-se a fazê-lo como um observador científico, com o máximo apagamento da subjetividade.

19 “Queneau a revendiqué le droit, pour le roman et, au-delà, pour tous les écrits 'sérieux', de renoncer au 'français sclérosé' ou 'figé' légué par la tradition, pour adopter 'une langue nouvelle', 'un langage vrai' : 'le néofrançais', à savoir la langue effectivement utilisée dans la vie d'aujourd'hui, 'le français parlé contemporain', ou encore 'la langue française véritable, la langue parlée'" (FOURCAUT, Laurent. Le texte en perspective. In : Zazie dans le métro. Paris: Gallimard, 2006, p. 246.). 
A partir de 1890, no entanto, o gênero passou por uma crise que consistiu na recusa dessa forma de arte que tinha como base a filosofia positivista. Predominava o sentimento de que o romance não tinha mais futuro. Representar a realidade por meio da linguagem mostrava-se insuficiente e mesmo impossível. A tentativa de ter no romance uma forma de retratar a sociedade e de espelhar o mundo tal como ele era parecia frustrada. $\mathrm{O}$ mundo mudava com o progresso de outras artes, como o cinema, e com a influência crescente dos romances estrangeiros, e era preciso que o romance também mudasse.

A personagem do romance, bem definida física e psicologicamente, já não é mais aceita. Depois da psicanálise, não é mais possível um herói tão íntegro; o homem passa a ter consciência de sua incompletude e de sua precariedade. Já na década de 1950, Nathalie Sarraute escreve sobre os resultados da crise romanesca, movimento que se estendeu, com várias tentativas de resposta (Proust, Gide, Céline, Queneau, os existencialistas), até a metade do século, com o Nouveau Roman:

Hoje todos desconfiam, sem que haja necessidade de dizer, de que 'a Bovary - sou eu'. E uma vez que o que importa agora é, mais do que alongar indefinidamente a lista dos tipos literários, mostrar a coexistência de sentimentos contraditórios e representar, na medida do possível, a riqueza e a complexidade da vida psicológica, o escritor, com toda a honestidade, fala de si. ${ }^{20}$

Era necessário, pois, que o gênero se renovasse. Nas vésperas da primeira guerra mundial, surge o primeiro volume de Em Busca do Tempo Perdido. Analisando a crise romanesca na França, num artigo publicado no Québec, na revista La molle page - littérature \& imaginaire, o professor Réjean Thomas, escreve sobre o romance de Proust que, completamente diferente do romance clássico, é um livro que

abandonando a sacrossanta intriga, dava conta da totalidade de uma experiência e que, liberado de seu jugo, se abria a tudo o que os romancistas, até então, eram tentados a negligenciar, tão ocupados estavam em correr em direção ao desfecho. $\mathrm{O}$ que se tornava o assunto era 'o próprio mundo, no seu tecido de sensações e de imagens'. 21

\footnotetext{
20 “Aujourd'hui chacun se doute bien, sans qu'on ait besoin de le lui dire, que 'la Bovary - c'est moi'. Et puisque ce qui maintenant importe c'est, bien plutôt que d'allonger indéfiniment la liste des types littéraires, de montrer la coexistence de sentiments contradictoires et de rendre, dans la mesure du possible, la richesse et la complexité de la vie psychologique, l'écrivain, en toute honnêteté, parle de soi." (SARRAUTE, Nathalie. L'ère du soupçon. Paris : Gallimard, 1956, p.72).

$21 \quad$ "... délaissant la sacro-sainte intrigue, rendait compte de la totalité d'une expérience et qui, libéré de ses carcans, s'ouvrait à tout ce que les romanciers, jusque-là, étaient tentés de négliger, occupés qu'ils étaient à courir vers le dénouement. Ce qui devenait le sujet, c'était " le monde même, dans son tissu de sensations et d'images." (THOMAS, Réjean. La molle page - littérature \& imaginaire. v.8, n. 0.02, jan. 2009).
} 
Na mesma época, Gide, que sob a influência de Dostoievski começava a conceber o romance como uma obra de grandes dimensões que apresentava uma multiplicidade de acontecimentos e de personagens, publica Os Subterrâneos do Vaticano. Mais tarde, em Os Falsos Moedeiros, Gide dizia que o que importava era a história da obra: “... a história da obra, de sua gestação! Mas isso seria apaixonante... mais interessante que a obra em si..." 22 . O romancista questiona sobre o romance no próprio interior deste. Comentando essa frase de Gide, Thomas interroga-se "não seria o eco de um tempo em que, como o romancista não tem mais nada a dizer, resta-lhe chamar a atenção sobre a maneira que utiliza para não dizer nada?" 23

Depois da primeira grande guerra, quando o mundo começava a entrar numa civilização de massa, a era das individualidades parecia terminada e o herói romanesco já não podia ser, como no romance do século XIX, o representante da sociedade. Thomas afirma em seu artigo que "O herói dos tempos modernos é um medíocre, um pobre homem, um esquizofrênico, atormentado pela timidez e pelas neuroses; às vezes está à procura de um emprego, ao mesmo tempo um intelectual e um desempregado." ${ }^{24}$ Corinne François, por sua vez observará que "a contestação das velhas receitas torna-se radical e se traduz pela condenação das próprias noções de literatura e de civilização" ${ }^{25}$.

Nesse cenário, um mundo em que a guerra veio mostrar a falência do discurso positivista, surgem movimentos como o dadaísta, fundado por Tristan Tzara, que é a negação de tudo o que produz a civilização responsável pela guerra e pela destruição e do qual participaram escritores como Aragon e André Breton. Este último, depois da ruptura com o movimento Dada, funda o Surrealismo, que preconiza a escrita automática ditada pelo inconsciente, sem nenhuma preocupação estética ou moral. Queneau participa do movimento surrealista até 1929, quando rompe com ele e procura inverter a proposição dos surrealistas e propõe, ao contrário, escrever sob regras (contraintes) que controlam a forma e o conteúdo.

\footnotetext{
22 “.... l'histoire de l'œuvre, de sa gestation! Mais ce serait passionnant... plus intéressant que l'œuvre elle-même...” (GIDE, André. Les Faux-Monnayeurs. 226 édition. Paris: Gallimard, 1951, p. 241).

23 "... était-ce l'écho d'un temps où, comme le romancier n'a plus rien à dire, il lui reste à attirer l'attention sur la manière dont il s'y prend pour ne rien dire ?" (THOMAS, Réjean. La molle page - littérature \& imaginaire. v.8, n. 0.02, jan. 2009), p. 4).

24 "Le héros des temps modernes, c'est un médiocre, un pauvre homme, souvent un adolescent prolongé, un schizophrène, tourmenté par sa timidité et ses névroses ; il est souvent à la recherche d'un emploi, déjà tout à la fois intellectuel et chômeur" (THOMAS, Réjean. La molle page - littérature \& imaginaire. v.8, n. 0.02, jan. 2009), p. 4)

25 "... la contestation des vieilles recettes se fait radicale et se traduit par la condamnation des notions même de littérature et de civilisation." (FRANÇOIS, Corinne. Connaissance d'une auvre : Les Fleurs bleues. Rosny: Bréal, 1999 p. 16).
} 
No período entre guerras, com Céline, Malraux e Aragon, não estamos mais no mesmo universo das gerações precedentes: já não há segurança burguesa nem serenidade intelectual. Busca-se a maneira de viver com as ameaças que pesam sobre o mundo. Novas técnicas são utilizadas no romance: a realidade não é mais contada, mas apresentada de modo segmentado como numa montagem cinematográfica. É nesse ambiente literário, na já citada viagem à Grécia, que desponta a literatura de Raymond Queneau.

\title{
1.2 QUENEAU E A LÍNGUA FALADA
}

A partir dos anos 1930, época em que Queneau começa a escrever, há uma grande preocupação com a língua, considerada um dos fatores de afirmação das nações, e particularmente com a língua popular, pois, como diz Philippe Roussin:

\begin{abstract}
a língua era um dos pontos nevrálgicos da redefinição dos termos da cultura e de suas instituições. A importância central que a literatura deveria conceder às questões de sua unidade, da língua falada e popular ao longo dos anos trinta, tanto na América quanto na Europa, (...) era o melhor exemplo da vontade de aproximar literatura e leitores numa comunidade de língua e de pertencimento ${ }^{26}$.
\end{abstract}

$\mathrm{Na}$ França, autores como Céline e Queneau têm essa preocupação com a linguagem e, dando-se conta da distância entre a língua falada e a escrita, procuram empregar essa última em seus romances. “Fala-se em sua própria língua, escreve-se em língua estrangeira' notará Sartre em As Palavras, retomando Proust. A literatura do falado e o romance dos anos trinta quiseram ir contra a evidência de tal constatação" ${ }^{27}$. Em toda a obra de Queneau encontramos exemplos de sua militância a favor da aceitação do francês falado (neo-francês) que, segundo ele, está para o francês escrito, como o francês estava para o latim até o século XVII.

Em 1932, enquanto Queneau, durante sua viagem à Grécia, começava a escrever seu primeiro romance, Céline publicava Viagem ao Fim da Noite. Esse romance logo provocou polêmica, pela denúncia de uma sociedade que embrutecia e humilhava o homem, mas principalmente pelo estilo surpreendente, pelo narrador em primeira pessoa que confundia personagem e autor e pela introdução da língua falada. Na época, a introdução da

\footnotetext{
26 "La langue était alors un des lieux névralgiques de la redéfinition des termes de la culture et de ses partages institués. L'importance centrale que la littérature devait accorder aux questions de son unité, de la langue parlée et populaire tout au long des années trente, en Amérique comme en Europe, (...) était le meilleur exemple de la volonté de rapprocher littérature et lecteurs dans une communauté de langue et d'appartenance." (ROUSSIN, Philippe. Misère de la littérature, terreur de l'histoire. Paris: Gallimard, 2005, p. 255).

27 "'On parle dans sa propre langue, on écrit en langue étrangère', notera Sartre dans Les Mots en démarquant Proust. La littérature du parlé et le roman des années trente ont voulu aller contre l'évidence d'un tel constat." (ROUSSIN, Philippe. Misère de la littérature, terreur de l'histoire. Paris: Gallimard, 2005, p. 271).
} 
língua popular na literatura era rara, tanto mais quando era o narrador que falava essa língua, normalmente reservada aos diálogos. Isso ocasionou o questionamento, na época, do caráter literário da obra. Bruno Jouy, um dos comentaristas da obra de Céline, explica assim o impacto causado pelo romance:

Céline se opunha, na realidade, a toda uma tradição literária que fazia da língua escrita - definida como uma língua que utiliza construções sintáticas, verbais e modais banidas da língua falada - a única língua válida. Desse modo, o livro de Céline devia necessariamente incomodar os defensores de uma concepção tradicional da literatura. ${ }^{28}$

Para Céline, a língua clássica, a língua acadêmica, a dos dicionários, era uma língua morta. No entanto, a preocupação com a introdução da língua falada no romance, levou-o a criar uma linguagem própria, com elementos de oralidade, mas que não se confundia com a língua popular, falada nas ruas. Céline militava em favor da língua falada popular, mas se a língua popular é uma espécie de relaxamento da língua, o que Céline fez, em vez de utilizar essa língua relaxada, foi criar uma língua extremamente precisa e elaborada que visava a dar a aparência de relaxamento.

No romance tradicional, a oralidade está presente apenas nos diálogos das personagens, opondo-se à escrita objetiva do narrador onisciente que sempre se utiliza da modalidade culta da língua. Raramente, há incursões de oralidade no narrador, sob a forma de contaminação lexical ou de discurso indireto livre, por exemplo. No entanto, mesmo a fala das personagens, embora tente representar a língua falada, não apresenta muitas de suas características, pois é submetida sempre à correção gramatical: não raro, uma personagem inculta e analfabeta exprimia-se no romance numa língua de nível elevado, com um vocabulário e uma sintaxe perfeitamente adequados à norma culta. Pouilloux observa que o romance tradicional traz diálogos "dos quais o mínimo que se pode dizer é que são 'escritos', pronunciá-los em voz alta é quase impossível; e, ao contrário, a transcrição de um diálogo gravado tem todas as chances de deixar os leitores perplexos, e mais ainda os participantes, ao ponto de parecer até incompreensível" ${ }^{29}$. Isso fez com que a língua criada por Céline, sem ser

\footnotetext{
28 "Céline s'opposait, en effet, à toute une tradition littéraire qui faisait de la langue écrite - à définir comme une langue qui utilise des tournures syntaxiques, verbales et modales bannies de la langue parlée - la seule langue valable. A ce titre, le livre de Céline devait nécessairement déranger les défenseurs d'une conception traditionnelle de la littérature." (JOUY, Bruno. Voyage au bout de la nuit - Étude d'une réception. Disponível em: <http://louisferdinandceline.free.fr/index2.htm>. Acesso em 24/01/2011.)

${ }_{29} 2 . .$. dont le moins qu'on puisse dire est qu'ils sont 'écrits', les prononcer à haute voix est presque impossible ; et, à l'inverse, la transcription d'un dialogue enregistré a toutes chances de rendre tout à fait perplexes les lecteurs et plus encore les participants, au point même de paraître incompréhensible." (POUILLOUX, Jean-Yves. Les fleurs bleues de Raymond Queneau. Paris: Gallimard, 1991, p. 34).
} 
a língua falada, mas não sendo a língua culta, fosse um grande passo na aproximação das duas modalidades. George Orwell, num artigo sobre Henry Miller em que escrevia sobre Trópico de Câncer, obra que ele aproximava de Viagem ao Fim da Noite, observa:

[essas obras lançam] uma ponte sobre o terrível abismo que separa, nas obras de imaginação, o intelectual do homem da rua. As obras de ficção inglesas são, geralmente, no seu mais alto nível, escritas por pessoas letradas que falam de pessoas letradas a outras pessoas letradas (...) os livros que descrevem pessoas comuns comportando-se de modo comum são raríssimos. ${ }^{30}$

Queneau, que em 1933 publica seu primeiro romance, Le Chiendent, também se preocupa com a inclusão da língua falada no romance, constata a distância que existe entre o francês escrito e o francês falado e não vê inconvenientes à intervenção da linguagem popular na literatura. Essa preocupação fica evidente quando Queneau cita em seu ensaio "Écrit en 1955", trecho de uma carta do escritor cubano Alejo Carpentier, que conheceu na França em 1928: "a conversação tem um ritmo, um movimento, uma falta de sequência nas ideias, com, em compensação, associações, lembranças curiosas, que não se parecem em nada com os diálogos que preenchem, habitualmente, qualquer romance." 31

Apesar da utilização da língua falada no romance a partir do início da década de 1930, há uma grande resistência a sua aceitação por parte do público e da crítica. Queneau vai estender sua militância pela língua falada, reivindicando seu uso mesmo em textos científicos. Quase 20 anos depois, no entanto, constata em seu ensaio "Connaissez-vous le Chinook ?":

o francês falado, até o momento, só tem direito ao diálogo, e apenas há alguns anos ao narrativo no romance. Mas ele continua a ser objeto de indignidade nacional: ele não tem o direito de exprimir 'ideias'. (...) O francês contemporâneo só se tornará uma língua verdadeira e fecunda quando os próprios filósofos a utilizarem, e naturalmente os sábios. ${ }^{32}$

$30 \quad$ “... un pont pardessus le terrible gouffre qui sépare, dans les œuvres d'imagination, l'intellectuel de l'homme de la rue. Les œuvres de fiction anglaises sont, généralement, à leur plus haut niveau, écrites par des gens de plume qui parlent de gens de plume à d'autres gens de plume (...) les livres dépeignant des gens ordinaires se comportant de manière ordinaire sont rarissimes." (ORWELL, George, apud ROUSSIN, Philippe. Misère de la littérature, terreur de l'histoire. Paris: Gallimard, 2005,, p. 259).

31 "... la conversation a um rythme, un mouvement, une absence de suite dans les idées, avec, par contre, d'étranges associations, de curieux rappels, qui ne ressemblent en rien aux dialogues qui remplissent, habituellement, n'importe quel roman." . (QUENEAU, Raymond. Bâtons, chiffres et lettres. Ed. revue et augmentée. Paris: Gallimard, 1965, p. 90).

32 "Le français parlé n'a droit, jusqu'à présent, qu'au dialogue, et même depuis quelques années, au narratif dans le roman. Mais il demeure toujours frappé d'indignité nationale : il n'a pas le droit d'exprimer des «idées ». [...] Le français contemporain ne deviendra une langue véritable et féconde que lorsque les philosophes eux-mêmes l'utiliseront, et naturellement les savants". (QUENEAU, Raymond. Bâtons, chiffres et lettres. Ed. revue et augmentée. Paris: Gallimard, 1965, pp. 58-63). 
Em Les Fleurs bleues, Queneau trata de assuntos profundos com uma linguagem cheia de elementos de língua falada. Temas filosóficos são abordados através de jogos de palavras e de trocadilhos que ele mesmo chama de miseráveis. Por que a língua da filosofia tem que ser diferente da língua do cotidiano? Queneau trata da filosofia em linguagem ordinária, trata das ideias de Hegel com humor e trocadilhos, enfim, com uma linguagem que seria mais adequada a almanaques que a textos filosóficos ou literários.

\subsection{LÍNGUA FALADA E ORALIDADE}

Antes de analisarmos a utilização de elementos de oralidade por Queneau, cumpre fazer uma distinção entre dois termos que muitas vezes são confundidos e empregados indiferentemente: língua falada e oralidade. Na realidade, o que chamamos oralidade não se confunde com a língua falada.

$\mathrm{Na}$ língua falada, como há interação entre falantes, além dos elementos linguísticos propriamente ditos, toda a situação de enunciação contribui para a eficiência da transmissão da mensagem: gestos, expressões faciais, entonação, postura e ritmo. Hudinilson Urbano diz a esse respeito que "com efeito, na língua falada cabe considerar a presença dos interlocutores com o seu comportamento vocal, gestual, fisionômico e, principalmente, emocional, somado ao contexto físico e social de ambos, que está presente e, em princípio, lhes é ao menos parcialmente idêntico" 33 .

Num texto escrito, como num romance, a situação de enunciação não é dada, mas construída no próprio texto: não temos acesso ao tom, à expressão facial, aos gestos, a nenhum dos elementos extra-linguísticos que a definem, tudo são palavras, "tudo num romance tem de ser contado; nada pode ser mostrado" ${ }^{34}$, diz W. Booth. É necessário, portanto, descobrir a enunciação tomando-se por base o enunciado. O texto escrito "precisa, por assim dizer, 'construir' lingüisticamente os momentos, indivíduos e lugares a que faz referência", ${ }^{35}$, diz R. Ilari.

A língua escrita utiliza-se, normalmente, da linguagem culta, observando o padrão linguístico, sintaxe mais completa, vocabulário mais amplo, maior ligação com a gramática,

33 URBANO, Hudinilson. Oralidade na Literatura (O caso Ruben Fonseca). São Paulo: Cortez, 2000, p.

BOOTH, W. apud URBANO, Hudinilson. Oralidade na Literatura (O caso Ruben Fonseca). São Paulo: Cortez, 2000, p. 19.

35 ILARI, R. apud URBANO, Hudinilson. Oralidade na Literatura ( $O$ caso Ruben Fonseca). São Paulo: Cortez, 2000, p. 87. 
ao passo que na língua falada prevalece a linguagem popular, com situações menos formais, simplificação sintática, vocabulário mais restrito, fora dos padrões da gramática tradicional.

A língua falada é aquela cujo suporte é o som, mas há elementos sintáticos e lexicais que lhe são próprios e que podem ser representados na escrita. São várias as características da língua falada que a distinguem da língua escrita: o canal (sonoro e não visual), as condições de realização (presença física dos interlocutores), traços prosódicos, grande frequência de dêiticos, reduções e mudanças fonéticas e entonação.

A língua falada pode, pois, ser representada na escrita como mimetização do oral, como na fala de personagens nos romances realistas do século XIX. Essa "representação da língua falada", no entanto, não é o que entendemos por "oralidade". A oralidade não é um fenômeno da fala, mas da escrita. Tal como inserida nos romances do século XX, ela ultrapassa a representação da fala das personagens. Aí, a oralidade atinge uma dimensão maior e é utilizada conscientemente pelo escritor. Não há mais separação entre a fala objetiva do narrador e a fala subjetiva da personagem. Assim, a representação vacila, o que é permitido pelo trabalho de primazia do significante que induz a um modo particular de significação. Trata-se de uma linguagem específica, que não se confunde com a língua falada.

É o ritmo que, segundo Meschonnic, vai definir o oral, ou a oralidade, como um modo que não se confunde nem com o escrito nem com o falado:

Mas se o ritmo é a organização do movimento de um discurso por um sujeito, com seu acompanhamento prosódico, sua significação, podem-se distinguir três termos e não mais dois: o escrito, o falado, e um terceiro modo, que o dualismo do signo mascarava: pode-se chamar oral o modo de significar caracterizado por uma primazia do ritmo e da prosódia no movimento do sentido. (...) O oral, assim novamente definido, pode ocorrer tanto no falado quanto no escrito. ${ }^{36}$

A oralidade não depende do suporte "voz" para existir, depende do texto, de como os valores da voz são integrados ao texto escrito e são sentidos pelo leitor, mesmo que este o leia em silêncio. Não há necessidade de realização oral para que os elementos de oralidade, sobretudo o ritmo, se façam observar:

36 "Mais si le rythme est l'organisation du mouvement d'un discours par un sujet, avec son accompagnement prosodique, sa signifiance, on peut distinguer trois termes et non plus deux : l'écrit, le parlé, et un troisième mode, que le dualisme du signe masquait : on peut appeler oral le mode de signifier caractérisé par un primat du rythme et de la prosodie dans le mouvement du sens.(...) L'oral, ainsi nouvellement défini, peut advenir autant dans le parlé que dans l'écrit." (MESCHONNIC, Henri \& DESSONS, Gérard. Traité du rythme: Des vers et des proses. Paris: Armand Colin, 2005, pp. 45-46). 
É que o ritmo, se não o esquecermos, para a poética, não é mais da esfera ORAL, não é mais (somente) um fenômeno sonoro. Há também um ritmo visual. O menor cartaz mostra-o. Leonardo da Vinci dizia que a pintura é 'coisa mental', o ritmo de um texto também é coisa mental, conhecemos há muito tempo a relação poética que existe entre a oralidade e o visual. ${ }^{37}$

A oralidade, como encontramos em Céline, nasce no próprio ato da escrita, e não na tentativa de representar por essa escrita uma eventual realização oral, de mimetizar uma eventual "língua falada". Queneau, por sua vez, procura exatamente a reprodução da linguagem que se ouve todos os dias e que, segundo ele, deveria ser a única a ser utilizada tanto oralmente quanto na escrita. Apesar de a oralidade ser um fenômeno da escrita, em Queneau encontramos não uma elaboração literária de suas manifestações, como em Céline, mas um estilo natural, a utilização de trocadilhos corriqueiros, a fonetização da escrita, a redução do vocabulário filosófico em proveito de uma oralidade que se aproxima o máximo possível da língua falada.

Queneau procura manter elementos de oralidade tais como são encontrados no francês falado, ainda que isso implique deformações sintáticas e também ortográficas para dar conta da realização fonética efetivamente encontrada. Esses elementos estão presentes não só na fala das personagens, mas também nas palavras do narrador, o que rompe com as regras da narrativa tradicional, e é uma característica do romance francês do século XX. Espinasse, a propósito do projeto de Queneau, observa que "ele [Queneau] pensa que o engajamento do escritor deve ser exclusivamente literário. Ele vai preconizar um engajamento pela renovação da língua escrita" 38 .

Na língua falada usa-se normalmente um vocabulário mais vulgar, expressões populares e uma sintaxe descuidada, caracterizada por "uma quantidade muito grande de frases inacabadas, interrompidas, retomadas, elípticas ou enfáticas" ${ }^{39}$, características próprias para o tratamento de assuntos ligados ao cotidiano e ao concreto, ao passo que na língua escrita encontram-se um vocabulário de nível mais elevado, expressões mais

37 'C'est que le rythme, si on ne l'a pas oublié, pour la poétique, n'est plus de la sphère ORAL, n'est plus (seulement) un phénomène sonore. Il y a aussi un rythme visuel. La moindre affiche l'affiche. Léonard de Vinci disait que la peinture est 'chose mentale', le rythme d'un texte aussi est chose mentale, on sait depuis longtemps le rapport poétique qui existe entre l'oralité et le visuel." (MESCHONNIC, Henri \& DESSONS, Gérard. Traité du rythme: Des vers et des proses. Paris: Armand Colin, 2005, p. 194).

$38 \quad$ “...il [Queneau] pense que l'engagement de l'écrivain doit être exclusivement littéraire. Il va prôner un engagement pour le renouveau de la langue écrite." (ESPINASSE, Magali. Étude sur Les Fleurs bleues. Paris: Ellipses, 1999, p. 12).

39 "un très grand nombre de phrases inachevées, interrompues, reprises, elliptiques ou emphatiques" (CHISS, J-L; FILLIOLET, J \& MAINGUENEAU, D. Introduction à la linguistique française - tome 2: syntaxe, communication, poétique. Paris: Hachette, 2001) 
elaboradas e elitistas e a sintaxe correta estabelecida pela norma culta. Nessa língua são tratados assuntos metafísicos, científicos e abstratos. Queneau procura justamente subverter essa situação utilizando-se da língua falada para tratar de assuntos como filosofia, psicologia e história.

Depois da publicação de Le Chiendent, Queneau publica suas primeiras reflexões sobre o neo-francês e a ortografia fonética. Em seu ensaio "Écrit en 1937", ele se coloca a questão "da língua falada, ou melhor, da língua falada escrita, pois se tratará aqui exatamente da passagem para uma língua nova (a saber, o francês tal qual se fala atualmente) da fase oral à fase escrita" 40 .

Logo em seguida, no mesmo ensaio, defende que "o francês moderno devia enfim se desligar das convenções da escrita que o envolvem ainda (convenções tanto de estilo quanto de ortografia e de vocabulário) e que ele alçaria voo, borboleta, deixando atrás de si o casulo tecido pelos gramáticos do século XVI e pelos poetas do século XVII" ${ }^{41}$.

O neo-francês caracteriza-se por uma sintaxe e um vocabulário típicos da língua falada e por uma ortografia mais ou menos fonética, que Queneau chama ortograffonétik. "O francês falado funciona efetivamente segundo regras totalmente diferentes das do francês escrito: a pronúncia aglutina os fonemas, o que faz com que a frase pronunciada seja muito diferente da frase ortografada" 42 .

Em sua obra Bâtons, Chiffres et Lettres, Queneau define a "ortograf fonétik" utilizando-a na própria definição:

...a reforma da ortografia, ou melhor a adosão de uma ortografia fonétika si impõe porke ela tornará manifesto o esensial: a preeminênsia do oral sobre o eskrito... Mais uma veis, a ortografia é mais ki um mau ábito, é uma vaidade. Nosas línguas são línguas populares, vulgares, faladas. Noso alfabeto reteve muinto poko du valor ieroglífiko das grafias semântikas, i suas kombinasões, kuja natureza é feita di akazos i di konvensões, não provokam o respeito ki si deve às eskrituras sagradas. Em xinês, em ejípsio antigo, em semântika, as grafias são signifikativas; mas não

\footnotetext{
40 "du langage parlé, ou plutôt du langage parlé écrit, car il s'agira ici très exactement du passage, pour une langue nouvelle (à savoir le français tel qu'il se parle actuellement) de la phase orale à la phase écrite" ". (QUENEAU, Raymond. Bâtons, chiffres et lettres. Ed. revue et augmentée. Paris: Gallimard, 1965, p. 12).

"le français moderne devait enfin se dégager des conventions de l'écriture qui l'enserrent encore (conventions tant de style que d'orthographe et de vocabulaire) et qu'il s'envolerait, papillon, laissant derrière lui le cocon de soie filé par les grammairiens du XVI ${ }^{e}$ et les poètes du XVII siècle.”. (QUENEAU, Raymond. Bâtons, chiffres et lettres. Ed. revue et augmentée. Paris: Gallimard, 1965, p. 16).

42 "Le français parlé fonctionne en effet selon des règles totalement différentes de celles du français écrit : la prononciation agglutine les phonèmes, ce qui fait que la phrase prononcée est souvent fort éloignée de la phrase orthographiée." (FRANÇOIS, Corinne. Connaissance d'une æeuvre : Les Fleurs bleues. Rosny: Bréal, 1999, p. 26).
} 
em fransês, em ke só tem o valor do kustume, sentimentais i xeias di lembransas. A venerasão não deve si perder nakilo ki não é digno dela.. A konstituisão desa nova língua, reenkontrando sua natureza oral i muzikal, si tornará logo uma lingua poétika i a substânsia abundante i vivás di uma nova literatura... ${ }^{43}$

É claro que essa escrita fonética não é utilizada por Queneau a não ser esporadicamente, já que seria quase impossível ler uma obra totalmente escrita segundo essas regras. Deve-se notar ainda que o francês é uma língua em que a ortografia está muito mais distante da representação da fonética do que no português. Por isso a preocupação com a ortografia é muito mais presente para o francês do que para o brasileiro que, muitas vezes, sequer se dá conta de eventuais discrepâncias entre a pronúncia e a representação gráfica das palavras, como se pode notar em comentários de alunos de língua estrangeira que dizem que “em português é mais fácil porque se escreve como se fala". Consequentemente, o impacto da utilização da "ortograf fonétik" sobre o leitor francês dificilmente poderá ser reproduzido sobre o leitor brasileiro numa tradução.

$43 \quad$ "... la réforme de l'ortograf, ou pluto l'adoption d'une ortograf fonétik s'impose parce qu'elle rendra manifeste l'essenciel : la prééminence de l'oral sur l'écrit... Encor une foi, l'ortograf est plus qu'une mauvaise abitude, c'est une vanité. Nos langues sont des langues populaires, vulgaires, parlées. Notre alfabet n'a que peu retenu de la valeur iéroglife des grafies sémantik, et leurs combinaisons, dont les azards et les convensions font sans doute la nature, n’appelent poin le respè ki se doit o zécritures sacrés. En chinoi, en égipsien ansien, en sémentik, les grafies sont significatives; mais non en français, ou elle n'ont de valeur que de coutume, sentimentales et gonflées de souvenirs. La vénérassion ne doit point s'égarer sur ce qui n'en è pas digne... La constitussion de cette nouvelle langue, retrouvant sa nature orale et musikale, deviendra biento une lang poétik et la substance abondante et vivace d'une nouvelle litérature..." (QUENEAU, Raymond. Bâtons, chiffres et lettres. Ed. revue et augmentée. Paris: Gallimard, 1965, p. 25). 


\section{ENTRE HISTÓRIA E FICÇÃO}

\subsection{DESTINOS ENTRELAÇADOS}

As duas personagens principais, o duque de Auge e Cidrolin, estão uma no sonho da outra. Cidrolin vive na atualidade, em 1964, ano em que o romance foi escrito, e tem sonhos contínuos nos quais o duque vive aventuras ao longo de sete séculos, em saltos de exatos 175 anos. Tudo se passa como um espelho nas vidas das duas personagens: os dois têm três filhas e três genros, os dois são viúvos e assim por diante, cada personagem que aparece numa das histórias tem seu correspondente na outra. O leitor não sabe nunca qual das histórias é real e qual é apenas sonho. O romance traz, portanto, não uma intriga, mas duas intrigas que seguem paralelamente e que só se juntam no final, quando as duas personagens se encontram em 1964. No entanto, trata-se de intrigas pobres e, como veremos, não é a elas que se restringe o interesse do romance. Ainda assim, essas duas intrigas entrelaçadas compelem o leitor a circular todo o tempo num mundo duplo em que, por sua vez, personagens, lugares, assuntos, tudo também é duplo:

A presença obstinada dos contrários-complementares que avançam lado a lado em todos os níveis (mobilidade e imobilidade, sonho e realidade, passado e presente, história linear e história circular, etc.) e que acabam por se juntar e se fundir como Auge e Cidrolin, permitem reconhecer a vontade obstinada de Queneau de ultrapassar a dualidade do ser e do mundo 'que nos exila de nosso próprio lugar', definido como 'uma parábola espiritual', talvez seja, através de sua plurivocidade, fundamentada na ideia essencial do taoísmo na versão simplificada que passou no Ocidente, que tem em seu centro a ultrapassagem do dualismo e cuja figura bem conhecida do yin e do yang une, num mesmo círculo, ao mesmo tempo o branco e o negro. ${ }^{44}$

De início perguntamo-nos porque o título Les Fleurs bleues (As Flores Azuis). Em francês, ser "fleur bleue" (flor azul) significa ser excessivamente sentimental, ingênuo, algo como "água com açúcar" em português. No entanto, como diz Corinne François, esse

\footnotetext{
44 "La présence obstinée des contraires-complémentaires qui avancent côte à côte à tous les niveaux (mobilité et immobilité, rêve et réalité, passé et présent, histoire linéaire et histoire circulaire, etc.) et qui finissent par se rejoindre et se fondre, comme Auge et Cidrolin, permettent de reconnaître la volonté obstinée de Queneau de dépasser la dualité de l'être et du monde «qui nous exile de notre propre lieu », défini comme « une parabole spirituelle», est peut-être bien, à travers ses voies et ses voix plurielles, fondé sur l'idée essentielle du taoïsme dans la version simplifiée passée en Occident, qui a en son centre le dépassement du dualisme et dont la figure bien connue du yin et du yang unit, dans un même cercle, à la fois le blanc et le noir." (JATON,Anne Marie. Les Fleurs Bleues - Bilan Provisoire. In : Europe - revue littéraire mensuelle - avril 2003, pp. 56-57).
} 
"romance nega a sentimentalidade, reduzindo o amor à sexualidade" ${ }^{45}$. Esse sentido da expressão não justifica, portanto, o título do romance a não ser que o entendamos como um título por antinomia, ou seja, que mostre exatamente o oposto, frustrando as expectativas de quem lê o romance. Assim, como Zazie dans le métro conta as aventuras da menina que não consegue entrar no metrô, Les Fleurs bleues seria um romance em que não há nenhuma personagem "flor azul". Ao contrário, as personagens de Les Fleurs bleues não só não têm sentimento amoroso, como também não demonstram interesse por coisa alguma. Auge passa pela história sem tomar parte dela; Cidrolin, todo o tempo sem fazer absolutamente nada. De fato, agrada a Queneau a utilização de antinomias, como por exemplo, no próprio romance, no momento em que Cidrolin explica a sua namorada Aalice por que a chata em que vivem chama-se "Arca":

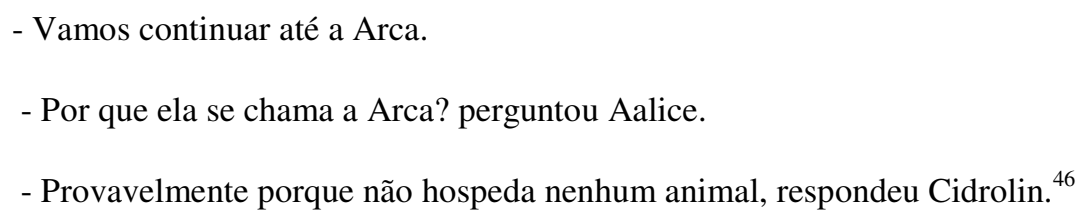

A expressão "flores azuis" é citada apenas duas vezes em todo o romance: no primeiro capítulo quando, depois de considerar a situação histórica, o duque resolve partir em viagem e diz a seu cavalo: “- Longe! Longe! Aqui nossas várzeas não têm flores. -... azuis, eu sei." 47 e no último, quando depois do dilúvio, o duque novamente considera a situação histórica e constata que "aqui e ali, já desabrochavam pequenas flores azuis" ${ }^{48}$. Esta é, aliás, a última frase do romance, que funciona como um recomeço, indicando uma história cíclica.

Há, no entanto, uma outra passagem em que aparece a palavra "flores", ainda que sem o adjetivo "azuis". E talvez seja essa ocorrência que explique melhor o título. Trata-se de uma cena do capítulo $\mathrm{V}$, em que o duque conversa com o seu chefe de cozinha e, quando este observa que ele está se repetindo, responde, retomando uma metáfora usual, que "a repetição

\footnotetext{
$45 \quad$ "notre roman déjoue la sentimentalité, ramenant l'amour à la sexualité." (FRANÇOIS, Corinne. Connaissance d'une cuvre : Les Fleurs bleues. Rosny: Bréal, 1999 p. 29)

$46 \quad$ “- On va continuer jusqu'à l'Arche.

- Pourquoi ça s'appelle l'Arche ? demanda Lalix.

- Sans doute parce qu'il n'y loge aucun animal, répondit Cidrolin.” (QUENEAU, Raymond. Les Fleurs bleues. Paris: Gallimard, 1965. p. 183).

47 Nossa tradução para “ - Loin! Loin! Ici la boue est faite de nos fleurs. - ... bleues, je le sais.” (QUENEAU, Raymond. Les Fleurs bleues. Paris: Gallimard, 1965, p. 15). Essa tradução, estranha aparentemante, será explicada mais adiante.

48 "ici et là, s'épanouissaient déjà de petites fleurs bleues." (QUENEAU, Raymond. Les Fleurs bleues. Paris: Gallimard, 1965. p. 276).
} 
é uma das mais odoríferas flores da retórica" ${ }^{49}$. Ora, a retórica é uma das preocupações de Queneau que em seu livro "Exercices de style" conta 99 vezes a mesma história, uma história curta e sem interesse, sendo que o importante é que em cada uma dessas 99 vezes, são apresentadas diferentes figuras de retórica. Não podemos deixar de citar o ensaio Les Fleurs de Tarbes, de Jean Paulhan, publicado em 1941, de quem certamente Queneau, secretáriogeral da editora Gallimard, era leitor, e que trata exatamente da linguagem e da literatura. Paulhan defende o uso da retórica, durante muito tempo tido como uma espécie de vício que provocava a perda da força da linguagem, submetida à beleza de palavras vazias. Assim como no Jardim Público de Tarbes era proibido entrar com flores, na literatura era proibido entrar com as flores da retórica. Ora, em Les Fleurs bleues, um romance em que o trabalho com a linguagem, os jogos de palavras, os elementos de língua falada estão presentes todo o tempo, é muito provável que as flores azuis sejam precisamente as flores da retórica. Se em nenhum momento vemos personagens sentimentais, flores azuis, podemos dizer que a retórica é tratada durante todo o romance, já que a linguagem é o seu principal objeto.

Les Fleurs bleues é um romance que oferece elementos para um aprofundamento da análise de muitos pontos de vista, (histórico, filosófico, social, psicológico), pois nele é questionada a História em contraponto com a atualidade, há mistura de sonho e realidade, existem dois personagens que são o duplo um do outro e que se veem em sonho como num espelho até seu encontro final. Apesar disso, como observa Jean-Yves Pouilloux, à primeira leitura parece que nenhum desses elementos tem importância:

O que impressiona é o humor, a piada. Como em Pantagruel, tem-se (pode-se ter) a
impressão de que a história (a narrativa) serve de pretexto, um tanto vago, para pôr
em cena uma série de "bons mots", nem sempre bons aliás, como constata o próprio
duque de Auge no início do texto.

Sendo um romance da maturidade de Queneau, o autor procura reunir nele elementos de várias áreas do conhecimento, na tentativa de compor um romance "total", embora, ainda segundo Pouilloux, à primeira leitura nem sempre isso seja observado:

À primeira leitura, Les Fleurs bleues se caracterizam pela aparência burlesca das personagens, dos acontecimentos e do tom. (...) Continuando, poder-se-á no entanto

$49 \quad$ "la répétition est l'une des plus odoriférantes fleurs de la rhétorique." (QUENEAU, Raymond. Les Fleurs bleues. Paris: Gallimard, 1965, p. 69).

$50 \quad$ "Ce qui frappe d'abord, c'est le canular. Comme dans Pantagruel, on a (on peut avoir) l'impression que l'histoire (la narrative) sert de prétexte, plutôt vague, à mettre en scène une suite de bons mots, pas toujours bons d'ailleurs, comme le constate lui-même le duc d'Auge au début du texte." (POUILLOUX, Jean-Yves, Les fleurs bleues de Raymond Queneau. Paris: Gallimard, 1991, p. 15). 
observar mais de um detalhe mostrando discreta ou explicitamente que a intenção cômica não é o único motor do texto. ${ }^{51}$

\subsection{ASSUNTOS SÉRIOS}

De fato, Queneau aborda neste romance todos os temas que lhe interessam e que podem intrigar o leitor. O romance trata de tantos assuntos e tão variados que, como disse um crítico do jornal Le Canard enchaîné, citado por Corinne François, "é preciso parar, sob pena de proliferação de células cinzentas. Pois o autor pôs nesse livro mais coisas do que poderemos encontrar. Mas corre-se o grande risco de encontrar justamente aquelas que ele não pôs" 52 .

Há referências à tecnologia, elemento sempre presente na obra de Queneau. Na viagem de Auge através dos séculos, citam-se armas inventadas na época como também os automóveis que ele vê em sonho. Se por um lado Auge atualiza-se na tecnologia segundo os séculos que atravessa, por outro lado é na atualidade de Cidrolin que encontramos as referências mais explícitas às tecnologias que modificavam a sociedade no século XX, como a televisão e o cinema. Isso é observado por Bourdette-Donon:

... Queneau experimenta, à sua maneira, o poder dominante das mídias, seu papel na formação das opiniões e das ideias. São essas ameaças de invasão tecnológica, vividas por Cidrolin que seu duplo Auge combate e perpetua o mundo da cultura face ao da comunicação, através de uma perpétua oscilação entre o real e seu simulacro. ${ }^{53}$

A filosofia também surge sob o verniz superficial do humor e da ligeireza. Apesar de os textos filosóficos de Queneau serem raros, encontramos em sua obra reflexões que demonstram sua formação filosófica, pois a filosofia surge tanto na ficção quanto na poesia do autor. Ela surge em forma de referência direta, de referência intertextual, ou por meio de personagens-filósofos que assumem discursos pseudo-filosóficos ou encarnam atitudes filosóficas:

\footnotetext{
51 “À première lecture, Les Fleurs bleues se caractérisent par l'allure burlesque des personnages, des événements et du ton. (...) Chemin faisant, on aura pourtant relevé plus d'un détail signalant soit discrètement soit explicitement que l'intention comique n'est pas le seul moteur du texte." (POUILLOUX, Jean-Yves, Les fleurs bleues de Raymond Queneau. Paris: Gallimard, 1991. p. 84).

$52 \quad$ "Il faut s'arrêter, sous peine de prolifération de cellules grises. Car l'auteur a mis dans ce livre plus de choses qu'on y trouvera jamais. Mais on risque fort d'y trouver celles, justement, qu'il n'a pas mises." (FRANÇOIS, Corinne. Connaissance d'une œuvre : Les Fleurs bleues. Rosny: Bréal, 1999, p. 122).

53 "... Queneau expérimente, à sa façon. le pouvoir dominant des médias, leur rôle dans la formation des opinions et des idées. Ce sont ces menaces d'invasion techologique, vécues par Cidrolin, que combat Auge, son double, qui perpétue le monde de la culture face à celui de la communication, à travers une perpétuelle oscillation entre le réel et son simulacre." (BOURDETTE-DONON, Marcel. Queneau et les nouveaux vecteurs d'information In : Europe - revue littéraire mensuelle - avril 2003. p. 137).
} 
Os problemas filosóficos abordados por Queneau são universais, em particular as questões de epistemologia (que posso saber?) e as de ética (que devo fazer?), sem esquecer as metafísicas (o que me é permitido esperar?): citemos o absurdo, a história, o conhecimento, a sabedoria, o tempo, a ciência, etc. ${ }^{54}$

Com humor, o romance questiona o sonho, a psicanálise, a História, e a linguagem. A História é retratada dentro de uma visão hegeliana: a realidade histórica é vivida pelos homens como uma sucessão temporal linear incoerente e trágica. Quando o duque diz que a história humana não passa de um trocadilho, quer dizer que as pessoas pensam compreendê-la, mas que sempre perdem o essencial.

Reflexões sobre sonho e realidade surgem já no primeiro capítulo, a oscilação entre duas narrativas paralelas, dentre as quais o leitor não consegue determinar qual é a da realidade e qual é a do sonho. O sonho é, pois, um dos grandes temas abordados em Les Fleurs bleues. Talvez o principal seja a História, mas o sonho também é fundamental e é anunciado como tal desde a página 7 , na sinopse escrita pelo próprio autor:

Conhecemos o célebre apólogo chinês: Tchouang-tseu sonha que é uma borboleta, mas não seria a borboleta que sonha que é Tchouang-tseu? Acontece o mesmo neste romance, é o duque de Auge que sonha que é Cidrolin ou Cidrolin que sonha que é o duque de Auge? ${ }^{55}$

e na página 11, há uma citação de Platão, em grego, colocada como exergo e que significa "sonho por sonho" ${ }^{56}$, confirmando a importância desse elemento.

O duque é o primeiro que adormece, na página 16 "o duque de Auge acaba por adormecer" e essa frase serve de transição entre o episódio Auge e o episódio Cidrolin. Ela opera como um sinal para o leitor que compreende rapidamente que o sono, noite ou sesta, é um elemento de estrutura da narrativa. Uma das funções do sonho é, pois, imprimir um ritmo à narração. A mudança de estado das personagens é constante ao longo do romance e cabe ao leitor ficar atento a cada uma delas:

\footnotetext{
54 "Les problèmes philosophiques abordés par Queneau sont universels, en particulier les questions d'épistémologie (que puis-je savoir ?) et les questions d'éthique (que dois-je faire ?), sans oublier les questions métaphysiques (que m'est-il permis d'espérer ?) : citons en vrac l'absurde, l'histoire, le savoir, la sagesse, le temps, la science, etc." (CHABANNE, Jean-Charles. Rire et philosophie dans l'œuvre de Raymond Queneau. p.3)

55 “On connaît le célèbre apologue chinois : Tchouang-tseu rêve qu'il est un papillon, mais n'est-ce point le papillon qui rêve qu'il est Tchouang-tseu ? De même dans ce roman, est-ce le duc d'Auge qui rêve qu'il est Cidrolin ou Cidrolin qui rêve qu'il est le duc d'Auge?" (QUENEAU, Raymond. Les fleurs bleues. Paris: Gallimard, 1965, p. 7).

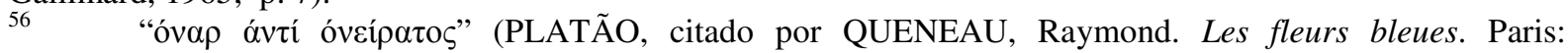
Gallimard, 1965, p. 11).
} 
Contam-se trinta e quatro passagens de um estado que parece desperto a um outro que parece sonhado; na metade dos casos, essa mudança é abrupta. Cidrolin adormece e Auge parte para a aventura, um pouco como quando se adormece sem se aperceber. (...) Instala-se assim um jogo de vai-e-vem que se acelera à medida que os dois protagonistas se aproximam um do outro até o seu encontro. ${ }^{57}$

A primeira dúvida do leitor, dúvida essa que não vai se esclarecer, é saber qual é a personagem que sonha e qual é a que faz parte do sonho. Como Cidrolin vive na época contemporânea, tem-se a impressão de que ele é mais verdadeiro do que o duque que viaja no tempo. Mas logo essa impressão de que Cidrolin é real e Auge fictício é colocada em cheque:

Mas, pouco a pouco, Auge adquire uma consistência e uma espessura que faltam evidentemente a Cidrolin. (...) E, paradoxalmente, a série 'narrativa fantástica' parece mais real que a série 'realidade atual', como se Queneau tivesse um prazer especial em nos fazer acreditar em acontecimentos inverossímeis (do tipo caçar mamute a tiros de canhão) e suspeitar da realidade daquilo que no entanto conhecemos muito bem. ${ }^{58}$

Isso ocorre porque Auge é a personagem da ação e Cidrolin é completamente inativo. É a inação que o caracteriza. Enquanto na vida de Auge há viagens, cruzada, revolta, complô, casamento, traição, duelo, pesquisa alquimista, pinturas rupestres, emigração, Cidrolin passa o tempo bebendo, dormindo e sonhando seu sonho contínuo com o duque.

Notamos, pois, que a "inação" de Cidrolin tem uma função narrativa importante, pois, se ele dormisse menos, o duque não poderia viver tantas aventuras, já que o sonho de Cidrolin é essencial para que elas possam ocorrer:

Cidrolin teve 'narrativamente' o papel de ser ao mesmo tempo aquele que, sonhando, permitiu a cavalgada fantástica de Auge através dos séculos e aquele que, desaparecendo, permite a Auge prosseguir seu destino, sem ele; é uma espécie de mediador que, terminada sua função, desaparece. ${ }^{59}$

57 "On compte trente-quatre passages d'un état qui semble éveillé à un autre qui semble rêvé ; dans la moitié des cas, cette mutation est abrupte. Cidrolin s'endort et Auge part à l'aventure, un peu à la façon dont on s'endort sans s'en apercevoir. (...) S'installe ainsi un jeu de va-et-vient qui s'accélère au fur et à mesure que les deux protagonistes se rapprochent l'un de l'autre jusqu'à leur face-à-face." (POUILLOUX, Jean-Yves, Les fleurs bleues de Raymond Queneau. Paris: Gallimard, 1991, pp. 126-128).

58 "Mais, peu à peu, Auge prend une consistence et une épaisseur dont manque très évidemment à Cidrolin (...) Et, paradoxalement, la série « récit fantastique » semble plus réelle que la série « réalité actuelle », comme si Queneau avait pris un malin plaisir à nous faire croire à des événements invraisemblables (jusqu'à chasser le mammouth à coups de canon) et suspecter d'irréalité ce que nous connaissons pourtant très bien." (POUILLOUX, Jean-Yves, Les fleurs bleues de Raymond Queneau. Paris: Gallimard, 1991, p. 75).

59 "Cidrolin a eu «narrativement » pour rôle d'être à la fois celui qui, en rêvant, a permis la chevauchée fantastique d'Auge à travers les siècles et celui qui, en disparraissant, permet à Auge de poursuivre sa route, sans lui ; il est une sorte de médiateur qui, son rôle une fois accompli, s'efface." (POUILLOUX, Jean-Yves, Les fleurs bleues de Raymond Queneau. Paris: Gallimard, 1991, p. 79). 
Essa função narrativa percebida poderia novamente fazer pensar que Cidrolin é a personagem real e que Auge é apenas o produto de seu sonho; para Cidrolin é importante sonhar e, como diz sua namorada Aalice, o sonho é seu melhor cinema:

... para Cidrolin a sesta não é apenas uma fraqueza ou passatempo, é uma verdadeira arte de viver: para ele o sonho é essencial à vida.(...) Mas Auge também é um sonhador e o objeto de seu sonho é Cidrolin. (...) Outros indícios fazem de Auge um sonhador, na medida em que o sonho lhe traz um saber. Graças ao sonho Cidrolin aprende a história, Auge, por sua vez, aprende as novas tecnologias. ${ }^{60}$

A dúvida sobre a realidade das personagens persiste ao longo de todo o romance e no final, em vez de ser resolvida, agrava-se ainda mais: “... é principalmente o momento do encontro final entre Auge e Cidrolin que arruína todas as hipóteses precedentes sobre o sonho" ${ }^{61}$, pois no final, como diz Magali Espinasse:

a presença de Auge convence todo o mundo de sua existência real, até mesmo o mais cartesiano, o guarda de camping (...) A partir desse momento é a ambiguidade que domina: não há mais fronteira possível entre sonho e realidade. (...) A ambiguidade chega a seu ápice quando nota-se que Auge e Cidrolin, uma vez juntos, não conseguem mais sonhar. ${ }^{62}$

Uma questão colocada várias vezes tanto por Cidrolin quanto por Auge é se se deve ou não contar os sonhos. Quando Cidrolin tenta contar os seus, Aalice é frontalmente contra. Felizmente para a narrativa, pois ao contrário não existiria o romance, como observa Pouilloux:

se por acaso Aalice aceitasse ouvir os sonhos de Cidrolin, surgiria de repente uma sequência linear ininterrupta contando as aventuras do duque de Auge através dos séculos, seria um outro romance e não Les Fleurs bleues, um romance histórico clássico, desprovido do que constitui sua tensão essencial. ${ }^{63}$

$60 \quad$ “... chez Cidrolin la sieste n'est pas seulement une faiblesse ou un passe-temps, c'est un véritable art de vivre : pour lui, le rêve est essentiel à la vie. (...) Mais Auge est aussi un rêveur et l'objet de son rêve est Cidrolin. (...) D'autres indices font d'Auge un rêveur, dans la mesure où le rêve lui apporte un savoir. Grâce au rêve, Cidrolin apprend l'histoire, Auge, lui, apprend les nouvelles technologies" (ESPINASSE, Magali. Étude sur Les Fleurs bleues. Paris: Ellipses, 1999 p. 46).

$61 \quad$ "c'est surtout le moment de la rencontre finale entre Auge et Cidrolin qui ruine toutes les hypothèses précédentes sur le rêve.” (ESPINASSE, Magali. Étude sur Les Fleurs bleues. Paris: Ellipses, 1999, p. 46).

62 "la présence d'Auge convainc tout le monde de son existence réelle, même le plus cartésien, le gardien de camping (...) À partir de ce moment-là c'est l'ambiguité qui domine : il n'y a plus de frontière possible entre rêve et réalité.(...) L'ambiguïté est à son comble quand on s'aperçoit qu'Auge et Cidrolin, une fois ensemble, ne parviennent plus à rêver." (ESPINASSE, Magali. Étude sur Les Fleurs bleues. Paris: Ellipses, 1999, p. 47).

"Si par hasard Lalix acceptait d'entendre les rêves de Cidrolin, on aurait tout à coup une suite linéaire ininterrompue racontant les aventures du duc d'Auge à travers les siècles, ce serait un autre roman que Les Fleurs bleues, un roman historique classique, dépourvu de ce qui constitue sa tension essentielle" (POUILLOUX, Jean-Yves. Les fleurs bleues de Raymond Queneau. Paris: Gallimard, 1991, p. 121). 
Uma discussão entre Cidrolin e Aalice, em que ele the explica o que é a psicanálise e a função do sonho, permite que se aborde a questão do ponto de vista dessa ciência:

A questão da narração de sonhos vai em seguida ser tratada diferentemente, graças ao concurso da psicanálise. (...) A psicanálise dá uma importância nova ao sonho, um valor até então desconhecido. Descobre-se, graças a ela, o laço existente entre sonho e realidade: o sonho pode mostrar a realidade de outra maneira, ou partes de verdades escondidas que o estado de vigília ignora. ${ }^{64}$

Desse ponto de vista psicanalítico, embora cada personagem tenha uma imagem real aos olhos do leitor, há uma possibilidade de leitura que as considera como uma só personagem. No final, quando o duque de Auge e Cidrolin se encontram em 1964, eles conhecem uma outra personagem, A Balança, que, ainda segundo a interpretação psicanalítica, é também uma outra manifestação da mesma personagem, de acordo com a crítica Anne Clancier, citada por Jaton:

... a crítica [Anne Clancier] propõe ler o trio Auge-Cidrolin-A Balança como a ilustração do id, do ego e do superego: Auge o belicoso encarnaria o id; Cidrolin, um ego cheio de sentimentos de culpa; e A Balança, um superego inflexível que libertará Cidrolin-ego somente quando, tendo completada a retomada de suas lembranças e nas manifestações de sua própria agressividade, o justiceiro será esmagado sob os escombros do edifício da neurose. ${ }^{65}$

Apesar de toda a discussão em torno do sonho, talvez o assunto principal abordado em Les Fleurs bleues seja o tempo e a história. Já a primeira frase do romance nos diz que o duque de Auge sobe ao torreão do seu castelo para considerar a situação histórica. Os pequenos acontecimentos também fazem parte da história e isso é discutido em vários pontos do romance, por personagens diferentes, como observa Corinne François:

A divisão entre Grande e Pequena História parece bastante justificada na medida em que Les Fleurs bleues é também uma reflexão sobre a História, ainda que se pudesse dizer que Auge se recusa precisamente a entrar na História (ele se recusa a fazer as

64 "La question du récit de rêves va par la suite être traitée différemment, grâce au concours de la psychanalyse. (...) La psychanalyse donne une importance nouvelle au rêve, une valeur jusque-là inconnue. On découvre, grâce à elle, le lien quiexiste entre rêve et réalite : le rêve peut dire la réalité autrement ou dire des parts de vérité cachées que l'état de veille ignore." (ESPINASSE, Magali. Étude sur Les Fleurs bleues. Paris: Ellipses, 1999, pp. 49-50).

65 “... la critique [Anne Clancier] propose de lire le trio Auge-Cidrolin-La Balance, l'illustration du ça, du moi et du surmoi : Auge le belliqueux incarnerait le ça, Cidrolin un moi plein de sentiments de culpabilité, et La Balance un surmoi inflexible qui libérera Cidrolin-moi seulement lorsque, la remontée de ses souvenirs et dans les manifestations de sa propre agressivité étant désormais accomplie, le justicier sera écrabouillé sous les décombres de l'édifice de la nevrose" (JATON, Anne Marie. Les Fleurs Bleues - Bilan Provisoire. In : Europe - revue littéraire mensuelle - avril 2003, p. 51). 
cruzadas ou a Revolução) e que as atualidades que constituem a vida quotidiana de Cidrolin talvez também façam parte da História. ${ }^{66}$

Depois de considerar a situação histórica, o duque diz que tudo não passa de alguns trocadilhos. O romance percorre sete séculos da história da França, através das viagens do duque de Auge, no sonho contínuo de Cidrolin. Elementos considerados importantes pela história oficial são colocados lado a lado com acontecimentos da vida quotidiana:

Les Fleurs bleues restituem a indistinção dos acontecimentos colocando no mesmo plano o humor do duque de Auge e as cruzadas, o processo de Gilles de Rais e o guisado de calhandras, a Revolução Francesa e os grafitis. E é exatamente assim, nessa espécie de equivalência imediata das horas que nós vivemos a atualidade. ${ }^{67}$

Misturando os acontecimentos históricos aos quotidianos, o passado ao presente, temos maneiras diferentes de marcar o tempo. O tempo de Auge é descontínuo, salta de 175 em 175 anos, enquanto o de Cidrolin está sempre na atualidade de 1964. As duas maneiras diferentes de representar o tempo, implicam uma maneira de representar a história: "Essa representação da história é complicada pelo fato de que se misturam duas concepções do tempo: uma dinâmica, a que concerne às aventuras do duque de Auge, outra estática, para a narrativa da vida de Cidrolin." 68

A própria definição de história está presente e é questionada em vários pontos do romance. O duque de Auge questiona o abade Biroton sobre a história universal em geral e a história geral em particular, questão reiterada em épocas distintas. Na época atual, numa discussão sobre a utilidade da televisão, os genros de Cidrolin estabelecem uma ligação entre história e atualidades. De fato, no romance, Queneau não diz claramente, em momento algum, qual a sua própria concepção da história. Ao contrário, deixando a discussão a cargo das personagens, apresenta várias possibilidades:

Cada personagem tem uma atitude pessoal face à história. Cidrolin tem uma atitude que poderíamos qualificar de romanesca. A partir do material histórico do qual

66 "La division entre Grande et Petite Histoire semble davantage fondée dans la mesure où Les Fleurs bleues est aussi une réflexion sur l'Histoire, encore que l'on pourrait dire qu'Auge refuse précisément d'entrer dans l'Histoire (il refuse de faire les croisades ou la Révolution) et que les actualités qui constituent la vie quotidienne de Cidrolin sont peut-être de l'Histoire." (FRANÇOIS, Corinne. Connaissance d'une auvre : Les Fleurs bleues. Rosny: Bréal, 1999, p. 32).

"Les Fleurs bleues restituent l'indistinction première des événements en mettant au même rang l'humour du duc d'Auge et les croisades, le procès de Gilles de Rais et le ragoût d'alouettes, la Révolution française et les graffitis. Et c'est bien ainsi, dans cette sorte d'équivalence immédiate des heures, que nous vivons l'actualité." (POUILLOUX, Jean-Yves. Les fleurs bleues de Raymond Queneau. Paris: Gallimard, 1991, p. 141).

68 "Cette représentation de l'histoire est compliquée par le fait que l'on mélange deux conceptions du temps : l'une dynamique, celle qui concerne les aventures du duc d'Auge, l'autre statique, pour le récit de la vie de Cidrolin.” (ESPINASSE, Magali. Étude sur Les Fleurs bleues. Paris: Ellipses, 1999, p. 79). 
dispõe, de seus conhecimentos, ele se conta uma história escolhendo um herói que ele faz viver em diferentes épocas. Ele confunde a ciência histórica e a história no sentido literal do termo, o romance. (...) Auge mostra que a história é ameaçada pelo esquecimento, no lugar de manter na memória os acontecimentos do passado e de narrá-los, ele observa que temos a tendência de esquecê-los. (...) A história, para Auge, é ainda mais perturbadora pelo jogo das profecias. (...) Tudo se passa, para ele, como se a história não existisse, o tempo passa, simplesmente, sem que possamos reter nada dele e principalmente sem que possamos de uma maneira qualquer classificar os fatos. ${ }^{69}$

Encontramos, pois, em Les Fleurs bleues não uma tese específica sobre a história, mas uma série de teses, às vezes conflitantes. Isso se dá porque fatos históricos conhecidos são colocados lado a lado com fatos corriqueiros que são apresentados como se tivessem a mesma importância. Na realidade, no momento em que são vividos os acontecimentos, não se sabe nunca qual será a sua importância do ponto de vista histórico: "Nós vivemos no desconhecimento da história e é a sequência das épocas, o encadeamento das causas e consequências, que vão fazer surgir o que será salvo do esquecimento". 70

O que fica evidente é que para Queneau só há história se houver infelicidade. De fato, é o próprio Queneau que nos dá a definição, pois "Segundo ele [Queneau] 'a história é a ciência da infelicidade dos homens' e nisso ela está, é claro, ligada ao romance que conta as infelicidades de certos homens" ${ }^{71}$. Isso fica claro no final do romance, quando, felizes, Cidrolin e Aalice saem do romance: "Eles [Cidrolin e Aalice] se amam, são aparentemente felizes e, como os povos felizes não têm história, eles não têm mais nada a fazer na narrativa." 72

69 "Chaque personnage a une attitude personnelle face à l'histoire. Cidrolin a une attitude que l'on pourrait qualifier de romanesque. À partir du matériel historique dont il dispose, de ses connaissances, il se raconte une histoire en choisissant un héros qu'il fait vivre à différentes époques. Il confond la science historique et l'histoire au sens littéraire du terme, le roman. (...) Auge montre que l'histoire est menacée par l'oubli, au lieu de garder en mémoire les événements du passé et d'en faire le récit, il remarque qu'on a tendance à les oublier. (...) L'histoire, chez Auge, est encore plus perturbante par le jeu des prophéties. (...) Tour se passe, chez lui, comme si l'histoire n'existait pas, le temps s'écoule, en aveugle, sans qu'on puisse rien en retenir et surtout sans qu'on puisse d'une manière quelconque classer les faits." (ESPINASSE, Magali. Étude sur Les Fleurs bleues. Paris: Ellipses, 1999, pp. 82-83).

70 "Nous vivons dans la méconnaissance de l'histoire et c'est la suite des temps, l'enchaînement des causes et conséquences, qui va faire apparaitre ce qui sera sauvé de l'oubli." (POUILLOUX, Jean-Yves. Op. cit. p. 142).

${ }_{71}$ "Selon lui [Queneau] 'l'histoire est la science du malheur des hommes.' et en ça elle est bien sûr liée au roman qui raconte les malheurs de certains hommes." (ESPINASSE, Magali. Étude sur Les Fleurs bleues. Paris: Ellipses, 1999, p. 89).

72 "Ils s'aiment, sont apparemment heureux et, comme les peuples heureux n'ont pas d'histoire, ils n'ont plus rien à faire dans la narration." (POUILLOUX, Jean-Yves. Les fleurs bleues de Raymond Queneau. Paris: Gallimard, 1991, p. 80). 
Para Queneau, essa história de infelicidades é feita de ciclos, com repetições de fatos e de situações. Isso é claramente notado em Les Fleurs bleues, em que há um vaivém contínuo entre as histórias de Auge e de Cidrolin, entre a situação contemporânea e os tempos mais distantes. São os ciclos históricos que permitem a identificação dos fatos e de sua importância histórica, pois, como observa Pouiloux:

Realmente, basta um sentimento de repetição para que acontecimentos
aparentemente equivalentes se distingam uns dos outros, e que sejamos tentados a
olhá-los não como eles são no presente, mas ligando-os àqueles a que eles se
parecem no passado. A partir do reconhecimento de uma similaridade (isto é como
aquilo), é possível uma saída do presente. ${ }^{73}$

Em Les Fleurs bleues vemos entre os ciclos mais similaridades que mudanças reais: "Tudo muda, pois, mas nada muda: a Idade Média pretensamente obscurantista tinha a Alquimia, o século XX pretensamente científico tem outros meios de se tentar produzir o ouro: as corridas de cavalo!". ${ }^{74}$

Outro questionamento presente em Les Fleurs bleues refere-se à veracidade da história ou do que é reconhecido como tal. Quando uma das filhas de Cidrolin fala de sua visita a grutas do Périgord em que havia desenhos pré-históricos, Cidrolin afirma que são todos falsos, que foram pintados por alguém no século XVIII, no caso, o duque de Auge, como ele tinha visto em sonho. Afinal, como se interroga François:

\begin{abstract}
A História, retrospectivamente, não é necessariamente mentirosa? Auge participa da sétima cruzada e volta com todo tipo de doenças, mas nem por isso deixa de se tornar uma lenda: 'Durante a sétima cruzada o cavalo do duque de Auge assustava os sarracenos'. As interpretações históricas mudam: 'Os especialistas pretendem agora que...'. Quem garante que a ciência histórica não é ficção? ${ }^{75}$
\end{abstract}

Todos os assuntos são tratados com a linguagem característica de Queneau, fiel a seu projeto de inclusão da língua falada na literatura. O escritor toca em assuntos que estão

\footnotetext{
73 "Il suffit en effet d'um sentiment de répétition pour que des événements au premier abord équivalents se distinguent les uns des autres, et qu'on soit tenté de les regarder non pas tels qu'ils sont dans un pur présent, mais en les reliant à ceux auxquels ils ressemblent dans le passé. À partir de la reconnaissance d'une similitude (ceci est comme cela), une sortie du présent est possible." (POUILLOUX, Jean-Yves. Les fleurs bleues de Raymond Queneau. Paris: Gallimard, 1991, pp. 142-143).

74 "Tout change, donc, mais rien ne change: le Moyen Âge prétendument obscurantiste avait l'alchimie, le $\mathrm{XX}^{\mathrm{e}}$ siècle prétendument scientiste a d'autres moyens de chercher à faire de l'or : le tiercé !" (FRANÇOIS, Corinne. Connaissance d'une ouvre : Les Fleurs bleues. Rosny: Bréal, 1999, p. 88).

75 'L'Histoire n'est-elle pas rétrospectivement forcément mensongère ? Auge fait la septième croisade et en revient avec toutes sortes de maladies, mais il n'en devient pas moins une légende : "Durant la septième croisade le cheval du duc d'Auge effrayait les Sarrasins ». Les interprétations historiques changent: "Les spécialistes prétendent maintenant que... ». Qui garantit que la science historique n'est pas de la fiction ?" (FRANÇOIS, Corinne. Connaissance d'une auvre : Les Fleurs bleues. Rosny: Bréal, 1999, pp. 90-91).
} 
em evidência no momento em que escreve: “... certos jogos verbais remetem diretamente a querelas da atualidade sobre a pureza da língua francesa e notadamente sua contaminação pelo inglês". ${ }^{76}$ Queneau utiliza nesse seu trabalho de modernização da língua, todos os elementos disponíveis: lexicais, sintáticos e ortográficos.

Em Les Fleurs bleues, notamos que a sintaxe utilizada, sobretudo nos diálogos que se passam na atualidade, é a sintaxe da língua falada, em que os elementos ausentes são supridos por gestos, expressão facial ou tonalidade dos falantes. Como é escrito com muito mais diálogos do que narração, Les Fleurs bleues é um romance em que Queneau procura criar uma escrita mais próxima possível da língua falada. A maioria desses diálogos tem

\begin{abstract}
uma sintaxe não habitual na língua escrita e uma leveza mais próxima da conversação real - em que as frases quase nunca são terminadas, em que frequentemente faltam os verbos, em que o essencial não é dito, expresso, mas subentendido, sugerido pelo encontro das duas ou três pessoas que falam. Acontece até de os interlocutores seguirem cada um sua fala em duas séries paralelas sem escutarem um ao outro ${ }^{77}$.
\end{abstract}

No que se refere ao vocabulário, encontramos sobretudo neologismos e arcaísmos que, assim como os desvios sintáticos resultam num francês que pode ser ouvido no dia-a-dia. O efeito de estranhamento é obtido não porque ele cria uma língua nova, mas porque o leitor não está habituado a encontrar escrita essa língua que ele usa quotidianamente: "Queneau nos surpreende talvez, mas, na realidade, ele inventa pouco. Ele escreve como nós falamos, uma língua que nós mal reconhecemos, e que, no entanto, é a nossa." 78

Quanto à ortografia, notamos em Les Fleurs bleues vários exemplos do que o escritor chamava "ortograf fonétik", recurso que já havia utilizado com mais frequência em Zazie no Metrô e que utiliza aqui de maneira mais parcimoniosa: "Les Fleurs bleues estão

\footnotetext{
76 "certains jeux verbaux renvoient directement à des querelles d'actualité sur la pureté de la langue française et notamment sa contamination par l'anglais." (POUILLOUX, Jean-Yves. Les fleurs bleues de Raymond Queneau. Paris: Gallimard, 1991, p. 30).

77 "une syntaxe inhabituelle dans la langue écrite et une légèreté si proche de la conversation réelle - où les phrases ne se terminent presque jamais, où les verbes manquent souvent, où l'essentiel n'est pas dit, exprimé, mais sous-entendu, suggéré par la rencontre des deux ou trois personnes qui parlent. Il arrive même que les interlocuteurs suivent chacun son fil dans deux suites parallèles sans s'écouter" (POUILLOUX, Jean-Yves. Les fleurs bleues de Raymond Queneau. Paris: Gallimard, 1991, p. 35).

"Queneau nous surprend peut-être, mais, en l'occurrence, il invente à peine. Il écrit comme nous parlons, une langue que nous reconnaissons tout juste, et pourtant c'est la nôtre.” POUILLOUX, Jean-Yves. Les fleurs bleues de Raymond Queneau. Paris: Gallimard, 1991, p. 31).
} 
recheadas de 'disgrafias' ridículas e não sistemáticas, ao contrário, surpreendentes. Elas intervêm não para reformar a língua francesa, mas, é evidente, para fazer sorrir ou rir." 79

As várias épocas atravessadas pelo duque servem também de pretexto para manifestações da língua francesa em sua evolução diacrônica. O duque sonha com Cidrolin e com coisas que não existem na época em que vive, e quando conta seus sonhos a seu capelão utiliza palavras de uso corrente no francês atual, como "voiture", "mouchoir" e "péniche", mas que são percebidas por seu interlocutor como neologismos.

Que espera Queneau com essa maneira de escrever? Demonstrar que existem duas línguas diferentes, a escrita e a falada, e que esta é mais importante que aquela.

Considerando que um romance é uma espécie de poema de forma fixa, Queneau utiliza em sua linguagem elementos retóricos característicos da poesia. Se o fato de ter caráter narrativo e ligação com a história define Les Fleurs bleues como romance, o que nos permite dizer que se trata também de um poema? Espinasse sugere uma resposta:

A estrutura geral de um poema, principalmente se for de forma fixa como o soneto, é dada por um quadro rígido. Aqui esse quadro é construído segundo uma estrutura binária constituída por uma narrativa dupla. (...) Essa macroestrutura do romance evoca a das estrofes de um poema e ela é completada por uma estrutura secundária, igualmente rigorosa, como a dos versos. No interior de cada narrativa, encontram-se elementos regulares, sejam eles temas desenvolvidos ou frases chaves. ${ }^{80}$

Esses elementos de poema encontrados na estrutura do romance dão a ele um ritmo próprio que é logo percebido pelo leitor:

A partir dessas noções de estrutura, chega-se a imprimir um ritmo à obra, romance ou poema, e desse ritmo se extrai uma certa musicalidade. (...) A originalidade de Queneau é de manter essa preocupação para o romance. Ele dá uma importância particular aos volumes de escrita. (...) A variação desses volumes imprime um ritmo

$79 \quad$ "Les Fleurs bleues sont truffées de "dysorthographies" cocasses et non systématiques, au contraire surprenantes. Elles interviennent non pour réformer la langue française, mais, de toute évidence, pour faire sourire ou rire." (POUILLOUX, Jean-Yves. Les fleurs bleues de Raymond Queneau. Paris: Gallimard, 1991, pp. 43-44).

80 "La struture générale d'un poème, surtout s'il est de forme fixe comme le sonnet, est donnée par un cadre rigide. Ici ce cadre est bâti selon une structure binaire constituée par un double récit. (...) Cette macrostructure du roman évoque celle des strophes d'un poème et elle est complétée par une structure secondaire, tout aussi rigoureuse, comme celle des vers. À l'intérieur de chaque récit, on retrouve des éléments réguliers, qu'il s'agisse de thèmes développés ou de phrases clés." (ESPINASSE, Magali. Étude sur Les Fleurs bleues. Paris: Ellipses, 1999, pp. 90-91). 
ao conjunto: ritmo lento quando as narrativas são longas e as alternância raras no capítulo, mais rápido quando as narrativas são mais numerosas. ${ }^{81}$

Um dos primeiros elementos que nos vêm à mente quando pensamos em poesia é a rima, isto é, a repetição de sons nos finais dos versos, para Queneau, as repetições de situações, de falas, o espelhamento das personagens funcionam como rimas no romance:

Queneau adapta o princípio da rima ao romance: 'Podemos fazer rimar situações ou personagens como fazemos rimar palavras, podemos até nos contentarmos com aliterações' (...) Esse jogo de repetições, rimas ou aliterações, pode também se aplicar às estruturas sintáticas, ao vocabulário e produzir um tipo de refrão. (...) Em Les Fleurs bleues, a essência de funcho tem também esse papel. ${ }^{82}$

Em Les Fleurs bleues, a repetição é notada logo no início, pois a dupla narrativa mostra dois mundos paralelos em que vivem personagens paralelas, mas encontramos também repetição até mesmo nos episódios, nas situações narradas.

Henry Godard nos mostra que a rima ou repetição não é característica unicamente de Queneau nem de Les Fleurs bleues, mas que pode ser encontrada em qualquer romance:

Uma situação, um cenário, o gesto de uma personagem, uma cena, representada uma primeira vez num romance, podem ser encontradas na sequência com mais ou menos variação. Todo romance tradicional de algum valor contém esses ecos ou essas simetrias (...) Para que tais efeitos sejam considerados uma vontade consciente do romancista, basta que eles ultrapassem um certo limite, em número de ocorrências e em identidade de uma a outra. Então elas tendem a fazer figura de repetição (...) Ora, a repetição, mesmo de uma única palavra, é banida pelas convenções do bom estilo. Queneau, com seu modo provocante, chega a repetir frases inteiras, às vezes em contexto próximo, às vezes em dois lugares espaçados do texto. A partir daí, o leitor não tem mais hesitação. A não ser que considere que há por parte do romancista negligência ou extrema imperícia, o que todo o resto do texto desmente, ele é forçado a considerar que a repetição, textual de início e depois temática, é uma decisão consciente. Queneau acabará por explicitar essa decisão no

81 “À partir de ces notions de structure, on en arrive à imprimer un rythme à l'œuvre, roman ou poème, et de ce rythme doit se dégager une certaine musicalité. (...) L'originalité de Queneau est de garder ce souci pour le roman. Il donne une importance particulière aux volumes d'écriture. (...) La variation de ces volumes imprime un rythme à l'ensemble : rythme lent quand les récits sont longs et les alternances rares dans le chapitre, plus rapide quand les récits sont plus nombreux." (ESPINASSE, Magali. Étude sur Les Fleurs bleues. Paris: Ellipses, 1999, pp. 91-92).

82 "Queneau adapte le principe de la rime au roman: 'On peut faire rimer des situations ou des personnages comme on fait rimer des mots, on peut même se contenter d'allitérations' (...) Ce jeu de répétitions, rimes ou allitérations, peut aussi s'appliquer aux structures syntaxiques, au vocabulaire et produire des sortes de refrains. (...) Dans Les Fleurs bleues, l'essence de fenouil joue aussi ce rôle.” (ESPINASSE, Magali. Étude sur Les Fleurs bleues. Paris: Ellipses, 1999, p. 31). 
seu penúltimo romance, Les Fleurs bleues, qualificando a repetição de 'a mais bela flor da retórica' ${ }^{83}$

\section{$2.3 O H U M O R$}

O humor está presente desde a primeira página. Trata-se de um humor demasiadamente fácil, feito de trocadilhos de almanaque. Nas palavras de Pouilloux, “... esses lamentáveis trocadilhos têm mais provavelmente um papel de advertência: que ninguém entre aqui se não estiver pronto a brincar sobre as palavras ou com elas". ${ }^{84}$ De fato é justamente esse humor que leva o leitor a perceber que o romance tem algo mais do que o que está na superfície, que algo mais deve ser procurado:

A tonalidade humorística do romance é incontestável, o leitor é levado para uma espécie de jogo que o autor propõe. Ele não pode se contentar em deixar-se guiar pela intriga; ela é muito pobre, aliás, e principalmente é construída como um enigma que exige do leitor uma participação constante. ${ }^{85}$

A crise do romance, como vimos, ocorreu por um esgotamento do gênero que já não conseguia dar conta da sociedade que pretendia retratar, mas foi também consequência de uma crise da própria linguagem, da filosofia positivista do fim do século XIX e do discurso político nacionalista que, sobretudo depois da Primeira Grande Guerra, perderam credibilidade.

Nesse contexto, o empreendimento de Queneau é o de romper toda a evidência da linguagem, e é no humor que esse empreendimento se manifesta de maneira mais evidente, por isso o escritor não perde a oportunidade de fazê-lo. Queneau cria acasos, recortando palavras de modo diferente, gerando um eco sonoro que interfere na sua apreensão.

83 "Une situation, un décor, le geste d'un personnage, une scène, figurés une première fois dans un roman, peuvent s'y retrouver dans la suite avec plus au moins de variation. Tout roman traditionnel de quelque valeur contient de ces échos ou de ces symétries. (...) Pour que de tels effets soient mis au compte d'une volonté consciente du romancier, il suffit qu'ils dépassent un certain seuil, en nombre d'occurrences et en identité de l'une à l'autre. Ils tendent alors à faire figure de répétition (...). Or la répetition, même d'un seul mot, est bannie par les conventions du beau style. Queneau, à sa manière provocante, va jusqu'à répéter des phrases entières, parfois dans le constexte proche, parfois à deux endroits espacés du texte. Dès lors, le lecteur n'a plus guère d'hésitation. Sauf à considérer qu'il y a de la part du romancier négligence ou extrême maladresse, ce que tout le reste du texte dément, il lui faut bien reconnaître que la répétition, textuelle d'abord et à partir de là thématique, est un parti pris. Queneau finira par expliciter celui-ci dans son avant-dernier roman, Les Fleurs bleues, en qualifiant la répétition de «plus belle fleur de la rhétorique »" (GODARD, Henry. Queneau et les problèmes de la construction du roman. In : Europe - revue littéraire mensuelle - avril 2003. pp. 29-30).

$84 \quad$ “... ces lamentables calembours jouent plus probablement un rôle d'avertissement : que nul n'entre ici s'il n'est pas prêt à jouer sur les mots ou avec eux." (POUILLOUX, Jean-Yves. Les fleurs bleues de Raymond Queneau. Paris: Gallimard, 1991, p. 18).

"La tonalité humoristique du roman est incontestable, le lecteur est entraîné dans une sorte de jeu que lui propose l'auteur. Il ne peut pas se contenter de se laisser guider par l'intrigue ; celle-ci est assez mince d'ailleurs et surtout elle est bâtie comme une énigme qui exige du lecteur une participation constante." (ESPINASSE, Magali. Étude sur Les Fleurs bleues. Paris: Ellipses, 1999. p. 37). 
O humor de Queneau não é gratuito. Embora seja um humor fácil, ele tem uma função. Chabannes observa, quanto às várias interpretações desse humor, que os leitores oscilam "completamente de uma posição que supervaloriza a ausência de sentido, o não-sério radical (divertido ou tedioso), a uma posição que dá a esse nonsense uma carga metafísica terrivelmente grave" ${ }^{86}$. O próprio Queneau, numa entrevista concedida a Pierre Berger e citada por Chabanne, respondendo a uma questão que pretendia fazê-lo admitir que seu humor era depreciativo e que ele ridicularizava suas personagens, rebate:

- É flagrante que seu humor está muito próximo do desprezo. O senhor não gosta de seus heróis. É verdade que o senhor os escolhe de preferência entre os grotescos [...] R.Q.: - Aí eu não concordo com o senhor. Eu não acho que meu humor esteja próximo do desprezo e eu gosto das minhas personagens. [...] Eu asseguro, o desprezo está bem longe de mim. [...] Eu as descrevo tal como eu as vejo. Parece-me que elas representam muito fielmente a humanidade. Incluindo eu. É o senhor que menospreza o mundo. E eu ao contrário que o aprecio. ${ }^{87}$

De fato, a primeira página do romance é uma amostra da maneira como o humor é trabalhado por Queneau. Ele não o faz acrescentando uma piada ou uma tirada aqui ou ali, mas agrupando, superpondo, acumulando diferentes formas de humor, de modo que, ao leitor, tudo parece ser apenas uma grande piada. Vejamos essa primeira página:

«Le vingt-cinq septembre douze cent soixante-quatre, au petit jour, le duc d'Auge se pointa sur le sommet du donjon de son château pour y considérer, un tantinet soit peu, la situation historique. Elle était plutôt floue. Des restes du passé traînaient encore çà et là, en vrac. Sur les bords du ru voisin, campaient deux Huns; non loin d'eux un Gaulois, Eduen peut-être, trempait audacieusement ses pieds dans l'eau courante et fraîche. Sur l'horizon se dessinaient les silhouettes molles de Romains fatigués, de Sarrasins de Corinthe, de Francs anciens, d'Alains seuls. Quelques Normands buvaient du calva.

Le duc d'Auge soupira mais n'en continua pas moins d'examiner attentivement ces phénomènes usés.

\footnotetext{
$86 \quad$ “... complètement d'une position qui surenchérit sur l'absence de sens, le non-sérieux radical (plaisant ou ennuyeux), à une position qui donne à ce non-sens une charge métaphysique terriblement grave." (CHABANNE, J-C. En lisant les lecteurs de Queneau. p. 8)

87 “- Il est flagrant que votre humour côtoie beaucoup la mépris. Vous n'aimez pas vos héros. Il est vrai que vous les choisissez de préférence parmi les grotesques. [...] R. Q.: - Là je ne suis pas d'accord avec vous. Je ne trouve pas que mon humour côtoie lê mépris et j'aime bien mes personnages. [...] Je vous assure, le mépris c'est très loin de moi. [...] Je les décris tels que je les vois. Il me semble qu'ils représentent très fidèlement l'humanité. Moi compris. C'est vous qui dépréciez lê monde. Et moi au contraire qui l'estime". (Entretien avec Raymond Queneau, humorista automatique. In: La Gazette des lettres, no 19, 15 avril 1952, 1964, p. 19, alud CHABANNE, J-C. En lisant les lecteurs de Queneau. P. 11-12)
} 
Les Huns préparaient des stèques tartares, le Gaulois fumait une gitane, les Romains dessinaient des grecques, les Sarrasins fauchaient de l'avoine, les Francs cherchaient des sols et les Alains regardaient cinq Ossètes. Les Normands buvaient du calva.

- Tant d'histoire, dit le duc d'Auge au duc d'Auge, tant d'histoire pour quelques calembours, pour quelques anachronismes. Je trouve cela misérable. On n'en sortira donc jamais ? ${ }^{88}$

De início, o efeito de humor surge da mistura de nível de língua. O romance começa num tom sério, com uma data em que o dia e o ano são escritos por extenso, cartorialmente, conforme o uso oficial. Em vez de "mille deux cent" o autor usa "douze cent", provocando um efeito arcaizante que é reafirmado pela expressão "un tantinet soit peu". Nesse contexto, é apresentado um duque que observa a "situação histórica" com afastamento e objetividade, como se não fizesse parte dela. Essa linguagem pomposa é, no entanto, entremeada por expressões de gíria como o verbo "se pointer" e a constatação do duque sobre a situação histórica "plutôt floue", onde restos do passado espalham-se "çà et là, en vrac".

Em seguida, ao descrever quais são esses "restos do passado", depois de uma descrição da paisagem em que se utiliza mais uma vez de uma palavra arcaizante, " $r u$ " e de uma expressão clichê "l'eau courante et fraîche", Queneau acumula uma série de trocadilhos com os nomes de povos do passado, construídos das mais diversas maneiras: com os hunos, trocadilho construído pela homofonia entre "Hun" et "un" e entre "deux" e "d'eux"; com os sarracenos, o trocadilho resulta da homofonia entre parte da palavra "Sarrasins" e a palavra "raisins" que Queneau obriga o leitor a perceber quando acrescenta a expressão "de Corinthe"; com os francos, trocadilho baseado na polissemia da palavra franco (o povo, e a moeda francesa da época); com os Alanos um trocadilho que foi construído a partir de uma homofonia entre parte do substantivo "Alains" e o adjetivo seguinte "Alains seuls" com a palavra "linceul", leitura forçada pela posição acentuada em fim de frase, pela perturbação

88 "Aos vinte e cinco de setembro de mil duzentos e sessenta e quatro, de manhãzinha, o duque de Auge plantou-se no alto do torreão de seu castelo para considerar, um tantinho que fosse, a situação histórica. Ela estava meio embaçada. Restos do passado se espalhavam ainda cá e acolá, ao léu. Às margens do riozinho vizinho, acampavam dois hunos; não longe dos dois um gaulês, eduano talvez, molhava os pés audaciosamente na água corrente e fresca. No horizonte desenhavam-se as silhuetas moles de romanos cansados, de sarracenos de Mans, de francos antigos, de ossetas velozes. Alguns normandos bebiam calvados. repetitivos.

O duque de Auge suspirou mas nem por isso deixou de examinar atentamente esses fenômenos

Os hunos preparavam bifes tártaros, o gaulês cantava de galo, os romanos desenhavam gregas, os sarracenos ceifavam cevada, os francos procuravam vinténs e os ossetas olhavam dois alanos. Os normandos bebiam calvados.

- Tanta história, disse o duque de Auge para o duque de Auge, tanta história para alguns trocadilhos, para alguns anacronismos. Acho isso miserável. Será que nunca vamos sair disso?” 
semântica e pela sequência de trocadilhos que faz com que o leitor espere por mais um. Se com "Romain" não há trocadilho, há alusão à expressão francesa "travail de Romain", que designa um trabalho muito pesado, pois os romanos estão cansados; e os normandos que bebem "calva", redução familiar da palavra "calvados", bebida típica da Normandia, original da cidade de mesmo nome.

Essa acumulação de trocadilhos óbvios e fáceis seria já suficiente, mas o duque, apesar de suspirar, continua a observar os "restos do passado". E dessa observação surge nova série de trocadilhos com os mesmos nomes de povos: os "gaulois" fumam "gitanes", construído sobre a polissemia, pois ambos os nomes, além de designar povos, são conhecidas marcas de cigarro francesas; os romanos desenham gregas, trocadilho construído sobre a polissemia da palavra "grega" que designa os típicos frisos ornamentais gregos; os sarracenos ceifam aveia, ainda a polissemia, agora da palavra sarraceno que designa, além do povo, uma espécie de trigo; os francos procuram "sols", baseado na polifonia das duas palavras, "franc" que como já dissemos designa tanto o povo quanto a moeda, e "sol" que pode ser "terra", mas é também uma antiga moeda, subdivisão do franco. Os hunos preparam bifes tártaros, prato que, segundo a anedota criada por Jules Verne no romance Michel Strogoff, teria sido criado por Átila, rei dos hunos. Quanto aos alanos, na falta de um trocadilho envolvendo esse nome, o duque os vê olhando cinco ossetas, que, em francês "cinq Ossètes" lembra, por paronímia, a expressão “cinq-à-sept”, que designa um lanche tomado à tarde, na hora do chá.

Terminada sua observação da História, o duque observa, usando de metalinguagem, que tanta História resultou apenas em alguns trocadilhos e alguns anacronismos. E diz que acha isso miserável. O leitor pode se perguntar se ele estaria se referindo à História ou aos próprios trocadilhos que são realmente muito pobres.

\subsection{UM ROMANCE OULIPIANO}

Em Les Fleurs bleues, mais do que o que é contado, o importante é como é contado, característica da literatura que nessa obra atinge o paroxismo. A linguagem é explorada em jogos semânticos, fonéticos e estruturais - tudo tem um significado.

Segundo Jacques Bens, Queneau construiu seus romances com um rigor laborioso e obstinado, sem deixar nada ao acaso. Há uma aparente contradição entre tal rigor e o incerto da potencialidade. Mas o escritor nunca disse que detesta a incerteza, mas a incerteza nascida do acaso. Ele admite soluções múltiplas, desde que ele mesmo tenha desencadeado o mecanismo, que ele os proponha, que ele os conduza. No entanto, Queneau não explica nada 
sobre esse mecanismo. Cabe ao leitor descobrir as diversas camadas possíveis de leitura, pois “... Queneau lembra que gosta dos enigmas: 'Por que não pedirmos um certo esforço ao leitor? Sempre se explica tudo ao leitor, ele acaba por ficar envergonhado de se ver tratado de forma tão menosprezada", 89 .

Diante de um romance oulipiano, o leitor não tem o direito de ser ingênuo ou passivo, mas tem que estar sempre atento para descobrir o que há sob a superfície do texto. As regras que o autor se impõe frequentemente não são reveladas explicitamente; é o leitor que tem que descobri-las e encontrar um sentido para elas. Por isso, numa primeira leitura, tem-se a impressão de um jogo. A intriga é cortada em vários episódios díspares e cabe ao leitor reconstituí-la como num quebra-cabeça. O leitor é levado a tentar reconstituir a unidade que julga existir no romance e só então percebe que há várias camadas a serem descobertas e que a intriga é apenas uma delas. Aliás, as intrigas e as aventuras das personagens são fracas, e, como diz Espinasse, "o essencial não é, pois, a intriga, mas os elementos de estrutura que ela gera, os temas que surgem nas curtas conversas entre as personagens e sobre os quais o leitor poderá se interrogar. A intriga não é um objetivo, mas apenas um ponto de partida" ${ }^{90}$.

Sendo um romance oulipiano, Les Fleurs bleues está regido por uma série de restrições (contraintes) que regulam sua estrutura formal: são 21 capítulos, número que, segundo Queneau, é significativo, pois $21=3 \times 7$, como a quantidade de letras de seus três nomes, Raymond Auguste Queneau. Nesses 21 capítulos são retratados 5 períodos históricos, o que causa um problema matemático quanto aos intervalos. Isso se resolve com a passagem de uma época a outra no interior dos capítulos: 1264 - capítulos I a V, 1439 - capítulos V a IX, 1614 - capítulos IX a XIII, 1789 - capítulos XIII a XVII e 1964 - capítulos XVII a XXI. A aparição do duque ao longo da História a cada 175 anos, também um múltiplo de 7; sua viagem que percorre 7 séculos.

Nos romances de Queneau, mesmo que tenham sido escritos antes da criação do Oulipo, não há liberdade de forma, pelo contrário, há regras rígidas a serem seguidas. Se no romance realista o romancista se apagava, no romance escrito sob regras, ele aparece

$89 \quad$ “... Queneau rappelle qu'il aime les énigmes : 'Pourquoi ne demanderait-on pas un certain effort au lecteur? On lui explique toujours tout, au lecteur, il finit par être vexé de ser voir si méprisamment traité, le lecteur'." (CHABANNE, Jean-Charles. Rire et philosophie dans l'œuvre de Raymond Queneau, paru dans Humoresques 9, « Rire et littérature », coord. Joë Friedemann, Presses Universitaires de Vincennes, 1998, pages 77-87.., p. 1).

90 'L'essentiel n'est donc pas l'intrigue, mais les éléments de structure qu'elle engendre, les thèmes que les courts échanges entre les personnages font surgir et sur lesquels le lecteur pourra s'interroger. L'intrigue n'est pas un but mais seulement un point de départ." (ESPINASSE, Magali. Étude sur Les Fleurs bleues. Paris: Ellipses, 1999, p. 53). 
justamente por causa dessas mesmas regras. “... é possível ao romancista lembrar sua existência sem mesmo se manifestar pessoalmente como narrador. Basta para isso, tendo-se imposto uma ordem formal, torná-la sensível ao leitor submetendo a ela a narrativa e a história" ${ }^{91}$. As regras podem ser de diferentes tipos e se manifestar de diferentes maneiras nos romances: podem determinar a linguagem utilizada, ou até mesmo a quantidade de capítulos ou de personagens. Outros escritores adotaram a escrita sob restrições, mas Godard observa:

ninguém na França explorou de forma mais metódica as possibilidades dessa via do que Raymond Queneau. Longe de se limitar a ela, ele procura outros meios de recolocar em questão a forma dominante do romance. (...) Com a ajuda da criação do Oulipo, essa prática [de uma construção voluntária] tornar-se-á novamente agente no fim da obra num romance como Les Fleurs bleues. ${ }^{92}$

A consequência do sistema de regras obriga o leitor a um papel ativo na leitura e na construção do sentido de um romance como Les Fleurs bleues. "Com efeito, no romance, o autor pode reunir vários tipos de restrições e combiná-las, criando um sistema complexo. O leitor não terá nunca um domínio completo desse sistema mas descobrir-lhe-á elementos a cada leitura: nunca se acaba de ler um romance oulipiano!" 93

São várias as técnicas de escrita que levam o leitor a assumir esse papel de decodificador e de criador de sentido:

\begin{abstract}
Jogando com a situação de comunicação (o contexto de enunciação, a circulação da informação, as competências ideológicas e culturais dos interlocutores ou suas determinações psicológicas), ele ataca vivamente os princípios de cooperação definidos por Grice. (...) A incompreensão, a falsificação, o silêncio são alguns dos meios para reestabelecer a comunicação (Les Fleurs bleues), ressuscitar uma arte que não tinha boa imagem: a retórica. A abundância de dêiticos, de pronomes pessoais, de modalizadores, a avaliação cujo desenvolvimento sempre apela ao contexto enunciativo, remete irremediavelmente à procura do enunciador sobre a
\end{abstract}

$91 \quad$ “... il reste possible à un romancier de rappeler son existence sans même se manifester en personne comme narrateur. Il lui suffit pour cela s'étant imposé à lui-même un ordre formel, de le rendre sensible au lecteur en y soumettant la narration et l'histoire." (GODARD, Henry. Queneau et les problèmes de la construction du roman. In : Europe - revue littéraire mensuelle - avril 2003, pp. 22-23).

92 "Personne en France n'a plus méthodiquement exploré les possibilités de cette voie que Raymond Queneau. Il est loin de s'y limiter : il saisit tour à tour au passage bien d'autres moyens de remettre en question la forme dominante du roman. (...) La création de l'Oulipo aidant, ces prestiges [d'une construction volontaire] redeviendront agissants à la fin de l'œuvre dans un roman comme Les Fleurs bleues." (GODARD, Henry. Queneau et les problèmes de la construction du roman. In : Europe - revue littéraire mensuelle - avril 2003, p. 23).

93 "En effet, dans le roman, l'auteur peut réunir plusieurs types de contraintes et les combiner, en créant un système complexe. Le lecteur n'aura jamais la maîtrise complète de ce système mais il en découvrira des éléments à chacune de ses lectures : on n'a jamais fini de lire un roman oulipien !" (ESPINASSE, Magali. Étude sur Les Fleurs bleues. Paris: Ellipses, 1999, p. 70). 
qual Queneau baseia seu jogo (Le Chiendent, Le Vol d'Icare, Les Fleurs bleues), assim como sobre o implícito que logo se revela exigir bem mais, da parte do destinatário, que a simples decodificação que fez o sucesso de Zazie. ${ }^{94}$

Ao ler um romance oulipiano, o leitor não pode se contentar com o humor e o lúdico, embora sejam importantes, mas tem que estar sempre atento para descobrir as várias camadas de significação:

A dimensão lúdica da leitura é essencial (...) A construção do romance pode fazer pensar num puzzle na medida em que vários elementos são dados separadamente, às vezes distantes um do outro, quando a lógica mandaria aproximá-los. A intriga é como que fatiada, cortada em vários episódios díspares, cabe ao leitor reconstituí-la como se juntasse as peças de um puzzle. ${ }^{95}$

Pode-se dizer que, numa obra oulipiana, o papel do leitor é levado ao extremo. Talvez por apresentar tantas formas de interpretação, por ter tantas camadas a descobrir, encontremos hoje tantos estudos sobre esse romance:

A história da recepção de Les Fleurs bleues mostra toda a complexidade e toda a riqueza do texto. A indispensável bibliografia de Charles T. Kestermeier da Creighton University oferece mais de 270 títulos só para esse romance, contando, é verdade, as notas breves e os artigos de jornal de uma só página, assim como importantes trabalhos universitários de que é difícil dar conta aqui. ${ }^{96}$

\footnotetext{
94 "Jouant sur la situation de communication (le contexte d'énonciation, la circulation de l'information, les compétences idéologiques et culturelles des interlocuteurs ou leurs déterminations psychologiques), il bat en brèche les principes de coopération définis par Grice. (...) L'incompréehension, la falsification, le silence sont autant de moyens pour relancer la communication (Les Fleurs bleues), ressusciter un art qui avait plutôt mauvaise presse: la rhétorique. L'abondance de déictiques, de pronoms personnels, de modalisateurs, l'évaluation dont le développement fait toujours appel au contexte énonciatif, renvoie irrémédiablement à la recherche de l'énonciateur sur laquelle Queneau fonde son jeu (Le Chiendent, Le Vol d'Icare, Les Fleurs bleues), de même que sur l'implicite qui se révèle vite exiger bien plus, de la part du destinataire, que le simple décodage qui fit le succès de Zazie." (BOURDETTE-DONON, Marcel. Queneau et les nouveaux vecteurs d'information. In $_{95}$ Europe - revue littéraire mensuelle - avril 2003, . p. 134).

95 "La dimension ludique de la lecture est essentielle (...) La construction du roman peut faire penser à un puzzle dans la mesure où plusieurs éléments sont donnés séparément, parfois éloignés l'un de l'autre, alors que la logique voudrait qu'on les rapproche. L'intrigue est comme hachée, découpée en plusieurs épisodes disparates, c'est au lecteur de la reconstituer comme s'il assemblait les pièces d'un puzzle." (ESPINASSE, Magali. Étude sur Les Fleurs bleues. Paris: Ellipses, 1999, p. 50).

$96 \quad$ 'L'histoire de la réception des Fleurs bleues montre toute la complexité et toute la richesse du texte. L'indispensable bibliographie de Charles T. Kestermeier de la Creighton University offre plus de 270 titres pour ce seul roman, en comptant, il est vrai, les notes brèves et les articles de journaux d'une seule page, ainsi que d'importants travaux universitaires dont il est difficile de rendre compte ici." (JATON,Anne Marie. Les Fleurs Bleues - Bilan Provisoire. In : Europe - revue littéraire mensuelle - avril 2003, p. 50).
} 


\section{TRADUZIR QUENEAU}

\subsection{A CONSTRUÇÃO DO SENTIDO}

A tradução é uma operação sobre a forma do texto, mas que, na tradição, pelo menos, se funda numa conservação do sentido. O tradutor é antes de tudo um leitor do original e, portanto, só pode pretender a preservação do sentido que ele próprio dá ao texto, pois este não possui um sentido intrínseco, mas sentidos que são construídos na operação de leitura, o que fica claro na frase em que Italo Calvino define a leitura ou o ato de ler:

Ler é sempre isto: há uma coisa que está aí, uma coisa feita de escrita, um objeto sólido, material, que não se pode mudar, e através dessa coisa nos confrontamos com alguma coisa diferente que não está presente, algo que faz parte do mundo imaterial, invisível, porque é apenas pensável, imaginável, atingível, no país dos mortos... (...) Ler é ir ao encontro de algo que está por ser e ainda ninguém sabe o que será... ${ }^{97}$

Se o que foi dito é válido para qualquer texto, verificamos que é ainda mais verdadeiro para um texto literário que, por definição, permite várias leituras, várias interpretações. Sartre, ao definir o texto literário dizia que "o objeto literário é um estranho pião, que só existe em movimento. Para fazê-lo surgir é necessário um ato concreto que se chama leitura, e ele só dura enquanto essa leitura durar. Fora daí, há apenas traços negros sobre o papel" ${ }^{98}$. O texto literário só existe como tal, quando um leitor se entrega à sua leitura e se dispõe a recebê-lo, a permitir que um sentido seja construído em si, como resultado desse processo de leitura e interpretação.

O sentido de um texto, sobretudo de um texto literário, além de não ser único não se encontra inteiramente no próprio texto, nem é inteiramente construído e transmitido pelo autor. Ao contrário, é o leitor que vai construí-lo mobilizando para isso sua própria experiência e sua própria bagagem cultural:

... uma parte do sentido que o leitor produz a partir do livro é facilmente dedutível do conteúdo deste último. Além disso, ele o constrói segundo uma lógica que lhe é própria, uma organização pessoal, que não tem muita coisa a ver com a acumulação

97 "Leggere è sempre questo: c'è una cosa che è lì, una cosa fatta di scrittura, un oggetto solido, materiale, che non si può cambiare, e attraverso questa cosa ci si confronta con qualcos'altro che non è presente, qualcos'altro che fa parte del mondo immateriale, invisibile, perché è solo pensabile, immaginabile, raggiungibile, nel paese dei morti... (...) Leggere è andare incontro a qualcosa che sta per essere e ancora nessuno sa cosa sarà.." (CALVINO, Italo. Se una notte d'inverno un viaggiatore. In: Romanzi e Racconti II. Milano: Arnoldo Mondadori, 2004. p. 680)

$98 \quad$ SARTRE, Jean-Paul. Que é literatura? São Paulo : Ática, 1989, p. 35. 
passiva de índícios reorganizados ulteriormente. (...) Uma parte do que o leitor compreende do livro coincide com as intenções explícitas do escritor, mas apenas uma parte; em compensação, o leitor experiente encontra no livro elementos que existem, e os interpreta ainda que eles tenham escapado à sagacidade do autor. ${ }^{99}$

Um texto literário permite, por meio das marcas deixadas consciente ou inconscientemente pelo autor, várias leituras em que podem ser construídos vários sentidos possíveis, pois "cada leitor, a partir de suas próprias referências, individuais ou sociais, históricas ou existenciais, dá um sentido, mais ou menos singular, mais ou menos compartilhado, aos textos de que ele se apropria" ${ }^{100}$.

Chega-se, nesse ponto, à compreensão de que a leitura não se reduz à procura de um sentido que o autor quer transmitir ou que esteja imanente ao texto, mas à criação de um sentido que é o resultado da própria leitura:

Ler é dar um sentido de conjunto, uma visão global e uma articulação dos sentidos produzidos pelas sequências. Não é descobrir o sentido que um autor pretendeu, o que implicaria que o prazer do texto se originasse da coincidência entre o sentido pretendido e o sentido percebido, numa espécie de acordo cultural, como às vezes se desejou numa ótica cujo positivismo e elitismo são evidentes. Ler é, pois, constituir e não reconstituir um sentido. ${ }^{101}$

É, pois, no leitor que o texto adquire seu sentido. O leitor é o interlocutor que desempenha um papel importante no dialogismo de cada texto, sem esse interlocutor, a significação do texto não pode ser apreendida, como diz Baktin:

A significação de um enunciado, com efeito, para Bakhtin, só é apreendido se se levar em conta não apenas o referente contextual, não somente o locutor, que colore todo o discurso com uma apreciação, com um julgamento de valor, com uma entonação (em todos os sentidos do termo), mas ainda o interlocutor, em relação ao

\footnotetext{
$99 \quad$ "une partie du sens que le lecteur produit à partir du livre est facilement déductible du contenu de ce dernier. Encore le construit-il selon une logique qui lui est propre, une organisation personnelle, qui n'a pas grand chose à voir avec l'accumulation passive d'indices réorganisés ultérieurement. (...) Une partie de ce que le lecteur comprend du livre coïncide avec les intentions explicites de l'écrivain, mais une partie seulement; en revanche, le lecteur chevronné trouve dans le livre des éléments qui existent, et les interprète alors même qu'ils échappaient à la sagacité de l'auteur." (POSLANIEC, Christian. De la Lecture à la Littérature. Paris : Sorbier, 1992, p. 132).

100 "chaque lecteur, à partir de ses propres références, individuelles ou sociales, historiques ou existentielles, donne un sens, plus ou moins singulier, plus ou moins partagé, aux textes qu'il s'approprie." (CHARTIER, Roger. Pratiques de la lecture. Paris: Rivages, 1985, p. 9).

101 “Lire, c'est donner un sens d'ensemble, une globalisation et une articulation des sens produits par les séquences. Ce n'est pas retrouver le sens voulu par un auteur, ce qui impliquerait que le plaisir du texte s'origine dans la coïncidence entre le sens voulu et le sens perçu, en une sorte d'accord culturel, comme on l'a parfois prétendu dans une optique dont le positivisme et l'élitisme n'échapperont à personne. Lire, c'est donc constituer et non pas reconstituer un sens." (GOULEMOT, Jean Marie. De la lecture comme production de sens. In: CHARTIER, Roger (Org) Pratiques de la lecture. Paris: Rivages, 1985, p. 116).
} 
qual toda mensagem se constrói ao mesmo tempo como resposta e como previsão de uma resposta. Em outras palavras, todo enunciado linguístico realizado, todo ato de linguagem é inevitavelmente, fundamentalmente, intrinsecamente dialógico. ${ }^{102}$

Se o autor teve alguma intenção e pretendeu dar um sentido ao texto, ler não é procurar esse sentido: o leitor pode até encontrá-lo, mas pode encontrar também outros, ou, ainda, pode encontrar apenas os outros com os quais o próprio autor não tenha se deparado, pois como diz Vincent Jouve, "O leitor real apreende o texto com sua inteligência, seus desejos, sua cultura, suas determinações sócio-históricas e seu inconsciente" ${ }^{103}$.

Esse fato é ressaltado por Maria Helena Martins, que opõe essa apreensão do leitor à eventual intenção do autor:

Tudo o que lemos, à exceção da natureza (isso se não considerarmos a interferência do homem nela), é fruto de uma visão de mundo, de um sistema de idéias e técnicas de produção, caracterizando um comprometimento do autor com o que produz e, por certo, com seus possíveis leitores. Há, portanto, relação entre texto e ideologias, pois estas são inerentes à intenção (consciente ou inconsciente) do autor, a seu modo de ver o mundo, tornando-se também elementos de ligação entre ele e os leitores de seu texto. (...) Mas se há uma intencionalidade na criação, ela sabidamente nem sempre corresponde ao modo como a leitura se realiza. A resposta do leitor depende de inúmeros fatores presentes no ato de ler. ${ }^{104}$

É necessário, portanto, além do emissor (autor), um receptor (leitor) para que se construa o sentido de um texto. No caso da tradução, inclui-se um terceiro agente, o tradutor, que exerce duas funções: primeiramente a de receptor, construindo em sua leitura o sentido do texto, para em seguida assumir a função do emissor e procurar transmitir para o seu leitor o sentido que construiu: "a tradução é uma reescritura, noutra língua, de uma leitura do texto" 105 .

Jouve, a propósito das possibilidades de interpretação, diz que o leitor tem uma liberdade quase total para a construção dos sentidos em sua leitura:

\footnotetext{
102 "La signification d'un énoncé, en effet, pour Bakhtine, n'est saisissable qu'à travers la prise en compte, non seulement du référent contextuel, non seulement du locuteur, qui colore tout discours d'une appréciation, d'un jugement de valeur, d'une intonation (à tous les sens du terme), mais encore de l'interlocuteur, par rapport auquel tout message se construit à la fois comme réponse et comme prévision d'une réponse. Autrement dit, tout énoncé linguistique réalisé, tout acte de langage est inévitablement, fondamentalement, intrinsèquement, dialogique." (ARON, Thomas. Le roman comme représentation de langages - Raymond Queneau à la lumière de Bakhtin. In : Europe - revue littéraire mensuelle - avril 2003, pp. 35-36).

103 JOUVE, Vincent. A Leitura. São Paulo : Unesp, 2003, p. 15.

104 MARTINS, Maria Helena. O que é leitura. 3. ed. São Paulo: Brasiliense, 1984, p. 60.

105 LARANJEIRA, Mário. Poética da Tradução. São Paulo: Edusp, 1993, p. 31.
} 
Ao distender a ligação que, no oral, une o locutor a seu discurso, o escrito permite aos leitores verem no texto outra coisa além do projeto do autor. (...) Como o autor não está mais presente para negar esta ou aquela leitura, o campo das significações pode se desenvolver quase infinitamente. ${ }^{106}$

$\mathrm{Na}$ realidade, essa liberdade não é total, pois a leitura, e a consequente produção de sentido, se dá com base em um texto escrito, cujas marcas textuais guiam o leitor. Se o texto não traz um sentido já pronto, é ele que traz os parâmetros que permitem a criação do sentido, parâmetros esses que agem antes, no trabalho de escrita, ou depois, na recepção. Christian Poslaniec classifica esses parâmetros em cinco tipos:

1 - ligados à língua (sintaxe, discriminação dos sons, conotações linguísticas, domínio dos campos lexicais, polissemia, conjugação e aspectos dos verbos);

2 - ligados às referências (linguísticas, contextuais, culturais);

3 - ligados à narração (contrato espaço-temporal, digressão, modo de determinação das personagens, estatuto do narrador, redundância);

4 - ligados ao estilo (figuras de estilo, estilo de estrutura);

5 - ligados à maturidade individual (capacidade de perceber a causalidade, capacidade de associar e de simbolizar, capacidade de projeção e de identificação, consciência metalinguística, capacidade de distinguir o verdadeiro e o verossímil) ${ }^{107}$.

Esse processo em que o sujeito se entrega à leitura de um texto de modo a permitir sua absorção na forma de um sentido construído, filtrando e decodificando a realidade pela literatura é a interpretação. A necessidade de traduzir leva, portanto, à necessidade de interpretar, pois, como diz Italo Calvino, “... toda tradução requer uma outra tradução, e assim por diante (...) Não interpretar é impossível, como é impossível evitar pensar" ${ }^{108}$. Para Calvino, como já dissemos, tudo é tradução, o ato da escrita é já a tradução de uma ideia "virtual" e abstrata que não pode ser apreendida a não ser pela linguagem, ou seja, mediante sua tradução em linguagem. Segundo esse raciocínio, a leitura, a interpretação, o que produz no leitor o sentido de um texto é também uma tradução.

\footnotetext{
106 Cf. JOUVE, Vincent. A Leitura. São Paulo:Unesp, 2003, pp. 24-25.

107 Cf. POSLANIEC, Christian. De la Lecture à la Littérature. Paris : Sorbier, 1992, pp. 138-160.

108 “... ogni traduzione richiede un'altra traduzione e così via.(...) Non interpretare è impossibile, come è impossibile trattenersi dal pensare." (CALVINO, Italo. Palomar, In Romanzi e Racconti II, Milano: Mondadori, 1992, p 956-957).
} 
Talvez seja por isso que o próprio Calvino diz que "traduzir é a verdadeira maneira de se ler um texto" ${ }^{109}$, título de um ensaio que escreveu em 1982, em que afirma ainda que "traduzir é uma arte: a passagem de um texto literário, qualquer que seja seu valor, para uma outra língua requer sempre um certo tipo de milagre. (...) o tradutor literário é aquele que se põe inteiro em jogo para traduzir o intraduzível" 110.

O tradutor, tendo-se apropriado do texto original, tendo construído seu sentido segundo sua leitura, procurará, na escrita do texto traduzido, manter as marcas textuais que ele identificou no original, deixando disponíveis aos seus leitores, parâmetros que possam conduzi-los em seu processo de construção de sentido.

Considerando-se esses parâmetros há, ainda assim, a possibilidade de várias leituras e de construção de sentidos diferentes de um texto literário, que podem variar entre os leitores, mas também entre leituras do mesmo leitor:

\begin{abstract}
Assim como há tantas leituras quantos são os leitores, há também uma nova leitura a cada aproximação do leitor com um mesmo texto, ainda quando mínimas as suas variações. Nessas ocasiões talvez ocorram mudanças de nível. Um poema ou uma canção que hoje não nos dizem nada, não fazem sentido, amanhã podem emocionar; agradar ao ouvido pela musicalidade e pelo ritmo, tempos depois; suscitar reflexões apenas após várias leituras. 111
\end{abstract}

Essa última observação, válida para qualquer obra literária, é ainda mais presente quando tratamos de uma obra oulipiana, que é construída sob regras e restrições que condicionam sua forma e seu conteúdo. A obra oulipiana leva o leitor a tentar encontrar, além do sentido do texto, as restrições (contraintes) que o autor se impôs, o que, muitas vezes, exige várias leituras para que possa encontrar o que se oculta sob a aparência lúdica característica dessas obras. A afirmação de Sartre sobre a leitura em geral, embora escrita antes da criação do Oulipo, poderia ser uma orientação específica para a atitude de um leitor diante de um romance oulipiano: “... é preciso que o leitor invente tudo, num perpétuo ir além da coisa escrita. Sem dúvida, o autor o guia, mas somente isso; as balizas que colocou estão separadas por espaços vazios, é preciso interligá-las, é preciso ir além delas. Em resumo, a leitura é criação dirigida". 112

\footnotetext{
109 "Tradurre è il vero modo di leggere un testo" (CALVINO, Italo. Saggi II, Milano: Mondadori, 1995)

110 "Tradurre è un'arte: il passaggio di un testo letterario, qualsiasi sia il suo valore, in un'altra lingua richiede ogni volta un qualche tipo di miracolo. (...) Il traduttore letterario è colui che mette in gioco tutto se stesso per tradurre l'intraducibile." (CALVINO, Italo. Saggi II, Milano: Mondadori, 1995, pp. 1781-1782).

111 MARTINS, Maria Helena. O que é leitura. 3. ed. São Paulo : Brasiliense, 1984, p. 79.

112 SARTRE, Jean-Paul, Que é literatura?. São Paulo: Ática, 1989, p. 38.
} 


\subsection{A POSSIBILIDADE DA TRADUÇ̃̃O}

A tradução se impõe como prática desde a Antiguidade como resposta à necessidade de permitir a falantes de uma língua o acesso a obras produzidas em outra. $\mathrm{Na}$ tradição ocidental, desde as primeiras traduções latinas de obras gregas e as várias traduções da Bíblia, jamais se parou de traduzir. Além dessa tradução entre línguas distintas, há tradução, segundo Schleiermacher, também quando se atualizam numa mesma língua textos escritos há muitos séculos, e mesmo quando há necessidade de reformulação de um discurso para que seja compreendido por pessoas de classes populares diferentes ou ainda entre pessoas parecidas, mas cuja sensibilidade e temperamento são diferentes. ${ }^{113}$.

Apesar de ser uma prática constante cuja existência é inegável, a tradução tem sido questionada seja quanto à sua possibilidade de refletir fielmente o que propõe o texto original, seja mesmo quanto à própria possibilidade de se traduzir. Podemos distinguir, como faz Luís Maia Varela em seu artigo, três correntes de pensamento sobre as possibilidades tradutórias: há os que, como Steiner (After Babel) defendem a intraduzibilidade absoluta, alegando que a percepção do mundo é diferente para cada indivíduo e que, portanto, cada discurso individual é uma descrição mais ou menos consciente dessa percepção; há os que defendem que a tradução normalmente é possível, mas que pode ser impossível em alguns casos pontuais, por exemplo, quando na língua de chegada não existem características formalmente correspondentes às da lingua de partida; finalmente há os que, como Danica Sekeskovich (Interpreter pour traduire), acreditam que tudo pode ser traduzido, desde que pensado de forma clara. ${ }^{114}$

Essa última posição implica considerar a existência do pensamento puro, não verbalizado, de forma que, na interpretação, o tradutor pudesse como que despir o pensamento de sua língua original, apropriar-se de sua forma pura, para em seguida expressálo na língua de chegada.

Italo Calvino assume uma posição ainda mais radical: segundo ele tudo é tradução, pois "primeiro vem essa língua sem palavras dos corpos vivos (...) depois as palavras com que se escrevem os livros e se procura inutilmente traduzir aquela primeira

\footnotetext{
113 Cf. SCHLEIERMACHER, Friedrich. Sobre os diferentes métodos de tradução. In: HEIDERMANN, Werner (org). Clássicos da teoria da tradução. Florianópolis: UFSC, 2001. p. 27

114 Cf. VARELA, Luís Maia. A Tradução Traduz o Tradutor. In: COSTA, Luiz Angélico (Org.) Limites da Traduzibilidade. Salvador: EDUFBA, 1996, pp. 42-43.
} 
língua" ${ }^{115}$. Isso se dá porque não é possível ter acesso ao pensamento puro, sem palavras, que seria o original e tudo a que podemos ter acesso é já uma tradução desse original inacessível. A tradução entre línguas seria não a tradução de um pensamento original, mas a tradução da tradução que o autor fez de seu pensamento para a sua língua materna.

Neste trabalho, quando tratamos de tradução, referimo-nos à transposição de um texto produzido numa língua natural, para outra língua natural, abstraindo os outros tipos de tradução. Essa tradução interlingual, segundo Katarina Reiss, "pode ser definida como um processo de comunicação bilingual mediado, cujo objetivo usual é a produção de um texto na língua alvo que seja funcionalmente equivalente a um texto na língua fonte". 116

No mesmo artigo, Reiss propõe uma classificação dos tipos de textos que se podem traduzir. Segundo ela, o texto pode ser informativo, quando o original foi escrito para comunicar conteúdo; pode ser expressivo, quando o original comunica conteúdo artístico; e pode ser operativo, quando original foi escrito para convencer e produzir impulsos de comportamento. Esses diferentes tipos de textos vão determinar o tipo de tradução a ser efetuada: no primeiro, a tradução deve comunicar o mesmo conteúdo do original; no segundo, deve conter uma organização artística análoga; no terceiro, deve ser capaz de produzir impulsos de comportamento análogos em seus leitores. ${ }^{117}$

Trataremos aqui de traduções do segundo tipo, a tradução literária. Nesse caso, como diz Reiss, a tradução deve conter uma organização artística análoga à do original, pois, no âmbito da literatura, não se trata apenas de traduzir palavras ou frases de uma língua para outra, para transmitir o conteúdo da mensagem, mas de traduzir o texto de modo a provocar, nos leitores da língua de destino, as imagens mentais e o efeito produzido pela obra nos leitores da língua de origem.

Isso implica, além dos aspectos linguísticos, uma "tradução" dos aspectos psicológicos, culturais, sociais e históricos. O tradutor seria, portanto, um mediador cultural, alguém que deve instaurar uma interação (a melhor possível) entre culturas diversas. Uma tarefa de tal complexidade pode levar, algumas vezes, ao encontro de textos ou de partes de

\footnotetext{
115 "Prima viene questa lingua senza parole dei corpi vivi (...) poi le parole con cui si scrivono i libri e si cerca inutilmente di tradurre quella prima lingua" (CALVINO, Italo. Se una notte d'inverno un viaggiatore. In: Romanzi e Racconti II. Milano: Arnoldo Mondadori, 2004. p. 679)

116 "may be defined as a bilingual mediated process of communication, which ordinarily aims at the production of a TL [target language] text that is functionally equivalent to an SL text [source language]" (REISS, Katharina. Type, kind and individuality of text - Decision making in translation. In: VENUTI, Lawrence. The Translation Studies Reader. New York: Routledge. p. 160).

117 Cf. REISS, Katharina. Type, kind and individuality of text - Decision making in translation. In: VENUTI, Lawrence. The Translation Studies Reader. New York: Routledge. pp. 167-168.
} 
textos "intraduzíveis", se considerarmos apenas a tradução literal, a busca da fidelidade semântica, isto é a transmissão do sentido, da mensagem contida no texto.

Há textos em que efetivamente o mais importante é a mensagem, o conteúdo, mas este não é o caso dos textos literários, pois, de acordo com Berman:

Um texto técnico (se for possível falar aqui de texto) é certamente uma mensagem visando a transmitir de forma (relativamente) unívoca uma certa quantidade de informações; mas uma obra não transmite nenhum tipo de informação, mesmo contendo algumas, ela abre à experiência de um mundo. ${ }^{118}$

No texto literário, segundo Mário Laranjeira, "a língua, o código, deixa de ser apenas um suporte, um veículo, para fazer parte integrante da própria mensagem. O significante ganha terreno sobre o significado, prepondera sobre ele, gera-o. (...) Para esses textos, sim, cabe realmente a discussão sobre a tradutibilidade" ${ }^{119}$. O autor afirma então que o intraduzível deixa de sê-lo se compreendermos que, em tradução literária, a tradução não visa à identidade absoluta, o que seria impossível em todos os casos, mas à equivalência. ${ }^{120}$ Entendemos aqui por equivalente um texto que cause no leitor de chegada a mesma impressão que o original causa no leitor de origem.

Nesse aspecto, o tradutor, como vimos mais acima é, antes de tudo, um leitor do original e, como tal, constrói um sentido do texto com base nas impressões que este lhe provoca. Em sua tradução deve procurar transmitir essas impressões, num texto o mais homólogo possível do original, de forma a permitir que seu leitor possa, como ele, construir seu próprio sentido do texto.

As considerações acerca da tradutibilidade são válidas tanto para a poesia, quanto para a prosa literária, pois esta apresenta características que a aproximam da tradução de poesia: o texto literário possibilita várias leituras, várias interpretações, como afirma Schnaiderman:

Costuma-se dizer que o trabalho de tradução de poesia é muito diferente do lidar com textos de prosa. Como eu acho que a diferença entre poesia e prosa é uma questão de maior ou menor concentração dos elementos de linguagem (Ezra Pound

\footnotetext{
118 BERMAN, Antoine. A tradução e a letra - ou o abergue do longínquo. Rio de Janeiro: Viveiros de Castro, 1985, p. 64.

119 LARANJEIRA, Mário. Poética da Tradução. São Paulo: Edusp, 1993, pp. 21-22.

$120 \quad$ Ibid, p. 19.
} 
falava em maior ou menor carga), penso que o trabalho do tradutor de prosa literária é menos distante da tarefa do tradutor de poesia do que geralmente se pensa. ${ }^{121}$

Mais ainda, pode-se pensar que não há distinção entre poesia e texto literário, particularmente no caso de Queneau, que não escondia seu gosto por obras cuja composição obedecesse a "regras tão estritas quanto as do soneto". Independente da forma, poemas ou romances, Jacques Bens afirma que “... tudo é poesia na obra de Raymond Queneau, tudo se transforma, jorra das palavras e põe-se a dançar ou a rir entre as linhas”. ${ }^{122}$ Para Queneau, o romance é, ou pelo menos deve ser um poema, um poema de forma fixa, com rígidas regras estruturais, em que o trabalho sobre a linguagem adquire uma importância fundamental.

A tradução não pode pretender se assemelhar ao original, pois, como afirma Walter Benjamin, "pode-se comprovar não ser possível existir uma tradução, caso ela, em sua essência última, ambicione alcançar alguma semelhança com o original”. ${ }^{123}$

O tradutor deve, portanto, manter na língua de chegada, as marcas textuais que permitiram que o sentido construído em sua leitura se produzisse nele, e, na medida do possível, manter a polissemia e a intertextualidade, pois não cabe ao tradutor resolver ambiguidades que o autor incluiu no original. Como diz Michelle Bourjea, "completar elipses sintáticas, explicitar ligações apagadas pela parataxe (justaposição de orações) é querer designar arbitrariamente ao leitor um significado único, sacrificando a pluralidade do texto". 124

Como vimos, não se pode buscar na tradução a identidade absoluta e, segundo Laranjeira nem mesmo a equivalência de sentido, que é construído pelo leitor, mas, um texto que seja o mais homólogo possível do original. Cabe aqui uma consideração relativa aos termos empregados acima, homólogo, por Laranjeira, e análogo, por Reiss. Acreditamos que se trata do mesmo conceito que, referindo-se a uma tradução, significa que, embora esta não deva buscar na sua relação com o original a identidade, o que seria impossível, deve ser um texto que mantenha as características do original de forma a transmitir a seu leitor impressões próximas às provocadas por aquele. Para isso, é preciso ir além do sentido e buscar a significância, como afirma Mário Laranjeira, "Assim, não é raro que a fidelidade à

\footnotetext{
121 SCHNAIDERMAN, Boris. Os Limites da Traduzibilidade. In: COSTA, Luiz Angélico (Org.) Limites da Traduzibilidade. Salvador: EDUFBA, 1996, p. 24.

122 “... tout est poésie dans l'œuvre de Raymond Queneau, tout se transforme, jaillit des mots et se met à danser ou à rire entre les lignes.” (BENS, Jacques. Queneau. Paris: Gallimard, 1962, p. 57).

123 BENJAMIN, Walter. A Tarefa-Renúncia do Tradutor. In: Clássicos da Teoria da Tradução. Florianópolis: UFSC, 2001.

124 BOURJEA, Michelle. Traduzir Clarice Lispector assim como ela escreve. In: COSTA, L. A. (Org). Limites da Traduzibilidade. Salvador: EDUFBA, 1996. p. 124.
} 
significância do texto, que deve sempre prevalecer, imponha, na tradução do poema, infidelidades no nível estritamente semântico (...)". ${ }^{125}$

Benveniste criou o conceito de significância para designar a propriedade de significar inerente à linguagem humana e o estendeu posteriormente, no ensaio Sémiologie de la langue, de 1969, a todo o sistema de signos (escrita, sinais de trânsito, monetários, estéticos, códigos sociais, etc). Ele distingue dois modos de significância que denomina semiótico e semântico. O semiótico designa o modo de significância próprio do signo e o semântico o modo de significância próprio do discurso:

O semiótico caracteriza-se como uma propriedade da língua, o semântico resulta de uma atividade do locutor que coloca a língua em ação. O signo semiótico existe em si, funda a realidade da língua, mas não comporta aplicações particulares; a frase, expressão do semântico, é apenas particular. Com o signo, atinge-se a realidade intrínseca da língua; com a frase, estamos ligados às coisas fora da língua; e enquanto o signo tem como parte constituinte o significado que lhe é inerente, o sentido da frase implica referência à situação de discurso, e à atitude do locutor. ${ }^{126}$

Posteriormente, o conceito é reformulado por Henri Meschonnic. Benveniste define a significância como a atividade de significar em si, por oposição a significação, vinculada à relação entre o signo e seu referente, sempre ligada, no entanto, à propriedade do signo de significar. Meschonnic aplica o termo à produção significante dos discursos, sobretudo dos textos literários em que, segundo ele, a oposição entre significante e significado é neutralizada em prol de um "significante múltiplo, estrutural, que constrói sentido a partir de tudo, uma significância (significação produzida pelo significante) constantemente se fazendo e se desfazendo". ${ }^{127}$ Esse significante, Meschonic vai denominar "ritmo", que ele define como:

a organização das marcas pelas quais os significantes, linguísticos e extralinguísticos (sobretudo no caso da comunicação oral) produzem uma semântica específica, distinta do sentido lexical, e que denomino significância: isto é, os

\footnotetext{
125 LARANJEIRA, Mário. Poética da Tradução. São Paulo: Edusp, 1993, p. 126.

126 "Le sémiotique se caractérise comme une propriété de la langue, le sémantique résulte d'une activité du locuteur qui met en action la langue. Le signe sémiotique existe en soi, fonde la réalité de la langue, mais il ne comporte pas d'applications particulières ; la phrase, expression du sémantique, n'est que particulière. Avec le signe, on atteint la réalité intrinsèque de la langue ; avec la phrase, on est relié aux choses hors de la langue; et tandis que le signe a pour partie constituante le signifié qui lui est inhérent, le sens de la phrase implique référence à la situation de discours, et à l'attitude du locuteur" (BENVENISTE, E, Problèmes de linguistique générale, t. II, p. 225)

“... signifiant multiple, structurel, qui fait sens de partout, une signifiance (signification produite par le signifiant) constamment en train de se faire et de se défaire” (MESCHONNIC, H. Le Signe et le poème, Paris, Gallimard, 1975, p. 512.)
} 
valores próprios de um discurso e apenas a ele. Essas marcas podem se situar em todos os 'níveis da linguagem: de entonação, prosódicos, lexicais, sintáticos ${ }^{128}$

É o ritmo que tem a primazia no texto literário e é ele que, segundo Meschonnic, constitui a oralidade: "através da sintaxe, há um ritmo. E a primazia desse ritmo, assim como seu reconhecimento, estabelece uma oralidade específica. Ela não é nem o falado, nem o escrito. Ela pode ter lugar tanto num quanto noutro. (...) [a literatura obriga a] postular uma tripartição: o oral, o falado e o escrito". ${ }^{129}$

Podemos dizer, de acordo com esses conceitos que, se o significado é construído a partir do léxico e da sintaxe, a significância, por sua vez, é construída a partir do ritmo, através do qual percebe-se a presença do sujeito que se constitui no texto:

O sujeito-linguagem é, portanto, duplo. Sujeito linguistico da enunciação, no sentido de Benveniste. (...) E há um sujeito poético da enunciação, tanto que o discurso é transformado pelo sujeito e o sujeito advém ao estatuto de sujeito por esse discurso. O que só acontece pela primazia do ritmo e da prosódia na organização do sentido. 130

De fato, o texto, como afirma Roland Barthes, não pode mais ser visto como um produto depositário de uma significação objetiva criada no momento de sua escrita, mas como uma produção em que estão implicados tanto o escritor quanto o leitor:

\begin{abstract}
quando o texto é lido (ou escrito) como um jogo móvel de significantes, sem referência possível a significados fixos, torna-se necessário distinguir bem a significação, que pertence ao plano do produto, do enunciado, da comunicação, e o trabalho significante que, esse, pertence ao plano da produção, da enunciação e da simbolização: é o trabalho que denominamos significância. ${ }^{131}$
\end{abstract}

\footnotetext{
128 " l'organisation des marques par lesquelles les signifiants, linguistiques et extra-linguistiques (dans le cas de la communication orale surtout) produisent une sémantique spécifique, distincte du sens lexical, et que j'appelle la signifiance : c'est-à-dire les valeurs propres à un discours et à un seul. Ces marques peuvent se situer à tous les "niveaux" du langage : accentuelles, prosodiques, lexicales, syntaxiques." (MESCHONNIC, H. Critique du rythme. Anthropologie historique du langage, Lagrasse, Verdier, 1982, p. 216-217).

129 "À travers la syntaxe, c'est un rythme. Et le primat de ce rythme, sa reconnaissance aussi, établissent une oralité spécifique. Elle n'est ni le parlé, ni l'écrit. Elle peut avoir lieu dans l'un comme dans l'autre. (...) [la littérature impose] de postuler une tripartition: l'oral, le parlé et l'écrit." (MESCHONNIC, H. La rime et la vie. Paris: Verdier. 1989, p. 253)

130 "Le sujet-langage est donc double. Sujet linguistique de l'énonciation, au sens de Benveniste. (...) Et il y a un sujet poétique de l'énonciation, tel que le discours est transformé par le sujet et le sujet advient au statu de sujet par ce discours. Ce qui n'arrive que par le primat du rythme et de la prosodie dans l'organisation du sens." (MESCHONNIC, H. La rime et la vie. Paris: Verdier. 1989, p.269)

131 "lorsque le texte est lu (ou écrit) comme un jeu mobile de signifiants, sans référence possible à un ou à des signifiés fixes, il devient nécessaire de bien distinguer la signification, qui appartient au plan du produit, de l'énoncé, de la communication, et le travail signifiant, qui, lui, appartient au plan de la production, de l'énonciation, de la symbolisation : c'est ce travail qu'on appelle la signifiance." (BARTHES, R. Théorie du texte. p. 5)
} 
O texto não se confunde, pois com a obra, que é o objeto físico, o livro, por exemplo, dentro do qual há texto, "a obra se toma na mão, o texto, na linguagem" ${ }^{132}$. Em seguida, Barthes ressalta a importância da leitura e do papel do leitor na constituição da significância e chega a falar de equivalência produtiva da escrita e da leitura e observa que a teoria do texto

não considera mais as obras como simples 'mensagens', ou mesmo 'enunciados' (isto é, produtos acabados, cujo destino estaria selado uma vez que tivessem sido emitidos), mas como produções perpétuas, enunciações, através das quais o sujeito continua a se debater; esse sujeito que é o do autor talvez, mas também o do leitor. 133

O que faz de um texto um texto literário é, portanto, a primazia do ritmo, que permite a presença do sujeito e que implica "um modo específico de engajamento do leitor que participa do texto" ${ }^{134}$. A oralidade assim compreendida está presente no texto em todos os níveis da linguagem e permite perceber a presença não só da voz, mas do corpo no discurso:

Como o ritmo não é mais redutível ao sonoro, ao fônico, à esfera ORL, mas envolve um imaginário respiratório que concerne ao corpo vivo inteiro (...) o ritmo é ao mesmo tempo um elemento da voz e um elemento da escrita. O ritmo é o movimento da voz na escrita. Com ele, não ouvimos o som, mas o sujeito. ${ }^{135}$

Queneau, em Les Fleurs bleues, em seu trabalho com a linguagem e com sua preocupação pela introdução da língua falada na literatura, sempre se utilizando do humor, coloca no texto marcas lexicais, sintáticas, ortográficas que são claramente perceptíveis pelo leitor como ruptura e que o obriga a considerá-las na sua construção de sentido, atingindo a significância, tal como definida acima. Isso porque, como afirma Chabanne, "o humor pressupõe ou impõe a necessidade de uma cumplicidade, de uma cooperação na operação da

\footnotetext{
132 "l'œuvre se tient dans la main, le texte dans le langage." (BARTHES, R. Théorie du texte. p. 6)

133 "ne considère plus les œuvres comme de simples «messages », ou même des «énoncés » (c'est-à-dire des produits finis, dont le destin serait clos une fois qu'ils auraient été émis), mais comme des productions perpétuelles, des énonciations, à travers lesquelles le sujet continue à se débattre ; ce sujet est celui de l'auteur sans doute, mais aussi celui du lecteur." (BARTHES, R. Théorie du texte. p. 8)

134 "un mode spécifique d'engagement du lecteur qui participe au texte" (MESCHONNIC, H. La rime et la vie. Paris: Verdier. 1989, p. 256)

135 "Comme le rythme n'est plus réductible au sonore, au phonique, à la sphère ORL, mais engage un imaginaire respiratoire qui concerne le corps vivant tout entier (...) le rythme est à la fois un élément de la voix et un élément de l'écriture. Le rythme est le mouvement de la voix dans l'écriture. Avec lui, on n'entend pas du son, mais du sujet." (MESCHONNIC, H. La rime et la vie. Paris: Verdier. 1989, p.270)
} 
leitura. [...] O humor é um modo de interação verbal que exige uma grande mobilização do destinatário: daí o lugar deixado, na obra de Queneau, ao leitor". ${ }^{136}$

Apesar disso, o autor não se limita a deixar ao leitor essa possibilidade, mas chama sua atenção explicitamente para a importância do significante, utilizando-se de metalinguagem. Isso ocorre praticamente para todos os tipos de trabalho efetuado sobre a linguagem e sobre o significante:

a) Se o leitor pudesse passar sem perceber pelos trocadilhos enfileirados logo nas primeiras páginas, Queneau o obrigaria a voltar, pela fala do duque: "Tanta história, disse o duque de Auge para o duque de Auge, tanta história para alguns trocadilhos, para alguns anacronismos";

b) Depois de uma série de provérbios criados pelo próprio autor, o narrador conclui "e outros prouvérbios de vasto alcance tirados do fundo falso, amorfo ou clórico da proverbial sapiência francesa";

c) $\mathrm{O}$ intertexto e a métrica, utilizados várias vezes ao longo do texto, são objeto de uma conversa em que Cidrolin diz a um passante: "Eu fazia uma citação, disse Cidrolin. (...) De um poeta, é claro. O senhor não ouviu os doze pés?”;

d) A mistura de línguas, tão evidente no próprio diálogo de Cidrolin com os campistas, é explicitada pela reflexão do próprio Cidrolin "será que fala o europeu vernacular ou o neobabélico?";

e) As repetições, presentes em vários níveis ao longo de todo o texto, também é objeto de reflexão, quando o duque observa que "a repetição é uma das mais odoríferas flores da retórica";

f) Os desvios ortográficos, também recorrentes, assim como a ortografia fonética proposta por Queneau, fica evidente quando o narrador diz que "Tout le monde part. Cidrolin aperçoit la tête des chevaus. Ils ont l'air de chevaux.", em que o leitor não pode deixar de observar a diferença de grafia entre as palavras "chevaus" e "chevaux";

g) Algumas expressões idiomáticas são explicadas, quanto à sua origem e ao seu significado;

\footnotetext{
136 "l'humour présuppose ou impose la nécessité d'une complicité, d'une coopération dans l'opération de la lecture. [...] L'humour est un mode d'interaction verbale qui exige une grande mobilisation du destinataire: d'où la place laissée, dans l'œuvre de Queneau, au lecteur" (CHABANNE, J-C. En lisant les lecteurs de Queneau. p. 17-18)
} 
h) Sobre a existência de neologismos, há uma discussão entre o duque e o abade, em que as próprias regras de derivação são explicitadas, assim como há uma reflexão sobre os arcaísmos, em que se pergunta o porquê do desaparecimento de algumas palavras.

Se a presença da oralidade não pode ser ignorada pelo leitor, se o próprio autor faz questão de garantir que ela não passe despercebida, é evidente que essa deve ser também uma das principais preocupações do tradutor em relação ao seu próprio leitor. Há que se ter em mente que, em muitos casos, é o significante que conta na construção da significância e que, portanto, o significante na língua de chegada deve cumprir essa mesma função. Ainda segundo Meschonnic, "O escrever, o traduzir só se realizam se forem uma prática da oralidade. E talvez só haja uma escrita se houver a invenção de sua própria oralidade”. ${ }^{137}$

\subsection{O TEXTO A SER TRADUZIDO}

Como vimos, Les Fleurs bleues é um romance oulipiano. Há na sua construção, várias contraintes sobretudo as de tipo numérico. Além dessas contraintes numéricas, há ainda as repetições que Queneau dizia corresponder na prosa às rimas na poesia, e a construção dos dois enredos paralelos, em que as vidas de Auge e de Cidrolin são como espelhos, uma refletindo a outra, as personagens que entram em uma das histórias tendo sempre uma correspondente na outra: Auge é viúvo e se casa com Russula, filha de um lenhador. Cidrolin é viúvo, passa a viver com Aalice, filha de um lenhador. Auge tem três filhas, Belusina, Pigranela e Feliza, e três genros, o sir de Ciry, o conde de Torves e o vidama de Malplaquet. Cidrolin tem três filhas, Bertranda, Sigismunda e Aamélia, e três genros, Iolando, Lizeto e Cuveton. Se na corte de Auge há o abade Onesíforo Biroton e o diácono Rifinge, do lado de Cidrolin há Onesíforo, dono do bar Bitúrico e o "quase-padre". Se Auge tem cavalos que falam, Cidrolin tem os nômades campistas com quem conversa em diversas línguas. Na história do duque há personagens que marcam as diferentes épocas, São Luís (1264), o arauto (1439), Timoleu Timolei (1614), Altaviva y Altamira (1792); na história de Cidrolin há os passantes que surgem e desaparecem.

Ao se pensar na tradução de uma obra oulipiana, pensa-se primeiramente na contrainte utilizada e na possibilidade de conseguir um efeito semelhante ao adotá-la na outra língua. O lipograma, por exemplo, utilizado por Georges Perec no romance La Disparition totalmente escrito sem a utilização da letra "e", a mais frequente em francês. A aplicação

\footnotetext{
137 "L'écrire, le traduire ne s'accomplissent que s'ils sont une pratique de l'oralité. Et sans doute on n'est une écriture que si on est l'invention de sa propre oralité." ( MESCHONNIC, H. La rime et la vie. Paris: Verdier. 1989, 291)
} 
dessa contrainte levou o tradutor espanhol a suprimir, em El secuestro, a letra "a", o que resultou não numa tradução no sentido estrito do termo, mas um exercício lipogramático em espanhol como o que havia sido feito em francês. Embora procurasse respeitar o enredo e a estrutura do original, numa tradução frase por frase, houve mudanças importantes para que se pudesse manter o lipograma adotado, como podemos ver ao compararmos os trechos seguintes:

L'ami d'Anton Voyl avait pour nom Amaury Conson. Il avait six fils. Son plus grand, qui, par un hasard coïncidant, avait pour nom Aignan, avait disparu, au moins vingthuit ans auparavant, à Oxford, au cours d'un Symposium qu'organisait la Fondation Martial Cantaral, non sans la participation du grand savant anglais Lord Gadsby V. Wright. Son fils suivant, Adam, avait, quant à lui, connu la mort dans un sanatorium où, n'arrivant plus à avoir faim, il tombait d'inanition. Puis, par trois fois, avait surgi la mort: À Zanzibar, un gros poisson avalait Ivan; à Milan, Odilon, qui assistait Lucchino Visconti, succombait, un os trop pointu s'incrustant dans son pharynx. À Honolulu, Urbain mourait d'hirudination: un lombric colossal lui suçait tout son sang, on lui faisait, mais trop tard, vingt transfusions. Amaury n'avait donc plus qu'un fils survivant, Yvon; mais il aimait moins Yvon car Yvon, vivant au loin, voyait son papa trois fois l'an, jamais plus. 138

$\mathrm{Na}$ tradução espanhola foram alterados todos os nomes próprios, de personagens e de lugares, além de outras adaptações como, por exemplo, a morte de Odilon que, no original teve um osso (os) atravessado na laringe e na tradução foi engolido por um urso (oso):

El íntimo de Tonio Vocel tiene por nombre Emery Consonte. Tuvo seis hijos. Su primogénito, cuyo nombre - es curioso - es Gustín K. se esfumó, de eso hizo, por lo menos, dos decenios y pico, en Quebec, en el curso de un Simposio dirigido por el centro de estudios del científico de Locus Solus y presidido por el erudito inglés Lord Ernest Vincent Wright. Su siguiente hijo, Ernesto, sucumbió por el sinérgico poder que los helmintos desenvolvieron en su intestino. Después, el exterminio se repitió tres veces: en el Sind Isidoro murió desnutrido por no poder pedir de comer en sindhi; en Turín Odilón, script de Luchino Visconti, fue engullido por un oso de los del filme. En Honolulú, Ugolino, pese el seguimiento médico de que gozó, murió por fuerte crisis de sinusitis. Emery sólo tiene, pues, un hijo superviviente, Yvon, pero no lo quiere mucho porque Yvon, que vive lejos, en doce meses sólo suele verlo tres veces, y eso como mucho. 139

\footnotetext{
138 PEREC, Georges. La disparition. Paris: Denoël, 1969, p. 59

139 PEREC, Georges. El sequestro. Tradução de Marisol Arbués, Mercè Burrel, Marc Parayre, Hermes Salceda e Regina veja. Barcelona: Anagrama, 1997, p. 56
} 
Em Les Fleurs bleues, no entanto, não são as contraintes que determinam o tipo de tradução a ser feita, pois elas incidem sobre o a estrutura do romance, e por isso não acarretam problemas específicos para a tradução: a estrutura binária do romance, o número de capítulos, o intervalo entre os períodos históricos são naturalmente mantidos numa tradução de forma transparente. Se, por um lado, uma tradução pela contrainte, como a de La disparition não seria adequada pelo fato de as contraintes não incidirem sobre o significante, por outro lado, como a ambientação do romance na França é essencial já que ele é pautado pelos elementos da história e da geografia francesas, também não seria adequada uma tradução totalmente livre como a que foi realizada por Luiz Rezende para os Exercices de style. Nesse livro o narrador conta seu encontro, num ônibus, com um jovem de pescoço comprido, que usava um chapéu com uma trança em vez de fita. Esse jovem troca algumas palavras com outro passageiro e vai sentar-se num lugar livre. Mais tarde, o narrador revê o jovem discutindo com um amigo que o aconselha a mudar o botão superior de seu sobretudo. Essa história é contada 99 vezes, em cada uma com um estilo diferente. Nesse caso, o importante é o estilo e não a história, por isso a tradução, como diz Márcia Arbex, "comporta criações e adaptações, tendo o tradutor por diversas vezes radicalizado e ampliado os efeitos dos jogos de linguagem de Queneau, optando por lançar mão, sempre que possível, do repertório oral e escrito brasileiro". ${ }^{140}$ Rezende introduz inclusive pontos de referência geográfica brasileiros, como, por exemplo no texto "Metaforicamente", em que traduz " $A u$ centre du jour, jeté dans le tas des sardines voyageuses d'un coléoptère à l'abdomen blanchâtre..." ${ }^{141}$ por "O astro apolíneo parecia ter imobilizado seu tão célere curso em zenital posição e dardejava implacável no meridião escaldante como as dunas de Copacabana, exasperando o sufoco da massa compacta num coleóptero de alvo abômen, tal sardinhas em lata..." ${ }^{142}$, ou ainda em "Negatividades", em que traduz "Ce n'était ni la gare du Nord, ni la gare de Lyon, mais la gare Saint-Lazare." 143 por "Nem a Luz nem a Central, mas São Lázaro." 144

\footnotetext{
140 ARBEX, Márcia. Exercícios de estilo com "sotaque tupiniquim": Luiz Rezende tradutor de Raymond Queneau. disponível em $<$ http://www.letras.ufmg.br/poslit/08_publicacoes_pgs/Eixo\%20e\%20a\%20Roda\%2018,\%20n1/07-MarciaArbex.pdf>, p. 133

141 QUENEAU, Raymond. Exercices de style. Paris: Gallimard, 1947. p. 11

142 Id. Exercícios de Estilo. Tradução de Luiz Rezende. Rio de Janeiro: Imago, 1995, p. 22

143 Id. Exercices de style. Paris: Gallimard, 1947. p. 29

144 Id. Exercícios de Estilo. Tradução de Luiz Rezende. Rio de Janeiro: Imago, 1995, p. 36
} 
Em Les Fleurs bleues, uma "adaptação" à brasileira, em nome de uma “domesticação" do original, para retomar o conceito de Venuti ${ }^{145}$, ou aclimatada, em nome de uma apropriação cultural, são soluções que, certamente, não contemplam o que entendemos por tradução. Nesse romance, o jogo do significante não é imposto pelas contraintes, mas é um trabalho muitas vezes elaborado pelo autor pelo puro prazer de jogar com a língua francesa, fiel a seu objetivo de inclusão da língua falada na literatura. Ele cria provérbios, trocadilhos, e neologismos, provoca aliterações e faz alusões ou citações, mas esse trabalho não contribui para a evolução do enredo, ao contrário, quebra-o, interrompendo o fluxo dos acontecimentos e chamando para si a atenção do leitor, o que, aliás, é feito algumas vezes de modo explícito pelas próprias personagens ou pelo narrador. Ao traduzir, há, pois, a necessidade de adaptações para que esses trabalhos com a língua sejam restituídos em português, pois trata-se aí de manipulação de significantes da língua de chegada.

Para que seja possível a tradução para o português de um romance tão peculiar em relação ao uso da língua francesa, há que se levar em conta as características dos dois sistemas linguísticos.

\subsection{OS SISTEMAS FRANCÊS E BRASILEIRO}

O tradutor deve manter, no texto traduzido, as marcas textuais encontradas no original, mas como fazê-lo se cada língua é um sistema diferente, se sua evolução se processa de modo diferente e suas características fonéticas, prosódicas e ortográficas são diferentes?

No Brasil, no início do século XX, a preocupação não era, como na França, a diferença entre língua falada e escrita, mas a distinção entre o português falado no Brasil e o português de Portugal. "No Brasil, a questão de uma língua nacional e popular distinta do português era colocada através do romance social do Nordeste de Jorge Amado e, em 1928, pelo modernismo de Mário de Andrade em Macunaíma, a personagem do índio negro branqueado". 146

\footnotetext{
145 No sentido dado por Lawrence Venuti: "o fato da tradução é apagado através da supressão das diferenças lingüísticas e culturais do texto estrangeiro, assimilando-o aos valores dominantes na cultura da língua-alvo, tornando-o reconhecível e, dessa forma, aparentemente não traduzido. Com essa domesticação o texto traduzido passa por original, uma expressão da intenção do autor estrangeiro" (Venuti, L. O escândalo da tradução. In: Tradterm 3, São Paulo, 1996. p. 111)

146 "Au Brésil, la question d'une langue nationale et populaire distincte du portugais était posée à travers le roman social du Nordeste de Jorge Amado et, en 1928, par le modernisme de Mário de Andrade dans Macounaïma, le personnage de l'Indien noir blanchi." (ROUSSIN, Philippe. Misère de la littérature, terreur de l'histoire. Paris: Gallimard, 2005, p. 263).
} 
A afirmação de Philippe Roussin é corroborada por Mário de Andrade, que escreve na introdução de sua Gramatiquinha:

Essa língua oficial se chama língua portuguesa e vem feitinha de cinco em cinco anos dos legisladores lusitanos. O governo encomenda gramáticas de lá e os representantes da nossa maquinaria política, os chamados empregados públicos, que com mais acerto se chamariam de empregados governamentais, presidentes, deputados, senadores, chefes-de-seção etc. etc. etc. são martirizados pela obrigação diária de falar essa coisa estranha que de longe vem. Só por eles, os empregados governais de graduação rica, essa língua escrita é mais ou menos, muito menos, falada. ${ }^{147}$

Uma das possibilidades de se restituir numa tradução brasileira os elementos de língua falada do francês seria a utilização dessa língua brasileira. De fato, há um certo paralelismo entre língua brasileira e língua portuguesa e francês falado e francês escrito, mas isso não basta, porque a diferença entre a língua escrita e a língua falada em que "há a espontaneidade que envolve e dá cor à expressão do pensamento e torna a gramática instável" 148,, c aracterística que Queneau identificou no francês e procurou introduzir em seus romances, está presente em todas as línguas vivas, inclusive na própria língua brasileira. pois "a língua escrita não pode (...) fazer descobrir as verdadeiras características de uma língua viva; pois, por sua própria essência, ela está fora das condições da vida real" ${ }^{149}$.

Há, no entanto, diferenças importantes entre os sistemas linguísticos francês e português. O francês possui categorias e ferramentas especializadas para a escrita. Há, por exemplo, sistemas verbais distintos para a narrativa e para o discurso, o sistema do "passé simple", praticamente obrigatório na narrativa, e o do "passé composê", utilizado na língua falada. Trata-se de dois tempos verbais concorrentes, cuja distribuição corresponde - em parte - ao escrito e ao oral, uma vez que o primeiro é um tempo verbal que manifesta a ruptura com a situação de enunciação, e o outro, ao contrário, revela uma relação com a situação de enunciação. Em português, embora tenhamos um tempo verbal, o mais-que-perfeito simples, que não é mais utilizado na língua falada, assim como a questão da colocação pronominal, em que a mesóclise também já não se encontra na língua falada, essas características não podem ser comparadas ao "passé simple" do francês, porque não são obrigatórias nem na narrativa,

147 PIMENTEL PINTO, Edith. A Gramatiquinha de Mário de Andrade. São Paulo: Duas Cidades, 1990, p. 321.

148 "il y a la spontanéité qui enveloppe et colore l'expression de la pensée et rend la grammaire instable" (ROUSSIN, Philippe. Misère de la littérature, terreur de l'histoire. Paris: Gallimard, 2005, p. 272).

149 "la langue écrite ne peut (...) faire découvrir les véritables caractères d'une langue vivante ; car, par son essence même, elle est en dehors des conditions de la vie réelle" (ROUSSIN, Philippe. Misère de la littérature, terreur de l'histoire. Paris: Gallimard, 2005, p. 275). 
isto é, se sua presença caracteriza a língua escrita, sua ausência não caracteriza a língua falada.

Além disso, o francês possui uma grafia muito variada para representar o mesmo som, resultado de um grande número de palavras homófonas que só são distinguidas pela ortografia, e que se prestam à elaboração de trocadilhos e jogos de palavras. Nesses casos são consoantes não pronunciadas, na maior parte de origem etimológica, que permitem que se distingam, na escrita, palavras de sentidos diferentes, mas que na pronúncia são exatamente idênticas. São exemplos disso as 12 formas gráficas diferentes que correspondem ao mesmo som [o]: “au, aux, aulx, eau, eaux, haut, hauts, ho, o, o, oh, os”, significando respectivamente "ao, aos, alhos, água, águas, alto, altos, ho, o, ho, ó, ossos”, e ainda as sete formas para o som [vér]: "vair, ver, verre, verres, vers, vert, verts", significando "pele de animal, verme, vidro, vidros, verso, verde, verdes". De modo geral, como diz Jean-Pierre Jaffré em seu artigo Pourquoi distinguer les homophones?, a ambiguidade dessas palavras pode ser resolvida por vários meios de que a língua dispõe: muitas vezes ela é resolvida pelo contexto e outras vezes pelo fato de a palavra pertencer a categorias gramaticais distintas, mas a heterografia permanece um excelente meio distintivo quando os outros fatores linguísticos falham. Em seguida, chega à conclusão de que "distinguindo o que o oral não distingue, a ortografia dispõe efetivamente de um certo número de procedimentos que, se não existissem, deveriam ser compensados na melhor das hipóteses por opções linguísticas comuns ao oral e ao escrito". 150

Em um livro didático antigo, em que se defende a necessidade da distinção dos homônimos pela ortografia, encontramos a seguinte observação: "Contam-se, em francês, cerca de dois mil homófonos" ${ }^{151}$ seguida de uma extensa lista dos mais freqüentes, entre os quais amandelamende, ancrelencre, dessein/dessin, maître/mettre, raisonner/résonner, tante/tente, voie/voix, que se traduzem respectivamente por amêndoa/multa, âncora/tinta, desígnio/desenho, mestre/metro, raciocinar/ressoar, tia/tenda e via/voz. O falante do francês tem consciência dessa diferença entre grafia e fonética, ao passo que o português, tendo uma representação gráfica mais próxima da fonética, dá a seu falante a impressão, como já dissemos, de que "se escreve como se fala", não tendo, portanto, a mesma preocupação com a ortografia. Isso explica porque a sociedade francesa sempre foi muito avessa a qualquer

\footnotetext{
150 "En distinguant ce que l'oral ne distingue pas, l'orthographe dispose en effet d'un certain nombre de procédés qui, s'ils n'existaient pas, devraient être compensés dans le meilleur des cas par des options linguistiques communes à l'oral et à l'écrit". (JAFFRÉ, Jean-Pierre. Pourquoi distinguer les homophones ?, p. 35 .

151 THIMONNIER, René \& DESMEUZES, Jean. Les 30 problèmes de l'orthographe, p. 63.
} 
reforma ortográfica, pois apenas a ortografia atesta fenômenos fonéticos há muito desaparecidos, enquanto as reformas ortográficas do português ocorrem com relativa frequência, sempre que se percebe um afastamento muito grande entre a realização fonética e a ortografia, pois a escrita é sentida como a representação da fala. ${ }^{152}$

No entanto, ainda que seja considerada como representação da fala, é inegável que em português também existe a diferença entre a língua escrita, culta, e a língua popular, falada quotidianamente e que "a essa língua popular, que se confunde com a língua falada, prestamse um conjunto de traços de qualidade que faltam à língua escrita e que os linguistas atribuem à emoção e à necessidade de expressividade dos falantes" ${ }^{153}$. As distinções entre a língua falada e a escrita não se resumem à representação ortográfica, mas se manifestam também no registro, no nível de língua, com diferenças sintáticas e lexicais. Essas manifestações ocorrem tanto no francês quanto em português, pois sempre "há uma discordância entre língua falada e língua escrita, uma vez que, em favor da economia, da naturalidade, da simplicidade e da expressividade, a língua oral sacrifica a concordância, a regência, a ordem; quando não, sons, sílabas, palavras e frases". 154

Essa discordância se manifesta, evidentemente, de modo particular em cada língua. No francês ocorre, por exemplo, a supressão do "ne" na negação, que é uma marca de oralidade (deformação sintática) que ocorre no francês falado e que não pode ser reproduzida em português, devendo, pois, ser compensada de outra forma, para que seja mantido o efeito de fala espontânea. "A fala popular (...) parece caracterizar o aspecto espontâneo da língua: a ordem das palavras, a topicalização, a justaposição dos enunciados, as frases inacabadas" 155 .

Para que se possam compensar as marcas de língua falada encontradas num texto francês a ser traduzido para o português, deve-se verificar quais as características do português falado que são encontradas no português do Brasil. Urbano cita, entre outras, as seguintes características do português falado no Brasil:

\footnotetext{
152 Cf. DAHLET, V. B. L'orthographe française: entre langue et résistences. e FIORIN, J. L. L'accord sur l'orthographe: une question de politique linguistique. In: Synergies Brésil Numéro spécial 1/année 2010

153 "À cette langue populaire, confondue avec la langue parlée, sont prêtés un ensemble de traits et de qualités censés faire défaut à la langue écrite, que les linguistes rapportent à l'émotion et au besoin d'expressivité des sujets parlants." (ROUSSIN, Philippe. Misère de la littérature, terreur de l'histoire. Paris: Gallimard, 2005, p. 279). 104.

URBANO, Hudinilson. Oralidade na Literatura (O caso Ruben Fonseca). São Paulo: Cortez, 2000, p.

155 "Le parlé populaire (...) paraît caractériser l'aspect spontané de la langue : l'ordre des mots, la mise en relief, la juxtaposition des énoncés, l'inachèvement des phrases." (ROUSSIN, Philippe. Misère de la littérature, terreur de l'histoire. Paris: Gallimard, 2005, p. 280).
} 
a) fonéticas:

redução de ditongo (mantega por manteiga);

reduções aferéticas ou sincopadas (tava por estava ou pra por para);

redução de nd a $\mathbf{n}$ e de $\mathbf{m b}$ a $\mathbf{m}$ (falano por falando ou tamém por também);

adições e prolongamentos (voceis por vocês);

supressão do $\mathbf{r}$ final dos infinitivos em ar (precisamos pará por parar);

b) sintáticas:

colocação pronominal (Me dá um copo d'água?);

regência verbal (assistir [a] um filme / tenho a impressão [de] que ele ficou magoado / fui na feira);

concordância (aqueles monte de pedra / temos que se unir);

correlação de tempos verbais (se eu pudesse, também era empresário).

Esses são, segundo Urbano, os recursos disponíveis para que se possam apresentar, em português do Brasil, diálogos em que se reconheçam elementos de língua falada.

Nossa tradução do romance Les Fleurs bleues pretende ser uma tradução que permita ao leitor brasileiro perceber as camadas de sentido percebidas pelo leitor do original. Katharina Reiss, quando trata da tradução de um texto literário, afirma que, nesses textos, os conteúdos no texto alvo devem ser transmitidos em uma organização artística análoga. Nesse caso é necessária uma tradução por identificação, em que o tradutor identifica-se com a intenção artística e criativa do autor a fim de manter a qualidade artística do texto ${ }^{156}$.

Cabe aqui uma consideração que julgamos importante sobre a "intenção do autor". O tradutor tem diante de si um texto, cujas marcas textuais e organização lhe permitem, na sua leitura, construir um sentido, sentido que não é, pois, inerente ao texto. Não é possível, portanto, saber qual o sentido que o autor quis dar ao texto nem qual a intenção do autor. Na realidade, como já dissemos, o tradutor enquanto leitor do original identifica nele os elementos que lhe permitiram construir um sentido e se propõe, como sua intenção, transmitir esses elementos ao seu leitor.

156 REISS, Katharina. Type, kind and individuality of text - Decision making in translation. In: VENUTI, Lawrence. The Translation Studies Reader. New York: Routledge. p. 167. 
O tradutor, na sua leitura do original constrói um sentido, mas esse sentido não é único, por isso, na criação do texto traduzido, ele deve procurar manter as características do original para que seu leitor também possa construir um sentido na sua leitura do texto traduzido. Segundo Laranjeira, "não se trata, para o tradutor, de 'conseguir dizer' aquilo que o autor 'quis dizer', mas sim de 'fazer' algo semelhante ao que o autor 'quis fazer'" 157. Imbuído do sentido criado nele pelo original, o tradutor escreve seu próprio texto, segundo sua intenção em relação ao seu leitor, "o bom tradutor é o que produz um bom texto, um bom poema, autônomo, como objeto que, uma vez criado, passa a valer e a viver por si mesmo na relação que gera com seu leitor" ${ }^{158}$.

O resultado dessas considerações é uma tradução que, com o objetivo proposto de permitir ao leitor brasileiro ter a mesma percepção que o leitor do original, procura manter as marcas textuais e a oralidade do original. Trata-se de uma tradução em que ocorrem negociações que não pretende ser nem completamente domesticadora a ponto de, como diz Vanuti, produzir a invisibilidade do tradutor, 159 nem essencialmente estrangeirizadora, mas que, considerando o texto como um conjunto de marcas a serem transpostas para outra língua, adota soluções que permitam ao seu leitor brasileiro a construção da significância, procurando, seguindo Meschonnic, "abandonar a representação da tradução como 'transporte', e encará-la como 'relação' (...) a relação ética não implica num literalismo rigoroso, como pensava Berman, mas um respeito ao texto em sua coerência material, isto é, antes de tudo, sua rítmica". 160 Procuramos realizar uma tradução que, poderíamos denominar "transcriativa", segundo a poética de Haroldo de Campos: "Então, para nós, tradução de textos criativos será sempre recriação, ou criação paralela, autônoma porém recíproca. [...] Numa tradução dessa natureza, não se traduz apenas o significado, traduz-se o próprio signo, ou seja, sua fisicalidade, sua materialidade mesma". ${ }^{161}$

Veremos, no próximo capítulo, exemplos de oralidade e de língua falada presentes em Les Fleurs bleues e as soluções por nós adotadas na tradução.

\footnotetext{
157 LARANJEIRA, Mário. Poética da Tradução. São Paulo: Edusp, 1993, p. 35.

158 Ibid, p. 38.

159 Cf. VENUTI, L. The Scandals of Translation: Towards an Ethics of Difference, New York: Routledge, 1998 p. 11

160 "abandonner la représentation de la traduction comme «transport », et l'envisager comme « rapport » (...) le rapport éthique n'implique pas un rigoureux littéralisme, comme le pensait Berman, mais un respect du texte dans sa cohérence matérielle, c'est-à-dire, avant tout, sa rythmique." (SUCHET, M. Outils pour une traduction postcoloniale. Paris: Éditions des archives contemporaines, 2009, p. 173)

161 CAMPOS, H. "Da tradução como criação e como crítica", In: Metalinguagem \& outras metas. São Paulo: Perspectiva, 2004. p. 35
} 


\section{ANÁLISE DA TRADUÇÃ $O^{162}$}

\subsection{A QUESTÃO DOS NOMES PRÓPRIOS}

De acordo com o Tratado de Ortografia da Língua Portuguesa, de Rebelo Gonçalves, publicado pela primeira vez em 1947, pela Livraria Atlântida (Coimbra), a regra é a manutenção dos nomes próprios segundo a sua língua de origem, "exceto nos casos consagrados pelo uso".

Em nossa tradução, procuramos seguir essa regra, sobretudo nos nomes de lugares, em que foram mantidos como no original Périgord, Arcueil, Sainte Chapelle, e Notre-Dame, entre outros; e traduzidos para o português Égypte (Egito), Cartage (Cartago), Florence (Florença), e Bastille (Bastilha), por exemplo. Quando se tratava de nomes fictícios, de hospedarias e bares como Sirène torte ou Bar Biture, traduzimos para Sereia Torta e Bar Bitúrico, respectivamente.

O mesmo critério foi adotado em relação aos personagens históricos. Mantivemos nomes como Anne Vladimirovitch e Gilles de Rais e traduzimos aqueles que são conhecidos em português, como Scipion (Cipião), Hannibal (Aníbal), Louis IX (Luís IX), Adam (Adão), Ève (Eva), Quichotte (Quixote), Achille (Aquiles), e Homère (Homero), entre outros.

O problema maior se coloca quando se trata das personagens fictícias. A recomendação de se manter os nomes próprios como na língua de origem prende-se ao fato de considerá-los como não portadores de sentido.

Benveniste afirma que, no signo linguístico, a relação entre a imagem acústica que é o significante e o conceito que é o significado não é arbitrária, mas necessária: "O significante é a tradução fônica de um conceito; o significado é a contrapartida mental do significante. Essa consubstancialidade do significante e do significado garante a unidade estrutural do signo linguístico."163 Em seguida, uma vez estabelecida essa constituição do signo como união indissolúvel de significante e significado, define o que é a arbitrariedade do signo: "O que é arbitrário é que um signo, mas não outro, se aplica a determinado elemento da realidade, mas não a outro.",164

Segundo a definição de que o nome próprio não significa, apenas indica o objeto que nomeia, assim como a fumaça indica que há fogo, não tendo significado, ele seria um

\footnotetext{
162 Neste capítulo, nas citações do romance Les Fleurs bleues, anotaremos apenas os números das páginas.

163 BENVENISTE, E. Problemas de Lingüística Geral I. Campinas: Pontes, p. 56.

$164 \quad$ Ibid, p. 56.
} 
significante ligado diretamente ao objeto, numa ligação que, como vimos, é arbitrária. Dessa forma, não haveria por que traduzi-lo.

No entanto, essa concepção de nome próprio é contestada desde Platão, que afirma nas palavras de Crátilo, citadas por Barthes em seu artigo Proust et les noms que "A propriedade do nome consiste em representar a coisa tal qual ela é". ${ }^{165}$ Segundo essa definição o nome próprio seria um signo cuja ligação com o objeto que nomeia não é arbitrária, mas motivada. Diz Barthes : "o nome próprio também é um signo, e não um simples índice que designaria, sem significar, como quer a concepção corrente". ${ }^{166}$

Em literatura, é dificil imaginar que o autor cria os nomes de forma aleatória. Um escritor trabalha com a língua e é provável que na escolha dos nomes de suas personagens, procure aquele que mais se adapte ao perfil físico ou psicológico destas:

Quando um escritor inventa um nome próprio, na verdade está preso às mesmas regras de motivação que o legislador platônico quando quer criar um nome comum; ele deve de um certo modo, 'copiar' a coisa, e como isso evidentemente é impossível, pelo menos copiar a maneira pela qual a própria língua criou alguns de seus nomes. $^{167}$

Além desse tipo de motivação "cultural”, baseada na forma de criação de palavras na língua, Barthes identifica, no caso de Proust, um outro tipo, que seria baseado na "fonética simbólica" e dá exemplos em que a nobreza estaria relacionada com nomes em que há vogais longas:

... sistema onomástico, articulado sobre a oposição entre aristocracia e plebeus de um lado, e sobre a das longas com finais mudos (finais em que há de algum modo uma longa cauda) e as breves abruptas de outro lado: de um lado o paradigma dos Guermantes, Laumes, Agrigente, do outro o dos Verdurin, Morel, Jupien, Legrandin, Sazerat, Cottard, Brichot, etc ${ }^{168}$

165 "La propriété du nom consiste à représenter la chose telle qu'elle est." (BARTHES, Roland. Proust et les noms. In: Le degré zéro de l'écriture suivi de Nouveaux essais critiquesParis: Éditions du Seuil, 1953, et 1972, p. 128).

166 "Le Nom propre est lui aussi un signe, et non bien entendu, un simple indice qui désignerait, sans signifier, comme le veut la conception courante" (BARTHES, Roland. Proust et les noms. In: Le degré zéro de l'écriture suivi de Nouveaux essais critiquesParis: Éditions du Seuil, 1953, et 1972, p. 125).

167 "Lorsqu'un écrivain invente un nom propre, il est en effet tenu aux mêmes règles que le législateur platonicien lorsqu'il veut créer un nom commun; il doit, d'une certaine façon, 'copier' la chose, et comme ç'est évidemment impossible, du moins copier la façon dont la langue elle-même a créé certains de ses noms." (BARTHES, Roland. Proust et les noms. In: Le degré zéro de l'écriture suivi de Nouveaux essais critiquesParis: Éditions du Seuil, 1953, et 1972, p. 130-131).

168 “... système onomastique, articulé sur l'opposition de l'ariscocratie et de la roture d'une part, et sur celle des longues à finales muettes (finales pourvues em quelque sorte d'une longue traîne) et des brèves abruptes d'autre part: d'un côté le paradigme des Guermantes, Laumes, Agrigente, de l'autre celui des Verdurin, Morel, 
Barthes chega mesmo a caracterizar a escrita literária como aquela em que está sempre presente o "realismo que pretende que os nomes sejam um 'reflexo' das ideias" que ele observou em Proust:

... podemos nos perguntar se ele não está mais ou menos conscientemente presente em todo ato de escrita e se é realmente possível ser um escritor sem acreditar, de uma certa maneira, na relação natural dos nomes e das essências: a função poética, no sentido mais largo do termo, seria definida assim por uma consciência cratiliana dos signos e o escritor seria o recitador desse grande mito secular que quer que a linguagem imite as ideias e que, contrariamente às precisões da ciência linguística, os signos sejam motivados. ${ }^{169}$

Assim, não poderíamos simplesmente manter os nomes dos personagens de Les Fleurs bleues como no original, sem antes pelos menos analisá-los. Se Queneau trabalha a linguagem de forma que notamos a cada página uma profusão de jogos de palavras, trocadilhos, aliterações, etc, seria pouco provável que, ao escolher os nomes das personagens, ele o fizesse ao acaso. De fato, o próprio Queneau anotou em seus diários algumas reflexões sobre os nomes de suas personagens. ${ }^{170}$ Como veremos a seguir, o escritor se utiliza de vários artifícios para dar significado a esses nomes: nomes comuns, como no caso de Auge, Empoigne, Cidrolin (cidre), Cuveton (cuve), Riphinte (rit/feinte); homofonia, caso de Cidrolin (si drôle, hein), Bélusine (belle usine), Cuveton (que veut-on), Pouscaillou (pousse cailloux), Hégault (égaux e égo); recurso à etimologia, como em Pigranelle (lat. pigra), Phélise (lat. felix), Onésiphore (gr. onesis e phore); derivação, como em Mouscaillot (de mouscaille); referência a personagens históricas, como Démostènes (ao filósofo grego), Stéphane (ao santo católico ou talvez a Mallarmé), Timoleo Timolei (a Galileo Galilei). Mesmo quando se trata de um nome próprio de uso corrente como Joachim, Queneau encontra uma motivação, ainda que seja explicá-lo por meio de um acróstico.

O nome do duque, Auge, designa uma região da Normandia. A Normandia é a região em que Queneau nasceu, e citada algumas vezes em expressões como "Les Normands

Jupien, Legrandin, Sazerat, Cottard, Brichot, etc" (BARTHES, Roland. Proust et les noms. In: Le degré zéro de l'écriture suivi de Nouveaux essais critiquesParis: Éditions du Seuil, 1953, et 1972,p. 132)

$169 \quad$ “... on peut se demander s'il n'est pas plus ou moins consciemment présent dans tout acte d'écriture et s'il est vraiment possible d'être écrivain sans croire, d'une certaine manière, au rapport naturel des noms et des essences: la fonction poétique, au sens le plus large du terme, se définirait ainsi par une conscience cratyléenne des signes et l'écrivain serait le récitant de ce grand mythe séculaire qui veut que le langage imite les idées et que, contrairement aux précisions de la science linguistique, les signes soient motivés." (BARTHES, Roland. Proust et les noms. In: Le degré zéro de l'écriture suivi de Nouveaux essais critiquesParis: Éditions du Seuil, 1953, et 1972,p. 134)

170 As análises dos nomes das personagens de Les Fleurs bleues, assim como as citações dos diários de Queneau foram extraídos do site www.ac-versailles.fr/pedagoge/Lettres/queneau/fbnomp.htm 
buvaient du calva" (13 e 15), repetida três vezes, "une plage normande" (50) e "quelque pâturage normand" (228). Como substantivo comum, "auge" é o cocho, recipiente de madeira onde se dá de comer aos animais, particularmente aos porcos. Queneau havia anotado em seu diário outra grafia para esse nome: Oge, que é o palíndromo de Ego, retomado posteriormente no pseudônimo Hégault, usado pelo duque d'Auge durante a Revolução Francesa. A tradução mantém Auge, que em português também provoca um estranhamento, pois como substantivo comum que significa o topo, o ponto máximo, e, apesar de, ao contrário de seu significado em francês, não ter uma conotação negativa, nada nobre (mangedoura de porcos), permite pensar no alto do torreão de onde o duque observa a situação histórica.

Cidrolin, pela sonoridade da terminação, faz imediatamente lembrar o Verdurin, citado por Barthes como exemplo de nome plebeu. Ainda a sonoridade, já na primeira leitura, nos fez pensar em "si drôle, hein?" (tão engraçado, hein?). Há ainda uma alusão à cidra, bebida feita de maçã, própria da Normandia, região do duque. Em português, Cidrolin também pode aludir à cidra, e além disso, sua pronúncia, que soa como um diminutivo, faz com que pareça um apelido com a mesma conotação plebeia percebida por Barthes na terminação francesa "in". Consideramos a possibilidade de aportuguesar a ortografia para Cidrolim, mas, finalmente, optamos por não fazê-lo e por manter a grafia do original, pois é um nome que situa o personagem no ambiente francês do romance. Afinal, Cidrolin passa seu tempo tomando essência de funcho (pastis), e um Cidrolim brasileiro tomaria provavelmente destilado de cana de açúcar (cachaça).

Outros nomes foram mantidos no original, como Ciry, Torves, Malplaquet, Cuveton, Mouscaillot, Empoigne, Martin, Élodie e Pouscaillou. Alguns desses nomes têm em francês alguns significados que foram perdidos na tradução: Cuveton, por exemplo, é um jogo de palavras com "cuvette" (cuba) e com a expressão "cuver son vin" (deixar passar a ressaca), e além disso lembra frases como "que veut-on" (o que querem); Mouscaillot deriva de "mouscaille" que é ao mesmo tempo excremento e miséria, azar; Empoigne, de "empoigner", agarrar; e Pouscaillou "pousse cailloux", empurra pedras. Consideramos que uma tradução que mantivesse as alusões do original seria uma tentativa vã que resultaria em nomes exóticos em português, além de perder a aparência francesa que permite integrá-los no ambiente do romance.

Alguns nomes, no entanto, tiveram a sua grafia aportuguesada, como Hector (Heitor) e Albert (Alberto), por serem de uso corrente em português. 
Em outros casos, finalmente, optamos por traduzir ou adaptar, pois com poucas modificações, poderiam manter em português as alusões contidas no francês, sem que acarretasse numa adaptação tão grande a ponto de tornar inverossímil a existência do nome num romance ambientado na França. Vejamos esses casos.

Pigranelle pode fazer referência ao adjetivo latino "pigra" (preguiçosa), embora essa referência não seja evidente na história. Na tradução optamos pela forma aportuguesada Pigranela.

Bélusine, além da referência a Mélusine, fada de lendas medievais francesas, soa como "belle usine". Optamos também por aportuguesar, pois Belusina mantém tanto a referência a Melusina, embora ela não seja tão evidente para os brasileiros, quanto a sonoridade "bela usina".

Phélise, forma feminina de "felix" (feliz), traduzimos por Feliza, que mantém a mesma referência de forma ainda mais imediata, uma vez que o adjetivo "feliz" não obriga o leitor a passar pelo latim para chegar a "Feliza", ao contrário do que ocorre em francês, em que o adjetivo é "heureux".

Os nomes das filhas de Cidrolin, Bertrande e Sigismonde são comuns no masculino, mas raros no feminino, e os de seus maridos, Yoland e Lucet, ao contrário, são comuns no feminino e raros no masculino. Na tradução, procuramos seguir o mesmo critério e usamos Orlanda, Sigismunda, Iolando e Lizeto.

O nome da filha mais nova de Cidrolin, Lamélie é um nome frequente, Amélie ao qual foi incorporado o artigo definido cujo uso é muito familiar diante de um nome próprio. Também encontramos o artigo incorporado no nome de Lalix, noiva de Cidrolin. Seguindo o mesmo procedimento em português, traduzimos respectivamente por Aamélia e Aalice. Cumpre observar que Amélia, para o leitor brasileiro, é uma referência imediata à música popular em que se afirma que "Amélia que era mulher de verdade", sempre disposta a trabalhar sem pedir nada em troca; essa referência, inexistente em francês, é pertinente dentro do romance, já que, quando a personagem se casa, a única preocupação de seu pai foi a de encontrar uma substituta que cozinhasse para ele e mantivesse a sua chata limpa e em ordem.

Entre as personagens que acompanham o duque há dois religiosos o abade Onésiphore Biroton e o diácono Riphinte. Onésiphore, que é também o nome do dono do Bar Bitúrico, soa como "on est si fort" (somos tão fortes) e vem do grego onesis (lucro) e phore (que traz). Embora perdendo a alusão a ser forte, traduzimos de acordo com as regras de 
derivação do grego para Onesíforo. O sobrenome, Biroton, alude ao abade Birotteau, personagem de Le Curé de Tours, de Balzac; mantivemos Biroton na tradução, lembrando que em português, evoca algo como "birutão", gíria significando "meio louco". Quanto a Riphinte, em francês lembra "rit" e "feinte" ("ri" e "fingimento"). Em português, traduzimos por Rifinge, que mantém as mesmas alusões.

Russule, nome da esposa do duque, significa "avermelhado" e é também o nome de um tipo de cogumelo. Aportuguesamos para Russula, que em português tem os mesmos significados.

Muitos nomes tinham um efeito particular na história e por isso também tiveram que ser traduzidos ou mesmo adaptados. É o que ocorreu nos seguintes casos:

a) os nomes e os apelidos dos cavalos Démosthène, Démo e Sthène; e Stéphane, Sthéphe fazem clara referência ao filósofo grego e ao santo católico, o que obrigou a tradução para Demóstenes, Demós e Stenes; e Estêvão;

b) num episódio são citados os nomes dos cinco cachorros do duque: Tä̈au, Tä̈o, Thaillault, Allali e Cétera. Além de ser homófono de "taïaut", chamado de caçadores para indicar a caça, o efeito de humor é provocado pelo fato de que os três primeiros se pronunciam da mesma maneira apesar da variedade de grafias. Apesar da impossibilidade de manter o sentido referente à caça, procuramos produzir o mesmo efeito de homofonia, usando um nome de cachorro comum no Brasil e, mesmo não contando com os mesmos recursos do francês, criando três grafias diferentes para o mesmo som: Rex, Recs, Recse, Idem e Tcétera;

c) o alquimista do duque chama-se Timoleo Timolei em clara referência a Galileu Galilei. Nesse caso, usamos a grafia portuguesa Timoleu Timolei;

d) num certo momento, Cidrolin usa o sobrenome Dupont, talvez o mais comum em francês, para permanecer incógnito. Nesse caso, usamos da Ponte, que, embora não seja o mais comum em português, existe e permite manter a conotação com o fato de que Cidrolin mora ao lado de uma ponte;

e) também o duque de Auge, na época da Revolução Francesa, para viajar sem ser identificado, hospeda-se com o nome de Hégault, cuja pronúncia é idêntica à de égaux (iguais) e à de égo (ego) latino, que, embora não seja usado em francês, permite pensar na psicanálise. Traduzimos por Higuau, que em português se pronuncia como "igual” e, embora perca a conotação do "ego", mantém o humor da situação em que um nobre viaja incógnito, durante a Revolução, procurando passar por um cidadão igual aos outros. 


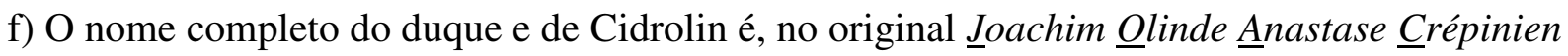
Honorat Irénée Médéric, que é um acróstico do primeiro. Tendo aportuguesado o primeiro para Joaquim, tivemos que procurar nomes que formassem o acróstico: Joaquim Olindo

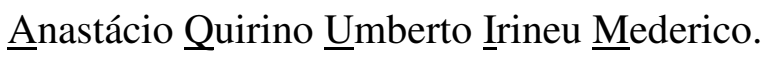

g) O nome do justiceiro Labal é na realidade uma redução de La Balance, símbolo da justiça e

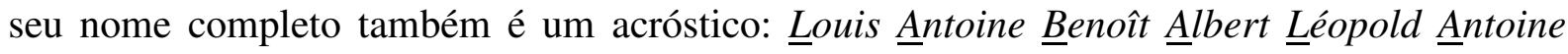
Nestor Charles Émile. Em português, o símbolo da justiça é A Balança, cuja redução passa a

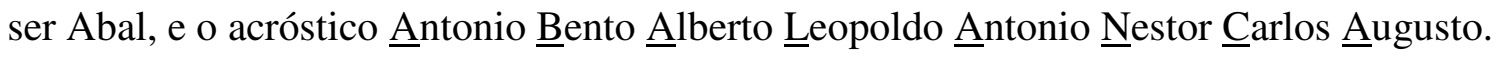

O trabalho com o nome próprio ilustra bem o modo de Queneau tratar o significante e o modo de significação. Ele perturba a relação do signo com o objeto que identifica. O significante passa a ser motivado e Queneau lança mão de qualquer artifício para fazê-lo significar.

\subsection{PROVÉRBIOS}

No episódio em que o povo toma conhecimento do boato de que o cavalo do duque fala, começa a comentar o caso citando vários provérbios. No entanto, não se trata de provérbios existentes, mas inventados por Queneau. Nesse caso, o que importa não é o sentido, mas o aspecto temático, todos os provérbios devem referir-se a animais, já que são motivados pelo cavalo que fala. Mais importante, no entanto, é o aspecto formal, pois como diz Hudinilson Urbano, provérbios "apresentam características recorrentes semelhantes com muita frequência, como rimas, ritmo, paralelismo, estrutura binária, prótase e apódose”. ${ }^{171}$

Vejamos os provérbios criados por Queneau e a sua tradução literal:

Animal qu'a parlé, âme damnée. (34) Animal que falou, alma danada.

Si le coq a ri tôt, l'haricot pue trop.(34) Se o galo riu cedo, o feijão fede demais.

Quand l'huître a causé, l'huis est très Quando a ostra conversou, a porta está cassé. (34) muito quebrada.

$\grave{A}$ poisson qui cause, petit cochon peu Para peixe que conversa, porquinho pouco rose. (35) rosa.

171 URBANO, Hudinilson. Da fala para a escrita: o caso de provérbios e expressóes populares. In Investigações: Linguística e Teoria Literária. Recife, v. 21, n. 2, p. 31-56, jul. 2008, disponível em: http://www.ufpe.br/pgletras/Investigaçoes/Volumes/Vol.21.2/Hudinilson_Urbano.pdf 
Si bêle le zèbre ut, voilà Belzébuth. (35) Se bale a zebra uh, eis Belzebu.

Notamos que há alguns desvios sintáticos como em "animal qu'a parlê" em vez de "animal qui a parlé" e "l'haricot" em vez de "le haricot", ambos de uso corrente no francês falado popular.

Além disso, nos provérbios de Queneau, há um efeito de humor no fato de que a expectativa criada pela prótase não é satisfeita pela apódose que, ao contrário, não tem nenhuma relação com ela. Por isso, embora se reconheça a forma corrente de provérbios, seu ritmo e suas rimas, não podemos reconhecer seu sentido lógico, ligado a situções da vida cotidiana, ou a expressão de uma verdade preestabelecida na cultura popular.

Em nossa tradução, procuramos recriar os provérbios, de acordo com os seguintes critérios: citar animais, manter ritmo e rima e não ter nenhuma relação lógica entre a prótase e a apódose. Quanto aos desvios sintáticos, procuramos compensar com fenômenos próprios do português falado popular, como a redução do ditongo de "feijão" para "fejão" e a redução "pra” por "para". Além disso, modificamos o nome Belzebu para Balzebu, de forma a manter o paralelismo fonético com o verbo balir.

Dessa forma, a tradução final foi:

Animal qu'a parlé, âme damnée. (34) Animal falou, alma se danou.

Si le coq a ri tôt, l'haricot pue trop.(34) Se o galo canta cedo, o fejão fica azedo.

Quand l'huître a causé, l'huis est très Se a ostra cisma, é o ostracismo. cassé. (34)

$\grave{A}$ poisson qui cause, petit cochon peu Pra peixe que prosa, leitãozinho rosa. rose. (35)

Si bêle le zèbre ut, voilà Belzébuth. (35) Se bale a zebra uh, quem fala é Balzebu.

\subsection{TROCADILHOS}

Segundo a definição do dicionário Houaiss, trocadilho é "um jogo de palavras com sons semelhantes e significados diferentes, de que resultam equívocos por vezes engraçados." Os trocadilhos podem resultar do uso de parônimos (palavras semelhantes quanto à forma e ao som), de palavras homófonas (com o mesmo som, ainda que com formas 
diferentes), ou ainda da polissemia das palavras. Resultado dos sons, podemos dizer que os trocadilhos constituem uma manifestação de oralidade, pois embora possamos percebê-los numa leitura silenciosa, isso só é possível porque, na realidade, mesmo na leitura silenciosa, sentimos ecoar o som.

Numa tradução direta, apenas semântica, normalmente o trocadilho se perde, pois as palavras que são parônimas, homófonas ou polissêmicas na língua de partida raramente o são na língua de chegada. Dessa forma, é necessário que se façam adaptações, ou alterações nas frases, as vezes com acréscimos para que os trocadilhos sejam restituídos na língua de chegada.

Queneau, na sua busca incessante do humor e da inclusão de elementos da língua falada, utiliza muito frequentemente esse tipo de jogo de palavras, muitas vezes provocando ou criando expressamente a homofonia com a junção de partes de duas palavras que resultem numa terceira, ou ainda alterando ou criando palavras para provocar o trocadilho. Veremos a seguir exemplos dos vários tipos.

\section{a) homofonia}

Um exemplo de trocadilho criado com o uso de palavras homófonas é: "Sur les bords du ru voisin, campaient deux Huns, non loin d'eux un Gaulois" (13), onde "Huns" (hunos) é homófona de "un" (um) e "d'eux" (deles) é homófona de “deux" (dois), provocando a percepção de uma contagem regressiva "dois um", repetida duas vezes. Nossa tradução, mantivemos a tradução literal "dois hunos", um trocadilho diferente, com alguma perda, já que em português "uno" não é o numeral, mas significa "único". No segundo caso, fizemos uma adaptação ao traduzir "d'eux" por "dos dois" de forma a manter o trocadilho. O resultado foi “Às margens do riozinho vizinho, acampavam dois hunos; não longe dos dois um gaulês”.

Outro exemplo encontramos em "Sarrasins de Corinthe" (13), em que o final da palavra "Sarrasins" é homófona de "raisins" (uvas). Acrescentando "de Corinthe", Queneau força uma leitura separando a primeira sílaba "Sa rasins de Corinthe" resultando na expressão "raisins de Corinthe" que designa a uva passa. Na tradução, alteramos o nome da cidade já que Corinto só foi colocado para construir o trocadilho e, usando o mesmo procedimento, traduzimos por "sarracenos de Mans", em que o final da palavra "sarracenos", homófona de "acenos", permite a leitura "acenos de mão", expressão que é retomada algumas páginas adiante, no capítulo III. 


\section{b) polissemia}

Em maior número, encontramos os trocadilhos baseados na polissemia das palavras. Quando o duque observa a situação histórica, dentre os vários povo, ele vê " $\underline{\text { Francs }}$ anciens" (13); depois, descrevendo o que faziam, "le Gaulois fumait une gitane, les Romains dessinaient des grecques, les Sarrasins fauchaient de l'avoine" (13). No primeiro caso, o trocadilho vem da polissemia da palavra "franc" que, além de designar o povo, designa também a moeda francesa da época, de forma que a expressão "francs anciens" faz alusão à moeda antiga. A tradução literal "francos antigos" permite o mesmo efeito pois em português a palavra "franco" também tem os mesmos sentidos. Já no segundo, a polissemia depende de um fato cultural francês, pois "gauloises" et "gitanes" são duas marcas muito populares de cigarros franceses. Nesse caso a polissemia não existe em português e o trocadilho é totalmente perdido na tradução. Optamos então por uma compensação, fazendo um trocadilho entre "gaulês" e "galo" e usando ainda uma expressão idiomática, traduzimos por " o gaulês cantava de galo". O terceiro exemplo resulta da polissemia de "grecque" que, além de designar a mulher nascida na Grécia, designa também um tipo de ornato geométrico usado em frisos e barras. Mantivemos a tradução literal "os romanos desenhavam gregas”, já que em português a palavra também tem os dois significados. Finalmente, o último trocadilho vem da polissemia de "Sarrasins" que, além do povo, designa uma espécie de trigo. Embora tenha esse sentido também em português, a referência não é tão imediatamente reconhecida por brasileiros quanto por franceses. Em nossa tradução, em vez de "aveia" (avoine) usamos "cevada", de forma a, além de permitir a referência aos cereais, criar uma aliteração em /s/: "os sarracenos ceifavam cevada".

Outro exemplo de trocadilho baseado na polissemia encontramos no momento em que Cidrolin recebe uma campista canadense em sua chata: "Encore une Canadienne que je

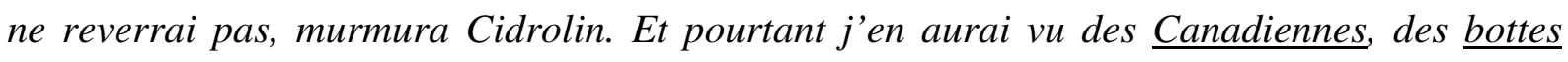

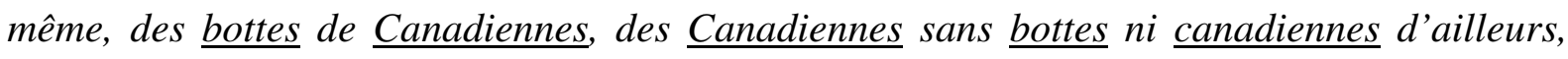
parce que toutes celles que je vois c'est en été." (39). Aqui temos duas palavras polissêmicas, "canadienne" que designa a mulher natural do Canadá mas pode ser também uma roupa longa forrada de pele de carneiro e ainda uma pequena barraca de camping. A outra palavra é "botte" que, além de significar "bota" significa também "feixe". Com esse último sentido, é retomada, dois parágrafos abaixo, descrevendo o momento em que o duque desperta: "couché à ses pieds sur une botte de paille, le fidèle page Mouscaillot". Em nossa tradução o trocadilho com "canadienne" se perdeu, mas para mantermos pelo menos o segundo, fizemos 
uma adaptação usando a palavra "forrado" que tanto pode significar "revestido", pode também dar ideia de grande quantidade. Além disso, essa palavra também pôde ser retomada na descrição do despertar do duque. Conscientes das perdas, traduzimos por "Mais uma canadense que eu não vou ver mais, murmurou Cidrolin. E no entanto o que já vi de canadenses, já vi isso aqui cheio de canadenses, forrado mesmo, forrado de canadenses, de canadenses de botas forradas, de canadenses sem forro, até porque todas as que eu vejo é no verão. (...) ... deitado a seus pés no chão forrado de palha, o fiel pajem Mouscaillot".

Finalmente, quando um dos genros do duque admira a mobília moderna, estilo Louis XIII, Mouscaillot comenta "Monsieur le duc tient à être tout à fait à la page, dit le page" (118), em que a palavra "page" é usada, no sentido de "página" na expressão "être à la page", (estar na moda) e em seguida como "pajem". Em português, a palavra "pajem" não sendo polissêmica, criamos um trocadilho por homofonia entre o final da palavra "roupagem", que, segundo o dicionário Houaiss significa “conjunto de roupas”, mas também, em sentido figurado "aspecto exterior, aparência" e que portanto faz sentido no comentário de Mouscaillot: "O senhor duque faz questão de atualizar a roupagem, diz o pajem”.

\section{c) paronímia}

Quanto ao uso de parônimos, podemos citar dois exemplos. O primeiro, quando, discutindo sobre o perigo de contar histórias, Cidrolin diz a Lalix: "Elles révèlent ce que vous êtes au fond. Tout comme les rêves. Rêver et révéler, c'est à peu près le même mot." (159). Aqui a paronímia entre os verbos "rêver" e "révéler" é explicitada na própria fala da personagem. Ora, em português entre "sonhar" e "revelar" não há nenhuma semelhança, de forma que, na tradução, introduzimos a palavra "sondar" que mantém o sentido e permite o trocadilho explícito: "Nelas pode-se sondar o que se é no fundo. Exatamente como os sonhos.

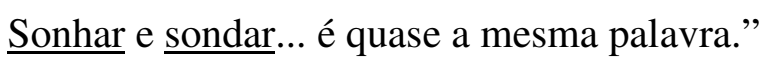

O outro exemplo é um pouco mais complexo. Primeiramente, porque há referência a uma expressão conhecida e facilmente identificada por um francês, "Honni soit qui mal y pense", divisa da Ordem da Jarreteira, criada por Eduardo III da Inglaterra, referência essa que não seria percebida pelo leitor brasileiro. Em seguida porque o duque, de muito bom humor, decide expressamente fazer trocadilho e repete-o três vezes com pequenas alterações. Em cada uma dessas vezes ele retoma alguma palavra recém proferida que rima com "honni" et que pode substituí-la na divisa. Finalmente porque a última dessas palavras é "Copernic", cuja doutrina acaba de ser citada e que, portanto, é necessária no contexto 
devendo obrigatoriamente ser mantida na tradução. Eis os trocadilhos originais: "Nenni, nenni, ma chère. Nenni soit qui mal y pense." (146) "Sthène en était fort satisfait ; quand on

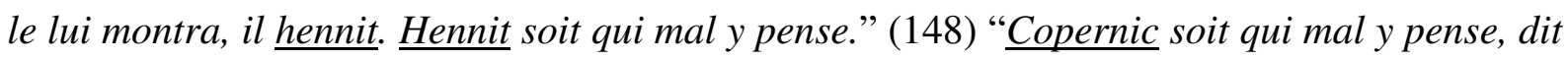
le duc distraitement" (151). Nesse caso, fizemos uma adaptação mais radical. Para que os trocadilhos funcionassem em português, escolhemos uma frase que fosse facilmente reconhecida pelo leitor brasileiro. Essa frase deveria ter uma palavra com o som /é/ para poder soar como Copérnico. Optamos então pelo provérbio "Quem com ferro fere com ferro será ferido". Em seguida, alteramos o cotexto anterior ao trocadilho para introduzir a palavra a ser retomada. O resultado foi: "Não, minha querida, está tudo certo. Quem com certo fere com certo será ferido", "Stenes ficou mui satisfeito; quando lhe mostraram ele disse: esse pintor é fera. Quem com fera fere com fera será ferido", e "Quem Copérnico fere, com pérnico será ferido, disse o duque distraidamente".

\section{d) homofonia criada pela junção de palavras}

Queneau não perde a oportunidade, ao longo de todo o texto de criar humor e exemplo disso são as ocasiões em que deliberadamente ele provoca a homofonia para gerar um trocadilho e consequentemente um efeito de humor. Um exemplo é quando entre os povos que o duque observa, há "Alains seuls" (13) em que o final da primeira palavra mais a seguinte criam uma homofonia com "linceul" (mortalha). Esse trocadilho seria perdido na tradução "alanos solitários". Como no caso o povo citado não é o mais importante, mas sim o jogo de palavras resultante dele, optamos por uma adaptação em que invertemos as referências a alanos e a ossetas de forma a produzir jogos de palavras em português. Em vez de "alanos solitários", o duque vê "ossetas velozes" em que a homofonia do final da palavra permite a leitura "setas velozes". Em outra referência aos mesmos povos, Queneau diz que "les Alains regardaient cinq Ossètes", em que há um trocadilho provocado pela junção das palavras "cinq" et "Ossètes" com a expressão "cinq à sept" que designa uma reunião no fim da tarde, um "happy hour". A opção de alterarmos os povos citados permitiu a tradução por "os ossetas apontavam dois alanos", em que mais uma vez há a possibilidade de leitura "setas apontavam".

Temos outro exemplo quando, conversando com o rei Luís IX o duque diz: “mon saint homme de chapelain, l'abbé Onésiphore Biroton, me mène vers les voies de la sanctification" (25). Aqui a junção das duas palavras "saint homme" (santo homem) é homófona de "symptôme" (sintoma), leitura justificada pelo contexto em que se fala sobre doenças adquiridas nas cruzadas. Duas páginas depois as mesmas palavras são repetidas 
quando o duque fala do rei: “Lui, Louis, ce n'est pas comme moi, c'est un saint homme" (27). Nesse caso, introduzimos algumas palavras que, sem alterar o sentido, permitem que se observe o trocadilho: "meu capelão, o abade Onesíforo Biroton, sim toma medidas para me conduzir ao caminho da santificação" e "Ele, Luís, não é como eu, sinto mas é um santo homem".

O mesmo procedimento é utilizado quando, Cidrolin conversa com uma canadense que procura o camping: “- Je sommes iroquoise, dit-elle, et je m'en flattons. - Il y a de quoi. - C'est de l'ironie? - Non, non. Ne mettez pas d'ire au quoi' (38). Aqui as três palavras juntas são lidas como "iroquois" (iroquês). Procurando manter efeito semelhante em português, traduzimos por “- Eu ser iroquesa, disse ela e me orgulhar muito disso. - Tem de quê. - Isso é ironia? - Ir o quê? Não, não é isso".

Finalmente, um último exemplo, quando, discutindo com o abade sobre a natureza dos sonhos, o duque diz que não falava com serpentes nos sonhos como Eva, ao que o abade responde que Eva não sonhava: “- Bon. Voilà qui me satisfait fort, car jamais n'eus conversation avec un serpent en rêve; ce n'est point comme notre mère Ève. -Elle ne rêvait point." (44), Aqui “mère Ève" é homófona de "mes rêves" (meus sonhos). Na impossibilidade de manter o mesmo trocadilho, introduzimos as palavras "mais sã" que no contexto em que se fala de Eva e de serpente, permite identificar o fruto proibido "maçã”; “- Bom. Isso me deixa mui satisfeito, pois nunca conversei com uma serpente em sonho; não é como nossa mãe Eva. - Eva, mais sã, não sonhava.”.

\section{e) palavras criadas}

Em duas oportunidades, Queneau cria palavras expressamente para criar trocadilhos. Na primeira, tentando convencer o duque a participar de mais uma cruzada, Luís IX diz 'D'abord, cette fois-ci, nous n'allons pas en Égypte (à quoi na sert?) mais nous voguons vers Carthage." (25). Aqui, Queneau usa a palavra "na" em vez de "ça" para possibilitar a leitura de "na sert" como "Nasser", nome do presidente egípcio na época em que o livro foi escrito. Optamos por uma adaptação em que o verbo "nascer", com o acréscimo de um acento também fosse lido em português como "Nasser": "Pra começar, desta vez, nós não vamos ao Egito (o que poderia náscer daí?) mas vogamos na direção de Cartago.".

Na outra passagem, Queneau inventa a palavra "lorique", quando, depois de uma série de provérbios, diz: "Et autres prouverbes de vaste salaison issus du fin fond aussi faux 
que lorique de la sapience îledefrançouèse." (35). Dessa forma "faux que lorique" é lido como "folklorique" (folclórico). Adotamos o mesmo procedimento, criando a palavra "clórico", mas acrescentamos ainda o adjetivo "amorfo": "E outros prouvérbios de vasto alcance tirados do fundo falso amorfo ou clórico da proverbial sapiência francesa." Desta forma, a última sílaba do adjetivo permite a leitura de "fo ou clórico" como "folclórico", causando o mesmo efeito em português.

Novamente, notamos que Queneau não perde uma oportunidade para fazer com que o significante ganhe autonomia e importância. Se o acaso não cria o trocadilho, Queneau cria o acaso, acrescenta, altera ou cria palavras, de modo a forçar uma leitura em que o trocadilho apareça. Tudo é válido para que a evolução da trama e o semântico sejam perturbados pela preponderância do significante.

\subsection{INTERTEXTO E MÉTRICA}

O intertexto só funciona se o leitor for capaz de perceber a referência ou alusão do autor aos outros textos. Nos exemplos citados abaixo, a métrica exerce um papel fundamental pois, mesmo que o leitor não identifique o texto citado, ele percebe o ritmo ditado pela métrica e o fato de ele identificar num texto em prosa um alexandrino, por exemplo, leva a que ele pelo menos imagine que se trata de uma citação ou de uma alusão a um poema existente.

Les Fleurs bleues está repleto de alusões a outras obras literárias, a começar pelo início do primeiro capítulo estruturado, como observou Anne Clancier, como o início do romance Salammbô, de Flaubert. Há ainda muitas alusões a Rabelais. Essas alusões, no entanto, são restituídas na tradução ainda que passem despercebidas pelo tradutor. Caso o leitor conheça as obras referenciadas, ele pode perceber mesmo as alusões que o tradutor não percebeu.

Os casos que analisaremos abaixo são aqueles em que há métrica e que por isso não passam despercebidos. Ainda que não se reconheça o texto referenciado, se houver, percebe-se na leitura que há alguma coisa, que não é por acaso que um alexandrino surge na fala de um personagem.

O primeiro exemplo surge no primeiro capítulo quando, falando da história, o duque diz "Elle flétrit en moi tout ébaudissement" (14). Percebe-se imediatamente o ritmo de um alexandrino perfeito. Além da métrica há a utilização de um léxico não usual na conversação, mais próprio da poesia. Embora não tenhamos encontrado nenhuma referência 
literária, tendo o verso sido criado provavelmente pelo próprio Queneau, procuramos utilizar também na tradução um vocabulário não usual (fenecer, júbilo) e uma construção sintática inesperada (dentro em mim) além de manter a métrica. O resultado foi "Ela faz fenecer dentro em mim todo o júbilo".

O segundo exemplo, também no primeiro capítulo, quando, interrogado pelo cavalo sobre o destino de sua viagem, o duque responde "Loin! Loin! Ici la boue est faite de nos fleurs." (15), a que o cavalo responde “...bleues", citando o título do romance, num efeito de "enjambement". Aqui há uma citação de Baudelaire, um verso de seu poema Moesta et Errabunda, em que há apenas a mudança de uma letra, Baudelaire diz "pleurs" e não "fleurs". Em nossa tradução, optamos por uma adaptação, pois a citação de uma tradução brasileira do verso de Baudelaire não seria possível, já que a mudança de uma letra não criaria a palavra flores, essencial, já que é uma das duas únicas ocasiões em que o título "flores azuis" aparece no romance. Optamos então por um verso do poema Canção do Exílio, de Gonçalves Dias, que além de terminar com a palavra "flores", permitindo o "enjambement", é facilmente reconhecível pelo leitor brasileiro, uma vez que também inspirou um verso do Hino Nacional Brasileiro. A tradução ficou "Longe! Longe! Aqui nossas várzeas não têm flores".

O terceiro exemplo, uma citação do poema "Signe", de Apollinaire, é uma fala de Cidrolin, que percebendo que os campistas começam a partir com a aproximação do outono, diz "Mon automne éternel, ô ma saison mentale." (165). Segue-se uma conversa entre ele e um passante em que Cidrolin explicita que se trata de uma citação "de um poeta, claro. O senhor não ouviu os doze pés?". Nesse caso, utilizamos a tradução de André Dick, "Meu outono eterno ó minha estação mental.", disponível na internet em (http://www.revistazunai.com/traducoes/guillaume_apollinaire.htm), em que a eliminação da vírgula permite a manutenção da métrica, com a leitura da última sílaba de "eterno" e da interjeição "ó” como uma só sílaba.

O último exemplo encontra-se na fala do cavalo Demóstenes que, com saudade de casa, pergunta-se quando reverei minha estrebaria natal "qui m'est une province et beaucoup davantage." (189). Trata-se de uma citação do poema XXXI de "Les regrets" (Heureux qui, comme Ulysse, a fait un beau voyage), de Joachim du Bellay. Nesse caso, utilizamos a tradução de E. Vilhena de Morais, disponível na internet em (http://www.clubedapoesia.com.br/franceses/frajoaqcont.htm): “que é para mim província, ou antes reino." 


\subsection{MISTURA DE LÍNGUAS}

Há no romance várias frases em latim, como a do padre de mobilete que a cada aparição diz "Ad majorem Dei gloriam”, ou nas discussões do duque com o abade, este último entremeira seu discurso de expressões como "distinguo", "ad primam respondi", etc. Essa utilização do latim não traz maiores implicações para a tradução, uma vez que podem simplesmente ser mantidas. Há, no entanto, um episódio em que Cidrolin conversa com um casal de campistas em um diálogo em que se misturam várias línguas europeias e que o próprio Cidrolin chama de neo-babélico. Nesse caso há três procedimentos distintos e para cada um optamos por recursos tradutórios também distintos. Há palavras escritas em língua estrangeira, como "wie sind lost", por exemplo, que na tradução permanecem como no original; há palavras estrangeiras cuja pronúncia é reproduzida com a grafia francesa, como "esquiouze euss" para o inglês "excuse us", que na tradução teve a pronúncia reproduzida pela grafia do português "exquiuzi-ãs"; e há palavras francesas como "bon début", que traduzimos para o português "bom começo". Reproduzimos abaixo um pequeno trecho do início desse diálogo que, no romance, ocupa várias páginas. O trecho reproduzido está na página 18.

- Esquiouze euss, dit le campeur mâle, mà - Exquiuzi-ãs, disse o campista macho, ma wie sind lost. wie sind lost.

- Bon début, réplique Cidrolin.

- Bom começo, replica Cidrolin.

- Capito ? Egarrirtes... lostes. - Capito? Egarrirtes... lostes.

- Triste sort.

- Triste sorte.

- Campigne ? Lontano ? Euss... smarriti... - Câmpingue? Lontano? Âs... smarriti...

- Il cause bien, murmura Cidrolin, mais - Ele fala bem, murmurou Cidrolin, mas parle-t-il l'européen vernaculaire ou le será que fala o europeu vernacular ou o néo-babélien? neo-babélico?

- Ah, ah, fit l'autre avec les signes - Ah, ah, fez o outro com sinais manifestos manifestes d'une vive satisfaction. Vous de uma viva satisfação. Você falar ferchtéer l'iouropéen? iuropeu?

- Un poco, répondit Cidrolin; mais posez - Un poco, respondeu Cidrolin; mas tirem là votre barda, nobles étrangers, et prenez suas tralhas, nobres estrangeiros, e tomem donc un glass avant de repartir. um glass antes de partir. 


\subsection{REPETIÇÕES, RIMAS, ALITERAÇÕES}

A repetição, que o duque de Auge diz ser "uma das mais odoríferas flores da retórica" é utilizada em várias ocasiões. Muitas vezes são repetidos diálogos inteiros, como a discussão dos genros de Cidrolin sobre a televisão. Mas a repetição em si não traz problemas para a tradução. O que comentaremos aqui são os casos em que a repetição comporta outros elementos, como rimas, aliterações ou expressões inusitadas.

Uma expressão que aparece tanto na história de Cidrolin quanto na do duque é “essence de fenouil". Essa expressão que é repetida 64 vezes é inusitada para designar o pastis, bebida alcoólica feita de anis muito comum na França. O efeito de humor vem justamente do fato de, em vez de designar a bebida pelo seu nome corrente, designá-la por uma perífrase que, em vez de simplificar, complica, com uma palavra (fenouil) de uso menos corrente. Num certo momento (p. 246), o duque comenta que não há nenhuma outra palavra que rime com fenouil. Aalice responde que a única forma de encontrar uma rima é mudando o gênero. Traduzimos por "essência de funcho", palavra que também não é muito corrente em português e que permite o comentário sobre a dificuldade de se encontrar rimas, embora perca-se então a alusão maliciosa e irreverente da rima francesa.

Outra expressão "encore un de foutu" é repetida oito vezes por Cidrolin e pelo duque, referindo-se a suas refeições que normalmente lhes desagradam. Usamos na tradução a expressão "mais uma que vai pro brejo" que, não sendo a tradução literal, dá a mesma noção de desapontamento com a utilização de uma expressão popular.

Há, no capítulo IV, uma frase repetida três vezes com alteração na ordem dos termos: "Hagarde, Lamélie le regarde", "Lamélie, hagarde, le regarde" (48) e "Lamélie le regarde, hagarde" (49). Aqui o mais importante é o ritmo e a rima, por isso optamos, na tradução por sacrificar a semântica em seu benefício. Usamos então o verbo avermelhar que permite inferir o estado de espírito de Aamélia e que assim como o adjetivo "séria" rima com o nome. Traduzimos então por "Avermelha Aamélia e olha séria", "Aamélia avermelha e olha séria" e "Aamélia olha séria e avermelha".

Mais um exemplo de rima, provocada pela inversão do verbo e do sujeito, encontramos na frase "Horrifié par ces propos, se signa le héraut" (55). Nesse caso, 
acrescentamos uma palavra para manter a rima: "Horrorizado pelo pensamento incauto, persignou-se o arauto".

O próprio duque chama a atenção para o fato de que há rima, depois de dizer a frase: "On a bien fourré mon excellent ami Donatien à la Bastille pour des peccadilles. Tiens, cela rime." (176). Na tradução, já que a referência à Bastilha era importante no contexto, para a manutenção da rima, alteramos o gênero da palavra "pecadilho", o que não compromete a compreensão e permite a rima e o comentário: "Eles enfiaram meu excelente amigo Donatien na Bastilha por umas pecadilhas. Olha, rimou".

Um último exemplo de repetição com rima encontramos no capítulo $\mathrm{XV}$, quando o duque leva o abade Rifinge para uma caverna no Périgord. A cena é assim descrita: "Ils avancent en silence. (...) Sans cadence, ils avancent, la corde se balance et la lanterne aussi, c'est toujours le silence." (205), e logo em seguida, a repetição "Le duc avance en silence, la corde se balance, l'abbé suit de confiance, la petite lumière aussi se balance" (206). Como em português "avançam" não rima com "silêncio", procuramos compensar com a utilização de palavras como "mudança" e "dança". O resultado foi: "Avançam em silêncio. (...) Sem mudança, o duo avança, a corda balança e a lanterna dança, continua o silêncio." e "Em silêncio, o duque avança, a corda balança, o abade segue com confiança a pequena luz que balança".

A seguir, veremos exemplos de aliterações, encontramos no capítulo IV uma frase com uma flagrante aliteração em /f/: "Lamélie fit demi-tour et voulut fendre le flot de la foule en file" (49). Em nossa tradução, para manter a aliteração, em vez da tradução corrente de foule por multidão, optamos pela palavra "fula", rara, mas existente em português: "Aamélia fez meia volta e quis fender o fluxo da fula em fila”.

No capítulo VII, uma frase com aliteração em /t/, “Hm! tu m'as l'air de tisser toute l'étoffe d'un traître. (87), traduzida por "Hm! você me parece ter toda a tessitura de um traidor.”, em que a aliteração se mantém. Logo em seguida uma sequência de aliterações em /t/ e /b/: "qui tomba d'un tub $\underline{\text { to }}$ tubulaire tant bien que mal" (95), em que fizemos uma adaptação com a inclusão das palavras "um tanto tonta": "que tomb $\underline{\text { a }}$ um tanto tonta de um tub bo tubular". Na página seguinte há uma frase com aliteração em /k/: “ćconsidérations des deux consommateurs concernant le tiercê" (96), traduzida por "considerações dos dois consumidores sobre a corrida de cavalos". 
Finalmente, há no capítulo XII, uma frase com aliteração em /p/: “Cidrolin donne encore quelques coups de pinceau; c'est fini. Il laisse le pinceau dans le pot de peinture et prend le pot de peinture par l'anse" (166). Aqui, para mantermos essa aliteração traduzimos "pot de peinture" por "pote de pintura" em vez de "lata de tinta" que seria a tradução mais corrente: "Cidrolin dá ainda algumas pinceladas; pronto. Ele pousa o pincel dentro do pote de pintura e pega o pote de pintura pela alça".

\subsection{MUDANÇAS ORTOGRÁFICAS E ORTOGRAF FONÉTIK}

Segundo Josette Rey-Debove, não se pode considerar a palavra escrita como posterior à oral e como representação desta, o que reduziria a palavra escrita a um "signo de signo". Na realidade Rey-Debove reconhece "a independência semiótica dos sistemas atuais em relação ao conteúdo que eles veiculam no discurso" ${ }^{172}$. Assim, a ligação do signo escrito com o referencial se processa diretamente, assim como a do signo oral e não indiretamente por meio deste. A representação gráfica do oral só existe na transcrição fonética, já que esta é metalinguística e só é empregada para falar da linguagem. Dessa forma, a representação gráfica correspondente à palavra "doigt" é $[d w a]$ e não “doua” como utiliza Queneau, já de acordo com convenções da ortografia francesa.

De acordo com seu projeto de inserção da língua falada, Queneau emprega muitas alterações ortográficas, seja para representar palavras estrangeiras com a grafia francesa, seja para conseguir um efeito arcaizante, ou ainda, mais frequentemente, alterando palavras ou mesmo juntando várias palavras na tentativa de representar a cadeia sonora, na grafia que ele chama de ortograffonétik.

\section{a) representação de palavras estrangeiras}

Nos casos em que há a utilização da grafia francesa para representar palavras inglesas, utilizamos o mesmo critério, transpondo para a grafia do português a realização sonora dessas palavras. Vejamos alguns exemplos:

A palavra "camping" aparece 25 vezes no romance, sempre escrita "campigne". Na tradução, transcrevemos como "câmpingue".

172 "l'indépendence sémiotique des systèmes actuels par rapport au contenu qu'ils véhiculent em discours" (REY-DEBOVE, J. À la Recherche de la Distinction Oral/Écrit. In: CATACH, N. Pour une Theorie de la Langue Écrite. Paris: CNRS, 1990, p. 78). 
As palavras inglesas "strip-tease", "cash", "western" e "girl", transcritas em francês como "stripeutise" (101), "cache" (102), "ouesterne" (183) e "gueurle" (184), foram traduzidas respectivamente por "estripitise", "quéche", "uésterne" e "guerl”.

A palavra "newtonienne", derivada do nome próprio Newton, é escrita "nioutonienne", de acordo com regras ortográficas francesas. Em português, grafamos "niutoniana", aportuguesando a escrita da palavra.

Há ainda a sigla inglesa "WC", que foi transcrita como "vécés" (216), e que transcrevemos como "dabliucê"; ainda que seja muito pouco usada em português, ao passo que "vécés" é de uso corrente em francês.

\section{b) efeito arcaisante}

À medida que o duque viaja pelas várias épocas da história, o plural da palavra "cheval" é apresentada em três grafias diferentes "chevals", "chevaus" e "chevaux", monstrando sua evolução diacrônica. Para reproduzir o efeito usamos, na tradução, “caballo(s)", "cavallo(s)" e "cavalo(s)", pois, ainda que a evolução da palavra na língua possa não ter sido essa, remete de qualquer modo à palavra latina de origem, "caballus".

A palavra "catholique" é escrita "catoliche" (18) e "catholiche" (41), grafia que permite em francês a pronúncia do "ch" como /k/ em certas palavras de origem grega. Em português, na impossibilidade desse procedimento, grafamos "cathólico", que mantém a pronúncia da palavra ao mesmo tempo em que remete à sua origem, do grego "katholikós", através do latim "catholicus", e dá uma aparência arcaisante, uma vez que o dígrafo "th" não existe mais na ortografia do português.

Finalmente, temos a palavra "asteure", que, ao mesmo tempo que resulta da transcrição em ortograf fonétik da expressão "à cette heure", é uma palavra arcaica do francês, ainda utilizada no Quebec e na Louisiânia. Na tradução para o português, optamos por "aestora", em que se mantém o procedimento de ortograf fonétik para "a esta hora", embora se perca a alusão ao arcaísmo.

\section{c) ortograf fonétik}

Como a ortografia do português, tendo sofrido várias reformas, é muito mais próxima da realização fonética do que a do francês, nem sempre o efeito das modificações fonéticas é tão forte como em francês. Ainda assim, optamos por utilizar em português alguns elementos fonéticos próprios da lingua falada. 
A palavra "voiture" aparece 33 vezes no texto escrita "houature", corruptela que reproduz a fala. Nesse caso, como em português a palavra mais comum "carro" não se presta a deformações ortográficas, traduzimos por "otomóvel” ou "otomóvis".

Várias outras palavras ou frases aparecem com a grafia alterada, reproduzindo a fala, para restituir o efeito em português utilizamos várias adaptações:

1) "je mdemande si... je mdemande..." (79) em que se omite o "e" não pronunciado de "je me demande si... je me demande...". Traduzimos por "eu mi pergunto si... eu mi pergunto..." em que o "e" de "me" é escrito "i”, também reproduzindo a fala.

2) "ses douas" (118) por "ses doigts", em que utilizamos em português "os dedo", retratando a tendência do falante brasileiro de omitir a marca redundante de plural do substantivo.

3) "Oui, msieu" (154), por "Oui, monsieur"; "Vsêtes gentil. Merci, msieu." (155), por "Vous êtes gentil. Merci, monsieur" e "Grammercy" (160), por "Grand merci”. Utilizamos vários desvios encontrados no português falado no Brasil e traduzimos respectivamente por "Sim, sinhor", "O sinhor é muigentil. Brigada." e "Tobrigado".

4) o francês popular, assim como as crianças francesas, pronunciam as palavras "des haricots", fazendo a ligação "desaricots", ignorando a presença de um $\mathrm{h}$ aspirado que a impediria. Para reproduzir esse fato, Queneau escreve "des zaricots". Na tradução, utilizamos a palavra "fejão", reproduzindo a tendência da fala brasileira de reduzir o ditongo "ei" em "e".

Chegamos finalmente aos casos mais radicais do emprego da ortograf fonétik, com a ligação de palavras ou mesmo uma frase inteira escrita como se fosse a mesma palavra. Embora reproduza a cadeia sonora, isso provoca grande estranheza mesmo ao leitor francês que, em alguns casos, tem dificuldade para decodificar e compreender a frase.

Encontramos, por exemplo, “cexê" (63) em vez de "ce que c'est”. Traduzimos por “uquiéquié” (o que é que é), ligando as palavras e usando a repetição própria do oral.

A frase "Stènnes se tut" é escrita numa só palavra "Stènnstu" (72), Usando o mesmo procedimento, grafamos "Stenessicalô" (Stenes se calou).

“Tu ne feras jamais tèrstène" (177) representa a frase "Tu ne feras jamais taire Sthène". Nesse caso, além da ligação das palavras, utilizamos ainda a redução de "você" e a omissão dos "r" finais dos infinitivos, todos desvios encontrados no português falado: "Cê nunca vai fazê Stenessicalá” (Você nunca vai fazer Stenes se calar). 
Duas frases, representadas como duas palavras encontramos em "Stèfstu esténoci" (202), por "Stèphe se tut, Sthène aussi”. Também aqui, além da ligação das palavras, utilizamos a omissão do "r" final do infinitivo e a redução de "mb" para "m": "Estêvãossicalô stenestamém” (Estêvão se calou. Stenes também).

Finalmente, encontramos a frase "tummplupeu ce matin" (256), por "tu me plus peu ce matin". Nesse caso, não ligamos palavras e compensamos por vários desvios do português: "cê num mi agradô essa manhã" (você não me agradou essa manhã).

\subsection{EXPRESSÕES IDIOMÁTICAS}

Cada língua possui um certo número de expressões particulares para falar de fenômenos ou de situações do dia-a-dia. Essas expressões não podem ser interpretadas e traduzidas literalmente, pois são criadas segundo diferenças de percepção e representação da realidade próprias das diversas culturas.

A expressão idiomática pode ser definida como uma unidade sintática, lexicológica e semântica. O seu significado não pode ser calculado pelos significados das palavras contidas numa expressão e apresenta uma distribuição única ou muito restrita dos seus elementos lexicais.

A expressão idiomática atualiza-se no discurso, por isso o seu sentido pleno também só se atualiza inteiramente quando a expressão aparece contextualizada numa dada situação. Traduzir expressões idiomáticas é ter em conta a especificidade de cada tipo de texto, mas também a especificidade de cada língua, de cada povo, os seus usos e costumes, a sua expressividade.

Tratando-se de expressões de uso popular, Queneau as utiliza em grande número, algumas vezes com algumas alterações e outras ainda com o uso de metalinguagem para explicá-las.

\section{a) expressões traduzidas pela correspondente em português}

Falando do rei, o duque diz que já esperava que ele tomasse medidas antifeudais para "nous rogner les ongles" e "nous mettre au pas" (68), literalmente "aparar nossas unhas" e "nos colocar no passo", significando diminuir nosso poder, nos controlar. Traduzimos por "nos cortar as asas" e "nos passar a perna". 
Outros exemplos de expressões traduzidas pela correspondente em português são:

“c'est de la toute petite bière" (75), literalmente "é cerveja muito pequena", significando “coisa sem importância", traduzida por "é café pequeno";

"serre la pince" (98 e 103), "serrer la pince", literalmente "apertar a pinça", significando "apertar a mão", traduzida por "aperta os ossos";

"menue voletaille" (129), "pequena ave", significando "empregados subalternos", traduzida por "arraia miúda";

"tout était au poil" (130), "tudo estava no pelo", significando "tudo estava perfeito", traduzida por "estava tudo em cima";

“croit l'affaire cuite" (151), "acha o assunto cozido", significando "acha que já ganhou", traduzida por "a vitória estava no papo";

"mais vous avez apporté de l'eau à mon moulin" (209) "você trouxe água para o meu moinho", significando "trazer vantagem", traduzida por "mas o senhor puxou a brasa para minha sardinha".

\section{b) expressões com adaptações}

Referindo-se ao trânsito e seus perigos, observa que “c'était l'heure où les houatures vont boire" (31), numa referência à expressão “c'est l'heure où les éléphants vont boire" (é a hora em que os elefantes vão beber). Na expressão correspondente em português "é a hora da onça beber água", embora perdendo a possibilidade de imaginar que o carro bebe gasolina e não água, traduzimos por "era a hora do carro beber água", pois a omissão da palavra água tornaria difícil o reconhecimento da expressão.

Reclamando da pouca quantidade de comida, o duque diz que há "à peine de quoi se mettre sous la grosse dent" (32), adicionando o adjetivo à expressão corrente. Na tradução não adicionamos nenhum termo, o que descaracterizaria a expressão e traduzimos por "não dá nem pra encher a cova do dente".

Num episódio em que o duque é multado por ter matado algumas pessoas, o valor da multa é calculado "par tête de pipe cassée" (54). A expressão francesa "casser la pipe", literalmente "quebrar o cachimbo" significa "morrer" e corresponde à expressão portuguesa "bater as botas". Dessa forma, na tradução, mantendo o passado, dissemos que a multa foi aplicada "para cada par de botas batidas". 
Em outra ocasião, falando de corrida de cavalos, o duque usa a expressão "comme des chevaus sur la soupe" (257) em que a expressão "comme des cheveux sur la soupe" (como cabelos na sopa) foi alterada, criando um trocadilho com "chevaus" (cavalos), objeto da conversa. Usamos o mesmo procedimento em português, traduzindo por "como um caballo na sopa”.

\section{c) expressões explicadas}

Referindo-se à suposta gravidez de Aamélia, seu pretendente diz "qu'elle avait un polichinelle dans le tiroir" (77) (que ela tinha um polichinelo na gaveta), e acrescenta "comme disait mon grand-père" (como dizia meu avô) para indicar que se trata de uma expressão um tanto em desuso. Encontramos em português a expressão correspondente, também em desuso, e a mantivemos na tradução "que tinha um bolo no forno como dizia meu avô".

Quando Cidrolin soube que as filhas e os genros almoçariam num restaurante de luxo para comemorar o casamento de Aamélia, sem tê-lo convidado, ele resmunga "ils font la noce sans moi" (112). Em seguida, questionado por um passante, ele mesmo reconhece a ambiguidade da expressão e explica seu significado: “deux sens : petit a, se taper la cloche, et petit b, célébrer un mariage". Traduzimos por "fazem a festa sem mim" e, como aí se perde a noção de casamento, optamos por um acréscimo na explicação dada por Cidrolin: "dois sentidos: a minúsculo, encher o bucho, e b minúsculo, festejar, no caso, um casamento".

Há ainda a expressão "Jeter le manche après la cognée" (jogar o cabo depois do machado). Essa expressão significa desistir, algo como "jogar a toalha" em português. No entanto, como ela também vem seguida de uma explicação que era importante manter porque serve para introduzir uma história de lenhador, optamos por traduzi-la ao pé da letra.

\section{d) expressões adaptadas por causa da sintaxe textual}

Depois de o duque quebrar um banco nas costas do cozinheiro este lhe suplica que não discuta mais "à bâtons rompus" (69). Essa expressão que literalmente seria "a bastões quebrados", referência ao banco que foi quebrado em suas costas, significa "falar sem parar, de modo desconexo". Optamos por traduzir "não quebrar o pau quando discutimos", que, significando simplesmente discutir, perde o sentido de falar desconexo, mas guarda a referência à agressão ao cozinheiro, caso seja interpretada literalmente.

Duas vezes encontramos a expressão "revenir à ses moutons" (69 e 134), literalmente "voltar a seus carneiros", que significa voltar ao assunto depois de uma digressão e que corresponde em português a "voltar à vaca fria", expressão usada na tradução. No 
entanto, essa tradução determinou a adaptação de outra expressão, pois quando o duque diz "j'ai d'autres chats à fouetter" (191) (tenho outros gatos para chicotear), significando "tenho outros assuntos a tratar", tivemos que encontrar uma outra expressão que contivesse um animal, ainda que o sentido não fosse o mesmo, para permitir o diálogo em que a expressão é retomada. Traduzimos por "tenho alguns coelhos para tirar da cartola". Dessa forma, quando o abade diz "revenons à nos moutons qui sont d'ailleurs des chats" (192), traduzimos por "voltemos às vacas frias que no caso são coelhos", e quando o duque pergunta "Quels chats? - Ceux que vous fouettez, monsieur Hégault", traduzimos por "Que coelhos? - Os que o senhor vai tirar da cartola, senhor Hegoal".

\subsection{ARCAÍSMOS E NEOLOGISMOS}

\subsubsection{Arcaísmos}

Em todo o texto há palavras ou expressões arcaizantes, especialmente durante a "viagem" do duque através da história. Encontramos com frequência os advérbios fort e moult, exemplos de um nível de língua elevado e com um certo ar arcaizante. Na tradução, procuramos produzir o mesmo efeito com a utilização de "mui", forma apocopada de "muito", do pronome "vós" e de algumas mesóclises.

Além dessas expressões que se repetem, há casos específicos de emprego de palavras arcaicas, como em "nous préparons un nouveau croisement" (24), em que "croisement" é empregado no sentido de "croisade", e que traduzimos por "estamos preparando um novo cruzamento". Se em português a palavra "cruzamento" não corresponde a um arcaísmo para "cruzada", de qualquer forma ela produz um estranhamento e o cotexto permite a apreensão do sentido.

Outro exemplo encontramos na frase "On vuide des pintes" (73), em que há "vuider" forma arcaica de "vider", e "pinte", antiga unidade de medida. Na tradução, em vez de "esvaziar" usamos a palavra "esvaciar", que faz alusão à origem da palavra, do latim "vacivus": "Esvaciam garrafas".

Há ainda uma discussão metalinguística sobre o desaparecimento das palavras que origina os arcaísmos: Cidrolin usa a palavra "boquillon" e explica que se trata de uma palavra antiga para "bûcheron". Em seguida há a reflexão de seu interlocutor: "Por que, senhor, existem palavras assim que saem de uso? Eu que estou falando com o senhor, cheguei a ver, durante minha vida, desaparecer algumas debaixo dos meus olhos: cinématographe, taximètre, chef d'îlot" (127). Traduzimos "boquillon" e "bûcheron" respectivamente por 
"bosqueador" e "lenhador". No caso das palavras que desapareceram em uma geração, no entanto, não foi possível manter as mesmas na tradução pois em português "taxímetro" ainda é utilizada e "chef d'îlot" não tem correspondente em português. Nesse caso, procuramos palavras que caíram em desuso em português nas últimas décadas, e traduzimos por "cinematógrafo, vitrola, decalcomania".

\subsubsection{Neologismos}

Os neologismos aparecem em quantidade maior que os arcaísmos e podemos classificá-los em diferentes tipos: neologismos criados a partir de palavras existentes com o acréscimo de sufixos, palavras usadas com um novo sentido, e palavras derivadas de siglas. Além disso, há uma discussão que se passa na Idade Média, em que palavras que hoje são de uso corrente e dicionarizadas são tratadas como neologismos: assim como palavras de ontem são os arcaísmos de hoje, palavras de hoje são os neologismos de ontem.

\section{a) palavras criadas}

Logo no início, o duque, comentando a construção da catedral usa quatro neologismos criados a partir de nomes de religiões orientais: “- Si on traîne tellement, on finira par bâtir une mahomerie. - Pourquoi pas un bouddhoir ? un confuciussonnal ? un sanct-lao-tsuaire" (15). Aquí, os neologismos criados a partir de Maomé, Buda, Confúcio e Lao Tsé, fazem ainda trocadilhos com "boudoir" (pequeno aposento para senhoras), "confessionnal" (confessionário) e "sanctuaire" (santuário). Os dois últimos puderam ser mantidos em português e ao primeiro acrescentamos o adjetivo "santo", fazendo alusão ao santo sudário: “- Se as obras se arrastam desse jeito, vão acabar construindo uma maomeria. Por que não um santo budário? um confucionário? um santu-lao-tsuário?”.

A partir do substantivo "calembour" é derivado o verbo "calembourder": "je le calembourderai de telle façon qu'il en perdra sa morgue." (147). Usamos o mesmo procedimento na tradução "vou trocadilhá-lo de tal maneira que ele vai perder a pose".

O verbo "pénicher" é criado a partir do substantivo "péniche" quando o pretendente de Aamélia pergunta a Cidrolin "où péniche mademoiselle Lamélie Cidrolin?" (77), estabelecendo um trocadilho com o verbo "nicher" (ter seu ninho, morar). Como a palavra "péniche" em todo o romance foi traduzida por "chata", em vez da criação de uma nova palavra, utilizamos o verbo "chatear" com um sentido que não lhe é próprio: "onde chateia a senhorita Aamélia Cidrolin?". O contexto permite apreender o sentido de "morar", mas cria também uma ambiguidade, pois no capítulo anterior, numa discussão sobre o fato de 
que Cidrolin não possuía um aparelho de televisão, uma de suas filhas diz que ele deveria comprar uma para que "Aamélia se chateie menos".

A partir de nomes próprios Pouscaillou et Cidrolin, por sufixação e prefixação, são criados os adjetivos "pouscailloutiennes" (192), “anticidrolinique” (253) e "cidrolinophile" (254). Usando o mesmo procedimento traduzimos respectivamente por "pouscailloucianas", "anticidrolínico" e "cidrolinófilo".

A palavra "grottesque", derivada de "grotte" (gruta) faz um trocadilho com "grotesque" (grotesco), na frase "dans la ténèbre grottesque" (206). O mesmo processo de derivação permitiu a manutenção do trocadilho em português: "na treva grutesca".

O último exemplo desse tipo de neologismo encontramos no adjetivo "faitdiverse", derivado da expressão "fait divers", na frase "cette activité faitdiverse" (270). Nesse caso, na tradução não foi possível manter o neologismo, uma vez que a expressão correspondente, culturalmente importante em francês, não existe em português. Traduzimos por uma palavra existente que mantém o sentido, embora perdendo o neologismo: "essa atividade policialesca".

\section{b) palavras usadas com sentido novo}

Outra forma de criação de neologismos é o uso de uma palavra que pertence à língua, mas dando-lhe um sentido diferente. Queneau utiliza esse procedimento uma única vez no romance quando falando da pesca, um passante pergunta a Cidrolin "ne trouvez-vous pas l'hameçon plus sournois et vicieusement barbare que l'espadrille?" (30). A palavra "espadrille", que é um tipo de calçado, aqui é utilizada referindo-se à espada com que se ferem os touros nas touradas, sentido esse explicitado na discussão que se segue entre as duas personagens. Traduzimos por "o senhor não acha o anzol mais traiçoeiro e viciosamente bárbaro do que a espadilha?", "espadilha" em português refere-se ao sete de espadas num conhecido jogo de baralho.

\section{c) derivação de siglas}

Outra forma de criação de neologismos utilizada por Queneau é a derivação a partir de siglas de uso corrente em francês.

Logo depois da discussão citada acima sobre a palavra "espadilha", concluindo que independentemente do significado os dois se entendiam, o passante exorta Cidrolin a apegar-se "à ces prémices de la compréhension mutuelle et unescale entre les peuples et de la 
paix future" (31), em que temos o adjetivo "unescale" derivado de "Unesco". Em nossa tradução, criamos o mesmo adjetivo: "a essas primícias da compreensão mútua e unescal entre os povos e da paz futura".

Descrevendo os casais que namoram no terraço do café, o narrador diz que "parmi les plus acharnés à faire la ventouse se trouvaient Lamélie et un ératépiste, Lamélie surtout, car l'ératépiste n'oubliait pas de regarder sa montre..." (48), frase em que surge pela primeira vez a palavra "ératépiste", derivada da sigla RATP (Régie Autonome des Transports Parisiens), que é a companhia que administra os transportes da região parisiense e que é uma sigla conhecida pelos franceses. Como a sigla provavelmente não seria reconhecida por um leitor brasileiro, optamos por incluir uma explicação na primeira vez em que o termo aparece: "entre os que se faziam de ventosa com mais ardor estavam Aamélia e um cobrador da RATP, principalmente Aamélia, pois o erriatepista não se esquecia de olhar o relógio...”. A explicação "um cobrador da RATP”e o contexto permitem que o leitor entenda o neologismo "erriatepista", repetida ainda 31 vezes.

Em outro exemplo, “À l'horizon apparut un détachement des compagnies royales de sécurité (...) - Les céhéresses arrivent, dit le duc en se frottant les mains." (53), o próprio autor sentiu a necessidade de explicar a sigla CRS porque atualmente ela designa uma espécie de tropa de choque, as "Compagnies Républicaines de Sécuritê", mas no texto, na época do duque de Auge o adjetivo não poderia ser "républicaines". Na tradução, mantivemos o procedimento, embora perdendo a referência ao significado atual: "No horizonte apareceu um destacamento das companhias reais de segurança (...) - Os ceerriesses estão chegando, disse o duque esfregando as mãos". A explicação inicial permite o reconhecimento da palavra nas outra 8 vezes em que é repetida.

Outra sigla utilizada é HLM (Habitation à Loyer Modéré), que designa habitações populares. A partir dela foi criada a palavra "achélème" (78), usada ainda mais duas vezes. Como a sigla, de uso corrente na França, não seria reconhecida por um leitor brasileiro, optamos por uma adaptação, fazendo referência ao BNH (Banco Nacional de Habitação) que, embora já extinto no Brasil, pode ainda ser reconhecido pelos brasileiros. A partir dessa sigla, criamos a palavra "beeneagá".

A outra sigla utilizada SS, talvez uma alusão à polícia nazista, também é explicada pelo autor no próprio texto: “... le déficit de la Sécurité Sociale. (...) Monsieur ne cotise peut-être pas à la éssésse ?" (124). O mesmo procedimento permite a compreensão do 
leitor brasileiro: “... o déficit da Seguridade Social. (...) o senhor não contribui para a essiesse?".

\section{d) pseudo-neologismos}

Aqui, trata-se de um episódio em que o duque conta a seu capelão os sonhos em que vê objetos do século XX cujos nomes são desconhecidos do capelão. Não se trata de neologismos, mas na Idade Média são entendidos como tal. Há discussão metalinguística em que o capelão faz uma referência explícita a neologismo usando, ele mesmo, uma palavra que só surgiria em 1787:

- Sieste... mouchoir... péniche... qu'est-ce que c'est que tous ces mots-là ? Je ne les entrave point.

- Ce sont des mots que j'ai inventés pour désigner des choses que je vois dans mes rêves.

- Vous pratiqueriez donc le néologisme, messire?

- Ne néologise pas toi-même: c'est là privilège de duc. Aussi de l'espagnol pinaça je tire pinasse puis péniche, du latin sexta hora l'espagnol siesta puis sieste et, à la place de mouchenez que je trouve vulgaire, je dérive du bas-latin mucare un vocable bien françoué selon les règles les plus acceptées et les plus diachroniques. (42).

A explicação sobre a origem e evolução das palavras "sieste", "mouchoir" e "péniche" trouxe alguns problemas para a tradução. Primeiramente porque traduzimos "péniche" por "chata", mas principalmente porque a evolução da palavra "lenço", do latim "linteum" (pano de linho) é muito simples e não permitiria o comentário final do duque. Assim, substituímos "lenço" por "espreguiçadeira”, outro objeto que o duque vê em sonho, de modo a criar uma explicação etimológica aceitável. O resultado foi:

- Sesta... espreguiçadeira... chata... o que é que são todas essas palavras? Eu não as estou sacando.

- São palavras que inventei para designar as coisas que vejo nos meus sonhos.

- Então praticaríeis neologismo, senhor?

- Não neologize você: isso é privilégio de duque. Assim, do italiano chiatta eu tiro chiata e depois chata, do latim sexta hora o espanhol siesta depois sesta e, do latim pigritia, pigriça, priguiça e, depois, de preguiça eu derivo um vocábulo de nossa língua tudo de acordo com as regras mais aceitas e mais diacrônicas. 


\subsection{OUTRAS MANIFESTAÇÕES DE ORALIDADE}

\subsubsection{Nivel de língua}

\subsubsection{Supressão do sujeito}

A supressão do sujeito, principalmente do "il" impessoal é uma característica da sintaxe do francês falado que, embora contrarie a norma culta, hoje é encontrado independentemente do grau de instrução ou da classe social do falante. Além do "il" impessoal, encontramos em alguns casos a supressão, mais rara, da primeira pessoa.

Como em português o sujeito pode ser suprimido mesmo na norma culta da língua, na tradução procuramos compensar por outros desvios próprios do português falado, como a supressão do "s" final de alguns verbos, a supressão do "r" final do infinitivo e outras reduções por aférese ou síncope como "tô" por "estou”, "cê”" por "você”, "pra” por "para”, etc.

Vejamos as ocorrências encontradas no texto e a solução dada em cada caso na tradução. As palavras e letras omitidas estão indicadas entre colchetes:

"Dressé? [nous ne] Comprenons pas." (20), traduzido por "Amestrado? Num [es]tamo[s] entendendo." Nesse caso, além do sujeito há também o "ne" da negação que foi suprimido. Na tradução utilizamos "num" no lugar de "não";

“[Il] Faut que je me tire” (48), "Tenho que puxá[r] o carro";

"[Il] Va y avoir du monde" (49), "Vai tê[r] muita gente";

“[Je] M'en fous. [Je] M'en irai trouver le roi" (74), "[Es]Tô me lixando. Vô[u] encontrá[r] o rei;

"Tu vois; [il ne] faut jamais se désespérer" (99), "[Vo]Cê vê: num pode se desesperá[r];

"[Il] Faudrait que j'aille te voir un de ces jours, mais, tu sais" (99), "Eu devia te visitá[r] um dia desses, mas, [vo]cê sabe;

"Bon. Bon. Mais [il] faut que ce soit toi” (102), "Bom, [es]tá bem. Mas só porque é p[a]ra você";

“[Il] Faut faire quelque chose" (114), "Temo[s] que fazê[r] alguma coisa;

"[Il] Faut pourtant bien qu'on déjeune" (114), "Mas a gente tem que almoçá[r]";

“[Je ne] Comprends pas" (143), "Num [es]tô[u] entendendo." 
"[Il ne] Faut pas décourager ma bonne volontê" (144), "O senhor num deve desencorajá[r] minha boa vontade";

“À propos, ici, [il] y a la tévé?" (145), "Por falá[r] nisso, aqui tem tevê?”;

"[Il ne] Faut pas les raconter" (154), "Num se deve contá[r]";

"[Il] Y aura des frites?" (224), "Vai tê[r] fritas?";

“[Je] M'en fous, dit le duc" (229), "Tô nem aí, disse o duque";

"[Il] Faut être timbé pour faire des choses pareilles" (263), "Tem que sê[r] doido p[a]ra fazê[r] uma coisa dessas".

\subsubsection{Supressão do "ne” da negação}

A negação, em francês, é constituída de duas partes, colocadas antes e depois do verbo. A primeira, sendo átona, muitas vezes é suprimida na língua falada. Essa característica do francês foi compensada, em nossa tradução, pelo emprego da forma "num" no lugar do advérbio de negação "não", que é uma característica do português falado no Brasil.

Alguns casos, em que essa supressão encontra-se na mesma frase em que há supressão do sujeito, foram tratados no item anterior. Vejamos os outros exemplos:

"Vous [n']allez pas faire la course" (61), "Vocês num vão apostá[r] corrida";

“j[e n]'avais pas l'intention" (82), "eu num tinha intenção";

"c[e n]'est pas tous les jours qu'on se marie" (114), "num é todo dia que a gente se casa";

“C[e n]'est pas du travail ça." (142), "Isso aqui num é trabalho";

“On [ne] répond pas" (143), "num se responde";

"Vous [ne] pouvez pas" (144), "O senhor num pode";

"Décidément vous [ne] savez rien faired'autre que questionner" (144), "O senhor só sabe fica fazendo pergunta.";

"vous [ne] vous connaissez pas" (144), "o senhor num se conhece";

"[ne] vous en faites pas" (144), "num se preocupe";

"C[e n]'est pas grand" (145), "Num é grande";

"[Ne] Vous cognez pas la tête" (145), "Num vai batê[r] a cabeça". 


\subsubsection{Elisão de vogal tônica}

A elisão é uma característica do francês em que a vogal átona de uma palavra gramatical monossilábica (artigo, pronome) é suprimida e substituída, na escrita, por um apóstrofo. Na língua falada, no entanto, em alguns casos ocorre a supressão de uma vogal tônica, o que caracteriza um desvio sintático não aceitável no francês escrito.

Em Les Fleurs bleues, encontramos um único caso em que houve a omissão do "ne" da negação e a elisão do "u" de "tu": "T[u n]'es pas sûre de monter" (49). Na tradução, além do uso de "num" no lugar do "não", compensamos essa elisão pelo uso de "cê" por "você" e pela supressão do "r" final dos infinitivos: "[Vo]Cê num sabe nem se vai consegui[r] subi[r]".

\subsubsection{Imitação de língua falada}

\subsubsection{Sotaque}

O sotaque é uma manifestação de oralidade característica de uma determinada região. Na tradução, não é possível mantê-lo pois o sotaque de uma região francesa não seria reconhecido como tal por um leitor brasileiro. Além disso, substituir pelo sotaque de uma região brasileira, além de não causar o mesmo efeito, ficaria totalmente deslocado em relação ao ambiente em que se passa a trama. Por isso, na única ocorrência do fenômeno no texto, a transcrição do sotaque do taberneiro da região de Auvergne, optamos por fazer apenas uma compensação com a redução do ditongo "ou" em "o" da palavra "couve", fenômeno que ocorre na língua falada brasileira:

"Du bortch qui est de la choupe aux chous echclavons et des tripes à la viducasse, le tout arrosé de vin des coteaux de Suresnes." (31) foi, pois, traduzido por "Bortsch, que é uma sopa de cove eslava e tripas à viducasse, tudo regado a vinho das costas de Suresnes",

\subsubsection{Gagueira}

Cabe mencionar a imitação da gagueira por se tratar também de um fenômeno que ocorre na língua falada. No entanto sua presença não acarreta problemas de tradução uma vez que o mesmo fenômeno pode ser reproduzido na língua de chegada. Há, no romance duas ocorrências que reproduzimos a seguir com as respectivas traduções:

"un cheche, un vaval... un cheval... qui qui... caucause..." (139), na tradução "um caca, um vava... um cavalo... queque... fafala...";

“Quequelle revovolutiontion ?” 169, traduzido por "Queque revovolulução?”. 


\subsubsection{Sobreposição de turnos conversacionais}

Da mesma forma que a gagueira, essa manifestação de língua falada não traz dificuldades para a tradução, uma vez que pode ser reproduzida em português, produzindo o mesmo efeito sobre o leitor. Esse fenômeno, em que cada interlocutor segue seu próprio raciocínio sem levar em conta a fala do outro, ocorre duas vezes no romance. A primeira entre Cidrolin e um passante (p. 30) e a segunda, entre Cidrolin e Aamélia (p. 51). Por se tratar de trechos longos, reproduziremos abaixo apenas o primeiro com sua tradução.

- Vous êtes de ces nomades...? demanda - O senhor é um desses nômades...?

Cidrolin poliment.

- Moi? Point. J'habite l'hôtel...

- et moi cette péniche...

- un hôtel de luxe même...

- immobile...

- il y a des vatères dans la salle de bains... - tem latrina no banheiro...

- amarrée...

- l'ascenseur...

- je pourrais même avoir le téléphone...

- le téléphone dans les chambres...

- il y a un numéro bleu avec des chiffres comme pour une maison...

- avec l'automatique pour l'étranger..

- c'est le vingt et un...

- et au rez-de-chaussée, il y a un bar... - e no térreo, tem um bar...

- de ma chambre, je pourrais pêcher... - do meu quarto, eu podia pescar...

- américain...

- je pourrais pêcher, si je pêchais, mais je - eu podia pescar, se eu pescasse, mas não n'aime pas pêcher. gosto de pescar. perguntou Cidrolin educadamente.

- Eu? De jeito nenhum. Moro no hotel...

- e eu nessa chata...

- um hotel de luxo mesmo...

- imóvel...

- amarrada...

- elevador...

- eu poderia até ter telefone...

- telefone nos quartos...
- com discagem direta para o exterior...

- é o vinte e um...

- americano...

-Vous avez bien raison, dit le passant - O senhor tem toda a razão, disse o 
s'intéressant brusquement aux propos de passante interessando-se de repente pela son interlocuteur; la pêche c'est aussi conversa de seu interlocutor; a pesca é tão cruel que les courses de taureaux... cruel quanto as corridas de touro...

\subsubsection{Conjugação}

Esta não é propriamente uma marca de oralidade normal do francês, mas é utilizada nas falas das canadenses que procuram o camping. Nesse caso, o verbo é conjugado na primeira pessoa do plural em vez da primeira do singular. Como trata-se da fala de uma canadense que Cidrolin identifica com uma pele-vermelha, decidimos manter os verbos no infinitivo, reproduzindo um tipo de fala que, graças aos filmes americanos, tornou-se o estereótipo da fala dos pele-vermelhas:

"Je préférons l'eau pure" (21), "Eu preferir água pura";

“Je vous étonnons ?” (38), "Eu espantar você?";

"Je sommes iroquoise, dit-elle, et je m'en flattons." (38), "Eu ser iroquesa, disse ela e me orgulhar muito disso.";

“Je vous avons réveillé ?” (38), "Eu acordar você?”;

“Je vous remercions, dit l'Iroquoise canadienne, et je vous prions de m'excuser" (38), "Eu agradecer, disse a iroquesa canadense, e pedir que me desculpe". 


\section{CONSIDERAÇÕES FINAIS}

A tradução é um processo que representa sempre um desafio, uma vez que não há a possibilidade de reproduzir numa determinada língua um texto totalmente equivalente ao produzido originalmente em outra. Um texto totalmente equivalente não seria uma tradução, mas uma reprodução do original, como a tradução de Dom Quixote de Menard, no conhecido conto de Jorge Luís Borges. O tradutor, Pierre Menard, decide fazer a mais perfeita tradução do Quixote. Ele não quer escrever um Quixote contemporâneo, nem compor outro Quixote, nem copiar mecanicamente o original. O método que imagina é relativamente simples: conhecer bem o espanhol, recuperar a fé católica, guerrear contra os mouros ou contra o turco, esquecer a história da Europa entre os anos de 1602 e 1918, ser Miguel de Cervantes. Pierre Menard conseguiu o que queria: produzir umas páginas que coincidiam - palavra por palavra e linha por linha - com as de Miguel de Cervantes. ${ }^{173}$

Sem pretensão ao trabalho utópico de Menard, cujo resultado não é uma tradução, só podemos pretender, ao traduzir um texto, restituir seu sentido em outra língua. No caso das obras de Queneau, há elementos que tornam ainda maior o desafio do tradutor: a presença da oralidade representada pela inclusão de elementos do francês falado, de níveis de língua diferentes, de arcaísmos e de um grande trabalho sobre o significante, como jogos de palavras, trocadilhos, rimas e aliterações que nem sempre podem ser reproduzidas em português pela tradução sugerida pelo dicionário. Com a crise do discurso, no início do século XX, já não se pode pensar numa correspondência biunívoca entre palavra e objeto do mundo. A ideia do signo como união de significante e significado já não satisfaz, visto que a significação trai, engana. Assim, o significante ganha autonomia e chega a comandar a significância do texto. Passa-se assim da significação à significância, e o significante, os jogos de palavra, os trocadilhos, por mais pobres que pareçam, têm uma função na construção dessa significância.

Se pensarmos no romance Les Fleurs bleues, podemos dizer que é justamente através desse trabalho com o significante e do humor que dele resulta, que Queneau se permite encarar as tragédias da História que, observadas pelo duque de Auge, resistem pouco, uma vez que para ele o que importa na realidade é a sua vida individual e seus interesses particulares que defende sem nenhum questionamento de ordem moral. Do outro lado, a vida de Cidrolin, totalmente inativo, talvez assassino, certamente alcoólico, provavelmente incestuoso, também não sofre nenhum peso moral - pode ser até que ele tenha matado o vigia 
do edifício, seu superego. Esses dois destinos entrelaçados pintam um quadro um tantinho melancólico do destino humano, mas Queneau com seu estilo transforma a tragédia em tragicomédia. Não será melhor assim?

Les Fleurs bleues é um romance escrito depois da criação do Oulipo e que obedece a regras matemáticas e a contraintes que, embora limitadas, determinam sua estrutura. Apesar disso, como vimos, não se trata de um simples exercício oulipiano, trata-se de um romance em que, embora haja elementos relegados ao acaso do signo e ao trabalho com as palavras, há também uma história em que são tratados assuntos diversos e no qual se pode observar a posição de Queneau com sua simpatia pelo homem comum contra a grande História e seus heróis. As intrigas se desenrolam para chegar a um final melancólico, com a personagem Cidrolin saindo da história e o duque voltando para observar uma situação histórica muito semelhante à que observara no início.

Procuramos, na tradução, dar conta do projeto de Queneau de inclusão do francês falado no romance. Para isso utilizamos elementos da língua portuguesa falada no Brasil, mas sempre com o cuidado de não descaracterizar a obra, pois sua referência externa não é acessória, mas, ao contrário, essencial à construção do sentido e faz parte da poética de Queneau. Uma tradução que modificasse essa referência, situando o enredo no Brasil e não na França, por exemplo, seria um outro romance, mas não a tradução de Les Fleurs bleues.

Tentamos, pela apreensão do significante, perceber os procedimentos da escrita de Queneau, pois seu trabalho com o significante é essencial, e acreditamos que deva ser, na medida do possível, reproduzido em português, sem no entanto se resumir à execução de um exercício oulipiano, esquecendo a história contada. Há casos, como o dos provérbios, em que basta o trabalho com o significante da língua de chegada para construir estruturas semelhantes, mas há outros em que isso não é possível, como por exemplo, no caso dos arcaísmos e de palavras do francês medieval que não encontram correspondentes em português e que remetem a um imaginário que não existe na cultura brasileira. Procuramos dar motivação ao signo, como no caso dos nomes próprios, e fazer uso da recorrência fônica não com um intuito de criar efeitos imitativos ou onomatopaicos, mas de, com jogos sonoros gratuitos, derrubar, como faz Queneau, a pompa da linguagem literária e a possibilidade de se entender seu discurso como portador de um sentido a ser absorvido passivamente pelo leitor.

Entendemos, pois, que a tradução é possível, desde que se levem em consideração as condições da produção do texto, o ambiente em que foi criado e os elementos que o compõem, como a oralidade e o ritmo para que, com os recursos próprios da língua de 
chegada, se possa não reproduzir o que o autor fez na língua de partida, mas recriar um texto homólogo que procure manter, na língua de chegada os elementos detectados no original. Dessa forma, teremos um produto que, sem se descolar do original, tenha vida própria na língua/cultura de chegada e permita aos seus leitores a construção de sentidos a partir das marcas textuais observadas. 


\section{REFERÊNCIAS BIBLIOGRÁFICAS}

ARAÚJO, A. M. Bilingüismo e crioulização nos países lusófonos. Palestra proferida em 27/06/2000 e publicada no site da Academia Brasileira de Letras. Disponível em $<$ http://www.academia.org.br/abl/cgi/cgilua.exe/sys/start.htm?infoid=4287\&sid=531>. Acesso em $12 / 02 / 2011$.

ARBEX, Márcia. Exercícios de estilo com "sotaque tupiniquim": Luiz Rezende tradutor de Raymond Queneau. disponível em

<http://www.letras.ufmg.br/poslit/08_publicacoes_pgs/Eixo\%20e\%20a\%20Roda\%2018,\%20 n1/07-Marcia-Arbex.pdf> . Acesso em 15/06/2011

ARON, Thomas. Le roman comme représentation de langages - Raymond Queneau à la lumière de Bakgtin. In : Europe - revue littéraire mensuelle - avril 2003.

BARTHES, Roland. Proust et les noms. In: Le degré zéro de l'écriture suivi de Nouveaux essais critiques. Paris: Éditions du Seuil, 1953, et 1972).

Théorie du texte. Disponível em <http://pt.scribd.com/doc/6545354/Roland-Barthes-Theorie-

Du-Texte>. Acesso em 15/05/2011.

BENJAMIN, W. A Tarefa-Renúncia do Tradutor. In: Clássicos da Teoria da Tradução. Florianópolis: UFSC, 2001.

BENS, Jacques. Queneau. Paris: Gallimard, 1962.

BENVENISTE, E. Problemas de Lingüística Geral I. Campinas: Pontes, 2005, Tradução de Maria da Glória Novak e Maria Luísa Neri.

Problèmes de linguistique générale, t. II. Paris : Gallimard, 1974.

BERMAN, Antoine. A tradução e a letra - ou o abergue do longínquo. Rio de Janeiro: Viveiros de Castro, 1985.

BOURDETTE-DONON, Marcel. Queneau et les nouveaux vecteurs d'information. In: Europe - revue littéraire mensuelle - avril 2003.

BOURJEA, Michelle. Traduzir Clarice Lispector assim como ela escreve. In: COSTA, L. A. (Org). Limites da Traduzibilidade. Salvador: EDUFBA, 1996. p. 121-133.

CALVINO, Italo. Palomar, In Romanzi e Racconti II, Milano: Mondadori, 2004, pp. 871-979. Se una notte d'inverno un viaggiatore. In: Romanzi e Racconti II. Milano: Arnoldo Mondadori, 2004. pp. 613-870. Saggi II, Milano: Mondadori, 1995.

CAMPOS, H. "Da tradução como criação e como crítica", In: Metalinguagem \& outras metas. São Paulo: Perspectiva, 2004. 
CHABANNE, Jean-Charles. En lisant les lecteurs de Queneau: les théories implicites de l'humour dans le discours critique. In: Temps-Mêlés-Documents Queneau 150+65-68 et dernier, printemps 1996, actes du Colloque "Pleurire avec Queneau" (Thionville, octobre 1994), p. 295-300. Disponível em

$<\mathrm{http}: / /$ chabanne.jeancharles.perso.neuf.fr/publis/lisant_lecteurs.pdf $>$. Acesso em: 25 mai. 2011.

. Rire et philosophie dans l'œuvre de Raymond Queneau, paru dans Humoresques 9, « Rire et littérature », coord. Joë Friedemann, Presses Universitaires de Vincennes, 1998, pages 77-87. Disponível em: <http://chabanne.jeancharles.perso.neuf.fr/publis/rire\&phi.pdf>. Acesso em: 01 dez. 2008.

CHARTIER, Roger. Pratiques de la lecture. Paris : Rivages, 1985.

CHISS, Jean-Louis; FILLIOLET, Jacques \& MAINGUENEAU, Dominique. Introduction à la linguistique française - tome 2: syntaxe, communication, poétique. Paris: Hachette, 2001.

DAHLET, V. B. L'orthographe française: entre langue et résistences. In: Synergies Brésil Numéro spécial 1/année 2010 pp. 159-166.

DURAND, André. «Les Fleurs bleues - roman de Raymond Queneau» In: Comptoir Littéraire. Disponível em <www.comptoirlitteraire.com>. Acesso em 10/12/2010.

ECO, Umberto. Quase a mesma coisa - experiências de tradução. Rio de Janeiro: Record, 2007, Tradução de Eliana Aguiar.

ESPINASSE, Magali. Étude sur Les Fleurs bleues. Paris: Ellipses, 1999.

FIORIN, J. L. L'accord sur l'orthographe: une question de politique linguistique. In: Synergies Brésil Numéro spécial 1/année 2010 pp. 59-68

FOURCAUT, Laurent. Le texte en perspective. In : Zazie dans le métro. Paris: Gallimard, 2006.

FRANÇOIS, Corinne. Connaissance d'une auvre : Les Fleurs bleues. Rosny: Bréal, 1999.

GIDE, André. Les Faux-Monnayeurs. 226e édition. Paris: Gallimard, 1951.

GODARD, Henry. Queneau et les problèmes de la construction du roman. In : Europe revue littéraire mensuelle - avril 2003.

GOULEMOT, Jean Marie. De la lecture comme production de sens. In: CHARTIER, Roger (Org) Pratiques de la lecture. Paris : Rivages, 1985.

JAFFRÉ, Jean-Pierre. "Pourquoi distinguer les homophones?" disponível em <www.cairn.info/load_pdf.php?ID_ARTICLE=LF_151_0025 . Acesso em 16/05/2011.

JATON, Anne Marie. Les Fleurs Bleues - Bilan Provisoire. In : Europe - revue littéraire mensuelle - avril 2003. 
JOUVE, Vincent. A Leitura. São Paulo:Unesp, 2003.

JOUY, Bruno. Voyage au bout de la nuit - Étude d'une réception. Disponível em: <http://louisferdinandceline.free.fr/index2.htm>. Acesso em 24/01/2011.

LARANJEIRA, Mário. Poética da Tradução. São Paulo: Edusp, 1993.

MARTINS, Maria Helena. O que é leitura. 3. ed. São Paulo : Brasiliense, 1984.

MESCHONNIC, Henri \& DESSONS, Gérard. Traité du rythme: Des vers et des proses.

Paris: Armand Colin, 2005.

MESCHONNIC, Henri. Le Signe et le poème, Paris, Gallimard, 1975.

. Critique du rythme. Anthropologie historique du langage, Lagrasse, Verdier, 1982. .La rime et la vie. Paris: Verdier. 1989.

OULIPO. La Littérature potentielle. Paris: Gallimard, 1973.

PEREC, Georges. La disparition. Paris: Denoël, 1969

El sequestro. Tradução de Marisol Arbués, Mercè Burrel, Marc Parayre, Hermes

Salceda e Regina veja. Barcelona: Anagrama, 1997

PINO, Claudia Amigo. A ressignificação do mundo, Cult 52, novembro de 2001. p. 46-53.

PIMENTEL PINTO, Edith. A Gramatiquinha de Mário de Andrade. São Paulo: Duas Cidades, 1990.

POSLANIEC, Christian. De la Lecture à la Littérature. Paris : Sorbier, 1992.

POUILLOUX, Jean-Yves. Les fleurs bleues de Raymond Queneau. Paris: Gallimard, 1991.

QUENEAU, Raymond. Exercices de style. Paris: Gallimard, 1947.

Bâtons, chiffres et lettres. Ed. revue et augmentée. Paris: Gallimard, 1965.

Les fleurs bleues. Paris: Gallimard, 1965.

I fiori blù, tradução de Italo Calvino. Torino: Einaudi, 1967.

Exercícios de Estilo. Tradução de Luiz Rezende. Rio de Janeiro: Imago, 1995

REISS, Katharina. Type, kind and individuality of text - Decision making in translation. In:

VENUTI, Lawrence. The Translation Studies Reader. New York: Routledge.

REY-DEBOVE, J. À la Recherche de la Distinction Oral/Écrit. In: CATACH, N. Pour une Theorie de la Langue Écrite. Paris: CNRS, 1990.

ROUSSIN, Philippe. Misère de la littérature, terreur de l'histoire. Paris: Gallimard, 2005.

SARRAUTE, Nathalie. L'ère du soupçon. Paris: Gallimard, 1956.

SARTRE, Jean-Paul. Que é literatura?. São Paulo: Ática, 1989.

SCHLEIERMACHER, Friedrich. Sobre os diferentes métodos de tradução. In: HEIDERMANN, Werner (org). Clássicos da teoria da tradução. Florianópolis: UFSC, 2001. 
SCHNAIDERMAN, Boris. Os Limites da Traduzibilidade. In: COSTA, Luiz Angélico (Org.) Limites da Traduzibilidade. Salvador: EDUFBA, 1996.

SUCHET, Myriam. Outils pour une traduction postcoloniale. Paris: Éditions des archives contemporaines, 2009.

THIMONNIER, René \& DESMEUZES, Jean. Lês 30 problèmes de l'orthographe. Paris: Hachette, 1979.

THOMAS, Réjean. La molle page - littérature \& imaginaire. v.8, n. 0.02, jan. 2009. Disponível em: <http://www.ed4web.collegeem.qc.ca/prof/rthomas/textes/existentia.htm>. Acesso em: 03 dez. 2008.

URBANO, Hudinilson. Oralidade na Literatura (O caso Ruben Fonseca). São Paulo: Cortez, 2000.

Da fala para a escrita: o caso de provérbios e expressões populares. In Investigações: Linguística e Teoria Literária. Recife, v. 21, n. 2, p. 31-56, jul. 2008, disponível em: <http://www.ufpe.br/pgletras/Investigacoes/Volumes/Vol.21.2/Hudinilson_Urbano.pdf>. Acesso em: 25/04/2011.

VARELA, Luís Maia. A Tradução Traduz o Tradutor. In: COSTA, Luiz Angélico (Org.) Limites da Traduzibilidade. Salvador: EDUFBA, 1996.

VENUTI, LAWRENCE. O escândalo da tradução. In: Tradterm 3, São Paulo, 1996. The Scandals of Translation: Towards an Ethics of Difference, New York: Routledge, 1998. 


\section{APÊNDICE}

Apresentamos a seguir a íntegra de nossa tradução do romance Les Fleurs bleues, em duas colunas, original e tradução. Na margem esquerda, entre colchetes, estão os números de página do original, na edição constante das Referências Bibliográficas. 


\section{Les Fleurs bleues}

Raymond Queneau
On connaît le célèbre apologue chinois : Tchouang-tseu rêve qu'il est un papillon, mais n'est-ce point le papillon qui rêve qu'il est Tchouang-tseu ? De même dans ce roman, est-ce le duc d'Auge qui rêve qu'il est Cidrolin ou Cidrolin qui rêve qu'il est le duc d'Auge?

On suit le duc d'Auge à travers l'histoire, un intervalle de cent soixante-quinze années séparant chacune de ses apparitions. En 1264, il rencontre Saint Louis; en 1439, il s'achète des canons. en 1614, il découvre un alchimiste; en 1789, il se livre à une curieuse activité dans les cavernes du Périgord. En 1964 enfin, il retrouve Cidrolin qu'il a vu dans ses songes se consacrer à une inactivité totale sur une péniche amarrée à demeure. Cidrolin, de son côté, rêve... Sa seule occupation semble être de repeindre la clôture de son jardin qu'un inconnu souille d'inscriptions injurieuses.

Tout comme dans un vrai roman policier, on découvrira qui est cet inconnu. Quant aux fleurs bleues...

\section{As Flores Azuis}

\author{
Raymond Queneau \\ Tradução: Roberto de Abreu
}

\begin{abstract}
Conhecemos o célebre apólogo chinês: Chuang-Tzu sonha que é uma borboleta, mais não seria a borboleta que sonha que é Tsuang-tsé? Acontece o mesmo neste romance, é o duque de Auge que sonha que é Cidrolin ou Cidrolin que sonha que é o duque de Auge?
\end{abstract}

Seguimos o duque de Auge ao longo da história, com um intervalo de cento e setenta e cinco anos separando cada uma de suas aparições. Em 1264, ele encontra São Luís; em 1439, compra canhões; em 1614, descobre um alquimista; em 1789 dedica-se a uma curiosa atividade nas cavernas do Périgord. Em 1964 finalmente, ele encontra Cidrolin que ele tinha visto em sonho dedicar-se a uma inatividade total numa chata amarrada como moradia. Cidrolin, por seu lado, sonha... Sua única ocupação parece ser pintar a cerca de seu jardim que um desconhecido macula com inscrições injuriosas.

Como num verdadeiro romance policial, descobriremos quem é esse desconhecido. Quanto às flores azuis... 
Le vingt-cinq septembre

[13] douze cent soixante-quatre, au petit jour, le duc d'Auge se pointa sur le sommet du donjon de son château pour y considérer, un tantinet soit peu, la situation historique. Elle était plutôt floue. Des restes du passé traînaient encore çà et là, en vrac. Sur les bords du ru voisin, campaient deux Huns; non loin d'eux un Gaulois, Eduen peut-être, trempait audacieusement ses pieds dans l'eau courante et fraîche. Sur l'horizon se dessinaient les silhouettes molles de Romains fatigués, de Sarrasins de Corinthe, de Francs anciens, d'Alains seuls. Quelques Normands buvaient du calva.

Le duc d'Auge soupira mais n'en continua pas moins d'examiner attentivement ces phénomènes usés.

Les Huns préparaient des stèques tartares, le Gaulois fumait une gitane, les Romains dessinaient des grecques, les Sarrasins fauchaient de l'avoine, les Francs cherchaient des sols et les Alains regardaient cinq Ossètes. Les Normands buvaient du calva.

- Tant d'histoire, dit le duc d'Auge au duc d'Auge, tant [14] d'histoire pour quelques calembours, pour quelques anachronismes. Je trouve cela misérable. On n'en sortira donc jamais?

Fasciné, il ne cessa pendant quelques heures de surveiller ces déchets se refusant à l'émiettage; puis, sans cause extérieure décelable, il quitta son poste de guet pour les étages inférieurs du château en se livrant au passage à son humeur qui était de battre.
Aos vinte e cinco de setembro de mil duzentos e sessenta e quatro, de manhãzinha, o duque de Auge plantou-se no alto do torreão de seu castelo para considerar, um tantinho que fosse, a situação histórica. Ela estava meio embaçada. Restos do passado se espalhavam ainda cá e acolá, ao léu. Às margens do riozinho vizinho, acampavam dois hunos; não longe dos dois um gaulês, eduano talvez, molhava os pés audaciosamente na água corrente e fresca. No horizonte desenhavamse as silhuetas moles de romanos cansados, de sarracenos de Mans, de francos antigos, de ossetas velozes. Alguns normandos bebiam calvados.

O duque de Auge suspirou mas nem por isso deixou de examinar atentamente esses fenômenos repetitivos.

Os hunos preparavam bifes tártaros, o gaulês cantava de galo, os romanos desenhavam gregas, os sarracenos ceifavam cevada, os francos procuravam vinténs e os ossetas apontavam dois alanos. Os normandos bebiam calvados.

- Tanta história, disse o duque de Auge para o duque de Auge, tanta história para alguns trocadilhos, para alguns anacronismos. Acho isso miserável. Será que nunca vamos sair disso?

Fascinado, durante algumas horas não parou de observar esses dejetos que se recusavam a se esmigalhar; depois, sem causa exterior aparente, deixou seu posto de observação e foi para os andares inferiores do castelo, deixando-se levar de passagem por seu humor 
Il ne battit point sa femme parce que défunte, mais il battit ses filles au nombre de trois; il battit des serviteurs, des servantes, des tapis, quelques fers encore chauds, la campagne, monnaie et, en fin de compte, ses flancs. Tout de suite après, il décida de faire un court voyage et de se rendre dans la ville capitale en petit arroi, accompagné seulement de son page Mouscaillot.

Parmi ses palefrois, il choisit son percheron favori nommé Démosthène parce qu'il parlait, même avec le mors entre les dents.

- Ah ! mon brave Démo, dit le duc d'Auge d'une voix plaintive, me voici bien triste et bien mérancolieux.

- Toujours l'histoire ? demanda Sthène.

- Elle flétrit en moi tout ébaudissement, répondit le duc.

- Courage, messire ! Courage ! Mettez-vous donc en selle que nous allions promener.

- C'était bien là mon intention et même plus encore.

- Quoi donc? jours.

- Partir pendant quelques

- Voilà qui me réjouit fort. Où, messire, voulez-vous que je vous emmène ?

- Loin ! Loin ! Ici la boue

[15] est faite de nos fleurs. encore?

- ... bleues, je le sais. Mais

- Choisis.

Le duc d'Auge monta sur le dos de Sthène qui fit la proposition suivante:

- Que diriez-vous d'aller voir où en sont les travaux à l'église Notre-Dame?

- Comment ! s'écria le duc, que estava para bater.

Não bateu na mulher porque defunta, mas bateu nas filhas que eram três; bateu em servos, em servas, em tapetes, em ferros em brasa, bateu cabeça, carteira e, no fim das contas, em retirada. Logo depois, ele resolveu fazer uma curta viagem e a ir à cidade capital em pequeno séquito, acompanhado apenas por seu pajem Mouscaillot.

Dentre seus palafréns, escolheu seu manga-larga favorito que se chamava Demóstenes porque falava, mesmo com o freio na boca.

- Ah! meu bravo Demós, disse o duque de Auge com uma voz queixosa, aqui estou muito triste e merencório.

- Ainda a história? perguntou Stenes.

- Ela faz fenecer dentro em mim todo o júbilo, respondeu o duque.

- Animai-vos, senhor! Animai-vos! Ponde-vos pois na sela para passearmos.

- Era essa mesma a minha intenção e até mais do que isso.

- O que então?

- Ficar fora alguns dias.

- Eis o que me deixa mui contente. Onde quereis que eu vos leve, senhor?

- Longe! Longe! Aqui nossas várzeas não têm flores. então?

-... azuis, eu sei. Mas, e

- Escolha você.

$\mathrm{O}$ duque de Auge montou em Stenes que fez a seguinte proposta:

- O que achais de ir ver a quantas andam as obras na igreja de Notre-Dame?

- Mas como! exclamou o 
ils ne sont pas encore terminés ?

- C'est ce dont nous nous rendrons compte.

- Si on traîne tellement, on finira par bâtir une mahomerie.

- Pourquoi pas un bouddhoir ? un confuciussonnal ? un sanct-lao-tsuaire? Il ne faut pas broyer du noir comme ça, messire ! En route ! et par la même occasion nous présenterons notre feudal hommage au saint roi Louis neuvième du nom.

Sans attendre la réponse de son maître, Sthène se mit à trotter vers le pont-levis qui s'abaissa fonctionnelement. Mouscaillot, qui ne proférait mot de peur de recevoir un coup de gantelet dans les gencives, suivait, monté sur Stéphane, ainsi nommé parce qu'il était peu causant. Comme le duc remâchait son amertume et que Mouscaillot, suivant sa prudente politique, persévérait dans le silence, seul Sthène continuait à bavarder gaiement et il lançait des gabances réjouissantes à ceux qui le regardaient passer, les Celtes d'un air gallican, les Romains d'un air césarien, les Sarrasins d'un air agricole, les Huns d'un air unique, les Alains d'un air narte et les Francs d'un air sournois. Les Normands buvaient du calva.

Tout en saluant très bas leur bien amé suzerain, les manants grommelaient des menaces redoutables mais qu'ils savaient [16] inefficaces, aussi ne dépassaientelles pas les limites de leurs moustaches, s'ils en portaient.

Sur la grand'route, Sthène allait bon train et finit par se taire, ne trouvant plus d'interlocuteur, la circulation étant nulle; il ne voulait importuner son cavalier qu'il duque, ainda não estão terminadas? - É disso que vamos nos inteirar.

- Se as obras se arrastam desse jeito, vão acabar construindo uma maomeria.

- Por que não um santo budário? um confucionário? um santu-lao-tsuário? Não se deve ficar assim, remoendo tristezas, senhor! A caminho! e aproveitaremos a ocasião para apresentarmos nossa feudal homenagem ao santo rei Luís nono do nome.

Sem esperar a resposta de seu mestre, Stenes pôs-se a trotar em direção à ponte levadiça que se abaixou funcionalmente. Mouscaillot, que não proferia palavra com medo de levar a manopla nas fuças, seguia, montado em Estêvão, assim chamado porque era de poucas palavras. Como o duque estava remoendo sua amargura e Mouscaillot, seguindo sua prudente política, perseverava no silêncio, só Stenes continuava falando alegremente e fazendo meneios animadores para os que o viam passar, os celtas com um ar galicano, os romanos com um ar cesariano, os sarracenos com um ar agrícola, os hunos com um ar único, os ossetas com um ar cético e os francos com um ar falso. Os normandos bebiam calvados.

Inclinando-se muito baixo para saudar seu bem amato suserano, os campônios resmungavam ameaças terríveis mas que sabiam ineficazes, por isso elas não passavam dos limites de seus bigodes, se os tivessem.

$\mathrm{Na}$ estrada real, Stenes seguia a bom passo e acabou por se calar, não encontrando mais interlocutores, o trânsito sendo nulo; não queria importunar seu 
sentait somnoler; comme Sthèphe et Mouscaillot partageaient cette réserve, le duc d'Auge finit par s'endormir.

Il habitait une péniche amarrée à demeure près d'une grande ville et il s'appelait Cidrolin. On lui servait à manger de la langouste pas trop fraîche avec une mayonnaise glauque. Tout en décortiquant les pattes de la bête avec un casse-noisettes, Cidrolin dit à Cidrolin:

- Pas fameux tout ça, pas fameux; Lamélie ne saura jamais faire la cuisine.

Il ajouta, s'adressant toujours à lui-même:

- Mais où donc allais-je ainsi monté sur un cheval ? Je ne m'en souviens plus. D'ailleurs, c'est bien ça les rêves; jamais de ma vie je ne suis monté à cheval. Jamais de ma vie non plus je ne suis monté à bicyclette et jamais en rêve je ne monte à bicyclette et pourtant je monte à cheval. Il doit y avoir une explication, c'est sûr. Décidément cette langouste n'est pas fameuse et cette mayonnaise encore moins et si j'apprenais à monter à cheval ? Au Bois, par exemple. Ou bien à bicyclette ?

- Et tu n'aurais pas besoin de permis de conduire, lui fait-on remarquer.

- Passons, passons. fromage.

On apporte ensuite le Du plâtre.

Un fruit.

Des vers s'y logeaient.

[17] Cidrolin s'essuie la goule et murmure:

- Encore un de foutu.

- Ce n'est pas ça qui t'empêchera de faire ta sieste, lui cavaleiro que ele percebia estar adormecendo; como Estêvão e Mouscaillot partilhavam dessa reserva, o duque de Auge acabou por adormecer.

Ele morava numa chata sempre amarrada perto de uma grande cidade e se chamava Cidrolin. Estavam lhe servindo uma lagosta não muito fresca com uma maionese suspeita. Enquanto descascava as patas do animal com um quebra-nozes, Cidrolin disse a Cidrolin:

- Nada bom tudo isso, nada bom; Aamélia nunca vai aprender a cozinhar.

E acrescentou, continuando a falar consigo mesmo:

- Mas aonde eu ia assim montado num cavalo? Não me lembro mais. Aliás, os sonhos são assim mesmo; nunca na minha vida montei a cavalo. Nunca na minha vida montei numa bicicleta e nunca em sonho eu monto em bicicleta e no entanto eu monto a cavalo. Deve haver uma explicação, com certeza. Decididamente essa lagosta não está nada boa e essa maionese menos ainda e se eu aprendesse a andar a cavalo? No Bois de Boulogne, por exemplo. Ou então de bicicleta?

- E você não precisaria de carta de motorista, observam.

continuemos.

Continuemos, queijo.

Em seguida, trazem o

Isopor.

Uma fruta.

Cheia de caruncho.

Cidrolin limpa a boca e murmura:

- Mais uma que vai pro brejo.

- Não é isso que vai te impedir de fazer tua sesta, dizem- 
dit-on.

Il ne répond pas ; sa chaise longue l'attend sur le pont. Il se couvre le visage d'un mouchoir et le voilà bientôt en vue des murailles de la ville capitale, sans se préoccuper du nombre des étapes.

- Chouette, s'écria Sthène, nous y sommes.

Le duc d'Auge s'éveillait, avec l'impression d'avoir fait un mauvais repas. C'est alors que Stèphe, qui n'avait rien dit depuis le départ, éprouva le besoin de prendre la parole en ces termes:

- Alme et inclyte cité...

- Silence ! dit Sthène. Si l'on nous entendait parler, notre bon maître serait accusé de sorcellerie.

- Brrr, fit le duc.

Et son page itou.

- Brrr, fit Mouscaillot.

Et pour montrer de quelle façon il convenait de s'exprimer pour un cheval, Sthène hennit.

Le duc d'Auge descendit à la Sirène torte, qu'un trover de passage lui avait un jour recommandée.

- Nom, prénoms, qualités ? demanda Martin, l'hébergeur.

- Duc d'Auge, répondit le duc d'Auge, Joachim me prénomme et suis accompagné de mon dévoué page Mouscaillot, fils du comte d'Empoigne. Mon cheval a pour nom Sthène et l'autre a pour nom Stèphe.

- Domicile?

- Larche, près du pont.

- Tout cela me semble fort

[18] catoliche, dit Martin.

- Je l'espère bien, dit le duc, car tu commences à m'embrener avec tes méchantes questions. lhe.

Ele não responde; sua espreguiçadeira 0 espera no convés. Cobre o rosto com um lenço e logo se vê diante das muralhas da cidade capital, sem se preocupar com o número de paradas.

- Legal, exclamou Stenes, chegamos.

O duque de Auge acordava, com a impressão de ter feito uma refeição indigesta. Foi então que Estêvão, que não tinha dito nada desde a partida, sentiu a necessidade de tomar a palavra nestes termos:

- Alme et inclyte cidade...

- Silêncio! disse Stenes. Se alguém nos ouvisse falar, nosso bom mestre seria acusado de bruxaria.

- Brrr, fez o duque.

E seu pajem também.

- Brrr, fez Mouscaillot.

E para mostrar de que maneira era conveniente um cavalo se expressar, Stenes relinchou.

$\mathrm{O}$ duque de Auge parou na Sereia Torta, que um trovador de passagem tinha lhe recomendado um dia.

- Nome, sobrenome, títulos? perguntou Martin, o hospedeiro.

- Duque de Auge, respondeu o duque de Auge, Joaquim eu me chamo e estou acompanhado de meu devotado pajem Mouscaillot, filho do conde de Empoigne. Meu caballo tem por nome Stenes e o outro tem por nome Estêvão.

- Domicílio?

- Harca, perto da ponte.

- Tudo isso me parece mui cathólico, disse Martin.

- Espero que sim, disse o duque, porque você já está começando a me enfezar com essas perguntas chatas. 
- Que Messire me pardonne, c'est ordre du roi.

- Tu ne vas pas encore me demander ce que je viens faire dans la ville capitale?

- Nul besoin! Messire vient voir nos putains qui sont les plus belles de toute la chrétienté. Notre saint roi les hait fort; mais elles participent avec ardeur aux finances de la prochaine croisade.

- Moult te goures, hébergeur. Je viens voir où en sont les travaux de l'église Notre-Dame.

- La tour au sud est bien avancée et l'on va commencer celle au nord et la galerie qui les joint. On refait aussi les parties hautes pour donner plus de lumière.

- Assez ! hurla le duc. Si tu me racontes tout, je n'aurai plus qu'à m'en retourner chez moi, ce que point ne souhaite.

- Ni moi non plus, aussi vous apporterai-je incontinent le souper.

Le duc mangea copieusement, puis il alla se coucher et dormit de fort bon appétit.

Il n'avait pas encore terminé sa sieste que deux nomades le réveillèrent en l'interpellant $\mathrm{du}$ haut de la berge. Cidrolin leur répondit par signes, mais sans doute les autres n'entendaient-ils pas ce langage, car ils descendirent le talus jusqu'à la planche passerelle et montèrent sur la péniche. Il y avait un campeur mâle et un campeur femelle.

- Esquiouze euss, dit le campeur mâle, mà wie sind lost.

Cidrolin.

- Bon début, réplique

[19] lostes.

- Capito ? Egarrirtes...

- Triste sort.
- Perdoai-me, senhor, é ordem do rei.

- Você não vai me perguntar o que eu venho fazer na cidade capital?

- Não há necessidade! O senhor vem ver nossas putas que são as mais belas de toda a cristandade. Nosso santo rei as odeia muito; mas elas participam com ardor das finanças da próxima cruzada.

- Estás mui enganado, hospedeiro. Eu venho ver como andam as obras da igreja de NotreDame.

- A torre do sul está bem adiantada e agora vão começar a do norte e a galeria que as une. Estão refazendo também as partes altas para dar mais luz.

- Basta! urrou o duque. Se você me contar tudo, nada mais me restará a não ser voltar para casa, e isso eu não quero de jeito nenhum.

- Nem eu tampouco. Assim, vou trazer-vos a ceia sem mais delongas.

O duque comeu copiosamente, depois foi se deitar e dormiu com mui bom apetite.

Ele ainda não tinha terminado sua sesta e dois nômades despertaram-no chamando-o do alto da margem. Cidrolin respondeu-lhes por sinais, mas provavelmente os outros não entendiam essa linguagem, pois desceram o barranco até a passarela e subiram na chata. Havia um campista macho e um campista fêmea.

- Exquiuzi-ãs, disse o campista macho, ma wie sind lost. Cidrolin.

- Bom começo, replica

- Capito? Egarrirtes... lostes.

- Triste sorte. 
- Campigne ? Lontano ? Euss... smarriti...

- Il cause bien, murmura Cidrolin, mais parle-t-il l'européen vernaculaire ou le néo-babélien ?

- Ah, ah, fit l'autre avec les signes manifestes d'une vive satisfaction. Vous Ferchtéer l'iouropéen?

- Un poco, répondit Cidrolin; mais posez là votre barda, nobles étrangers, et prenez donc un glass avant de repartir.

- Ah, ah, capito: glass.

Radieux, le noble étranger posa donc son barda, puis, dédaignant les meubles destinés à cet usage, il s'accroupit sur le plancher en croisant ses jambes sous lui avec souplesse. La demoiselle qui l'accompagnait fit de même.

- Seraient-ils japonais ? se demanda Cidrolin à mi-voix. Ils ont pourtant le cheveu blond. Des Aïnos peut-être.

Et s'adressant au garçon :

- Ne seriez-vous pas aïno ?

I ? No. Moi: petit ami de tout au monde.

- Je vois: pacifiste ?

- Iawohl ! Et ce glass ?

- Perd pas le nord, l'Européen.

Cidrolin tapa dans ses mains et appela :

- Lamélie ! Lamélie !

On apparut.

- Lamélie, à boire pour ces nobles étrangers.

- Quoi ?

- De l'essence de fenouil, par exemple, avec de l'eau plate.

On s'eclipsa.

Cidrolin se pencha vers les nomades.

- Alors, mes petits oisillons,

[20] vous voilà égarrirtes ?

- Paumés, dit la fille.
- Câmpingue? Lontano? Âs... smarriti...

- Ele fala bem, murmurou Cidrolin, mas será que fala o europeu vernacular ou o neobabélico?

- Ah, ah, fez o outro com sinais manifestos de uma viva satisfação. Você falar iuropeu?

- Un poco, respondeu Cidrolin; mas tirem suas tralhas, nobres estrangeiros, e tomem um glass antes de partir.

- Ah, ah, capito: glass.

Radiante, o nobre estrangeiro tirou sua tralha, depois, desdenhando dos móveis destinados a esse fim, acocorou-se no chão cruzando as pernas com flexibilidade. A senhorita que o acompanhava fez o mesmo.

- Seriam japoneses? perguntou-se Cidrolin a meia voz. Mas eles têm o cabelo loiro. São ainos talvez.

E dirigindo-se ao rapaz:

- Você não seria aino?

- I? No. Eu: amiguinho de tudo no mundo.

- Ah, sei: pacifista?

- Iawohl! E esse glass?

- Não perde o rumo, o europeu.

Cidrolin bateu palmas e chamou:

- Aamélia! Aamélia!

Apareceram.

- Aamélia, algo de beber

para esses nobres estrangeiros.

- O que?

- Essência de funcho, por exemplo, com água sem gás.

Eclipsaram-se.

Cidrolin inclinou-se para os nômades.

- Então, meus pombinhos, vocês estão extraviatti?

- Perdidos, disse a moça. 
Complètement paumés.

- Seriez-vous française, ma mie?

- Pas encore : canadienne.

- Et ce glass ? demanda l'accroupi. Schnell qu'on trinque ! dit Cidrolin.

- Il est un peu casse-pieds,

- Oh, ce n'est pas le mauvais gars.

- Et naturellement vous allez comme ça tous les deux au camp de campigne pour les campeurs.

- Nous le cherchons.

- Vous êtes quasiment arrivés. C'est le long du fleuve, à moins de cinq cents mètres d'ici en amont.

- Wie sind arrivati ? s'écria le garçon en se remettant sur pieds d'un seul mouvement. Sri hundred yards ? Andiamo !

Il remit son barda sur le dos, un barda qui devait bien faire la tonne.

- On attend l'essence de fenouil, dit la fille sans bouger.

- Ouell, ouell.

Il redescendit sa tonne de paquetage et se rassit avec le même naturel que si le plancher avait été un lotus.

Cidrolin sourit à la fille et lui dit d'un air complimenteur:

- C'est dressé.

- Dressé ? Comprenons pas.

- Eh bien oui, il obéit au doigt et à l'œil.

Elle haussa les épaules.

- Vous êtes un feignant de la méninge, dit-elle. Il reste parce qu'il est libre, pas parce qu'il est dressé. S'il était dressé, il irait tout de suite au camp de campigne pour [21] les campeurs. Il reste parce qu'il est libre.

- Il y en a de l'idée dans une
Completamente perdidos.

minh'amiga?

- Você seria francesa,

- Ainda não: canadense.

- E esse glass? perguntou o acocorado. Schnell brindemos!

- Ele é um pouco chato, disse Cidrolin.

- Oh, não é um mau sujeito.

- E naturalmente vocês dois vão ao campo de câmpingue para os campistas.

- Estamos procurando.

- Vocês quase chegaram. Fica na beira do rio, a menos de quinhentos metros a montante.

-Wie sind arrivati? exclamou o rapaz pondo-se em pé com um só movimento. Tri hundred yards? Andiamo!

Ele pôs a mochila nas costas, uma mochila que devia pesar bem uma tonelada.

- Estamos esperando a essência de funcho, disse a moça sem se mexer.

- Uéu, uéu.

Ele tirou novamente sua tonelada de bagagem e sentou-se com a mesma naturalidade como se o chão fosse um lótus.

Cidrolin sorriu para a moça e disse-lhe com um ar adulador:

- É amestrado.

- Amestrado? Num tamo entendendo.

- Bem, ele obedece ao gesto e ao olhar.

Ela sacudiu os ombros. - Você é fraco das idéias, disse ela. Ele fica porque é livre, não porque é amestrado. Se fosse amestrado, iria imediatamente ao campo de câmpingue para campistas. Ele fica porque é livre.

- Tem idéias numa 
petite tête comme ça, murmura Cidrolin en regardant plus attentivement la Canadienne et notamment le blond duvet de ses cuisses et la semelle de ses souliers. Eh oui, de l'idée...

Là-dessus, on apporta l'essence de fenouil et l'eau plate. Ils burent.

- Et comment nomadezvous ? demanda Cidrolin. À pied, à cheval, en voiture ? en hélico, en vélo, en auto ?

- En stop, répondit la fille.

- En auto-stop?

- Bien sûr en auto-stop.

- Moi, je voyage parfois en autotaxi. C'est moins économique.

- L'argent on s'en fout.

- D'accord. Et mon essence de fenouil ?

- Pas mauvais. Je préférons l'eau pure.

- Ici elle n'est jamais pure. Le fleuve c'est l'égout et le robinet le chlore.

- Vous ne voulez pas qu'il vous chante quelque chose?

- Pour quoi faire?

- Pour vous remercier.

- De l'essence de fenouil ?

- De l'accueil.

- C'est gentil. Merci.

La fille se tourna vers le garçon et lui dit :

- Chante.

Il fouilla dans son équipement et en retira un banjo de taille minime dont aussitôt il gratta les cordes. Après quelques accords préliminaires, il ouvrit la bouche et ils entendirent ces mots :

- J'aime Paimpol et sa falaise, son clocher et son vieux pardon...

- Où a-t-il appris ça ? demanda Cidrolin lorsque ce fut cabecinha dessas, murmurou Cidrolin olhando mais atentamente a canadense, principalmente a penugem loira de suas coxas e a sola de seus sapatos. É, tem idéias...

Foi aí que trouxeram a essência de funcho e a água sem gás. Eles beberam.

E como vocês nomadeiam? perguntou Cidrolin. A pé, a cavalo, de carro? de helicóptero, de bicicleta, de automóvel?

- De carona, respondeu a moça.

- De carona de carro?

- Claro, de carona de carro.

- Eu, às vezes vou de táxi. É mais caro.

- Não ligamos a mínima para o dinheiro.

- Está certo. E minha essência de funcho?

- Não é ruim. Nós preferir água pura.

- Aqui ela nunca é pura. O rio é esgoto e a torneira é cloro.

- Você não quer que ele cante alguma coisa?

- Para quê?

- Para agradecer-lhe.

- Pela essência de funcho?

- Pela acolhida.

- É muito gentil. Obrigado.

A moça virou-se para $o$ rapaz e disse:

- Cante.

Ele fuçou em sua mochila e retirou de lá um banjo de tamanho mínimo cujas cordas arranhou logo depois. Após alguns acordes preliminares, ele abriu a boca e eles ouviram estas palavras:

- Eu gosto de Paimpol e de sua falésia, de seu campanário e de seu velho pendão da procissão...

- Onde ele aprendeu isso? perguntou Cidrolin assim que a 
fini et qu'il eut remercié le virtuose.

- À Paimpol, bien sûr, répondit la Canadienne.

- Suis-je bête, dit Cidrolin en se tapant le front. Je n'y avais pas pensé.

Le minibanjo réintégra le rucksack. Le garçon reprit de nouveau la position debout et il tendit la main à Cidrolin.

rivedertchi.

- Sanx, dit-il, et à

Et à la fille:

- Schnell! Onivati oder onivatipa?

La fille se lève avec grâce et se harnache illico.

- C'est dressé, dit Cidrolin à mi-voix.

Le nomade protesta :

- Nein ! Nein ! Pas tressé: libre. Sie eze libre. Anda to the campus bicose sie eze libre d'andare to the campus.

- Je sais, je sais.

- Adieu, dit la fille en tendant à son tour la main à Cidrolin. Merci encore et on reviendra peut-être vous voir si on a le temps.

- C'est ça, dit Cidrolin.

Il les regarda grimper le talus avec tout leur bagage.

- C'est un métier de costaud, murmura-t-il.

- Ils vont revenir? demanda Lamélie.

- Je ne crois pas. Non, ils ne reviendront jamais. Qu'est-ce que j'en aurais fait ? Ils sont à peine partis que c'est tout juste si je me souviens d'eux. Ils existent pourtant, ils méritent sans doute d'exister. Ils ne reviendront jamais s'égarer dans le labyrinthe de ma mémoire. C'était un incident sans importance. Il y a des rêves qui se déroulent comme des incidents música terminou e que ele agradeceu o virtuose.

- Em Paimpol, é claro, respondeu a canadense.

- Como sou besta, disse Cidrolin batendo na testa. Não tinha pensado nisso.

O minibanjo reintegrou o rucksack. $\mathrm{O}$ rapaz retomou a posição ereta e estendeu a mão a Cidrolin.

rivedertchi.

- Sanx, disse ele e a

E à moça:

- Schnell! Simbora oder numvamu?

A moça levanta-se graciosamente e se apruma imediatamente.

- É amestrada, disse Cidrolin a meia voz.

O nômade protestou:

- Nein! Nein! Non amestrata: livre. Sie ize livre. Anda to the campus bicose sie ize livre pra andare to the campus.

- Sei, sei.

- Adeus, disse a moça estendendo por sua vez a mão a Cidrolin. Obrigado mais uma vez e talvez voltemos a visitá-lo, se tivermos tempo.

- Está bem, disse Cidrolin.

Ele os olhou escalar o barranco com toda sua bagagem.

- É coisa pra quem tem muque, murmurou ele.

- Vão voltar? perguntou Aamélia.

- Acho que não. Não, não vão voltar nunca mais. O que eu faria se voltassem? Eles mal partiram e mal me lembro deles. No entanto, eles existem, provavelmente eles merecem existir. Eles não voltarão nunca mais para se perder no labirinto de minha memória. Foi um incidente sem importância. Há sonhos que se desenrolam como incidentes sem 
sans importance, de la vie éveillée on ne retiendrait pas des choses comme ça et cependant ils intéressent lorsqu'on les saisit au matin se poussant en désordre contre la porte des paupières. Peutêtre ai-je rêvé ?

Lamélie n'avait pas à lui dire oui ou non; d'ailleurs elle n'avait pas attendu la fin de ce discours.

Cidrolin consulta l'horloge dans le carré et constata, non sans satisfaction, que l'épisode des nomades n'avait été qu'un intermède assez bref dans le temps qu'il accordait à sa sieste et que celle-ci pouvait être reprise décemment pendant encore quelques minutes. Il s'étendit donc sur sa chaise longue et réussit à s'endormir de nouveau. importância, na vida desperta a gente não guardaria lembrança de coisas assim e no entanto eles interessam quando a gente os pega de manhã empurrando-se em desordem contra a porta das pálpebras. Será que eu sonhei?

Aamélia não tinha a dizer nem sim nem não; aliás ela nem tinha esperado o fim do discurso.

Cidrolin consultou o relógio no saguão e constatou, com satisfação, que o episódio dos nômades tinha sido apenas um breve intervalo no tempo que ele dedicava a sua sesta e que podia retomá-la decentemente ainda por alguns minutos. Estendeu-se então na sua espreguiçadeira e conseguiu adormecer de novo. 
- Que vois-je! s'écria le roi assis sous son chêne, n'est-ce point là mon bien aimé Auge qui s'avance?

- Lui-même, sire, répondit le hoberau en s'inclinant bien bas. Mes respects, ajouta-t-il.

- Je suis heureux de te voir en florissante santé, dit le roi. Comment va ta petite famille?

- Ma femme est morte, sire.

- Tu ne l'as pas tuée, au moins? Avec toi, on ne sait jamais.

Le roi sourit de sa bénévolente indulgence et la flote qui l'entourait ne l'en admira que plus.

demanda le roi.

- Et toujours pas d'héritier?

- Hélas! dit le duc. Je n'ai que mes triplées, ce qui est, je vous assure, un calvaire.

- À propos de calvaire, dit le roi, je suis bien heureux de te voir. Nous préparons un nouveau croisement et nous comptons bien que tu te joindras à nous.

grand'chose.

- Cela ne me dit pas

- Ttt, ttt. Ne prends pas parti avant d'avoir écouté le détail de la chose. D'abord, cette fois-ci, nous n'allons pas en Égypte (à quoi na sert?) mais nous voguons vers Carthage.

- Cela ne me dit pas plus.

- Carthage? mais voyons, mon bien aimé Auge, rien que pour les souvenirs historiques... saint Augustin... Jugurtha... Scipion... Hannibal... Salammbô... cela ne te dit rien?

- Rien du tout, sire. Moi pas être un intellectuel.

- Ah Auge, mon bien aimé Auge, il faudra bien que tu m'accompagnes pour éventrer du
- O que vejo! exclamou o rei sentado sob seu carvalho, não é meu bem amado Auge que vem vindo?

- O próprio, senhor, respondeu $\mathrm{o}$ fidalguinho inclinando-se bem baixo. Meus respeitos, acrescentou.

- Estou feliz por vê-lo com florescente saúde, disse o rei. E a família, como vai?

- Minha mulher morreu, senhor.- Mas você não a matou, não é? Com você, nunca se sabe.

O rei sorriu com sua benevolente indulgência e a multidão que o rodeava admirou-o ainda mais por isso.

- Ainda sem herdeiro? perguntou o rei.

- Ai de mim! disse o duque. Só tenho minhas trigêmeas, e vos garanto que é um calvário.

- Por falar em calvário, disse o rei, estou muito feliz por vê-lo. Estamos preparando um novo cruzamento e fazemos questão de que você se junte a nós.

- Isso não me diz nada.

- Ttt, ttt. Não decida antes de ter ouvido todos os detalhes. Pra começar, desta vez, nós não vamos ao Egito (o que poderia náscer daí?) mas vogamos na direção de Cartago.

- Também não me diz nada.

- Cartago? mas veja bem, meu bem amado Auge, nem que seja só pelas lembranças históricas... santo Agostinho... Jugurta... Cipião... Aníbal... Salammbô... isso não lhe diz nada? - Nada, senhor. Eu não ser intelectual.

- Ah Auge, meu bem amado Auge, é preciso que você me acompanhe para estripar infiéis. 
mécréant.

- Nenni, sire. Cette fois-ci, je ne suis mis dans le coup.

- Tu ne veux plus déconfire les adorateurs de Mahom?

- Voyez, sire, je me suis retiré à la campagne dans mon petit châtiau, j'y élève les filles dont le bon Dieu m'a affligé, j'y soigne sans les sancier les fièvres paludéennes que j'ai ramenées de Damiette et autres colonies lointaines, mon saint homme de chapelain, l'abbé Onésiphore Biroton, me mène vers les voies de la sanctification, pourquoi, sire, oui, pourquoi quitterais-je ma petite province pour qu'on m'y ramène l'an suivant salé dans une jarre?

Le saint roi soupira.

- Bref, dit-il, tu ne veux pas aller pourfendre el Mostanser Billah?

- Qu'il se pourfende tout seul, sire, tel est mon dernier mot.

- Ah! je vois que j'aurai bien du mal à mener cette huitième croisade.

Le bon saint roi en fut tout attristé.

- Allons, allons, dit le duc d'Auge, vous trouverez toujours bien un quarteron de coyons pour vous accompagner sur ces rives lointaines.

- Je l'espère bien, dit le roi avec mélancolie. congé?

- Puis-je prendre mon

Le roi donna son acort.

Comme il se retirait, le duc reçut sur le coin du visage toute une cargaison d'œufs pourris et de tomates fanées; la flote qui écoutait le saint roi discourir sous son chêne estimait que le dit saint roi se montrait d'une faiblesse coupable devant ce lâche vassal qui préférait
- Nananinanão, senhor.

Desta vez, não vou me meter na história.

- Você não quer desbaratar os adoradores de Muhammad?

- Vede, senhor, eu me retirei para o campo, pru meu castelinho, lá crio as filhas com as quais o bom Deus me afligiu, lá cuido sem curá-las das febres paludianas que eu trouxe de Damieta e de outras colônias longínquas, meu capelão, o abade Onesíforo Biroton, sim toma medidas para me conduzir ao caminho da santificação, por que, senhor, é, por que eu deixaria minha terrinha para que me tragam de volta no ano seguinte salgado num jarro?

O santo rei suspirou.

- Resumindo, disse ele, você não quer ir transpassar o Mostanser Billah?

- Que ele se transpasse sozinho, senhor, essa é minha última palavra.

- Ah! estou vendo que vai ser difícil conduzir essa oitava cruzada.

O bom santo rei ficou muito entristecido.

- Vamos, vamos, disse o duque de Auge, vós encontrareis um bom punhado de coiós para acompanhar-vos a essas plagas longínquas.

- Assim espero, disse o rei com melancolia.

- Posso retirar-me?

O rei deu seu de acordo.

Quando se retirava, o duque recebeu na cara uma carga de ovos podres e de tomates moles; a multidão que escutava o santo rei discorrer sob seu carvalho achava que o dito santo rei se mostrava de uma fraqueza inaceitável diante 
le confort de son petit châtiau aux aléas d'une chrétienne expédition du côté de Bizerte; et ce, d'autant plus qu'eux-mêmes, borgeois, artisans, ou manants, ne risquaient en aucune façon de se voir expédier sur les rivages autrefois carthaginois pour y recevoir des coups de cimeterres ou y attraper d'insanciables maladies.

- Hou hou, la salope, qu'ils criaient, oh le vilain dégonflé, le foireux lardé, la porcine lope, le pétochard affreux, le patriote mauvais, le marcassin maudit, la teigne vilaine, le pleutre éhonté, le poplican félon, la mauviette pouilleuse, le crassou poltron, l'ord couard, le traître pleutre qui veut laisser le tombeau de sire Jésus aux mains des païens et qui répond mal à son roi. Vive Louis de Poissy! Hou hou, la salope!

Et ils continuaient à lancer bourses saignantes et crottins truffés sur le duc, lequel finit par s'énerver. Dégainant son braquemart, il fit de larges moulinets qui mirent en fuite manants, artisans et borgeois, lesquels s'égaillèrent rapidement à la ronde mais non sans se piétiner fort, ce qui en occit quelques dizaines pour le repos de l'âme desquels le saint roi pria plus tard efficacement.

Écœuré, le duc se dirigea vers une baignoirie afin de s'y nettoyer des résidus de l'hostilité publique.

- Ah! les salopards, grommelait-il, il n'y a plus de liberté si les vilains s'en mêlent. Lui, Louis, n'oublie pas les services que je lui rendis à Damiette et à Mansourah. La guerre aux colonies, il sait ce que c'est, il me comprend. Lui, Louis, il veut y retourner: c'est son affaire. Lui, Louis, ce n'est pas comme desse vassalo frouxo que preferia o conforto de seu castelinho aos riscos de uma expedição cristã em Bizerta; ainda mais que eles mesmos, burgueses, artesãos ou campônios, não corriam nenhum risco de se ver expedidos para as plagas outrora cartaginesas para lá receberem golpes de cimitarras ou pegar doenças insanáveis.

- Huu, huu, filha duma égua, gritavam, oh o patife preguiçoso, o cagão safado, o porcino nojento, o biltre medroso, o mau patriota, o porco maldito, o cão sarnento, o canalha sem vergonha, o velhaco poltrão, o covarde imundo, o traidor patife que quer deixar o túmulo do senhor Jesus nas mãos dos pagãos e que responde mal a seu rei. Viva Luís de Poissy! Huu, huu, filha duma égua!

E continuavam a atirar bosta fresca e merda seca sobre o duque, o qual acabou por se irritar. Desembainhando a catana, fez largos movimentos que puseram em fuga campônios, artesãos e burgueses, os quais se dispersaram rapidamente pelos arredores mas não sem se pisotearem, o que matou algumas dezenas para o repouso da alma dos quais o santo rei rezou mais tarde eficazmente.

Enojado, o duque dirigiu-se a uma casa de banhos a fim de se limpar dos resíduos da hostilidade pública.

- Ah! filhos da mãe, rosnava ele, não há mais liberdade se os vilões se intrometem. Ele, Luís, não esquece os serviços que lhe prestei em Damieta e em Almançora. A guerra nas colônias, ele sabe o que é isso, ele me compreende. Ele, Luís, quer voltar para lá: é problema dele. Ele, Luís, não é como eu, sinto mas é um 
moi, c'est un saint homme, on finira par voir son nom sur le calendrier; tandis que ces vilains qui me huent, qu'est-ce qu'ils veulent au fond? Libérer le saint sépulcre? Ils s'en moquent. Ce qu'ils veulent, c'est voir tous les nobles seigneurs comme moi étripés par les Chleuhs pour envahir nos châtiaux, boire notre vin clairet dans nos caves et qui sait? violenter nos mères, nos femmes, nos filles, nos servantes et nos brebis.

- Et nos juments, dit Sthène.

Un passant sursauta. à haute voix.

- Et nos juments, dit le duc

Il se pencha vers le quidam:

- C'est moi qui ai dit: "et nos juments". C'est moi, tu entends, vilain?

Comme le duc roulait de gros yeux, l'autre répondit bien poliment: messire.

- Point ne vous contredis, rassuré.

Puis il disparaît, peu

- Il est grand temps que nous quittions cette ville, dit le duc. Nous avons vu les travaux de Notre-Dame, admiré la Sainte Chapelle, ce joyau de l'art gothique, rendu hommage comme il faut à notre saint roi, tout cela est fort bien, mais je sens que cela va se gâter avec la population; aussi, après la baignerie, nous irons dîner dans une taverne de luxe pour nous réconforter et partirons sitôt après.

Tandis qu' on nettoyait ses vêtements et qu'il mijotait dans l'eau chaude, le duc s'endormit.

Après avoir fermé le portillon derrière lui, Cidrolin santo homem, a gente ainda vai acabar vendo seu nome no calendário; enquanto que esses vilões que estão me vaiando o que querem afinal? Libertar o santo sepulcro? Estão pouco ligando pra isso. $\mathrm{O}$ que eles querem, é ver todos os nobres senhores como eu estripados pelos pagãos para invadir nossos castelos, beber nosso vinho clarete nas nossas adegas e quem sabe? violentar nossas mães, nossas mulheres, nossas filhas, nossas empregadas e nossas cabritas. - E nossas éguas, disse Stenes.

Um passante sobressaltouse.

- E nossas éguas, disse o duque em voz alta.

sujeito:

Ele inclinou-se para o

- Fui eu que disse: "e nossas éguas". Fui eu, entendeu, vilão?

Como o duque estava olhando feio, o outro respondeu bem educado:

- Não vos contradigo de forma alguma, senhor. tranquilo.

$\mathrm{E}$ desaparece, não muito

- Já é tempo de deixarmos essa cidade, disse o duque. Vimos as obras de Notre-Dame, admiramos a Sainte Chapelle, essa jóia da arte gótica, prestamos a devida homenagem a nosso santo rei, tudo isso está mui bem, mas sinto que com a população vai tudo por água abaixo; então, depois do banho, vamos jantar numa taberna de luxo para nos reconfortarmos e partiremos logo depois.

Enquanto lavavam suas roupas e ele ficava de molho na água quente, o duque adormeceu.

Depois de fechar o portão atrás de si, Cidrolin verificou se 
regarda si des inscriptions souillaient la clôture qui séparait du boulevard le terrains en pente attenant à la péniche. Il n'y en avait point. Cela fait, il décida de traverser pour aller voir les travaux qui se faisaient en face; il devait se construire là un immeuble, pour le moment il n'y avait qu'un trou.

Ayant pris les précautions nécessaires, Cidrolin se retrouva sain et sauf de l'autre côté de la chaussée. Il s'approche prudemment de la palissade, sur laquelle il était noté Danger-Sortiede-camions. Dans le fond, une pelle mécanique ramasse des débris de caves pour en remplir un de ces camions dont la sortie s'annonce si dangereuse. Des hommes casqués de blanc vont et viennent. Il se décharge des choses dans un coin. Pour un bâtisseur, tout cela doit être intelligible.

Un passant est venu se joindre à Cidrolin; ils regardent tous deux le camion se remplir. Lorsqu'il fut plein, le camion grimpa la rampe qui le sortait du trou. Cidrolin s'écarta prudemment. Une fois sur le plat, le camion fonça sur le boulevard; le passant fit un bond en arrière tandis que grinçaient des freins de houatures.

- Vous avez vu? dit à

Cidrolin le passant tout pâle. Cet enfant de salaud a failli m'écraser.

- Il n'en a rien fait, répondit Cidrolin objectivement.

- Il a fait tout ce qu'il a pu.

- Vous étiez prévenu. C'était écrit: "Danger-Sortie-decamions". À l'école, je me demandais pourquoi on apprenait à lire; maintenant j'ai compris: pour éviter les camions.

- Soit, mais supposez que moi aussi j'aie appris à lire, mais une autre langue que la vôtre. Dois- inscrições maculavam a cerca que separava do bulevar o terreno em declive que ia até a chata. Nada havia. Feito isso, ele resolveu atravessar para ver a obra que estavam fazendo em frente; iam construir um prédio ali, por enquanto era só um buraco.

Tendo tomado as precauções necessárias, Cidrolin chegou são e salvo do outro lado da rua. Ele se aproxima prudentemente da paliçada, na qual estava escrito Perigo-Saída-decaminhões. No fundo, uma escavadeira apanha os entulhos para encher um desses caminhões cuja saída se anuncia tão perigosa. Homens de capacete branco vão e vêm. Descarregam-se coisas num canto. Para um construtor, tudo aquilo deve ser inteligível.

Um passante veio se juntar a Cidrolin; os dois olham o caminhão se encher. Quando ficou cheio, o caminhão subiu a rampa que o tirava do buraco. Cidrolin afastou-se prudentemente. Uma vez no plano, o caminhão avançou para o bulevar; o passante deu um salto para trás enquanto chiavam freios de otomóvis.

- O senhor viu? disse a Cidrolin o passante branco como cera. Esse filho da mãe quase me atropelou.

- Mas não fez nada, respondeu Cidrolin objetivamente.

- Ele fez tudo o que pôde. O senhor estava prevenido. Estava escrito: "Perigo-Saída-decaminhões". Na escola, eu me perguntava por que se aprendia a ler; agora entendi: para evitar os caminhões.

- Que seja, mas suponha que eu também tenha aprendido a ler, mas uma língua diferente da 
je alors être nécessairement écrasé?

Un monsieur, monté sur une mobylette, freina sec, mit pied à terre et, menant son véhicule par une oreille, s'approcha d'eux. Il était vêtu d'une longue robe noire et coiffé d'un sombrero de même couleur, à bords roulés.

- Ad majorem Dei gloriam, dit-il en tendant la main.

- Monsieur ne sait pas le français, dit Cidrolin.

- Sed tu?

- Je le comprends à peine.

- Bon, bon.

Il se remit en selle, fit un bout de trajet sur le trottoir contrairement aux règlements et reprit la chaussée un peu plus loin, se mêlant à la coulée des houatures.

-Aussi conciliant qu'un père conciliaire, dit le passant.

Cidrolin bâilla.

- Vous avez sommeil? demanda le passant.

- Non, j'ai faim. L'heure du déjeuner approche. Je vous prie de m'excuser, je vais continuer ma promenade antéprandiale dont je n'ai pas achevé le circuit.

- Je, continua le passant en élevant le ton, vous disais donc que j'étais étranger. Vous vous souvenez du camion?

- Vous êtes de ces nomades...? demanda Cidrolin poliment.

l'hôtel...

- Moi? point. J'habite

- et moi cette péniche...

- un hôtel de luxe même...

- immobile...

- il y a des vatères dans la

salle de bains...

- amarrée...

- l'ascenseur... téléphone... sua. Então tenho necessariamente que ser atropelado?

Um senhor, montado numa mobilete, freou seco, apeou e, puxando seu veículo pela orelha, aproximou-se deles. Vestia um longo vestido preto e um sombrero da mesma cor, com abas enroladas.

- Ad majorem Dei gloriam, disse ele estendendo a mão.

- O senhor não sabe francês, disse Cidrolin.

- Sed tu?

- Eu mal entendo.

- Bom, bom.

Ele montou de novo na mobilete, fez um trecho do trajeto pela calçada contra os regulamentos e pegou a rua um pouco mais longe, misturando-se ao fluxo dos zotomóvis.

- Tão conciliador quanto um padre conciliário, disse o passante.

Cidrolin bocejou.

- O senhor está com sono? perguntou o passante.

- Não, estou com fome. Está quase na hora do almoço. Peço que me dê licença, vou continuar meu passeio anteprandial cujo circuito não completei ainda.

- Eu, continuou o passante elevando o tom, dizia que era estrangeiro. O senhor se lembra do caminhão?

- O senhor é um desses nômades...? perguntou Cidrolin educadamente.

- Eu? De jeito nenhum. Moro no hotel...

- e eu nessa chata...

- um hotel de luxo mesmo...

- imóvel...

- tem latrina no banheiro...

- amarrada...

- elevador...

- eu poderia até ter telefone... 
chambres...

- le téléphone dans les

- il y a un numéro bleu avec

des chiffres comme pour une maison..

-avec l'automatique pour

l'étranger...

- c'est le vingt et un...

- et au rez-de-chaussée, il y

a un bar...

-de ma chambre, je pourrais pêcher...

-américain...

- je pourrais pêcher, si je pêchais, mais je n'aime pas pêcher.

-Vous avez bien raison, dit le passant s'intéressant brusquement aux propos de son interlocuteur; la pêche c'est aussi cruel que les courses de taureaux...

- Je n'avais jamais fait la comparaison, dit modestement Cidrolin.

- Réfléchissez cinq minutes.

Ce sont des maniaques sadiques, les pêcheurs à la ligne. Ils ont une réputations usurpée de philosophes bons. Franchement, ne trouvezvous pas l'hameçon plus sournois et vicieusement barbare que l'espadrille?

- L'espadrille?

- Ces trucs qu'ils enfoncent dans le cou du fauve.

- Vous êtes sûr que cela s'appelle comme ça?

- Pour le moment, moi j'appelle ça comme ça, donc ça s'appelle comme ça et comme c'est

[31] avec moi que vous causez en ce moment et avec nul autre, il vous faut bien prendre mes mots à leur valeur faciale.

- Le fait est que je vous comprends parfaitement.

- Vous voyez! Eh bien, brisons là cette conversation et tenons-nous-en à ces prémices de la compréhension mutuelle et unescale entre les peuples et de la
- telefone nos quartos...

- tem um número azul com algarismos como uma casa...

- com discagem direta para o exterior...

- é o vinte e um...

- e no térreo, tem um bar...

- do meu quarto, eu podia pescar...

- americano...

- eu podia pescar, se eu pescasse, mas não gosto de pescar.

- O senhor tem toda a razão, disse o passante interessando-se de repente pela conversa de seu interlocutor; a pesca é tão cruel quanto as corridas de touro...

- Eu nunca tinha feito essa comparação, disse modestamente Cidrolin.

- Pense um pouco. São maníacos sádicos, os que pescam com vara. Eles têm a falsa fama de filósofos bons. Francamente, o senhor não acha o anzol mais traiçoeiro e viciosamente bárbaro do que a espadilha?

- Espadilha?

- Essas coisas que enfiam no pescoço da fera.

- Tem certeza de que isso se chama assim?

- Nesse momento, eu chamo isso assim, logo isso se chama assim e como é comigo que o senhor está conversando nesse momento e com ninguém mais, o senhor tem que tomar minhas palavras pelo seu valor nominal.

- O fato é que eu o compreendo perfeitamente.

- Está vendo! Bom, interrompamos esta discussão e apeguemo-nos a essas primícias da compreensão mútua e unescal entre os povos e da paz futura. O senhor 
paix future. Vous permettez que je continue ma promenade? Enchanté de vous avoir rencontré.

Le passant s'éloigna tandis que le contremaître sifflait la pause. Cidrolin entreprit de traverser le boulevard, ce qu'il fit avec une prudence accrue, car c'était l'heure où les houatures vont boire. Parvenu sain et sauf de l'autre côté de la chaussée, il put constater que clôture comme poortillon étaient vierges de tout graffite.

L'essence de fenouil et l'eau plate, le litron de rouge et le pot de moutarde attendaient Cidrolin. On lui servit des anchois beurre, du boudin de campagne pomme en l'air pomme en bas, du roquefort et trois babas. Les anchois sont des harengs pluvieux, le boudin et ses pommes se montrent inconsistants, le roquefort grince sous le couteau, le rome des babas mous ne put jamais prétendre qu'à la dénomination d'eau.

murmure:

Cidrolin soupire et

- Encore un de foutu.

- Que mange-t-on en votre taverne de luxe? demande le duc d'Auge.

Le tavernier répondit:

- Du bortch qui est de la choupe aux chous echclavons et des tripes à la viducasse, le tout arrosé de vin des coteaux de Suresnes.

- À peine de quoi se mettre sous la grosse dent, dit le duc avec mépris.

- Messire a-t-il déjà mangé $\mathrm{du}$ bortch? répliqua le tavernier vexé jusqu'à l'insolence.

- Ma parole! s'écria le duc en s'adressant à Mouscaillot, il me prend pour un béda! Je connais cela depuis le temps de la reine Anne!

Impressionné, le tavernier permite que eu continue meu passeio? Prazer em tê-lo encontrado.

O passante distanciou-se no momento em que o contramestre apitava a pausa. Cidrolin atravessou o bulevar, desta vez com prudência redobrada, pois era a hora do carro beber água. Tendo chegado são e salvo do outro lado, ele pôde constatar que tanto cerca quanto portão estavam virgens de qualquer grafíti.

A essência de funcho e a água sem gás, o garrafão de vinho e o pote de mostarda esperavam Cidrolin. Serviram-lhe anchovas com manteiga, chouriço caipira com maçãs por cima e por baixo, queijo e três babas-de-moça. As anchovas são arenques aguados, o chouriço e suas maçãs mostram-se inconsistentes, o queijo range na faca, as babas tão insossas que não pareciam de moça.

murmura:

Cidrolin suspira e brejo

- Mais uma que vai pro

- O que se come em sua taberna de luxo? pergunta o duque de Auge.

O taberneiro respondeu:

- Bortsch, que é uma sopa de cove eslava e tripas à viducasse, tudo regado a vinho das costas de Suresnes.

- Não dá nem pra encher a cova do dente, disse o duque com desprezo.

- O senhor já comeu bortsch? replicou o taberneiro contrariado até a insolência.

- Claro! exclamou o duque dirigindo-se a Mouscaillot, ele pensa que eu sou caipira! Conheço isso desde o tempo da rainha Anne! Impressionado, o taberneiro 
s'inclina profondément.

- Je vois à ta mine, continua

le duc, que tu te demandes qui est la reine Anne.

- Voyons... messire...

Il était bien évident que le tavernier n'en savait effectivement rien.

- Ah, Mouscaillot, dit le duc, nos bons rois et gentes reines sont vite oubliés par le peuple. Deux cents ans ont tout juste passé et ce tavernier ne sait plus qui fut Anne Vladimirovitch, ce qui ne l'empêche pas de servir du bortch. Passons!

Profitant de son avantage, le duc continue en ces termes:

- Auparavant, tavernier, je prendrai un petit verre d'une liqueur ecphractique, de d'essence de fenouil par exemple. Est-ce que tu peux me servir un petit verre d'essence de fenouil?

- Ah messire! s'écria le tavernier au bord des larmes, je vous supplie très humblement de ne point ternir le blason de mes trois étoiles.

Là-dessus il fit plusieurs courbettes.

- Cela, dit le duc, me rappelle les salamalecs des adorateurs de Mahom.

- Si je peux vous servir de l'essence de fenouil? reprit le tavernier d'une voix déchirante.

[33] Messire, j'en ai même de plusieurs fabriques.

- Alors, sers-m'en de la meilleure! Et qu'on nourrisse mes chevals de bon foin, de bonne paille et de belle avoine.

On s'empressa. Le duc vuida plusieurs petits verres d'essence de fenouil avec une goutte d'eau plate. Deux serviteurs dapifers et musclés apportaient une inclinou-se profundamente.

- Estou vendo pela sua cara, continuou o duque, que você está se perguntando quem é a rainha Anne.

- Bem... senhor...

Era evidente que o taberneiro não sabia de quem se tratava.

- Ah, Mouscaillot, disse o duque, nossos bons reis e gentis rainhas são logo esquecidos pelo povo. Nem bem se passaram duzentos anos e esse taberneiro já não sabe mais quem foi Anne Vladimirovitch, o que não o impede de servir bortsch. Relevemos!

Aproveitando sua vantagem, o duque continua nesses termos:

- Antes, taberneiro, vou tomar um copinho de um licor ecfrático, essência de funcho por exemplo. Será que você pode me servir um copinho de essência de funcho?

- Ah senhor! exclamou o taberneiro à beira das lágrimas, suplico humildemente que não mancheis o brasão de minhas três estrelas.

Então ele fez várias mesuras.

- Isso, disse o duque, me lembra os salamaleques dos adoradores de Muhammad.

- Se eu posso vos servir essência de funcho? retomou o taberneiro com uma voz dilacerante. Senhor, eu as tenho e de várias procedências.

- Então, sirva-me da melhor! E que alimentem meus caballos com bom feno, com boa palha e com boa aveia.

Atenderam-no prontamente. $\mathrm{O}$ duque esvaziou vários copinhos de essência de funcho com uma gota de água sem gás. Dois serviçais dapíferos e musculosos 
grande ole de bortch, lorsque surgit un personnage qui poussait des clameurs d'épouvantement. Il tremblait et son visage jaune et vermillon marbré de vert tendait à devenir blanc comme craie.

- Hou là là, qu'il disait en dansant sur place. Hou là là.

- Hector, dit le tavernier, n'as-tu point honte et vergogne de venir ainsi troubler mon réfectoire? Je vais te donner du bâton. C'est mon serviteur palefrenier, ajouta-til à l'intention du duc.

- Hou là là, doux Jésus, continuait à se lamenter le serviteur palefrenier. Hou là là, j'ai eu grand'peur, la plus grande de toute ma pauvre et humble vie de serviteur palefrenier. Hou là là, que j'ai eu peur!

- Mais raconte donc!

- Ne pourrais-je boire un petit verre d'essence de fenouil pour me conforter?

Hector tendit la main pour prendre la bouteille sur la table du duc, mais celui-ci lui tapa vertement sur les doigts.

- Aïe, dit Hector.

- Mais raconte donc! raconte donc!

Le tavernier s'énervait.

- Ne pourrais-je goûter à mon bortch? demanda le duc avec une ironie redoutable. Que ces [34] serviteurs dapifers et musclés mettent cette ole sur la table et...

- Son cheval parle! se mit à hurler Hector. Le cheval à messire, ajouta-t-il en montrant du doigt le duc fort malhonnêtement, il parle comme vous et moi! Hou là là!

- Quelle andouille, dit le duc.

- Ah, fit le tavernier d'un air menaçant, si tu as menti... traziam um grande tacho de bortsch, quando surgiu uma personagem aos brados de espantamento. Ele tremia e seu rosto amarelo e vermelhão marmoreado de verde tendia a tornar-se branco como cal.

- Ai Jesus, ele dizia dançando sem sair do lugar. Ai Jesus.

- Heitor, disse o taberneiro, você não tem vergonha nem pudor de vir perturbar assim meu refeitório? Vou lhe dar uma paulada. É meu serviçal cavalariço, acrescentou dirigindo-se ao duque.

- Ai Jesus, Jesus amado, continuava a se lamentar o serviçal cavalariço. Ai Jesus, tive muito medo, o maior medo de toda minha pobre e humilde vida de serviçal cavalariço. Ai Jesus, como tive medo!

- Mas conte logo!

- Não poderia eu tomar um copinho de essência de funcho para me confortar?

Heitor estendeu a mão para pegar a garrafa na mesa do duque, mas este energicamente deu-lhe um tapa nos dedos.

- Ai, disse Heitor.

- Mas conte logo! conte $\log 0$ !

O taberneiro estava se irritando.

- Não poderia eu saborear meu bortsch? perguntou o duque com uma ironia terrível. Que esses serviçais dapíferos e musculosos ponham esse tacho na mesa e...

- O caballo dele fala! pôs-se a urrar Heitor. O caballo desse senhor, acrescentou apontando o duque mui mal educadamente, ele fala como vocês e eu! Ai Jesus!

- Que idiota, disse o duque.

- Ah, fez o taberneiro com um ar ameaçador, se você estiver mentindo... 
- Je jure que c'est vrai! Je jure que c'est vrai! Le cheval à messire parle! il cause! il jacte!

- Mais c'est là œuvre du diable! s'écria le tavernier.

À ces mots, les serviteurs musclés et dapifers lâchèrent la grande ole dont le contenu se répandit sur le sol. Toute la maisonnée s'agenouillait dans la choupe en se brûlant les genous et en faisant moult signes de croix; on entendait des patenôtres fuser de toutes parts.

- À défaut de bortch, dit le duc avec calme, nous pourrions manger des tripes.

Mais le queux, gagné par l'émotion ambiante, venait d'en laisser tomber le plat dans le feu.

gueula le duc.

- Encore un de foutu!

Cependant, commençait à courir par les rues environnantes le bruit qu'à la taverne des Trois Étoiles un cheval parlait; aussi le bon peuple de la ville capitale en profitait-il pour jacasser à tout berzingue et commenter l'événement en ces termes: damnée.

- Animal qu'a parlé, âme

- Si le coq a ri tôt, l'haricot pue trop.

- Quand l'huître a causé, l'huis est très cassé.

- À poisson qui cause, petit cochon peu rose.

[35] - Si bêle le zèbre ut, voilà Belzébuth.

Et autres prouverbes de vaste salaison issus du fin fond aussi faux que lorique de la sapience îlede françouèse.

- Messire, dit Mouscaillot, voilà les choses qui se gâtent comme vous l'aviez prévu. Si nous nous en retournions chez nous?

- Sans dîner?

Dehors on commençait à
- Juro que é verdade! Juro que é verdade! O caballo do senhor fala! conversa! tagarela!

- Mas isso é obra do diabo! exclamou o taberneiro.

A essas palavras, os serviçais musculosos e dapíferos largam o grande tacho cujo conteúdo se esparrama pelo chão. Todos os presentes se ajoelhavam na schopa queimando os joelhos e fazendo múltiplos sinais da cruz; ouviam-se ladainhas vindas de todos os lados.

- Na falta de bortsch, disse o duque calmamente, poderíamos comer tripas.

Mas o cuca, tomado pela emoção ambiente, acabava de deixar cair a travessa no fogo.

- Mais uma que vai pro brejo! gritou o duque.

Entretanto, começava a correr pelos arredores o boato de que na taberna das Três Estrelas um cavalo falava; assim o bom povo da cidade capital aproveitava para palrar sem parar e comentar o acontecimento nestes termos:

danou.

- Animal falou, alma se

- Se o galo que canta cedo, o fejão fica azedo.

- Se a ostra cisma, é o ostracismo.

- Pra peixe que prosa, leitãozinho rosa.

- Se bale a zebra uh, quem fala é Balzebu.

E outros prouvérbios de vasto alcance tirados do fundo falso, amorfo ou clórico da proverbial sapiência francesa.

- Senhor, disse Mouscaillot, as coisas estão indo por água abaixo como tínheis previsto. E se voltássemos para casa?

- Sem jantar?

Fora começavam a gritar. 
crier.

- Au bûcher, le nigroman! au bûcher, le sourcier!

- Tu as raison, reprit le duc. Nous ne sommes point populaires dans le quartier.

Il se leva; suivi de Mouscaillot, il se dirigea vers l'écurie, ce qui provoqua fuite, bousculade et glapissements.

- Ah, mon brave Démo, dit le duc, qu'est-ce qui t'a pris de montrer tes dons à ce palefrenier? Nous voilà bien embrenés avec cette flote hurlante qui nous voudrait bien ardoir.

- Eh, messire, répondit Sthène, ce coquin faisait de la gratte, il ne me donnait point mon avoine. Eussiez-vous souhaité que je me laissasse faire?

- Non, non, mon bon Démo, tu as eu raison. Ce méchant palefrenier mourra de male peur, c'est tout ce qu'il mérite. En route!

Dehors une flote considérable les attendait.

- Oh, oh, s'écrièrent plusieurs paroissiens, mais c'est le vilain hobereau qui refuse de se croiser! Cet albigeois doit adorer Mahom et son palefroi se nomme à coup sûr Satan.

Étrons et cailloux se mirent à pleuvoir sur le duc et sur Mouscaillot; puis ce furent bûches flambantes, lardoires, escabelles et parpaings. Le duc avait tout pour

[36] déplaire et le bon peuple s'énervait fort contre l'herétique,

l'aristocrate et le provincial; mais on ne prend pas la Bastille tous les jours, surtout au treizième siècle.

Dégainant son braquemart pour la seconde fois de la journée, Joachim d'Auge fonça dans la flote et occit deux cent seize personnes, hommes, femmes, enfants et autres, dont vingt-sept borgeois patentés et

- Pra fogueira, bruxo! pra fogueira, feticheiro!

- Você tem razão, retomou o duque. Não somos nada populares na redondeza.

Ele levantou-se; seguido de Mouscaillot, dirigiu-se à estrebaria, o que provocou fuga, empurraempurra e ganidos.

- Ah, meu bravo Demós, disse o duque, o que o levou a mostrar seus dons a esse serviçal cavalariço? Estamos bem enfezados com a turba ululante que nos quer bem ardentes.

- Ah, senhor, respondeu Stenes, esse malandro só queria fazer seu pé de meia, e não me dava minha aveia. Queríeis que eu me deixasse enganar?

- Não, não, meu bom Demós, você está certo. Esse perverso serviçal cavalariço morrerá de mau medo, e é isso que ele merece. Pé na estrada!

Fora uma multidão considerável estava esperando.

- Ora, ora, exclamavam vários paroquianos, mas é o fidalguinho covarde que se recusa a se cruzar! Esse albigense deve adorar Mahom et o palafrém dele com certeza se chama Satã.

Troços e pedregulhos começaram a chover sobre o duque e sobre Mouscaillot, depois foram achas acesas, espetos, escabelos e tijolos. O duque tinha tudo para desagradar e o bom povo estava mui irritado contra o herege, o aristocrata e o provinciano; mas não se toma a Bastilha todos os dias, sobretudo no século treze.

Desembainhando a catana pela segunda vez do dia, Joaquim de Auge avançou sobre a multidão e matou duzentas e dezesseis pessoas, homens, mulheres, crianças e outras, entre as quais 
vingt-six sur le point de le devenir.

Pour sortir de la ville, il fallut également déconfire des archers. vinte e sete burgueses patentes e vinte e seis em vias de sê-lo.

Para sair da cidade, foi preciso desbaratar também os arqueiros. 
- Hou hou, cria-t-on.

Cidrolin ne bouge pas; sa respiration fait se soulever à petits intervalles réguliers le mouchoir dont il s'est couvert le visage.

fort.

- Hou hou, cria-t-on plus

- Encore une Canadienne et son joueur de banjo, murmura Cidrolin sous son mouchoir.

- Hou hou.

C'est un hou hou qui se rapproche.

- Elle est seule. Elle ne manque pas de culot.

Cidrolin se décide à sortir de sa sieste. Il bâille et se lève. De l'autre côté de la planche passerelle, il y a effectivement une donzelle équipée en campeuse.

- Pardon, monsieur, dit-elle.

Le camp de campigne pour les campeurs, s'il vous plaît?

À cette question, il répond par une autre question.

- Ne seriez-vous pas canadienne par hasard ?

$\mathrm{Si}$ fait, elle est bien canadienne et ce n'est pas un hasard mais une nécessité puisqu'elle est née comme ça et qu'elle ne s'est pas mariée avec un étranger (elle n'assure pas qu'elle est vierge) et qu'elle ne s'est pas fait naturaliser roubanche ou zanzébienne. En la regardant plus attentivement, Cidrolin s'aperçut

[38] qu'il ne l'avait pas encore regardée bien attentivement et que, n'étant pas raciste, il n'avait pas vu qu'elle était peau-rouge.

- Je vous étonnons? sussurra-t-elle.

Cidrolin.

Nullement, répondit

- Je sommes iroquoise, ditelle, et je m'en flattons.

- Il y a de quoi.
- Hu hu, gritaram.

Cidrolin não se mexe; sua respiração faz levantar a pequenos intervalos regulares o lenço com o qual cobriu o rosto.

- Hu hu, gritaram mais alto.

- Mais uma canadense e seu tocador de banjo, murmurou Cidrolin sob seu lenço.

- Hu hu. aproxima.

É um hu hu que se

- Está sozinha. Coragem é o que não lhe falta.

Cidrolin resolve sair de sua sesta. Ele boceja e se levanta. Do outro lado da passarela, há efetivamente uma donzela equipada de campista.

- Desculpe, senhor, disse ela. O campo de câmpingue para campistas, por favor?

A esta pergunta, ele responde com outra pergunta.

- A senhorita não seria canadense, por acaso?

De fato, ela é realmente canadense e não é um acaso mas uma necessidade já que ela nasceu assim, que não se casou com um estrangeiro (ela não garante ser virgem) e que não se naturalizou robanche nem zanzebiana. Olhando-a mais atentamente, Cidrolin se deu conta de que ainda não a tinha olhado atentamente e de que, não sendo racista, não tinha visto que ela era pele-vermelha.

sussurrou ela.

- Eu espantar você? - De jeito nenhum, respondeu Cidrolin.

- Eu ser iroquesa, disse ela e me orgulhar muito disso.

- Tem de quê. 
- C'est de l'ironie?

- Non, non. Ne mettez pas

d'ire au quoi.

- Je vous avons réveillé ?

- Je mentirais en disant que non.

- Alors vous m'en voulez?

- Ma mie, ne marivaudez point.

- Et ce campigne? Vous allez finir par me dire où il perche ?

Cidrolin fit des gestes qui déterminèrent la situation du lieu à dix centimètres près.

- Je vous remercions, dit l'Iroquoise canadienne, et je vous prions de m'excuser d'avoir troublé votre sieste, mais on m'avait dit que les Français étaient si obligeants..., si serviables...

- C'est un on-dit.

- Alors je me suis permise...

- Permis.

- Permis. Pourtant...

l'accord du participe?

- Vous y croyez encore?! Comme à la serviabilité et à l'obligeance de mes compatriotes? Seriez-vous crédule, mademoiselle ?

- Comment? il ne faudrait pas croire à la grammaire française ?... si douce... si pure... enchanteresse... ravissante... limpide...

Allons, allons. mademoiselle, vous n'allez pas pleurer pour si peu. Tenez, pous vous réconforter, ne voulez-vous [39] pas prendre un petit verre d'essence de fenouil à bord de ma péniche ?

- Nous y voilà ! un satyre ! ça aussi, on me l'avait bien dit. Tous les Français...

bien...

- Mademoiselle... croyez

- Si vous pensez, monsieur, que vous parviendrez à vos fins
- Isso é ironia?

- Ir o quê? Não, não é isso.

- Eu acordar você?

- Eu estaria mentindo se dissesse que não.

- Então está com raiva de $\operatorname{mim} ?$

- Minh'amiga, não faça drama.

- E esse câmpingue? Não vai me dizer onde é que fica?

Cidrolin fez gestos que determinaram a localização do lugar com uma aproximação de cerca de dez centímetros.

- Eu agradecer, disse a iroquesa canadense, e pedir que me desculpe por ter perturbado sua sesta, mas diz que os franceses são tão prestativos... tão prestimosos...

- É um diz que diz que. - Então, se eu me permiti...

- Permitir.

- Permitir? Mas... e a conjugação verbal?

- A senhorita ainda acredita nisso?! Como na prestância e na prestabilidade de meus compatriotas? Devo crer que é crédula, senhorita?

- Como? não se deve mais crer na gramática francesa?... tão doce... tão pura... encantadora... charmosa... límpida...

- Vamos, vamos, senhorita, não vá chorar por tão pouco. Olhe, para se confortar, a senhorita não quer tomar um copinho de essência de funcho a bordo de minha chata?

- Ora vejam só! um tarado! isso também dizem. Todos os franceses...

- Senhorita... acredite...

- Se o senhor pensa, que atingirá seus objetivos descarados e 
trombinatoires et lubriques en me dégoisant de galants propos pour m'attirer dans votre pervers antre, moi, pauvre oiselle, pauvre iroquoiselle même, ce que vous vous grourez, monsieur! ce que vous vous gourez!

Faisant aussi sec demi-tour, la jeune demoiselle regrimpa le talus en mettant en évidence l'harmonieuse musculature de son arrière-train.

- Encore une Canadienne que je ne reverrai pas, murmura Cidrolin. Et pourtant j'en aurai vu des Canadiennes, des bottes même, des bottes de Canadiennes, des Canadiennes sans bottes ni canadiennes d'ailleurs, parce que toutes celles que je vois c'est en été. $\mathrm{Ou}$ en printemps. $\mathrm{Ou}$ à l'automne. Tiens, j'aurais dû lui faire remarquer qu'il fait une belle journée d'automne aujourd'hui ; peut-être ne l'aurait-elle pas mal pris.

Il alla dans le carré regarder l'heure et, comme conséquence de cet examen, il s'étendit de nouveau sur sa chaise longue pour achever sa sieste interrompue.

Lorsqu'il ouvrit de nouveau l'œil, il aperçut autour de lui tout ce qu'il avait l'habitude d'y voir, les murs de sa chambre, l'étroite fenêtre qui y donnait un peu de jour et, couchè à ses pieds sur une botte de paille, le fidèle page Mouscaillot entouré de quelques chiens qui tous avaient des noms: Taïau, Taïo, Thaillault, Allali et Cétéra. Ce [40] spectacle familier rassura fort le duc qui, s'étant levé, réveilla tout ce petit monde à coups de pied, ce qui provoqua pleurnichements et abois.

Après avoir dit ses patenôtres et soulagé sa vessie dans l'escalier, il se dirigea vers la chapelle pour y entendre la messe lúbricos me enchendo os ouvidos com suas propostas galantes para me atrair ao seu perverso antro, eu, tão inocentinha, tão iroquentinha mesmo, está muito enganado, senhor! Redondamente enganado!

Girando sobre os calcanhares, a jovem senhorita subiu o barranco pondo em evidência a harmoniosa musculatura de seu traseiro.

- Mais uma canadense que eu não vou ver mais, murmurou Cidrolin. E no entanto o que já vi de canadenses, já vi isso aqui cheio de canadenses, forrado mesmo, forrado de canadenses, de canadenses de botas forradas, de canadenses sem forro, até porque todas as que eu vejo é no verão. Ou na primavera. Ou no outono. Poxa, eu devia ter-lhe dito que está um belo dia de outono hoje; talvez isso ela não tivesse levado a mal.

Ele foi ao saguão olhar a hora e, como consequência desse exame, estendeu-se de novo na espreguiçadeira para terminar a sesta interrompida.

Quando abriu de novo o olho, ele percebeu a sua volta tudo o que estava habituado a ver, as paredes do seu quarto, a estreita janela que dava um pouco de luz e, deitado a seus pés no chão forrado de palha, o fiel pajem Mouscaillot cercado de alguns cães, que tinham os nomes: Rex, Recs, Recse, Idem e Tcétera. Esse espetáculo familiar tranquilizou o duque que, levantando-se, acordou todo esse povo a pontapés, o que provocou choramingos e latidos.

Depois de ter rezado seus padrenossos e aliviado sua bexiga na escada, ele se dirigiu à capela para ouvir a missa rezada por seu 
dite par son chapelain Onésiphore Biroton. Onésiphore Biroton était un abbé de choc; si le duc lui flanquait un coup de pied, il en rendait deux, aussi le duc l'aimaitil fort et, ce jour-là, il avait hâte de s'entretenir avec lui de plusieurs points importants. L'abbé Biroton n'eut pas plutôt itamissaesté que le duc d'Auge l'entraîna sur le baile et lui dit :

Écoute-moi bien, Onésiphore, j'ai moult soucis que je te vais déverser dans les oreilles.

- Vous eûtes des ennuis en la ville capitale ?

- Il ne s'agit pas de cela, dit le duc agacé. Au fait, tu le sais ou tu le supposes?

- Hm, hm, fit Onésiphore. Durant votre absence, vos filles furent sages comme des images collées à la porte d'un savetier.

- Ouais. Nous verrons cela plus tard. Pour le moment, j'ai trois questions à te poser, qui sont : primo ce que tu penses des rêves, secundo ce que tu penses du langage des animaux, tertio ce que tu penses de l'histoire universelle en général et de l'histoire générale en particulier. J'écoute.

\section{Distinguo..}

- Hm, hm, dit Onésiphore.

- Pas de distinguo! hurla le duc en tapant du pied. Tu entends ? Pas de distinguos, pas de dialectique, rien de tout cela. Je veux du solide. J'écoute.

- Hm, hm, fit Onésiphore. Je ne puis répondre aux trois questions simultanément: mon

[41] discours est linéaire, comme tout discours humain.

- Où veux-tu en venir?

- À ceci : il faut que je réponde d'abord à une question, puis à une autre, enfin à la dernière. capelão Onesíforo Biroton. Onesíforo Biroton era um abade de briga; se o duque lhe dava um pontapé, ele devolvia dois, por isso o duque gostava muito dele e, nesse dia, estava com urgência de ponderar com ele vários pontos importantes. $\mathrm{O}$ abade Biroton mal tinha itamissaestado e o duque arrastou-o pelo páteo e disse-lhe:

- Escute bem, Onesíforo, tenho muitas preocupações que vou lhe despejar nas orelhas.

- Tivestes problemas na cidade capital?

- Não se trata disso, disse o duque irritado. Por que? você sabe de alguma coisa ou só desconfia?

- Hm, hm, fez Onesíforo.

Durante vossa ausência, vossas filhas comportaram-se tão bem como as imagens penduradas na porta de uma sapataria.

- Tá bom. Veremos isso mais tarde. No momento, tenho três perguntas a fazer-lhe, que são: primo o que você pensa dos sonhos, secundo o que você pensa da linguagem dos animais, tertio o que você pensa da história universal em geral e da história geral em particular. Estou esperando.

- Hm, hm, fez Onesíforo. Distinguo...

- Nada de distinguo! berrou o duque batendo os pés. Está ouvindo? nada de distinguos, nada de dialética, nada de tudo isso. Eu quero algo sólido. Estou esperando.

- Hm, hm, fez Onesíforo. Não posso responder às três perguntas simultaneamente: meu discurso é linear, como qualquer discurso humano.

- Aonde você quer chegar?

- Nisso: é preciso que eu vos responda primeiro a uma pergunta, depois a outra e 
Par laquelle désirez-vous que je comence?

- Par la seconde.

- Optime. Et quelle était la seconde?

- Âne bâté, as-tu déjà oublié mes questions? Et tu voudrais encore que je les répète, hein, petite tête de clerc?

Le duc fit suivre ces paroles d'une bonne taloche derrière l'oreille droite. L'abbé riposta par un gnon en pleine tronche et un marron en pleine poire.

- Alors, dit le duc d'Auge en crachant une incisive, commence par où tu voudras. Par la première, par exemple.

- Je n'ai pas oublié vos questions, simplement leur ordre. tu voudras.

- Eh bien, commence par où rêves.

- Je commencerai par les

- Bon. Dis-moi ce que tu penses des rêves.

- Les uns viennent de Dieu et les autres du Diable. par hasard ?

- Ne serais-tu pas albigeois,

- Nenni, messire, et c'est d'un bon catholiche de dire : il y a deux sortes de rêves, les uns viennent de Dieu et les autres du Diable.

- Comment les distinguer ?

- Oh, ça se reconnaît tout de suite.

- Comment? Boufre, comment les distingues-tu ? Moi je ne les distingue pas.

- C'est pourtant facile. Si on voit le ciel, des anges, ou même simplement des oiseaux, à condition qu'ils ne soient pas de nuit, le rêve vient de Dieu; si l'on même simplement des animaux rampants et tout spécialement des serpents, alors le rêve vient du

finalmente à última. Por qual desejais que eu comece?

- Pela segunda. segunda?

- Optime. E qual era a

- Besta quadrada, já esqueceu minhas perguntas? E ainda quer que eu as repita, hein, seu cabeça de padre?

$\mathrm{O}$ duque acompanhou essas palavras com um bom tapa no pé da orelha direita. $\mathrm{O}$ abade respondeu com um murro em plena cara e um soco em plena fuça.

- Então, disse o duque de Auge cuspindo um incisivo, comece por onde quiser. Pela primeira, por exemplo.

- Não esqueci as vossas perguntas, somente a ordem. onde quiser.

- Está bem, comece por

- Começarei pelos sonhos. dos sonhos.

- Bom. Diga o que pensa

- Uns vêm de Deus e outros do Diabo. por acaso?

- Você não seria albigense,

- Nãnão, senhor, e é bem cathólico dizer: há dois tipos de sonhos, uns vêm de Deus e outros do Diabo.

- Como distingui-los?

- Ah, dá pra reconhecer de cara.

- Como? Raios, como você os distingue? Eu não os distingo.

- Mas é fácil. Se se veem o céu, os anjos, ou mesmo simples pássaros, desde que não sejam noturnos, o sonho vem de Deus; se se vêm labaredas, demônios ou mesmo simples animais rastejantes e em especial serpentes, então o sonho vem do Diabo. 
Diable.

- Je ne rêve jamais de tout cela. messire?

- Et de quoi rêvez-vous,

- Je rêve souvent que je suis sur une péniche, je m'assois sur une chaise longue, je me mets un mouchoir sur la figure et je fais une petite sieste.

- Sieste... mouchoir... péniche... qu'est-ce que c'est que tous ces mots-là ? Je ne les entrave point.

- Ce sont des mots que j'ai inventés pour désigner des choses que je vois dans mes rêves.

- Vous pratiqueriez donc le néologisme, messire?

- Ne néologise pas toimême : c'est là privilège de duc. Aussi de l'espagnol pinaça je tire pinasse puis péniche, du latin sexta hora l'espagnol siesta puis sieste et, à la place de mouchenez que je trouve vulgaire, je dérive du baslatin mucare un vocable bien françoué selon les règles les plus acceptées et les plus diachroniques.

- Nous voilà bien loin de l'onirologie sapientiale et chrétienne. Votre science sémantique, messire, a fumet d'hérésie.

- En quoi serait-il hérétique derêver de péniche?

- Je reconnais qu'il n'est point courant de voir en songe les anges et les saints. Le plus souvent, si je puis en juger par mon expérience propre, les rêves n'ont pour objet que les menus incidents de la vie courante.

- Alors, ceux-là, boufre, sont-ils du Diable ou de Dieu ?

- Ni de l'un ni de l'autre. Ils sont indifférents. Positivement indifférents. Ad primam respondi.

- Oh là! ne te satisfais pas
- Eu nunca sonho com nada disso.

- E com que sonhais, senhor?

- Sonho sempre que estou numa chata, que me sento numa espreguiçadeira, que ponho um lenço na cara e que faço uma pequena sesta.

- Sesta... espreguiçadeira... chata... o que é que são todas essas palavras? Eu não as estou sacando.

- São palavras que inventei para designar as coisas que vejo nos meus sonhos.

$\begin{array}{cc}- & \text { Então } \\ \text { neologismo, } & \text { senhor? }\end{array}$

- Não neologize você: isso é privilégio de duque. Assim, do italiano chiatta eu tiro chiata e depois chata, do latim sexta hora o espanhol siesta depois sesta e, do latim pigritia, pigriça, priguiça e, depois, de preguiça eu derivo um vocábulo de nossa língua tudo de acordo com as regras mais aceitas e mais diacrônicas.

- Estamos nos afastando muito da onirologia sapiencial e cristã. Vossa ciência semântica, senhor, cheira a heresia.

- Em que seria herético sonhar com uma chata?

- Reconheço que não é frequente ver em sonho anjos e santos. O mais normal, se posso julgar pela minha própria experiência, é os sonhos terem como objeto apenas os incidentes menores da vida cotidiana.

- E então, esses aí, raios, são do Diabo ou de Deus?

- Nem de um nem de outro. Esses são indiferentes. Positivamente indiferentes. Ad primam respondi.

- Opa! não se satisfaça tão 
aussi vite, l'abbé. Je n' ai pas besoin de toi pour d'aussi médiocres propos, je serais bien capable de les inventer tout seul. Crois-tu que je vais continuer à te donner ta pâtée quotidienne si tu te contentes de pareilles banalités? J'exige une autre réponse.

Et il dirigea vers le tibia droit de l'abbé un bon coup de savate qui atteignit son but. Onésiphore voulut répliquer d'une ruade dans le ventre, mais elle fut esquivée et il alla s'étaler. Le duc aussitôt lui saute dessus et commence à le piétiner en criant :

- Réponds, petite tête de clerc! Réponds !

L'autre fait signe que oui.

- Alors, demande le duc en descendant de sur sa victime.

- Alors, dit l'abbé en se remettant sur pieds, ce sont rêves de ce monde intermédiaires où vivent gobelins, fées, gnomes, farfadets, elfes, leprechauns, lutins, korrigans, ondines et vouivres, êtres qui ne sont ni de Dieu, ni du Diable et qui ne sont voués ni au mal ni au bien.

- Te voilà devenu bien bénigne. Qu'en penserait la sainte Inquisition?

- Optime. Et voilà comment je réponds à votre question. Ad secundam, qui est du langage des bêtes...

- Tu cours bien vite maintenant.

- ... je dirai qu'il n'est point universellement admis que la faute d'Adam ait entraîné dans la chute le monde animal. Les plus

[44] éminents théologiens le contestent. D'autre part, comme ils ne participèrent pas de toute évidence à la construction de la tour de Babel, rien n'empêche qu'ils se comprennent entre eux.

- Les théologiens? depressa. abade. Não preciso de você para proposições tão medíocres, eu seria bem capaz de inventá-las sozinho. Você acha que vou continuar a lhe dar sua ração de cada dia se você se contenta com tais banalidades? Exijo outra resposta.

E ele dirigiu à canela direita do abade um bom chute que atingiu sua meta. Onesíforo quis replicar com um coice na barriga, mas o duque esquivou-se e o abade estatelou-se. O duque logo salta-lhe em cima e começa a pisoteá-lo gritando:

- Responda, cabeça de padre! Responda!

O outro fez sinal que sim.

- Então, pergunta o duque descendo de cima de sua vítima.

- Então, diz o abade pondose em pé, são sonhos do mundo intermediário onde vivem duendes, fadas, gnomos, fadetes, elfos, leprechauns, ninfas, anões, ondinas e sereias, seres que não são nem de Deus nem do Diabo e não são devotados nem ao mal nem ao bem.

- Você está ficando bem benigno. O que pensaria disso a Santa Inquisição?

- Optime. Eis como respondo a vossa pergunta. Ad secundam, que é sobre a linguagem dos animais...

- Você está indo muito depressa agora.

- ... diria eu que não é universalmente admitido que o pecado de Adão tenha arrastado na queda o mundo animal. Os mais eminentes teólogos contestam-no. Por outro lado, como, ao que tudo indica, eles não participaram da construção da torre de Babel, nada impede que se compreendam entre si.

- Os teólogos? 
animaux.

Non, messire, les

- Trivial! J'entendais parler non des animaux qui parlent entre eux, ce qui est banal, mais des animaux qui parlent le langage des hommes; et toi, tu parles pour ne rien dire.

Le duc lève la main pour lui donner une mornifle, mais l'abbé, plus rapide, lui décoche un direct au menton qui fait vaciller son interlocuteur.

- Ad tertiam, respondeo..., s'empressa de dire le chapelain.

- Ttt, ttt, fit le duc en se remettant la mâchoire en place. Pas si vite. Je voudrais maintenant t'entendre parler des animaux qui parlent dans les rêves. Viennent-ils de Dieu ou du Diable?

- Aucune importance. Tout à fait indifférent. Ad tertiam...

- Ttt, ttt. Tout à l'heure tu m'as dit qu'en rêve les animaux rampants venaient du Diable.

- Dixi.

- Et s'ils parlent?

- Bis diabolici.

- Et si on leur parle?

- Ter diabolici.

- Et s'ils répondent?

- Quater.

- Bon. Voilà qui me satisfait fort, car jamais n'eus conversation avec un serpent en rêve; ce n'est point comme notre mère Ève.

-Elle ne rêvait point.

- À quoi rêvait Adam

[45] lorsque Dieu l'endormit pour lui soutirer la côte ?

- C'est là quarte question que nous pouvons remettre à demain. Ad tertiam, respondeo.

- Ttt, ttt. Je n'en ai pas encore fini avec les animaux qui parlent. Et les houatures ? Viennent-elles de Dieu ou du Diable?
- Não, senhor, os animais.

- Trivial! Eu queria falar não dos animais que falam entre si, o que é banal, mas dos animais que falam a linguagem dos homens; e você fala, fala e não diz nada.

O duque levanta a mão para lhe dar uma bofetada, mas o abade, mais rápido, lhe acerta um direto no queixo que faz vacilar seu interlocutor.

- Ad tertiam, respondeo..., apressou-se a dizer o capelão.

- Ttt, ttt, fez o duque recolocando o maxilar no lugar. Não tão rápido. Agora eu queria ouvi-lo falar dos animais que falam nos sonhos. Eles vêm de Deus ou do Diabo?

- Não tem importância. Totalmente indiferente. Ad tertiam...

- Ttt, ttt. Agora mesmo você me disse que nos sonhos os animais rastejantes vinham do Diabo.

- Dixi.

- E se eles falam?

- Bis diabolici.

- E se falam com eles?

- Ter diabolici.

- E se eles respondem?

- Quater.

- Bom. Isso me deixa mui satisfeito, pois nunca conversei com uma serpente em sonho; não é como nossa mãe Eva.

- Eva, mais sã, não sonhava.

- Com que sonhava Adão quando Deus o adormeceu para subtrair-lhe a costela?

- Eis aí quarta pergunta que podemos deixar para amanhã. Ad tertiam, respondeo.

- Ttt, ttt. Ainda não acabei com os animais que falam. $\mathrm{E}$ os zotomóvis? Vêm de Deus ou do Diabo? 
- Les houatures? Point ne sais ce que c'est.

- Ce sont bestioles vives et couinantes qui courent en tous sens sur leurs pattes rondes. Elles ne mangent rien de solide et ne boivent que du pétrole. Leurs yeux s'allument à la nuit tombante.

- Onques n'en vis.

- J'en aperçois dans mes rêves. Des milliers, des myriades, des légions. Je les vois qui envahissent les rues et les routes. Ce sont elles qui, passant sur le quai, font ce grondement continu que j'entends de la péniche...

Comme les récits de rêves ne l'intéressaient pas, l'abbé Biroton s'endormit. de Dieu.

- Pour la plus grande gloire

Cidrolin se retourna.

- Oh pardon, dit un homme vêtu d'un complet gris fer élégamment coupé. Je vous connais, je ne voulais pas vous importuner. Vous êtes du quartier.

- J'habite la péniche en face, dit Cidrolin, et...

- Suffit. A Dieu vat!

Le quasi-clergyman

remonta sur sa mobylette et se dirigea vers le camp de campigne pour les campeurs. Cidrolin, qui regardait les travailleurs du bâtiment à l'œuvre, continua lui aussi sa promenade dans cette direction. Derrière des fils de fer barbelés, Godons, Brabançons, Néderlandais, Suomiphones, Pictes, Gallois, Tiois et Norois

[46] vaquaient à leurs occupations, ce qui consistait à aller de leur caravane ou de leur tente aux vécés, des vécés aux douches, des douches à la cantine et de la cantine à leur caravane ou à leur tente, en attendant de reprendre le chemin d'Elseneur, de Salzbourg, d'Upsal ou d'Aberdeen. Des musiques
- Os zotomóvis? Não tenho idéia do que seja.

- São bestas vivas e esganiçadas que correm em todos os sentidos com suas patas redondas. Elas não comem nada de sólido e só bebem petróleo. Seus olhos iluminam-se ao cair da tarde.

- Dessas nunca vi.

- Eu vejo nos meus sonhos. Milhares, miríades, legiões. Eu os vejo invadir as ruas e as estradas. São eles que, passando no cais, fazem esse ronco contínuo que ouço da chata...

Como a narração de sonhos não lhe interessavam, o abade Biroton adormeceu.

- Pela maior glória de Deus.

Cidrolin voltou-se.

- Oh perdão, disse um homem vestido com um terno cinza grafite, de corte elegante. $\mathrm{Eu} \mathrm{o}$ conheço, não queria importuná-lo. O senhor é das redondezas.

- Moro na chata em frente, disse Cidrolin, e...

- Basta. Fique com Deus!

$\mathrm{O}$ quase-padre montou em sua mobilete e partiu na direção do campo de câmpingue para campistas. O próprio Cidrolin, que olhava os trabalhadores do prédio em construção, continuou seu passeio naquela direção. Atrás de arame farpado, godões, brabanções, nederlandeses, suomífonos, pictos, galeses, tedescos, e noruegos dedicavam-se a suas ocupações, que consistiam em ir de seu trailler ou de sua barraca ao dabliucê, do dabliucê às duchas, das duchas à cantina e da cantina a seu trailler ou a sua barraca, enquanto esperavam para retomar o caminho de Elsinor, de Salzburgo, de Upsalla ou de Aberdeen. Músicas variadas acompanhavam essas diferentes 
variées accompagnaient ces différentes activités, et le chant lancinant de multiples transistors était parfois couvert par des chœurs en langues étrangères avec accompagnement de cornemuse, de bugle ou d'ocarina. Des personnages particulièrement optimistes poussaient de grands cris de satisfaction en percutant leur poitrine avec leurs poings pour évoquer le roulement du tambour.

D'autres badauds examinaient la situation à côté de Cidrolin ; l'un d'eux luit dit :

- On les regarde comme des bêtes curieuses ; ce n'est pourtant pas le zoo.

- Presque, dit Cidrolin.

- Vous n'allez tout de même pas me raconter que ce sont des animaux et pas de hommes.

- Prouvez-le, dit Cidrolin.

- Ils parlent.

- Et les perroquets, dit Cidrolin, ils ne parlent pas ?

- Ils ne comprennent pas ce qu'ils disent.

- Prouvez-le, dit Cidrolin.

-Quel emmerdeur! Il n'y a pas de conversation possible avec un emmerdeur comme vous.

- Nous venons d'en avoir une pourtant, et fort intéressante. Ce n'est pas tous les jours que la vue d'un camp de campigne pour campeurs suscite des réflexions qui mériteraient presque d'être [47] enregistrées sur un magnétophone.

- Magnétophone mes narines, dit le badaud écœuré qui s'éloigna grommelant.

De loin le quase-clergyman fit à Cidrolin un petit signe de main cordial. Cidrolin lui répondit fort poliment, puis il s'en retourna chez lui. Sur la clôture et le portillon, des inscriptions injurieuses avaient été barbouillées. Cidrolin alla chercher un pot de peinture et un atividades, e o canto lancinante de múltiplos transístores era às vezes coberto pelos coros em línguas estrangeiras com acompanhamento de gaita de foles, de flauta ou de ocarina.

Personagens particularmente otimistas davam grandes gritos de satisfação batendo no peito com os punhos para imitar o rufar do tambor.

Outros curiosos examinavam a situação ao lado de Cidrolin; um deles disse-lhe:

- A gente olha como se fossem animais curiosos; mas não é o zoológico.

- É quase, disse Cidrolin.

- O senhor não vai me dizer que são animais e não homens.

- Prove, disse Cidrolin.

- Eles falam.

- E os papagaios, disse Cidrolin, não falam?

- Eles não entendem o que dizem.

- Prove, disse Cidrolin.

- Que cara chato! Não há conversa possível com um chato como o senhor.

- No entanto, acabamos de ter uma, e mui interessante. Não é sempre que a visão de um campo de câmpingue para campistas suscita reflexões que quase mereceriam ser gravadas num gravador.

- Gravador seu nariz, disse o curioso zangado que se afastou resmungando.

De longe o quase-padre fez a Cidrolin um pequeno aceno de mão cordial. Cidrolin respondeu mui educadamente, depois voltou para casa. Na cerca e no portão, inscrições injuriosas tinham sido rabiscadas. Cidrolin foi buscar uma lata de tinta e um pincel para 
pinceau pour faire disparaître ces graffiti. apagar esses graffiti. 
À la terrase du café, des couples pratiquaient le bouche à bouche, et la salive dégoulinait le long de leurs mentons amoureux ; parmi les plus acharnés à faire la ventouse se trouvaient Lamélie et un ératépiste, Lamélie surtout, car l'ératépiste n'oubliait pas de regarder sa montre de temps à autre vu ses occupations professionnelles. Lamélie fermait les yeux et se consacrait religieusement à la languistique.

Vint la minute de séparation; l'ératépiste commença lentement les travaux de décollement et, lorsqu'il fut parvenu à ses fins, cela fit flop. Il s'essuya du revers de la mains et dit :

- Faut que je me tire.

Et il répandit un peu de bière sur ses muqueuses asséchées. regarde.

Hagarde, Lamélie le

Il tire des francs de sa poche et tape avec sur la table. Il dit d'une voix assez haute :

- Garçon.

Lamélie, hagarde, le regarde.

Le garçon s'approche pour encaisser. À ce moment, Lamélie se jette sur son ératépiste et repique un truc. L'autre se voit obligé de [49] s'exprimer par signes, faciles d'ailleurs à comprendre. Le garçon ramasse la monnaie. Le spectacle ne l'excite pas du tout. Il s'éloigne.

L'ératépiste entreprend un nouveau décollement. Il y parvient en douceur et cela fait de nouveau flop. Il s'essuie les lèvres du revers de la main et dit : me tire.
No terraço do café, casais praticavam o boca a boca, e a saliva escorria pelos seus queixos apaixonados; entre os que se faziam de ventosa com mais ardor estavam Aamélia e um cobrador da RATP, principalmente Aamélia, pois o erriatepista não se esquecia de olhar o relógio de tempos em tempos em vista de suas ocupações profissionais. Aamélia fechava os olhos e se dedicava religiosamente à linguástica.

É chegado o momento da separação; o erriatepista começou lentamente os trabalhos de descolamento e, quando conseguiu atingir seus objetivos, houve um flop. Ele se enxugou com as costas da mão e disse:

- Tenho que puxá o carro.

E esparramou um pouco de cerveja em suas mucosas ressecadas.

Avermelha Aamélia e olha séria.

Ele puxa uns francos do bolso e bate com eles na mesa. Diz em voz bem alta:

- Garçom.

Aamélia avermelha e olha séria.

O garçom se aproxima para cobrar. Nesse momento, Aamélia atira-se sobre seu erriatepista e recai na atividade. $\mathrm{O}$ outro se vê obrigado a se exprimir por sinais, aliás fáceis de entender. $\mathrm{O}$ garçom recolhe o dinheiro. O espetáculo não o excita nem um pouco. Ele se afasta.

O erriatepista recomeça um novo descolamento. Ele consegue com jeito e há um novo flop. Ele enxuga os lábios com as costas da mão e diz:

- Desta vez, eu tenho que puxá o carro. 
Il assèche son demi et se lève prestement.

Lamélie le regarde, hagarde. Elle suit le mouvement et dit :

- Moi, je ne suis pas pressée, je vais faire un parcours avec toi.

- Tu sais, asteure y a de la circulation, on prend toujours du retard, j'aurai pas de temps pour bavarder avec toi.

- Je te verrai tourner ta petite manivelle sur ton ventre, j'entendrai ta voix quand t'annonceras les sections, je serai heureuse comme ça.

- T'es pas sûre de monter. Va y avoir du monde.

Il y en avait. Deux cent dixsept personnes poireautaient, formant une queue constituée conformément aux instructions officielles. Lamélie attendit, les gens montèrent, l'autobus s'emplit et elle était encore bien loin dans le flot des postulants lorsque son jules fit, élégant, d'un geste, basculer la pancarte complet et tira sur sa petite sonnette. Tout cela démarra. L'ératépiste fit un geste de la main qui s'adressait peut-être à quelqu'un perdu dans la file d'attente qui ne cessait de s'allonger. Lamélie fit demi-tour et voulut fendre le flot de la foule en file. Comme elle essayait de remonter le courant, on lui disait : ce qu'on veut?

- Alors, cocotte, on sait pas

- Encore une qui croit qu'on n'a pas assez d'emmerdements comme ça.

- Les bonnes femmes qui changent d'avis, c'est un monde.

- Ça fait la queue à l'envers et ça s'étonne qu'on soit pas content.

Une dame gueula:

- Vous n'avez pas fini de
Ele seca seu chope e levanta-se com presteza.

Aamélia olha séria e avermelha. Ela acompanha a onda e diz:

- Eu não estou com pressa, vou te acompanhar uma parte do caminho.

- Sabe o que é? Aestora tem trânsito, a gente está sempre acaba atrasando, não vou ter tempo de conversar com você.

- Eu vou ver você girar a manivela na barriga, vou ouvir sua voz anunciando as paradas, estarei feliz assim.

- Cê num sabe nem se vai consegui subi. Vai tê muita gente.

E tinha. Duzentas e dezessete pessoas estavam paradas esperando, formando uma fila constituída de acordo com as instruções oficiais. Aamélia esperou, as pessoas subiram, o ônibus lotou e ela ainda estava bem longe no fluxo de postulantes quando seu amado fez, elegante, com um gesto, cair o cartaz lotado e puxou a campainha. E tudo arrancou. O erriatepista fez um gesto com a mão que se dirigia talvez a alguém perdido na fila de espera que não parava de crescer. Aamélia fez meia volta e quis fender o fluxo da fula em fila. Como ela tentava ir contra a corrente, diziam-lhe: que quer?

- E aí, sirigaita, não sabe o

- Mais uma que acha que a gente já não tem aporrinhação de sobra.

- Mulheres que mudam de idéia, é o que há.

- Pega a fila ao contrário e ainda acha ruim quando a gente reclama.

Uma senhora berrou:

- Quer parar de empurrar? 
pousser? Vous n'avez pas vu mon ventre?

- Si vous êtes enceinte, répliqua Lamélie hargneusement, faut vous mettre avec les priorités.

Un citoyen qui n'avait rien compris à ce dialogue explosa.

- Place! qu'il gueula, place! une femme enceinte se trouve mal!

- Place! nom de dieu, vous avez pas compris? Une femme enceinte!

- Faites place! Respect aux femmes enceintes et gloire à la maternité !

- Place! Place!

- Faites place!

Lamélie se trouva rejetée hors du flot des attentistes, comme une touffe de varech sur une plage normande. Elle s'éloigna. Elle repassa devant le café; des couples, à la terrasse, y faisaient toujours la ventouse. Toute mélancolo, Lamélie rejoignit le quai.

Petit à petit, elle finit par se trouver devant l'Arche.

Cidrolin se reposait sur le pont arrière; bien installé mais ne sommeillant pas, il regardait au loin. L'arrivée de Lamélie ne change en rien son manque de comportement. Ce n'est que lorsqu'on apporta l'essence de fenouil et l'eau plate qu'il modifia son attitude en prenant d'un même coup la position assise et la parole en ces termes :

L'inspecteur des contributions corbitaires est passé. répliqua-t-on.

$$
\text { - J'ai pris l'autobus, }
$$

- Il a tout inspecté.

- Le receveur, il était marrant.

- J'ai eu droit à des félicitations.
Você não viu minha barriga?

- Se você está grávida, retrucou Aamélia venenosamente, deveria ir para a fila exclusiva.

Um cidadão que não tinha entendido nada do diálogo explodiu.

- Afastem-se! berrou ele, afastem-se! uma mulher grávida está passando mal!

- Afastem-se! porra, vocês não entenderam? Uma mulher grávida!

- Afastem-se! Respeito às mulheres grávidas e glória à maternidade!

- Afastem-se! Afastem-se!

- Façam espaço!

Aamélia viu-se jogada para fora do fluxo dos esperantistas, como um tufo de algas na maré baixa. Ela se afastou. Passou de novo diante do café; casais, no terraço, continuavam a se fazer de ventosa. Toda jururu, Aamélia chegou ao cais.

Pouco a pouco ela acabou por encontrar-se diante da Arca.

Cidrolin repousava no convés de popa; bem instalado, mas não cochilando, ele olhava ao longe. A chegada de Aamélia não muda em nada sua falta de ação. Só quando trouxeram a essência de funcho e a água sem gás ele modificou sua atitude tomando ao mesmo tempo a posição sentada e a palavra nestes termos: contribuições nautográficas passou. - $\mathrm{Eu}$ tomei o ônibus, responderam.

- Ele inspecionou tudo.

- Era engraçado, o cobrador.

- Eu recebi felicitações. 
- Il racontait des choses drôles à chaque voyageur.

- Il a trouvé que l'Arche méritait deux ancres dans la catégorie A.

- À moi-z-aussi, il m’a parlé.

- Pas encore trois ancres. Deux ce n'est tout de même pas mal.

- Vous êtes vachement mieux balancée qu'une carte hebdomadaire, qu'il m'a dit, et drôlement plus rebondie qu'un carnet de tickets.

- Évidemment, je paierai plus d'impôts, mais ça fera standigne.

- Vous alors, ah ça, vous alors, voilà ce que je lui ai rétorqué.

- Il m'a fait remarquer une chose.

- Mais je pouvais pas m'empêcher de rigoler.

- Vous appelez ça l'Arche ? m'a-t-il dit, il n'y a aucun animal à bord; c'est paradoxal. Ça, c'est vrai, lui ai-je répondu, c'est paradoxal ; mais c'est comme ça. Bon, bon, a-t-il ajouté, lui : vous savez, moi, ce que je vous en disais. Et moi donc, ai-je ajouté à mon tour. Alors il est parti. Il était content de lui et moi j'étais content de moi. Jusqu'à ce moment, à part la nourriture, ça a été plutôt une [52] bonne journée ; mais elle n'est pas finie. Tout peut encore arriver.

- Ce type-là, il me plaît.

- Qui ça?

- Le réceveur du 421.

- Il n'y en a pas qu'un, je suppose.

- Celui que je connais.

- Moi, je ne le connais pas.

- Je viens de te raconter.

- Alors, ça ne t'intéresse pas que l'Arche soit promue deux ancres dans la catégorie A ?

- Minable. Pourquoi pas
- Ele dizia gracinhas a todos os passageiros.

- Ele achou que a Arca merecia duas âncoras na categoria A.

- Ele falou pra mim tamém.

- Ainda não são três âncoras. Mas duas também não está mal.

- Você é muito mais sacudida que um bilhete único, ele me disse, e muito mais cheiinha que um carnet de passes.

- É claro que eu vou pagar mais impostos, mas isso dá status.

- Aí virei pra ele e falei você hein, você hein.

- Ele me chamou a atenção para uma coisa.

-Mas não pude deixar de rir.

- Você chama isso de Arca? ele me disse, não há nenhum animal a bordo; é paradoxal. É verdade, respondi, é paradoxal; mas é assim mesmo. Bom, bom, acrescentou ele: só falei por falar. E eu então, acrescentei por minha vez. Aí ele se foi. Ele estava contente consigo e eu estava contente comigo. Até agora, exceto pela comida, está sendo um dia bastante bom; mas ainda não acabou. Tudo ainda pode acontecer.

- Aquele cara, eu gosto dele. - Quem?

- O cobrador do 421.

- Deve haver mais de um, suponho.

- Aquele que eu conheço.

- Eu não conheço.

- Eu acabei de contar.

- Então não lhe interessa que a Arca tenha sido promovida duas âncoras na categoria A?

- Muito mixo. Por que não 
trois ? Je brique assez pourtant.

- Il faut attendre un peu. On les aura un jour les trois ancres.

- Et pourquoi pas quatre?

- Je sais, je sais.

Il tendit la main vers la bouteille d'essence de fenouil pour s'en servir une nouvelle lampée.

- Tu bois trop, lui fit-on remarquer.

Il haussa les épaules et se servit largement.

- Alors, demanda-t-il, et ton receveur?

- L'essence de fenouil, ça rend fou, c'est écrit dans les journaux.

Cidrolin fronça les sourcils, les défronça pour vider son verre et les fronça de nouveau avec intensité. Quatre rides profondes creusèrent sa glabelle. Il bougonna :

- Tu m'as gâché mon plaisir. Encore un de foutu.

On emporte la bouteille, l'eau plate et les verres.

- Parle-moi de ton receveur.

- J'ai du travail. peinture ?

- Je prends le pot de

- Non, rien à signaler.

Cela étant, il s'étendit de nouveau sur sa chaise longue et se remit à regarder au loin.

À l'horizon apparut un détachement des compagnies royales de sécurité ; le guetteur vint en avertir le duc d'Auge, qui donna les ordres nécessaires en gueulant si fort que l'abbé Biroton se réveilla.

- Les céhéresses arrivent, dit le duc en se frottant les mains. Nous allons les ratatiner.

$$
\text { - Que se passe-t-il ? }
$$

três? Não é falta de eu esfregar.

- Precisa esperar um pouco.

Um dia a gente vai conseguir as três âncoras.

- E por que não quatro?

- Tá, tá.

Ele estendeu a mão para a garrafa de essência de funcho para se servir de mais um gole.

- Você bebe demais, disseram-lhe.

Ele deu de ombros e se serviu de uma grande dose.

- E então, perguntou ele, e seu cobrador?

- A essência de funcho deixa louco, está nos jornais.

Cidrolin franziu o cenho, desfranziu-o para esvaziar seu copo e franziu de novo com intensidade. Quatro rugas profundas marcaramlhe a glabela. Ele rosnou.

- Você é uma desmancha prazeres. Mais uma que vai pro brejo.

Levam a garrafa, a água sem gás e os copos.

- Fale-me de seu cobrador.

- Estou ocupada.

- Pego a lata de tinta?

- Não, não há nada de novo.

Sendo assim, ele se estendeu de novo na espreguiçadeira e pôs-se a olhar ao longe.

No horizonte apareceu um destacamento das companhias reais de segurança; o sentinela veio avisar o duque de Auge, que deu as ordens necessárias berrando tão alto que o abade Biroton acordou.

- Os ceerriesses estão chegando, disse o duque esfregando as mãos. Vamos esmagá-los.

- O que está acontecendo? 
Pourquoi les céhéresses?

- Ah! ah! je ne te l'avais pas encore dit. J'ai occis quelques bourgeois qui m'embrenaient.

- L'ire est mauvaise conseillère. Il faudra faire pénitence.

- Tant qu'on veut, mais ceux-ci ont sûrement des intentions plus sournoises.

- Notre saint roi ne plaisante point avec les écarts des seigneurs.

- Il nous prend au sérieux, dit le duc avec satisfaction.

C'était maintenant plusieurs détachements qui approchaient du châtiau, venant de différents points de l'horizon.

- Ça se gâte, murmura l'abbé, ça se gâte.

- Ne t'inquiète pas, s'ils se montrent méchants, je te l'ai dit : je les ratatine!

- Seigneur! vous voulez devenir rebelle pardessus le marché ?

Les céhéresses cernaient maintenant le châtiau; le plus héraut d'entre eux s'approcha du pont-levis et, par signes tant sonores qu'héraldiques, fit comprendre qu'il voulait transmettre un message au seigneur de ce lieu.

[54] histoire!

L'abbé se lamentait :

- Quelle histoire! quelle

- Au fait, tu n'as pas encore répondu à ma troisième question sur l'histoire universelle en général et l'histoire générale en particulier.

Mais on amène le héraut, qui se met à expliquer au duc que le saint roi n'est pas content du tout, qu'occire des bourgeois pour minces raisons cela ne se fait plus,
Por que os ceerriesses?

- Ah! ah! eu ainda não tinha lhe contado. Eliminei alguns burgueses que estavam me enfezando.

- A ira é má conselheira. Tereis que fazer penitência.

- Quantas quiser, mas esses aí com certeza têm intenções mais traiçoeiras.

- Nosso santo rei não brinca com os deslizes dos senhores.

- Ele nos leva a sério, disse o duque com satisfação.

Agora eram vários destacamentos que se aproximavam do castelo vindos de diferentes pontos do horizonte.

- Isso vai acabar mal, murmurou o abade, isso vai acabar mal.

- Calma, se eles forem maus, eu já disse: eu os esmago!

- Senhor! quereis tornar-se rebelde ainda por cima?

Agora os ceerriesses cercavam o castelo; o mais arauto dentre eles aproximou-se da ponte levadiça e, por sinais tanto sonoros quanto heráldicos, deu a entender que queria transmitir uma mensagem ao senhor do lugar.

O abade lamentava-se:

- Que história! que história!

- É mesmo, você ainda não respondeu a minha terceira pergunta sobre a história universal em geral e a história geral em particular.

Mas trazem o arauto, que se põe a explicar ao duque que o santo rei não está nem um pouco contente, que matar burgueses por razões fúteis não se faz mais, e que 
et que les seigneurs doivent se le tenir pour dit qu'on ne décervelle point à tort et à travers, en conséquence de quoi, Joachim duc d'Auge devra extraire de son trésor cent écus tournois d'or raffiné pur et sans alliage par tête de pipe cassée, ce qui ne va pas manquer de faire une somme considérable d'autant plus qu'il y en a des fêlées qui n'ont pas fini d'agoniser, et que Joachim duc d'Auge se dise bien que cette somme ne sera que partiellement utilisée pour indemniser les veufs, veuves ou orphelins mais servira surtout à substantiellement subventionner la croisade en cours de préparation.

De plus, Joachim duc d'Auge devra réciter six mille six cent cinquante-sept paters, autant d'avés et trois fois moins de confiteors et faire dire autant de messes qu'il y a d'occis, auxquelles messes il assitera pieds nus, en chemise et la tête couverte de cendres, froides ou chaudes à son gré.

Que d'ailleurs Joachim d'Auge se dise bien que le saint roi l'aurait fait pendre par les deux oreilles jusqu'à ce que mort s'ensuive, si le sant roi n'avait eu souvenance des services rendus par Joachim d'Auge à la cause chrétienne tant à Damiette qu'à Mansourah.

Enfin, que Joachim d'Auge pourrait garder ses écus tournois d'or raffiné pur et sans alliage et diminuer de moitié le nombre de ses paters et le nombre de ses avés bien que ce nombre fût impair et du quart le nombre de ses confiteors, bien que quatre soit une partie aliquante de deux mille deux cent dix-neuf, rien n'étant changé quant aux messes avec cependant licence os senhores devem entender que não se degola assim a torto e a direito, em consequência do que, pelos mortos, Joaquim duque de Auge deverá extrair de seu tesouro cem escudos torneses de ouro refinado puro e sem liga para cada par de botas batidas, o que não vai deixar de perfazer uma soma considerável ainda mais que há estropiados que não acabaram de agonizar, e que Joaquim duque de Auge entenda bem que essa soma só será parcialmente utilizada para indenizar os viúvos, viúvas ou órfãos mas servirá sobretudo para substancialmente subvencionar a cruzada que está em vias de preparação.

Além disso, Joaquim duque de Auge deverá rezar seis mil seiscentos e cinquenta e sete padrenossos, outro tanto de avemarias e três vezes menos de confiteors e mandar rezar tantas missas quantos forem os mortos, missas essas a que ele assistirá descalço, em camisa e com a cabeça coberta de cinzas, frias ou quentes a seu gosto.

Que aliás Joaquim de Auge entenda bem que o santo rei tê-lo-ia mandado pendurar pelas duas orelhas até que a morte chegasse, se o santo rei não tivesse levado em conta os serviços prestados por Joaquim de Auge à causa cristã tanto em Damieta quanto em Almançora.

Enfim, que Joaquim duque de Auge poderia ficar com seus escudos torneses de ouro refinado puro e sem liga e diminuir pela metade o número de seus padrenossos e o número de suas avemarias ainda que esse número seja ímpar e de um quarto o número de seus confiteors, ainda que dois mil duzentos e dezenove não seja divisível por quatro, nada 
pour le duc d'y assister chaussé et vêtu à sa guise, tout cela à la simple, bénigne, benoîte et pardonnante condition qu'il se joigne au saint roi pour aller découdre du Sarrasin à la croisade prochaine.

- Jamais, répondit le duc d'Auge. Je lui ai déjà expliqué que je ne voulais plus remettre les pieds dans ces bleds impossibles. Une croisade, c'est beaucoup ; deux c'est trop.

- Alors, messire, dit le héraut, vous ne vouler point arracher le Saint Sépulcre des mains des infidèles ?

- Mais c'est foutu, pauvre faraud! On va encore prendre un chaud-froid de bouillon. Notre Saint-Père lui-même n'y croit plus. Cela va bientôt faire deux cents ans qu'on s'escrime à vouloir le reprendre, mais il y est toujours, aux mains des infidèles, le sépulcre.

Horrifié par ces propos, se signa le héraut.

- Et, continua le duc d'Auge, vous croyez que c'est en allant en Tunisie qu'on l'arrachera des mains des infidèles, le sépulcre! La Tunisie! Pourquoi pas le pays des Amaurotes ou des Hamaxobiens? Tant qu'il y est, notre saint roi, pourquoi n'irait-il pas jusque chez les Indiens ou les Sères ? Pourquoi ne s'embarque-til pas sur la mer Océane jusqu'audelà de l'île de Thulé, peut-être bien qu'il trouverait par là une terre

[56] inconnue avec des infidèles supplémentaires à ratatiner ?

- Modérez-vous, messire, murmura l'abbé Biroton. se signer.

Le héraut n'arrêtait pas de

- Non, non et non, conclut mudando quanto às missas mas com licença para o duque de assistir a elas calçado e vestido a seu gosto, tudo isso à simples, benigna, bendita e perdoante condição de se juntar ao santo rei para ir estripar sarracenos na próxima cruzada.

- Jamais, respondeu o duque de Auge. Já expliquei para ele que eu não queria mais pôr os pés naqueles cafundós impossíveis. Uma cruzada já é muito; duas é demais.

- Então, senhor, disse o arauto, não quereis arrancar o Santo Sepulcro das mãos dos infiéis?

- Mas já foi pro brejo, seu fanfarrão! Ainda vamos entrar pelo cano. Nem mesmo Nosso SantoPadre acredita mais nisso. Logo vai fazer duzentos anos que nós nos esgrimimos querendo retomá-lo, mas ele está sempre lá, nas mãos dos infiéis, o sepulcro.

Horrorizado pelo pensamento incauto, persignou-se o arauto.

- E, continuou o duque de Auge, vocês acham que é indo à Tunísia que vamos arrancá-lo das mãos dos infiéis, o sepulcro! A Tunísia! Por que não o país dos amaurotas ou dos hamaxobienses? Do jeito que está, nosso santo rei, por que não iria até a terra dos índios ou dos hunos? Por que não navega no mar Oceano até além da ilha de Thule, quem sabe ele não encontrasse por lá uma terra desconhecida com mais infiéis ainda para esmagar?

- Moderai-vos, senhor, murmurou o abade Biroton.

$\mathrm{O}$ arauto não parava de se persignar.

- Não, não e não, concluiu 
le duc d'Auge. Moi pas aller croisade. Je dirai ces ribambelles de patravéfiteors, j'assisterai à toutes ces messes cendrées et je me dessaisirai de mes beaux écus tournois d'or raffiné pur et sans alliage, mais pour ce qui est d'aller me traîner du côté du rivage des Syrtes, alors je le répète : non, non et non. Telle est ma réponse, et cela dit, je ferai remarquer que le saint roi nous a défendu à nous autres qui avons droit de monnayage de faire circuler nos sols et nos écus en dehors de nos domaines, mais qu'il veut tout de même bien en voir la couleur. Pour conclure, héraut, je t'enjoins de débarrasser nos terres de ta déplaisante présence et de celle de tes acolytes qui ne l'est pas moins. J'ai dit.

- Je m'empresserai de le faire mais je ne puis partir sans toucher un à-compte provisionnel de l'emmende qui vous frappe, messire, à-compte qui se monte à euh... voyons voir... sept mille deux cents écus tournois d'or raffiné pur et sans alliage plus douze sols parisis pour les frais d'enregistrement et quatre liards pour le timbre.

- Je n'ai pas droit à une réduction en tant que croisé de la septième? demanda le duc avec une pâle grimace, la pâle grimace qu'il avait accoutumé de faire dès qu'on voulait toucher à ses sous. fermeté :

Le héraut répondit avec

- Non. Le compte est juste.

Il ajouta :

- Il n'est susceptible que de

croître, jamais de diminuer.

Joachim d'Auge se tut et fit la mine de réfléchir.

Le chapelain devina que le duc envisageait de passer à la o duque de Auge. Eu não ir cruzada. Direi essa porrada de padraveconfiteors, assistirei a todas essas missas cinzentadas e desfarme-ei de meus belos escudos torneses de ouro refinado puro e sem liga, mas se é para ir para o lado da costa das sirtes, então repito: não, não e não. Essa é minha resposta, e dito isso, ressalto que o santo rei nos proibiu a nós que temos direito de cunhagem de pôr pra circular nossas libras e nossos escudos fora de nossos domínios, mas mesmo assim ele quer ver a cor deles. Para concluir, arauto, eu o intimo a livrar nossas terras de sua desagradável presença e da não menos desagradável de seus acólitos. Tenho dito.

- Fá-lo-ia de bom grado mas não posso partir sem levar um adiantamento provisional da murta que vos toca, senhor, adiantamento que totaliza ahn... vamos ver... sete mil duzentos escudos torneses de ouro refinado puro e sem liga mais doze soldos parisis para as taxas de registro e quatro tostões para o selo.

- Não tenho direito a uma redução enquanto cruzado da sétima? perguntou o duque com uma cara de sonso, a cara de sonso que ele tinha-se acostumado a fazer sempre que queriam mexer em seus vinténs.

$\mathrm{O}$ arauto respondeu com firmeza:

correta.

- Não. A conta está

E acrescentou:

- Ela só é suscetível de crescer, jamais de diminuir.

Joaquim de Auge calou-se e fez a cara de refletir.

O capelão adivinhou que o duque pretendia passar à rebelião 
rébellion ouverte. Le héraut devina la même chose. Le duc devina que les deux autres avaient deviné. Le chapelain devina que le duc avait deviné qu'il avait deviné, mais ne devinait point si le héraut avait lui aussi deviné que le duc avait deviné qu'il avait deviné. Le héraut, de son côté, ne devinait point si le chapelain avait deviné que le duc avait deviné qu'il avait deviné, mais il devinait que le duc avait deviné qu'il avait deviné.

Cette rude tension disposait au silence, ce qui permit à tout un chacun d'entendre Bélusine et Pigranelle chanter des chansons de toile, des chevaux hennir, des chiens aboyer, des céhéresses piétiner et Phélise bêler.

- Jarnicoton, finit par s'écrier le duc, décision ai prise, point ne verra le saint roi la couleur de mes écus tournois d'or raffiné pur et sans alliage, point n'écouterai messes cendrées, point ne dirai ribambelles de patravéfiteors, et point ne me croiserai. Hors d'ici, faraud céhéresse! Que toi et tes pareils s'éloignent de mes murailles car je les vais régaler d'huile bouillante et de plomb fondu, excellente recette culinaire pour accommoder les compagnies royales de sécurité qui feraient mieux d'aller à la croisade que d'embrener de bons et nobles seigneurs comme moi. $\mathrm{Si}$ les Capets commencent à nous traiter de la sorte, on verra bientôt les aristocrates à la lanterne. Ne m'astu pas entendu, héraut? Je t'ai dit hors d'ici et hors de mes terres, et, si tu ne te décides pas plus vite, je na.

L'horrifié héraut terrifié,

aberta. $\mathrm{O}$ arauto adivinhou a mesma coisa. O duque adivinhou que os outros dois tinham adivinhado. $\mathrm{O}$ capelão adivinhou que o duque tinha adivinhado que ele tinha adivinhado, mas não adivinhava se o arauto também tinha adivinhado que o duque tinha adivinhado que ele tinha adivinhado. $\mathrm{O}$ arauto, por seu lado, não adivinhava se o capelão tinha adivinhado que o duque tinha adivinhado que ele tinha adivinhado, mas adivinhava que o duque tinha adivinhado que ele tinha adivinhado.

Essa dura tensão dispunha ao silêncio, o que permitiu que todos e cada um ouvissem Belusina e Pigranela cantarem canções de amigo, os cavalos relincharem, os cães latirem, os ceerriesses baterem os pés e Feliza balir.

- Maldição, acabou por exclamar o duque, decisão tomei, não será o rei que verá a cor de meus escudos torneses de ouro refinado puro e sem liga, eu não escutarei missas cinzentadas, tampouco direi porradas de padraveconfiteors, e não me cruzarei. Fora daqui, ceerriesse fanfarrão! Que você e os seus pares vão para longe de minhas muralhas pois vou regalá-los com óleo fervente e chumbo derretido, excelente receita culinária para sustentar as companhias reais de segurança que fariam melhor indo à cruzada do que enfezando bons e nobres senhores como eu. Se os Capetos começarem a nos tratar dessa forma, logo veremos os aristocratas na forca. Não me ouviu, arauto? Eu lhe disse fora daqui e fora de minhas terras, e se você não se decidir logo, eu lhe abro a pança com os dentes, viu?

O horrorizado arauto 
après s'être maintes fois signé, rétrograda du nombre de pas nécessaire pour disparaître de la vue du duc d'Auge. Le pont-levis se baissa pour le laisser sortir, puis aussitôt se releva.

- Qu'on fasse chauffer l'huile! hurla le duc. Qu'on fasse fondre le plomb et que cela saute ! heup!

- Vous allez peut-être un peu fort, dit timidement le chapelain. Après tout, ce n'est pas terrible les messes, les prières.

- Oui, mais c'est à mon or qu'il en veut, le Capet.

- Allons, allons, messire, vous ne croyez tout de même pas que vous allez vous livrer à votre humeur massacreuse sur de bons borgeois et malheureux manants sans payer une petite redevance à leurs veuves et à leurs orphelins ?

- Une petite redevance, moi, je veux bien. Ils n'ont qu'à venir la chercher ici. Pas la peine qu'ils passent par le roi qui en ratissera une partie au passage.

- Vous calomniez votre souverain, messire.

- Je ne parle pas pour lui. Le pauvre homme, lui, c'est un bon gars. Ce seront ses baillis et les officiers de la cassette qui se gobergeront avec mes bons et beaux écus tournois d'or raffiné pur et sans alliage. Il ne faut pas me raconter d'histoires ! Allez ! Heup! Faites bouillir la friture et rissoler le métal!

Il se frottait les mains avec satisfaction, cependant que les compagnies royales de sécurité, a bonne distance des murs du château, commençaient à mettre la au ravitaillement du duc, des siens et de ses bêtes.

Comme l'abbé Biroton lui

aterrorizado, depois de ter-se persignado várias vezes, retrocedeu o número de passos necessários para desaparecer da vista do duque de Auge. A ponte levadiça baixouse para deixá-lo sair, logo depois se levantou.

- Mandem esquentar o óleo! urrou o duque. Mandem derreter o chumbo e logo, xô, xô! upa!

- Vós talvez tenhais ido longe demais, disse timidamente o capelão. Afinal, não é tão terrível as missas, as rezas.

- Sim, mas é o meu ouro que ele quer, o Capeto.

- Calma, calma, senhor, vós não acreditais de verdade que ides entregar-vos a vosso humor massacrante sobre bons borgueses e infelizes campônios sem pagar uma pequena contribuição para suas viúvas e órfãos.

- Uma pequena contribuição, tudo bem. Eles só têm que vir buscá-la aqui. Não têm porque passar pelo rei que raspará uma parte na passagem.

soberano, senhor.

Caluniais vosso

- Eu não falo por ele. O pobre homem, ele é um bom sujeito. Serão seus bailios e tesoureiros que se regalarão com meus bons e belos escudos torneses de ouro refinado puro e sem liga. Não adianta me contar histórias! Vamos! Upa! Mandem ferver a fritura e tostar o metal!

Ele esfregava as mãos com satisfação, enquanto as companhias reais de segurança, a boa distância dos muros do castelo, começavam a pôr a mão na comida destinada ao sustento do duque, dos seus e de seus animais.

Como o abade Biroton 
faisait remarquer cette sournoise action, le duc se tapa sur les cuisses en signe de dérision.

- J'ai pris mes précautions. Mes réserves me permettront de tenir le temps que le roi très chrétien aille à sa croisade et s'en revienne, s'il en revient.

- Dieu le garde ! dit l'abbé machinalement.

- $\mathrm{Si}$ besoin est nous mangerons de la chair humaine! Cuite naturellement; on dit qu'elle a son charme. Lorsque nous voudrons des crudités, nous ferons une sortie et nous pilerons ces méchants céhéresses. Je me réjouis déjà de voir leurs cors engraisser mes champs de radis, desquels je suis fort friand. Et maintenant, l'abbé, tu vas répondre à la troisième de mes questions, à savoir ce que tu penses de l'histoire universelle en général et de l'histoire générale en particulier. Le moment me semble bien choisi: j'écoute. estava lhe chamando a atenção para essa traiçoeira ação, o duque bateu nas coxas em sinal de escárnio.

- Eu tomei minhas precauções. Minhas reservas permitir-me-ão aguentar o tempo que o rei muito cristão levará para ir a sua cruzada e voltar, se ele voltar.

- Deus o guarde! disse o abade maquinalmente.

- Se preciso for comeremos carne humana! Cozida é claro; dizem que ela tem seu charme. Quando quisermos algo pra comer cru, faremos uma excursão e pilharemos esses perversos ceerriesses. Já estou até vendo seus corpus engordando meus campos de rabanete, dos quais sou mui apreciador. E agora, abade, você vai responder à terceira de minhas perguntas, a saber o que você pensa da história universal em geral e da história geral em particular. $\mathrm{O}$ momento me parece bem adequado: estou esperando. 
Bertrande.

- Alors, tu viens? dit

\section{Quelle corvée.}

- Tu ne m'as pas épousée rien que pour le plaisir. Allez, ouste, en route!

- Ta sœur, je veux bien la voir , mais ton père, tu sais...

- Je sais quoi ?

- Rien. Suffit.

- J'espère bien.

- Je m'entends.

- Tu es bien le seul, j'espère. Et viens ici que je t'arrange ta cravate. Tu ne seras jamais fichu de faire un nœud convenable. entendre.

- Qu'est-ce qu'il ne faut pas

Ils ont rendez-vous avec Sigismonde et Lucet.

- Tiens, dit Sigismonde, vous avez une nouvelle houature?

- Ce n'est pas la peine de le faire remarquer, dit Lucet, ça se voit.

- Vous montez? dit Yoland.

- On prend la nôtre, dit Lucet.

- Tiens, dit Bertrande, vous aussi vous avez une nouvelle houature?

$$
\text { Ça n'a rien }
$$

d'extraordinaire, dit Yoland. Tout

[61] le monde a toujours de nouvelles houatures.

- Surtout, vous allez pas faire la course, dit Sigismonde.

Non, ils ne font pas la course, mais ils arrivent à peu près en même temps devant l'Arche. Cidrolin est en train de repeindre la clôture le long du quai. Lamélie attend sur la péniche; elle a préparé l'essence de fenouil, l'eau plate et les verres. Les femmes
- Você vem ou não vem? disse Orlanda.

- Que maçada, disse Iolando. Que carma.

- Você não se casou comigo só pelo prazer. Vamos, chispa, pé na estrada!

- Sua irmã, até gosto de vêla, mas seu pai, você sabe...

- Sei o quê?

- Nada. Chega.

- Acho bom.

- Eu me entendo.

- Você é o único, espero. E venha aqui que eu arrumo sua gravata. Você nunca vai conseguir fazer um nó decente.

- A gente tem que ouvir cada uma.

Eles tinham um encontro com Sigismunda e Lizeto.

- Ei, diz Sigismunda, vocês estão com otomóvil novo?

- Não precisa falar nisso, diz Lizeto, está na cara.

- Vocês vêm conosco? diz Iolando.

- Nós vamos com o nosso, diz Lizeto.

- Ei, diz Orlanda, vocês também estão de otomóvil novo?

- Não tem nada de extraordinário nisso, diz Iolando. Todo mundo sempre tem otomóvis novos.

- Vocês num vão apostá corrida, né? diz Sigismunda.

Não, eles não apostam corrida, mas chegam mais ou menos ao mesmo tempo diante da Arca. Cidrolin está pintando a cerca ao longo do cais. Aamélia está esperando na chata; ela preparou a essência de funcho, a água sem gás e os copos. As 
descendent le talus. Les deux hommes s'attardent pour regarder Cidrolin donner quelques ultimes coups de pinceau; ils le regardent d'un air connaisseur, en silence.

- Du travail bien fait, finit par dire Lucet.

- De la belle ouvrage, dit Yoland.

- Et la péniche, demande Lucet à Cidrolin, vous allez la repeindre?

- L'année prochaine, répond Cidrolin. Tous les deux ans. Elle a été repeinte l'année dernière. Là, ça y est.

Il prend le pot de peinture et descend le talus. conseille-t-il.

- Vous cassez pas la gueule,

Sur la passerelle, il dit :

- Attention de ne pas vous foutre dans la flotte.

Leur verre d'essence de fenouil les attend; les femmes sont en train de parler de la tévé.

- Tu devrais t'en faire acheter une, dit Bertrande à Lamélie. Qu'est-ce que tu peux fabriquer le soir? Tu dois t'emmerder.

- Je patiente, dit Lamélie. Je ne resterai pas toujours ici.

- Qu'est-ce que tu feras?

- Je me marierai, pardine!

- Tu as quelqu'un en vue?

- Ah voilà.

Elle minaude.

- Vous vous embêterez quand elle ne sera plus là, dit Lucet à Cidrolin.

- Oh, moi, vous savez. Pour que je m'embête, il en faut beaucoup.

- Il trouve toujours quelque chose à ne rien faire, dit Lamélie. Il sait très bien ne pas s'occuper.

- On le connaît aussi bien mulheres descem o barranco. Os dois homens param um pouco para olhar Cidrolin dar suas últimas pinceladas; eles olham com jeito de conhecedores, em silêncio.

- Trabalho bem feito, acaba por dizer Lizeto.

- Uma bela obra, diz Iolando.

- E a chata, pergunta Lizeto a Cidrolin, o senhor vai pintá-la?

- Ano que vem, responde Cidrolin. A cada dois anos. Ela foi pintada no ano passado. Pronto, acabei.

Ele pega a lata de tinta e desce o barranco.

- Não vão quebrar o pescoço, aconselha ele.

Na passarela, ele diz:

- Cuidado pra não cair na água.

Seus copos de essência de funcho os esperam; as mulheres estão falando da tevê.

- Você deveria pedir pra lhe comprarem uma, diz Orlanda a Aamélia. O que você fica fazendo à noite? Deve ficar de saco cheio.

- Estou esperando, diz Aamélia. Não vou ficar aqui para sempre.

- O que você vai fazer?

- Vou me casar, ora! vista?

- Você tem alguém em

- Pode ser.

Ela sorri dengosa.

- O senhor vai se aborrecer quando ela não estiver mais aqui, diz Lizeto a Cidrolin.

- Oh, eu, vocês sabem. Pra que eu me aborreça, precisa muito.

- Ele sempre acha alguma coisa pra não fazer, diz Aamélia. Ele sabe muito bem não se ocupar.

- A gente o conhece tão 
que toi, disent en chœur Sigismonde et Bertrande.

- Bien sûr, dit Cidrolin, j'aimerais mieux qu'elle reste, mais il faut qu'elle ait une vie à elle, cette petite, c'est normal.

- C'est normal, dit

Bertrande.

- C'est normal, dit

Sigismonde.

- Alors, tu as quelqu'un en vue? dit Bertrande.

- Ah voilà, dit Lamélie.

Elle minaude.

- C'est vrai, dit tout à coup Lucet, pourquoi que vous avez pas la tévé ? Ça distrait.

Yoland.

- Ça instruit même, dit

- Alors, Lamélie, dit Cidrolin, en attendant de te marier, veux-tu te distraire ou t'instruire ? c'est baiser

- Non, papa, ce que je veux,

- À la tévé on ne baise guère, remarqua Lucet.

- On ne baise même pas du tout, dit Yoland.

- Vous êtes bêtes, dit Bertrande, c'est parce qu'il y a les mômes qui regardent.

- Les tiens, demande Sigismonde, tu les laisseras regarder tant qu'ils voudront?

- Rien que ce qui est instructif, répond Yoland. Surtout les actualités. Ça leur apprendra l'histoire de France, l'histoire universelle même.

- Comment ça ? dit Lucet.

- Eh bien oui, les actualités d'aujourd'hui, c'est l'histoire de demain. C'est ça de moins qu'ils auront à apprendre à l'école, puisqu'ils la connaîtront déjà.

- Là, mon vieux, tu déconnes, dit Lucet. L'histoire ça n'a jamais été les actualités et les actualités c'est pas l'histoire. Faut bem quanto você, dizem em coro Sigismunda e Orlanda.

- Claro, diz Cidrolin, eu preferia que ela ficasse, mas ela tem que ter uma vida própria, essa menina, é normal.

- É normal, diz Orlanda.

- É normal, diz Sigismunda.

- E aí, você tem alguém em vista? diz Orlanda.

- Pode ser, diz Aamélia.

Ela sorri dengosa.

- É mesmo, diz de repente Lizeto, por que o senhor não tem tevê? Tevê distrai.

- Até instrui, diz Iolando.

- E então, Aamélia, diz Cidrolin, enquanto espera pra se casar, você quer se distrair ou se instruir?

- Não, papai, o que eu quero, é transar.

- Na tevê quase não se transa, observou Lizeto.

- Na tevê não se transa de jeito nenhum, diz Iolando.

- Vocês são bestas, diz Orlanda, é porque tem crianças que assistem.

- E as suas, pergunta Sigismunda, você vai deixar elas assistirem o quanto quiserem? - Só o que for instrutivo, responde Iolando. Principalmente atualidades. Isso vai ensinar-lhes a história da França, até mesmo a história universal.

- Ensinar como? diz Lizeto.

- Claro, as atualidades de hoje, são a história de amanhã. É menos coisa pra elas terem que aprender na escola, pois já vão sabendo..

- Aí, meu caro, você está falando besteira, diz Lizeto. A história nunca foi atualidades e atualidades num é história. Num se 
pas confondre.

- Mais si, justement! au contraire!! faut confondre !!! Regarde un peu voir. Suppose que tu es devant la tévé, tu vois, je dis bien et je répète: tu vois, Lucien Bonaparte qui agite sa sonnette, son frère dans un coin, les députés qui gueulent, les grenadiers qui se ramènent, enfin quoi tu assistes au dix-neuf brumaire. Après ça, tu vas te coucher, tu dors pendant cent ans et puis tu te réveilles; alors, à ce moment-là, le dix-neuf brumaire c'est devenu de l'histoire et tu n'as pas besoin de regarder dans les livres pour savoir cexé.

$$
\text { C'est idiot, dit }
$$

Sigismonde, il n'y avait pas la tévé dans ce temps-là.

- Mettons, dit Yoland ; mais regarde alors les actualités au cinéma; des fois on t'en repasse des vieilles. Tu vois alors le tsar Nicolas qui serre la main de Poincaré, les taxis de la Marne, Guillaume II, le Kronprinz, Verdun: c'est pas de l'histoire, ça ? Pourtant ça a été des actualités.

- Ça reste des actualités, dit

Lucet. A preuve, c'est que tu les vois dans un cinéma et qu'on te prévient : c'est des actualités.

- C'est idiot, dit Yoland. Alors l'histoire pour toi, qu'est-ce que c'est ?

- C'est quand c'est écrit.

- Ça c'est vrai, dit Bertrande.

- Il a raison, dit Sigismonde.

- Il a cent fois raison, dit Lamélie.

Yoland tape sur la table.

- Faites attention de ne pas renverser l'essence de fenouil, dit Cidrolin.

Yoland tape sur la table en faisant attention de ne pas renverser l'essence de fenouil. Il joint au deve confundir.

- Mas claro, justamente! ao contrário!! é preciso confundir!!! Olhe um pouco, veja. Suponha que você esteja diante da tevê, você vê, eu digo e repito: você vê, Lucien Bonaparte agitando a sineta, o irmão dele num canto, os deputados berrando, os granadeiros se achegando, enfim você assiste ao dezenove de brumário. Depois disso, você se deita, dorme durante cem anos e depois acorda; então, nesse momento o dezenove de brumário tornou-se história e você não tem necessidade de olhar nos livros pra saber uquiéquié.

- Besteira, diz Sigismunda, não havia tevê naquele tempo.

- Que seja, diz Iolando; mas olhe então as atualidades no cinema; às vezes eles passam as velhas. Então você vê o czar Nicolas apertando a mão de Poincaré, os táxis do Marne, Guilherme II, o Kronprinz, Verdun: isso não é história? No entanto foram atualidades.

Continuam sendo atualidades, diz Lizeto. A prova é que você as vê num cinema e eles anunciam: atualidades.

- Besteira, diz Iolando. Então o que é história pra você?

- É quando é escrito.

- Isso é verdade, diz Orlanda.

- Ele tem razão, diz Sigismunda.

- Ele tem mil vezes razão, diz Aamélia.

Iolando bate na mesa.

- Tome cuidado para não derramar a essência de funcho, diz Cidrolin.

Iolando bate na mesa tomando cuidado para não derramar a essência de funcho. Ele 
geste la parole :

- Faut-il que vous soyez cons, tout de même, pour ne pas comprendre ce que je veux dire.

- On a très bien compris, dit Bertrande, mais c'est idiot.

- Réfléchis cinq minutes, voyons. Un jour, y a eu des gens qu'ont signé un armistice, en mil neuf cent dix-huit par exemple...

- Mettons.

- ... on a filmé ça. Ce jourlà, c'était les actualités et puis, après, maintenant par exemple, c'est devenu de l'histoire. C'est clair, non?

- Non, dit Lucet. Ça ne tient pas debout. Parce que tes actualités, tu les vois pas en même temps que la chose se passe. Tu les vois quelquefois huit jours, quinze jours après. T'as même des cinémas de quartier qui te passent le Tour de France au mois de novembre. Alors, dans ce conditions-là, à quel moment ça devient de l'histoire ?

- Tout de suite! Illico presto subito! la tévé c'est de l'actualité qui se congèle en histoire. Aussitôt fait, aussitôt dit.

- Et quand il y avait pas la tévé, dit Sigismonde, alors y avait pas d'histoire?

- Tu vois, dit Lucet, tu n'as rien à répondre à ça.

- Reprenez donc un peu de cette essence de fenouil, dit Cidrolin.

- Et toi, papa, dit Lamélie, qu'est-ce que tu en penses ?

- Moi, je n'ai pas la tévé.

- On le sait, on le sait, dit Bertrande, puisqu'on explique à Lamélie que tu devrais lui en offrir une pour qu'elle s'emmerde moins.

- Oui, mais, dit Cidrolin, puisque tout ce à quoi elle pense, c'est à baiser. junta ao gesto a palavra:

- Vocês têm que ser muito idiotas, para não entender o que eu quero dizer.

- A gente entendeu muito bem, diz Orlanda, mas é besteira.

- Reflita cinco minutos, ora.

Um dia umas pessoa assinaram um armistício, em mil novecentos e dezoito por exemplo...

- Que seja.

- ... filmaram isso. Naquele dia, era atualidade e depois, mais tarde, agora por exemplo, tornou-se história. Ė claro, não?

- Não, diz Lizeto. Isso não se sustenta. Porque suas atualidades, cê num vê elas ao mesmo tempo em que a coisa acontece. Você vê algumas vezes oito dias, quinze dias depois. Tem até cinemas de bairro que passam o Tour de France em novembro. Aí, nessas condições, em que momento isso torna-se história?

- Logo em seguida! Imediatamente presto subito! a tevê é a atualidade que se congela em história. Tão logo é feito, tão logo é dito.

- E quando não havia tevê, diz Sigismunda, não havia história?

- Está vendo, diz Lizeto, você não tem o que responder.

- Tomem mais um pouco dessa essência de funcho, diz Cidrolin.

- E você, papai, diz Aamélia, o que pensa disso?

- Eu, não tenho tevê.

- A gente sabe, a gente sabe, diz Orlanda, já que estamos dizendo a Aamélia que você deveria lhe dar uma para que ela se chateie menos.

- Sim, diz Cidrolin, mas já que ela só pensa em transar. 
- À la tévé, dit Lucet, on ne baise guère.

- On ne baise même pas du tout, dit Yoland.

- Vous êtes bêtes, dit Bertrande, c'est parce qu'il y a les mômes qui regardent.

- Les tiens, demande Sigismonde, tu les laisseras regarder tant qu'ils voudront ?

- Rien que ce qui est instructif, dit Yoland. Surtout les actualités. Ça leur apprendra l'histoire de France, l'histoire universelle même.

- Comment ça ? dit Lucet.

- Et bien oui, les actualités d'aujourd'hui, c'est l'histoire de demain. C'est ça de moins qu'ils auront à apprendre à l'école puisqu'ils le connaîtront déjà.

- C'est marrant, dit Cidrolin. Il me semble que ça recommence, que j'ai déjà entendu tout ça autre part.

- Pourtant, dit Lucet, ce qu'on dit c'est pas si fréquent. Ça n'a pas dû vous arriver souvent d'entendre des propos d'une si haute tenue philosophique et morale.

- Surtout dans le milieu où vous venez de vivre, dit Yoland.

Bertrande lui flanque un coup de pied dans les tibias.

- Aïe, dit Yoland.

- Vous souffrites? demande Cidrolin.

- La brute, dit Yoland.

- Enfin, bref, dit Cidrolin, je suis bien content de vous avoir vus. Vous êtes bien aimables avec moi.

- Tu nous fiches à la porte ? dit Bertrande.

- Ça en a tout l'air, dit Sigismonde.

- Pas du tout, dit Cidrolin, seulement voilà, quand ça se met à touner en rond, que je me demande
- Na tevê, diz Lizeto, quase não se transa.

- Na tevê não se transa de jeito nenhum, diz Iolando.

- Vocês são bestas, diz Orlanda, é porque tem crianças que assistem.

- As suas, pergunta

Sigismunda, você vai deixar elas assistirem o quanto quiserem?

- Só o que for instrutivo, diz Iolando. Principalmente atualidades. Isso vai ensinar-lhes a história da França, até mesmo a história universal.

- Ensinar como? diz Lizeto.

- Claro, as atualidades de hoje são a história de amanhã. É menos coisa pra elas terem que aprender na escola, pois já vão sabendo.

- Engraçado, diz Cidrolin. Parece que está recomeçando, acho que já ouvi isso em algum lugar.

- No entanto, diz Lizeto, o que estamos dizendo não é tão frequente. $\mathrm{O}$ senhor não deve ter tido muita oportunidade de ouvir assuntos de tão elevado teor filosófico e moral.

- Principalmente no lugar de onde acaba de sair, diz Iolando.

Orlanda dá-lhe um chute nas canelas.

- Ai, diz Iolando.

Cidrolin.

- Vós sofrestes? pergunta

- Que bruta, diz Iolando.

- Enfim, resumindo, diz Cidrolin, fiquei muito contente de vê-los. Vocês são muito amáveis comigo.

- Você está nos pondo pra fora? diz Orlanda.

- É o que parece, diz Sigismunda.

- De modo algum, diz Cidrolin, só que, quando a conversa começa a rodar sem sair 
où je vais basculer, il vaut mieux que ça s'arrête tout de suite, je perdrais les pédales, j'arriverais dans les temps anciens, ou futurs on ne sait pas, ou bien nulle part encore, des trucs à vous foutre une trouille épouvantable.

- Si, dit Yoland à Lucet, on se cotisait pous lui offrir une tévé pour son anniversaire, ça empêcherait son cerveau de ruminer.

- On verra, dit Lamélie. Pour le moment le mieux c'est de lui laisser faire sa sieste: c'est encore son meilleur cinéma.

Des céhéresses, il ne restait plus que des tombes en ruine que rongeait la mousse; on les avait bien oubliés, les céhéresses morts au combat du temps du roi Louis neuvième du nom.

Le duc d'Auge ouvrit l'œil et se souvint que l'abbé Biroton devait répondre à une certaine troisième question et qu'il n'en avait rien fait. Ouvrant son second et dernier œil, le duc d'Auge n'aperçut dans son champ visuel aucun abbé Biroton.

- Ah le frocard, le pendard, le flemmard, grogna le duc. Je parierais bien qu'il est parti pour le concile de Bâle, à moins que ce ne soit pour celui de Ferrare ou de Florence, on ne s'y reconnaît plus. [67] En tout cas, me voilà bien dépité.

Il se lève et se pointe sur la plate-forme du donjon de son châtiau pour y considérer un tantinet soit peu la situation historique.

Aucun Godon n'était en vue, aucun homme d'arme de quelque bord ou nation que ce fût. C'était même plutôt désert. Quelques manants, çà et là, grattaient le sol misérable, mais ils do lugar, e eu me pergunto onde vou parar, é melhor parar logo, ou eu perderia o juízo, chegaria aos tempos antigos, ou futuros não se sabe, ou ainda a lugar nenhum, coisas que iriam fazer vocês se borrarem incontrolavelmente.

- E se a gente fizesse uma vaquinha pra dar-lhe uma tevê no aniversário, diz Iolando a Lizeto, isso impediria seu cérebro de ficar remoendo.

- Veremos, diz Aamélia. Por enquanto, o melhor é deixá-lo fazer a sesta: pra ele ainda é o melhor cinema.

Dos ceerriesses, só restavam os túmulos em ruína que o musgo corroía; todos já tinham esquecido os ceerriesses mortos em combate no tempo do rei Luís nono do nome.

O duque de Auge abriu o olho e lembrou-se de que o abade Biroton devia responder a uma certa terceira pergunta e que ele ainda não tinha feito isso. Abrindo seu segundo e último olho, o duque de Auge não encontrou no seu campo de visão nenhum abade Biroton.

- Ah, fradeco, velhaco, preguiçoso, praguejou o duque. Aposto que ele partiu para o concílio de Basiléia, a menos que tenha sido para o de Ferrara ou o de Florença, não se sabe mais. De qualquer jeito, encontro-me bem despeitado.

Ele se levanta e se posta na plataforma do torreão de seu castelo para considerar um tantinho que fosse a situação histórica.

Não havia nenhum godão à vista, nenhum homem de armas de nenhum país ou nação que fosse. Estava mesmo bem deserto. Alguns campônios, aqui e ali, arranhavam o solo miserável, mas eles 
comptaient peu dans le paysage, à peine perceptibles.

Le duc regarda ce spectacle d'un œil morne et soupira; puis il descendit vers les cuisines afin d'y dévorer au passage un ragoût d'alouettes, rien que pour s'aiguiser les dents. Quelques marmitons qui ne l'avaient pas aperçu reçurent de solides coups de savate qui les envoyèrent choir à droite et à gauche. Le queux, connaissant les goûts du seigneur, s'empressa de lui apporter le ragoût convoité. Le duc se régale, broie les os, lèche ses douas, vide des pintes. Il s'épanouit. Il sourit.

- Tout cela est délicieux, déclare-t-il, mais ne vaut point un petit enfant de cinq ans rôti à la broche.

Il s'esclaffe.

- Messire, messire, dit le queux, je vous supplie humblement de ne point plaisanter avec de pareilles horreurs.

- Je ne plaisante pas, je parle sérieusement.

- Alors, messire, plaisantez plutôt.

- Qu'est-ce que tu veux à la fin, maître queux ? Que je plaisante ou que je parle sérieusement?

- Messire, je crois qu'il vaut mieux ne pas aborder ce sujet de conversation : les ogres n'ont point bonne renommée par les temps qui courent. Surtout les ogres bougres.

- Tu sais bien que je ne mange pas de cette viande-là ! Ogre ne daigne, bougre ne veut, Auge suis.

- Messire, nul n'ignore que vous avez de coupables indulgences...

- Et quoi ! me reprocheraistu ma fidélité à mon bon vieux compagnon d'armes, le noble seigneur Gilles de Rais? contavam pouco na paisagem, mal eram perceptíveis.

O duque olhou esse espetáculo com um olho enfastiado e suspirou; depois desceu para as cozinhas a fim de devorar de passagem um guisado de calhandras, só para aguçar os dentes. Alguns ajudantes de cozinha que não tinham percebido sua presença receberam sólidos pontapés que os fizeram cair aqui e acolá. O cuca, conhecendo os gostos do senhor, apressou-se a trazer-lhe o guisado desejado. $\mathrm{O}$ duque se regala, tritura os ossos, lambe os dedos, esvazia garrafas. Ele se farta. Ele sorri.

- Tudo isso está delicioso, declara ele, mas não chega aos pés de uma criancinha de cinco anos assada no espeto.

Ele caiu na gargalhada.

- Senhor, senhor, disse o cuca, suplico-vos humildemente que não brinqueis com tais horrores.

- Eu não estou brincando, estou falando sério.

- Então, senhor, seria melhor que brincásseis.

- O que quer afinal, mestre cuca? Que eu brinque ou que fale sério?

- Senhor, acho que é melhor não abordar esse assunto na conversa: os ogros não têm boa reputação nos tempos que correm. Principalmente os ogros hereges.

- Você bem sabe que dessa carme eu não como! Ogro não se digna, herege não quer, Auge sou.

- Senhor, ninguém ignora que tendes indulgências culpáveis...

- O quê! você reprova minha fidelidade a meu bom velho companheiro de armas, o nobre senhor Gilles de Rais? 
- C'est-à-dire...

- Eh quoi ! j'aurais, pour la cause de notre roi, pourfendu tant de Godons en sa compagnie sous le commandement de Jehanne la Pucelle et je le laisserais tomber maintenant qu'il est dans le pétrin ? Non, non et non ! Ce ne serait point noble.

- On dit que c'est un bien grand criminel.

- Des potins de commère! Ce sont là contes faits pour médire des nobles seigneurs de son genre ou du mien. Ce Charles septième du nom, maintenant qu'il a à peu près gangné la guerre de Cent Ans, et cela fait même un peu plus de cent ans qu'elle dure, et remarque au passage que nos bons rois, si malins qu'ils soient, ils en mettent $\mathrm{du}$ temps pour gagner une guerre, bref que disais-je ? oui maintenant que s'accélère la déconfiture des Godons, avec ces pas pressés de Capétiens, il n'y en a peut-être plus que pour une quinzaine d'années, oui, maintenant que notre roi n'a plus tellement besoin de nous pour achever l'expulsion des Anglais, je m'attends à ce qu'il prenne des mesures antiféodales pour nous rogner les ongles et nous mettre au pas. Je m'en méfie comme du diable.

- Hou hou, messire, n'invoquez point cette vilaine bête.

[69] - Ce procès de notre bon ami Gilles annonce des mesures antiféodales et sournoises pour nous rogner les ongles et nous mettre au pas.

- Messire, vous vous
répétez.

- D'abord, ce n'est pas tout à fait exact : j'ai ajouté un adjectif et ensuite apprends, épaisse brute, que la répétition est l'une des plus odoriférantes fleurs de la rhétorique.
- Quer dizer...

- O quê! pela causa de nosso rei, teria eu eliminado tantos godões na companhia dele sob o comando de Joana, a Donzela, e eu o abandonaria agora que ele está em maus lençóis? Não, não e não! Não seria nada nobre.

- Dizem que ele é um grande criminoso.

- São mexericos de comadre! Histórias inventadas para difamar nobres senhores do seu gênero ou do meu. Esse Carlos sétimo do nome, agora que está quase ganhando a guerra dos Cem Anos, e na verdade faz um pouco mais de cem anos que ela dura, e note-se de passagem que nossos bons reis, por mais espertos que sejam, sempre levam bastante tempo para ganhar uma guerra, enfim o que eu estava dizendo? ah agora que se aproxima a derrota dos godões, com esses Capetos pouco apressados, não vai levar mais que uns quinze anos, agora que nosso rei não tem mais tanta necessidade de nós para completar a expulsão dos ingleses, eu já esperava que ele tomasse medidas antifeudais para nos cortar as asas e nos passar a perna. Desconfio dele como do demo.

- Uh, uh, senhor, não invoqueis essa besta terrível.

- Esse processo de nosso bom amigo Gilles anuncia medidas antifeudais e traiçoeiras para nos cortar as asas e nos passar a perna.

repetindo.

- Senhor, estais vos - Pra começar, não é totalmente exato: eu acrescentei um adjetivo e depois aprenda, besta estúpida, que a repetição é uma das mais odoríferas flores da retórica. 
- J'en douterais volontiers, messire, si je n'avais grand'peur de vos coups.

Provoqué de cette sorte, le duc se lève, prend une escabelle et la brise sur le dos du cuisinier.

- Messire, messire, dit le maître queux, je vous supplie humblement d'avoir la suprême bonté de ne plus discuter à bâtons rompus.

- Tiens, tu me dégoûtes et tu me donnes faim. Apporte-moi quelques confitures sèches pour me dégraisser les dents.

Le duc dévore ses confitures, puis revient à ses moutons :

- Alors, maître queux, tu trouves cela bien, toi, de faire passer en justice un maréchal de France?

- Messire, c'est à coup sûr très mal et très vilain.

- On lui cherche des noises à ce cher ami. Mettons qu'il ait violé une dizaine de petits garçons et qu'il en ait zigouillé trois ou quatre, il n'y a tout de même pas là de quoi fouetter un maréchal de France, et surtout un compagnon de combat de notre bonne Lorraine qu'Anglais brûlèrent à Rouen.

- Messire, on dit qu'il y en a mille et trois.

- Mille et trois quoi ?

- Petits enfants torturés,

[70] égorgés, bouffés par ce vilain ladre de maréchal. C'est affreux, tout de même, c'est affreux.

Le cuisinier pleurait comme un veau. Le duc le regardait moins furieux qu'étonné.

- Ne lirais-tu point, par chance, les romans de la Table Ronde? lui demanda-t-il avec douceur.
- Bem que eu duvidaria, senhor, se não tivesse muito medo de apanhar.

Provocado desta maneira, o duque se levanta, pega um banco e o quebra nas costas do cozinheiro.

- Senhor, senhor, disse o mestre cuca, suplico-vos humildemente, tende a suprema bondade de não mais quebrar o pau quando discutirmos.

- Ah, você me enoja e me dá fome. Traga algumas geléias secas para me desengordurar os dentes.

O duque devora suas geléias, depois volta à vaca fria:

- E então, mestre cuca, você acha que está certo mandar para a justiça um marechal da França?

- Senhor, certamente é muito errado e muito mau.

- Isso é armação contra esse caro amigo. Admitamos que ele tenha violado uma dezena de meninos e que tenha massacrado três ou quatro deles, de qualquer modo isso não é motivo para perturbar um marechal da França, e principalmente um companheiro de combate de nossa boa lorena que ingleses queimaram em Rouen.

- Senhor, dizem que foram mil e três.

- Mil e três o que?

- Crianças torturadas, degoladas, comidas por esse perverso marechal libertino. É terrível, de qualquer modo, é terrível.

O cozinheiro chorava como um bezerro desmamado. $\mathrm{O}$ duque $\mathrm{o}$ olhava menos furioso do que espantado.

- Por sorte, você não estaria lendo os romances da Távola Redonda? perguntou ele suavemente. 
lire.

- Messire, je ne sais point

- Alors, peut-être s'est-il insinué dans le conduit de ton oreille quelque complainte inventée par un trouvère de basse extrace ?

- Voilà, messire ! voilà : c'est un trouvère qui a corrompu mon âme avec une chanson vengeresse qui demandait justice au très chrétien roi de France pour les pauvres parents dont ce bougre de maréchal a occis les mômes.

- Quelle époque, dit le duc d'Auge avec un soupir. Quelle époque! Eh bien, moi, tel que tu me vois, je vais de ce pas, ou plutôt de celui de mon cheval, ce bon Démo, je vais, dis-je, trouver notre sage roi Charles, le septième du nom, pour lui demander la liberté grande et entière de Gilles, maréchal de Rais, délivrance immédiate et, de plus, châtiment de tous ces légistes, gieres latinisants et marauds de droit romain qui s'avisent d'embrener un bon soldat comme mouches merdeuses un noble coursier, et même un soldat victorieux, ce qui est rare. Holà ! où est mon écuyer Mouscaillot? qu'il se prépare et selle mon bon Démo!

Lors donc sella Sthène Mouscaillot et voilà le duc parti pour la ville capitale, accompagné du ménin monté sur Stèphe. Le duc se sentait d'humeur causante.

- Viens là donc auprès de moi, Mouscaillot, que je te dise la raison de notre voyage.

Mouscaillot fit trotter son cheval au même niveau que celui de son seigneur, mais en essayant de maintenir entre eux la distance qu'il jugeait nécessaire pour éviter une baffe subite.

- Approche, approche donc,
- Senhor, eu nem sei ler.

- Então, pode ser que alguém tenha insinuado nos dutos de seu ouvido algum lamento inventado por um trovador de quinta categoria?

- É isso, senhor! é isso: foi um trovador que corrompeu minha alma com uma canção vingativa que pedia justiça ao muito cristão rei de França para os pobres pais cujas crianças foram mortas por esse marechal herege.

- Que tempos, disse o duque de Auge com um suspiro. Que tempos! Pois é, eu, tal como você me vê, vou nesse passo, ou melhor no do meu cavallo, esse bom Demós, vou, dizia eu, procurar nosso sensato rei Carlos, o sétimo do nome, para pedir-lhe a liberdade total e irrestrita de Gilles, marechal de Rais, libertação imediata e, além disso, castigo para todos esses rábulas, chicaneiros latinizantes e patifes do direito romano que resolveram enfezar um bom soldado como moscas varejeiras um nobre corcel, e um soldado vitorioso, o que é raro. Olá! onde está meu escudeiro Mouscaillot? que ele se prepare e sele meu bom Demós.

Então pois selou Stenes Mouscaillot e o duque partiu para a cidade capital, acompanhado do moleque montado em Estêvão. O duque estava com um humor conversativo.

- Venha para perto de mim, Mouscaillot, que vou the dizer a razão de nossa viagem.

Mouscaillot fez seu cavalo trotar no mesmo nível do de seu senhor, mas tentando manter entre eles a distância que julgava necessária para evitar um tabefe repentino.

- Aproxime-se, aproxime- 
disait le duc.

- J'approche, messire, j'approche.

- Approche donc, nigaud, dit Sthène, tu vois bien que notre duc est asteure de bonne composition.

- Voilà qui est bien vrai, dit le duc. Approche donc !

Mouscaillot dut donc se mettre éperon contre éperon.

- Sais-tu, mon ami, lui demanda le duc, pourquoi je me rends ainsi dans la ville capitale ?

- Je ne sais.

- Devine!

- Pour y prendre un bain?

- J'en profiterai peut-être. Cherche autre chose.

- Pour y voir putes et jaëls ?

- J'en profiterai peut-être. Cherche autre chose.

- Pour aller admirer le beau porche flamboyant de SaintGermain l'Auxerrois, porche que vient d'achever maître Jehan Gaussel ?

- J'en profiterai peut-être. Cherche autre chose.

- C'est inutile, dit Sthène, il ne trouvera jamais et vous finirez par le battre. D'ailleurs ne le voulez-vous point surprendre?

- Tu es un sage dada. Écoute bien, Mouscaillot: je vais trouver le roi de France pour lui

[72] demander justice pour mon compagnon d'armes Gilles de Rais, maréchal de France.

bougre?

- Quoi! de ce vilain

Mouscaillot va rouler dans la poussière.

Stèphe s'arrête.

Sthène demande au duc :

- Je m'arrête aussi ?

- Continue! il nous rattrapera bien. Ce petit me déçoit et je n'ai plus envie de faire la se, dizia o duque.

- Estou me aproximando, senhor, estou me aproximando.

- Aproxime-se, palerma, disse Stenes, você está vendo que nosso duque aestora está em boa disposição.

- É verdade, disse o duque. Aproxime-se.

Então Mouscaillot teve que se pôr espora contra espora.

- Você sabe, meu amigo, perguntou-lhe o duque, por que estou indo para a cidade capital?

- Num sei não.

- Adivinhe!

- Para tomar um banho?

- Pode ser que eu aproveite pra isso. Tente outra coisa.

meretrizes?

- Para ver putas e

- Pode ser que eu aproveite pra isso. Tente outra coisa.

- Para ir admirar o belo pórtico flamejante de SaintGermain Auxerrois, pórtico esse que o mestre Jehan Gaussel acaba de terminar?

- Pode ser que eu aproveite pra isso. Tente outra coisa.

- É inútil, disse Stenes, ele nunca vai descobrir e vós acabareis batendo nele. Aliás, vós não quereis surpreendê-lo?

- Você é um cavalinho sábio. Ouça bem, Mouscaillot: vou procurar o rei de França para pedirlhe justiça para meu companheiro de armas Gilles de Rais, marechal de França. malvado?

- O que! para esse herege

Mouscaillot vai rolar na poeira.

Estêvão para.

Stenes pergunta ao duque:

- Paro também?

- Continue! ele nos alcançará. Esse moleque me decepciona e não tenho mais 
conversation.

- Alors, je peux chanter?

- Si tu veux, mon bon

Démo.

Sthène se mit alors à dégoiser son répertoire à tue-tête. Il en était à un rondeau que Charles d'Orléans s'apprêtait à écrire : Hyver, vous n'êtes qu'un vilain, lorsqu'ils arrivèrent en vue de la porte d'une ville fortifiée que gardaient des borgeois en armes. Prudemment, Stènnstu et c'est en silence que s'acheva l'étape. vontade de praticar a conversação. - Então, posso cantar?

- Se você quiser, meu bom Demós.

Stenes pôs-se então a desfiar seu repertório a plenos pulmões. Ele estava num rondó que Carlos de Orleans estava se dispondo a escrever: Inverno, não passas de um vilão, quando chegaram perto da porta de uma cidade fortificada que era guardada por borgueses armados. Prudentemente, Stenessicalô e foi em silêncio que completaram a etapa. 
Tandis que Mouscaillot se [73] faisait soigner ses plaies et bosses par un mire de quartier, le duc d'Auge attendait le souper à l'auberge du Mont-à-Lambert en dévorant un fromage d'anguilles dont il arrosait chaque bouchée d'une bonne lampée de vin clairet. Cela le mit d'autant meilleure humeur que chaque instant le rapprochait du moment où le repas allait pour de bon commencer. Aussi accueillit-il avec bénévolence un personnage qui avait l'air de qualité et qui vint le saluer en lui tournant telles gracieuses politesses que le duc l'invite à sa table. Le jeune seigneur accepte sans barguigner et se nomme: Adolphe, vicomte de Péchiney.

Comme Mouscaillot vient d'arriver pansé par le mire, on entame le souper qui débute par trois potages de couleurs différentes: du potage de macarons, du potage de poires et du potage de tripes. Ensuite on se tape du rôti avec de la sauce aux bourgeons et de la sauce à la noix muscade. On vuide des pintes. Après cela on attaque le second rôt bien épicé, on vuide d'autres pintes, on achève sur des confitures sèches et des sucreries. Encore était-ce la famine dans les rues avoisinantes, mais il fallait bien en terminer.

- Mon jeune ami, dit alors le duc au vicomte de Péchiney, n'avez-vous point entendu parler $\mathrm{du}$ noble seigneur Gilles de Rais, maréchal de France?

- Si donc, messire.

- Ce fut mon compagnon d'armes! Maréchal de France à vingt-cinq ans, qu'est-ce que vous en dites ?
Enquanto um curandeiro de bairro cuidava das feridas $\mathrm{e}$ calombos de Mouscaillot, o duque de Auge esperava a ceia no albergue de Mont-à-Lambert devorando um pavê de enguias regando cada bocado com uma tragada de vinho clarete. Seu humor melhorava à medida que se aproximava o momento em que a refeição propriamente dita ia começar. Assim ele recebeu com benevolência uma personagem que parecia ser de qualidade e que veio saudá-lo com uma polidez tão graciosa que o duque o convida à sua mesa. O jovem senhor aceita sem hesitar e se apresenta: Adolfo, visconde de Péchiney.

Como Mouscaillot acaba de chegar enfaixado pelo curandeiro, começam a ceia que se inicia com três sopas de cores diferentes: sopa de macarrão, sopa de peras e sopa de tripas. Em seguida traçam um assado com molho de brotos e com molho de noz moscada. Esvaciam garrafas. Depois disso atacam o segundo assado bem temperado, esvaciam outras garrafas, terminam com geléias secas e docinhos. Ainda havia fome nas ruas da vizinhança, mas era preciso acabar com isso.

- Meu jovem amigo, disse então o duque ao visconde de Péchiney, o senhor não ouviu falar do nobre senhor Gilles de Rais, marechal de França?

- Claro que sim, senhor.

- Foi meu companheiro de armas! Marechal de França aos vinte e cinco anos, o que me diz disso? 
- J'en dis que c'est un bel âge pour un maréchal.

- N'est-ce pas ? Et savezvous ce qui lui arrive?

- J'ai ouï dire qu'on l'a mis en prison.

- On veut même le dácapiter.

- Voilà qui m'attriste fort.

- Eh bien, mon jeune ami, savez-vous pourquoi j'ai quitté mon châtiau pour aller passer quelques jours dans la ville capitale?

- Je l'ignore.

- Eh bien, mon jeune ami, je vais demander au roi la grâce du maréchal. J'estime qu'on ne peut pas traiter ainsi un libérateur de la France. Ce n'est pas parce qu'il aurait rôti quelques mômes qu'il faudrait oublier les services rendus à son pays.

- Ne parlez point si haut, messire, l'opinion publique est fortdéfavorable au maréchal.

- M'en fous. M'en irai trouver le roi quand même.

- Où cela?

- Comment : où cela ? Mais

à Paris bien sûr!

- Il n'y est point.

- Comment!? le roi n'est pas en son palais du Louvre aux barrières duquel veille la garde ? Où est-il donc?

- Sur les bords de la Loire.

- C'est bien la peine qu'on

[75] ait délivré des Godons sa bonne ville capitale si c'est pour n'y pas mettre les pieds.

- Messire, je ne me permettrais point de critiquer notre roi Charles, septième du nom.

- Moi, je me le permets. Je suis duc et j'ai droit à huit piliers pour mes fourches patibulaires. Je descends en ligne directe de Mérovée, c'est vous dire que les
- Digo que é uma bela idade para um marechal.

- Não é mesmo? E o senhor sabe o que está acontecendo com ele?

- Ouvi dizer que o puseram na prisão.

- Querem até decapitá-lo.

- Isso muito me entristece.

- Pois é, meu jovem amigo, o senhor sabe por que deixei meu castelo para ir passar alguns dias na cidade capital?

- Não sei, não.

- Pois é, meu jovem amigo, vou pedir ao rei graça para o marechal. Acho que não se pode tratar assim um libertador da França. Não é porque ele teria assado algumas crianças que se podem esquecer os serviços prestados ao seu país.

- Não faleis tão alto, senhor, a opinião pública é mui desfavorável ao marechal.

- Tô me lixando. Vô encontrá o rei assim mesmo.

- Onde?

- Como: onde? Em Paris, é claro!

- Ele não está lá.

- Como!? o rei não está em seu palácio do Louvre em cujas barreiras vigia a guarda? Onde está então?

- Nas margens do Loire.

- E para que é que libertaram dos godões sua bela cidade capital se é para ele não pôr os pés lá.

- Senhor, eu não me permitiria criticar nosso rei Carlos, sétimo do nome.

- Pois eu me permito. Eu sou duque e tenho direito a oito pilares para minhas forcas patibulares. Descendo em linha direta de Meroveu, isso quer dizer 
Capets pour moi c'est de la toute petite bière. Qu'est-ce qu'il ne se croit pas ce Capet-ci : sans nous et la bergerette, il ne faut pas oublier la bergerette, sans nous, dis-je, ce serait encore l'Anglais qui régnerait. Lors donc je trouve particulièrement mal séant que le roi ne se trouve pas dans sa ville capitale lorsque je viens l'y trouver.

- Messire, vous n'êtes pas le seul à penser ainsi.

Vous m'étonnez.

D'habitude, je suis seul à penser ce que je pense.

- En ce qui concerne le roi de France, vous trouveriez des amis.

- Je l'espère bien! Tout noble seigneur ressentirait comme moi l'affront qui lui est fait.

- Et en tirerait vengeance!

- Dame oui, mais cela, ce serait plus difficile. Avec toute cette armée régulière, ces francs archers, ces compagnies d'ordonnance et cette artillerie des frères Bureau, allez vous y frotter maintenant !

- A propos des frères Bureau, ne trouvez-vous point que notre roi s'entoure un peu beaucoup de petites gens comme lesdits frères, et Jacques Cœur, et cet Étienne Chevalier...

- Ma parole, dit le duc d'Auge, vous parlez comme un livre.

- Il me semble avoir lu ça dans un livre, dit Cidrolin, les moines mendiants ça remonte au Moyen Âge.

- Et les bonnes sœurs, dit le passant, elles mendient sans arrêt, je ne sais pas si c'est le Moyen Âge ou quoi.

- Pourtant on en est sorti du Moyen Âge, dit Cidrolin. Enfin... il paraît... que pra mim, os Capetos são café pequeno. O que ele pensa que é, esse Capeto: sem nós e a pastorinha, não se deve esquecer a pastorinha, sem nós, eu digo, seria ainda o inglês que reinaria. Então pois acho particularmente de mau gosto que o rei não se encontre na sua cidade capital quando vou para lá procurá-lo.

- Senhor, não sois o único a pensar assim.

- O senhor me espanta. Habitualmente sou o único a pensar o que penso.

- No que se refere ao rei de França, vós encontraríeis amigos.

- Espero! Todo nobre senhor se ressentiria como eu da afronta que lhe é feita.

- E procuraria vingança!

- Por Deus sim, mas isso seria mais difícil. Com todo esse exército regular, esses francos arqueiros, esses regimentos e essa artilharia dos irmãos Bureau, vai se meter com eles agora!

- A propósito dos irmãos Bureau, o senhor não acha que o rei se cerca um pouco demais de gentinha como os ditos irmãos, e Jacques Cœur e esse Etienne Chevalier...

- Poxa, disse o duque de Auge, o senhor fala como um livro.

- Tenho a impressão de ter lido isso num livro, diz Cidrolin, os monges mendigos remontam à Idade Média.

- E as boas irmãs, diz o passante, elas mendigam sem parar, não sei se é a Idade Média ou o quê.

- No entanto saímos da Idade Média, diz Cidrolin. Enfim... parece... 
- Ce quasi-clergyman avec sa mobylette, dit le passant, après tout c'est peut-être un escroc.

- Il ne m'a jamais escroqué, dit Cidrolin, je ne lui donne rien.

- Vous pourriez penser aux autres, dit le passant, à ceux qu'il a peut-être escroqués.

- Je ne veux de mal à personne, dit Cidrolin.

- C'est vous qui le dites.

Cidrolin regarde le passant dont la figure n'exprime rien et, à ce moment, on les hèle.

- C'est à vous, que ce discours s'adresse, dit le passant à Cidrolin. dit Cidrolin.

- Bonjour, mademoiselle,

- C'est à vous, monsieur, que ce discours s'adresse, dit la demoiselle au passant.

- Si je comprends bien, mademoiselle, dit le passant, vous faites de l'auto-stop.

- Je sommes campeuse et canadienne et...

Le passant fait un signe, une grosse houature vient se ranger le long du trottoir, il y a toujours de la place pour les grosses houatures, un chauffeur en livrée descend, ouvre la porte, la demoiselle monte, le passant dit à Cidrolin :

- Vous avez-vu comme la petite a subodoré la grosse houature?

Il monte à son tour et tout cela disparaît. Cidrolin dit à [77] Cidrolin :

- Combien y a-t-il de passants? Le fait est qu'il y a beaucoup plus de passants qu'il n'en faudrait ou bien alors c'est le même passant qui se répercute de jour en jour. Et le quasi-clergyman sur sa mobylette, c'est bien le
- Esse quase-padre com sua mobilete, diz o passante, além de tudo talvez seja um escroque.

- Ele nunca me extorquiu nada, diz Cidrolin, eu não lhe dou nada.

- O senhor deveria pensar nos outros, diz o passante, naqueles que ele talvez tenha extorquido.

- Não quero mal a ninguém, diz Cidrolin.

dizendo.

- É o senhor que está

Cidrolin olha o passante cujo rosto não exprime nada e, nesse momento, chamam-nos de longe.

- É ao senhor que esse chamado se dirige, diz o passante a Cidrolin.

- Bom dia, senhorita, diz Cidrolin.

- É ao senhor mesmo que esse chamado se dirige, diz a senhorita ao passante.

- Se estou entendendo, diz o passante, a senhorita viaja de carona.

- Eu ser campista e canadense e...

O passante faz um sinal, um grande otomóvil vem parar ao longo da calçada, sempre tem lugar para os grandes zotomóvis, um motorista de libré desce, abre a porta, a senhorita entra, o passante diz a Cidrolin:

- O senhor viu como a pequena farejou o grande otomóvil?

Ele por sua vez também sobe e tudo desaparece. Cidrolin diz a Cidrolin:

- Quantos passantes existem? O fato é que há muito mais passantes do que o que seria necessário ou então é o mesmo passante que repercute a cada dia. E o quase-padre na sua mobilete, é sempre o mesmo... pelo que eu 
même... autant qu'on en puisse juger ; mais les Canadiennes ? toutes différentes sans doute puisqu'il y en a d'iroquoises et de babéliennes. Il doit peut-être y en avoir qui tirent sur le mauve ou sur le grenat et qui parlent des langues inconnues. Celle-ci virait un peu à l'ébène ; après tout elles sont peutêtre toutes identiques. Comme les passants. Celui-ci n'est pas un vrai passant: il a un uniforme. Vous désirez, monsieur?

- Pourriez-vous me dire où péniche mademoiselle Lamélie Cidrolin ?

- Ici même, répond Cidrolin.

- Vous avez quelque chose à voir avec cette jeune personne ? demande le nouveau venu d'un air soupçonneux.

- Je veux, dit Cidrolin. Je suis son père.

- Alors ça tombe bien, s'exclame l'autre avec une vive satisfaction. Je viens justement lui demander sa main.

- Pour être verni, vous êtes verni : vous tombez tout de suite sur la personne adéquate.

- C'est oui ou c'est non? Oh, vous savez, ce n'est pas que j'y tienne tellement, mais, tout bien réfléchi, pourquoi pas après tout, et puis elle m'a insinué qu'elle avait un polichinelle dans le tiroir comme disait mon grand-père qui était lui aussi porté sur la chose, à preuve que j'ai au moins soixantedouze cousins illégitimes ou bien issus d'adultérins, et, comme je suis un homme d'honneur, [78] remarquez que pour nous, dans notre métier, ça nous est facile de semer des enfants à droite et à gauche sur tout le trajet, j'ai même un collègue qui en a fait un entre la rue des Petits-Champs et l'Opéra, c'est vous dire si je connais la posso julgar; mas as canadenses? todas diferentes sem dúvida já que existem das iroquesas e das babelianas. Devem existir talvez das que puxam para o lilás ou para o grená e das que falam línguas desconhecidas. Essa aqui puxava um pouco para o ébano; enfim talvez sejam todas idênticas. Como os passantes. Esse aqui não é um verdadeiro passante: ele está de uniforme. O que deseja, senhor?

- O senhor poderia me dizer onde chateia a senhorita Aamélia Cidrolin?

Cidrolin.

- Aqui mesmo, responde

- O senhor tem alguma coisa a ver com essa jovem? pergunta o recém-chegado com um ar desconfiado.

- Tenho, diz Cidrolin. Sou pai dela.

- Então deu certo, exclama o outro com viva satisfação. Eu venho justamente pedir-lhe a mão dela.

- Se é pra ser sortudo, o senhor é sortudo mesmo: veio dar de cara com a pessoa certa.

- É sim ou é não? Oh, o senhor sabe, não é que eu faça tanta questão, mas, pensando bem, por que não, e depois ela me insinuou que tinha um bolo no forno como dizia meu avô que também era entendido no assunto, prova é que eu tenho pelo menos setenta e dois primos ilegítimos ou de origem adulterina, e, como sou um homem honrado, note que para nós, na nossa profissão, é fácil semear crianças a torto e a direito em todo o trajeto, eu mesmo tenho um colega que fez um entre a rua Petits-Champs e a Ópera, quer dizer que se eu conheço a questão e se eu não quisesse reparar não haveria nada de estranho, mas é 
question et que si je ne voulais pas réparer ça n'aurait rien d'inattendu, mais voilà c'est comme ça, je suis disposé à réparer, alors je vous invite à profiter de l'occasion. Et puis ça ne me déplairait pas d'habiter sur une péniche.

Cidrolin.

$$
\text { - N'y comptez pas, it }
$$

- Y a de la place pourtant sur votre vaisseau.

- Mes filles, dit Cidrolin, quand elles se marient, elles vont habiter ailleurs. C'est comme ça.

- Alors vous nous condamnez à l'achélème ?

- Mon cher, dit Cidrolin, c'est vous que ça regarde. Remarquez qu'il n'y a pas que l'achélème, il y a le pavillon de banlieue, le petit quatrième sans ascenseur, la roulotte immobile et j'en passe.

- Tout de même, c'est pas la place qui manque.

- Qui voulez-vous épouser ? demande Cidrolin, Lamélie ou la péniche?

- C'est que je n'avais pas encore vu la péniche.

- Il faut reconnaître, dit Cidrolin, que pour une péniche c'est une péniche, et j'ajouterai même que pour une belle péniche, c'est une belle péniche. Vous voulez visiter?

- Ça va me faire de la peine, si je pense que j'y habiterai jamais.

- Faut vous faire une raison, dit Cidrolin. Vous pouvez toujours venir y boire un verre d'essence de fenouil. Au fait, je vous en offre un.

Cidrolin montre le chemin, ils descendent le talus, s'engagent sur la planche passerelle, [79] l'ératépiste manque de se flanquer dans la fange du fleuve.

- On voit que vous n'avez assim mesmo, estou disposto a reparar, então o aconselho a aproveitar a ocasião. E depois não me desagradaria nada morar numa chata.

- Não conte com isso, diz Cidrolin.

- No entanto, tem lugar na sua nave.

- Minhas filhas, diz Cidrolin, quando se casam, vão morar em outro lugar. É isso aí.

- Então estamos condenados ao beeneagá?

- Meu caro, diz Cidrolin, isso é problema seu. Mas veja que não há só o beeneagá, há o sobradinho na periferia, o apartamentinho de quarto andar sem elevador, o trailler imóvel e tudo o mais.

- Mesmo assim, não falta lugar aqui.

- Com quem o senhor quer se casar? pergunta Cidrolin. Com Aamélia ou com a chata?

- É que eu ainda não tinha visto a chata.

- É preciso reconhecer, diz Cidrolin, que para uma chata é uma chata mesmo, e acrescentarei mesmo que para uma bela chata, é uma bela chata mesmo. Quer visitá-la?

- Isso vai me deixar triste, se eu pensar que não vou habitá-la nunca.

- É preciso se conformar, diz Cidrolin. O senhor pode vir aqui beber um copo de essência de funcho. Aliás, eu o convido para um.

Cidrolin sobe o caminho, eles descem o barranco, atravessam a prancha passarela, o erriatepista quase cai no rio.

- Bem se vê que o senhor 
jamais servi dans les bateaux mouches, lui dit Cidrolin aimablement.

Ensuite il crie :

- Voilà ton jules !

C'est à Lamélie que ces paroles s'adressent et on apparaît aussitôt.

- Qui est ce monsieur? demande Lamélie à Cidrolin.

- Ton futur à ce qu'il paraît.

- Je le connais pas, dit Lamélie, mais, s'il veut prendre un verre d'essence de fenouil, on peut lui en offrir un.

- C'est déjà fait. Tu n'as plus qu'à nous apporter le rafrîchissement.

Lamélie s'esbigne pour réaliser ce projet.

- Alors, mon cher, dit Cidrolin à l'ératépiste, comment trouvez-vous ma péniche ?

- C'est chouette, répond l'ératépiste distraitement. Elle s'appelle bien Lamélie ?

l'Arche.

- Non, elle s'appelle

l'Arche?

- Votre fille s'appelle

Lamélie.

Ma fille s'appelle

- Vous en êtes sûr?

- Vous ne la reconnaissez

pas?

L'ératépiste se gratte ostensiblement la tête

Maintenant... je mdemande si... je mdemande... Enfin quoi, elle s'appelle bien Lamélie ?

- C'est un fait.

- Ce serait bien étonnant qu'une autre Lamélie, la mienne, habite aussi une autre péniche dans le coin.

- Pourquoi pas?

- Bin... le calcul des

[80] probabilités...

- Prétexte à devinettes et à nunca serviu nos bateaux-mouches, diz-lhe Cidrolin amavelmente.

Em seguida ele grita:

- Olha o seu namorado!

É para Aamélia que essas palavras se dirigem e aparecem imediatamente.

- Quem é esse senhor? pergunta Aamélia a Cidrolin.

- Teu futuro ao que parece.

- Não conheço ele, diz Aamélia, mas, se ele quiser tomar um copo de essência de funcho, pode-se oferecer-lhe um.

- Já ofereci. Você só tem que nos trazer o refresco.

Aamélia sai para realizar esse projeto.

- E aí, meu caro, diz Cidrolin ao erriatepista, o que acha de minha chata?

- É legal, responde o erriatepista distraidamente. Ela se chama Aamélia mesmo?

- Não, ela se chama Arca.

- Sua filha se chama Arca? Aamélia.

- Minha filha se chama

- O senhor tem certeza?

- O senhor não a reconhece?

O erriatepista coça a cabeça ostensivamente.

- Agora... eu mi pergunto si... eu mi pergunto... Afinal, ela se chama Aamélia mesmo?

- Isso é fato.

- Seria muito espantoso que uma outra Aamélia, a minha, morasse também numa outra chata por aqui.

- E por que não?

- Bom... o cálculo das probabilidades...

- Pretexto para adivinhações 
paradoxes. Sur les péniches le long $\mathrm{du}$ fleuve, toutes les filles s'appellent peut-être Lamélie.

L'ératépiste eut l'air d'en douter.

- Sur les péniches qui ne bougent pas, ajouta Cidrolin.

L'ératépiste eut l'air presque convaincu. Il aurait eu bien tort de l'être complètement car Lamélie, apportant l'essence de fenouil, lui dit :

- Alors, mon chou, je t'ai fait peur?

- C'est bien elle! s'écria le chou joyeusement.

- Tu as parlé à papa ?

- Oui, dit le chou.

- Il est d'accord?

- Demande, toi.

- Papa, tu veux bien que j'épouse l'ératépiste?

- Oui, dit Cidrolin, qui ajoute non sans mélancolie : Voilà une bonne chose de faite.

On trinque. On bavarde. On parle de l'installation future puisqu'il n'est pas question d'habiter ici, d'ailleurs ça ne dirait rien à l'ératépiste, l'humidité, c'est bien connu, ça donne des rhumatismes, et il craint très fort les rhumatismes, l'ératépiste. Et puis le môme, puisqu'il est question d'avoir un môme, il pourrait choir dans l'infâme bouillasse égoutière qui stagne autour de la péniche, alors on va chercher un petit pavillon en banlieue, mais avec quel argent on se le demande. Cidrolin aussi se le demande.

L'ératépiste n'ose le lui demander.

Il faudra peut-être attendre pour le petit pavillon de banlieue.

On peut toujours demander.

- Ça sera combien que vous

[81] lui donnerez ? demanda l'ératépiste. e para paradoxos. Nas chatas ao longo do rio, talvez todas as moças se chamem Aamélia.

duvidar.

O erriatepista pareceu

- Nas chatas que não se movem, acrescenta Cidrolin.

$\mathrm{O}$ erriatepista pareceu quase convencido. Ainda bem que não estava completamente pois Aamélia, trazendo a essência de funcho, diz-lhe: assustei?

- E aí, meu chuchu, te

- É ela mesmo! exclamou o chuchu alegremente.

- Você falou com papai?

- Sim diz o chuchu.

- Ele concordou?

- Pergunte você.

- Papai, você quer que eu me case com o erriatepista?

- Sim, diz Cidrolin, que acrescenta não sem melancolia: Pronto, está feito.

Comem. Conversam. Falam sobre a instalação futura já que está fora de questão morar aqui, aliás isso não agradaria nada ao erriatepista, a umidade, sabe-se bem, dá reumatismo, e ele tem muito medo de reumatismo, o erriatepista. E depois o bebê, pois é claro que vai haver um bebê, ele poderia cair na infame cultura de esgoto que estagna ao redor da chata, então vamos procurar um pequeno barraco na periferia, mas com que dinheiro perguntam-se. Cidrolin também se pergunta. perguntar-lhe.

O erriatepista não ousa

Será preciso esperar pelo barraco de periferia.

Perguntar não ofende.

- Quanto o senhor vai dar pra ela? perguntou o erriatepista. 
- Combien quoi ? qui lui ? dit Cidrolin. Moi, vous savez, les questions d'argent...

- Bin, dit l'ératépiste, bin, la dot quoi, ce qu'on appelait autrefois la dot, la petite somme à la clé du mariage, quoi...

- Ce n'est pas clair ce que vous racontez là, dit Cidrolin.

- Enfin, quoi, Lamélie, pour son marige, vous lui donnez rien ?

- Rien, dit Cidrolin.

- Vraiment rien?

- Vraiment rien.

- Tout de même, vous devez bien avoir un peu d'argent devant vous.

- Sans doute, mais je vais avoir des frais.

- Des frais de quoi ?

- Des frais de remplacement. Vous ne vous imaginez pas que je vais rester sans femme? Que je vais cirer mes souliers, faire la bouffe et le reste ? Faut que je m'en procure une autre, de femme. Et ça peut me coûter cher.

- Mais, dit l'ératépiste, inquiet, Lamélie, c'est pas votre dame, c'est bien votre fille?

- Ne craignez rien à ce sujet, déclare Cidrolin avec autorité, Lamélie est la troisième des triplées dont ma défunte épouse accoucha en trépassant.

- J'en savais rien, dit l'ératépiste accablé.

-Faites donc pas cette têtelà, c'est plutôt pittoresque d'épouser un triplée. Vous épaterez vos copains quand ils l'apprendront.

- Ça c'est vrai.

- Et pour revenir aux questions d'argent, qu'est-ce que [82] vous voulez, moi, il me faut quelqu'un pour passer un coup de
- Quanto o que? ela quem? diz Cidrolin. Comigo, sabe, as questões de dinheiro...

- Bem, diz o erriatepista, bem, o dote oras, o que outrora chamavam de dote, a pequena soma por ocasião do casamento, oras.

- Não está claro o que o senhor está dizendo, diz Cidrolin.

- Enfim oras, Aamélia, pro casamento dela, o senhor não vai dar nada?

- Nada, diz Cidrolin.

- Nada mesmo?

- Nada mesmo.

- Mas no entanto, o senhor deve ter um pouco de dinheiro.

- Pode ser, mas eu vou ter despesas.

- Despesas de que?

- Despesas de substituição. O senhor não pensa que eu vou ficar sem uma mulher? Que vou engraxar meus sapatos, fazer a comida e o resto? Eu tenho que conseguir uma outra, mulher. $\mathrm{E}$ isso pode me custar caro.

- Mas, diz o erriatepista, inquieto, Aamélia, não é sua mulher, é sua filha, não é?

- Não tenha receios quanto a isso, declara Cidrolin com autoridade, Aamélia é a terceira das trigêmeas que minha falecida esposa deu à luz ao morrer.

- Eu não sabia de nada disso, diz o erriatepista chateado.

- Não faça essa cara, é um tanto pitoresco casar com uma trigêmea. $\mathrm{O}$ senhor vai surpreender seus amigos quando eles souberem.

- Isso é verdade.

- E voltando às questões de dinheiro o que é que o senhor quer, pra mim, vai ser preciso alguém para dar uma varrida no convés e 
faubert sur le pont et hisser le grand pavois les jours de fêtes carillonnées. Ce n'est pas moi qui vais faire ça, n'est-ce pas, alors il me faut des sous pour trouver l'oiseau rare, par conséquent pour vous : tintin.

- Dans ce cas-là, dit l'ératépiste, je me demande si... je me demande si...

- Souviens-toi de nos baisers, lui dit Lamélie.

- Allons, allons, ajoute Cidrolin, vous n'allez pas prétendre que vous êtes un homme d'argent.

- Non bien sûr, et puis une triplée, tout de même une triplée, j'ai peut-être même une chance d'avoir ma photo dans les journeaux ou de passer aux actualités à la tévé, vous croyez pas?

- Sans l'ombre d'un doute, dit Cidrolin gravement.

- Alors, s'écria l'ératépiste, cochon qui s'en dédit, je prends Lamélie, fric ou pas !

- Brave garçon, dit Cidrolin. Alors, comment l'avez-vous trouvée, mon essence de fenouil ?

- De première, dit l'ératépiste. De première.

Il y a un silence.

- Eh bien, finit par dire l'ératépiste, voilà une bonne chose de faite. Si vous permettez, je rentre à la maison pour prévenir maman.

- Je vous avertis tout de suite, dit Cidrolin, si c'est pour remplacer Lamélie, rincer le pont et racler le gouvernail, je n'en veux pas de votre maman.

- Mais j'avais pas

l'intention de lui proposer.

- Je l'espère bien.

Cidrolin se lève, l'ératépiste en fait autant. Cidrolin dit à [83] Lamélie :

- Je le raccompagne ; sur la hastear o grande pavilhão nos dias de festa solene. Não sou eu que vou fazer isso, não é, então vou precisar de grana para encontrar o pássaro raro, consequentemente para $\mathrm{o}$ senhor: necas.

- Nesse caso, diz o erriatepista, eu me pergunto se... eu me pergunto se...

- Lembre-se de nossos beijos, diz-lhe Aamélia.

- Vamos, vamos, acrescenta Cidrolin, o senhor não vai agir como um mercenário.

- Não é claro, e depois uma trigêmea, afinal uma trigêmea, posso até ter a chance de ter minha foto nos jornais ou de passar nas atualidades na tevê, o senhor não acha?

- Sem sombra de dúvidas, diz Cidrolin gravemente.

- Então, exclamou o erriatepista, sou de palavra, eu caso com Aamélia, com grana ou sem!

- Bom rapaz, diz Cidrolin. E aí, o que o senhor achou da minha essência de funcho?

- De primeira, diz o erriatepista. De primeira.

Há um silêncio.

- Bom, diz finalmente o erriatepista, pronto, está feito. Se me permite vou pra casa avisar mamãe.

- Vou deixar claro desde já, diz Cidrolin, se é para substituir Aamélia, enxaguar o convés e esfregar o timão, não quero saber de sua mamãe.

- Mas eu num tinha intenção de fazer-lhe essa proposta.

- Ainda bem.

Cidrolin levanta-se, o erriatepista faz o mesmo. Cidrolin diz a Aamélia:

- Eu o acompanho; na 
planche passerelle, il a le vertige.

- Il lui tient la main de peur qu'il ne choie dans la vase ; ensuite ils remontent le talus.

- Au revoir, dit Cidrolin à l'ératépiste.

Il regarde la clôture et le portillon, couverts d'inscriptions. L'ératépiste dit :

- Je comprends pas les gens qui éprouvent le besoin d'écrire. Ça vous concerne?

- Au revoir, lui dit Cidrolin.

Tandis que l'ératépiste s'éloigne lentement, Cidrolin va chercher le pot de peinture et, d'un pinceau soigneux, étend de belles couches de vert sur la lettre A; il s'applique; il en remet au point de faire réapparaître ladite lettre par trop de couleur, puis il passe à la lettre $S$ et sa ferveur ne diminue pas. Il n'entend plus le pas du passant qui passe, ni le passage sur le boulevard de milliers et de milliers de houatures. Le vicomte de Péchiney parle à voix basse au duc d'Auge. La Trémouille, Dunois, le duc d'Alençon vont mettre un peu le Capétien au pas et lui rappeler les égards qu'il doit avoir envers les gens bien nés. Quelqu'un de plus important encore s'est même joint à eux. Le duc d'Auge demande qui cela peut bien être, il ajoute qu'il n'en a pas la moindre idée. Après s'être fait prié un moment, le jeune seigneur avoue que le quelqu'un n'est autre que le dauphin.

- Quoi! s'écrie de duc d'Auge. Le fameux Louis le onzième ?

- Soi-même, répond le vicomte de Péchiney, mais remarquez qu'onzième il ne l'est pas encore.

papa ?

- Et il conspirerait contre le prancha passarela, ele tem vertigem.

Ele segura-lhe a mão de medo de que ele caia no lodaçal; em seguida sobem o barranco. - Até logo, diz Cidrolin ao erriatepista.

Ele olha a cerca e o portão, cobertos de inscrições. $\mathrm{O}$ erriatepista diz:

- Eu não entendo as pessoas que sentem necessidade de escrever. Isso tem a ver com você?

- Até logo, diz Cidrolin.

Enquanto o erriatepista afasta-se lentamente, Cidrolin vai buscar a lata de tinta e, com pinceladas cuidadosas, estende belas camadas de verde sobre a letra A; ele capricha; chega ao ponto de fazer reaparecer a dita letra por excesso de cor, depois passa à letra $\mathrm{S}$ e seu fervor não diminui. Ele não ouve mais o passo do passante que passa, nem a passagem no bulevar de milhares e milhares de zotomóvis. $\mathrm{O}$ visconde de Péchiney fala em voz baixa ao duque de Auge. La Trémouille, Dunois, o duque de Alençon vão pôr o Capeto em seu lugar e lembrar-lhe a consideração que ele deve ter para com as pessoas bem nascidas. Alguém ainda mais importante juntou-se a eles. $\mathrm{O}$ duque de Auge pergunta quem poderia ser, ele acrescenta que não tem a mínima idéia. Depois de fazer mistério por um momento, o jovem senhor confessa que o alguém não é outro senão o delfim.

- O que! exclama o duque de Auge. O famoso Luís onze?

- O próprio, responde o visconde de Péchiney, mas note que onze ele ainda não é.

- E ele conspira contra o papai? 
[84] - Nous ne conspirons point, mais défendons nos droits légitimes.

- Je le reconnais; et mon bon ami Gilles de Rais, qu'est-ce qu'il deviendrait dans tout cela?

- Nous irions le délivrer.

- Je vous offre un cent de clous de girofle, s'il en advient ainsi. En attendant, beuvons!

Et ils beuvèrent.
- Nós não conspiramos, nós defendemos nossos direitos legítimos.

- Eu reconheço; e meu bom amigo Gilles de Rais, o que será dele nisso tudo?

- Nós iríamos libertá-lo.

- Eu lhes ofereço um cento de cravos-da-índia, se tudo se passar assim. Enquanto esperamos, bebamos!

E eles beberam. 
Le guetteur aperçut deux personnages montés sur des mulets [85] qui se dirigeaient vers le châtiau. Le duc d'Auge fut aussitôt prévenu. On reconnut alors l'abbé Biroton suivi du diacre Riphinte.

- On va leur faire une bonne blague, dit le duc d'Auge. On va leur tirer dessus un coup de bombarde et quelques coups de couleuvrine. Après vous irez récupérer les boulets.

Les novices artilleurs n'étaient point trop rassurés, car c'était la première fois qu'ils allaient utiliser les nouvelles acquisitions du duc d'Auge. La bombarde fonctionna de façon satisfaisante et un boulet alla s'enterrer à moins de trois cents mètres d'Onésiphore, lequel, non plus que le diacre Riphinte, ne comprit ce qui se passait.

Lorsque les billes des couleuvrines vinrent atterir dans le voisinage immédiat, le chapelain se jeta bas de son mulet pour implorer la protection divine, imité aussitôt par le diacre Riphinte. Un tube de couleuvrine éclata, ce qui arrêta le tir, le duc ne voulant pas risquer de faire péter, pour une simple plaisanterie, un matériel qui lui avait coûté fort cher.

Tandis que les artilleurs survivants allaient récupérer les

[86] boulets, l'abbé Biroton, suivi du diacre Riphinte, se présentait au duc.

- Quel accueil, messire, dit l'abbé Biroton. Je sais que vous n'aviez point de mauvaises intentions, mais nous l'avons échappé belle.

- Le résultat fut plus satisfaisant que je ne pensais.
A sentinela percebeu duas personagens montadas em mulas que se dirigiam ao castelo. $\mathrm{O}$ duque de Auge logo foi avisado. Reconheceram então o abade Biroton seguido do diácono Rifinge.

- Vamos pregar-lhe uma boa peça, disse o duque de Auge. Vamos dar-lhes um tiro de bombarda e alguns de colubrina. Depois vocês vão recolher as balas.

Os artilheiros noviços não estavam muito seguros, pois era a primeira vez que eles iam utilizar as novas aquisições do duque de Auge. A bombarda funcionou de maneira satisfatória e uma bala foi se enterrar a menos de trezentos metros de Onesíforo, o qual, não mais que o diácono Rifinge, não entendeu o que se passava.

Quando as balas das colubrinas vieram aterrissar na vizinhança imediata, o capelão jogou-se embaixo de sua mula para implorar a proteção divina, imitado imediatamente pelo diácono Rifinge. Um cano de colubrina explodiu, o que fez parar os tiros, pois o duque não queria se arriscar a explodir, por uma simples brincadeira, um material que lhe havia custado mui caro.

Enquanto os artilheiros sobreviventes iam recuperar as balas, o abade Biroton, seguido do diácono Rifinge, apresentou-se ao duque.

- Que recepção, senhor, disse o abade Biroton. Eu sei que não tínheis más intenções, mas nós escapamos por pouco.

- O resultado foi mais satisfatório do que eu pensava. 
- Alors, messire, vous aussi possédez la diabolique bombe ?

- Il me faut me défendre, mon cher. J'attends d'un jour à l'autre les compagnies royales de sécurité et, comme je n'ai pas envie de me laisser piétiner, j'ai pris mes précautions et me suis ravitaillé en inventions modernes et dernières nouveautés.

- Vous avez encore des démêlés avec le roi ?

- Cela n'arrête pas. Cette

fois-ci, à cause de mon bon ami Gilles de Rais...

- Hou ! le vilain bougre !

- Tais-toi, prêtre. Manquerais-tu de charité chrétienne ? Mon bon ami Gilles de Rais a été bel et bien exécuté, tout comme un manant, lui, noble seigneur et vaillant guerrier, alors que la guerre de Cent Ans n'est même pas encore terminée. Comme cela ne m'a pas plu, je me suis joint à d'autres nobles seigneurs et vaillants guerriers pour faire la leçon au roi ; et sais-tu qui était avec nous ?

- Point ne le devine.

- Le dauphin.

- Quoi ! le célèbre Louis le onzième?

- Onzième, pas encore. Je ne te raconte pas tout ce qui s'est passé ; en fin de compte les nobles seigneurs se sont conduits comme des cloches et le dauphin nous a laissé tomber, tant et si bien que je reste seul en face du roi de France, en état de rébellion ouverte. Heureusement que j'ai mes petits canons. Tiens, puisque tu es là, pas d'histoire, tu vas me les bénir.

L'abbé Biroton s'exécute sur-le-champ, sans discuter. La chose faite, le duc lui tape cordialement dans le dos, s'enquiert de sa santé, demande :
- $\begin{aligned} & \text { Então, senhor, vós } \\ & \text { também possuís a diabólica } \\ & \text { bomba? }\end{aligned}$

- Preciso me defender, meu caro. Estou esperando a qualquer momento as companhias reais e, como não tenho vontade de me deixar pisotear, tomei minhas precauções e me abasteci de invenções modernas e de últimas novidades.

- Tendes ainda vossas rusgas com o rei?

- Isso não acaba nunca.

Desta vez, por causa de meu bom amigo Gilles de Rais...

- Oh! o vilão herege!

- Cale-se, padre. Você não tem caridade cristã? Meu bom amigo Gilles de Rais foi muito bem executado, como um campônio, ele, um nobre senhor e valente guerreiro, ainda que a guerra dos Cem Anos nem tenha terminado ainda. Como isso não me agradou nem um pouco, eu me juntei a outros nobres senhores e valentes guerreiros para dar uma lição no rei; e sabe quem estava conosco?

- Não faço a mínima idéia.

- O delfim.

onze?

- O que! o célebre Luís

- Onze, ainda não. Nem lhe conto tudo o que aconteceu; no fim das contas os nobres senhores agiram como idiotas e o delfim nos abandonou, de modo que fiquei sozinho diante do rei de França, em estado de franca rebelião. Felizmente tenho meus canhõezinhos. Bom, já que você está aqui, não quero saber de história, você vai benzê-los para mim.

O abade Biroton atende imediatamente, sem discutir. Feita a coisa, o duque bate-lhe cordialmente nas costas, informa-se sobre sua saúde, pergunta: 
- Alors, et ce concile ?

- Il a déposé Eugène IV pour le remplacer par Amédée, et le roi de France va promulguer la Pragmatique Sanction qui défend les libertés de l'Église gallicane.

- Si je comprends bien, tu prends le parti du roi.

- Ne vous emportez point, messire, je n'étais là-bas que comme simple observateur.

- Hm ! tu m'as l'air de tisser toute l'étoffe d'un traître.

- Messire ! un traître ! moi ? un simple observateur, je vous le répète.

- Tu peux bien le répéter, mais je t'aurai à l'œil et je me demande si ce n'est pas mon ange gardien qui m'a conseillé d'agrémenter ton retour de quelques coups de canon. Moi, je suis guelfe et féodal. $\mathrm{Si}$ mon chapelain s'éprend des idées modernes, je n'aurai plus rien d'autre à faire qu'à l'attacher à la bouche d'une bombarde pour l'envoyer aux cieux en petits morceaux.

L'abbé Biroton s'abstint de commenter ce propos, et, dans le silence qui suivit, se firent entendre les voix de Pigranelle et Bélusine qui chantaient un rondeau que Charles d'Orléans s'apprêtait à écrire: Hyver, vous n'êtes qu'un vilain. Dans les écuries, Sthène et Stèphe les accompagnaient en fredon.

- Vos filles semblent de gaie humeur, dit le chapelain pour [88] parler d'autre chose que de luimême.

- Oui, répondit le duc. Je les marie.

- Toutes les trois?

- Oui.

- Même Phélise ?

-Même Phélise. Tu vois,
- E aí, e esse concílio?

- Ele depôs Eugênio IV para substituí-lo por Amadeu, e o rei de França vai promulgar a Pragmática Sanção que defende as liberdades da Igreja galicana.

- Se estou entendendo bem, você está tomando o partido do rei.

- Não vos aborreçais, senhor, eu estava lá somente como simples observador.

- Hm! você me parece ter toda a tessitura de um traidor.

- Senhor! traidor! eu? um simples observador, repito.

- Você pode repetir, mas eu vou ficar de olho em você e me pergunto se não foi meu anjo da guarda que me aconselhou a festejar teu retorno com uns tiros de canhão. Eu sou guelfo e feudal. Se meu capelão deixa-se dominar por idéias modernas, a única coisa que posso fazer é amarrá-lo na boca de uma bombarda para enviálo aos céus em pedacinhos.

$\mathrm{O}$ abade Biroton absteve-se de comentar esse assunto, e, no silêncio que se seguiu, fizeram-se ouvir as vozes de Pigranela e Belusina que cantavam um rondó que Carlos de Orleans estava se dispondo a escrever: Inverno, não passas de um vilão. Nos estábulos, Stenes e Estêvão as acompanhavam em surdina.

- Vossas filhas parecem de bom humor, disse o capelão para mudar de assunto e não falar de si mesmo.

- Sim, respondeu o duque. Vou casá-las.

- As três?

- Sim.

- Até Feliza?

- Até Feliza. Veja, 
Onésiphore, depuis mon veuvage, elles ne voyaient plus personne, ces petites. Grâce aux intrigues auxquelles je me suis mêlé, je me suis fait des amis et des alliés, des cloches je te l'ai dit, et, parmi les plus cloches d'entre ces cloches, j'ai mis la main sur trois jeunes niais à qui je refile mon petit tiercé : Pigranelle au sire de Ciry, Bélusine au comte de Torves et Phélise au vidame de Malplaquet. Et voilà une bonne chose de faire. J'espère qu'on pourra célébrer ces noces avant l'arrivée des archers du roi.

déconfire?

$$
\text { Que vous espérez }
$$

- Avec mes petits canons, je ne crains plus personne.

Le duc d'Auge se frotta les mains en manifestant tous les signes de la plus vive satisfaction, puis, brusquement, sa mine devint soucieuse.

Et cette histoire universelle à propos de laquelle je t'ai, il y a bien longtemps déjà, interrogé, j'attends toujours ta réponse.

juste?

- Que voulez-vous savoir au

- Ce que tu penses de l'histoire universelle en général et de l'histoire générale en particulier. J'écoute.

- Je suis bien fatigué, dit le chapelain.

- Tu te reposeras plus tard. Dis-moi, ce Concile de Bâle, est-ce de l'histoire universelle?

-Oui-da. De l'histoire universelle en général.

- Et mes petits canons ?

- De l'histoire générale en particulier.

- Et le mariage de mes filles ?

- À peine de l'histoire événementielle. De la
Onesíforo, desde que fiquei viúvo, elas não veem mais ninguém, essas meninas. Graças às intrigas em que me meti, fiz amigos e aliados, uns idiotas eu já disse, e, dentre os mais idiotas desses idiotas, pus a mão em três jovens bobalhões para os quais eu empurro meu pequeno trio: Pigranela ao sir de Ciry, Belusina ao conde de Torves e Feliza ao vidama de Malplaquet. Está aí uma boa coisa pra se fazer. Espero que possamos celebrar essas núpcias antes da chegada dos arqueiros do rei.

- Que esperais derrotar?

- Com meus canhõezinhos, não tenho medo de mais ninguém.

$\mathrm{O}$ duque de Auge esfregou as mãos manifestando todos os sinais da mais viva satisfação, depois, bruscamente, ficou com ar preocupado.

- E essa história universal a propósito da qual o interroguei, já há muito tempo, continuo esperando sua resposta.

exatamente?

- O que quereis saber

- O que você pensa da história universal em geral e da história geral em particular. Estou ouvindo.

- Estou muito cansado, disse o capelão.

- Você repousará mais tarde. Diga-me, esse Concílio de Basiléia, é história universal?

- Sim, claro. História universal em geral.

- E meus canhõezinhos?

particular.

- História geral em

- E o casamento de minhas filhas?

Somente história acontecimental. Microhistória, no 
microhistoire, tout au plus.

- De la quoi ? hurle le duc d'Auge. Quel diable de langage est-ce là ? Serait-ce aujourd'hui ta Pentecôte?

Veuillez m'excuser, messire. C'est, voyez-vous, la fatigue. Et l'énervement. Ces boulets sont terribles: diabolique invention!

fainéant!

- Mais tu les as bénis, boulets.

- Les canons, pas les

Oh! le vilain hypocrite !

Cache-toi sinon je te massacre.

Onésiphore disparaît.

Le duc fait le tour des remparts, examine l'horizon vide de tout archer, caresse bombarde et couleuvrines, félicite ses soudards. Il prononce même une petite allocution :

- Et si le chapelain vient vous dire que c'est là diabolique invention, vous lui répondrez que si l'on avait eu de l'artillerie du temps des Croisades, le saint sépulcre serait encore entre mains chrétiennes.

Cela dit, il descend du côté des cuisines pour voir s'il n'y aurait pas quelque chose de bon à grappiller, puis, changeant brusquement d'intention, il fait appeler ses filles par devers lui.

Ces trois jeunes personnes se présentent aussitôt. Elles commencent par remercier vivement leur papa pour le réjouissant spectacle qu'il leur a offert en bombardant et couleuvrinant l'abbé Biroton et le diacre Riphinte, puis elles s'informent respectueusement des intentions paternelles quant à la en leur demandant tout d'abord si elles vont finir par le laisser parler. Qu'elles ne s'inquiètent point,

máximo.

- O que? urra o duque de Auge. Que diabo de linguagem é essa? Será que hoje é o seu Pentecostes?

- Querei me desculpar, senhor. Vede, é o cansaço. E o nervosismo. Essas balas são terríveis: diabólica invenção!

- Mas você as benzeu, seu inútil!

- Os canhões, não as balas.

- Ah! vilão hipócrita! Desapareça senão eu te arrebento.

Onesíforo desaparece.

O duque dá volta nas muralhas, examina o horizonte vazio de qualquer arqueiro, acaricia bombarda e colubrinas, felicita seus soldados. Ele até pronuncia uma breve alocução:

- E se o capelão vier dizer que essa é uma diabólica invenção, vocês respondam que se a gente tivesse tido artilharia no tempo das Cruzadas, o santo sepulcro ainda estaria nas mãos dos cristãos.

Dito isso, ele desceu para o lado das cozinhas para ver se não havia alguma coisa de bom para mordiscar, depois, mudando bruscamente de intenção, manda chamar suas filhas para perto de si.

As três jovens apresentamse depressa. Elas começam por agradecer vivamente seu papai pelo divertido espetáculo que ele lhes havia oferecido bombardeando e colubrinando o abade Biroton e o diácono Rifinge, depois se informam respeitosamente sobre as intenções paternas quanto à data de suas núpcias. $\mathrm{O}$ duque responde perguntando-lhes primeiramente se elas vão deixá-lo falar. Que elas não se inquietem, continua ele, tudo está pronto, os senhores estão 
continue-t-il, tout est prêt, les seigneurs arrivent à grand troton ; quant aux archers du roi, il y a les petits canons pour les recevoir et, s'ils s'avisaient de se présenter devant les murs du châtiau, leur ratatinage ne serait somme toute que prétexte à réjouissances supplémentaires. Ce discours lui paraissant achevé, le duc, changeant encore une fois d'humeur, invite les triplées à le débarrasser immédiatement de leur présence, sans cela, gare les coups. Tandis qu'il grimpe au sommet de son donjon pour voir se les archers $\mathrm{du}$ roi se pointent dans le voisinage, ses filles se précipitent à la recherche du chapelain qu'elles trouvent en train de se réconforter dans les cuisines où il s'est replié pour décortiquer quelques harengs saurs qu'il mouille de vin clairet. Elles l'interviouvent, mais il ne peut que leur avouer qu'il n'en sait guère long sur la question qui les intéresse et les invite à recommander leur âme à Dieu en faisant pieuses prières.

- Bê, bê, dit Phélise.

Elle approuve.

Lorsque les filles sont parties, le chef des cuisines propose au chapelain de se revigorer un peu plus en mangeant une tourte qui est en train de cuire, une au suint de mouton et à la cannelle.

- Grands mercis, dit Onésiphore. Brrr, ces boulets volant comme mouches autour de ma tonsure, ce fut une rude épreuve pour un prêtre pacifique comme moi.

- Pourtant, chapelain, dit le maître queux, vous ne craignez point les coups, que je sache.

- Tu crois? Je changerais donc...

- En tout cas, m'est avis que la couleuvrinade que vous subîtes vindo o mais rápido possível; quanto aos arqueiros do rei, há os canhõezinhos para recebê-los e, se eles cismarem de se apresentar diante das muralhas do castelo, seu esmagamento será no fim das contas apenas um pretexto para alegrias suplementares. Quando esse discurso pareceu-lhe terminado, o duque, mudando de humor mais uma vez, convida as trigêmeas a desembaraçá-lo imediatamente de sua presença, senão, tomam pancadas. Enquanto ele trepa ao alto de seu torreão para ver se os arqueiros do rei despontam na vizinhança, suas filhas se precipitam em busca do capelão que elas encontram reconfortando-se nas cozinhas onde ele se curvava para descascar alguns arenques defumados que ele rega com vinho clarete. Elas o entrevistam, mas ele só pode confessar que não sabe muito mais sobre a questão que interessa a elas e as convida a encomendar sua alma a Deus fazendo pias preces.

- Bê, bê, diz Feliza.

Ela aprova.

Quando as jovens saíram, o chefe das cozinhas propõe que o capelão se revigore um pouco mais comendo uma torta que está assando, de sebo de carneiro com canela.

- Muito obrigado, diz Onesíforo. Brrr, essas balas voando como moscas em volta de minha tonsura, foi uma dura prova para um padre pacífico como eu.

- No entanto, capelão, diz o mestre cuca, o senhor não tem medo de pancadas, que eu saiba.

- Você acha? Então eu mudaria...

- Em todo caso, na minha opinião a colubrinada que o senhor 
n'est qu'un petit commencement. Cela va se bagarrer ferme dans le coin, et d'ici peu. Dès que notre roi très chrétien, Charles le septième, aura liquidé les Godons et même avant, il viendra donner une leçon à notre duc qui fait le jacques; et cette histoire de défendre ce vilain bougre d'ogre de Gilles de Rais, ce n'est pas cela qui l'aura rendu populaire, notre duc. Pas à mes yeux en tout cas; moi, je ne suis pas pour le cannibalisme, même considéré comme une farce. Je ne suis pas non plus pour les armes à feu, cette plaie de notre temps. On est obligé de tuer, éventrer, étriper les animaux, soit: il faut bien vivre ; et puis, ils n'ont pas d'âme, n'est-ce pas, messire chapelain ?

- Cela ne pourrait effleurer que l'esprit d'un albigeois, et, Dieu merci, il n'en reste plus.

- Alors je vous apporte ma tourte au suint de mouton et à la cannelle.

Onésiphore y goûte.

- Voilà, dit-il, qui me console d'être venu échouer de nouveau en ce châtiau alors que j'aurais pu décrocher quelque évêché en intriguant au Concile; mais je ne suis pas un intrigant. Tout de même ici, nous sommes quelque peu pris comme rats au piège. Et ces mariages, tu y crois, toi, à ces mariages ?

- En aucune façon, répondit le maître queux, rien n'est prêt, les fournisseurs ne sont pas prévenus, les réserves dont je dispose ne me permettraient pas de nourrir trente nobles personnes, encore moins de soutenir un siège.

- Et notre duc se fait bien des illusions sur son artillerie. Cela tombe à droite à gauche, ces boulets, pour tout dire n'importe où : ce n'est pas encore l'arme sofreu é apenas o comecinho. Vai ter muita briga por aqui, e não vai demorar muito. Assim que nosso rei muito cristão, Carlos o sétimo, tiver liquidado os godões e até antes, ele virá dar uma lição a nosso duque que se faz de besta; e essa história de defender esse vilão ogro herege do Gilles de Rais, não tornou nosso duque nada popular. Não aos meus olhos pelo menos; eu não sou a favor do canibalismo, mesmo considerado como uma brincadeira. Tampouco sou a favor das armas de fogo, essa chaga de nosso tempo. A gente é obrigado a matar, estripar, destrinçar os animais, vá lá: é preciso viver; e depois, eles não têm alma, não é, senhor capelão?

- Essa idéia só poderia florescer no espírito de um albigense, e, graças a Deus, já não resta mais nenhum.

- Então eu lhe trago minha torta de sebo de carneiro e canela.

Onesíforo a saboreia.

- É isso, diz ele, que me consola de ter vindo parar de novo neste castelo quando eu poderia ter descolado algum bispado intrigando no Concilio; mas não sou intrigante. De qualquer maneira, aqui nós estamos meio que pegos como ratos na ratoeira. $\mathrm{E}$ esses casamentos, você acredita nesses casamentos?

- De jeito nenhum, respondeu o mestre cuca, não tem nada pronto, os fornecedores não foram prevenidos, as reservas de que eu disponho não me permitiriam alimentar trinta nobres, quanto mais sustentar um cerco.

- E nosso duque está cheio de ilusões sobre sua artilharia. Aquelas balas caem a torto e a direito, quer dizer em qualquer lugar: ainda não é uma arma 
intégrale; et puis le roi en possède aussi. Quelques bons boulets dans le pont-levis et les archers du roi entrent dans le châtiau comme ils veulent.

- Voilà maintenant que le frocard fait de la stratégie! s'écria le duc qui était entré en catimini. Et de la stratégie défaitiste, par-dessus le marché ! Je ne sais ce qui me retient de le pendre par ses glandes extérieures.

En attendant, il ne peut se retenir de lui tirer une oreille. Indigné, l'abbé Biroton se met à gueuler très fort, et, comme cela n'empêche pas l'autre de continuer, il prend une lardoire sur le feu et commence à griller la main tractrice. Le duc pousse un épouvantable cri et lâche prise en secouant l'appendice comburé. Ainsi libéré, Onésiphore énonce d'une voix claire ses griefs :

- Me faire cela à moi! Un représentant de Dieu sur la terre! Un observateur au Concile de Bâle! Un membre de l'Église apostolique, romaine et gallicane ! À genous, Joachim duc d'Auge! Implore pardon sinon je te fais excommunier; alors plus de mariages, plus d'onctions, plus rien! À genous, Joachim duc d'Auge !

- Et cela se révolte en plus, dit le duc grommelant qui étale du beurre frais sur sa brûlure. Je le prévoyais depuis un certain temps ; le clergé veut tout commander.

- À genous, Joachim duc d'Auge ! continue à gueuler l'abbé Biroton. Implore pardon pour ton irrespect envers la sainte mère l'Église. À genous, et plus vite que cela! Je commence à voir de petits diablotins galoper autour de toi qui n'attendent que le bon moment pour emporter ton âme en Enfer. integral; e depois o rei também as tem. Algumas boas balas na ponte levadiça e os arqueiros do rei entram no castelo em debandada.

- Agora o fradeco faz estratégia! exclamou o duque que tinha entrado às escondidas. E estratégia derrotista, ainda por cima! Não sei o que me impede de pendurá-lo por suas glândulas exteriores.

Enquanto espera, ele não pode se impedir de puxar-lhe uma orelha. Indignado, o abade Biroton se põe a berrar muito alto, e, como isso não impede o outro de continuar, ele pega um espeto do fogo e começa a grelhar a mão que $\mathrm{o}$ segura. $\mathrm{O}$ duque solta um grito assustador e larga a presa sacudindo o apêndice queimado. Assim liberado, Onesíforo enuncia com voz clara seus protestos:

- Fazer isso comigo! Um representante de Deus sobre a terra! Um observador no Concílio de Basiléia! Um membro da Igreja apostólica, romana e galicana! De joelhos, Joaquim duque de Auge! Implore perdão senão eu mando excomungá-lo, e aí não mais casamentos, não mais unções, mais nada! De joelhos, Joaquim duque de Auge!

- E ainda se revolta, disse o duque resmungando espalhando manteiga fresca na queimadura. Eu já previa há algum tempo; o clero quer mandar em tudo.

- De joelhos, Joaquim duque de Auge! continua a berrar o abade Biroton. Implore perdão por seu desrespeito para com a Santa Madre Igreja. De joelhos, e rápido! Estou começando a ver pequenos diabretes galoparem em volta de você só esperando o momento certo para levar sua alma para o Inferno. 
- Et il a des visions pardessus le marché.

- Et penses-y bien; plus rien! plus d'onctions! plus de mariages !

Le duc hausse les épaules, soupire et s'agenouille.

- Pardon, dit-il.

- Cela manque de chaleur, dit le chapelain. Allons, allons, un peu plus de componction... un peu plus de foi...

Le duc se décide à mettre la bonne dose.

- J'implore le pardon de ma sainte mère l'Église et celui du non moins saint abbé, Onésiphore Biroton.

Il lui est pardonné.

-Tout de même, expliqua-til un peu plus tard à Mouscaillot, je n'allais pas risquer d'aller en Enfer pour une oreille de chapelain. Remarque que ces diablotins, je n'y crois pas. Lui-même, y croit-il ? Enfin, je ne peux pas me mettre tout le monde à dos, faut bien ruser dans la vie. Tiens, pour me changer les idées, je vais aller chasser la grosse bête, l'aurochs ou l'urus, par exemple. Selle les chevaux et que la meute soit prête... j'emmènerai aussi une couleuvrine... évidemment, si je tape en plein dans le gibier, il n'en restera plus lourd... plus lourd...

Quand Cidrolin rouvre les yeux, un soleil orange descend vers les achélèmes de la zone suburbe. Il se lève, boit un bon verre d'essence de fenouil, brosse son complet le plus chouette et l'endosse. il va d'abord s'assurer que clôture et portillon sont vierges de tout graffite, puis il boucle derrière lui et le voilà qui marche vers les autobus. Il en choisit un qui le mène vers le centre de la ville capitale, et là il en prend un autre pour un foyer mineur de la même
- E ele tem visões ainda por cima.

- E pense bem; mais nada! nada de unções! nada de casamentos!

$\mathrm{O}$ duque ergue os ombros, suspira e se ajoelha.

- Perdão, diz ele.

- Está faltando fervor, diz o capelão. Vamos, vamos, um pouco mais de compunção... um pouco mais de fé...

$\mathrm{O}$ duque se decide a dar a dose certa.

- Eu imploro o perdão de minha Santa Madre Igreja e o do não menos santo abade, Onesíforo Biroton.

Ele é perdoado.

- De qualquer jeito, explicou ele um pouco mais tarde a Mouscaillot, eu não ia me arriscar a ir para o Inferno por causa de uma orelha de capelão. Saiba que nesses diabretes, eu não acredito. Será que ele mesmo acredita? Enfim, não posso brigar com todo mundo, tem que ser esperto nessa vida. Bom, para distrair as idéias, vou caçar animais grandes, auroques ou urus, por exemplo. Sele os cavalos e que a matilha esteja pronta... vou levar também uma colubrina... evidentemente, se eu atirar em cheio na caça, não vai sobrar nada... nadinha...

Quando Cidrolin reabre os olhos, um sol laranja desce na direção dos beeneagá da zona suburbana. Ele se levanta, bebe um bom copo de essência de funcho, escova seu terno mais elegante e veste-o. Primeiro vai se assegurar de que cerca e portão estão virgens de qualquer graffite, depois fecha atrás de si e anda na direção dos ônibus. Escolhe um que o leva para o centro da cidade capital, e lá toma um outro para um ponto longínquo do mesmo bairro. $\mathrm{O}$ 
cité. Le crépuscule se prolonge, mais cafés et boutiques s'éclairent déjà comme si c'était pleine nuit ; il est vrai que dans ce foyer mineur, c'est toujours pleine nuit de l'aube jusques au soir.

Cidrolin regarde à droite, à gauche dans tous les cafés comme s'il cherchait quelqu'un ou simplement une place, une table à sa convenance. Il traîne un peu et finit par entrer au bar Biture, un bar qui se donne l'air de ressembler à tous les autres. Cidrolin s'assied. Comme clients, il n'y a que deux types debout qui parlent du tiercé. Derrière le comptoir, le patron, inactif, écoute les commentaires sur les pronostics; il porte une casquette carrée semi-ronde ovale en drap orné de pois blancs. Le fond est noir. Les pois sont de forme elliptique; le grand axe de chacun d'eux a six millimètres de long et le petit axe quatre, soit une superficie légèrement inférieure à dix-neuf millimètres carrés. La voisière est faite d'une étoffe analogue, mais les pois sont plus petits et de forme ovale. Leur superficie ne dépasse pas dix-huit millimètres carrés Il y a une tache sur le troisième pois à partir de la gauche, en comptant face au porteur de la casquette et au plus près $\mathrm{du}$ bord. C'est une tache d'essence de fenouil. Elle est infime, mais, malgré son étendue réduite, elle conserve la couleur propre à la substance originelle, une couleur un peu pisseuse, intermédiaire entre l'infrarouge et l'ultraviolet. En examinant avec soin le pois voisin, toujours en continuant à compter à partir de la gauche face au porteur de la casquette et en longeant au plus près $\mathrm{du}$ bord, on distingue une souillure minuscule ayant également pour origine la crepúsculo se prolonga, mas cafés e butiques já se iluminam como se fosse noite escura; é verdade que nesse bairro longínquo, é sempre noite escura da madrugada até a noite.

Cidrolin olha à direita, à esquerda em todos os cafés como se procurasse alguém ou simplesmente um lugar, uma mesa que lhe agradasse. Ele anda um pouco e acaba por entrar no bar Bitúrico, um bar que se dá ares de se parecer com todos os outros. Cidrolin senta-se. Como clientes, há apenas dois sujeitos em pé falando de corridas de cavalos. Atrás do balcão, o dono do bar, inativo, escuta os comentários sobre os prognósticos; ele usa um boné quadrado semi-redondo oval em tecido ornado de bolinhas brancas. O fundo é preto. As bolinhas são de forma elíptica; o eixo maior de cada uma delas tem seis milímetros de comprimento e o eixo menor quatro, ou seja uma superfície ligeiramente inferior a dezenove milímetros quadrados. A viseira é feita de um tecido análogo, mas as bolinhas são menores e de forma oval. Sua superfície não passa de dezoito milímetros quadrados. Há uma mancha na terceira bolinha a partir da esquerda, contando de frente do portador do boné e mais perto da borda. É uma mancha de essência de funcho. Ela é ínfima, mas, apesar de sua extensão reduzida, conserva a cor própria da substância original, uma cor que parece de mijo, intermediária entre o infravermelho e o ultravioleta. Examinando-se com cuidado a bolinha vizinha, sempre continuando a contar a partir da esquerda de frente do portador do boné e margeando a borda, distingue-se uma mácula minúscula 
projection d'une goutte d'essence de fenouil, mais ses dimensions sont telles qu' on pourrait croire que c'est simplement un fil du drap noir environnant qui se serait égaré là et $\mathrm{y}$ aurait pris une teinte jaunâtre sous l'effet de la lumière au néon qui tombe d'un tube tubulaire tant bien que mal; en effet, il y a des àcoups dans le fonctionnement de l'appareil et, parfois, on pourrait songer qu'il émet des signaux en cet alphabet inventé par ce peintre américain fameux qui naquit à Charlestown (Mass.) en 1791 et mourut à Poughkeepsie en 1872. Par une singulière coïncidence est accrochée juste au-dessus de la tête de Cidrolin une reproduction de l'Hercule mourant de SamuelFinlay-Breese Morse, qui avait obtenu en 1813 la médaille d'or de la Société des Arts Adelphi.

Comme elle est accrochée juste au-dessus de sa tête, Cidrolin ne peut voir directement cette reproduction qui se reflète d'ailleurs dans le vaste miroir qui couvre tout le mur opposé, mais Cidrolin ne peut la voir non plus indirectement, car l'un des deux consommateurs est de très haute taille et cache entièrement l'image de l'Hercule mourant de SamuelFinlay-Bresse Morse. L'autre consommateur, sensiblement moins grand que son interlocuteur puisqu'il ne mesure pas plus d'un mètre quarante-trois centimètres, porte de temps à autre ses yeux sur cette gravure dont il a une vue directe, car il s'appuie contre le comptoir et tourne presque entièrement le dos au patron, qui, brusquement, semble s'apercevoir de la présence d'un nouveau client, [96] et de loin, sans se déplacer, sans même faire un geste et encore tendo igualmente como origem a projeção de uma gota de essência de funcho, mas suas dimensões são tais que poder-se-ia crer que é simplesmente um fio do tecido preto circundante que estaria solto lá e teria tomado uma cor amarelada sob o efeito da luz de néon que tomba um tanto tonta de um tubo tubular; com efeito há falhas no funcionamento do aparelho e, às vezes, poder-se-ia pensar que ele emite sinais naquele alfabeto inventado por aquele pintor americano famoso que nasceu em Charlestown (Mass.) em 1791 e morreu em Poughkeepsie em 1872. Por uma singular coincidência está pendurada logo acima da cabeça de Cidrolin uma reprodução da Morte de Hércules de Samuel-Finlay-Breese Morse, que tinha ganhado em 1813 a medalha de ouro da Sociedade das Artes Adelphi.

Como ela está pendurada logo acima da sua cabeça, Cidrolin não pode ver diretamente essa reprodução que aliás se reflete num grande espelho que cobre toda a parede oposta, mas Cidrolin não pode vê-la tampouco indiretamente, pois um dos dois consumidores é de estatura muito alta e esconde inteiramente a imagem da Morte de Hércules de Samuel-Finlay-Breese Morse. O outro consumidor, sensivelmente menos alto que seu interlocutor já que não mede mais de um metro e quarenta e dois centímetros, dirige de tempos em tempos seu olhar para essa gravura da qual tem uma visão direta, pois ele se apóia no balcão e vira as costas quase totalmente ao dono do bar, que, bruscamente, parece perceber a presença de um novo cliente, e de longe, sem sair do lugar, sem nem mesmo fazer um gesto e menos 
moins enlever sa casquette, demande à Cidrolin ce qu'il a envie de consommer.

Cette question ne déconcerte point Cidrolin qui la prévoyait depuis quelques instants et se préparait à y répondre ; aussi sa réponse ne se fait-elle pas attendre. Elle consiste en une suite de mots formant une phrase grammaticalement bien formée et dont le sens ne peut laisser aucun doute, même dans l'esprit d'un patron de bistro aussi lourd que celui qui tient le bar Biture. Le patron du bistro écoute encore un instant les considérations des deux consommateurs concernant le tiercé, puis il apporte à Cidrolin la boisson demandée, qui est l'essence de fenouil un peu tiède avec une goutte d'eau plate. Cidrolin fabrique un sourire manifeste pour démontrer sa gratitude indescriptible, immense et perpétuelle devant tant de gentillesse et tant d'exactitude, et, toujours grave, l'homme à la casquette de drap noir semé de pois blancs se retire majestueusement derrière son comptoir.

Il se passe ensuite quelques minutes durant lesquelles les deux consommateurs essaient de résoudre les mystérieux problèmes que pose le tiercé du dimanche suivant, l'un des consommateurs est de très haute taille, l'autre est tourné de trois quarts, appuyant son dos contre le zinc, ce qui lui permet de jeter, de temps à autre, un coup d'œil sur la reproduction de l'œuvre de Samuel-Finlay-Breese Morse. Il regarde aussi de temps à autre l'homme qui est assis là et qui semble déguster son essence de fenouil. Il ne doit pas lui trouver un intérêt quelconque, car son regard ne s'attarde jamais plus de trois à quatre secondes sur ce personnage ainda tirar seu boné, pergunta a Cidrolin o que ele quer consumir.

Esta pergunta não desconcerta Cidrolin que a previa já há alguns instantes e se preparava para respondê-la; assim sua resposta não se fez esperar. Ela consiste em uma sequência de palavras formando uma frase gramaticalmente bem formada $\mathrm{e}$ cujo sentido não pode deixar nenhuma dúvida, mesmo no espírito de um dono de bar tão pesado quanto aquele que tem o bar Bitúrico. O dono do bar escuta ainda um instante as considerações dos dois consumidores sobre a corrida de cavalos, depois traz a Cidrolin a bebida pedida, que é essência de funcho meio morna com uma gota de água sem gás. Cidrolin dá um largo sorriso para demonstrar sua gratidão indescritível, imensa e perpétua diante de tanta gentileza e de tanta exatidão, e, sempre grave, o homem de boné de tecido preto semeado de bolinhas brancas retirase majestosamente para trás de seu balcão.

Passam-se em seguida alguns minutos durante os quais os dois consumidores tentam resolver os misteriosos problemas suscitados pelas corridas de cavalo do domingo seguinte, um dos consumidores é de estatura muito alta, o outro virou-se cerca de três quartos, apoiando suas costas contra o balcão, o que lhe permite dar, de tempos em tempos, uma olhadela na reprodução da obra de Samuel-Finlay-Breese Morse. Ele olha também de tempos em tempos o homem que está sentado lá e que parece degustar sua essência de funcho. Não deve encontrar nele nenhum interesse, pois seu olhar não demora nunca mais de três a 
[97] sans signes distinctifs. Il semble préférer nettement l'Hercule mourant de Samuel-Finlay-Breese Morse. Comme son interlocuteur déclare avoir épuisé toutes les combinaisons raisonnables à envisager, il pivote légèrement, sort de la monnaie de sa poche et paie les deux verres asséchés qui traînent encore sur le comptoir. Il serre ensuite la main du patron et sort suivi de son compagnon, l'homme à la très haute taille. La porte se referme derrière eux.

L'homme à la casquette nettoie les verres. Il n'adresse pas la parole à Cidrolin.

Cidrolin ne lui adresse pas la parole.

C'est alors qu'entre Albert. quatro segundos nessa personagem sem sinais particulares. Ele parece nitidamente preferir a Morte de Hércules de Samuel-Finlay-Breese Morse. Como seu interlocutor declara ter esgotado todas as combinações razoáveis a considerar, ele gira ligeiramente, tira uns trocados do bolso e paga os dois copos vazios que permanecem ainda sobre o balcão. Em seguida aperta a mão do dono do bar e sai seguido de seu companheiro, o homem de muito alta estatura. A porta fecha-se atrás deles.

O homem de boné limpa os copos. Ele não dirige a palavra a Cidrolin.

Cidrolin não dirige a palavra a ele.

É aí que entra Alberto. 
En voyant Cidrolin, Albert s'abstient de tout témoignage de [98] surprise, de reconnaissance ou de joie. Il s'assoit tranquillement, il lui serre la pince, il demande au patron une coupe de champagne. Lorsque la coupe est pleine, l'homme à la casquette de drap noir à pois blancs bat en retraite derrière son zinc et il parvient à s'y faire tout petit.

voix basse.

- Ça va comme tu veux? demande Albert.

- À peu près.

- Tu te refais à la vie civile ?

- Ça va. On s'habitue.

- Tu habites toujours la péniche?

- Oui.

- Tu dois être tranquille làdessus.

- À peu près. Sauf que, depuis quelque temps, il y a un con qui s'amuse à barbouiller des inscriptions sur la clôture qui longe le boulevard. Je passe mon temps à la repeindre. La clôture.

- Tu te fais du mouron pour bien peu de chose. Les graffiti, qu'est-ce que c'est ? tout juste de la littérature.

-Bien sûr, mais j'aime mieux peindre dessus. encore?

- Et qu'est-ce qui ne va pas

- À part ça, tout va. Je marie ma fille. La dernière.

- Bravo. Alors tu es content. Elles sont toutes casées.

- Faut reconnaître: je ne pensais pas qu'elle réussirait.
Vendo Cidrolin, Alberto se abstém de qualquer manifestação extravagante de surpresa, de reconhecimento ou de alegria. Senta-se tranquilamente, aperta-lhe os ossos, pede ao dono do bar uma taça de champanha. Quando a taça está cheia, o homem de boné de tecido preto com bolinhas brancas bate em retirada para trás de seu balcão e lá consegue quase desaparecer.

Alberto e Cidrolin falam em voz baixa.

- Está tudo em ordem? pergunta Alberto.

- Mais ou menos.

- Está se refazendo na vida civil? acostuma.

- Vai indo. A gente se

- Você continua morando na chata?

- Sim.

- Você deve estar tranquilo lá.

- Mais ou menos. Só que, há algum tempo, tem um babaca que se diverte rabiscando inscrições na cerca que margeia o bulevar. Eu passo meu tempo repintando. A cerca.

- Você fica estressado com muito pouco. O que são graffiti? é só literatura. por cima.

- É claro, mas prefiro pintar errado?

- E o que mais tem de - Tirando isso, está tudo certo. Estou casando minha filha. A última.

- Parabéns. Então você deve estar contente. Estão todas encaminhadas.

- Tenho que reconhecer: eu num pensava que ela fosse 
- Tu vois : faut jamais se désespérer.

- Oh, je ne désespérais pas. C'était surtout pour elle.

- Bien sûr.

Voilà. Et je vais me retrouver tout seul sur ma péniche.

-Faudrait que j'aille te voir un de ces jours, mais, tu sais, avec mes occupations.

- C'est justement à cause de ça que je voulais te parler.

- Je ne vois pas ce que tu peux avoir à me dire à propos de mes occupations.

- Si, si, tu vas comprendre.

- Je ne demande pas mieux.

- Voilà, je vais me retrouver tout seul sur ma péniche. Il faudra que je fasse la cuisine, lave mon linge, raccommode mes chaussettes, donne un coup de faubert sur le pont, toutes occupations qui m'emmerdent et sont d'ailleurs exclusivement féminines. Tu vois ce que je veux dire ?

- Je voudrais voir de plus près.

- Tu ne connaîtrais pas une jeune personne, pas trop jeune quand même, qui pourrait s'occuper de tout ça, faire la cuisine, laver mon linge, raccommoder mes chaussettes, donner un coup de faubert sur le pont. Remarque que je ne tiens pas essentiellement à la tringler, pas du tout même, non, non, ça serait tout

[100] juste pour ça, pour ce que je t'ai dit, cuire la tambouille, repasser mes liquettes, repriser mes slips, et tenir la péniche en son état coquet. Dans la marine, tu sais, on n'arrête pas de briquer.

- Pourquoi ne t'adresses-tu pas à un bureau de placement ? conseguir.

desesperá.

- Cê vê: num pode se

- Oh, eu não desesperava.

Era só por ela.

- Claro.

- Então. E eu vou ficar completamente sozinho na minha chata.

- Eu devia te visitá um dia desses, mas, cê sabe, com minhas ocupações.

- É justamente sobre isso que eu queria falar com você.

- Não vejo o que você possa ter a me dizer sobre minhas ocupações.

- Sim, sim, você vai entender.

- Espero que sim.

- Então, vou ficar completamente sozinho na minha chata. Vou ter que cozinhar, lavar minha roupa, remendar minhas meias, dar uma varrida no convés, todas ocupações que me deixam de saco cheio e que aliás são exclusivamente femininas. Você tá vendo o que eu quero dizer?

- Eu gostaria de ver de mais perto.

- Você não conheceria uma pessoa jovem, não jovem demais, que pudesse cuidar de tudo isso, cozinhar, lavar minha roupa, remendar minhas meias, dar uma varrida no convés. Veja que não faço questão absoluta de comer, nenhuma mesmo, não, não, seria somente para isso, para o que eu te disse, fazer o rango, passar minhas camisas, cerzir minhas cuecas, e manter a chata em seu estado atraente. Na marinha, você sabe, não se para de limpar.

- Por que você não procura numa agência de empregos? 
- Avec la réputation qu'on m'a faite...

- Tu crois qu'on pense encore à toi ? On t'a oublié.

- Mais non, puisqu'il y a le type qui barbouille mon portillon.

- Ce sont des idées.

- C'est pas des idées. C'est écrit.

- Moi, je te conseille le bureau de placement.

- J'aurais pensé que parmi les filles que tu connais y en a des tas qui préféreraient ma péniche au bordel argentin ou au harem pétrolier.

- Là, alors, je peux te dire que tu te trompes. Ce n'est pas un avenir ce que tu leur proposes; le travail les écœure, tu peux m'en croire.

- Tout de même. Tout de même. Ce n'est pas terrible, ce que je demande: rincer le gaillard d'avant et le gaillard d'arrière, tricoter un poul, faire bouillir la lessive et acheter des patates au supermarket, c'est pas un monde. Il me semble que ça devrait sembler plus agréable que de se faire trombiner par des nuées de gauchos ou un sheikh polygame et roteur.

- Comme tu te trompes. Les petites qui me passent entre les mains, j'en garderais bien quelques-unes ici, je leur trouve de véritables sinécures...

- En voilà une.

- ... mais ce sont elles qui

[101] me supplient de partir pour les pays lointains. Elles sont colonisatrices en diable.

- Elles sont idiotes, tes mousmés. Tu les baratines, tu leur fais croire. Pour une fois, trouvesen une, à qui tu feras croire la vérité, à savoir que ma péniche est une demeure chaste et pure qui vaut mieux que le stripeutise dans un bocard tropical et minable.
- Com a reputação que eu tenho...

- Você acha que ainda pensam em você? Já esqueceram.

- Não, não, pois tem o sujeito que rabisca meu portão.

- São só idéias.

- Não são idéias. Está

escrito.

- Aconselho a agência de empregos.

- Eu pensei que entre as moças que você conhece deve haver um monte que preferiria minha chata ao bordel argentino ou ao harém petroleiro.

- Aí, posso dizer que você se engana. Não é um futuro o que você propõe pra elas: o trabalho lhes dá náuseas, pode acreditar.

- Mesmo assim. Mesmo assim. Não é demais o que estou pedindo: enxaguar o tombadilho dianteiro e o tombadilho traseiro, tricotar um pulôver, ferver a roupa e comprar batatas no supermarket, não é um fim de mundo. Parece-me que isso deveria parecer mais agradável do que ser derrubada por enxames de gaúchos ou por um sheik polígamo e arrotador.

- Como você está enganado. As pequenas que passam pelas minhas mãos, bem que eu ficaria com algumas aqui, eu lhes ofereço verdadeiras mamatas...

- E essa é uma.

- ... mas são elas que me suplicam para partir para os países distantes. São colonizadoras por natureza.

- São idiotas, suas meninas. Você as engambela, você as engana. Pelo menos uma vez, encontre uma, a quem você fará acreditar na verdade, a saber que minha chata é uma morada casta e pura que vale mais a pena do que o estripitise numa espelunca tropical 
- Minute. Moi, je ne fais pas le bocard miteux. Les boîtes que je fournis sont tout ce qu'il y a de plus standigne.

- Ma péniche aussi est standigne. L'inspecteur des contributions corbitaires est venu l'autre jour et il m'a laissé espérer que bientôt l'Arche passerait dans les trois ancres catégorie A.

- Compliments, dit Albert impressionné.

- Tu es un copain, non? dit Cidrolin.

- Tu en doutes ? dit Albert indigné.

- Alors, trouve-moi ce que je cherche.

- Ce sera difficile.

- Mais non. Tu te pointes avenue du Maine...

- Tu ne vas pas m'apprendre mon métier.

- ... tu vois une fille qui descend du train d'Avranches, tu lui dis mademoiselle je connais une péniche je ne vous dis que ça, vous aurez tout juste un peu de ménage et la frigousse à faire et vous pourrez prendre des bains de soleil en regardant les rameurs d'un club sportif, de beaux garçons. Et ça sera vrai : elle ne se retrouvera pas à bord d'un cargo libérien à destination des patelins les plus perdus de la terre.

C'est un peu contre mes principes, ce que tu me demandes [102] là.

- Hésiterais-tu entre les principes et l'amitié ?

- Bon. Bon. Mais faut que ce soit toi. Onésiphore!

L'homme à la casquette de drap noir à pois blancs accomplit avec lenteur une rotation de trentesept degrés.

- Donne-nous, dit Albert, une bouteille de champ. Ma cuvée e miserável.

- Minuto. Eu não trabalho com espelunca miserável. As boates que eu abasteço são tudo o que há de mais chique.

- Minha chata também é chique. $\mathrm{O}$ inspetor das contribuições nautográficas veio outro dia e me deu esperança de que logo a Arca passaria para as três âncoras categoria A.

- Parabéns, diz Alberto impressionado.

- Você é meu amigo, não? diz Cidrolin.

- Você duvida? diz Alberto indignado.

- Então, encontre pra mim o que estou procurando.

- Vai ser difícil.

- Não, não. Você aparece na avenida do Maine...

- Você não vai me ensinar meu trabalho.

- ... você vê uma moça descendo do trem de Avranches, você lhe diz senhorita conheço uma chata e não digo mais nada, você só terá que fazer um pouco de faxina e o rango e você poderá tomar banhos de sol olhando os remadores de um clube esportivo, belos rapazes. $\mathrm{E}$ isso vai ser verdade: ela não vai estar a bordo de um cargueiro liberiano com destino às bibocas mais perdidas da terra.

- É um pouco contra meus princípios, isso que você está me pedindo.

- Você hesitaria entre os princípios e a amizade?

- Bom, tá bem. Mas é só porque é pra você. Onesíforo!

O homem de boné de tecido preto com bolinhas brancas completou com lentidão uma rotação de trinta e sete graus.

- Traga, diz Alberto, uma garrafa de champ. Minha safra 
spéciale. C'est, dit-il à Cidrolin, la même que chez les Rothschild, Onassis ou des gens comme ça.

Onésiphore ouvre une petite trappe et disparaît.

- Mais, dis-moi, ajoute Albert embarrassé, il y a aussi une question qu'on n'a pas encore abordée.

- Je ne veux pas que tu y sois de ta poche, dit Cidrolin. Je paierai cache à la livraison exactement ce que tu aurais touché pour l'exportation.

- Je te ferai vingt pour cent de rabais.

-Tu es un pote.

Onésiphore apporte la cuvée spéciale.

Ils sablent.

Onésiphore a droit aussi à sa coupe ; mais il ne se mêle pas aux débris de la conversation finissante.

- Tâche, dit Cidrolin, qu'elle ne soit ni moche ni trop conne, la fille.

- J'essaierai, dit Albert. Pour ce qui est du minois, je m'y connais, mais la connerie, c'est parfois insondable.

- Maintenant je vais rentrer, dit Cidrolin.

- Mon chauffeur va te reconduire, dit Albert.

- Non, merci, dit Cidrolin. Je préfère l'autobus.

- Toujours les mauvais souvenirs, hein ?

Cidrolin ne répond pas. Il serre la pince à Albert, salue [103] poliment l'homme à la casquette de drap noir à pois blancs, prend les deux autobus requis et, une fois sur sa péniche, il s'ouvre une boîte de mousse de pâté de foie et se la tartine. Il déguste ensuite trois verres et demi d'essence de fenouil, et, en fin de compte, il se couche et s'endort. Il se trouve face à face especial. É, diz a Cidrolin, a mesma dos Rothschild, Onassis ou gente assim.

Onesíforo abre um pequeno alçapão e desaparece.

- Mas, diga-me, acrescenta Alberto embaraçado, ainda tem uma pequena questão que a gente ainda não abordou.

- Não quero que você fique no prejuízo, diz Cidrolin. Eu pagarei queche contra entrega exatamente o que você teria ganhado pela exportação.

- Te faço vinte por cento de desconto.

- Você é um amigão.

Onesíforo traz a safra especial.

Eles bebem.

Onesíforo também tem direito a sua taça; mas ele não se mete no resto da conversa que termina.

- Cuide, diz Cidrolin, para que não seja nem muito feia nem muito babaca, a moça.

- Vou tentar, diz Alberto. Quanto à formosura, eu me garanto, mas a babaquice, às vezes é insondável.

Cidrolin.

- Agora vou pra casa, diz

- Meu motorista vai levá-lo, diz Alberto.

- Não obrigado, diz Cidrolin. Prefiro o ônibus. hein?

- Ainda as más recordações,

Cidrolin não responde. Ele aperta os ossos de Alberto, cumprimenta polidamente $\mathrm{o}$ homem de boné de tecido preto com bolinhas brancas, toma os dois ônibus necessários e, uma vez na chata, abre uma lata de mousse de patê de fígado e passa no pão. Degusta em seguida três copos e meio de essência de funcho, e, no fim das contas, deita-se e 
avec un mammouth, un vrai.

Le duc jauge froidement l'animal. Il dit à Mouscaillot :

- J'avais pensé à un aurochs ou à un urus, mais pas à cette bestiole. Je croyais qu'il n'y en avait plus sur mes terres. Artilleurs! heup! à votre pièce ! Objectif : le mammouth ! En joue...

Le mammouth, après avoir pris sa respiration, fonce à petit trot sur ses agresseurs.

- Sauve qui peut! hennit Sthène qui grignotait des lichens au pied d'un arbre.

- Il se met à donner des ordres maintenant! dit le duc avec indulgence.

Mouscaillot.

- Sauve qui peut! bêle

- Tu quoque fili...

Le duc d'Auge veut flanquer une taloche au page, mais celui-ci a déguerpi ainsi que les artilleurs, la meute et les chevaus. Cette désertion ne l'impressionne pas; il dégaine son braquemart et s'apprête à férir le fauve, mais celui-ci dédaigne le compagnon d'armes de Jeanne d'Arc et de Gilles de Rais. D'un pied puissant il enfonce la couleuvrine en terre et poursuit à toute trompe son chemin dans le pachydermique espoir de réduire en bouillie la vermine qu'il aperçut, mais les chiens sont déjà dans leur niche, les chevaux à l'écurie et les artilleurs tout près du pont-levis. Le duc d'Auge reste

[104] donc sur place, indemne, pantois et nobiliaire.

Il regarde attristé sa pièce d'artillerie transformée en racine, en voilà deux qu'il paume dans la même journée, ça finit par lui revenir cher les inventions modernes. Il remet son braquemart dans son fourreau et entreprit de considérer, un tantinet soit peu, la adormece. Ele se encontra cara a cara com um mamute, de verdade.

$\mathrm{O}$ duque analisa friamente $\mathrm{o}$ animal. Ele diz a Mouscaillot:

- Eu tinha pensado num auroque ou num uru, mas não nesse bichinho. Eu pensava que nem existissem mais nas minhas terras. Artilheiros! atenção! a seus postos! Objetivo: o mamute! Apontar...

O mamute, depois de ter tomado a respiração, investe trotando contra os agressores.

- Salve-se quem puder! relincha Stenes que mordiscava líquens ao pé de uma árvore.

- Agora ele se mete a dar ordens! diz o duque com indulgência.

- Salve-se quem puder! muge Mouscaillot.

- Tu quoque fili...

$\mathrm{O}$ duque de Auge quer dar um coice no pajem, mas este debandou assim como os artilheiros, a comitiva e os cavallos. Essa deserção não o impressiona; ele aponta seu bacamarte e prepara-se para ferir a fera, mas esta desaponta o companheiro de armas de Joana d'Arc e de Gilles de Rais. Com um pé firme ela enfia a colubrina na terra e prossegue a toda tromba seu caminho na paquidérmica esperança de reduzir a mingau os vermes que tinha visto, mas os cães já estão nas suas casinhas, os cavalos no estábulo e os artilheiros bem perto da ponte levadiça. O duque de Auge permanece então no lugar, ileso, estupefato e nobiliário.

Ele olha entristecido a sua peça de artilharia transformada em raiz, já são duas que ele perde no mesmo dia, assim vão acabar saindo caro as invenções modernas. Ele guarda seu bacamarte na bainha e começa a considerar, um tantinho que fosse, a situação histórica. 
situation historique.

Elle était, pour le moment, forestière et dépeuplée. Les arbres poussaient en silence et le règne animal limitait sa présence à des actes obscurs et muets. Le duc d'Auge, qui consacrait habituellement peu de temps à la contemplation de la nature, décida de rejoindre des régions plus habitées; pour ce faire, il jugea particulièrement intelligent de reprendre le chemin qu'il avait suivi pour venir en ces lieux et qui, normalement, devrait le reconduire à son châtiau.

Sans hésiter, il identifie le sentier qui lui paraît adéquat et marche d'un bon pas pendant une petite heure environ. Il s'aperçoit alors que le sentier était heideggerien. Bien embrené, il fait demi-tour et marche d'un bon pas pendant une petite heure environ, espérant retrouver la clairière où sa couleuvrine gisait, l'âme emplie d'humus et de feuilles pourrissantes. Il débouche bien dans une clairière, mais il n'y trouve trace de son petit canon. Examinant avec attention les données du problème, il conclut que : de deux choses l'une, ou bien ce n'est pas la même éclaircie ou bien sciurus communis et tineola biselliella lui ont bouffé sa pièce d'artillerie. Comme Buridan l'avait enseigné quelques lustres plus tôt, un tel dilemme ne pouvait conduire qu'à la famine, et le duc d'Auge redoutait par-dessus tout les repas sommaires, à plus forte raison les

[105] inexistants. Utilisant une méthode probabiliste, il s'engagea dans une direction non moins aléatoire qu'arbitraire et il se mit à errer ainsi jusqu'à ce que vint le crépuscule.

- Évidemment, dit le duc à haute voix pour se tenir compagnie,
Ela era, no momento, florestal e despovoada. As árvores cresciam em silêncio e o reino animal limitava sua presença a atos obscuros e mudos. O duque de Auge, que dedicava habitualmente pouco tempo à contemplação da natureza, decidiu procurar regiões mais habitadas; para isso, julgou particularmente inteligente retomar o caminho que tinha seguido para vir para esses lugares e que, normalmente, deveria reconduzi-lo a seu castelo.

Sem hesitar, identifica o caminho que lhe parece adequado e anda num bom passo durante cerca de uma boa hora. Percebe então que o caminho era heideggeriano. Muito enfezado, faz meia-volta e anda num bom passo durante cerca de uma boa hora, esperando reencontrar a clareira onde sua colubrina jazia com a alma repleta de húmus e de folhas podres. Ele desemboca numa clareira, mas não encontra nem sombra do seu canhãozinho. Examinando com atenção os dados do problema, conclui que: de duas uma, ou bem não é a mesma clareira ou bem sciurus communis et tineola biselliella devoraram sua peça de artilharia. Como Buridan havia lhe ensinado alguns lustros antes, um tal dilema só poderia levar à fome, e o duque de Auge temia mais que tudo as refeições sumárias, e mais ainda as inexistentes. Utilizando um método probabilístico, ele tomou uma direção não menos aleatória que arbitrária e pôs-se a errar assim até que chegou o crepúsculo.

- Evidentemente, diz o duque em voz alta para se fazer 
j'aurai pu joncher mon itinéraire de petits caillous blancs, mais, d'une part, je n'en avais pas sous la main et, de l'autre, ça m'avancerait bien maintenant qu'il va faire nuit et même nuit noire.

Effectivement, il fit nuit et même nuit noire. Le duc s'obstinait à cheminer, mais tombait dans des fourrés ou s'écrasait le nez contre des chênes séculaires en poussant des hurlements de rage et en jurant de la façon la plus malséante qui fût, sans respect pour la nocturne beauté de ces lieux. Il commençait à en avoir mare, mais vraiment mare, lorsqu'il aperçut, piquée sur le sombre satin des ténèbres, une lueur.

- Je vais aller voir ce que c'est, dit le duc à haute voix pour se tenir compagnie. Peut-être après tout n'est-ce qu'un ver luisant de grande taille, mais j'ai telle faim que j'en ferais bien une collation.

Ce n'était point un ver luisant, mais une chaumière.

- Je dois encore piétiner ici mes terres, murmure le duc rassuré, et qui loge dans cette escreigne doit être de mes serfs. Un bûcheron, sans doute. Si Sthène était là, il pourrait me dire comment il se nomme, il connaît tout le monde, lui, mais le salaud s'est enfui et moi, je suis perdu comme un pauvre petit poucet, voilà ce que c'est que d'aller à la chasse au canon sans emporter quelque cassecroûte, des portulans et la liste de ses corvéables.

[106] Il veut pousser la porte (n'est-il pas sur ses terres ?) mais la porte résiste : la lourde et bouclée. Du pommeau de son épée, il cogne et, en même temps, annonce la couleur :

- Ouvre, manant, voici ton duc ! companhia, eu poderia ter jogado pedrinhas brancas para marcar o caminho, mas, por um lado, eu não as tinha à mão e, por outro, isso adiantaria pouco agora que já vai se fazer noite e noite escura.

Efetivamente, fez-se noite e noite escura. $\mathrm{O}$ duque obstinava-se em caminhar, mas caía nas pedras e raízes ou esmagava o nariz contra os carvalhos seculares dando urros de raiva e xingando da maneira mais inconveniente, sem respeito pela noturna beleza desses lugares. Ele começava a ficar cheio, mas cheio mesmo, quando percebeu, pregado no sombrio cetim das trevas, um clarão.

- Vou ver o que é, diz o duque em voz alta para se fazer companhia. Pode ser que seja apenas um vaga-lume tamanho grande, mas estou com tanta fome que eu faria um bom lanche com ele.

Não era um vaga-lume, mas uma choupana.

- Ainda devo estar pisando minhas terras, murmura o duque mais tranquilo, e quem mora nessa maloca deve ser um dos meus servos. Um lenhador, talvez. Se Stenes estivesse aqui, poderia me dizer como ele se chama, ele conhece todo mundo, mas o canalha fugiu e estou perdido como um pobre pequeno polegar, veja o que dá ir à caça a canhão sem levar algo de merenda, uns portulanos e a lista dos contribuintes.

Ele quer empurrar a porta (não está em suas terras?) mas a porta resiste: a porta está trancada. Com a empunhadura de sua espada, ele bate e, ao mesmo tempo, diz a que vem:

- Abra, campônio, é o seu duque! 
Il attend, mais rien ne se modifie dans la situation ambiante et il répète :

- Ouvre, manant, voici ton duc!

Et ainsi de suite, plusieurs fois. Le résultat : toujours nul.

Le duc, ayant réfléchi, exprime sa pensée pour lui-même :

- Il a peur, ce pauvre diable. Il doit me prendre pour quelque esprit noctambule et sylvain. Il n'a pas mon courage: il est de trop pauvre extrace, mais peut-être n'est-il pas insensible à la pitié ! Essayons de la ruse...

Larmoyant, il pousse un cri désespéré :

- J'ai faim!

Aussitôt la porte s'ouvre comme par enchantement et une radieuse apparition fait son apparition.

L'apparition susdite consiste en une pucelle d'une insigne saleté mais d'une esthétique impeccable. Le duc a le souffle coupé.

- Pauvre messire, dit la jeune personne d'une voix vachement mélodieuse, venez vous asseoir au coin du feu et partager ma modeste pâtée de châtaignes et de glands. bouffer?

- C'est tout ce qu'il y a à

- Hélas oui, messire. Mon papa est allé à la ville acheter quelques onces de morue fumée, mais il n'est pas encore rentré et sans doute ne rentrera-t-il plus maintenant qu'à l'aube.

$\mathrm{Ce}$ propos laisse le duc rêveur : il n'a d'ailleurs pas besoin

[107] de toute la nuit pour manger la modeste pâtée, surtout s'il la doit partager avec la tendre enfant qui
Ele espera, mas nada se modifica na situação ambiente e ele repete:

- Abra, campônio, é o seu duque!

E assim sucessivamente, várias vezes. O resultado: sempre nulo.

O duque, tendo refletido, exprime seu pensamento para si mesmo:

- Está com medo, esse pobre diabo. Deve achar que sou algum espírito noctâmbulo e silvícola. Ele não tem minha coragem: é de extrato pobre demais, mas talvez não seja insensível à piedade! Vamos tentar a astúcia...

Choramingando, dá um grito desesperado.

- Estou com fome!

Logo a porta se abre como por encanto e uma radiante aparição faz sua aparição.

A aparição supracitada consiste de uma donzela de uma sujeira insigne mas de uma estética impecável. O duque perde o fôlego.

- Pobre sire, diz a jovem pessoa com uma voz tremendamente melodiosa, vinde sentar-vos perto do fogo e compartir meu modesto patê de castanhas e de bolotas.

comer?

- É tudo o que tem pra

- Ai de mim, sim, senhor. Meu papai foi à cidade comprar algumas onças de bacalhau defumado, mas ainda não voltou e agora talvez só volte quando amanhecer.

Esse assunto deixa o duque sonhador: aliás ele não precisa da noite inteira para comer o modesto patê, principalmente se tem que dividi-lo com a tenra criança que 
le regarde maintenant avec une timidité de bon aloi. Lui, il l'examine.

- Vous êtes un rien gironde, dit le duc.

Elle fait semblant de ne pas réceptionner le madrigal.

- Asseyez-vous, asseyezvous, messire. Voulez-vous que je mette du poivre dans la tambouille? J'en possède un précieux sachet que ma marraine m'a donné à la Noël dernière. Il vient du Malabar, ce poivre, et des plus authentiques, pas falsifié du tout.

- Ma foi, dit le duc rougissant, je ne dis pas non. Quelques grains...

- Tout le sachet, messire! tout le sachet! Cela vous confortera.

- Ai-je donc l'air bon à ravauder?

- Votre seigneurie fait grande figure, mais elle a dû avoir des émotions.

comme ça...

- Dame... perdre un canon... canon?

- Un canon? vous avez un

- J'en ai même plusieurs, dit le duc fièrement.

La petite sauta de joie en l'air et battit des mains.

- Oh! vous avez des canons ? Moi, j'adore les canons ! Ça c'est moderne au moins !

Et elle se mit à courir autour de la chambre au petit périmètre en chantant: Dansons la Carmagnole, Vive le son, vive le son... Dansons la Carmagnole, vive le son du canon...

- Elle est charmante cette petite, murmura le duc d'Auge, mais sa ritournelle ne me dit rien qui vaille.

Et il lui demande :

- Qui t'a appris cette agora está olhando pra ele com uma timidez de qualidade. Ele a examina.

- Você é bem jeitosinha, diz o duque.

Ela finge não ter entendido o madrigal.

- Sentai-vos, sentai-vos, senhor. Quereis que eu ponha pimenta no rango? Tenho um precioso sachê que minha madrinha me deu no último Natal. Vem de Malabar, essa pimenta, e das mais autênticas, nem um pouco falsificada.

- Com efeito, diz o duque corando, não digo não. Alguns grãos...

- Todo o sachê, senhor! todo o sachê! Isso vos confortará.

abatido?

- Então estou parecendo

- Vossa senhoria tem uma bela figura, mas deve ter tido emoções.

- Nossa Senhora... perder um canhão... assim...

- Um canhão? vós tendes um canhão?

- Tenho vários, diz o duque orgulhosamente.

A pequena pulou de alegria e bateu as mãos.

- Oh! tendes canhões? Adoro canhões! Pelo menos é moderno!

E ela se pôs a correr em volta do quarto de pequeno perímetro cantando: Dancemos a Carmanhola, Viva o som, viva o som... Dancemos a Carmanhola, viva o som do canhão...

- Tem charme essa pequena, murmurou o duque de Auge, mas sua cantilena não me diz nada que preste.

E ele pergunta:

- Quem lhe ensinou essa 
[108] chanson, ma mignonne ?

- C'est papa.

- Et qu'est-ce qu'il fait ton papa?

- Il est bûcheron, pardine.

- Et à qui appartient-il ?

- Au haut et puissant seigneur Joachim duc d'Auge.

- Autrement dit à moimême. C'est bien: je le ferai pendre.

- Et pourquoi ça vous feriez pendre mon papa, monsieur le duc?

- Il t'apprend des vilaines choses.

- Quoi ! vous n'aimez pas le son du canon? Moi je chantais ça pour vous faire plaisir.

- C'est la carmagnole qui ne me plaît guère.

- Vous êtes pas gentil. Je vous accueille chez nous et puis vous voulez pendre mon papa. Et les lois de l'hospitalité, alors ?

- Je suis chez moi, ma petite. Tout m'appartient ici: la forêt, le bois, le bûcheron, la chaumière, la fille.

- N'allez pas si vite, monsieur le duc. Si vous voulez pendre mon papa, je renverse la tambouille dans le feu !

- Par le sang Dieu, tu ne vas pas faire une chose pareille !

- Alors promettez-moi que vous ne ferez pas de mal à mon papa.

- Promis ! promis !

- Je n'ai pas confiance. Vous avez une sale réputation. Vous allez avaler mes glands, mes châtaignes et mon sachet de poivre, et puis ensuite vous n'en ferez qu'à votre idée.

- Mais non, mais non. C'est promis, n'en parlons plus et [109] apporte-moi cette bonne poivrade : tu me fais languir! canção, minha pequena?

- O papai.

- E o que faz seu papai?

- Ele é lenhador, oras.

- E a quem ele pertence?

- Ao alto e poderoso senhor Joaquim duque de Auge.

- Em outras palavras a mim mesmo. Pois bem: vou mandar enforcá-lo.

- E por que mandaríeis enforcar meu papai, senhor duque?

- Ele te ensina coisas feias.

- O que! não gostais do som do canhão? Cantei isso só pra agradar-vos.

- É a carmanhola que não me agrada.

- Vós não sois gentil. Eu vos recebo na nossa casa e depois vós quereis enforcar meu papai. E as leis da hospitalidade, como ficam?

- Estou em casa, minha pequena. Tudo aqui me pertence: a floresta, a madeira, o lenhador, a choupana, a garota.

- Não tão depressa, senhor duque. Se quiserdes enforcar meu papai, eu jogo o rango no fogo!

- Pelo amor de Deus, você não vai fazer uma coisa dessas!

- Então prometei-me que não fareis mal a meu papai.

- Prometido! prometido!

- Não confio em vós. Tendes uma péssima reputação. Engolireis minhas bolotas, minhas castanhas e meu sachê de pimenta, e depois só fareis o que quiserdes.

- Não, não. Está prometido, não falemos mais disso e traga-me essa boa pimentada: você me faz perder as forças e a paciência! 
- Vous promettez parce que vous avez faim. Mais après...

- Que veux-tu que je fasse d'autre que promettre?

- Il y a bien la promesse par écrit, mais de votre part, elle ne vaudrait guère mieux.

- Une promesse par écrit! Ah! ah! ah! Tu aurais donc ici un gallimard et du parchemin? C'est trop drôle, vraiment!

- Vous vous moquez cruellement de notre analphabétisme, monsieur le duc.

- Mais non de la qualité de ta cuisine. Allons, allons, apportemoi vite cette odoriférante poivrade. Apporte, apporte. Petit, petit, petit.

Le duc s'était levé sournoisement, prêt à bondir sur le poêlon, au risque de se brûler les doigts, mais la fillette surveille attentivement son suzerain. Quand il finit par s'élancer, vlan, voilà les châtaignes, les grands et les grains de poivre précipités dans le feu. Ils s'y transforment en braise.

- Encore un de foutu, murmure le duc qui n'a même pas le courage de rosser la bûcheronnette.

Il se ressoit sur son escabeau, et, le dos rond, il se lamente :

- J'ai faim, oh là là, j'ai faim, oh là là, ce que je peux avoir faim.

Il gronde la fillette :

- C'est idiot, ce que tu as fait là. D'abord, il est toujours lamentable de gâcher de la nourriture, et ensuite je ne suis plus lié par aucune promesse, et enfin les lois de l'hospitalité, ça tu peux

[110] en parler : quelle hospitalité !

Il regarde autour de lui :

- Il n'y a vraiment rien d'autre à bouffer ici ?
- Vós prometeis porque estais com fome. Mas depois...

- O que você quer que eu faça além de prometer?

- Poderia ser uma promessa por escrito, mas de vossa parte, também não valeria nada.

- Uma promessa por escrito! Ah! ah! ah! Será que você teria penas e pergaminho? É muito engraçado, de verdade!

$$
\text { Estais caçoando }
$$

cruelmente de nosso analfabetismo, senhor duque.

- Mas não da qualidade de tua cozinha. Vamos, vamos, tragame logo essa odorífera pimentada. Traga, traga. Logo, logo, logo.

O duque tinha se levantado traiçoeiramente, pronto a saltar sobre o fogão, arriscando-se a queimar os dedos, mas a garota vigia atentamente seu suserano. Quando ele acaba por se lançar, vlan, eis que as castanhas, as bolotas e os grãos de pimenta se precipitam no fogo. Eles se transformam em brasa.

- Mais uma que vai pro brejo, murmura o duque que não tem mais força nem para bater na lenhadorinha.

Torna a sentar-se no tamborete, e, costas curvadas, lamenta-se:

- Estou com fome, ai ai ai, estou com fome, ai ai ai, como estou com fome.

Ele ralha com a garota:

- É idiota, o que você fez. Primeiro, é sempre lamentável estragar comida, e depois não estou mais ligado por nenhuma promessa, e finalmente as leis da hospitalidade, você ainda fala delas: que hospitalidade!

Ele olha em volta:

- Não tem mesmo mais nada de comer aqui? 
Son oil se fixe :

- Évidemment, il y a cette jeune personne. Mon ami et compagnon d'armes Gilles de Rais n'aurait pas hésité un seul instant, mais j'ai déjà assez d'histoires sur les bras. Dans le pays, on pourrait prendre mal la chose. Mes futurs gendres n'apprécieraient peut-être pas. Et puis... sans poivre...

Il s'effondre en une méditation morose qui tourne à la somnolence. Il ne sent plus la terre ferme sous ses pieds, il a l'impression e vaciller, la chaumière commence à voguer incertaine, il va pouvoir s'étendre sur la chaise longue sur le pont, mais une fillette le réveilla :

- Monsieur le duc, monsieur le duc!

- Quoi quoi quoi!

- Si on jouait à un jeu en attendant l'aube et le retour de papa?

- Quel jeu?

- Un jeu.

- Quel enjeu?

- La vie de papa.

- Quelle bonne idée, s'écria le duc ragaillardi. l'aube.
Seu olho se fixa:

- Evidentemente, tem essa jovem pessoa. Meu amigo e companheiro de armas Gilles de Rais não teria hesitado um só instante, mas eu já tenho problemas suficientes nas costas. Por aqui, poderiam levar a coisa a mal. Meus futuros genros talvez não apreciassem. E depois... sem pimenta...

Ele mergulha numa meditação morosa que leva à sonolência. Ele não sente mais a terra firme sob seus pés, ele tem a impressão de vacilar, a choupana começa a vagar incerta, ele vai poder se estender na sua espreguiçadeira no convés, mas uma garota o despertou:

- Senhor duque, senhor duque!

- O que foi, o que foi!

- E se a gente jogasse um jogo enquanto esperamos $\mathrm{o}$ amanhecer e a volta do papai?

- Que jogo?

- Um jogo.

- Qual aposta?

- A vida de papai.

- Que boa idéia exclamou o duque revigorado.

E eles brincaram até o amanhecer. 
Depuis qu'il avait passé dix-huit mois en prison, Cidrolin

[111] n'était jamais retourné dans un de ces restaurants gastronomiques qu'il fréquentait autrefois. Il craignait d'être reconnu. Parfois il achetait la Semaine du Bedon, une publication qui donnait une liste des meilleurs endroits, il y en avait que Cidrolin ne connaissait pas, il essaierait bien celui-ci ou celui-là, mais il ne se décidait jamais.

L'intérim entre Lamélie, devenue madame Cuveton, et la protégée d'Albert encore à venir, et même à trouver, n'étant assuré que par lui-même et les résultats s'avérant, comme prévu, monotones et médiocres, il estima judicieux d'en profiter pour expérimenter un de-luxe particulièrement recommandé et de lui jusqu'à ce jour inconnu afin de faire pour une fois un repas réussi.

À peine eut-il pénétré dans l'antre qu'il s'entendit interroger sur ses intentions, pourtant bien faciles à deviner. Ayant objectivement et modestement répondu qu'il venait ici pour déjeuner, il lui fut demandé s'il avait une table retenue. Comme il n'avait rien de la sorte, il lui fut notifié que tout était complet. Il ne lui restait plus qu'à se retirer; ce qu'il fit en examinant au passage

[112] des hors-d'œuvre et les desserts mis en montre et qui avaient l'air très engageant.

- Encore un de foutu, murmura-t-il en se retrouvant sur le trottoir.

Il se demandait s'il allait tenter une nouvelle expérience ailleurs lorsqu'il aperçut ses filles et ses gendres descendant de deux houatures. Le groupe était complet
Desde que tinha passado dezoito meses na prisão, Cidrolin não tinha mais voltado a um desses restaurantes gastronômicos que frequentava outrora. Ele temia ser reconhecido. Às vezes comprava a Semana do Glutão, uma publicação que dava uma lista dos melhores lugares, havia alguns que Cidrolin não conhecia, bem que ele experimentaria este ou aquele, mas nunca se decidia.

No ínterim entre Aamélia, transformada em senhora Cuveton, e a protegida de Alberto ainda por vir, e até mesmo por encontrar, mantendo-se por si mesmo e os resultados revelando-se, como previsto, monótonos e medíocres, ele julgou pertinente aproveitar para experimentar um de-luxo particularmente recomendado e por ele até então desconhecido a fim de fazer pelo menos uma vez uma refeição bem sucedida.

Nem bem penetrou no antro e viu-se interrogado sobre suas intenções, entretanto bem fáceis de adivinhar. Tendo objetiva e modestamente respondido que tinha vindo para almoçar, perguntaram-lhe se tinha uma mesa reservada. Como ele não tinha nada do gênero, informaram-lhe que estavam todas ocupadas. Não lhe restava senão retirar-se; o que ele fez examinando de passagem as entradas e as sobremesas que estavam expostas e que tinham uma aparência muito atraente.

- Mais uma que vai pro brejo, murmurou ele já na calçada.

Ele se perguntava se iria tentar uma nova experiência em outro lugar quando percebeu as filhas e os genros descendo de dois zotomóvis. $\mathrm{O}$ grupo estava 
puisqu'il y avait même là l'ératépiste, le nommé Cuveton. Tandis que Yoland et Lucet allaient ranger les véhicules on ne sait où, le reste pénétra dans le de-luxe d'un pas assuré.

- Ils se mettent bien, dit Cidrolin à mi-voix. Ils font la noce sans moi.

passant.

- Pardon? demanda le

Cidrolin le regarda: c'en était un autre. Ou le même qu'il ne reconnaissait pas.

- Rien, répondit-il. Je me parlais à moi-même. Une habitude qu'on prend lorsqu'on vit seul longtemps.

- Vous devriez essayer de la perdre, dit le passant. On croit que vous voulez un renseignement, on s'apprête avec plaisir à vous le donner; comme il n'en est rien, ensuite on est déçu.

- Je vous prie de m'excuser. Vous me voyez désolé.

- Et qu'est-ce que vous disiez ?

- Qu'est-ce que je disais ? Oui, au fait, qu'est-ce que je disais?

Il fit mine de le rechercher et fronça les sourcils d'un air grave, comme on doit le faire en pareille circonstance. Puis il reprit la parole en ces termes : sans moi.

- J'ai dit : ils font la noce

- Et qu'entendiez-vous par là ?

- Je reconnais que l'expression est ambiguë et le fait

[113] est que je l'utilisais dans les deux sens : petit a, se taper la cloche, et petit $b$, célébrer un mariage ; mais je ne vais pas vous assommer avec toutes mes histoires.

- Pourquoi pas? demanda l'autre d'un air engageant. completo já que estava até o erriatepista, o que se chama Cuveton. Enquanto Iolando e Lizeto iam guardar os veículos sabe-se lá onde, o resto penetrou no de-luxo com passo seguro.

- Se tratam bem esses aí, disse Cidrolin a meia voz. Fazem a festa sem mim.

passante.

- Como? perguntou o

Cidrolin olhou para ele: era um outro. Ou o mesmo que ele não estava reconhecendo.

- Nada, respondeu ele. Eu estava falando comigo mesmo. Um hábito que a gente pega quando vive muito tempo sozinho.

- Você deveria tentar perdêlo, disse o passante. A gente pensa que você quer uma informação, se prepara para dá-la com prazer; como não é nada, a gente fica decepcionado.

- Peço que me desculpe. Realmente sinto muito.

- E o que você estava dizendo?

- O que eu estava dizendo? É, de fato, o que é que eu estava dizendo?

Ele fez cara de tentar lembrar e franziu a testa com um ar grave, como deve-se fazer em tal circunstância. Depois retomou a palavra nestes termos:

- Eu disse: fazem a festa sem mim. com isso?

- E o que você queria dizer expressão é ambígua e o fato é que eu a utilizava nos dois sentidos: a minúsculo, encher o bucho, e b minúsculo, festejar, no caso, um casamento; mas não vou importuná-lo com as minhas histórias.

- Por que não? perguntou o outro com ar interessado. 
- Parce que je ne vais pas le faire, répondit Cidrolin.

- Dans ce cas, dit l'autre sans se vexer, je ne voudrais pas abuser de vos instants...

- Je vous en prie...

Délivré, Cidrolin fut aperçu par les deux gendres qui avaient fini de garer leurs houatures et qui ne purent faire mine de rien. Ils le saluèrent avec une bonhomie protectrice.

- Alors ? dit Yoland, c'est comme ça qu'on laisse la péniche à l'abandon?

- C'est vrai qu'il fait beau, dit Lucet, alors on se promène.

- Et vous deux, dit Cidrolin, on se promène? On passait.

- Bin oui, on se promène. ces jours !

- Et bien, passez. À un de

Cidrolin demeure immobile. Les deux autres avancèrent de quelques pas. Ils se retournent et saluent encore une fois d'un petit signe de main.

Cidrolin leur répond, mais il n'a pas bougé.

- Qu'est-ce qu'on fait? demande Lucet. On rentre ou on rentre pas?

- S'il a vu les autres entrer, dit Yoland, on a bonne mine.

- On va tout de même pas louper un gueuleton pareil.

- Il est toujours là ?

- Il bouge pas.

- Il a sûrement vu les autres

[114] entrer. Il se fout de nous en ce moment.

- On a l'air de cons. Faut faire quelque chose.

- Invitons-le.

- Il va prendre ça mal.

\section{Cidrolin.}

- Porque não, respondeu

- Nesse caso, disse o outro sem se vexar, não vou mais abusar do seu tempo...

- Fique à vontade...

Liberado, Cidrolin foi notado pelos dois genros que tinham acabado de estacionar seus zotomóvis e que não puderam fingir não notá-lo. Eles cumprimentaram-no com uma simpatia efusiva.

- E aí? disse Iolando, como é que se deixa a chata assim abandonada?

- É verdade que o dia está muito bonito, disse Lizeto, então a gente passeia.

- E vocês dois, diz Cidrolin, também estão passeando?

- É isso, a gente está passeando. Estávamos passando.

- Então, passem. Até qualquer dia!

Cidrolin permanece imóvel. Os outros dois avançaram alguns passos. Voltam-se e cumprimentam mais uma vez com um leve aceno de mão.

Cidrolin responde-lhes, mas não se mexe.

- O que a gente faz? pergunta Lizeto. Entramos ou não entramos?

- Se ele viu os outros entrarem, diz Iolando, estamos bem arranjados.

- De qualquer jeito não vamos perder um banquete desses.

- Ele ainda está lá?

- Nem se mexe.

- Com certeza viu os outros entrarem. Está caçoando da gente agora.

- Estamos parecendo babacas. Temo que fazê alguma coisa.

- Vamos convidá-lo.

- Ele vai levar a mal. 

déjeune.

- Faut pourtant bien qu'on

- Tu parles! Surtout que ça doit pas être sale! Tu as vu ce deluxe au passage? C'est au moins un cinq étoiles. Qu'est-ce qu'on va se taper.

- Alors on fait demi-tour?

- Oui. C'est toi qui expliqueras le truc.

- Toujours les corvées, quoi.

Cidrolin les regarde revenir vers lui d'un air anodin. C'est donc Yoland qui lui cause.

- Une chance qu'on vous ait rencontré. Il n'y avait pas eu de petite fête pour le mariage de Lamélie, alors on a pensé qu'on pourrait s'offrir un bon déjeuner à cette occasion. Comme on vous voit dans les environs, ça serait que trop juste que vous soyez de la partie.

- Et qui est-ce qui paie?

- Chacun pour soi.

- Dites donc, vous êtes prospères. Vous n'avez pas choisi la taverne miteuse, hein. Et l'ératépiste, il peut s'offrir ça ?

- On l'a prévenu. Bah! c'est pas tous les jours qu'on se marie.

- Mais ce n'est pas aujourd'hui qu'il s'est marié, voilà bien huit jours, non?

- Il n'est jamais trop tard pour bien faire.

-Une drôle d'idée tout de même. Une curieuse idée.

- Alors vous venez? dit Lucet avec impatience. On nous [115] attend.

- Pas moi, dit Cidrolin. Moi on ne m'attend pas.

- Allons, allons, ne boudez pas!

- D'ailleurs, dit Cidrolin, je n'ai pas retenu de table. almoçá.

- Mas a gente tem que

- É claro! Principalmente que não deve ser nada mau! Você viu o de-luxo quando passamos? É um cinco estrelas, no mínimo. A gente vai se regalar.

então?

- Fazemos meia-volta

- Sim. Mas é você que vai explicar.

- Os pepinos sempre sobram pra mim, bolas.

Cidrolin fica olhando eles voltarem em sua direção com um ar anódino. E então é Iolando que lhe fala.

- É uma sorte tê-lo encontrado. Não houve festa no casamento de Aamélia, então a gente pensou que poderia ter um bom almoço pela ocasião. Já que o senhor está nas redondezas, seria muito justo que participasse.

- E quem é que paga?

- Cada um por si.

- Muito bem, vocês estão prósperos. Vocês não escolheram nenhuma espelunca, hein. E o erriatepista, pode se dar o luxo?

- Ele foi avisado. Bom! num é todo dia que a gente se casa.

- Mas não foi hoje que ele se casou, já faz bem uns oito dias, não?

- Nunca é tarde demais pra fazer bem feito.

- Uma idéia engraçada mesmo assim. Uma curiosa idéia. - E então, o senhor vem? diz Lizeto com impaciência. Estão nos esperando.

- Não a mim, diz Cidrolin. A mim ninguém está esperando.

- Vamos, vamos, não fique amuado.

- E além disso, disse Cidrolin, eu não reservei mesa. 
- Nous on a retenu.

- Non, dit Cidrolin j'y suis allé tout à l'heure, il n'y avait pas de place pour moi.

- Vous vouliez déjeuner là ?

- Pourquoi pas? dit Cidrolin.

Les deux gendres se turent.

- J'avais l'intention de faire un bon repas, dit Cidrolin. Ce sera pour une autre fois.

Il prend l'autobus et, au coin du quai, il achète du pain; mais les autres commerçants du quartier sont fermés. Il y a encore quelques conserves sur la péniche. La clôture a encore été souillée par des graffiti infamants.

Cidrolin pose le pain et va chercher le pot de peinture. Il s'applique à bien recouvrir les inscriptions. Il a faim, mais il s'applique. Des nomades désœuvrés s'arrêtent pour le regarder faire. Ils le regardent en silence. Cidrolin, lui, ça ne le gêne pas. Il a l'habitude aussi bien de repeindre que des nomades. Il n'engage pas la conversation avec eux. Contrairement à un usage fort répandu, il ne chante pas non plus, ni ne sifflote. Quand il a fini, les nomades s'en vont.

Il remet le pot de peinture à sa place et se verse ensuite un verre d'essence de fenouil.

- Je bois trop, murmure-t-il, Lamélie n'est plus là pour me le dire.

Ensuite il va voir dans la cambuse ce qui reste comme [116] conserves. Il y en a encore pour une quinzaine de jours, en n'exagérant pas. Cidrolin ne sait pas si, d'ici quinze jours, Albert lui aura trouvé quelqu'un. Si Albert n'a rien trouvé, Cidrolin devra renouveler son stock; il voit poindre le scorbut à l'horizon. Pour
- Nós reservamos.

- Não, disse Cidrolin, estive lá agora mesmo, não havia lugar para mim.

- O senhor ia almoçar lá?

- Por que não? disse Cidrolin.

Os dois genros ficaram calados.

- Eu tinha intenção de fazer uma boa refeição, disse Cidrolin. Fica para outra vez.

Ele toma o ônibus e, na esquina do cais, compra pão; mas os outros comerciantes do bairro estão fechados. Ainda tem umas conservas na chata. A cerca ainda estava suja com graffiti difamantes.

Cidrolin guarda o pão e vai buscar a lata de tinta. Ele se aplica em cobrir bem as inscrições. Está com fome, mas se aplica. Uns nômades desocupados param para olhá-lo trabalhar. Olham em silêncio. A Cidrolin, isso não incomoda. Está acostumado tanto a pintar quanto aos nômades. Não entabula conversação com eles. Contrariamente ao uso mui corrente, ele não canta, nem assobia. Quando terminou, os nômades foram embora.

Ele guarda a lata de tinta no lugar e em seguida serve-se de um copo de essência de funcho.

- Estou bebendo demais, murmura ele, Aamélia não está mais aqui pra me dizer isso.

Em seguida vai ver na despensa o que resta de conservas. Ainda tem para uma quinzena, não exagerando. Cidrolin não sabe se, daqui a quinze dias, Alberto já terá encontrado alguém. Se Alberto não tiver encontrado ninguém, Cidrolin terá que renovar seu estoque, ele vê despontar o escorbuto no horizonte. Para o momento, escolhe uma lata 
le moment, il se choisit une boîte de filets de thon à l'huile d'arachide purifiée. Il y a un système intelligent pour ouvrir ladite boîte, Cidrolin n'a pas besoin de recourir au marteau et au ciseau à froid comme il a coutume de le faire. Il fend ensuite le pain en deux et déverse le contenu entre les deux tranches qu'il ferme soigneusement afin de reconstituer l'aspect primitif de la baguette, à cette différence qu'il coule de l'huile par les incisions. Lorsque le tout est consommé, Cidrolin murmure :

- Ça n'était pas si mauvais. Seulement, si on abuse, il y a le scorbut.

Il s'essuie les mains et la bouche à un torchon polyvalent et remonte voir ce que devient sa clôture. Aucune inscription n'y a été réinscrite, mais un con, en s'appuyant dessus, vient de se foutre plein de peinture sur son veston. Il interpelle Cidrolin :

- Eh vous ! là! c'est à vous cette péniche ? c'est à vous cette barrière? vous pourriez au moins mettre un écriteau peinture fraîche. C'est la moindre des choses. Maintenant mon veston, il est bon pour le teinturier. C'est vous qui allez me payer la note ?

- Bien entendu, répondit Cidrolin. Ça fait combien ?

- Et vous vous croyez drôle, par-dessus le marché ! C'est un [117] monde !

- Remarquez, dit Cidrolin, que vous avez détérioré la couche de peinture que je venais d'appliquer. Il va falloir que je recommence mon travail et j'ai autre chose à faire.

- Quoi?

- La sieste.

Le futur client d'une des nombreuses teitureries existantes de filé de atum ao óleo de amendoim purificado. Há um sistema inteligente para abrir a dita lata, Cidrolin não precisa recorrer ao martelo e à talhadeira como costuma fazer. Em seguida corta o pão em dois pedaços que fecha cuidadosamente a fim de reconstituir o aspecto primitivo da baguete, com a diferença de que escorre óleo pelas incisões. Quando tudo está consumado, Cidrolin murmura:

- Não estava mal. Só que se a gente abusar, vem o escorbuto.

Enxuga as mãos e a boca num pano de prato polivalente e sobe para ver como está a cerca. Nenhuma inscrição foi reinscrita, mas um babaca, apoiando-se nela, acaba de encher o casaco de tinta. Ele interpela Cidrolin:

- Ei, o senhor aí! é sua essa chata? é sua essa cerca? o senhor poderia pelo menos pôr um cartaz tinta fresca. É o mínimo. Agora meu casaco tem que ir para o tintureiro. É o senhor que vai pagar a conta?

- Combinado, respondeu Cidrolin. E quanto é?

- O senhor se acha engraçado, ainda por cima! Cada uma!

- Veja, disse Cidrolin, que o senhor deteriorou a camada de tinta que eu tinha acabado de aplicar. Vou ter que recomeçar meu trabalho e tenho mais o que fazer.

- O que?

- A sesta.

O futuro cliente de uma das numerosas tinturarias existentes 
regarde pensivement Cidrolin, puis il s'éloigne.

Cidrolin va chercher son pot de peinture et répare les dégâts ; puis il confectionne un petit écriteau peinture fraîche qu'il place consciencieusement d'une façon bien visible.

Il s'installe ensuite sur sa chaise longue. Il murmure :

- J'ai oublié de dire à Albert que je ne voulais pas d'une mineure.

Il ferme les yeux.

- Je me demande quelle tête elle aura, murmure-t-il encore.

- Nous verrons cela tout à l'heure, dit le sire de Ciry à ses deux beaux-frères, le comte de Torves et le vidame de Malplaquet.

- Qu'importe! dit le comte de Torves. Qu'il se remarie, soit ; mais voyons les dédommagements qu'il nous propose.

- S'il nous en propose, dit le sire de Ciry.

- Il faudrait beau voir, dit Malplaquet en lissant ses moustaches.

Mouscaillot les conduit dans la salle à manger pour qu'ils se restaurent un brin. Le sire de Ciry examine le mobilier d'un air appréciateur.

- Eh, eh, murmure-t-il, du pur style Louis le treizième.

[118] - Monsieur le duc tient à être tout à fait à la page, dit le page qui, maintenant, a le droit de porter son titre de vicomte d'Empoigne.

On apporta des pâtés de sanglier et autre matinales friandises et l'on versa de l'essence de fenouil dans des verres en cristal de Venise.

- L'argent coule à flots, murmure le sire de Ciry qui ajoute à l'intention du vidame qui utilise ses douas: Servez-vous donc de olha Cidrolin pensativamente, depois se afasta.

Cidrolin vai buscar sua lata de tinta e repara os estragos; depois confecciona um pequeno cartaz tinta fresca que coloca conscienciosamente de maneira bem visível.

Em seguida instala-se na sua espreguiçadeira. Ele murmura:

- Esqueci de dizer a Alberto que eu não quero nenhuma menor.

Ele fecha os olhos.

- Eu me pergunto que cara ela terá, murmura ainda.

- Isso nós veremos daqui a pouco, diz o sir de Ciry a seus dois concunhados, o conde de Torves e o vidama de Malplaquet.

- O que importa! diz o conde de Torves. Que se case, vá lá; mas vamos ver o que ele vai nos propor como ressarcimento.

- Se é que vai propor alguma coisa, diz o sir de Ciry. - Vamos ver, diz Malplaquet alisando o bigode.

Mouscaillot os conduz à sala de jantar para que se restaurem um pouco. O sir de Ciry examina o mobiliário com um ar apreciador.

- Eh, eh, murmura ele, puro estilo Luís treze.

- O senhor duque faz questão de atualizar a roupagem, diz o pajem que, agora, tem o direito de usar seu título de visconde d'Empoigne.

Trouxeram patês de javali e outras guloseimas matinais e derramaram essência de funcho nos copos de cristal de Veneza.

- O dinheiro corre como água, murmura o sir de Ciry que acrescenta dirigindo-se ao vidama que usa os dedo: sirva-se pois deste 
cette fourchette.

Car il y en avait des fourchettes, et en argent encore.

- Je ne m'y ferai jamais, dit Malplaquet. Et tout d'abord je ne trouve pas cela propre, ces outils. On ne sait pas où ils ont traîné avant, tandis que ses douas, on sait toujours où on les a mis.

- Il faut bien marcher avec son temps, dit Torves en manipulant maladroitement un de ces objets.

- Messieurs, dit Ciry, si vous alliez à la cour...

- Mais nous n'y allons pas, dit Malplaquet.

- Qui sait, dit Ciry.

En attendant le duc, ils continuent à croquer du pâté de sanglier et autres matinales friandises, en vuidant maints vidrecomes de vin clairet.

- Dites-moi, Empoigne, dit soudain Malplaquet d'une voix aiguë, Auge a-t-il pensé à nous ?

- Je ne sais, dit Empoigne avec prudence, mais je crois que les nouvelles sont bonnes. Torves.

- Je bous d'impatience, dit

- J'entends un pas, dit Ciry.

Il l'a entendu malgré les bruits de mastication et de digestion commençantes ou finissantes. Effectivement le duc apparaît, suivi de l'abbé Biroton,

[119] du maître d'hôtel et de quelques valets.

- Vertuchou, s'écrit le duc. Comment trouvez-vous ma barbe ? J'ai fait venir un barbier de la ville pour me l'accommoder.

Les gendres s'exclament : elle est sublime.

Le duc montre du doigt Onésiphore.

- Regardez-le bien, dit-il. garfo.

Pois havia garfos, e de prata ainda por cima.

- Eu não o farei jamais, diz Malplaquet. Antes de mais nada não acho limpos, esses utensílios. A gente nunca sabe onde andaram, enquanto que os dedo, a gente sempre sabe onde pôs.

- É preciso agir de acordo com o seu tempo, diz Torves manipulando desajeitadamente um daqueles objetos.

- Senhores, diz Ciry, se vocês fossem à corte...

- Mas nós não vamos, diz Malplaquet.

- Quem sabe, diz Ciry.

Esperando o duque, eles continuam a comer patê de javali e outras guloseimas matinais, esvaciando vários cântaros de vinho clarete.

- Diga-me, Empoigne, diz de repente Malplaquet com uma voz aguda, será que Auge pensou em nós?

- Não sei, diz Empoigne com prudência, mas acho que as notícias são boas.

- Estou me ardendo de impaciência, diz Torves.

Ciry.

- Estou ouvindo passos, diz

Ele os ouviu apesar dos ruídos de mastigação e de digestão iniciais ou terminais. Efetivamente o duque aparece, seguido do abade Biroton, do maître d'hôtel e de alguns criados.

- Por Deus, exclama o duque. $\mathrm{O}$ que vocês acham da minha barba? Eu chamei um barbeiro da cidade para apará-la.

Os genros exclamam: ela está sublime.

O duque aponta Onesíforo com o dedo.

- Olhem bem para ele. 
C'est un évèque !

Les gendres s'exclament et veulent baiser son anneau; mais l'évêque in partibus de Sarcellopolis n'en est pas encore pourvu.

Et regardez-moi maintenant, ajoute le duc. Vous avez devant vous un homme qui a reçu de Sa Majesté trois cent mille livres pour se marier.

Les gendres s'exclament, ils crient: vive la Reine! vive le maréchal d'Ancre! Le duc rit de plaisir. Il se frotte les mains. Il attrape un pâté au passage et, sans utiliser de fourchette, le dévore.

- Et nous? demande alors le comte de Torves.

- Oui et nous? ajoute le vidame de Malplaquet.

Ciry.

- Et moi ? dit le sire de

Le duc continue à rire en dévorant son pâté. C'est dangereux ça de rire en mangeant; aussi manque-t-il de s'étouffer. On lui verse vidrecomes sur vidrecomes.

- Est-ce qu'il va se décider? dit à voix basse Ciry à Malplaquet.

- Et s'il n'avait rien obtenu pour nous, murmure Malplaquet qui grimoisse d'angace.

- Je bous, je bous, je bous, soupire Torves.

La faim et la soif du duc sont maintenant colmatées et ses spasmes calmés grâce à l'essence de fenouil. Il est devenu grave et certainement qu'il va se mettre à parler et à énoncer les bonnes nouvelles annoncées par le vicomte

[120] d'Empoigne, lorsqu'il devient manifeste, au grand désespoir des gendres, qu'une nouvelle idée lui passe par la tête.

il.

- Et mes filles? demande-t-
Agora é bispo!

Os genros exclamam e querem beijar seu anel; mas o bispo in partibus de Sarcelópolis ainda não está provido de um.

- E olhem para mim agora, acrescenta $o$ duque. Vocês têm diante de vocês um homem que recebeu de Sua Majestade trezentas mil libras para se casar.

Os genros exclamam, eles gritam: viva a Rainha! viva o marechal d'Ancre! O duque ri de prazer. Ele esfrega as mãos. De passagem pega um patê e, sem utilizar o garfo, devora-o.

- E nós? pergunta então o conde de Torves.

- É e nós? acrescenta o vidama de Malplaquet.

- E eu? diz o sir de Ciry.

$\mathrm{O}$ duque continua a rir devorando seu paté. É perigoso isso de rir comendo; então por pouco ele não sufoca. Oferecem-lhe cântaros e mais cântaros.

- Será que ele vai se decidir? diz Ciry em voz baixa a Malplaquet.

- E se ele não tiver obtido nada para nós, murmura Malplaquet que estrebústia de angucha.

- Estou me ardendo, ardendo, ardendo, suspira Torves.

A fome e a sede do duque estão agora mitigadas e seus espasmos acalmados graças à essência de funcho. Ele ficou grave e certamente vai se pôr a falar e a enunciar as boas novas anunciadas pelo visconde d'Empoigne, quando torna manifesto, para grande desespero dos genros que uma nova ideia passa-lhe pela cabeça.

- E minhas filhas? pergunta ele. 
$\begin{array}{clr}\begin{array}{c}\text { Elles } \\ \text { l'appartement }\end{array} & \begin{array}{l}\text { sont } \\ \text { des }\end{array} & \begin{array}{r}\text { dans } \\ \text { dames, }\end{array}\end{array}$ naturellement.

- Qu'elles viennent! ordonne-t-il, je ne ferai pas mon discours deux fois.

Les gendres piétinent d'impatience, ils en pisseraient bien de rage, mais ils doivent se résigner. Le duc fait apporter d'autres gâteries, des beignets de marcassin, des soufflés au foie de morue, des pieds de porc pannés. Il demande qu'on verse de l'hypocras et de l'hydromel, pour ne pas trop abuser de l'essence de fenouil.

Il s'informe bien poliment auprès de ses gendres de ce que furent leurs voyages respectifs ; ils répondent en grinçant des dents. Comme ce sujet ne l'intéresse d'ailleurs pas, il se tourne vers Monseigneur Biroton et lui rappelle que c'est lui qui lui offrira son améthyste, quoique le bénéfice soit assez substantiel pour qu'Onésiphore se le paie. Enfin, il s'informe de l'emplacement de Sarcellopolis. Cette curiosité saugrenue montre de toute évidence aux gendres qu'il ne pense pas à eux et cela ne leur laisse rien prévoir de bon. Monseigneur Biroton qui ignore totalement où se trouve son évêché, et il n'a nul besoin de le savoir puisqu'il n'aura jamais à s'y rendre, Monseigneur Biroton commence par un pieux mensonge et répond que Sarcellopolis se trouve en Asie Mineure. alors ?

- Aux mains des Ottomans

- Vous l'avez dit.

Cela rend le duc songeur :

- Et si j'organisais une petite croisade pour te récupérer [121] ton évêché ?
Estão no aposento das damas, naturalmente.

- Que elas venham! ordena ele, não farei meu discurso duas vezes.

Os genros batem os pés de impaciência, bem que eles mijariam de tanta raiva, mas têm que se resignar. $\mathrm{O}$ duque manda trazer outros mimos, salgadinhos de filhotes de javali, suflês de fígado de bacalhau, pés de porco empanados. Ele pede que sirvam hipocraz e hidromel, para não abusar demais da essência de funcho.

Ele se informa bem polidamente com seus genros de como foram suas respectivas viagens: eles respondem rangendo os dentes. Como esse assunto não o interessa mesmo, ele volta-se para Monsenhor Biroton e lembra-lhe que é ele que vai oferecer-lhe sua ametista, ainda que o lucro fosse suficientemente substancial para que Onesíforo pagasse por ela. Finalmente, ele se informa sobre a localização de Sarcelópolis. Essa curiosidade bizarra mostra com toda a clareza aos genros que ele não pensa neles e isso não lhes permite prever nada de bom. Monsenhor Biroton que ignora totalmente onde se encontra sua diocese, e que não tem nenhuma necessidade de sabê-lo já que nunca precisará ir até lá, Monsenhor Biroton começa por uma piedosa mentira e responde que Sarcelópolis encontra-se na Ásia Menor.

- Nas mãos dos otomanos então?

- O senhor é quem diz. Isso faz o duque divagar:

- E se eu organizasse uma cruzadinha para recuperar sua diocese para você? 
Les gendres sont épouvantés: ils voient tout le pognon de papa disparaître dans le détroit des Dardanelles.

Onésiphore est là pour calmer le duc :

- Beau mouvement de piété, messire, beau mouvement, mais Dieu veut que mon évêché soit in partibus : que sa volonté soit faite.

- Tu ne veux vraiment pas? C'est une occasion qui a peu de chances de se renouveler.

- Grands mercis, messire. Grands mercis.

Les gendres ont eu chaud. Ils soupirent de soulagement. Le sire de Ciry en vient même à faire le bel esprit :

- Vous êtes un vrai donquichotte, dit-il au duc avec un fin sourire.

- Quoi ? quoi ? qu'est-ce que c'est que ça?

- Don Quichotte? Le meilleur livre étranger paru en l'année 1614. Je l'ai lu dans la traduction de César Oudin. pitié.

Le duc regarde Ciry avec il.

- Quel précieux, murmure-t-

Mais l'autre n'entend pas, car se rapprochent des piaillements de femmes. Elles se taisent en entrant dans la salle à manger et viennent s'incliner respectueusement devant leur papa. Tout le monde s'étant mis en place, le duc d'Auge énuméra tous les gouvernements, bénéfices et privilèges que, par le traité de Sainte-Menehould, il venait d'obtenir pour ses gendres et conséquemment pour ses filles.

- Bê, bê, dit Phélise en exprimant ainsi la satisfaction générale.

Les gendres virent donc sans amertume leur beau-père
Os genros ficam apavorados: eles vêem toda a grana do papai desaparecer no estreito de Dardanelos.

Onesíforo está lá para acalmar o duque:

- Belo impulso de piedade, senhor, belo impulso, mas Deus quer que minha diocese seja in partibus: seja feita Sua vontade.

- Você não quer mesmo? É uma ocasião que tem poucas chances de se repetir.

- Muito obrigado, senhor. Muito obrigado.

Os genros sentiram-se aquecidos. Eles suspiraram de alívio. O sir de Ciry chegou a mostrar-se espirituoso:

- O senhor é um verdadeiro donquixote, diz ele ao duque com um leve sorriso.

é isso?

- O que? o que? o que é que

- Don Quixote? O melhor livro estrangeiro surgido no ano de 1614. Eu o li na tradução de César Oudin.

O duque olha Ciry com pena. murmura ele.

- Que precioso ridículo,

Mas o outro não ouve, pois aproxima-se a algazarra de mulheres. Elas se calam ao entrar na sala de jantar e vêm se inclinar respeitosamente diante de seu papai. Todo mundo em seus lugares, o duque de Auge enumerou todas as disposições, benefícios e privilégios que, pelo tratado de Sainte Menehould, ele acabara de conseguir para seus genros e consequentemente para suas filhas.

- Bê, Bê, diz Feliza exprimindo assim a satisfação geral.

Então os genros viram sem amargura seu sogro desposar, em 
[122] Russule Péquet, une manante, la fille d'un bûcheron.

Cidrolin se réveille en sursaut ; il lui semblait qu'on avait sonné à la porte qui donnait sur le quai. Il se leva pour aller voir; il n'y avait personne. Il faisait nuit maintenant. Il regarda si l'on avait barbouillé de nouvelles inscriptions mais n'en vit point. Il redescendit s'habiller du plus correct qu'il put et sut, boucla tout sur la péniche et se dirigea vers le bistro qui faisait le coin du quai et de l'avenue.

Quelques couples s'attardaient encore à se biser ; des ératépistes mangeaient des sandwiches et buvaient des demis, en commentant les menus incidents du service. Cidrolin se commanda une essence de fenouil avec de l'eau plate, fit l'acquisition d'un jeton de téléphone et consulta l'annuaire. Après avoir attendu dixsept minutes qu'un couple qui faisait la ventouse dans la cabine veuille bien laisser la place libre, il se mit en rapport avec le de-luxe qui l'avait refoulé ce midi même.

- Je voudrais retenir une table. Pour ce soir.

personnes ?

$$
\text { - Pour combien de }
$$

- Une. Une seule.

Il sentit le récepteur se refroidir dans sa main, à l'autre bout du fil on ne devait pas être content. Ce n'était pas ça ce qu'il aurait fallu dire.

- Mais je mange comme quatre, ajouta Cidrolin.

Le récepteur reprit sa tiédeur. On lui demanda son nom.

Dicornil. Monsieur

Dicornil. D comme duc, I comme Joachim, C comme Capétien, O comme Onésiphore, $\mathrm{R}$ comme Riphinte, $\mathrm{N}$ comme $\mathrm{N}$ et le reste à [123] l'avenant. segundas núpcias, Russula Péquet, uma campônia, filha de um lenhador.

Cidrolin desperta sobressaltado, parecia-lhe que tinham batido na porta que dava para o cais. Levantou-se para ir ver, não havia ninguém. Estava escuro agora. Olhou se tinham rabiscado novas inscrições mas não viu nenhuma. Ele desceu para se vestir do modo mais correto que pôde e soube, fechou tudo na chata $\mathrm{e}$ dirigiu-se ao bar da esquina do cais com a avenida.

Alguns casais ainda continuavam a se beijar; erriatepistas comiam sanduíches e bebiam chope, comentando os mínimos incidentes do serviço. Cidrolin pediu uma essência de funcho com água sem gás, adquiriu uma ficha de telefone e consultou a lista. Depois de ter esperado dezessete minutos que um casal que fazia ventosa na cabina decidisse deixar o lugar livre, ele ligou para o de-luxo que o havia recusado na hora do almoço.

- Eu gostaria de reservar uma mesa. Para esta noite.

- Para quantas pessoas?

- Uma. Só uma.

Ele sentiu o receptor esfriar em sua mão, do outro lado do fio não deviam estar contente. Ele não tinha dito a coisa certa.

- Mas eu como por quatro, acrescentou Cidrolin.

$\mathrm{O}$ receptor retomou seu calor. Perguntaram seu nome. - Dicornil. Senhor Dicornil. $\mathrm{D}$ de duque, I de Joachim, $\mathrm{C}$ de Capetos, O de Onesíforo, $\mathrm{R}$ de Rifinge, $\mathrm{N}$ de $\mathrm{N}$ e $\mathrm{o}$ resto combinando. 
- Dupont. C'est bien cela?

Pour monsieur Dupont?

- Vous m'avez compris.

Lorsqu'il pénétra dans le de-luxe, il s'aperçut aussitôt qu'il était bien inutile d'avoir téléphoné : le restaurant était vide. On y pratiquait le déjeuner d'affaires mais la clientèle dîneuse s'y montrait plutôt rare. Un maître d'hôtel demanda cependant avec hauteur si l'on avait retenu sa table. Cidrolin répondit que oui. À quel nom?

- Dupont. Monsieur Dupont.

- Si vous voulez venir par ici, monsieur Dicornil.

Cidrolin s'attendait à ce qu'on lui proposât une table dans un courant d'air ou près d'une desserte. Il n'en fut rien. C'était une belle et bonne table bien large déjà toute chargée de vaisselle et de couverts. Cidrolin en fut favorablement impressionné. En tendant la carte d'une superficie d'environ seize cents centimètres carrés, le maître d'hôtel lui demanda s'il désirait prendre un apéritif. Cidrolin opta pour l'essence de fenouil.

- Monsieur a une marque préférée?

- Le Cheval Blanc, répondit-il au sommelier.

Puis il regarda d'un air autoritaire le nom des différents plats. Le maître d'hôtel, du bout de son crayon, indiquait les spécialités, les plats du jour. Lorsque Cidrolin eut décidé de commencer par du caviar frais gros grain, la conversation devint des plus amicales. Elle devint franchement cordiale lorqu'il envisage d'affronter ensuite un coulibiac de saumon que suivrait un faisan rôti qu'accompagneraient
- Da Ponte. Está certo? Para senhor da Ponte?

perfeitamente.

Você entendeu

Quando penetrou no deluxo, ele logo percebeu que tinha telefonado à toa: o restaurante estava vazio. Ali praticava-se o almoço de negócios mas a clientela jantante mostrava-se bem rara. Mesmo assim, um maître d'hôtel perguntou com altivez se ele havia reservado sua mesa. Cidrolin respondeu que sim. Em nome de quem?

- Da Ponte. Senhor da Ponte.

- Por favor, queira acompanhar-me, senhor Dicornil.

Cidrolin esperava que fossem lhe propor uma mesa numa corrente de ar ou perto de uma saída. Não foi nada disso. Era uma bela e boa mesa bem larga já toda preparada com louças e talheres. Cidrolin ficou favoravelmente impressionado. Estendendo o cardápio de uma superfície de cerca de mil e seiscentos centímetros quadrados, o maître d'hôtel perguntou se ele desejava tomar um aperitivo. Cidrolin optou pela essência de funcho.

- O senhor tem uma marca preferida?

- Cavalo Branco, respondeu ao sommelier.

Depois olhou com um ar autoritário o nome dos diferentes pratos. O maître d'hôtel, com a ponta do lápis, indicava as especialidades, os pratos do dia. Quando Cidrolin decidiu-se a começar por caviar fresco de grãos grandes, a conversa tornou-se das mais amigáveis. Ela tornou-se francamente cordial quando ele pensou enfrentar em seguida um filé de salmão seguido de um faisão assado acompanhado de trufas do 
[124] réflexion, Cidrolin, qui était friand de vol-au-vent financière, estima qu'il pourrait en insérer un entre le coulibiac et le faisan. Après le fromage, il prendrait un soufflé aux douze liqueurs.

Le sommelier apportait l'essence de fenouil dans une bouteille sur laquelle était bien collée l'étiquette du Cheval Blanc ; il repartit avec la mission de ramener un carafon de vodka russe, une bouteille de chablis 1925 et une bouteille de château d'arcins 1955.

Le maître d'hôtel s'était effacé pour laisser opérer son confrère, mais, lorsque celui-ci fut retourné vers ses caves, il se pencha vers Cidrolin et, fort aimablement, lui demanda son permis.

- Mon permis? Quel permis?

- Votre permis de la Sécurité Sociale. - À quel sujet?

- Monsieur plaisante. Monsieur sait bien qu'il n'est pas possible de servir sans un permis de la Sécurité Sociale un repas de plus de trois mille calories, et le vôtre doit en faire six mille, au moins.

Cidrolin avait bien vu des chiffres sur la carte en face de chaque plat, mais il croyait que c'était les prix.

- Monsieur n'ignore pas que les indigestions et les entérites sont pour une grosse part dans le déficit de la Sécurité Sociale. Il a fallu prendre des mesures mais Monsieur ne cotise peut-être pas à la éssésse ? Pourtant, Monsieur doit bien être quelque chose comme président-administrateur géneral.

Il sourit, flatteur.

Cidrolin cotisait bien,
Périgord. Refletindo, Cidrolin, que era grande apreciador de vol-auvent à financière, achou que poderia inserir um entre o salmão e o faisão. Depois do queijo, ele comeria um suflê aos doze licores.

O sommelier trazia a essência de funcho numa garrafa sobre a qual estava bem colada a etiqueta do Cavalo Branco; ele partiu com a missão de trazer uma garrafa de vodka russa, uma garrafa de chablis 1925 e uma garrafa de château d'arcins 1955.

O maitre d'hôtel tinha-se afastado para deixar seu colega trabalhar, mas, quando este retornou para a adega, ele inclinouse para Cidrolin e, mui amavelmente, pediu sua licença.

licença?

- Minha licença? Que

- Sua licença da Seguridade Social.

- Para quê?

- O senhor está brincando. O senhor deve saber que não é possível servir sem uma licença da Seguridade Social uma refeição de mais de três mil calorias, e a sua deve chegar a seis mil, pelo menos.

Cidrolin tinha visto os algarismos no cardápio na frente de cada prato, mas ele pensava que eram os preços.

- O senhor não ignora que as indigestões e as enterites são responsáveis por uma grande parte do déficit da Seguridade Social. Foi preciso tomar medidas; mas o senhor não contribui para a essiesse? No entanto, o senhor deve ser alguma coisa como presidenteadministrador geral.

Ele sorriu, lisonjeiro.

Cidrolin contribuía sim, 
comme ancien détenu, mais il ne connaissait pas cette nouvelle loi. Il

[125] ne voyait pas le moyen de s'en sortir. Il murmura :

- Encore un de foutu.

- Mais non, Monsieur, mais non! s'écria le maître d'hôtel pitoyable. Il ne faut pas jeter le manche avant la cognée.

- Après, dit Cidrolin.

- Après ? Après?

Le maître d'hôtel avait l'air perplexe.

- Jeter le manche après la cognée, dit Cidrolin.

- Vous êtes sûr?

- Certain.

- Au fond, qu'est-ce que ça veut dire? d'où vient cette expression?

- C'est une expression du vieux temps, dit Cidrolin.

- Je ne la comprends pas. On dit ça comme ça, jeter le manche après la cognée, et puis, si l'on essaie de comprendre exactement, on ne comprend plus. Ah Monsieur, c'est terrible quand on se met à réfléchir.

- N'y pensez plus.

- C'est facile à dire! Je veux comprendre, moi. Pourquoi après ? Si on jette la cognée, on jette le manche avec. Pas après. Décidément, je ne comprends pas. - Je vais vous expliquer. Il y avait une fois un bûcheron...

Sur ce mot, Cidrolin se tut et sembla penser à autre chose. como antigo detento, mas não conhecia aquela nova lei. Ele não via meio de se sair dessa. Ele murmurou:

- Mais uma que vai pro brejo.

- De forma alguma, senhor, de forma alguma! exclamou o maître d'hôtel piedoso. Não se deve jogar o cabo antes do machado.

- Depois, disse Cidrolin.

- Depois? Depois?

O maître d'hôtel tinha o ar perplexo.

- Jogar o cabo depois do machado, disse Cidrolin.

- Tem certeza?

- Absoluta.

- No fundo, o que é que isso quer dizer? de onde vem essa expressão?

- É uma expressão francesa do tempo antigo, disse Cidrolin.

- Eu não a entendo. A gente fala assim, jogar o cabo depois do machado, e depois, se a gente tenta entender exatamente, a gente não entende. Ah, senhor, é terrível quando a gente se põe a refletir.

- Não pense mais nisso. - É fácil falar! Eu quero entender. Por que depois? Se a gente joga o machado, joga o cabo junto. Não depois. Decididamente, eu não entendo.

- Eu vou explicar. Era uma vez um lenhador.

A essas palavras, Cidrolin calou-se e pareceu pensar em outra coisa. 
Sthène rongeait son frein. Le duc lui avait bien recommandé [126] de se taire, comme il voyageait maintenant accompagné d'une suite nombreuse et qu'il ne voulait pas qu'à ce propos l'on jasât. Il en était d'ailleurs aussi triste que son cheval dont il appréciait le gai babillage. Stèphe trottait de même dans le plus grand mutisme, ce qui ne le changeait d'ailleurs pas de sa réserve ordinaire.

À défaut de Sthène, le duc bavardait avec le vicomte d'Empoigne. La perspective de ces États généraux l'emplissait d'une grande joie : excellente raison pour aller traîner ses chausses dans la ville capitale. La jeune Russule, la nouvelle épouse aurait bien voulu, elle aussi, goûter des plaisirs capitaux, elle avait même insisté et le duc s'était vu obligé de lui administrer une bonne raclée.

- Vous eûtes la main dure, messire, dit le vicomte.

- De quoi te mêles-tu, sigisbée ? Serais-tu amoureux de la duchesse ?

- Dieu m'en garde, messire.

- Tu n'es guère galant. Moi, j'espère bien que tu en es, de la duchesse, amoureux.

- En aucune façon, messire.

- Serais-tu hypocrite, par

[127] hasard ?

- Je vous assure, messire...

- Bien, bien, mais croismoi, si j'ai eu main un peu dure, c'est que je ne pouvais l'avoir plus légère que son père. Il y allait de ma dignité. J'ai jugé bon qu'elle ne trouvât pas ma brossée plus douce que celle d'un bûcheron...

- Monsieur, monsieur, dit le maître d'hôtel doucement, j'attends la suite.
Stenes roía o freio. O duque tinha-lhe recomendado muito para que se calasse, pois agora viajava acompanhado de uma comitiva numerosa e não queria que ficassem falando sobre o assunto. Aliás, isso o deixava tão triste quanto seu cavalo cuja alegre tagarelice apreciava. Estêvão trotava da mesma forma no maior mutismo, o que aliás não mudava nada em relação a sua reserva habitual.

$\mathrm{Na}$ falta de Stenes, o duque falava com o visconde de Empoigne. A perspectiva desses Estados Gerais o enchia de uma grande alegria: excelente razão para ir bater pernas na cidade capital. A jovem Russula, a nova esposa, bem que queria, ela também, gozar dos prazeres capitais, ela tinha até insistido e o duque tinha-se visto obrigado a administrar-lhe uma boa surra.

- Tivestes a mão pesada, senhor, disse o visconde.

- Por que se mete, serviçal?

Você estaria enamorado da duquesa?

- Deus me livre, senhor.

- Você não é nada galante.

Espero que você esteja, da duquesa, enamorado.

- De modo algum, senhor.

- Você seria hipócrita, por acaso?

- Eu vos asseguro, senhor...

- Bem, bem, mas acredite, se eu tive mão um pouco pesada, é porque não podia ter mais leve do que o pai dela. Tratava-se de minha dignidade. Julguei bom que ela não achasse meus tapas mais suaves que os de um lenhador...

- Senhor, senhor, disse o maître d'hôtel suavemente, estou esperando a continuação. 
- ... qui avait laissé tomber le fer de sa cognée au fond d'un abîme.

- D'un abîme?

- C'est comme cela qu'on raconte l'histoire, dit Cidrolin. Il ne pouvait aller l'y rechercher.

- Je pense bien, dit le maitre d'hôtel. Un abîme... boquillon...

- Alors, écœuré, le

- Pardon?

- Le bûcheron...

- C'était encore un ancien mot? Pourquoi, monsieur, y a-t-il comme ça des mots qui sortent de l'usage? Moi qui vous parle, en ai vu, de mon vivant même, disparaître quelques-uns sous mes yeux : cinématographe, taximètre, chef d'îlot, etcétéra.

- Voulez-vous connaître la fin ?

- J'ai deviné, répondit le maître d'hôtel d'un air malin. Écœuré, le bûcheron, le boquillon comme vous disiez, se jette à son tour dans l'abîme. Et c'est pour cela aussi que d'un type con on dit qu'il est con comme un manche. Le manche s'est jeté après la cognée.

- Voilà une variante intéressante, dit Cidrolin avec calme. En fait, le bûcheron s'est

[128] contenté de jeter le manche. Après la cognée. Si bien qu'il n'avait plus rien du tout. Tandis que le manche, au moins, aurait pu lui servir encore.

- C'est idiot, dit le maître d'hôtel. Qu'est-ce qu'il pouvait fiche avec son manche ? Rien. Ce qui était difficile à trouver, c'était le fer. Elle est idiote, votre histoire. Je préfère ma version.

- Elle est peut-être idiote, dit Cidrolin avec calme, mais, en tout cas, vous vous êtes instruit.

- Je vous remercie. Ah,
- ... que tinha deixado cair o ferro de seu machado no fundo de um abismo.

- De um abismo?

- É assim que contam a história, disse Cidrolin. Ele não podia ir buscá-lo.

- Entendo, disse o maître d'hôtel. Um abismo...

bosqueador...

- Então, furioso, o

- Como?

- O lenhador...

- Era mais uma palavra antiga? Por que, senhor, existem palavras assim que saem de uso? Eu que estou falando com o senhor, cheguei a ver, durante minha vida, desaparecer algumas debaixo dos meus olhos: cinematógrafo, vitrola, decalcomania, etcétera.

- O senhor quer saber o fim?

- Já adivinhei, respondeu o maître d’hôtel com ar esperto. Furioso, o lenhador, o bosqueador como o senhor dizia, por sua vez atira-se no abismo. E é por isso também que de um tipo idiota se diz que é idiota como um cabo de machado. O cabo se jogou depois do machado.

- Eis uma variante interessante, disse Cidrolin com calma. De fato, o lenhador contentou-se de jogar o cabo. Depois do machado. De modo que ficou sem nada. Enquanto que o cabo, pelo menos, ainda poderia ter-lhe servido.

- É idiota, disse o maître d'hôtel. O que é que ele poderia fazer com o cabo? Nada. $\mathrm{O}$ que é difícil de encontrar é o ferro. É idiota, sua história. Prefiro a minha versão.

- Ela pode ser idiota, disse Cidrolin com calma, mas, em todo caso, o senhor se instruiu.

- Eu agradeço. Ah, aqui está 
voilà votre caviar gros grain extrastandigne arrivé cet après-midi même par avion supersonique; avec une vodka bien glacée, vous allez vous régaler.

Cidrolin effectivement se régala.

Comme le restaurant était à peu près désert, le maître d'hôtel de temps à autre revenait voir si tout allait bien. Le coulibiac fut apprécié et le vol-au-vent financière dévoré. En attendant la suite, Cidrolin fit un peu de conversation.

- Je connais des personnes qui sont venues déjeuner ici, aujourd'hui même.

- À midi nous avons eu beaucoup de monde, dit l'autre d'un air important. couples.

- Six personnes. Trois

- Nous avons eu plusieurs tables de six personnes.

- Il y avait trois jeunes femmes, trois sœurs. Elles ne se ressemblent pas énormément, mais, en y faisant bien attention, on peut découvrir que ce sont trois jumelles.

- Des trimelles? Je ne vois pas. Pourtant je suis très physionomiste.

- Les messieurs, eux, n'avaient rien de bien remarquable.

[129] - Ah, alors, je vois. Des gens assez vulgaires.

- Vous trouvez?

- Oh ça, je peux vous le garantir. Ils ne mangeaient pas... comme Monsieur. Ils bâfraient. Et ils n'avaient même pas leur permis gastronomique. Ils ne savaient même pas ce que c'était: ils n'avaient pas l'habitude d'aller dans des restaurants à plus de trois mille calories. Vous connaissez vraiment ces personnes?

- Un peu. Et qu'est-ce que o seu caviar de grãos grandes extra chique que chegou esta tarde mesmo por avião supersônico; com uma vodka bem gelada, o senhor vai se regalar.

Cidrolin de fato se regalou.

Como o restaurante estava quase deserto, o maître d'hôtel de tempos em tempos voltava para ver se tudo estava bem. $\mathrm{O}$ salmão foi apreciado e o vol-au-vent à financière devorado. Enquanto esperava a sequência, Cidrolin puxou um pouco de conversa. - $\mathrm{Eu}$ conheço algumas pessoas que vieram almoçar aqui, hoje mesmo.

- No almoço tivemos muita gente, disse o outro com ar importante.

- Seis pessoas. Três casais.

- Tivemos várias mesas de seis pessoas.

- Havia três jovens senhoras, três irmãs. Elas não se parecem demais, mas, prestando bem atenção, pode-se descobrir que são três gêmeas.

- Trigêmeas? Não me lembro. No entanto sou muito fisionomista.

- Os cavalheiros não tinham nada de notável.

- Ah, então, já sei. Gente bem vulgar.

- O senhor acha?

- Ah isso, posso lhe garantir. Eles não comiam... como o senhor. Eles se empanturravam. E não tinham nem mesmo licença gastronômica. Nem sabiam do que se tratava: eles não têm o hábito de ir a restaurantes de mais de três mil calorias. $\mathrm{O}$ senhor realmente conhece essas pessoas?

- Um pouco. E o que o 
vous avez fait avec eux lorsqu'ils n'ont pas donné leur permis ?

- Que vouliez-vous que je fasse, monsieur? J'ai fait comme avec vous : je les ai servis.

Le maître d'hôtel sourit finement et, tandis que de la menue voletaille apportait truffes et faisan, il continue en ces termes :

- Je dois vous avouer, monsieur, que ce fameux permis gastronomique délivré par la éssésse est une pure invention. Ça n'existe pas. J'ai imaginé ça à moi tout seul et je m'amuse à distraire les clients avec cette fine plaisanterie. Quelques-uns tombent dans le panneau, alors ce n'en est que plus drôle. J'ai bien vu que Monsieur ne marchait pas, mais ces gens que vous dites connaître un peu, ils se sont mis en colère, ils voulaient tout casser. D'un comique.

- Vous dites que vous avez fini par les servir.

- Après les avoir calmés... après avoir insinué que par faveur insigne... parce que c'était eux... Enfin, vous voyez ce qu'on dégoise aux clients un peu benêts.

\section{- Je vois, dit Cidrolin.}

- Leur pourboire fut pourtant chiche. Des gens de peu. Pas du tout des gens de votre catégorie, monsieur. Et les dames : presque le mauvais genre. Vraiment: c'était des trimelles ? Curieux. Je ne l'avais pas deviné. Pourtant je suis physionomiste.

L'arrivée d'un couple de clients imprévus débarrassa Cidrolin de la présence du farceur. Il peut achever en paix son gibier et ses ascomycètes, se taper dans le calme quelques tranches de fromages variés, déguster dans la senhor fez com eles quando não lhe entregaram a licença?

- O que o senhor queria que eu fizesse? Eu fiz como com o senhor: eu os servi.

O maître d'hôtel sorri finamente $\mathrm{e}$, enquanto a arraia miúda trazia trufas e faisão, continua nestes termos:

- Tenho que confessar, senhor, que essa tal de licença gastronômica fornecida pela essiesse é uma pura invenção. Isso não existe. Eu imaginei isso por mim mesmo sozinho e me divirto distraindo os clientes com essa fina brincadeira. Alguns caem na esparrela, então é mais engraçado ainda. Logo vi que o senhor não caía, mas essa gente que o senhor diz conhecer um pouco, eles ficaram furiosos, queriam quebrar tudo. Uma piada...

- O senhor diz que acabou por servi-los...

- Depois de tê-los acalmado... depois de ter insinuado que por uma consideração especial... porque eram eles... Enfim, o senhor vê que a gente sabe enrolar os clientes meio bobos.

Cidrolin.

- Estou vendo, disse

- No entanto a gorjeta deles foi bem sovina. Gente de pouco. Não são de forma alguma gente de sua categoria, senhor. $\mathrm{E}$ as senhoras: quase o tipo ruim. Realmente: eram trigêmeas? Curioso. Eu não tinha adivinhado. No entanto, sou fisionomista.

A chegada de um casal de clientes imprevistos desembaraçou Cidrolin da presença do gozador. Ele pôde terminar em paz sua caça e seus ascomicetos, comer com calma algumas fatias de queijos variados, degustar em segurança o 
sécurité le soufflé aux douze liqueurs et s'envoyer en toute quiétude derrière la cravate un verre de chartreuse verte. Il demande l'addition qu'il paya. Il laissa quelques francs supplémentaires pour ne pas décevoir le maître d'hôtel qui le salua bien bas. Et lorsqu'il fut dans la rue, alors il s'émerveilla.

- Ce n'est pas croyable, ditil à mi-voix, tout était au poil.

- Pardon? demanda le passant.

Comme il faisait nuit noire, Cidrolin ne put le reconnaître.

- Rien, répondit-il. Je me parlais à moi-même. Une habitude que...

- Je sais, je sais, dit le passant un peu agacé. Je vous ai déjà conseillé d'essayer de la perdre, cette habitude.

- Ce n'est pas tous les jours fête.

- C'est fête pour vous, aujourd'hui ? En quel honneur?

- J'ai bien dîné.

- Et alors?

- Cela ne m'était pas arrivé depuis bien longtemps. Ou bien c'était franchement mauvais, ou bien il y avait toujours un quelque chose de raté. Là, c'était parfait. Au

[131] fur et à mesure que le repas avançait, j'étais pris d'angoisse. Je me disais : Ce n'est pas possible, ça ne peut pas durer comme ça, il y a quelque chose qui va louper. Mais non. Le faisan, succulent. Les truffes, entières et bien brossées. Les fromages, de première bourre. Alors j'ai pensé : Ça va être le soufflé - un soufflé aux douze liqueurs, monsieur, - ça va être le soufflé qui va être manqué. Pas du tout: gonflé comme une montgolfière, onctueux, savoureux. Rien à redire. Même la chartreuse était authentique. suflê aos doze licores e enfiar goela abaixo com toda a quietude um copo de chartreuse verde. Ele pede a conta e paga. Deixou alguns francos suplementares para não decepcionar o maître d'hôtel que o saudou curvando-se bem baixo. E quando chegou à rua, ele se maravilhou.

- É inacreditável, disse a meia-voz, estava tudo em cima.

- Como? perguntou o passante.

Como era noite escura, Cidrolin não pôde reconhecê-lo.

- Nada, respondeu ele. Eu falava comigo mesmo. Um costume que...

- Sei, sei, disse o passante um pouco irritado. Já o aconselhei a tentar perder esse costume.

- Nem todo dia é de festa.

- Hoje é festa para o senhor? Em honra de quê?

- Eu jantei bem.

- E daí?

- Isso não me acontecia há muito tempo. $\mathrm{Ou}$ era completamente ruim, ou havia sempre alguma coisa de errado. Hoje, estava perfeito. À medida que a refeição avançava, eu era tomado de angústia. Eu me dizia: Não é possível, isso não pode durar, com certeza alguma coisa vai dar errado. Mas não. $\mathrm{O}$ faisão, suculento. As trufas, inteiras e bem lavadas. Os queijos, de primeira qualidade. Então eu pensei: vai ser o suflê - um suflê aos doze licores, senhor, - vai ser o suflê que vai sair errado. De jeito nenhum: inflado como um balão, aveludado, saboroso. Nada a reparar. Até o chartreuse era autêntico. 
- Peuh, dit le passant, je ne vois pas là motif à vous réjouir. Vous payez cher, ce n'est pas malin. Parlez-moi du petit bistro.

- Il y a des restaurants chers où l'on mange comme des cochons. Non vraiment, je suis très étonné. Il $\mathrm{y}$ a quelque chose qui ne colle pas... mais je ne vais pas vous assommer avec toutes mes histoires.

- Pourquoi pas?

- Parce que je ne vais pas le faire.

- Dans ce cas, dit le passant sans se vexer, je ne voudrais pas abuser de vos instants... il se fait tard...

- Je vous en prie...

Cidrolin promène sa surprise à travers la nuit. Un de réussi; il n'en revient pas. Sans avoir fait attention au trajet, il se retrouve devant l'Arche. Il prend la lampe électrique qu'il a l'habitude de garer dans la boîte aux lettres et, à sa lueur, examine la clôture et ne découvre aucune inscription.

Il ouvrirait bien la bouche pour dire qu'il trouve tout cela bien singulier, mais il ne veut pas courir le risque de voir réapparaître le passant. Sur la péniche, tout est calme, rien n'a bougé.

Cidrolin boit encore un verre d'essence de fenouil pour faire passer le dîner qu'il trouve tout de même un peu lourd. Il se demande s'il va se coucher ou bien, à titre digestif, prendre le canot et ramer un peu. Il renonça bien vite à ces excès hygiéniques et décida de s'endormir. Il y eut quelque mal, mais finalement il y parvint. Un cheval lui adressait la parole.

- Je peux dire un mot? demanda Sthène. On est entre
- Bah, disse o passante, não vejo nenhum motivo para comemorar. O senhor pagou caro, não é vantagem nenhuma. Seria se fosse num restaurante simples.

- Há restaurantes caros onde se come como porcos. Não, de verdade, estou admirado. Há alguma coisa que não bate... mas não vou importuná-lo com todas as minhas histórias.

- Por que não?

- Porque não.

- Nesse caso, disse o passante sem se vexar, não vou abusar de seu tempo... já está tarde...

- Fique à vontade...

Cidrolin passeia sua surpresa através da noite. Uma bem sucedida; ele não se conforma. Sem prestar atenção ao trajeto, encontrase diante da Arca. Pega a lanterna que costuma deixar na caixa do correio e, com a luz, examina a cerca e não descobre nenhuma inscrição.

Ele bem que abriria a boca para dizer que acha aquilo tudo muito singular, mas não quer correr o risco de ver reaparecer o passante. $\mathrm{Na}$ chata, tudo está calmo, nada se mexeu.

Cidrolin toma ainda mais um copo de essência de funcho para ajudar na digestão do jantar que acha um pouco pesado. Ele pergunta-se se vai se deitar ou se vai, a título digestivo, pegar a canoa e remar um pouco. Desistiu bem depressa desses excessos higiênicos e decidiu dormir. Teve um pouco de dificuldade, mas finalmente conseguiu pegar no sono. Um cavalo dirigiu-lhe a palavra.

- Posso dar uma palavrinha? perguntou Stenes. Estamos entre 
compains.

Le duc en effet n'avait à côté de lui qu'Empoigne monté sur Stèphe. Le guide cavalait à cent toises devant et le reste de la compagnie suivait à bonne distance.

- Parle, mon brave Démo, dit le duc affectueusement.

- Un jour n'aurez-vous pas votre statue?

- Ma foi, dit le duc je n'y avais jamais pensé.

- Pourquoi pas?

- En effet, dit le duc ravi. Pourquoi pas?

- Une statue équestre, naturellement, comme celle du bon roi Henri que nous avons vue hier.

- Une statue équestre! Comme tu y vas: je ne suis pas le roi de France.

- Moi, dit Sthène, je ne la vois pas autrement : équestre.

- Ah ah, j'ai compris! c'est toi qui veux avoir ta statue!

- Ne la mérité-je point? Un cheval comme moi, on n'en a pas vu depuis Xanthe. Et encore, Xanthe ne parlait que par la voix d'Héra, tandis que moi, je n'ai besoin de personne pour savoir ce [133] que je veux dire.

- Et qui est ce Xanthe? demande Mouscaillot.

Sthène encensa pour montrer le peu d'estime qu'il avait pour la culture d'Empoigne.

Il daigne cependant répondre :

- Un des chevaux d'Achille. L'autre se nommait Balios.

-Sthène vient de relire tout Homère en trois jours, dit le duc.

- Ce bon Balios, dit Empoigne en tapant sur l'encolure de Stèphe. amigos.

O duque com efeito só tinha a seu lado Empoigne montado em Estêvão. O guia cavalgava cem toesas adiante e o resto da companhia seguia a boa distância.

- Fale, meu bravo Demós, disse o duque afetuosamente.

- Um dia não tereis vossa estátua?

- Meu Deus, disse o duque eu nunca havia pensado nisso.

- Por que não?

- Realmente, disse o duque radiante. Por que não?

- Uma estátua equestre, naturalmente, como a do bom rei Henrique que nós vimos ontem.

- Uma estátua equestre! Você vai depressa: não sou o rei de França.

- Eu, disse Stenes, não consigo imaginá-la sem ser equestre.

- Ah ah, entendi! é você que quer ter sua estátua!

- Eu não merecê-la-ia? Um cavalo como eu, não se viu desde Xanto. E mesmo assim, Xanto só falava pela voz de Hera, enquanto que eu não preciso de ninguém para saber o que quero dizer.

- E quem é esse Xanto? pergunta Mouscaillot.

Stenes balançou a cabeça para mostrar a pouca estima que tinha pela cultura de Empoigne. Ele se digna no entanto responder:

- Um dos cavalos de Aquiles. $\mathrm{O}$ outro se chamava Balios.

- Stenes acaba de reler todo Homero em três dias, disse o duque.

- Esse bom Balios, disse Empoigne dando um tapinha no pescoço de Estêvão. 
- Est-ce que j'aurai ma statue, moi aussi ? demanda Stèphe.

- Il la mériterait, dit Sthène qui était bon compagnon. Dans l'Iliade, Balios ne parle pas, seul Xanthe parle, or Stèphe parle, donc il a droit lui aussi à sa statue.

- On ne peut pas faire ma statue monté à la fois sur deux chevaux, fit remarquer le duc.

- Un bon sculpteur s'en sortirait peut-être, dit Sthène qui était de tempérament optimiste. En tout cas, commençons par la nôtre. Stèphe attendra. N'est-ce pas, Sthèphe?

Stèphe ne répondit point et Sthène ne poursuivit pas son discours, le guide s'étant arrêté. On apercevait maintenant les travaux en cours.

- Cette idée ne me déplaît pas du tout, dit le duc à Empoigne. Je sentais bien qu'il me manquait quelque chose: à savoir, cette statue équestre. Dès que nous serons rentrés à Paris, nous nous mettrons en quête d'un sculteur.

Ils arrivèrent à la hauteur du guide. Dans un petit galop, la suite les rejoignit.

- Nobles seigneurs, dit le cicérone d'une voix déconnante,

[134 vous avez devant vous la curiosité parisienne qui attire le plus de visiteurs à l'heure actuelle, après la statue de notre bon roi Henri le quatrième, bien entendu. Les travaux ont été commencés sur l'ordre de Sa Majesté la Reine Mère.

- Vive la reine ! cria le duc.

- Vive la reine ! crièrent les autres.

- Lorsqu'il sera terminé, l'aqueduc aura une longueur de douze cent trente et un pieds et une hauteur de quatre-vingt-quatorze pieds. La construction en est placée
- Será que eu também terei minha estátua? perguntou Estêvão.

- Ele mereceria, disse Stenes que era bom companheiro. Na Ilíada, Balios não fala, só Xanto fala, ora Estêvão fala, logo ele também tem direito a sua estátua.

- Não poderiam fazer minha estátua montado em dois cavalos de uma vez, observou o duque.

- Um bom escultor talvez resolvesse isso, disse Stenes que era de temperamento otimista. Em todo caso, comecemos pela nossa. Estêvão esperará. Não é, Estêvão?

Estêvão não respondeu e Stenes não prosseguiu com seu discurso, uma vez que o guia parou. Percebiam-se agora as obras em curso.

- Essa idéia não me desagrada nem um pouco, disse o duque a Empoigne. Eu sentia que me faltava alguma coisa: a saber, essa estátua equestre. Assim que chegarmos a Paris, procuraremos um escultor.

Eles chegaram à altura do guia. Num pequeno galope, a comitiva juntou-se a eles.

- Nobres senhores, disse o cicerone com uma voz esganiçada, os senhores têm diante de si a curiosidade parisiense que mais atrai os visitantes atualmente, depois da estátua de nosso bom rei Henrique quarto, bem entendido. As obras foram iniciadas por ordem de Sua Majestade a Rainha Mãe.

- Viva a rainha! gritou o duque. - Viva a rainha! gritaram os outros.

- Quando estiver terminado, o aqueduto terá um comprimento de mil duzentos e trinta e um pés e uma altura de noventa e quatro pés. A construção está sendo executada 
sous la direction de monsieur Salomon de Brosse...

- Fabrique-t-il aussi des statues ? demanda le duc.

- Pas que je sache... et du maestro ingeniere fiorentino Tomaso de Francini.

- Lui non plus ? demanda le duc.

- Plaît-il ? je ne comprends point.

- Je demande s'il fait lui aussi des statues ou s'il n'en fait pas, lui non plus. Lui non plus.

- Pas que je sache.

- Lorsque nous serons rentrés à Paris, vous me conduirez chez les plus illustres sculteurs de la capitale.

- À vos ordres, messire.

- À moins que je n'en fasse venir un d'Italie...

Le guide, revenant à ses moutons, propose aux nobles seigneurs de descendre de cheval et d'aller voir de plus près les travaux.

- Allez-y, messieurs, dit le duc. Moi, j'en ai assez vu comme ça.

Tandis que les autres s'éloignent, il se met en quête d'un endroit agréable et discret. De tous

[135] côtés, ce sont petits près ou jardins potagers. Le duc se sent attiré par un carré de poireaux qui lui paraît avoir besoin d'être fumé. Il s'installe donc lorsque voilà le ciel qui s'obscurcit, le vent qui se lève, l'orage qui éclate, la pluie qui tombe avec fracas. Le duc, qui a tout juste eu le temps d'accomplir sa tâche, cherche autour de lui un proche abri. Il n'y en a point ; mais une maison là-bas, au bout du chemin. Le duc fonce dans cette direction, il patine dans la boue immédiatement surgie, il est trempé de flotte, et de plus il court comme une poularde bancale de Bresse. Tout de même, à la fin, il y arrive, sob a direção do senhor Salomão de Brosse...

- Ele fabrica também estátuas? perguntou o duque.

- Não que eu saiba... e do

mestre engenheiro florentino Tomaso de Francini.

- Ele tampouco? perguntou o duque.

entendendo.

- Pouco? não estou

- Estou perguntando se ele faz também estátuas ou se ele não faz tampouco. Tampouco.

- Não que eu saiba.

- Quando tivermos chegado a Paris, o senhor vai me conduzir aos mais ilustres escultores da capital.

- Às vossas ordens, senhor.

- A menos que eu mande vir um da Itália...

- O guia, voltando à vaca fria, propõe que os nobres senhores desçam do cavalo e que vão ver as obras mais de perto.

- Podem ir, senhores, disse o duque. Eu já vi o suficiente.

Enquanto os outros se distanciam, ele se põe em busca de um lugar agradável e discreto. Por todos os lados, há pequenos pastos ou hortas. $\mathrm{O}$ duque se sente atraído por um canteiro de alho-poró que lhe parece precisar ser adubado. Ele se instala então quando eis que o céu escurece, o vento se eleva, a tempestade explode, a chuva cai com estrondo. O duque, que mal teve tempo de completar sua tarefa, procura em volta um abrigo próximo. Não há nenhum; apenas uma casa bem longe, no fim do caminho. $\mathrm{O}$ duque investe naquela direção, patina na lama imediatamente formada, está ensopado até os ossos, e ainda por cima corre como uma galinha manca. Mesmo assim, finalmente, 
à l'abri, à la maison. Encore faut-il pour que cette maison soit un abri que la porte s'en ouvre. Or la porte ne s'ouvre pas. Le duc a beau frapper, rien ne se passe et il continue à lui pleuvoir dans le cou.

L'averse redouble et le duc commence à être tout décrassé : il n'a jamais été aussi propre de longtemps, ce qui, s'il le savait, ne lui procurerait d'ailleurs aucun plaisir. Il donne des coups de pied dans l'huis, des coups d'épaule, et finalement chevillette et gonds cèdent, la porte décrit une trajectoire de quatre-vint-dix degrés pour se mettre à l'horizontale et $\mathrm{y}$ mettre également le furieux tout mouillé.

Lequel se relève en maugréant. Il s'ébroue, il se trouve dans une sorte d'étable ou d'écurie, à moins que ce ne soit une cave ou un grenier. Le tout est dans la pénombre, peu de jour entre par l'embrassure vidée, des nuages noirs couvrent toujours le ciel. Le duc finit par identifier le lieu : c'est un bûcher, un bûcher particulièrement bien fourni. Il y a aussi du charbon. Le duc alors se

[136] propose un programme.

- Je vais faire un petit feu pour mettre à sécher mes chausses, mon pourpoint et mon chapiau.

Le duc cherche une cheminée, mais il n'y en a point. Il aperçoit une porte dans le fond du bûcher, il y va, il l'ouvre tout doucement. Il ne comprend pas d'abord ce qu'il voit, lorsque le personnage penché sur le fourneau se redresse puis se tourne vers lui en criant :

- Arrière, imprudent! Ta présence humectée va souiller la dernière opération.

- Holà, fit le duc sans se laisser impressionner, je n'ai pas l'habitude qu'on me parle sur ce ele chega, ao abrigo, à casa. Ainda falta para que essa casa seja um abrigo que a porta se abra. Pois a porta não se abre. Por mais que o duque bata, nada acontece e continua a lhe chover na cabeça.

$\mathrm{O}$ aguaceiro dobra e o duque começa a ficar sem um cascão: há muito tempo ele não tinha estado tão limpo, o que, aliás, se ele soubesse, não lhe daria nenhum prazer. Ele dá pontapés na porta, golpes com o ombro, e finalmente cavilhas e gonzos cedem, a porta descreve uma trajetória de noventa graus para se colocar na horizontal e colocar na mesma posição o furioso todo molhado.

O qual se levanta vociferando. Ele se agita, encontrase numa espécie de estábulo ou de estrebaria, a menos que seja uma adega ou um celeiro. Tudo está na penumbra, pouca luz entra pelo buraco deixado pela porta, nuvens negras ainda cobrem o céu. $\mathrm{O}$ duque acaba por identificar o lugar: é um lenheiro, um lenheiro particularmente bem abastecido. Havia também carvão. $O$ duque então se propôs um programa.

- Vou fazer uma fogueirinha para secar meu culote, meu gibão e meu chapéu.

$\mathrm{O}$ duque procura uma lareira, mas não há nenhuma. Ele percebe uma porta no fundo do lenheiro, vai para lá, abre-a devagarinho. De início não entende o que vê, quando a personagem debruçada sobre o forno se levanta e volta-se para ele gritando:

- Para trás, imprudente! Sua presença umectada vai macular a última operação.

- Epa, fez o duque sem se deixar impressionar, não estou acostumado a que me falem nesse 
ton. Je vais sécher ces vêtements et me sécher moi-même.

- Arrière ! te dis-je. L'arbre de rubis s'est transformé en serin vert et le bec de celui-ci picore déjà l'or nutritiel.

- L'or! s'écria le duc. Il y a de l'or dans le coin?

L'autre, sans daigner lui répondre, se pencha sur le creuset et pousse un cri de désespoir.

- Malédiction! hurle-t-il. Le serin vert s'est transformé en poule de plomb. Tout est à recommencer!

- Eh bien, dit le duc, avec légèreté, vous recommencerez et moi je n'aurai pas attrapé de rheume.

- Recommencer! Messire, c'est vingt-sept ans de labeurs qui viennent d'échouer! Vingt-sept ans ! Et l'or allait bel et bien apparaître dans ce creuset lorsque vous avez fait cette malséante et profane irruption.

- Tout cela est fort intéressant, mais il faut en prendre

[137] votre parti. Je vais me sécher.

Il enlève ses chausses, son pourpoint, et les installe devant le fourneau; lui-même s'expose en évitant de se rôtir. Une buée se dégage du tout.

L'autre continue à se lamenter.

- Et cette humidité qui va se déposer partout!

Il se précipite pour boucher des bonbonnes, luter des vaisseaux. Il râle :

- Toutes mes substances essentielles vont demander une nouvelle dessiccation! Des années perdues ! que dis-je : foutues ! Et à cause d'un hobereau qui ne sait où s'abriter.

-Holà, fit le duc en souriant. tom. Vou secar essas roupas e me secar a mim mesmo.

- Para trás! estou falando. A árvore de rubis transformou-se em canário verde e o bico deste já está picando o ouro nutricional.

- Ouro! exclamou o duque. Há ouro por aqui?

$\mathrm{O}$ outro, sem se dignar responder-lhe, debruçou-se sobre o cadinho e dá um grito de desespero.

- Maldição! urla ele. O canário verde transformou-se em galinha de chumbo. Toca recomeçar tudo!

- Bom, bom, disse o duque, despreocupadamente, o senhor recomeçará e eu não terei pego um resfriado.

- Recomeçar! Senhor, são vinte e sete anos de trabalho que acabam de ir por água abaixo! Vinte e sete anos! E o ouro ia aparecer lindamente no cadinho quando fizestes essa inconveniente e profana irrupção.

- Tudo isso é mui interessante, mas é preciso ver o lado bom. Eu vou me secar.

Ele tira o culote, o gibão, e instala-os diante do forno; ele mesmo se expõe com cuidado para não se assar. Uma nuvem se desprende do conjunto.

$\mathrm{O}$ outro continua a se lamentar.

- E essa umidade que vai se espalhar por tudo!

Ele se precipita para arrolhar os garrafões, vedar as vasilhas. Ele resmunga:

- Todas as minhas substâncias essenciais vão requerer uma nova dessecação! Anos perdidos! o que estou dizendo: estragados! E por causa de um fidalguinho que não sabe onde se abrigar.

- Epa, fez o duque sorrindo. 
Un hobereau ? Sais-tu à qui tu parles, souffleur?

hobereau?

- Sais-tu à qui tu parles,

- Il y tient à son hobereau. Je suis le duc d'Auge et représente la noblesse de ma province aux États généraux.

- Pouah. Moi, je suis Timoleo Timolei, le seul alchimiste du monde chrétien à connaître la véritable recette de l'or potable ou non, sans compter mille autres merveilles.

- Lesquelles?

- Marcher au plafond comme une mouche et sur l'eau comme Notre-Seigneur JésusChrist, se trouver à la fois ici et en Nouvelle-Espagne, voyager dans le ventre d'une baleine, comme le fit le prophète Jonas, chevaucher les dauphins comme Arion et courir plus vite que ne le faisait Atalante, se déplacer dans une voiture sans chevaux, fendre les airs comme l'aigle et l'hirondelle...

- Tu sembles avoir un faible pour les moyens de transport.

- C'est que je traitais mon sujet méthodiquement. En voulez-

[138] vous une autre série ? Comprendre le langage des abeilles, parler la langue des Topinambous sans l'avoir apprise, converser avec une personne éloignée de mille lieues, entendre l'harmonie des sphères célestes, lire sans difficulté toutes les écritures secrètes, savoir par cœur le contenu de mille et trois ouvrages, discourir de toutes choses avec pertinence sans avoir jamais étudié.

- Tout ça ne vaut pas l'or, dit le duc que commençait à se rhabiller.

- Avec la poudre de projection qui allait naître, j'en aurais pu engendrer non pas des
Um fidalguinho? Você sabe com quem está falando, soprador?

- Você sabe com quem está falando, fidalguinho?

- Ele insiste no seu fidalguinho. Eu sou o duque de Auge e represento a nobreza de minha província nos Estados Gerais.

- Bah. Eu, eu sou Timoleu Timolei, o único alquimista do mundo cristão que conhece a verdadeira receita do ouro potável ou não, sem contar mil outras maravilhas.

- Quais?

- Andar no teto como uma mosca e sobre a água como Nosso Senhor Jesus Cristo, estar ao mesmo tempo aqui e em NovaEspanha, viajar na barriga de uma baleia, como fez o profeta Jonas, cavalgar os golfinhos como Arion e correr mais rápido que Atalanta, deslocar-se num carro sem cavalos, cortar os ares como a águia e a andorinha...

- Parece que você tem um fraco pelos meios de transporte.

- É que eu estava tratando meu assunto metodicamente. Você quer uma outra série? Entender a linguagem das abelhas, falar a língua dos Tupinambás sem tê-la aprendido, conversar com uma pessoa a mil léguas de distância, entender a harmonia das esferas celestes, ler sem dificuldade todas as escritas secretas, saber de cor o conteúdo de mil e três obras, discorrer sobre todas as coisas com pertinência sem ter jamais estudado.

- Nada disso vale o ouro, disse o duque que começava a se vestir.

- Com o pó de projeção que ia nascer, eu teria podido gerar não onças mas libras, o que estou 
onces, mais des livres, que dis-je ! des tonneaux, mais l'intrusion de messire duc a tout fait rater. J'ai de nouveau vingt-sept années de distillation devant moi ; il est vrai que, cette fois, je profiterai de l'expérience que j'ai acquise.

- Et combien de temps mettras-tu cette fois-ci ?

- Euh, fit Timoleo Timolei.

Trois... quatre ans...

- En trois quatre ans, tu te fais fort de trouver la pierre philosophale?

- Je me fais fort.

- Et l'élixir de longue vie?

- Dito.

- Bien, dit le duc maintenant prêt. Très bien même.

La pluie avait cessé. Il alla sur le pas de la porte et aperçut, à une bonne centaine de toises, sa suite qui le cherchait. Il se retourna vers l'alchimiste :

- Timoleo Timolei, que dirais-tu de venir t'installer dans mon châtiau et d'y souffler pour moi ? Je paierai toutes tes dépenses, je te protégerai contre les

[139] curiosités ecclésiastiques, je te nourrirai princièrement et tu me feras profiter de ton or et de ton élixir. Qu'en dis-tu ?

- Quitter Arcueil me daurrait : cela demande réflexion.

- C'est tout réfléchi. Lorsque les États généraux seront terminés, je ferai déménager ton galetas et même tes bûches et je les emmènerai avec nous.

Sthène, qui avait aperçu le duc, arrivait au petit trot et freina sec devant son maître auquel il fit de doux reproches :

- Messire, ce n'est pas possible, vous vous cachiez !

- Oooh, dit l'alchimiste devenu soudain pâle et bègue, un cheche, un vaval... un cheval... qui qui... caucause... dizendo! tonéis, mas a intrusão do senhor duque fez tudo dar errado. Tenho novamente vinte e sete anos de destilação diante de mim; é verdade que, desta vez, vou aproveitar a experiência que adquiri.

- E quanto tempo você vai levar desta vez?

- Ahn, fez Timoleu Timolei. Três... quatro anos...

- Em três quatro anos, você se acha capaz de que encontrar a pedra filosofal?

- Me acho capaz.

- E o elixir da longa vida?

- Dito.

- Bem, disse o duque já pronto. Muito bem.

A chuva tinha parado. Ele foi para a porta e percebeu, a uma boa centena de toesas, a comitiva que o procurava. Voltou-se para o alquimista:

- Timoleu Timolei, o que você diria de vir se instalar no meu castelo e de soprar para mim? Pagarei todas as suas despesas, o protegerei contra as curiosidades eclesiásticas, $\quad$ o alimentarei principescamente e você me deixará aproveitar de seu ouro e de seu elixir. O que me diz?

- Deixar Arcueil me deprimiria: isso exige reflexão. - Já está tudo decidido. Quando os Estados Gerais estiverem terminados, mando embalar seus trastes e até mesmo a sua lenha e os levo conosco.

Stenes, que tinha visto o duque, chegava trotando e freou seco diante de seu mestre o qual ele repreendeu suavemente:

- Senhor, assim não dá, vós vos escondíeis!

- Oooh, disse o alquimista que de repente ficou pálido e gago, um caca, um vava... um cavalo... queque... fafala... 
- Tu vois, lui dit le duc, tu ne seras pas en mauvaise compagnie.

Il enfourche Sthène et disparaît au galop.

Timoleo Timolei, sidéré, fit quelques pas en arrière et, basculant sur une bûche, s'évanouit sur un tas de charbon.
- Você está vendo, disse-lhe o duque, você estará em boa companhia.

Ele monta Stenes e desaparece a galope.

Timoleu

Timolei, boquiaberto, deu alguns passos para trás e, tropeçando num pedaço de lenha, desmaiou sobre um monte de carvão. 
Cidrolin se réveille au milieu de la nuit, il a très mal au [140] ventre et très mal à l'estomac. Il monte sur le pont et se penche sur l'eau: peut-être va-t-il vomir? Sans doute a-t-il songé au prix du repas et que ce serait un bien grand gâchis de le répandre ainsi; il rentre et se dirige vers les latrines et se soulage, entend un floc, encore quelque chose qui voguera jusqu'au prochain champ d'épandage ou même peut-être jusqu'à la mer.

Il se recouche, mais il a toujours très mal au ventre et très mal à l'estomac. C'est trop bête, pour une fois que c'était parfait. Il patiente. Il ne patiente plus. Il se relève et s'habille, prend une couverture, s'installe dans le canot et le détache ; il rame.

Sur le boulevard, le long du quai, il y a encore des camions qui passent de temps en temps; de même sur le pont. Sur les autres péniches voisines, on dort. Cidrolin suit le cours du fleuve, il ne rame plus, sinon, de temps à autre, pour rectifier la direction. Il avance silencieusement ; lorsque l'absence de véhicules le permet, il entend parfois une bulle qui crève, un poisson qui a fait surface ou le produit d'une fermentation née au fond du fleuve et qui vient exploser

[141] à sa modeste mesure entre deux rides semées par le vent.

De temps à autre, Cidrolin penche la tête, emporté par une bouffée de sommeil. Il oblique et amarre son canot à un piquet planté par quelque pêcheur. Il s'enroule dans la couverture et regarde le ciel qui commence à grisonner. Il n'a plus du tout mal au ventre ni à
Cidrolin desperta no meio da noite, está com muita dor de barriga e muita dor de estômago. Ele sobe até o convés e debruça-se na amurada: será que vai vomitar? Provavelmente pensou no preço da refeição e que seria um grande desperdício esparramá-la assim; ele entra e se dirige às latrinas e se alivia, ouve um floc, mais alguma coisa que vai vogar até a próxima estação de tratamento ou talvez mesmo até o mar.

Volta a deitar-se, mas continua com muita dor de barriga e muita dor de estômago. É sacanagem, na única vez em que estava perfeito. Ele aguarda. Ele não aguarda mais. Levanta-se e veste-se, pega uma coberta, instalase na canoa e a desamarra; ele rema.

No bulevar, ao longo do cais, ainda há caminhões que passam de tempos em tempos; assim como na ponte. Nas outras chatas vizinhas, estão dormindo. Cidrolin segue o curso do rio, não rema mais, a não ser, de tempos em tempos, para corrigir a direção. Ele avança silenciosamente; quando a ausência de veículos o permite, ouve às vezes uma bolha que estoura, um peixe que vem à superfície ou o produto de uma fermentação nascida no fundo do rio e que vem explodir em sua modesta medida entre duas rugas semeadas pelo vento.

De tempos em tempos, Cidrolin inclina a cabeça, dominado por uma onda de sono. Ele vira para a margem e amarra a canoa numa estaca plantada por algum pescador. Ele se enrola na coberta e olha o céu que começa a ficar cinza. Não tem mais nenhuma 
l'estomac, mais il ne parvient pas à se rendormir. Il reste là les yeux ouverts. Peu importe après tout, il fera une plus longue sieste après le déjeuner.

La circulation croît sur le pont comme sur le boulevard. Les premiers pêcheurs à la ligne apparaissent. Des membres ultramatinaux d'un club sportif pratiquent l'aviron. Une péniche vraie passe, les vagues viennent s'amortir le long de la rive. Cidrolin voit la cime des arbres monter et descendre.

Il a détaché le canot et maintenant il rame pour remonter le courant. Il peine un peu et met beaucoup plus de temps qu'à l'aller. Enfin il accoste et rentre après ce petit tour. Il va ranger la couverture, puis il marche de long en large sur le pont en se frottant les mains, soit qu'il ait eu un peu froid, soit qu'il veuille manifester une certaine satisfaction. Il fait comme ça une dizaine de fois le trajet, puis il monte sur le quai, un pot de peinture à la main. Il regarde si on lui a de nouveau barbouillé sa clôture avec des inscriptions injurieuses, mais il n'y en a pas. Cidrolin a l'air tout déconcerté, il donne distraitement et gratuitement des coups de pinceau çà et là.

Un type qui passait lui dit :

- C'est pas du travail ça.

- En effet, répond Cidrolin,

[142] c'est très exactement de la distraction. De la distraction gratuite.

- Vous vous amusez de peu.

- D’un rien, même. De ça, par exemple.

Et il montra l'immeuble qui se construisait de l'autre côté du boulevard.

- Ça, c'est du travail, dit le dor de barriga nem de estômago, mas não consegue adormecer. Ele fica lá de olhos abertos. Pouco importa afinal, fará uma sesta mais longa depois do almoço.

O trânsito aumenta na ponte assim como no bulevar. Os primeiros pescadores a vara aparecem. Membros madrugadores de um clube esportivo praticam remo. Uma chata verdadeira passa, as ondas vêm se amortecer ao longo da margem. Cidrolin vê as copas das árvores subirem e descerem.

Ele desamarrou a canoa e agora rema para subir contra a corrente. Ele pena um pouco e leva muito mais tempo do que na ida. Finalmente acosta e entra em casa depois desse pequeno passeio. Vai guardar a coberta, depois anda pra lá e pra cá no convés esfregando as mãos, seja por estar com um pouco de frio, seja por querer manifestar uma certa satisfação. Faz assim umas dez vezes o trajeto, depois sobe para o cais, com uma lata de tinta na mão. Ele olha se rabiscaram de novo sua cerca com inscrições injuriosas, mas não há nada. Cidrolin fica todo desconcertado, dá distraida e gratuitamente algumas pinceladas aqui e ali. diz:

Um sujeito que passava lhe

- Isso aqui num é trabalho.

- Realmente, responde Cidrolin, é mais exatamente distração. Distração gratuita.

- O senhor se diverte com pouco.

- Com quase nada, mesmo. Com isso, por exemplo.

E ele mostra o prédio que estão construindo do outro lado do bulevar.

- Isso é trabalho, diz o 
passant.

- C'est bien ce que je disais.

Quelqu'un à mobylette freina sec et les interpella :

- Pour la plus grande gloire de Dieu, dit-il en tendant la main.

- Qu'entendez-vous par là? demanda le passant avec hargne.

- Bon, bon, dit l'autre. Je ne vais pas me mettre à discuter.

Et il repartit. Il était vêtu très correctement, un peu comme un clergyman.

- C'est pas du travail, ça, dit le passant. De la façon dont il s'y prend, il ne doit pas récolter grand'chose.

- De quoi s'acheter de l'essence pour sa mobylette.

- Parce que vous croyez que l'argent qu'il ramasse, il ne le consacre pas à la gloire de Dieu ?

- Je ne crois rien du tout, dit Cidrolin. Il quête peut-être pour les pauvres.

- Les pauvres ? Est-ce qu'il $\mathrm{y}$ en a même dans le coin ? Commune riche, cossue. C'est à vous cette péniche?

- C'est à moi.

- Alors vous n'êtes pas à plaindre. Ce n'est pas pour vous qu'il quêtait, le bonhomme.

- Sait-on jamais. C'est peutêtre un escroc. Supposez que vous

[143] lui ayez donné quelque chose ; lorsque vous auriez été parti, il serait revenu et nous aurions partagé.

- J'avais bien raison de me méfier, dit le passant. Au revoir, monsieur.

Cidrolin le regarde s'éloigner, puis, s'étant retourné dans la direction opposée, il aperçut une silhouette féminine à l'horizon. La silhouette féminine à l'horizon est complétée par une passante.

- É exatamente o que eu estava dizendo.

Alguém de mobilete freou seco e os interpelou:

- Para a maior glória de Deus, disse ele estendendo a mão.

- O que o senhor quer dizer com isso? perguntou o passante de mau humor.

- Bom, bom, disse o outro. Não vou começar a discutir.

E partiu. Ele estava vestido muito corretamente, um pouco como um padre.

- Isso num é trabalho, disse o passante. Do jeito que ele se esforça, não deve arrecadar grande coisa.

- O suficiente para a gasolina da mobilete.

- Porque o senhor acredita que o dinheiro que recolhe, ele não o emprega para a glória de Deus?

- Eu não acredito em nada, disse Cidrolin. Pode ser que ele peça para os pobres.

- Os pobres? Será que tem pobres por aqui? Bairro rico, opulento. É sua essa chata?

- É minha.

- Então, o senhor não tem do que se queixar. Não é para o senhor que ele pedia.

- Nunca se sabe. Pode ser que ele seja um escroque. Suponha que o senhor tivesse lhe dado alguma coisa; quando o senhor tivesse partido, ele voltaria e nós dividiríamos.

- Eu estava certo em desconfiar, disse o passante. Até a vista, senhor.

Cidrolin olha-o afastar-se, depois, tendo-se virado para a direção oposta, percebeu uma silhueta feminina no horizonte. A silhueta feminina no horizonte é completada por uma valise, de 
valise, aussi ne progresse-t-elle pas très rapidement.

- Ça, c'est pour moi, dit Cidrolin à mi-voix.

Il redescend sur la péniche pour ranger le pot de peinture et s'étend sur sa chaise longue en attendant les événements. Les événements se passent de la façon suivante: arrivée devant le portillon qui donne sur le boulevard, la silhouette féminine complétée par une valise continue son chemin.

- Quelle gourde, dit Cidrolin, je parie que c'est l'envoi d'Albert.

Il abandonne la chaise longue et remonte sur le quai voir ce qui se passe. Effectivement, la silhouette féminine complétée par une valise est en train de se renseigner dix péniches plus loin. Elle fait demi-tour. Elle se dirige maintenant vers lui. Elle s'approche. Elle se rapproche. La voilà. Elle pose sa valise avant de prononcer ces mots:

- C'est vous le type dont m'a parlé monsieur Albert ?

- Qu'est-ce qu'il vous a dit de moi pour que je puisse m'identifier moi-même ?

- Comprends pas. Et puis on répond pas par une question à une question. Ça se fait pas.

- À qui monsieur Albert vous a-t-il envoyée ?

- Encore une question. Vous pouvez pas répondre à la mienne ?

[144] De question.

question?

- C'était quoi votre

- Encore ! Décidément vous savez rien faire d'autre que questionner.

- Franchement, je ne trouve pas que ce soit dans mon caractère.

- Peuh! vous vous forma que ela não avança muito rapidamente.

- É para mim, disse Cidrolin a meia voz.

Ele desce para a chata para guardar a lata de tinta e se estende na espreguiçadeira enquanto espera os acontecimentos. Os acontecimentos passam-se da seguinte maneira: chegando diante do portão que dá para o bulevar, a silhueta feminina completada por uma valise continua seu caminho.

- Que goiaba, disse Cidrolin, aposto que é a que Alberto enviou.

Ele abandona a espreguiçadeira e sobe para o cais para ver o que se passa. Realmente, a silhueta feminina completada por uma valise está pedindo informações dez chatas adiante. Ela faz meia volta. Ela agora se dirige para ele. Ela se aproxima. Ela se aproxima mais. Lá está. Ela põe a valise no chão antes de pronunciar estas palavras:

- É o senhor o sujeito de que o senhor Alberto me falou?

- O que é que ele disse de mim para que eu mesmo possa me identificar?

- Num tô entendendo. Além disso, num se responde com uma pergunta a uma pergunta. Isso não se faz. a enviou?

- A quem o senhor Alberto

- Mais uma pergunta. O senhor num pode responder a minha? Pergunta.

- E qual era a sua pergunta?

- Mais essa! O senhor só sabe fica fazendo pergunta.

- Francamente, não acho que isso esteja no meu caráter.

- Bah! o senhor num se 
connaissez pas.

- Comme vous ne me connaissez pas non plus, on se demande qui me connaît.

- Monsieur Albert.

- Très juste.

- Alors c'est bien vous le type qui cherchez une nana pour agrémenter sa péniche?

- Voilà.

- Et c'est ça, la péniche ?

- Oui.

- C'est rien chouette.

- N'exagérons rien.

- Au mois d'août, on ira à Saint-Trop dessus ?

- Non, elle ne bouge pas.

- Dommage. Oh mais, il y a quand même une petite barque. Elle est à vous, la barque ?

- Oui.

- On fera des promenades en barque ?

- À l'occasion.

- Vous savez, je sais ramer ; vous en faites pas: c'est moi qui vous baladerai.

- Je n'en demande pas tant.

- Faut pas décourager ma bonne volonté.

Cidrolin se gratta la tête.

- Vous êtes majeure ?

- Vous voulez voir ma carte d'identité ?

- Je veux bien.

Elle était majeure. Il regarda soigneusement si la date

[145] n'était pas falsifiée. Il lui sembla bien qu'elle ne l'était pas. Il lui rendit sa carte d'identité et prit sa valise.

- Venez, vous allez vous installer.

- Vous avez déjà pris votre petit déjeuner?

Il fit signe que non.

- Faites, dit-il, attention de ne pas vous casser la gueule. raide. conhece.

- Como a senhorita também não me conhece, me pergunto quem me conhece.

- O senhor Alberto.

- Correto.

- Então é o senhor mesmo o sujeito que procura uma garota para deixar sua chata mais bonita?

- É isso aí.

- E é essa, a chata?

- Sim.

- É muito bacana.

- Não exageremos muito.

- No mês de agosto, a gente vai até Saint-Trop com ela?

- Não, ela não se mexe.

- Pena. Ah mas, pelo menos tem um pequeno barco. É seu esse barco?

- Sim.

- A gente vai passear de barco?

- Quando calhar.

- Sabe, eu sei remar; num se preocupe: eu é que vou levá-lo passear.

- Eu não peço tanto.

- O senhor num deve desencorajá minha boa vontade.

Cidrolin coçou a cabeça.

- A senhorita é maior?

- Quer ver minha carteira de identidade?

- Eu gostaria.

Ela era maior. Ele olhou com atenção se a data não era falsificada. Parecia que não era. Devolveu a carteira de identidade e pegou a valise.

- Venha, a senhorita vai se instalar.

- O senhor já tomou o café da manhã?

Ele fez sinal que não.

- Cuidado para não quebrar o pescoço, disse ele.

$\mathrm{O}$ barranco descia em forte inclinação. 
l'eau.

- Et de ne pas vous foutre à

Ils passaient sur la planche passerelle au-dessus du bourbier. La jeune fille majeure dit :

- De loin, c'est chouette, mais de près c'est dégueulasse.

- L'eau paraît un peu sale, mais elle n'est pas stagnante. Ce ne sont pas toujours les mêmes ordures qu'on voit. Des fois, je les pousse avec un bâton, elles s'en vont au fil de l'eau. De ce côté-là, tout de même, en effet, ça croupit un peu.

Puis :

- Vous cognez pas la tête. Voilà, ça sera votre cabine, c'était celle de ma fille. C'est pas grand, mais sur les bateaux, vous savez, la place est toujours limitée. Je ne parle pas des transats comme on en montre au cinéma.

- À propos, ici, y a la tévé ?

- Non.

- Et mon feuilleton alors?

-Qu'est-ce que vous voulez que je vous dise?

- Ça remet tout en question.

- Je vous comprends. Albert ne vous avait pas prévenue?

- Vous n'allez pas me dire que vous n'avez pas les moyens de [146] vous payer une tévé !

- Je ne vous force pas à rester. Je remonte votre valise?

- Laissez. Tant pis pour le feuilleton. $\mathrm{Au}$ fond, je le trouve plutôt tarte. Mais vous savez ce que c'est. L'habitude. Soixante-six semaines que ça dure. Tant pis.

- Je vous laisse. La salle de bains se trouve là et le petit coin à côté.

- Vous bilez pas. Je me ramène dans cinq minutes pour préparer votre petit déjeuner.
- E para não cair na água.

Eles passavam pela passarela sobre o lodaçal. A moça maior diz:

- De longe é bacana, mas de perto é nojento.

- A água parece um pouco suja, mas não é estagnada. Não é sempre o mesmo lixo que a gente vê. Às vezes, eu o empurro com um pau, ele vai embora na correnteza. Desse lado aí, mesmo assim, realmente, está apodrecendo um pouco.

Depois:

- Num vai batê a cabeça. Olhe, essa será a sua cabina, era a da minha filha. Num é grande, mas nos navios, sabe como é, o espaço é sempre limitado. Não falo dos transatlânticos como os que mostram no cinema.

- Por falá nisso, aqui tem tevê?

- Não.

- E minha novela então? eu diga?

- O que a senhorita quer que

- Isso coloca tudo em questão.

tinha avisado?

- Entendo. Alberto não

- Não me diga que o senhor não tem condição de comprar uma tevê!

- Eu não a obrigo a ficar. Quer que eu leve sua valise de volta?

- Deixe. Azar da novela. No fundo, eu acho ela besta. Mas sabe como é. O costume. Setenta semanas ela dura. Azar dela.

- Vou deixá-la sozinha. O chuveiro é lá e a casinha ao lado.

- Não se preocupe. Eu me apronto em cinco minutos para preparar seu café da manhã. 
Cidrolin remonta sur le pont et s'étendit sur sa chaise longue en attendant les événements ; mais il ne tarda pas à fermer les yeux.

- Noble époux, dit Russule, en baisant respectueusement sa main, j'ai bien grande et joyeuse nouvelle à vous annoncer: vous allez avoir un héritier.

- Bravo, ma chère! Et quelle goule vont faire mes gendres. Mais... dites-moi, aimable Russule, comment savez-vous que c'est un héritier?

- L'astrologue me l'a dit.

- Quel astrologue ?

- Un astrologue que j'ai consulté. Et, pour qu'il surveille les étoiles au moment de la parturition, je l'ai installé dans le châtiau. Sous réserve de votre aimable autorisation, naturellement, noble époux.

- Diable, dit le duc dans sa barbe, moi qui ramène un alchimiste, cela va faire du monde.

- Ma décision vous déplairait-elle ? demanda Russule en baissant les yeux.

- Nenni, nenni, ma chère. Nenni soit qui mal y pense. Qu'en dis-tu, Empoigne? Ne rapporté-je point en notre province le plus pur suc de l'esprit de la cour? Je rentre

[147] bel esprit jusqu'au bout des ongles. Le sire de Ciry n'a qu'à bien se tenir : je le calembourderai de telle façon qu'il en perdra sa morgue. Et mon évêque ? Qu'on m'amène mon évêque ! Il faut que je lui présente mon alchimiste. Où est mon alchimiste? Qu'on m'amène mon alchimiste! Et mon héritier! c'est vrai, mon héritier. Où est-il mon héritier?

Il fait semblant de chercher autour de lui. Il tapote le ventre de
Cidrolin voltou para o
convés e se estendeu na espreguiçadeira aguardando os acontecimentos; mas não tardou a fechar os olhos.

- Nobre esposo, disse

Russula, beijando-lhe respeitosamente a mão, tenho uma notícia muito grande e alegre para lhe anunciar: o senhor vai ter um herdeiro.

- Parabéns, minha querida! Quero ver a cara que vão fazer meus genros. Mas... diga-me, amável Russula, como a senhora sabe que é um herdeiro?

- O astrólogo me disse.

- Que astrólogo?

- Um astrólogo que eu consultei. E, para que ele observe as estrelas no momento da parturição, eu o instalei no castelo. Sob condição de sua amável autorização, naturalmente, nobre esposo.

- Diabo, disse o duque para si mesmo, eu que trouxe um alquimista, vai ser gente demais. - Minha decisão o desagrada? perguntou Russula baixando a voz.

- Não, minha querida, está tudo certo. Quem com certo fere com certo será ferido. O que você diz disso, Empoigne? Eu não trouxe para nossa província a mais pura essência do humor da corte? Estou voltando com bom humor até a ponta dos cabelos. O sir de Ciry que me aguarde: vou trocadilhá-lo de tal maneira que ele vai perder a pose. E meu bispo? Que tragam o meu bispo! Tenho que apresentarlhe meu alquimista. Onde está meu alquimista? Que tragam o meu alquimista! E meu herdeiro! é verdade, meu herdeiro. Onde está o meu herdeiro?

Ele finge procurar em volta. Ele dá tapinhas na barriga de 
Russule :

- Il est là, mon héritier. Il se cache là, mon héritier. Charmante cachette. Ah, Russule, quel grand plaisir tu me fais et, moi aussi, je vais te faire un grand plaisir.

- Je vous écoute, noble époux.

- Je vais avoir ma statue. Et, tudieu, une statue équestre. On l'érigera devant l'orme, en face du pont-levis. Le sieur Francavilla m'a tiré le portrait et ce sieur Francavilla est un fameux sculteur qui est pour quelque chose dans la statue du bon roi Henri le quatrième qui se trouve sur le Pont Neuf...

- Que je regrette de ne l'avoir pas vue, dit Russule en soupirant.

- Ne crains rien, femme. Elle ne se sauvera pas. Je t'emmènerai la voir lors des prochains États généraux et cela ne saurait tarder, car la Reine Mère a grand besoin d'argent, donc d'impôts.

- Mille mercis, noble époux, dit Russule en faisant la révérence.

- Mais revenons à ma statue. Je serai donc à cheval, sur Sthène naturellement dont le sieur Francavilla a tiré également un portrait bien fidèle. Sthène en était fort satisfait; quand on le lui

[148] montra, il hennit. Hennit soit qui mal y pense.

- Ah, ah, dit Empoigne.

- Il aura aussi sa statue, dit le duc à Russule en désignant du doigt Mouscaillot. Une petite. Pendant que j'y étais. Pas pour lui (nouveau geste), mais pour que le brave Stèphe ne soit pas jaloux.

- Et moi, dit Russule en
Russula:

- Ele está aí, meu herdeiro. Está escondido aí, meu herdeiro. Esconderijo encantador. Ah, Russula, que prazer você me dá e, eu também, vou lhe dar um grande prazer.

- Estou ouvindo, nobre esposo.

- Vou ter minha estátua. E, por Deus, uma estátua equestre. Vão erigi-la diante do olmo, na frente da ponte levadiça. $O$ senhor Francavilla tirou meu retrato e esse senhor Francavilla é um famoso escultor que teve alguma coisa a ver com a estátua do bom rei Henrique quarto que se encontra na Ponte Nova...

- Que eu sinto tanto não ter visto, disse Russula suspirando.

- Não tenha medo, mulher. Ela não vai fugir. Eu a levarei para vê-la por ocasião dos próximos Estados Gerais e não vai demorar, pois a Rainha Mãe tem muita necessidade de dinheiro, portanto de impostos.

- Mil agradecimentos, nobre esposo, diz Russula fazendo reverência.

- Mas voltemos à minha estátua. Estarei pois a cavalo, em Stenes naturalmente do qual o senhor Francavilla também tirou um retrato bem fiel. Stenes ficou mui satisfeito; quando lhe mostraram ele disse: esse pintor é fera. Quem com fera fere com fera será ferido.

- Ah, ah, disse Empoigne.

- Ele também terá sua estátua, disse o duque a Russula apontando Mouscaillot com o dedo. Uma pequena. Enquanto eu estava lá. Não por ele (novo gesto), mas para que o bravo Estêvão não fique com ciúme.

- E eu, disse Russula 
baissant les yeux, ne l'aurai-je point ma statue?

- Si donc, femme. J'y ai pensé. Dans notre chapelle, vous aurez un magnifique tombeau bien plus beau encore que celui de ma défunte Élodie. On vous y verra sculptée dans la pierre. Moi je préfère le bronze.

Comme Russule s'inclinait, le duc lui dit :

- Inutile de me remercier. C'est tout naturel. $\mathrm{Ah}$ voilà l'astrologue, je pense. Approche. Comment t'appelles-tu ?

- Dupont. Pour vous servir, mon seigneur.

- Et tu lis dans les étoiles?

- Pour vous servir, mon seigneur.

- Et tu as vu que j'aurai un héritier?

- Pour vous servir, mon seigneur.

Le duc se tourna vers Russule et lui dit :

- C'est un con, votre astrologue.

Il reprit le dialogue avec Dupont en ces termes : cette nuit?

- Tu as regardé les étoiles seigneur.

- Pour vous servir, mon

-Et qu'est-ce qu'elles t'ont raconté ?

-Gloriam Dei, mon seigneur. Gloriam Dei.

- C'est tout?

- Comment, mon seigneur, s'écria l'astrologue avec un beau mouvement oratoire, vous ne trouvez pas que cela soit beaucoup, la gloire de Dieu ?

- Pour la gloriam Dei, j'ai mon évêque qui est tout à fait

[149] compétent sur la question. Parlemoi plutôt de ta spécialité.

- J'ai entendu la musique baixando os olhos, não terei minha estátua?

- Claro que sim, mulher. Eu pensei nisso. Na nossa capela, a senhora terá uma magnífica tumba bem mais bela ainda que a da minha finada Elodie. A senhora será vista esculpida em pedra. Pra mim, prefiro o bronze.

Como Russula se inclinava, o duque disse-lhe:

- Não precisa agradecer. É muito natural. Ah eis o astrólogo, acho. Aproxime-se. Como você se chama?

- Da Ponte. Para servi-lo, meu senhor.

- E você lê nas estrelas?

- Para servi-lo, meu senhor. herdeiro?

- E você viu que terei um

- Para servi-lo, meu senhor.

O duque virou para Russula é disse-lhe

- É um babaca, esse seu astrólogo.

Ele retomou o diálogo com da Ponte nestes termos:

- Você olhou as estrelas esta noite?

- Para servi-lo, meu senhor.

- E o que é que elas lhe contaram?

- Gloriam Dei, meu senhor. Gloriam Dei.

- Só isso?

- Como, meu senhor, exclamou o astrólogo com um belo movimento oratório, o senhor não acha que é muito, a glória de Deus?

- Para a gloriam Dei, eu tenho meu bispo que é muito competente nessa questão. Prefiro que você me fale de sua especialidade.

- Eu ouvi a música das 
des sphères.

- Et ça faisait quel bruit?

Divin.

- Divin, mon seigneur.

Le duc, écœuré, se tourna vers Russule.

- Il est tout à fait idiot.

Il mit de nouveau la main sur le ventre de la noble dame et reprit l'entretien avec l'astrologue :

- Et qu'est-ce qui doit sortir de là ? une biquette ou un héritier ?

- Un héritier, mon seigneur.

- Tu en es sûr et certain ?

- Les astres ne mentent pas.

- Mais toi, tu n'es pas un astre. Or quel homme n'a jamais menti ? C'est courant, le mensonge, tellement courant que c'est un péché du catéchisme. $\mathrm{Si}$ Monseigneur Biroton, évêque in partibus de Sarcellopolis, était là, il te le dirait tout de suite. Or tu as intérêt à mentir. Tu as trouvé ici le gîte et le couvert et tu te goberges à mes dépens. Tu croyais tomber sur un hobereau crédule comme une femme (geste du côté de Russule), et tu te trouves en face d'un noble seigneur qui vient de passer six mois à la Cour et dans la ville capitale, de quelqu'un qui prit la parole aux États généraux, et à qui l'on eut bien du mal à la reprendre, enfin, bref, Dupont, pars !

Russule se jette aux pieds du duc et le supplie en ces termes :

- Noble époux, moi qui étais si fière d'avoir un astrologue tout comme la reine Catherine. Je pensais à votre prestige... à votre standigne...

- Mais, ma chère, lui répondit le duc en s'énervant [150] quelque peu, c'est que je ramène un alchimiste de la ville capitale, d'Arcueil plus exactement. Je ne esferas.

- E que som ela tinha?

- Divino, meu senhor.

Divino.

$\mathrm{O}$ duque, furioso, virou-se para Russula.

- É completamente idiota.

Ele pôs de novo a mão na barriga da nobre dama e retomou a conversa com o astrólogo:

- E o que é que vai sair daqui? uma cabritinha ou um herdeiro?

- Um herdeiro, meu senhor.

- Você está certo e seguro?

- Os astros não mentem jamais.

- Mas você não é um astro. Ora, que homem nunca mentiu? A mentira é comum, tão comum que é um pecado do catecismo. Se o Monsenhor Biroton, bispo in partibus de Sarcelópolis, estivesse aqui, ele lhe diria isso agora mesmo. Ora, você tem interesse em mentir. Você encontrou aqui casa e comida e se trata bem às minhas custas. Você pensava lidar com um fidalguinho crédulo como uma mulher (gesto para o lado de Russula), mas você está diante de um nobre senhor que acaba de passar seis meses na Corte e na cidade capital, de alguém que tomou a palavra nos Estados Gerais, e de quem tiveram muita dificuldade de retomá-la, enfim, resumindo, da Ponte, fora!

Russula joga-se aos pés do duque e suplica-lhe nestes termos:

- Nobre esposo, eu que estava tão orgulhosa de ter um astrólogo igual à rainha Catarina. Eu pensava em seu prestígio... em seu status...

- Mas, minha cara, responde-lhe o duque enervando-se um pouquinho, é que eu trago um alquimista da cidade capital, de Arcueil mais precisamente. Não 
vais pas entretenir une nuée de nécromants. Moi, je préfère de beaucoup l'alchimiste; lorsqu'il m'aura trouvé la pierre philosophale...

Fumisterie ! s'écria Dupont.

- Toi, dit le duc, tu es un mauvais camarade. C'est très vilain de débiner le métier d'un confrère. Tu ne me plais pas.

Monseigneur Biroton parut, suivi de l'abbé Riphinte. Tous les deux reçurent de grandes embrassades de la part du duc, qui explique aussitôt la situation à l'évêque et lui demande conseil.

- Chassez-les tous les deux, dit Onésiphore.

- Tout de suite les exagérations! s'écria le duc. Je veux en garder un, moi.

- Moi aussi, dit Russule.

Le chapelain, bien ennuyé, se gratta la tête.

- Eh bien, demande le duc.

Qu'en dis-tu? L'astrologue? L'alchimiste? Biroton.

- Tout cela sent le fagot, dit

L'astrologue se tourna vers lui.

- Je suis un bon chrétien, dit-il. Ne m'avez-vous pas reçu en confession?

- C'est exact, dit l'évêque.

Le duc était de plus en plus écœuré :

- Ce qu'il peut être lèchecul, ce bonhomme. Décidément, il ne me plaît pas du tout.

- Il ne manque pas de piété, dit Onésiphore, et puis, après tout, ce n'est pas un péché de regarer les étoiles.

- Je trouve cela poétique, même, susurra Russule.

[151] - Et, ajouta l'abbé Riphinte, le sieur Dupont ne professe point l'hérétique doctrine du Polonais vou sustentar um enxame de necromantes. E prefiro, e muito o alquimista; quando ele tiver encontrado a pedra filosofal...

- Baboseira! exclamou da Ponte.

- Você, disse o duque, você é um mau colega. É muito feio falar mal do trabalho de um colega. Não gosto de você.

Monsenhor Biroton apareceu, seguido do abade Rifinge. Os dois receberam beijos efusivos da parte do duque, que logo explica a situação ao bispo e pede-lhe conselho.

- Expulse os dois, disse Onesíforo.

- Sempre exagerado! exclama o duque. Eu quero ficar com um.

- Eu também, disse Russula.

O capelão, muito aborrecido, coça a cabeça.

- E aí, pergunta o duque. O que você diz? O astrólogo? O alquimista?

- Tudo isso cheira a heresia, disse Biroton.

$\mathrm{O}$ astrólogo vira-se para ele.

- Eu sou um bom cristão, disse ele. $\mathrm{O}$ senhor não me ouviu em confissão?

- É verdade, disse o bispo.

O duque estava cada vez mais furioso:

- Como pode ser tão puxasaco, esse palerma. Decididamente, não gosto dele.

- Não lhe falta piedade, disse Onesíforo, e depois, no fim das contas, não é pecado olhar as estrelas.

- Eu acho até poético, sussurrou Russula.

- E, acrescentou o abade Rifinge, o senhor da Ponte não professa a herética doutrina do 
Copernic. C'est un bon point, cela.

- Copernic soit qui mal y pense, dit le duc distraitement.

- Ah, ah, dit Empoigne.

- Le soleil tourne autour de la terre, déclama l'astrologue, et bien fol et bien malicieux celui qui prétend le contraire.

- Comme il est savant, resusurra Russule. J'aurai sûrement un héritier.

- Il cherchent tous à m'embobiner, dit le duc d'un air ronchon.

- L'alchimie est recherche bien noire, reprit Onésiphore qui voyait la partie gagnée par la duchesse et son devin. Les feux de ses fourneaux évoquent ceux de l'Enfer et le désir de l'or est chose bien condamnable. Quant à l'élixir de longue vie, cela me rappelle que le démon dit à nos premiers parents: eritis sicut dei, en leur conseillant de manger cette pomme prétendue elle aussi de longue vie...

- Hm, dit l'abbé Riphinte.

- ... et vous savez tous ce qu'il est ensuite advenu.

- Amen, dit Dupont.

- Amen, reprirent également

Russule, Empoigne et l'abbé Riphinte.

Le duc ne dit rien. Il regarde l'astronome d'un sale œil et commence à s'impatienter, mais il ne le montre pas trop encore. Dupont, qui croit l'affaire cuite, se met à pérorer :

- O puissances célestes qui gérez les fortunes de ce monde, je [152] vous vois apportant vos dons et vos bénédictions au sublime héritier que va bientôt procréer le très fameux et très illustre duc polonês Copérnico. Isso é um ponto importante.

- Quem Copérnico fere, com pérnico será ferido, disse o duque distraidamente.

- Ah, ah, disse Empoigne.

- O sol gira em torno da terra, declamou o astrólogo, e bem louco e bem malicioso quem pretende o contrário.

- Como ele é sábio, ressussurrou Russula. Com certeza terei um herdeiro.

- Todo o mundo está tentando me enrolar, disse o duque com ar amuado.

- A alquimia é uma pesquisa bem negra, retomou Onesíforo que via a partida ganha pela duquesa e seu adivinho. Os fogos de seus fornos evocam os do Inferno e o desejo do ouro é coisa muito condenável. Quanto ao elixir da longa vida, me lembra o que o demônio disse a nossos primeiros pais: eritis sicut dei, aconselhandoos a comer aquela maçã considerada ela também de longa vida...

- Hm, disse o abade Rifinge.

- ... e vocês todos sabem no que deu.

- Amém, disse da Ponte. Amém, retomaram igualmente Russula, Empoigne e o abade Rifinge.

O duque não diz nada. Olha o astrônomo com um olhar fulminante e começa a perder a paciência, mas não o demonstra muito ainda. Da Ponte, que achava que a vitória estava no papo, põe-se a perorar:

- Oh forças celestes que governam os destinos deste mundo, eu vos vejo trazendo vossos dons e vossas bênçãos ao sublime herdeiro que logo vai gerar o mui famoso e mui ilustre duque de Auge... 
d'Auge...

- Comment, s'écrie le très fameux et très illustre duc d'Auge, comment : ... va bientôt... Alors, femme, vous n'êtes point enceinte?

- Point encore, noble époux, mais vous y porvoirez.

Et Russule baisse modestement les yeux, toute rosissante.

Le très fameux et très illustre duc d'Auge saute à la gorge de Dupont et commence à l'étrangler de ses deux puissantes mains. L'astrologue semble vouloir expulser ses yeux hors des orbites et tire une langue pâlote, tandis que Joachim lui explique ses griefs et lui fait part de son mépris pour les imposteurs.

Et il le secoue avec énergie tout en serrant de plus en plus fort. Russule se jette à ses pieds en implorant sa piété. Onésiphore demande à l'abbé Riphinte de lui apporter le nécessaire pour administrer l'extrême-onction à la victime. Le vicomte d'Empoigne se maintient fermement dans une attitude d'extrême prudence.

- Ah coquin! coquin! ne cesse de répéter le duc tandis que l'autre vire au violet.

- Grâce pour lui, noble époux, clame la duchesse, grâce pour lui !

- Allons, voyons, messire, dit Onésiphore sur un ton de doux reproche, un peu de modération ; je ne vais pas avoir le temps de lui donner les derniers sacrements.

Dupont va survivre à cette dure épreuve. Le duc finit par le lâcher encore vif et l'autre coule

[153] par terre comme fromage mol: on s'empresse de le balayer tandis que l'alchimiste, qui vient d'arriver, salue bien bas son hôte.
- Como, exclama o mui famoso e mui ilustre duque de Auge, como: ... logo vai... Então, mulher, a senhora não está grávida?

- Não ainda, nobre esposo, mas o senhor proverá.

E Russula baixa
$\begin{aligned} & \text { modestamente os olhos, toda } \\ & \text { corada. }\end{aligned}$

O mui famoso e mui ilustre duque de Auge salta no pescoço de da Ponte e começa a estrangulá-lo com suas duas possantes mãos. $\mathrm{O}$ astrólogo parece querer expulsar seus olhos para fora das órbitas e estende uma língua esbranquiçada, enquanto Joaquim explica-lhe suas reclamações e participa-lhe seu desprezo pelos impostores.

E ele o sacode com energia ao mesmo tempo em que aperta cada vez mais. Russula joga-se a seus pés implorando sua piedade. Onesíforo pede ao abade Rifinge para lhe trazer o necessário para administrar a extrema unção à vítima. $\mathrm{O}$ visconde de Empoigne mantém-se firmemente numa atitude de extrema prudência. - Ah canalha! canalha! não para de repetir o duque enquanto o outro vai tendendo ao violeta.

- Piedade para ele, nobre esposo, clama a duquesa, graça para ele!

- Vamos, vamos, senhor, disse Onesíforo num tom de suave reprimenda, um pouco de moderação; não vou ter tempo de lhe dar os últimos sacramentos.

Da Ponte vai sobreviver a esta dura provação. $\mathrm{O}$ duque acaba por soltá-lo ainda vivo e o outro escorre para o chão como queijo mole: apressam-se em varrê-lo enquanto o alquimista que acaba de chegar, curva-se bem baixo e saúda o seu anfitrião. 
Le duc manifeste une entière satisfaction.
O duque manifesta uma grande satisfação. 
Cidrolin ouvrit les yeux; on lui parlait doucement à l'oreille.

[154] C'était Lalix qui lui annonçait que le déjeuner était servi.

- Eh bien, ajouta-t-elle, vous avez vachement roupillé. Comme ça, vous avez sauté le petit déjeuner, mais je pouvais pas vous laisser dormir toute la journée, et je vous ai préparé un bon repas.

Cidrolin la regardait distraitement: comme c'était un souvenir récent, il ne la reconaissait pas encore très bien.

- J'en ai fait des rêves, murmura-t-il pour lui-même.

- Faut pas les raconter.

- Et pourquoi pas?

demanda Cidrolin intéressé.

- Ça ne se fait pas.

- Pourquoi donc ?

Elle se contenta de répondre :

- À table, à table.

Il faisait encore assez beau temps, la table était installée sur le pont. Un couvert était mis.

-Vous avez déjeuné ?

demanda Cidrolin.

- Oui, msieu.

- La prochaine fois, vous m'attendrez et vous mettrez un second couvert.

-Vsêtes gentil. Merci, msieu.

Cidrolin se dirigea vers la cambuse. Lalix se précipita.

- Vous désirez quelque chose?

- L'essence de fenouil.

- Vous allez vous taper de l'essence de fenouil avant déjeuner?

- Comme d'habitude.

- C'est malsain.

Cidrolin rit doucement.

- C'est vrai, reprend Lalix. C'est très malsain.
Cidrolin abriu os olhos; estavam-lhe falando baixinho no ouvido. Era Aalice anunciando que o almoço estava servido.

- Bom, acrescentou ela, o senhor dormiu demais. Por isso, pulou o café da manhã, mas eu num podia deixá o senhor dormir o dia inteiro, e preparei uma boa refeição.

Cidrolin olhava-a distraidamente: como era uma lembrança recente, ele ainda não a reconhecia muito bem.

- Eu estava tendo sonhos, murmurou ele para si mesmo.

- Num se deve contá.

- E por que não? perguntou

Cidrolin interessado.

- Isso não se faz.

- Mas por que?

Ela contentou-se em responder:

- Para a mesa, para a mesa.

O tempo ainda estava bom, a mesa tinha sido instalada no convés. Um lugar estava posto. - A senhorita já almoçou? perguntou Cidrolin.

- Sim, sinhor.

- Na próxima vez, a senhorita me espera e põe mais um lugar.

- O sinhor é muigentil. Brigada.

Cidrolin dirigiu-se à despensa. Aalice precipitou-se.

- O senhor quer alguma coisa?

- A essência de funcho. - O senhor vai se encher de essência de funcho antes do almoço?

- Como sempre.

- Isso faz mal.

Cidrolin riu baixinho.

- É verdade, retoma Aalice. Isso faz muito mal. 
- Si vous voulez aller faire votre valise, dit Cidrolin, je ne vous en empêche pas. Je vous paierais même un mois de gages si vous décampiez sur l'heure.

- Je ne tiens pas à ce que vous perdiez votre argent, dit Lalix.

Cidrolin va chercher la bouteille d'essence de fenouil et s'en verse un quart de verre qu'il complète avec de l'eau plate. Tout en buvant, il regarde vaguement une équipe d'aviron qui s'entraîne.

Quand son verre est vide, Lalix lui dit :

- Je peux servir?

- Allez-y.

Elle apporte du beurre et une boîte de filets de thon à l'huile d'arachide pure. Elle regarde Cidrolin manger.

- Ça m'agace que vous me regardiez comme ça, dit Cidrolin. Asseyez-vous et racontez-moi des histoires.

- Vous me prenez pour Schéhérazade, dit Lalix.

[156] - Eh, eh, dit Cidrolin. On a de l'instruction.

- Ça ne gâte rien. Vous ne trouvez pas?

- Tout à fait d'accord.

-Ah, fait Lalix d'un air satisfait.

- Vous avez de l'instruction, dit Cidrolin, et vous avez aussi des principes: ne pas boire de l'essence de fenouil avant déjeuner, ne pas raconter ses rêves. Au fait, pourquoi ne pas raconter ses rêves?

- C'est mal élevé, dit Lalix.

- La première fois que j'entends ça, dit Cidrolin.

- Les gens, continue Lalix, ils se croient des petites merveilles, tout ce qu'ils font, tout ce qu'ils sont. Ils s'attribuent une importance... Alors s'il fallait, par-
- Se a senhorita quiser fazer sua mala, diz Cidrolin, não a impeço. Pagarei um mês de salário, mesmo que você vá embora agora.

- Não quero que o senhor perca seu dinheiro, diz Aalice. Cidrolin vai buscar a garrafa de essência de funcho e enche um quarto de copo que completa com água sem gás. Enquanto bebe, olha vagamente uma equipe de remo que está treinando.

Quando o copo fica vazio, Aalice diz:

- Posso servir?

- Vá em frente.

Ela traz manteiga e uma lata de filés de atum ao óleo de amendoim puro. Ela olha Cidrolin comer.

- Me irrita a senhorita ficar me olhando assim, diz Cidrolin. Sente-se e conte-me histórias.

- O senhor acha que sou Sherazade, diz Aalice.

- Ora, ora, diz Cidrolin. Temos instrução, hein?

- Isso não faz mal nenhum. Não acha?

- Totalmente de acordo.

- Ah, faz Aalice com ar satisfeito.

- A senhorita tem instrução, diz Cidrolin, e tem princípios também: não beber essência de funcho antes do almoço, não contar os sonhos. A propósito, por que não contar os sonhos?

- É mal educado, diz Aalice. - É a primeira vez que ouço isso, diz Cidrolin.

- As pessoas, continua Aalice, se acham pequenas maravilhas, tudo o que fazem, tudo o que são. Elas se dão uma importância... Então se fosse 
dessus, encaisser le récit de leurs rêves, on n'en finirait plus.

- Mes rêves sont particulièrement intéressants, dit Cidrolin.

- Tout le monde croit ça. Rien ne le prouve puisqu'on ne peut pas les comparer.

- Les miens, dit Cidrolin, si je les écrivais, ça serait un vrai roman.

- Et vous ne croyez pas qu'il y en a assez comme ça des romans?

- Ne craignez rien, dit Cidrolin. Je ne suis pas un travailleur de l'écritoire.

- Oh mais, je ne crains rien.

- Vous voyez, dit Cidrolin, quand vous m'avez dit qu'il ne fallait pas raconter ses rêves, j'ai cru que c'était à cause de la psychanalyse et des psychanalystes.

- La quoi?

- La psychanalyse. Vous ne

[157] savez pas ce que c'est?

- Non.

- Je croyais que vous aviez de l'instruction.

- On ne peut pas tout savoir, dit Lalix.

- Comme c'est vrai.

Et, puisqu'il avait terminé les filets de thon, Cidrolin s'enquit de la suite en ces termes :

- Qu'est-ce qu'il y a après ? Ça ira?

- Une boîte de pâté de foie.

- Sans vouloir vous vexer, dit Cidrolin, j'en aurais fait autant.

- Monsieur Albert m'avait dit que vous étiez de bonne composition, mais vous râlez tout le temps.

- Bah, fait Cidrolin. C'était juste une petite critique.

- N'en parlons plus. preciso, ainda por cima, suportar o relato dos seus sonhos, não ia acabar nunca.

- Meus sonhos são particularmente interessantes, diz Cidrolin.

- Todo mundo pensa assim. Nada pode provar, já que não se pode compará-los.

- Os meus, diz Cidrolin, se eu os escrevesse, seria um verdadeiro romance.

- E o senhor não acha que já tem romances suficientes?

- Não tenha medo, diz Cidrolin. Não sou um trabalhador do escritório.

- Oh mas eu não tenho medo de nada.

- Veja, diz Cidrolin, quando a senhorita me disse que não se devia contar os sonhos, pensei que fosse por causa da psicanálise e dos psicanalistas.

- Da o quê?

- Da psicanálise. Não sabe o que é?

- Não.

- Eu pensava que a senhorita tivesse instrução.

- Não se pode saber tudo, diz Aalice.

- Como isso é verdade.

E, já que tinha terminado os filés de atum, Cidrolin informou-se da continuação nesses termos:

- O que mais tem?

- Uma lata de patê de fígado. Está bom?

- Sem querer ofendê-la, diz Cidrolin, isso eu mesmo teria feito.

- O senhor Alberto tinha me dito que o senhor era de boa disposição, mas o senhor resmunga o tempo todo.

- Bah, faz Cidrolin. É só uma pequena crítica.

- Não se fala mais nisso. 
Elle apporte donc la boîte de pâté de foie.

- Je me rassois ? demande-telle.

- Bien sûr.

Cidrolin, mélancoliquement, silencieusement, se tartine du pâté de foie.

- Alors, dit Lalix, ce truc dont vous me parliez tout à l'heure. À propos de rêves.

- La psychanalyse?

- Voilà.

- Et les psychanalystes?

- Voilà.

- Eh bien, dit Cidrolin en mâchant laborieusement son sandouiche, ce sont des gens qui interprètent les rêves. Et ça va loin. Ils découvrent le fin fond des choses. Enfin, des gens. Alors il y a justement des gens qui se méfient, qui ne veulent pas qu'on découvre leur fin fond, alors ils ne racontent plus leurs rêves. Lalix.

- Personne n'y perd rien, dit contre.

- Vous êtes décidément

- Contre quoi?

- Raconter ses rêves.

- Je vous l'ai déjà dit: je trouve ça mal élevé, et, pour ainsi dire, malpropre.

- Je me ferai une raison.

Il achève son pâté de foie en regardant distraitemet un pêcheur, sur l'autre rive, qui amarre sa barque à un piquet et prépare son matériel ; il est accompagné d'un chien qui le regarde lui aussi.

Lalix à Cidrolin.

- Vous pêchez? demande

À la rigueur elle aurait pu poser la même question au bonhomme en face, mais il aurait fallu qu'elle utilise un porte-voix.
Ela traz então a lata de patê de fígado.

- Sento novamente?

pergunta ela.

- Claro.

Cidrolin, melancolicamente, silenciosamente, passa patê de fígado no pão.

- E então, diz Aalice, aquele negócio de que o senhor me falava agora há pouco. Sobre os sonhos.

- A psicanálise?

- Isso.

- E os psicanalistas?

- Isso.

- Bem, diz Cidrolin mastigando laboriosamente seu sanduíche, são pessoas que interpretam os sonhos. E isso vai longe. Eles descobrem o fundo profundo das coisas. Isso é, das pessoas. Então justamente há pessoas que desconfiam, que não querem que se descubra seu fundo profundo, então elas não contam mais seus sonhos.

- Ninguém perde nada com isso, diz Aalice.

- A senhorita é decididamente contra.

- Contra o que?

- Contar os sonhos.

- Eu já disse: acho isso mal educado, e, por assim dizer, indecente.

- Desisto.

Ele termina o patê de fígado olhando distraidamente um pescador, na outra margem, que amarra a barca numa estaca e prepara o material; ele está acompanhado de um cão que também o olha.

- O senhor pesca? pergunta Aalice a Cidrolin.

A rigor ela poderia ter feito a mesma pergunta ao indivíduo que estava em frente, mas seria preciso que ela tivesse usado um megafone. 
- Non, répondit Cidrolin, et naturellement pas le pêcheur en face qui ne pouvait entendre et qui aurait d'ailleurs répondu: oui. Je n'aime pas ça. C'est cruel.

- C'est surtout idiot : rester comme ça à ne rien faire.

- Et qu'est-ce qu'il y a maintenant pour terminer cet excellent repas?

- Un bout de fromage et le fond d'un pot de confiture.

- Merveilleux, dit Cidrolin.

Le pêcheur a lancé sa ligne ; il allume une cigarette et fume, l'air absent. Le chien s'est couché en rond et dort.

- Ça va bientôt être l'heure de ma sieste, observe Cidrolin pour lui-même.

Lalix a apporté la conclusion de l'excellent repas et s'est assise de sa propre initiative, cette fois-ci.

- Alors, Schéhérazade, dit Cidrolin mastiquant le fromage rance tout en prévoyant que les confitures seraient moisies, vous ne me racontez pas d'histoires ?

inventées?

- Des vraies ou des - Méfiez-vous des inventées. Elles révèlent ce que vous êtes au fond. Tout comme les rêves. Rêver et révéler, c'est à peu près le même mot.

- Et les vraies, elles révèlent tout aussi bien ce qu'on est dans le fond. Vous ne trouvez pas?

- Si vous me racontez l'histoire de quelqu'un d'autre...

- Pourquoi je la raconterais si elle ne m'intéresse pas et, si elle m'intéresse, c'est comme si c'était moi.

- Alors vous ne voulez rien me raconter?

- Je ne sais pas moi. Vous êtes tournipilant à la fin. Vous êtes pas du tout comme monsieur
- Não, respondeu Cidrolin, e naturalmente não o pescador em frente que não podia ouvir e que aliás teria respondido: sim. Eu não gosto. É cruel.

- Mais que tudo é idiota: ficar assim sem fazer nada.

- E o que tem agora para terminar esta excelente refeição?

- Um resto de queijo e o fundo de um pote de geléia.

- Maravilha, disse Cidrolin.

O pescador lançou a linha; ele acende um cigarro e fuma, com ar ausente. $\mathrm{O}$ cão deita-se enrodilhado e dorme.

- Logo vai ser hora da minha sesta, observa Cidrolin para si mesmo.

Aalice trouxe a conclusão da excelente refeição e sentou-se por iniciativa própria, dessa vez.

- Então, Sherazade, diz Cidrolin mastigando o queijo rançoso já prevendo que a geléia estaria embolorada, a senhorita não me conta histórias?

inventadas?

Verdadeiras ou

- Desconfie das inventadas. Nelas pode-se sondar o que se é no fundo. Exatamente como os sonhos. Sonhar e sondar, é quase a mesma palavra.

- E as verdadeiras, elas também revelam o que se é no fundo. O senhor não acha?

- Se a senhorita me contar a história de alguma outra pessoa...

- Por que eu a contaria se ela não me interessa e, se ela me interessa, é como se fosse minha.

nada?

- Então não quer me contar

- Não sei. O senhor não para de dar voltas. O senhor não é de jeito nenhum como o senhor 
Albert me vous avait décrit, une espèce de père tranquille pas emmerdant pour un sou.

- Eh bien, tenez, monsieur Albert, racontez-moi comment vous avez fait sa connaissance. Mais avant je dois vous dire que, comme je l'avais prévu, la confiture était moisie.

- Vous voyez que vous râlez tout le temps.

l'habitude.

- Encore un de foutu, j'ai

- Vous n'allez pas pleurer pour des confitures.

- Alors? et monsieur Albert?

- Vous ne voulez pas une tasse de café ?

- Non, non ! s'écria Cidrolin en sursautant. Pas de café !

- Vous avez peur que je vous le fabrique dégueulasse?

- Et ma sieste? cela m'empêcherait de dormir.

- Vous allez encore faire la sieste ? Vous avez roupillé toute la matinée.

- Je m'allonge là, sur cette chaise longue, et vous allez me raconter comment vous avez connu monsieur Albert.

- Pour vous aider à faire dodo ?

- Si je m'assoupis, vous vous arrêtez et vous recommencez une autre fois.

encourageant.

$$
\text { Vous n'êtes pas }
$$

- Allez, Schéhérazade :

l'histoire d'Albert.

- Ben, voilà. Je suis la fille unique d'un père bûcheron .

- Ça me dit quelque chose, ça... une fille de bûcheron...

Vous n'allez pas m'interrompre tout le temps! Sinon, je préfère encore que vous dormiez.
Alberto me descreveu, um tipo de pai tranquilo que não se aborrece por pouco.

- Bom, é isso, o senhor

Alberto, conte-me como o conheceu. Mas antes devo dizer que, como eu tinha previsto, a geléia estava embolorada.

- Olha como o senhor resmunga o tempo todo.

- Mais uma que vai pro brejo, estou acostumado.

- O senhor não vai chorar pela geléia, não é?

- E então? e o senhor Alberto?

- Não quer uma xícara de café?

- Não, não! exclamou Cidrolin sobressaltando-se. Nada de café!

- O senhor tem medo de que eu não saiba fazer?

- E minha sesta? o café me impediria de dormir.

- O senhor ainda vai fazer a sesta? O senhor dormiu a manhã inteira.

- Eu me estendo aqui nesta espreguiçadeira, e a senhorita vai me contar como conheceu o senhor Alberto.

- Para ajudá-lo a fazer naninha?

- Se eu adormecer, a senhorita para e recomeça uma outra vez.

- O senhor não é nada animador.

- Vamos, Sherazade: a história de Alberto...

- Está bem. Eu sou a filha única de um pai lenhador.

- Isso me diz alguma coisa, isso... uma filha de lenhador.

- O senhor não vai ficar me interrompendo o tempo todo! Senão, eu prefiro que durma mesmo 
Cidrolin ne se fait pas faute de lui donner immédiate satisfaction. Le duc se promenait à cheval dans la forêt, silentaire et solicieux. Sthène se taisait également, mais la promenade s'allongeant et la taciturnité ducale ne semblant pas vouloir se dissiper, il finit par ouvrir les lèvres pour demander s'il pouvait parler.

- Parle, mon bon Démo, parle, dit le duc en lui tapotant affectueusement l'encolure.

- Grammercy, dit Sthène avec une vive satisfaction.

Il fit semblant de réfléchir un peu avant de poser la question qui le démangeait depuis un certain temps.

- Hm, hm, fit-il, où en est notre statue?

- Ma foi, répondit le duc, je n'en sais rien.

fondue ?

- Elle n'est pas encore

- Je n'en ai pas eu de nouvelles depuis un certain temps.

[161] Sthène ne cacha pas sa déception. Il crotta de dépit.

- Et, reprit-il, vous ne trouvez pas que vous devriez vous en inquiéter?

- En ce moment, point n'en ai souci.

- Et votre gloire, n'y pensez-vous donc plus? Ne songez-vous donc plus à toutes ces générations futures qui viendront vous contempler bronzé pour l'éternité devant l'orme féodal ? Ne tirez-vous donc plus fierté de savoir que votre qualité de statufié permettra d'insérer votre nom dans toutes les histoires de l'art, point nombreuses certes à notre époque, mais dont le nombre ne cessera de croître dans les siècles à venir. Tudieu, je prophétise, ma parole !

Ayant fait cette constatation, Sthène pique un petit
Cidrolin não deixa de lhe dar satisfação imediata. $\mathrm{O}$ duque passeava a cavalo na floresta, silentário e solicioso. Stenes também estava calado, mas o passeio prolongava-se e como a taciturnidade ducal parecia não querer se dissipar, ele acabou por abrir os lábios para perguntar se podia falar.

- Fale, meu bom Demós, fale, disse o duque dando-lhe um tapa afetuoso no pescoço.

- Tobrigado, disse Stenes com uma grande satisfação.

Ele pareceu refletir um pouco antes de fazer a pergunta que o consumia há um certo tempo.

- Hm, hm, fez ele, como está nossa estátua?

- Meu Deus, respondeu o duque, não sei de nada.

- Ainda não foi fundida?

- Não tenho tido notícias há um certo tempo.

Stenes não escondeu sua decepção. Ele se sujou de despeito.

- E, retomou ele, o senhor não acha que deveria se preocupar com isso?

- Nesse momento, não tenho essa preocupação.

- E sua glória, o senhor não pensa mais nela? Não pensa mais em todas as gerações futuras que virão contemplá-lo bronzeado para a eternidade diante do olmo feudal? Não fica mais orgulhoso em saber que sua qualidade de estatuado permitirá que seu nome seja inserido em todas as histórias da arte, não numerosas certamente em nossa época, mas cujo número não cessará de crescer nos séculos por vir. Meu Deus, estou profetizando, meu Deus!

Tendo feito essa constatação, Stenes começa um 
trot guilleret.

- Tout doux, dit le duc, tout doux.

Sthène reprend le pas de promenade, et, par la même occasion, la parole :

- Mes arguments ne vous convainquent point?

- Mais si, mais si, mon bon Démo. Je vais envoyer Empoigne voir ce qu'il advient de mon effigie.

- Voilà une excellente idée ! Par la même occasion, il pourra s'informer de celle de Stéphe et de la sienne.

- C'est un départ qui risquerait d'attrister la duchesse, dit le duc avec mélancolie.

- Pourquoi n'irait-elle pas, elle aussi ? Elle a tant envie de visiter la ville capitale.

- On jaserait.

- Joignez l'abbé Riphinte à l'expédition et coiffez le tout de

[162] Monseigneur Biroton. Pendant un mois ou deux, vous en serez débarrassé.

- Eh oui. Chaque jour entendre leurs admonitions et admonestations. C'est encore bien beau qu'ils ne me dénoncent pas comme athéiste ou sorcier.

- Ils gueulent pour la forme parce que c'est leur métier, mais si votre alchimiste parvenait à fabriquer l'élixir de longue vie, ils en boiraient bien un petit verre eux aussi.

- Nous n'en sommes pas encore à l'élixir de longue vie, et nous nous contentons pour le moment de la poudre de projection.

- Et ça marche ?

- Je n'en vois pas la fin.

Sthène se tut quelques instants avant de reprendre la parole en ces termes :

- Je commence à me demander, Joachim, si vous eûtes trotezinho alegre.

- Devagar, disse o duque, devagar.

Stenes retoma o passo de passeio, e, na mesma ocasião, a palavra:

- Meus argumentos não o convencem?

- Sim, sim, meu bom Demós. Eu vou mandar Empoigne ver em que pé está minha efígie.

- É uma excelente idéia! $\mathrm{Na}$ mesma ocasião, ele poderá se informar da de Estêvão e da dele.

- É uma partida que poderia entristecer a duquesa, disse o duque com melancolia.

- Por que não iria ela também? Ela tem tanta vontade de visitar a cidade capital.

- Iriam falar mal.

- Junte o abade Rifinge à expedição e coroe tudo com o Monsenhor Biroton. Por um mês ou dois, o senhor estará livre de todos.

- É mesmo. Todo dia ouvir suas advertências e admoestações. $E$ ainda tenho que agradecer que eles não me denunciem como ateu ou feiticeiro.

- Eles falam pró forma porque é a profissão deles, mas se o seu alquimista conseguisse fabricar o elixir da longa vida, eles bem que beberiam um copinho também.

- Ainda não estamos procurando o elixir da longa vida, no momento nós nos contentamos com o pó de projeção.

- E está indo bem?

- Ainda não vejo o fim.

Stenes calou-se alguns instantes antes de retomar a palavra nestes termos:

- Estou começando a me perguntar, Joaquim, se estáveis 
raison d'emmener en votre châtiau le sieur Timoleo Timolei. Depuis qu'il loge chez vous et y chauffe ses fourneaux, vous êtes devenu, Joachim, morose et taciturne et vous avez maintenant dépensé quasiment tous les bons écus que vous obtîntes par le traité de Sainte-Menehould. N'est-il pas vrai ?

- Le fait est que mes coffres sont vides et que je vais bientôt en être réduit à casser la tire-lire de mon héritier éventuel, ce qui me fait penser que j'aurais peut-être mieux fait de garder l'astrologue. Il m'aurait coûté moins cher et la duchesse eût été contente.

- Bah, fit Sthène, tous ces gens-là se valent.

- Serais-tu sceptique, mon bon Démo ?

- Si vous voulez que je vous dise le fin fond de ma pensée, moi, [163] aux horoscopes, je n'y crois pas.

- Et moi guère. non plus.

- À la pierre philosophale

- Ah, dit le duc, si tout autre que toi me disait une chose pareille, je lui morniflerais les ganaches.

-Je n'y crois pas, dit Sthène, mais je ne vous empêche pas d'y croire.

- J'espère bien! Ah, si tu nous voyais, Timoleo et moi, au milieu des athanors et des aludels, des pélicans et des matras, des cornues et des alambics, manipulant les sels et les métaux, les uns violets, les autres indigo, les uns bleus, les autres verts, les uns jaunes, les autres orangés et certains rouges, sans parler des blancs et des noirs, les observant passer d'une couleur à l'autre, de solides devenir liquides et de certo em trazer para o seu castelo o senhor Timoleu Timolei. Desde que ele mora em vossa casa e nela esquenta seus fornos, vos tornastes, Joaquim, sombrio e taciturno e agora gastastes quase todos os bons escudos que tínheis obtido pelo tratado de Sainte-Menehould. Não é verdade?

- O fato é que meus cofres estão vazios e que $\operatorname{logo}$ vou estar reduzido a quebrar o cofrinho do meu eventual herdeiro, o que me faz pensar que talvez eu tivesse feito melhor ficando com o astrólogo. Ele me teria custado menos e a duquesa teria ficado contente.

- Bah, fez Stenes, toda essa gente é farinha do mesmo saco..

- Você seria cético, meu bom Demós?

- Se o senhor quer que eu diga o fundo profundo de meu pensamento, eu, nos horóscopos, não acredito.

- Eu também quase que não.

- Na pedra filosofal também não.

- Ah, disse o duque, se qualquer outro além de você me dissesse uma coisa dessas, eu davalhe um tabefe nas ganachas.

- Eu não acredito, disse Stenes, mas não o impeço de acreditar.

- Espero que não! Ah, se você nos visse, Timoleu e eu, no meio dos atanores e dos aludéis, das provetas e dos matrazes, das retortas e dos alambiques, manipulando os sais e os metais, uns violetas, outros índigos, uns azuis, outros verdes, uns amarelos, outros alaranjados, e alguns vermelhos, sem falar dos brancos e dos pretos, observando-os passar de uma cor a outra, de sólidos tornarem-se líquidos e de líquidos 
liquides devenir solides, de palpables devenir impalpables et d'impalpables devenir palpables, et je ne te parle que de l'aspect le plus superficiel de nos opérations, alors, mon bon Démo, tu te dirais que ce n'est sûrement pas en vain que ton maître et son alchimiste se donnent tant et tant de mal. Le jour viendra où les anges récompenseront nos œuvres et ce n'est plus en bronze mais en or massif que je ferai fondre ma statue.

- Notre statue.

Le duc n'entendit point cette rectification et il retomba dans son humeur mélancolieuse dont Sthène n'osa plus le tirer. La promenade se poursuivit encore silencieusement pendant une lieue ; Sthène alors décida de rentrer, mais en choisissant un autre chemin; le duc n'y contredit point, toujours muet, le sourcil froncé, l'œil vague. Il sursauta lorsque, quelque temps plus tard, il s'entendit interpeller; ils traversaient une clairière où

[164] travaillaient des bûcherons, c'était une coupe de bois pour alimenter les fourneaux de Timoleo Timolei. Quant à l'interpellation, elle avait pour auteur l'un des boquillons et consistait en ces mots :

- Noble seigneur, ma duchesse de fille se porte-t-elle bien?

Cidrolin sursauta.

- Et vos frères et sœurs ? demanda-t-il.

- Je vous ai dit que j'étais fille unique! Vous avez bien dormi ?

- Euh... votre père était donc bûcheron...

- Je viens de finir de vous raconter comment j'ai connu monsieur Albert et comment il m'a envoyée ici.

Cidrolin bâilla. tornarem-se sólidos, de palpáveis tornarem-se impalpáveis et de impalpáveis tornarem-se palpáveis, e eu estou falando só do aspecto mais superficial de nossas operações, então, meu bom Demós, você diria que certamente não é em vão que seu mestre e seu alquimista se esforçam tanto. Chegará o dia em que os anjos recompensarão nossas obras e não vai mais ser em bronze mas em ouro maciço que mandarei fundir minha estátua. - Nossa estátua.

O duque não ouviu essa retificação e voltou a mergulhar em seu humor melancolioso do qual Stenes não ousou mais tirá-lo. O passeio prosseguiu ainda silenciosamente durante uma légua; Stenes então decidiu voltar, mas escolhendo um outro caminho; o duque não o contradisse, sempre mudo, com a sobrancelha arqueada, com o olhar vago. Ele sobressaltouse quando, algum tempo mais tarde, ouviu alguém interpelá-lo; eles atravessavam uma clareira onde trabalhavam lenhadores, era um corte para alimentar os fornos de Timoleu Timolei. Quanto à interpelação, ela tinha por autor um dos bosqueadores e consistia nessas palavras:

- Nobre senhor, minha filha duquesa vai bem?

Cidrolin sobressaltou-se.

- E seus irmãos e irmãs? perguntou ele.

- Eu disse que era filha única! $\mathrm{O}$ senhor dormiu bem? lenhador...

- Euh... então seu pai era

- Acabei de terminar de contar como conheci o senhor Alberto e como ele me enviou para cá.

Cidrolin bocejou. 
- Vous ne voudriez pas recommencer? ajouta-t-il.

- Certainement pas, dit Lalix. Vous n'aviez qu'à écouter.

- Eh bien, tant pis, dit Cidrolin. Ce sera pour une autre fois.

- Il n'y aura pas d'autres fois : une suffit.

- Je me ferai une raison, dit Cidrolin.

Il s'étira et se leva. Sur l'autre rive, le pêcheur était toujours là et le chien couché en rond dormait toujours dans la barque.

- Ils ne sont pas si cruels que cela, dit Cidrolin, ils ne prennent jamais de poisson.

Lalix regarda le pêcheur, mais ne fit aucun commentaire. Elle était restée assise mais à son tour se leva.

- Je n'ai pas voulu vous gâcher votre déjeuner ni votre sieste, dit-elle, mais sur votre

[165] clôture on a barbouillé des tas d'inscriptions. Désagréables. Plus que désagréables.

Cidrolin en silence alla chercher le pot de peinture et le pinceau.

- Des injures, dit Lalix, des insultes.

Cidrolin se dirigea vers la passerelle.

- C'est à vous qu'on en a ? demanda Lalix.

- Eh oui, répondit Cidrolin.

- Qu'est-ce que vous avez donc fait ?

-Je vous raconterai cela quand vous dormirez.

Cidrolin grimpe le talus. Il ne regarde même pas les écritures et commence à badigeonner. Lalix va faire la vaisselle. Une bande de
- A senhorita não gostaria de recomeçar? acrescentou ele.

- Claro que não, disse Aalice. O senhor só tinha que ter escutado.

- Bom, azar, disse Cidrolin. Fica para outra vez.

- Não haverá outra vez: uma basta.

- Desisto, disse Cidrolin.

Ele se espreguiçou e se levantou. Na outra margem, o pescador ainda estava lá e o cão deitado enrodilhado ainda dormia na barca.

- Eles não são tão cruéis assim, disse Cidrolin, nunca pegam peixe.

Aalice olhou para o pescador, mas não fez nenhum comentário. Ela tinha ficado sentada mas levantou-se por sua vez.

- Eu não queria estragar seu almoço nem sua sesta, disse ela, mas na sua cerca rabiscaram montes de inscrições. Desagradáveis. Mais que desagradáveis.

Cidrolin em silêncio foi buscar a lata de tinta e o pincel. insultos.

- Injúrias, disse Aalice,

Cidrolin dirigiu-se para a passarela.

- É do senhor que não gostam? perguntou Aalice.

Cidrolin.

- Sim sim, respondeu

- E o que é que o senhor fez?

- Vou lhe contar quando a senhorita estiver dormindo.

Cidrolin sobe o barranco. Ele nem olha para o que está escrito e começa a pincelar. Aalice vai lavar a louça. Uma turma de 
nomades, venant du camp, s'arrêtent pour demander quelque chose à Cidrolin ; ils savent dire en français métro. C'est ça ce qu'ils lui demandent. Il répond par gestes.

- Ils commencent à migrer, dit Cidrolin en les regardant s'éloigner. L'automne approche. Mon automne éternel, ô ma saison mentale. passant.

- Pardon? demanda un - Je faisais une citation, dit Cidrolin.

- De qui ?

- D'un poète, bien sûr. Vous n'avez pas entendu les douze pieds?

- Je n'ai pas fait très attention. J'ai cru que vous vouliez me demander un renseignement. L'heure peut-être.

- Je ne voulais rien du tout, dit Cidrolin.

Il se remit à peindre ; l'autre le regardait en silence.

Un nouveau groupe de nomades s'approcha; ils savaient dire métro en français et c'est ce qu'ils dirent au passant. Celui-ci mima l'ignorance.

- Il y a un métro par ici ? demanda-t-il à Cidrolin.

Cidrolin montra le chemin aux nomades qui remercièrent chaleureusement et s'éloignèrent.

Cidrolin se remit à peindre et dit à mi-voix :

- C'est bien ça. Ils commencent à migrer. L'automne approche.

Il continua son travail en silence.

- Et la suite ? demanda le passant.

- La suite de quoi ?

- La suite de la citation.

- Vous êtes impatient. Elle n'a pas encore commencé. nômades, vinda do campo, para para perguntar alguma coisa a Cidrolin; eles sabem falar metrô em francês. É isso que eles perguntam. Ele responde por gestos.

- Começam a migrar, disse Cidrolin olhando-os afastarem-se. O outono se aproxima. Meu outono eterno ó minha estação mental.

passante

- Como? perguntou um

- Eu fazia uma citação, disse Cidrolin.

- De quem?

- De um poeta, é claro. O senhor não ouviu os doze pés?

- Não prestei atenção. Pensei que o senhor quisesse me pedir uma informação. A hora talvez.

- Eu não queria nada, disse Cidrolin

Recomeçou a pintar; o outro o olhava em silêncio.

Um novo grupo de nômades aproximou-se; eles sabiam falar metrô em francês e é o que disseram ao passante. Este fez gestos de ignorância.

- Tem metrô por aqui? pergunta ele a Cidrolin.

Cidrolin mostrou o caminho aos nômades que agradeceram calorosamente e se afastaram.

Cidrolin recomeçou a pintar e disse a meia voz:

- É bem isso. Começam a migrar. $\mathrm{O}$ outono se aproxima.

Ele continuou seu trabalho em silêncio.

- E a continuação? perguntou o passante.

- A continuação do que?

- A continuação da citação.

- O senhor é impaciente. Ela nem começou ainda. 
- C'était de vous : «Ils commencent à migrer. L'automne approche »?

- Entièrement de moi.

- Et ces mots que vous recouvrez de peinture, c'était de qui ?

- D’un passant, je suppose.

- Vous m'accusez?

passant ?

- Seriez-vous le seul

Cidrolin, n'entendant pas de réponse, jeta un coup d'œil derrière lui : l'autre, lui ayant tourné le dos, faisait semblant de regarder l'immeuble que l'on achevait de construire. Cidrolin donne encore quelques coups de pinceau; c'est fini. Il laisse le pinceau dans le pot de peinture et prend le pot de peinture par l'anse, une anse mince et métallique qui coupe un peu les doigts.

Le passant a disparu.
- Era sua : "Começam a migrar. O outono se aproxima "?

- Inteiramente minha.

- E essas palavras que o senhor está cobrindo de tinta, são de quem?

- De um passante, suponho.

- O senhor está me acusando?

- Por acaso o senhor é o único passante?

Cidrolin, não ouvindo resposta, deu uma olhada atrás de si: o outro tendo virado as costas, fingia olhar o prédio que estavam acabando de construir. Cidrolin dá ainda algumas pinceladas; pronto. Ele pousa o pincel dentro do pote de pintura e pega o pote de pintura pela alça, uma alça fina e metálica que corta um pouco os dedos.

O passante desapareceu. 
Cinq heures avaient depuis longtemps sonné à l'église du

[167] village, lorsque le duc d'Auge sortit du château accompagné de Pouscaillou, le plus jeune frère du vicomte d'Empoigne, nouvellement à son service. Ils étaient tous deux à cheval, l'un montait Sthène et l'autre Stèphe. Le duc ne disait mot, Sthène ne bronchait pas. Stèphe et Pouscaillou en faisaient autant. En traversant le bourg, ils croisèrent sur la place un groupe de notables qui saluèrent le duc bien bas.

- Alors, messieurs, dit le duc distraitement, jouissons-nous d'une bonne santé ?

- Excellente, répondit le bailli. Excellente.

- Et à part cela, y a-t-il quoi que ce soit qui mérite attention ?

- Nous, répondit le bailli, allons de ce pas élire nos délégués aux États géneraux. généraux...

- Ah, c'est vrai, les États

Le duc n'en dit pas plus à ce sujet.

- Nous, reprit le bailli, avons commencé à rédiger notre cahier de doléances. Monseigneur Biroton et l'abbé Riphinte se joindront à nous et si Monsieur le duc daignait nous accorder son noble concours, nous pourrions envoyer à Paris un cahier unique

[168] pour les trois ordres du bailliage, ce qui montrerait à Sa Majesté l'union de tous les Français derrière la personne sacrée du roi.

- Vive le roi ! crièrent les notables. Vive le roi !

- Vive le roi ! crut bon de hurler Pouscaillou.

Une mornifle du duc envoya dans la poussière l'écuyer
Cinco horas já tinham soado havia muito tempo na igreja do lugarejo, quando o duque de Auge saiu do castelo acompanhado de Pouscaillou, o irmão mais novo do visconde de Empoigne, recentemente a seu serviço. Estavam ambos a cavalo, um montava Stenes e outro Estêvão. O duque não dizia uma palavra, Stenes não falava nada. Estêvão e Pouscaillou faziam o mesmo. Atravessando o burgo, eles cruzaram na praça com um grupo de notáveis que saudaram o duque inclinando-se muito baixo.

- Então, senhores, disse o duque distraidamente, gozamos de boa saúde?

- Excelente, respondeu o bailio. Excelente.

- E fora isso, há algo mais que mereça atenção?

- Nós, respondeu o bailio, estamos indo eleger nossos delegados para os Estados Gerais...

- Ah, é mesmo, os Estados Gerais...

O duque não disse mais nada sobre o assunto.

- Nós, retomou o bailio, começamos a redigir nosso caderno de reclamações. Monsenhor Biroton e o abade Rifinge juntarse-ão a nós e se o Senhor duque se dignasse oferecer seu nobre concurso, poderíamos enviar a Paris um caderno único para as três ordens do bailiado, o que mostraria a Sua Majestade a união de todos os franceses na pessoa sagrada do rei.

- Viva o rei! gritaram os notáveis. Viva o rei!

- Viva o rei! achou que era bom urrar Pouscaillou.

Uma bofetada do duque enviou para a poeira o escudeiro 
qui se ramassa pour remonter ensuite tout étourdi sur son cheval. Les notables s'abstinrent de commenter l'incident.

- Eh bien! dit le duc un peu ragaillardi, bon travail, messieurs.

Et il partit au galop dans la direction du cimetière. Il mit pied à terre et confia les rênes de Sthène à Pouscaillou qui avait suivi de son mieux.

- Macaque, lui dit le duc, qui t'a permis de crier «vive le roi »?

- J'ai fait comme tout le monde, répondit Pouscaillou en pleurnichant.

- Eh bien, apprends... Mais d'abord descends de cheval.

Lorsque ce fut fait, le duc lui prit une oreille, et, la pinçant assez fort, poursuivit son discours par ces mots :

- Apprends donc, cher petit page macaque et papegai, que tu ne dois pas faire comme tout le monde, mais comme moi, tu entends: comme moi, je fais. Compris ? goutte.

- Non. Je n’y comprends

Le duc, changeant d'oreille, continua en ces termes :

-Moi, qu'est-ce que je faisais ? Est-ce que je criais «vive le roi »? Non. Compris maintenant ?

- Oui, certes, mais, en toute circonstance, n'est-il pas

[169] recommandé de crier «vive le roi »?

- Peut-être, répondit le duc qui délaissa l'oreille devenue assez rougeaude et parut tout à coup fort songeur. Peut-être, reprit-il après quelques instants.

cimetière. que se levantou para tornar a montar completamente aturdido no seu cavalo. Os notáveis se abstiveram de comentar o incidente.

- Bom, bom! disse o duque um pouco mais alegre, bom trabalho, senhores.

E partiu a galope na direção do cemitério. Ele apeou e confiou as rédeas de Stenes a Pouscaillou que tinha seguido o melhor que pôde.

- Seu macaco, disse-lhe o duque, quem lhe deu permissão para gritar "viva o rei"?

- Eu fiz como todo mundo, respondeu Pouscaillou choramingando.

- Bom, então aprenda... Mas antes desça do cavalo.

Quando ele fez isso, o duque pegou-lhe uma orelha, e, puxando-a com força, prosseguiu seu discurso com estas palavras:

- Aprenda então, caro pequeno pajem macaco e papagaio, que você não deve fazer como todo mundo, mas como eu, está ouvindo: como eu faço. Entendido?

entendendo nada.

Não. Não estou

$\mathrm{O}$ duque, mudando de orelha, continuou nestes temos:

- Eu, o que é que eu estava fazendo? Eu estava gritando "viva o rei"? Não. Entendeu agora?

- Sim, claro, mas, em qualquer circunstância, não é recomendado gritar "viva o rei"?

- Pode ser, respondeu o duque que largou a orelha já bastante avermelhada e pareceu de repente mui sonhador. Pode ser, retomou depois de alguns instantes.

E penetrou no cemitério. 
Lorsque Pouscaillou l'estima suffisamment éloigné, il se frotta les oreilles en maugréant.

- C'est qu'il m'a fait mal, le sagouin. Et pour avoir crié « vive le roi ». Comme si, en l'an mil sept cent quatre-vingt-neuf de notre ère bien chrétienne, on n'avait plus le droit de crier «vive le roi ». Eh bien, moi, je continuerai à le crier « vive le roi ».

Ce qu'il fit en effet, mais à voix plutôt basse.

- Vous ne pouvez comprendre, jeune homme, dit Sthène. C'est parce que le duc ne fait pas de politique.

- Ah seigneur Jésus, s'écria le page, un cheval qui parle!

- Autant que vous soyez au courant tout de suite, cela facilitera nos rapports. D'ailleurs je ne suis pas le seul. Stèphe aussi parle. N'est-ce pas, Stèphe?

Oui, répondit compendieusement Stèphe.

- Mais ne tremblez donc pas comme ça, dit Sthène à Pouscaillou. Auriez-vous peur? À la veille d'une révolution, ce n'est pas conseillé.

- Une révolution? demanda Pouscaillou en claquant des dents. Quequelle revovolutiontion?

- Celle qui se prépare, répondit Sthène.

- Et il prophétise! s'écria Pouscaillou d'une voix aussi déchirante que déchirée. Comme

[170] l'ânesse de Balaam !

- Ce n'est pas un écuyer, dit Sthène avec mépris, c'est un séminariste. Et en plus de cela, il me prend pour une ânesse. Il ne m'a pas regardé sous le ventre.

Cette plaisanterie dérida le grave Sthèphe et les deux chevaux rirent, puis, s'entraînant l'un l'autre
Quando Pouscaillou achou que ele estava suficientemente longe, esfregou as orelhas reclamando.

- Me machucou, o sagui. E por ter gritado "viva o rei". Como se, no ano de mil setecentos e oitenta e nove de nossa era bem cristã, não se tivesse mais o direito de gritar "viva o rei". Bom, pois eu vou continuar a gritar "viva o rei".

O que ele fez realmente, mas em voz baixa.

- Você não pode entender, meu jovem, disse Stenes. É porque o duque não faz política.

- Ah senhor Jesus, exclamou o pajem, um cavalo que fala!

- Quanto mais depressa você souber, mais fácil será nosso relacionamento. Aliás, não sou o único, Estêvão também fala. Não é, Estêvão?

- Sim, respondeu Estêvão compendiosamente.

- Mas não trema tanto assim, disse Stenes a Pouscaillou. Está com medo? Às vésperas de uma revolução, não é aconselhável.

- Uma revolução? perguntou Pouscaillou batendo os dentes. Queque revovolulução?

- A que está se formando, respondeu Stenes.

- E ele profetiza! exclamou Pouscaillou com uma voz tão angustiante quanto angustiada. Como a jumenta de Balaão!

- Não é um escudeiro, disse Stenes com desprezo, é um seminarista. E ainda por cima, me toma por uma jumenta. Ele não me olhou por baixo da barriga.

Essa piada relaxou o grave Estêvão e os dois cavalos riram, depois um contagiando o outro 
fou-rirent, ce qui acheva de démoraliser Pouscaillout qui se roula par terre en pleurant. Lorsqu'il eut piqué sa crise et vidé un bon setier de liquide lacrymal, il se releva toujours tremblant et aperçut Sthène et Stèphe qui, paisiblement, muettement, recherchaient des friandises parmi les herbes pariétaires. Cette activité pourtant bien orthohippique acheva de l'emplir de terreur et il jugea prudent de chercher refuge auprès de son employeur. Il pénétra donc dans le cimetière et il aperçut tout au bout de l'allée le duc en méditation devant une tombe; il aperçut aussi juste devant lui deux fossoyeurs qui exhumaient des ossements et en faisaient des petits tas. Ce spectacle acheva d'écœurer le page qui fit demi-tour et, bon coureur, se retrouva bientôt sur la terrasse du château où quelques personnes buvaient du café et des liqueurs, notamment de l'essence de fenouil, en bavardant de choses et d'autres.

- Eh bien, Pouscaillou, s'écria son frère, que t'arrive-t-il donc? Tu as abandonné haut et puissant seigneur Joachim duc d'Auge?

On rit. Pas Pouscaillou qui, d'une voix larmoyante, énonce son plus cher désir : maman!

- Je veux retourner chez

- Eh quoi, Pouscaillou, dit son frère. Le haut et puissant seigneur t'aurait-il mis la main à la brayette?

On rit. Pas Pouscaillou qui continue à se lamenter :

- C'est pas le duc ! c'est pas le duc ! Ce sont les chevaux !

- Or çà, Pouscaillou, tu ne me feras pas croire que ces dadas gargalharam, o que acabou de desmoralizar Pouscaillou que rolou por terra chorando. Quando atravessou sua crise e esvaziou um bom sexteiro de líquido lacrimal, ele se levantou sempre tremendo e notou Stenes e Estêvão que, placidamente, mudamente, procuravam guloseimas entre as ervas parietárias. Essa atividade apesar de bem ortohípica acabou de enchê-lo de terror e ele julgou prudente procurar refúgio perto de seu empregador. Penetrou no cemitério e notou bem no fim da aleia o duque em meditação diante de uma tumba; notou também bem diante dele dois coveiros que exumavam ossadas e faziam com elas pequenos montes. $\mathrm{O}$ espetáculo acabou de assustar o pajem que deu meia volta e, bom corredor, logo se encontrava no terraço do castelo onde algumas pessoas bebiam café e licores, sobretudo essência de funcho, falando de coisas e outras.

- E aí, Pouscaillou, exclamou seu irmão, o que está acontecendo? Você abandonou o grande e poderoso senhor Joaquim duque de Auge?

Todos riem. Não Pouscaillou que, com uma voz lacrimejante, enuncia seu mais caro desejo: da mamãe!

- Quero voltar para a casa

- O que foi, Pouscaillou, disse seu irmão. $\mathrm{O}$ grande $\mathrm{e}$ poderoso senhor teria metido a mão na tua braguilha?

Todos riem. Não

Pouscaillou que continua se lamentando:

- Não é o duque! não é o duque! São os cavalos!

- Ora essa, Pouscaillou, não vai me dizer que esses cavalinhos 
ont un faible pour les petits garçons.

On rit. Pas Pouscaillou qui trépigne.

- Ils parlent! Ils parlent!

- Est-il bête, ce petit, dit la duchesse charmée.

- Imbécile, lui dit son frère furieux. Tu ne vas pas ajouter foi à cette légende gothique et surannée !

- On lit ça dans les romans de chevalerie, dit Monseigneur Biroton avec un petit rire de dérision. Durant la dernière ou l'avant-dernière croisade, je ne sais plus...

- La septième, dit l'abbé Riphinte.

- Quel érudit, s'écria la duchesse en agitant son face-àmain.

- Durant la septième croisade, reprit Onésiphore toujours sur un ton ironique, le cheval du duc d'Auge effrayait les Sarrasins, parce qu'il leur criait des injures.

- Voilà qui est bien sot, dit le vicomte d'Empoigne. A-t-on jamais vu parler un quadrupède ?

- Oui, certes, dit l'abbé Riphinte. Il y en a un : l'ânesse de Balaam.

- Sthène prophétise comme elle, dit Pouscaillou toujours épouvanté.

- Tu n'es pas très fort en catéchisme, lui dit sévèrement l'abbé Riphinte. L'ânesse de Balaam ne prophétisait pas, elle n'ouvrit la bouche que pour protester contre les coups que lui donnait son maître, car elle avait vu l'ange de Dieu. C'était un miracle.

- Moi, conclut Pouscaillou, je veux retourner chez maman.

- Tu resteras ici, lui dit son frère. C'est un ordre.

- Si maman savait qu'ici il y têm um fraco por rapazinhos.

Todos riem. Não Pouscaillou que bate os pés.

- Eles falam! Eles falam!

- É besta, esse rapaz, disse a duquesa encantada.

- Imbecil, disse-lhe o irmão furioso. Você não vai dar ouvidos a essa lenda gótica e fora de moda!

- Isso se lê nos romances de cavalaria, disse Monsenhor Biroton com um risinho de escárnio. Durante a última ou a penúltima cruzada, não sei mais...

- A sétima, disse o abade Rifinge.

- Que erudito, exclamou a duquesa agitando seu lornhão.

- Durante a sétima cruzada, retomou Onesíforo sempre num tom irônico, o cavalo do duque de Auge assustava os sarracenos, porque gritava-lhes injúrias.

- Isso é que é tolice, disse o visconde de Empoigne. Alguém já viu um quadrúpede falar?

- Sim certamente, disse o abade Rifinge. Há um: a jumenta de Balaão.

- Stenes profetiza como ela, disse Pouscaillou ainda assustado.

- Você não é muito bom de catecismo, disse-lhe severamente o abade Rifinge. A jumenta de Balaão não profetizava, ela só abriu a boca para protestar contra os golpes que o seu dono lhe dava, pois ela tinha visto o anjo de Deus. Foi um milagre.

- Eu, concluiu Pouscaillou, eu quero voltar para a casa da mamãe.

- Você vai ficar aqui, disselhe o irmão. É uma ordem.

- Se a mamãe soubesse que 
a des chevaux qui parlent, elle me dirait de rentrer tout de suite.

- Puisqu'on te dit que cela n'existe pas les chevaux qui parlent, dit l'abbé Riphinte. À moins d'un miracle.

- Et les miracles se font rares par les temps qui courent, ajouta Monseigneur Biroton avec un soupir.

- Alors, Pouscaillou, dit le duc, qu'on n'avait pas vu venir, c'est comme cela que tu gardes les chevaux? Tu peux retourner chez ta mère.

Sans même remercier, Pouscaillou disparut.

- Il est idiot ton frère, dit le duc à Empogne en se servant un verre d'essence de fenouil.

Il regarda quelques instants le liquide en silence et ajouta :

- Une recette de Timoleo Timolei. Hélas, pauvre Timoleo. Je suis encore allé aujourd'hui me recueillir sur sa tombe.

- Oubliez donc ce rebouteux, ce charlatan, dit Onésiphore. Qui peut encore croire de nos jours à l'élixir de longue vie et à la pierre philosophale ?

- Vous croyez bien que le monde a été créé fort exactement l'an quatre mille quatrième avant Jésus-Christ.

- Monsieur le duc, répliqua l'abbé Riphinte, nous avons de bonnes raisons pour le croire. duc.

- Lesquelles ? demanda le

- Que vous êtes ennuyeux, Joachim, dit la duchesse. Vous

[173] voulez maintenant faire le théologien?

- Ne vous en déplaise, cocotte, répondit le duc en remplissant son verre vide. Alors, l'abbé, quelles raisons? aqui tem cavalos que falam, ela me diria para voltar imediatamente.

- Estamos te dizendo que não existe isso de cavalos que falam, disse o abade Rifinge. A não ser por um milagre.

- E os milagres são raros nos tempos que correm, acrescentou Monsenhor Biroton com um suspiro.

- Então, Pouscaillou, disse o duque, que ninguém tinha visto chegar, é assim que você toma conta dos cavalos? Pode voltar para a casa da sua mãe.

Sem nem mesmo agradecer, Pouscaillou desapareceu.

- O seu irmão é um idiota, disse o duque a Empoigne enquanto se servia de um copo de essência de funcho.

Ele olhou alguns instantes para o líquido em silêncio e acrescentou:

- Uma receita de Timoleu Timolei. Que pena, pobre Timoleu. Ainda hoje fui me recolher diante de sua tumba.

- Pois esqueça esse farsante, esse charlatão, disse Onesíforo. Quem pode ainda em nossos dias acreditar no elixir da longa vida e na pedra filosofal?

- Mas você bem que acredita que o mundo foi criado mui exatamente no ano de quatro mil e quatro antes de Jesus Cristo.

- Senhor duque, replicou o abade Rifinge, nós temos boas razões para acreditar nisso.

- Quais? perguntou o duque.

- Como o senhor é chato, Joaquim, disse a duquesa. Agora quer se fazer de teólogo?

- Não se aborreça, sirigaita, respondeu o duque enchendo seu copo vazio. Vamos, abade, quais razões? 
- Mais les Saintes Écritures, monsieurs le duc! dit l'abbé Riphinte.

- Bien répondu, Riphinte, observa Monseigneur Biroton.

- Elles sont contradictoires, vos saintes écritures, dit le duc, il suffit d'y fourrer le nez pour s'en apercevoir. Et la raison, qu'en faites-vous ? En l'an quatre mille quatre avant Jésus-Christ, le monde existait depuis des milliers et des milliers d'années.

Onésiphore.

$$
\text { Absurde, s'écria }
$$

- Joachim, remarqua la duchesse, n'a jamais été très fort en astrologie. En astronomie, voulaisje dire.

- En chronologie, ajouta l'abbé Riphinte à titre de rectification. Et des hommes, demanda-t-il ironiquement au duc, en existait-il des milliers et des milliers d'années avant la création d'Adam ?

- Naturellement.

- Et quelle preuve en pouvez-vous donner, monsieur le duc?

- Ah ah, fit Monseigneur Biroton, voilà notre préadamite mis au pied du mur.

- Oui, quelle preuve, Joachim ? dit à son tour la duchesse.

- Vous l'embarrassez fort, remarqua le vicomte d'Empoigne qui jusqu'à présent n'avait osé se mêler à la discussion.

- Je ne suis nullement embarrassé, répliqua le duc avec

[174] calme. Les preuves doivent exister quelque part, il suffit de les trouver.

- Belle réponse, dit l'abbé Riphinte avec un petit rire. Monsieur le duc nous permettra de ne voir là qu'une simple échappatoire.
- Mas as Santas Escrituras, senhor duque! disse o abade Rifinge.

- Bem respondido, Rifinge, observou Monsenhor Biroton. - Elas são contraditórias, suas santas escrituras, disse o duque, é só enfiar o nariz nelas para perceber isso. $\mathrm{E}$ a razão, o que vocês fazem com a razão? No ano quatro mil e quatro antes de Jesus Cristo, o mundo já existia há milhares e milhares de anos.

Onesíforo.

Absurdo, exclamou

- Joaquim, observou a duquesa, nunca foi forte em astrologia. Em astronomia, quero dizer.

- Em cronologia, acrescentou $o$ abade Rifinge a título de retificação. E os homens, perguntou ele ironicamente ao duque, existiam milhares $\mathrm{e}$ milhares deles antes da criação de Adão?

- Naturalmente.

- E que prova pode dar, senhor duque?

- Ah ah, fez Monsenhor Biroton, olha o nosso preadamita colocado contra a parede.

- É, que prova, Joaquim? disse por sua vez a duquesa.

- Vocês estão deixando ele mui embaraçado, observou o visconde de Empoigne que até o momento não tinha ousado se meter na discussão.

- Não estou nem um pouco embaraçado, replicou o duque com calma. As provas devem existir em algum lugar, basta encontrá-las.

- Bela resposta, disse o abade Rifinge com um risinho. $\mathrm{O}$ senhor duque nos permitirá ver aí uma simples escapatória. 
- Riphinte, dit Monseigneur Biroton, vous l'avez mis quinaud!

- Joachim ! dit la duchesse, tu t'entêtes et tu as tort de vouloir discuter théologie avec l'abbé. Tu n'es pas de taille !

- Je ne m'y risquerais pas, ajouta le vicomte d'un air qu'il voulut fin.

- Jardidieu ! s'écria le duc en projetant la table dans les airs d'un énergique coup de pied, me prendriez-vous pour un zozo ?

Du service à café chinois époque Ming, il ne restait plus que des miettes, et des bouteilles et des verres, d'autres miettes. Le duc, debout, interpella véhémentement les personnes présentes :

- Bougres! ne seriez-vous que des bourgeois pour m'oser lamponner de la sorte! Les curés se croient tout permis, maintenant. Je ne sais ce qui me retient de rosser ces bêtes à bon Dieu.

- Joachim! s'écria la duchesse, tu n'es qu'un vilain féodal. fessée.

- Toi, cocotte, tu mérites la

Il la prit par le poignet. Russule n'était pas d'accord. Le duc prend l'autre poignet. Russule trépigne. Le duc tire : il l'entraîne vers la chambrette aux martinets. Un laquais ramasse porcelaine et verrerie. Monseigneur Biroton et l'abbé Riphinte s'éloignent d'un air pincé. Le duc tire toujours sur sa bonne femme qui freine énergiquement; ses talons font des [175] étincelles sur les pavés.

Le vicomte d'Empoigne voulut s'interposer.

- Monsieur le duc, dit-il d'une voix plus blanche qu'un linge, avec tout le respect que je vous dois...
- Rifinge, disse Monsenhor Biroton, você o deixou sem palavras!

- Joaquim! disse a duquesa, você encasquetou mas não está certo em discutir teologia com o abade. Você não está à altura!

- Eu não me arriscaria, acrescentou o visconde com um ar que ele achava esperto.

- Maldição! exclamou o duque projetando a mesa para os ares com um enérgico pontapé, vocês acham que sou bobo?

Do serviço de café chinês da época Ming, só restavam migalhas, e das garrafas e dos copos, outras migalhas. O duque, em pé, interpelou veementemente as pessoas presentes:

- Bugres! vocês não passam de burgueses para ousar me esculhambar dessa maneira! Os curas, agora, pensam que tudo lhes é permitido. Não sei o que me segura pra não dar uma sova nessas bestas de Deus.

- Joaquim! exclamou a duquesa, você não passa de um vilão feudal.

- E você, sirigaita, merece uma palmada.

Ele tomou-a pelo punho. Russula não concordava. $\mathrm{O}$ duque tomou o outro punho. Russula bate os pés. O duque puxa: ele a arrasta para o quartinho da palmatória. Um lacaio recolhe porcelana e vidros. O monsenhor Biroton e o abade Rifinge afastam-se com ar superior. $\mathrm{O}$ duque continua a puxar sua boa mulher que freia energicamente; seus saltos fazem faíscas no chão.

quis intervir.

O visconde de Empoigne

- Senhor duque, disse ele com uma voz mais branca que um lençol, com todo o respeito que eu lhe devo... 
- De quoi te mêles-tu, jeanfoutre ? hurla le duc exaspéré.

Il lâcha la duchesse qui tomba sur le postère et il gifla vigoureusement le vicomte qui trébucha. Celui-ci, par atavisme encore et plus que par courage, sortit son épée. Le duc sort la sienne et voilà Empoigne par terre, complètement mort et traversé. La dichesse se rue sur le cadavre en poussant des clameurs. Le duc essuie son épée au jupon de Russule et remet l'arme assassine dans son fourreau. Il examine la situation.

Quelqu'un d'autre qui
s'était timidement approché examinait également la situation.

Pouscaillou.

- Vous l'avez tué, murmura

Il avait son baluchon à la main, car il retournait chez sa maman.

- Il est vraiment mort ? ajouta-t-il.

- S'il ne l'était pas encore, répondit le duc, il le serait bientôt : cette dame l'étoufferait.

La duchesse ne cessait de glapir. Elle finit par proclamer :

- Il est mort ! Il est mort!

- Là, dit le duc à Pouscaillou, te voilà renseigné.

$\begin{array}{lcr}- & \text { Alors, } & \text { demanda } \\ \text { Pouscaillou, } & \text { le } & \text { vicomte } \\ \text { d'Empoigne, } & \text { c'est } & \text { moi } \\ \text { maintenant? } & & \end{array}$

- Sans doute, répondit le duc plein d'admiration.

- Ça c'est chouette.

Les cris de la duchesse

[176] faisaient rappliquer prêtres et valetaille.

- Eh bien, fit Monseigneur Biroton, encore du nouveau.

- Ce fut un duel, si je comprends bien, dit l'abbé
- O que é que você está se metendo, seu joão-bobo? urrou o duque exasperado.

Ele solta a duquesa que cai de bunda e esbofeteia vigorosamente $\mathrm{o}$ visconde que estrebucha. Este, mais por atavismo do que por coragem, desembainha a espada. $\mathrm{O}$ duque desembainha a sua e eis Empoigne por terra, completamente morto e atravessado. A duquesa precipita-se sobre o cadáver soltando clamores. $O$ duque enxuga sua espada no saiote de Russula e recoloca a arma assassina na bainha. Ele examina a situação.

Mais alguém que tinha se aproximado timidamente também examinava a situação.

- O senhor o matou, murmurou Pouscaillou.

Ele tinha uma trouxa na mão, pois estava voltando para a casa de sua mamãe.

- Ele está morto mesmo? acrescentou ele.

- Se ainda não estivesse, respondeu o duque, logo estaria: essa dama o sufocaria

A duquesa não parava de ganir. Ela acabou por proclamar:

- Está morto! Está morto!

- Pronto, disse o duque a Pouscaillou, agora você está bem informado.

$\begin{array}{ccc}- & \text { Então, } & \text { perguntou } \\ \text { Pouscaillou, } & \text { o visconde de }\end{array}$ Empoigne, sou eu agora?

- Provavelmente, respondeu o duque cheio de admiração.

- Isso é bem legal.

Os gritos da duquesa atrairam padres e criadagem.

- Bom, fez Monsenhor Biroton, mais essa agora.

- Foi um duelo, se estou entendendo bem, disse o abade 
Riphinte.

- Aucun doute, dit Onésiphore, Empoigne a encore l'épée à la main.

- Tuer un homme en duel n'est pas un petit péché, dit l'abbé Riphinte, mais c'est moins grave que de ne pas croire au calendrier.

- Monsieur le duc, dit l'évêque in partibus de Sarcellopolis, vous devrez faire pénitence pour cet incident et amende honorable pour vos convictions préadamites.

- Comme vous voyez, dit l'abbé Riphinte, la justice de Dieu est plus sévère que la justice des hommes qui vous absoudra.

- Je me méfie, dit le duc d'Auge, et, tout bien réfléchi, je préfère m'en aller promener, peutêtre même à l'étranger. Je n'attendrai pas les sergents du roi, ni le bon vouloir dudit. On a bien fourré mon excellent ami Donatien à la Bastille pour des peccadilles. Tien, cela rime.

l'abbé Riphinte.

- Pauvrement, remarqua

Le duc tira son épée, bien décidé à trucider séance tenante l'abbé qui décrivit une prudente trajectoire pour se placer derrière Onésiphore, mais le duc se contint et rengaina.

- Vous consolerez Russule, dit-il aux deux prêtres. Moi, j'ai une féssée rentrée dans la paume de la main. Adieu, messieurs.

- Et les États généraux, dit Monseigneur Biroton. Vous n'y assisterez pas?

- Foutaises! Pour le moment, je m'occupe de ma liberté.

Il se tourna vers

Pouscaillou :

- Va seller Sthène et Stèphe,
Rifinge.

- Sem dúvida, disse Onesíforo, Empoigne ainda está com a espada na mão.

- Matar um homem em duelo não é um pecado pequeno, disse o abade Rifinge, mas é menos grave do que não acreditar no calendário.

- Senhor duque, disse o bispo in partibus de Sarcelópolis, o senhor terá que fazer penitência por este incidente e pedir perdão por suas convicções preadamitas.

- Como o senhor pode ver, disse o abade Rifinge, a justiça de Deus é mais severa do que a justiça dos homens que o absolverá.

- Não confio nisso, disse o duque de Auge, e, pensando bem, prefiro ir passear, talvez no estrangeiro. Não vou ficar esperando os sargentos do rei, nem a boa vontade do dito cujo. Eles enfiaram meu excelente amigo Donatien na Bastilha por umas pecadilhas. Olha, rimou. abade Rifinge.

- Pobremente, observou o

O duque desembainhou sua espada, bem decidido a trucidar sem mais delongas o abade que descreveu uma prudente trajetória para colocar-se atrás de Onesíforo, mas o duque conteve-se e embainhou a espada.

- Vocês vão consolar Russula, disse ele aos dois padres. Estou com uma palmada encravada na palma da mão. Adeus, senhores.

- E os Estados Gerais, disse Monsenhor Biroton. O senhor não estará presente?

- Bobagens! No momento, estou tratando da minha liberdade.

Pouscaillou.

- Vá selar Stenes e Estêvão, 
vicomte, je t'emmène avec moi. Tu vas voir du pays.

- Oh, grands mercis, monsieur le duc, mais ces chevaux qui parlent...

tèrstène.

- $\mathrm{Tu}$ ne feras jamais

- Je ne suis pas rassuré...

Le duc fit pivoter Pouscaillou et, d'un bon coup de pied, l'envoya droit au but. Après avoir décrit un gracieux arc de parabole, Pouscaillou, tenant toujours son baluchon à la main, atterrissait devant la porte des écuries.

Lorsque le duc revint quelques instants plus tard avec son bagage, tout était prêt. On partit aussitôt.

La terrasse était maintenant désertée. La duchesse avait disparu, ainsi que feu Empoigne. Au pied de l'escalier, Monseigneur Biroton et l'abbé Riphinte attendaient le seigneur de ce lieu. Ils le saluèrent bien poliment.

- Vous avez bien réfléchi? demanda Monseigneur Biroton. Vous vous mettez dans votre tort.

- Et vous ne pourrez assister aux États généraux, ajouta l'abbé Riphinte.

- Mes amis, dit le duc, avec un air d'extrême satisfaction, vous n'avez pas compris pourquoi je pars.

- Pourquoi ? demandèrent en chœur les deux prêtres. preuves.

- Je vais chercher des

- Quelles preuves?

- Les preuves de votre ignorance. Et vive les préadamites!

[178] - Vive les préadamites, reprirent en chœur les deux chevaux auxquels ne se joignit le prudent Pouscaillou qu'avec un peu visconde, vou levá-lo comigo. Você vai conhecer muitos lugares.

- Oh, muito obrigado, senhor duque, mas esses cavalos que falam...

- Cê nunca vai fazê

Stenessicalá.

- Não me sinto muito tranquilo...

O duque fez Pouscaillou girar e, com um bom pontapé, enviou-o diretamente ao alvo. Depois de ter descrito um gracioso arco de parábola, Pouscaillou, sempre segurando sua trouxa, aterrissou diante da porta das estrebarias.

Quando o duque chegou alguns instantes mais tarde com sua bagagem, tudo estava pronto. Partiram em seguida.

Agora o terraço estava deserto. A duquesa tinha desaparecido, assim como o finado Empoigne. Ao pé da escada, Monsenhor Biroton e o abade Rifinge esperavam o senhor desse lugar. Eles o saudaram muito educadamente.

- O senhor pensou bem? perguntou Monsenhor Biroton. O senhor está admitindo a culpa.

- E não poderá ir aos

Estados Gerais, acrescentou o abade Rifinge.

- Meus amigos, disse o duque, com um ar de extrema satisfação, vocês não entenderam por que estou partindo.

- Por que? perguntaram em coro os dois padres.

- Vou procurar provas.

- Que provas?

- As provas da ignorância de vocês. E viva os preadamitas!

- Viva os preadamitas, retomaram em coro os dois cavalos aos quais juntou-se o prudente Pouscaillou com um pouco de 
de retard.

Et is partirent au grand galop, tous les quatre.

Ils firent ce jour-là une longue étape et c'est fourbus qu'ils arrivèrent à l'auberge de l'Homme Sauvage à Saint-Genouillat-lesTrous, gros bourg situé dans le Vésinois non loin de Chamburneen-Basses-Bouilles.

- Tudieu, dit le duc en s'attablant, nous méritons un bon repas. À boire et de l'andouille !

- Eh eh, petite, ajouta-t-il à l'intention de la servante en lui tapotant la croupe, j'ai une fessée rentrée dans le creux de la main.

nulle envie.

- Merci bien! j'en avons

- Eh eh ! une main de duc...

- Une main de vilain cochon, répliqua-t-elle en s'esquivant.

- Tu vois, dit allégrement le duc à Pouscaillou, c'est déjà républicain. Enfin on verra plus tard.

Et il se mit à dévorer de l'andouille.

- Maintenant, reprit-il la bouche pleine, que dis-tu de Sthène? n'est-ce pas un joyeux compagnon?

- Oh voui, dit Pouscaillou, je comprends pas comment j'en ai eu tellement peur la première fois. Asteure, je trouve ça tout naturel.

- Le naturel, il n'y a rien de plus naturel que le naturel. Telle est la devise de mon excellent ami Donatien.

- Dites, monsieur le duc, les préadamites qu' est-ce que c'est?

- Un truc pour taquiner le brave Onésiphore. Cela n'existe atraso. galope.

E os quatro partiram a

Nesse dia eles fizeram uma longa etapa e estavam esfalfados quando chegaram ao albergue do Homem Selvagem em SaintGenbouillat-les-Trous, grande burgo situado no Vésinois não longe de Chamburne-en-BassesBouilles.

- Por Deus, disse o duque pondo-se à mesa, nós merecemos uma boa refeição. Algo de beber e salsicha!

- Ei, ei, garota, acrescentou ele dirigindo-se à garçonete dandolhe um tapa no traseiro, estou com uma palmada encravada na palma da mão.

- Muito obrigada! num tamo com nenhuma vontade de palmadas.

- Ora ora! uma mão de duque...

- Uma mão de porco sujo, replicou ela esquivando-se.

- Está vendo, disse alegremente o duque a Pouscaillou, isso aí já é republicano. Enfim, veremos mais tarde. salsicha.

E pôs-se a devorar a

- Agora, retomou ele de boca cheia, o que você diz de Stenes? não é um companheiro alegre?

- Oh xim, disse Pouscaillou, num sei como tive tanto medo na primeira vez. Aestora, acho tudo natural.

- O natural, não há nada mais natural que o natural. Esta é a divisa do meu excelente amigo Donatien.

- Diga, senhor duque, preadamitas o que é que é isso?

- Um negócio para cutucar o bravo Onesíforo. Isso não existe. 
[179] pas. Mais si cela existait, le brave Onésiphore serait bien embêté.

-Mais qu'est-ce que c'est ?

- Des hommes qui auraient existé avant Adam.

-Comme c'est bête !

- On croirait entendre l'abbé Riphinte. Ne me fais pas regretter de t'avoir emmené avec moi.

- On a du mal à causer avec vous, monsieur le duc, vous dites que ça n'existe pas et, en même temps, vous ne voulez pas que je trouve ça bête.

- Une chose qui n'existe pas n'est pas forcément bête, imbécile. $\mathrm{Ah}$ ah, des chous gras, moi qui en suis friand.

- Bas les pattes, vieux cochon, dit la servante au duc qui voulait mêler anatomie et gastronomie. La prochaine fois, je vous renverse le plat sur la tête. Et ce sera du salmigondis.

- Elle n'est pas commode.

- Comment vous laissezvous traiter comme ça, monsieur le duc?

- N'oublie pas que je voyage incognito et liquidons ces chous gras.

Ils bâfraient en silence lorsqu'un postillon costumé en postillon surgit en manifestant avec ostentation une épouvante abjecte. Il gueulait :

- Incroyable mais vrai! Dans l'écurie, il y a... un cheval qui parle!

Tout le monde rit de bon cœur, le duc tout le premier; seul Pouscaillou, inquiet, demeura grave.

- Tu est encore saoul, dit l'aubergiste, tu n'as pas honte de venir semer le grabuge ?

- Laissez, laissez, dit un voyageur à l'aubergiste.

Et au postillon:
Mas se existisse, o bravo Onesíforo ficaria bem chateado.

- Mas o que é que é?

- Homens que teriam existido antes de Adão.

- Isso é muito besta!

- Parece que estou ouvindo o abade Rifinge. Não faça eu me arrepender de tê-lo trazido comigo.

- É difícil conversar com o senhor, senhor duque, o senhor diz que isso não existe e, ao mesmo tempo, não quer que eu ache isso besta.

- Uma coisa que não existe não é necessariamente besta, imbecil. Ah ah, couve-manteiga, gosto muito disso.

- Tira as patas, porco velho, disse a garçonete ao duque que queria misturar anatomia $\mathrm{e}$ gastronomia. Da próxima vez, eu viro o prato na sua cabeça. E será um angu.

- Ela não é fácil.

- Como o senhor se deixa tratar dessa maneira, senhor duque?

- Não se esqueça de que viajo incógnito e acabemos com essa couve-manteiga.

Eles se empanturravam em silêncio quando um postilhão vestido de postilhão surgiu manifestando com ostentação um terror abjeto. Ele se esgoelava:

- É incrível mas é verdade! $\mathrm{Na}$ estrebaria, há... um cavalo que fala!

Todo mundo riu desbragadamente, começando pelo duque; só Pouscaillou, inquieto, permaneceu sério.

- Você ainda está bêbado, disse o albergueiro, não tem vergonha de vir fazer esse bafafá?

- Deixe, deixe, disse um viajante ao albergueiro.

E ao postilhão: 
- Et qu'est-ce qu'il t'a dit le [180] cheval?

- En me voyant entrer dans l'écurie, il a crié : Vive les préadamites !

- Au fol, cria quelqu'un.

Tout le monde rit de bon cœur, le duc tout le premier; seul Pouscaillou, de plus en plus inquiet, demeurait grave.
- E o que é que o cavalo lhe disse?

- Quando me viu entrar na estrebaria, ele gritou: Viva os preadamitas!

- Está louco, gritou alguém. Todo mundo riu desbragadamente, a começar pelo duque; só Pouscaillou, cada vez mais inquieto, permanecia sério. 
XIV

Une troisième fois tout le monde se mit à rire de bon cœur,

[181] lorsque le postillon poursuivit en ces termes l'énoncé de ses émotions :

- Et le cheval ajouta: Tu n'en crois pas tes oreilles, hein ?

Seul Pouscaillou, fort inquiet, demeurait grave.

- Ça sûrement, continua le postillon, je n'en croyais pas mes oreilles, aussi m'ensauvis-je et me voilà ici et je ne suis pas près de retourner dans cette écurie du diable. Holà, aubergiste, donne-moi un pichet de clairet, pour me remettre les esprits en place.

- Je n'en ferai rien, dit l'aubergiste, tu as assez bu comme ça.

- Jarnicoton, je ne suis point ivre. Vas-y voir toi-même !

- Dieu m'en garde! Et d'abord quel cheval est-ce ?

- C'est le mien, dit le duc.

Tout le monde se tourna vers lui.

- Et il parle, ajouta-t-il. Il sait même lire. Par exemple, il est en train de lire le Voyage du Jeune Anacharsis en Grèce, qu'il apprécie beaucoup. Aubergiste, donnez donc un pichet de clairet à monsieur le

[182] postillon : il n'est point ivre.

Un murmure approbateur suivit ce discours court, chacun disant à son voisin: quel homme d'esprit.

- Tu en fais une tête, dit le duc à Pouscaillou. Tu vois pourtant qu'ils se contentent de peu. Comme, un jour ou l'autre, quelqu'un finira bien par le dire : en France, le ridicule tue. Voilà le postillon déconsidéré ; mais je dois reconnaître que Sthène a été bien
XIV

Uma terceira vez todo
mundo pôs-se a rir
desbragadamente, quando o
postilhão prosseguiu nestes termos
o enunciado de suas emoções:
- E o cavalo acrescentou:

Você não está acreditando em seus ouvidos, hein?

Só Pouscaillou, mui inquieto, permanecia grave.

- Com certeza, continuou o postilhão, eu não estava acreditando em meus ouvidos, tanto que fugi m'embora e estou aqui e não pretendo voltar àquela estrebaria do diabo. Oi, albergueiro, dê-me uma jarra de clarete, para eu pôr minhas idéias no lugar.

- De jeito nenhum, disse o albergueiro, você já bebeu demais.

- Por Deus, eu não estou bêbado. Vá ver você mesmo!

- Deus me livre! E pra começar que cavalo é esse?

- É o meu, disse o duque.

Todo mundo virou para ele.

- E ele fala, acrescentou ele. Ele sabe até ler. Por exemplo, está lendo a Viagem do Jovem Anacharsis na Grécia, que ele aprecia muito. Albergueiro, dê, pois, uma jarra de clarete ao senhor postilhão: ele não está bêbado.

Um murmúrio aprovador seguiu esse discurso curto, cada um dizendo a seu vizinho: que homem de espírito.

- Você está fazendo uma cara, diz o duque a Pouscaillou. No entanto está vendo que eles se contentam com pouco. Como, um dia ou outro, alguém vai acabar dizendo: na França, o ridículo mata. Aí está o postilhão desmoralizado; mas tenho que 
imprudent, il ne sait pas tenir sa langue.

- Et si les argousins faisaient une enquête ?

- Peuh! tout au plus le curé du coin.

La servante apportait une poularde dont les deux voyageurs vinrent facilement à bout, ainsi que des entremets, fromages et friandises qui suivirent. Ils vidèrent encore quelques pichets avant de s'en aller coucher et ils s'endormirent aussitôt bien repus et bien fatigués.

Lalix et Cidrolin écarquillèrent les yeux lorsque la lumière se fit de nouveau et sortirent un peu éberlués du cinéma.

- On prend un verre avant de rentrer, proposa Cidrolin.

Lalix était d'accord.

- J'ai un faible pour les films de cape et d'épée, dit Cidrolin.

- Vous croyez ? demanda Lalix. sûr.

- Je ne crois pas, j'en suis

- Ce n'est pas ça que je veux dire. Je veux dire: vous croyez que c'était un film de cape et d'épée ? rêvé.

- Oui, à moins que je n'aie

- Moi, il me semble que c'était un ouesterne. Mais il me

[183] semble aussi que j'ai dormi.

- Si on retournait voir ce qu'on jouait?

Ils retournèrent voir. Affiches et photos se référaient à Spartacus et Frankenstein contre Hercule et Dracula.

- C'est peut-être le programme de la semaine prochaine, suggéra Lalix. reconhecer que Stenes foi muito imprudente, ele não sabe segurar a língua.

- E se a polícia fizesse um inquérito?

- Bah, no máximo o padreco do lugar.

A garçonete trazia uma galinha com a qual os dois viajantes acabaram facilmente, assim como com os acompanhamentos, queijos e guloseimas que seguiram. Eles esvaziaram ainda algumas jarras antes de ir dormir e adormeceram logo muito saciados e muito cansados.

Aalice e Cidrolin arregalaram os olhos quando fez-se a luz de novo e saíram do cinema um pouco espantados.

- Vamos tomar alguma coisa antes de voltar, propôs Cidrolin. Aalice estava de acordo. - Tenho um fraco pelos filmes de capa e espada, disse Cidrolin.

- O senhor acha? perguntou

Aalice.

certeza.

- Eu não acho, tenho

- Não é isso que eu quero dizer. Eu quero dizer: o senhor acha que era um filme de capa e espada?

- Sim, a menos que eu tenha sonhado.

- Pra mim, parece que era um uésterne. Mas parece que eu também dormi.

- Vamos voltar e ver o que estava passando?

Eles voltaram pra ver. Cartazes e fotos referiam-se a Spartacus e Frankenstein contra Hércules e Drácula.

- Pode ser que seja o programa da próxima semana, sugeriu Aalice. 
- On ne saura jamais, dit Cidrolin. En tout cas, vous qui êtes contre, c'est comme si vous m'aviez raconté un rêve.

- Je suis vexée.

- Allons prendre un verre.

$\mathrm{Au}$ coin du quai, le bistro était vide; on y rangeait les tables. Les consommateurs devaient se contenter du comptoir et se tenir devant, debout.

- Ça ne me plaît pas, dit Cidrolin. On va continuer jusqu'à l'Arche.

- Pourquoi ça s'appelle l'Arche ? demanda Lalix.

- Sans doute parce qu'il n'y loge aucun animal, répondit Cidrolin.

- Comprends pas.

- L'astuce n'est pas retentissante, en effet. Disons que ça s'appelait comme ça quand je l'ai acheté.

- Cher?

- Entre les deux.

- Moi, il me plaît votre chaland. $\mathrm{Au}$ fond je suis bien contente d'avoir délaissé le musichall pour devenir gouvernante. Monsieur Albert a été de bon conseil.

- Comment vous a-t-il convaincue?

- À coups de pied. Ça, on peut dire que vous avez un bon [184] copain qui vous est tout dévoué.

- J'espère qu'il ne vous a pas fait trop mal.

- Eh, il n'y allait pas de pied mort, mais j'ai vite compris.

- Alors vous ne regrettez pas trop le music-hall ?

- Je vous le répète : j'aime bien votre chaland.

- Et qu'est-ce que vous auriez fait au music-hall ?

- J'aurais voulu être
- Nunca saberemos, disse Cidrolin. Em todo caso, a senhorita que é contra, é como se me tivesse contado um sonho.

- Estou vexada.

- Vamos tomar alguma coisa.

$\mathrm{Na}$ esquina do cais, o boteco estava vazio; estavam arrumando as mesas. Os consumidores tinham que se contentar com o balcão e ficar em pé.

- Isso não me agrada, disse Cidrolin. Vamos continuar até a Arca.

- Por que ela se chama a Arca? perguntou Aalice.

- Provavelmente porque não hospeda nenhum animal, respondeu Cidrolin.

- Num tô entendendo.

- A esperteza não é seu forte, de fato. Digamos que ela já se chamava assim quando eu a comprei.

- Caro?

- Médio.

- Eu gosto da sua chalana. No fundo estou muito contente por ter renunciado ao music-hall para tornar-me governanta. $\mathrm{O}$ senhor Alberto foi bom conselheiro.

- Como ele a convenceu?

- A pontapés. Pode estar certo de que o senhor tem um bom amigo que lhe é bastante dedicado.

- Espero que não a tenha machucado muito.

- Ah, ele não tinha o pé leve, mas eu entendi rápido.

- Então não sente muita falta do music-hall?

- Eu repito: gosto bastante de sua chalana.

- E o que a senhorita iria fazer no music-hall?

- Eu queria ter sido guerl. 
gueurle. Je danse pas mal et je suis bien balancée ; j'aurais voulu aussi chanter, mais monsieur Albert trouvait que c'était bien inutile.

- Et vous aviez des engagements en vue ?

- Oui, j'hésitais entre la Zanzébie et la république du Capricorne, mais tout ça, faut reconnaître, c'est des pays bien lointains. J'aime encore mieux rester par quarante-neuf degrés de latitude. Nord naturellement.

- Vous êtes calée en géographie.

- Je me préparais à tous ces grands voyages. C'est vrai qu'elle ne bouge jamais votre péniche?

- Elle en est tout à fait incapable. Il faudrait la remorquer.

- Un petit remorqueur, ça ne doit pas être tellement coûteux.

- C'est tout de même audessus de mes moyens.

- Mettons que je n'ai rien dit.

Ils marchaient depuis quelque temps en silence lorsqu'un groupe de boy-scouts adultes les dépassa. L'un d'eux s'arrêta pour leur demander

- Campigne?

Cidrolin fit le geste qui veut dire tout droit.

[185] L'autre fit le geste qui veut dire merci.

Les boy-scouts adultes continuèrent leur chemin au pas accéléré.

- Il y en a encore, dit Cidrolin, pourtant c'est déjà l'automne. Bientôt il en viendra jusqu'en plein hiver, des coriaces, qui se blottiront bien au chaud sous la neige.

- Qu'est-ce qu'on fait quand y a de la neige sur la péniche ?

- On la pousse dans l'eau et ça fait floc. Quelquefois, même, en
Não danço mal e sou bem sacudida; também queria cantar, mas o senhor Alberto achava que era completamente inútil.

- E já tinha alguma coisa em vista?

- Sim, eu estava em dúvida entre a Zanzébia e a república de Capricórnio, mas os dois, é preciso reconhecer, são países longínquos. Ainda prefiro ficar nos quarenta e nove graus de latitude. Norte naturalmente.

- Você é boa em geografia.

- Estava me preparando para todas essas grandes viagens. É verdade mesmo que sua chata não se mexe?

- Ela é totalmente incapaz de fazê-lo. Seria preciso rebocá-la.

- Um pequeno rebocador não deve ser tão custoso.

- De toda maneira está acima das minhas possibilidades.

- Não está mais aqui quem falou.

Andavam há algum tempo em silêncio quando um grupo de escoteiros adultos passou por eles. Um deles parou para perguntar-lhes

- Câmpingue?

Cidrolin fez o gesto que quer dizer em frente.

$\mathrm{O}$ outro fez o gesto que quer dizer obrigado.

Os escoteiros adultos continuaram seu caminho em passo acelerado.

- Ainda tem campistas, disse Cidrolin, no entanto já é outono. Daqui a pouco eles virão em pleno inverno, os casca-grossas, que vão se enroscar bem quente embaixo da neve.

- O que a gente faz quando tem neve na chata?

- A gente empurra para a água e faz floc. Algumas vezes, 
plein été, il y a comme de la neige sur l'eau, mais ce n'est pas de la neige, ça ressemble à de la mousse de savon ou à de la ouate, ça vient de l'usine de houatures qui se trouve en amont, je suppose qu'ils lavent les bagnoles avant de les refiler aux clients. Nous voilà arivés.

Cidrolin prit la lampe dans la boîte aux lettres et inspecta la clôture.

- On n'a rien écrit, dit Lalix. C'est ça que vous regardez?

- Oui.

- Parce que c'était pas la première fois ?

- Non. Presque tous les jours.

- Qui c'est qui fait ça?

- Je ne sais pas. Attention de ne pas vous casser la gueule, ça glisse.

- Une nuit, vous devriez vous cacher dans un coin, faire le guet et, quand ce type arriverait, lui flanquer une bonne tatouille et, en prime, vous sauriez qui c'est.

- Attention à ne pas vous foutre dans la flotte. Là, nous y voilà.

- Où vous allez comme ça ?

- Chercher l'essence de fenouil, une carafe d'eau et deux [186] verres.

- Et moi alors ? C'est moi qui dois faire ça. Asseyez-vous.

- Bon, dit Cidrolin. L'électricité est à droite.

- Je sais.

Cidrolin s'assit. Les ampoules sur le pont s'allumèrent.

- Il commence à faire frais, dit-il à Lalix lorsqu'elle revint avec l'essence de fenouil, une carafe d'eau et un verre. Je ne me vois pas restant toute la nuit dehors.

- Couvrez-vous. Mettez un mesmo em pleno verão, parece que há neve na água, mas não é neve, parece espuma de sabão ou algodão, vem da fábrica de otomóvis que fica a montante, acho que eles lavam os carangos antes de empurrá-los para os clientes. Chegamos.

Cidrolin pegou a lanterna na caixa de correio e inspecionou a cerca.

- Não tem nada escrito, disse Aalice. É isso que o senhor está olhando?

- É.

- Porque não era a primeira vez?

- Não. Quase todos os dias.

- Quem é que faz isso?

- Não sei. Cuidado para não quebrar o pescoço, isso escorrega.

- Uma noite, o senhor deveria se esconder num canto, ficar à espreita e, quando o sujeito chegasse, dar-lhe uma boa bofetada e, de brinde, o senhor ficaria sabendo quem é.

- Cuidado para não cair na água. Pronto, chegamos.

- Aonde o senhor vai?

- Buscar a essência de funcho, uma garrafa de água e dois copos.

- E eu então? Sou eu que devo fazer isso. Sente-se.

- Está bem, disse Cidrolin. A eletricidade está à direita.

- Eu sei.

Cidrolin senta-se. As lâmpadas do convés acendem-se.

- Está começando a esfriar, diz ele a Aalice quando ela volta com a essência de funcho, uma garrafa de água e um copo. Não me vejo ficando fora a noite inteira.

- Cubra-se. Coloque um 
poul en plus.

-Vous ne buvez pas?

- J'ai horreur de l'essence de fenouil.

- C'est un peu démodé, je reconnais. Prenez autre chose. ça.

- Non merci. Ça va comme reprit:

Elle le regarda se servir et

- Vraiment, vous n'aurez pas le courage de passer la nuit dehors pour corriger ce con?

- Ce n'est pas le courage qui manque, mais je préfère dormir.

- Et rêver.

- Voilà ; et rêver.

- Si c'est comme ça, eh bien, c'est moi qui vais y aller.

- Et vous le corrigerez? Ils sont peut-être plusieurs.

- Vous n'avez pas un revolver? une carabine ?

- Non! non! il n'y a pas d'armes à bord.

Dans son émotion, Cidrolin se servit un nouveau verre d'essence de fenouil.

- Vous buvez trop, remarqua Lalix.

- Tout le monde me le dit.

Lalix reprit :

[187]

- Je me cacherai et quand le type ou les types seront en train de gribouiller leurs trucs, je hurlerai hou hou pour leur faire peur. Je me mettrai même un drap sur la tête. Après ça, ils ne reviendront plus. $\mathrm{Ou}$ il ne reviendra plus. Pour moi, c'est un homme tout seul. Qui c'est qui peut vous en vouloir comme ça?

- Je ne sais pas, dit Cidrolin d'une voix lointaine. Je n'ai pas la moindre idée.

- Il y a tout de même une raison quelconque, dit Lalix. pulôver a mais.

- A senhorita não bebe?

- Tenho horror à essência de funcho.

- Está um pouco fora de moda, reconheço. Tome outra coisa.

- Não, obrigado. Está bem assim.

Ela o olhou se servir e retomou:

- O senhor não vai mesmo ter coragem de passar a noite fora para dar um corretivo nesse babaca?

- Não é coragem que falta, mas prefiro dormir.

- E sonhar.

- É isso aí; e sonhar.

- Se é assim, então, sou eu que vou.

- E a senhorita vai dar-lhe o corretivo? Pode ser que seja mais de um.

- O senhor não tem um revólver? uma carabina?

- Não! não! não há armas a bordo.

$\mathrm{Na}$ sua emoção, Cidrolin serviu-se de um novo copo de essência de funcho.

- O senhor bebe demais, observou Aalice.

- Todo mundo me diz isso. Aalice retoma:

- Vou me esconder e quando o sujeito ou os sujeitos estiverem rabiscando suas coisas, eu urro hu hu para assustá-los. Vou até colocar um lençol na cabeça. Depois disso, eles não voltarão mais. Ou ele não voltará mais. Para mim, é um homem só. Quem é que pode lhe querer tão mal?

- Não sei, disse Cidrolin com uma voz distante. Não faço a mínima idéia.

- De qualquer modo deve haver uma razão qualquer, disse 
- J'espère que vous ne croyez pas ce qu'il y avait d'écrit ? Je ne suis pas un assassin. Pas même un meurtrier. Rien. J'étais innocent. J'ai fait un an et demi de préventive. On a fini par reconnaître que j'étais innocent. Je croyais que c'était fini. Non, il y a ce con, comme vous dites, avec ses graffiti, comme je dis ; mais j'aime bien la peinture en bâtiment. Comme je n'ai pas beaucoup d'occupations, ça m'en fait une. Et puis, de cette façon, ma clôture est la mieux entretenue de tout le quai. Je vous raconte tout cela, mais, au fond, je n'y pense jamais. Cela ne me touche pas. Pas tellement.

- Vous n'êtes pas curieux de savoir qui ça peut bien être, ce type ?

- Pas tellement.

- Tout de même, vous devriez y aller voir.

Cidrolin eut l'air de réfléchir profondément, puis, après quelques instants de silence, il finit par dire :

- Vous aimeriez mieux que je passe la nuit dehors?

- Quand on fait l'amour sur une couchette, remarque Lalix, le

[188] type il doit se cogner la tête.

- Après tout, vous n'avez pas de mauvaises idées.

Il se leva pour aller chercher une couverture. Il prit aussi une bouteille de rome, une torche électrique et un manche à balai, la seule arme dont il disposât en dehors de dangereux couteaux de cuisine.

Ainsi équipé, il alla se cacher, conformément aux suggestions de Lalix.

Il lui cria :

- Éteignez sur le pont !

Ce qu'elle fit.
Aalice.

- Espero que a senhorita não acredite no que estava escrito? Não sou um assassino. Nem mesmo um matador. Nada. Eu era inocente. Fiquei um ano e meio na preventiva. Acabaram por reconhecer que eu era inocente. $\mathrm{Eu}$ pensava que tinha terminado. Mas não, tem esse babaca, como a senhorita diz, com seus graffiti, como eu digo; mas eu gosto da pintura de paredes. Como não tenho muitas ocupações, essa já é uma. E depois, desse modo, minha cerca é a mais bem conservada de todo o cais. Estou lhe contando tudo isso, mas, no fundo, não penso nisso nunca. Isso não me atinge. Não tanto.

- O senhor não fica curioso para saber quem pode ser esse sujeito?

- Não tanto.

- De qualquer modo, o senhor deveria ir ver.

Cidrolin pareceu refletir profundamente, depois, após alguns instantes de silêncio, acabou por dizer:

- A senhorita prefere que eu passe a noite fora?

- Quando se faz amor num colchonete, observa Aalice, é pra bater a testa.

- No fim das contas, até que a senhorita tem boas ideias.

Ele levantou-se para ir procurar uma coberta. Pegou também uma garrafa de rum, uma lanterna elétrica e um cabo de vassoura, a única arma de que dispunha fora as perigosas facas de cozinha.

Assim equipado, foi se esconder, conforme as sugestões de Aalice.

Ele gritou-lhe:

- Apague a luz do convés!

Ela o fez. 
Il connaissait un coin idoine et s'y installa, s'enroulant dans sa couverture. Il but une gorgée de rome et ne tarda pas à s'endormir.

Pouscaillou sursauta lorsque Sthène lui dit dans l'oreille :

- Voilà le patron.

Le nouveau vicomte d'Empoigne se reposait à l'ombre d'un arbre bien feuillu en compagnie des deux chevaux qui cherchaient à gauche à droite des friandises et savaient fort bien se garder eux-mêmes. Le duc était parti dans la nature depuis plusieurs heures ; il fit sa réapparition tenant en laisse la mule empruntée à l'auberge et sur laquelle il avait chargé son matériel.

- Voilà une bonne chose de faite ! cria-t-il de loin.

- Vous avez terminé ? demande Pouscaillou poliment lorsque le duc se fut rapproché.

- L'affaire est dans le sac. Demain, nous irons à Montignac. Un gamin m'a signalé quelque chose d'intéressant de ce côté-là. Et maintenant rentrons à Plazac !

[189] Il monta sur Sthène, sur Sthèphe Pouscaillou tenant en laisse la mule empruntée à l'auberge et sur laquelle le duc avait chargé son matériel.

Le train était rapide et Sthène d'humeur peu loquace. Le duc finit par s'en étonner.

- Eh bien, mon bon Démo, lui dit-il, nous ne sommes pas bavard aujourd-hui.

- Pour tout vous avouer, dit Sthène, je m'ennuie un peu loin du château et souvent je me demande quand je reverrai mon écurie natale qui m'est une province et beaucoup davantage.

- Hélas, dit le duc, il te faut
Ele conhecia um canto adequado e se instalou, enrolandose na coberta. Bebeu um gole de rum e não demorou a adormecer.

Pouscaillou sobressaltou-se quando Stenes disse-lhe ao ouvido: - Olha o patrão.

$\mathrm{O}$ novo visconde de Empoigne repousava à sombra de uma árvore bem copada em companhia dos dois cavalos que procuravam guloseimas de um lado e do outro, e que sabiam mui bem se guardar eles mesmos. $\mathrm{O}$ duque tinha partido para a natureza havia várias horas; ele fez sua reaparição segurando pelas rédeas a mula emprestada pelo albergueiro e sobre a qual tinha posto seu material.

- Pronto, está feito! gritou ele de longe.

$$
\begin{aligned}
& \text { - O senhor terminou? } \\
& \begin{array}{l}
\text { pergunta } \\
\text { educadamente } \\
\text { aproximou-se. }
\end{array}
\end{aligned}
$$

- Serviço de craque. Amanhã vamos a Montignac. Um rapaz me mostrou uma coisa interessante daquele lado. E agora vamos voltar para Plazac!

Ele montou em Stenes, em Estêvão Pouscaillou segurando pelas rédeas a mula emprestada pelo albergueiro e sobre a qual o duque tinha posto seu material.

$\mathrm{O}$ comboio ia rápido $\mathrm{e}$ Stenes de humor pouco loquaz. O duque acabou por se espantar.

- E aí, meu bom Demós, disse-lhe ele, não estamos muito falantes hoje.

- Para ser sincero, disse Stenes, me aborreço um pouco longe do castelo e sempre me pergunto quando reverei minha estrebaria natal que é para mim província, ou antes reino.

- Pena, disse o duque, você 
prendre ta mélancolie en patience. Je n'ai pas envie d'aller me jeter dans les pattes de la maréchaussée et je n'ai pas encore terminé mes travaux dans la région.

- C'est bien ce que je disais, soupira Sthène, le retour n'est pas pour demain.

- $\mathrm{Tu}$ souffres très exactement de nostalgie, dit Stèphe que la taciturnité de son compagnon poussait au bavardage.

- Nostalgie? dit Sthène, voilà un mot que je ne connais pas.

- Il est d'invention récente, dit Stèphe d'un ton doctoral. Il vient de nostos et d'algos, algos qui veut dire en grec souffrance et nostos qui dans la même langue veut dire retour. Il s'applique donc parfaitement à ton cas.

- Et toi, dit Sthène, tu est atteint de logorrhée.

- Logorrhée? dit Stèphe, voilà un mot que je ne connais pas.

- Je pense bien, dit Sthène, je viens de l'inventer. Il vient de logos et de...

- Je vois, je vois, dit Stèphe. J'ai compris.

[190] - Es-tu sûr d'avoir bien compris ? demanda Sthène.

Et les deux chevaux commencèrent à se chamailler jusqu'à l'entrée de Plazac. À l'auberge du Soleil d'Or où le duc s'était installé sous le nom de monsieur Hégault, un ecclésiastique vidait pot sur pot en parlant politique avec l'aubergiste. Tous deux étaient d'accord sur la nécessité des réformes mais s'inquiétaient un peu de cette transformation des États généraux en Assemblée Constituante et du renvoi de Necker.

Aubergiste! s'écria monsieur Hégault en entrant dans precisa carregar sua melancolia com paciência. Não tenho vontade de ir me jogar nas garras da guarda real e ainda não terminei meus trabalhos na região.

- É exatamente o que eu dizia, suspirou Stenes, o retorno não é pra amanhã.

- Você sofre exatamente de nostalgia, disse Estêvão que a taciturnidade de seu companheiro levava à tagarelice.

- Nostalgia? disse Stenes, eis uma palavra que eu não conhecia.

- É de invenção recente, disse Estêvão com um tom doutoral. Vem de nostos e de algos, algos que quer dizer em grego sofrimento e nostos que na mesma língua quer dizer volta. Aplica-se pois perfeitamente ao seu caso.

- E você, disse Stenes, você foi atingido pela logorréia.

- Logorréia? disse Estêvão, eis uma palavra que eu não conheço.

- Acredito, disse Stenes, eu acabo de inventá-la. Vem de logos e de...

- Tem certeza de que entendeu bem? perguntou Stenes.

$\mathrm{E}$ os dois cavalos começaram a discutir até a entrada de Plazac. No albergue do Sol de Ouro onde o duque tinha se instalado com o nome de senhor Higuau, um eclesiástico esvaziava um copo atrás do outro falando de política com o albergueiro. Os dois estavam de acordo sobre a necessidade das reformas, mas preocupavam-se um pouco com aquela transformação dos Estados Gerais em Assembléia Constituinte e com a demissão de Necker.

- Albergueiro! exclamou o senhor Higuau entrando na sala 
la salle où se tenaient les deux citoyens, tu ferais mieux de préparer le souper que de discutailler sur l'histoire contemporaine. Monsieur, ajouta-til, à l'intention de l'ecclésiastique, je ne vous connais pas.

Et à l'intention de l'aubergiste :

- J'ai grand soif et je veux du vin frais.

Dès que l'aubergiste eut disparu dans la cave, le duc s'exclama :

- Est-ce un hasard, l'abbé, ou bien faites-vous l'espion?

- Monsieur le duc...

- Monsieur Hégault.

- Vraiment ? faut-il...

- Appelez-moi monsieur Hégault, vous dis-je.

- Monsieur Hégault, je vous apporte de bonnes nouvelles.

- J'en doute, mais cela prouve donc que vous avez découvert ma cute. Comment diable avez-vous fait ?

- Je pourrais vous répondre par un pieux mensonge...

- Dispensez-vous-en.

- ... mais je vous donnerai l'explication bien simple: le jeune vicomte d'Empoigne écrivait à sa maman.

- Ah le coquin! Ah le traître ! Je vais lui tirer les oreilles de belle façon!

- Vous ne pouvez lui reprocher son amour filial. Je demande votre indulgence car nous avons demandé celle de Sa Majesté pour vous.

- Qui ça : Nous?

- Monseigneur Biroton qui siège actuellement à l'Assemblée Constituante.

L'Assemblée

Constituante, qu'est-ce que cela ? - Le nom que viennent de se donner les États généraux. Votre onde estavam os dois cidadãos, é melhor você preparar a ceia do que discutir sobre a história contemporânea. Senhor, acrescentou ele, dirigindo-se ao eclesiástico, não o conheço.

$$
\text { E dirigindo-se ao }
$$
albergueiro:

- Tenho muita sede e quero vinho fresco.

Assim que o albergueiro desapareceu na adega, o duque exclamou:

- É um acaso, abade, ou você virou espião?

- Senhor duque...

- Senhor Higuau.

- Realmente? é preciso...

- Chame-me de senhor Higuau, estou dizendo.

- Senhor Higuau, trago-vos boas notícias.

- Duvido, mas isso prova então que você descobriu meu esconderijo. Como diabos fez isso?

- Eu poderia responder com uma piedosa mentira...

- Nem tente.

- ... mas vou dar-lhe a explicação bem simples: o jovem visconde de Empoigne escrevia pra sua mamãe.

- Ah canalha! Ah traidor! Vou puxar tanto as orelhas dele que ele vai ver!

- O senhor não pode reprovar seu amor filial. Peço vossa indulgência pois nós pedimos a de Sua Majestade para o senhor.

- Nós, quem?

- Monsenhor Biroton que atualmente faz parte da Assembléia Constituinte.

- Assembléia Constituinte, o que é isso?

- O nome que acaba de ser dado aos Estados Gerais. Sua 
présence est réclamée à Paris. Le délégué du bailliage d'Auge manque beaucoup dans les rangs de la Noblesse et Sa Majesté vous absoudra; après tout vous n'avez rien fait d'autre que venger votre honneur, si...

- Il y a un si.

- Il n'est pas terrible: si vous ne rejoignez votre place à l'Assemblée Constituante.

- Ne comptez pas sur moi. Pour le moment, j'ai d'autres chats à fouetter.

- Peut-on savoir lesquels?

L'aubergiste revenait avec quelques pichets de vin frais.

- Laisse-nous, aubergiste, lui dit monsieur Hégault, tu vois bien que je suis en train de me confesser. Retourne à tes fourneaux et prépare-nous un souper du diable: c'est moi qui régale monsieur l'abbé.

L'aubergiste s'éclipsa, mais Pouscaillou fit son entrée. Il avait fini de soigner les chevaux et de ranger le matériel. Il s'exclama :

- Monsieur l'abbé !

Il avait l'air fort surpris.

- Viens ici, coquin ! traître! lui dit monsieur Hégault. C'est comme cela que je dois avoir confiance en toi ? Je vais te rosser.

Il se leva dans ce but.

- Mais j'ai rien fait de mal, dit Pouscaillou en faisant une marche arrière.

- Tu aurais pu me livrer à la maréchaussée.

- Je comprends pas. J'ai rien fait de mal.

- Tu écrivais à la comtesse d'Empoigne !

- Eh quoi ! monsieur le duc, c'est mal d'écrie à sa maman ?

- Et il m'appelle monsieur presença está sendo solicitada em Paris. O delegado do bailiado de Auge faz muita falta nas fileiras da Nobreza e Sua Majestade vai absolvê-lo; afinal o não fizestes nada além de vingar vossa honra, se...

- Há um se.

- Não é tão terrível: se tomardes vosso lugar na Assembléia Constituinte.

- Não conte comigo. No momento ainda tenho alguns coelhos pra tirar da cartola.

- Pode-se saber quais?

$\mathrm{O}$ albergueiro voltava com algumas jarras de vinho fresco.

- Deixe-nos, albergueiro, disse-lhe o senhor Higuau, você pode ver que estou me confessando. Volte aos seus fornos e prepare-nos uma ceia do diabo: sou eu que ofereço ao senhor abade.

O albergueiro sumiu, mas Pouscaillou fez sua entrada. Ele tinha acabado de cuidar dos cavalos e de guardar o material. Ele exclamou:

- Senhor abade!

Ele tinha um ar mui surpreso.

- Venha aqui, canalha! traidor! disse-lhe o senhor Higuau. É assim que tenho que confiar em você? Vou espancá-lo.

Ele levantou-se com esse objetivo.

- Mas eu num fiz nada de mal, disse Pouscaillou dando marcha a ré.

- Você poderia ter me entregado à guarda real.

- Num tô entendendo. Não fiz nada de mal.

- Você escrevia pra condessa de Empoigne!

- E daí! senhor duque, é fazer mal escrever pra sua mamãe?

- E ele me chama de senhor 
le duc !

Les

oreilles

pouscailloutiennes allaient tomber entre les mains ducales lorsque l'abbé Riphinte s'écria :

- Grâce, monsieur Hégault.

Grâce pour ce jeune lévite! J'ajouterai que la comtesse fut fort discrète.

fils.

- Ce n'est pas une qualité du

- N'en parlons plus..

- J'en parlerai, répliqua le duc.

- N'en parlons plus, reprit l'abbé Riphinte avec autorité, et revenons à nos moutons qui sont d'ailleurs des chats.

- Allons, dit monsieur Hégault à Pouscaillou, assieds-toi et rafraîchis-toi de ce vin clairet, mais sache bien que je hais fort les cachotteries.

- Si c'en est une d'écrire à ma maman, s'écria Pouscaillou

[193] d'un beau mouvement, je le ferai plus !

- Nous verrons cela plus tard, dit monsieur Hégault et, s'adressant à l'abbé Riphinte : Quels chats? demanda-t-il.

- Ceux que vous fouettez, monsieur Hégault.

- Ah! pour cela, je vous réserve une belle surprise! Mais parlez-moi donc de ma dame Russule.

L'abbé Riphinte donna des nouvelles de la duchesse, des nouvelles assez mauvaises puisqu'elle était morte de consomption, un mois après le meurtre d'Empoigne. Après avoir évoqué ce triste souvenir, l'abbé se leva pour dire une courte prière. Le duc et Pouscaillou conclurent : amen.

Puis ils soupèrent copieusement, et, comme ils étaient duque!

As orelhas pouscailloucianas iam cair entre as mãos ducais quando $\mathrm{o}$ abade Rifinge exclamou:

- Piedade, senhor Higuau. Piedade para esse jovem levita! Acrescentarei que a condessa foi mui discreta.

- Não é uma qualidade do filho.

- Não falemos mais nisso...

- Eu falarei, replicou o duque.

- Não falemos mais nisso, retomou $\mathrm{o}$ abade Rifinge com autoridade, e voltemos às vacas frias que no caso são coelhos.

- Vamos, disse o senhor Higuau a Pouscaillou, sente-se e refresque-se com esse vinho clarete, mas saiba que odeio segredinhos.

- Se escrever pra minha mamãe for segredinho, exclamou Pouscaillou com um belo movimento, num faço mais isso!

- Veremos isso mais tarde, disse o senhor Higuau e, dirigindose ao abade Rifinge: Que coelhos? perguntou ele.

- Os que o senhor vai tirar da cartola, senhor Higuau.

- Ah! quanto a isso, estou lhe reservando uma bela surpresa! Mas fale-me da minha dama Russula.

$\mathrm{O}$ abade Rifinge deu as notícias da duquesa, notícias muito más já que ela tinha morrido de consumação, um mês depois da morte de Empoigne. Depois de ter evocado essa triste lembrança, o abade levantou-se para dizer uma curta prece. $\mathrm{O}$ duque e Pouscaillou concluíram: amém.

Depois cearam copiosamente, e, como estavam os 
tous trois assez fatiguès, hop, au lit.

três muito cansados, upa, pra cama. 
Cidrolin ouvrit un œil : ce n'était pas encore l'aube. Il ouvrit

[194] les deux yeux : c'était encore la nuit. Il frissonna, ce qui lui suggéra de boire une lampée de rome, puis il regarda dans la direction du quai : désert, quant aux piétons. Parfois passait, rapide, une houature sur la chaussée. Au bout d'un certain temps, Cidrolin s'aperçut que, s'il y avait des gens sur le trottoir, l'obscurité ne lui permettrait pas de les voir. Il frissonna de nouveau et but une autre lampée de rome.

Il se leva doucement et s'avança vers la clôture en silence ; il alluma brusquement sa torche électrique avec laquelle il sabra l'obscurité. Personne ne se trouvait dans la trajectoire. Il sortit pour regarder si le lâche anonyme n'était pas encore passé, ou ne passerait peut-être pas cette nuit.

- Dommage, murmura-t-il, j'aurais pu aller me coucher.

Il se retourna et crut voir quelqu'un marcher sur le trottoir, en bas de l'immeuble achevé mais non encore habité. Il dirigea sa torche dans cette direction, mais elle était trop faible pour éclairer la silhouette devinée. Les phares d'une houature firent mieux et

[195] Cidrolin put voir que cette silhouette, ce n'était rien qui pût l'intéresser.

Il éteignit la torche et fit quelques pas.

- Tiens, dit-il à mi-voix, si j'allais voir comment c'est le camp de campigne des campeurs en pleine nuit... presque à l'aube...

Il attendit un peu, mais aucun passant ne se manifesta. Il inspecta les horizons, mais il n'y avait vraiment aucun passant. Il
Cidrolin abriu um olho: ainda não tinha amanhecido. Abriu os dois olhos: ainda era noite. Ele estremeceu, o que lhe sugeriu tomar uma golada de rum, depois olhou na direção do cais: deserto, quanto a pedestres. Às vezes passava, rápido, um otomóvil na rua. Ao fim de um certo tempo, Cidrolin percebeu que, se houvesse gente na calçada, a escuridão não lhe permitiria ver. Estremeceu de novo e bebeu uma outra golada de rum.

Levantou-se vagarosamente e avançou na direção da cerca em silêncio; acendeu bruscamente sua lanterna elétrica com a qual cortou a escuridão. Não havia ninguém na trajetória. Ele saiu para olhar se o covarde anônimo havia rabiscado seus insultos, mas o covarde anônimo ainda não tinha passado, ou talvez não passasse esta noite.

- Pena, murmurou ele, eu poderia ter ido me deitar.

Ele se virou e pensou ver alguém andando na calçada, embaixo do prédio terminado mas ainda não habitado. Dirigiu sua lanterna para aquela direção, mas ela era fraca demais para clarear a silhueta adivinhada. Os faróis de um otomóvil fizeram melhor e Cidrolin pôde ver que aquela silhueta não era nada que pudesse lhe interessar.

Apagou a lanterna e deu alguns passos.

- É, disse ele a meia voz, que tal ir ver como é o campo de câmpingue dos campistas em plena noite... quase alvorada...

Ele esperou um pouco, mas nenhum passante se manifestou. Inspecionou os horizontes, mas realmente não havia nenhum 
continua donc son chemin et parvint bientôt à destination. Calme et silencieux, tout ce petit monde dormait qui dans sa caravane, qui sous la tente, qui, peut-être même, dans un sac de couchage, non pas à la belle étoile car le ciel était couvert, mais à la fortune du pot.

Le pot commença bientôt à se déverser et la pluie se mit à tomber, automnale, fraîche et drue.

- Merde, dit Cidrolin, je vais me faire saucer.

- Venez donc vous abriter, monsieur.

Le gardien du camp de campigne des campeurs venait d'énoncer cette honnête proposition.

Cidrolin sursauta.

Le gardien cotinua :

- Je faisais comme vous une petite balade nocturne, mais avec cette pluie, je rentre. Comme vous le marmonniez tout à l'heure, vous allez vous faire saucer.

- Vous êtes bien aimable, dit Cidrolin qui suivit le gardien dans sa cabane.

Le gardien allume une veilleuse et fit signe à Cidrolin de s'asseoir. Il se mit à bourrer une pipe en proférant distraitement des propos du genre « voilà l'automne, ça commence à se dépeupler, bientôt y aura plus que les maniaques de la roulotte et les fanas du couche-par-terre », puis, [196] ayant réussi à transformer une partie de son tabac en braise, il dit brusquement :

- Je vous connais, vous savez? Une semaine sur deux je suis de jour. Je vous vois, vous venez regarder mes clients, vous les regardez comme si c'était le zoo. Je me demande ce que vous trouvez de curieux à regarder. Vous pouvez me croire, ça n'est pas bien passante. Continuou então seu caminho e logo chegou ao destino. Calmo e silencioso, todo aquele mundinho dormia, uns nos traillers, uns nas tendas, uns, talvez até mesmo, num saco de dormir, não sob as estrelas pois o céu estava encoberto, mas pro que der e vier.

$\mathrm{E}$ o que veio foi água. A chuva começou a cair, outonal, fresca e forte.

- Merda, disse Cidrolin, vou ficar ensopado.

- Pois venha se abrigar aqui, senhor.

O vigia do campo de câmpingue dos campistas acabava de enunciar essa honesta proposta.

Cidrolin sobressaltou-se.

$\mathrm{O}$ vigia continuou:

- Eu estava fazendo como o senhor um pequeno passeio noturno, mas com essa chuva, voltei. Como o senhor estava resmungando agora mesmo, vai se ensopar.

- O senhor é muito amável, disse Cidrolin que seguiu o vigia até sua cabana.

O vigia acende uma lamparina e faz sinal para que Cidrolin se sente. Ele se pôs a encher um cachimbo proferindo distraidamente frases do tipo "eis o outono, isso aqui começa a ficar deserto, logo haverá somente os maníacos do trailler e os fanáticos do deita-no-chão", depois, tendo conseguido transformar uma parte de seu tabaco em brasa, disse bruscamente:

- Eu o conheço, sabe? Semana sim, semana não, trabalho de dia. Eu o vejo, o senhor vem olhar meus clientes, o senhor os olha como se fosse o zoológico. Me pergunto o que acha de curioso para olhar. $\mathrm{O}$ senhor pode acreditar, isso não tem nada de 
intéressant. Je vous regarde, moi aussi, et je pense, car je pense, monsieur, je pense : Tiens, en voilà un qui n'a pas grand'chose à foutre dans la vie. Quand je viens ici, je vous aperçois sur votre péniche allongé sur votre chaise longue en train de roupiller et je pense, vous allez croire, monsieur, que je veux insinuer que je n'arrête pas de penser, mais c'est pourtant vrai, je pense certainement plus que la moyenne des gens, je pense : Tiens, en voilà un qui n'a pas grand-chose à fabriquer dans l'existence. Ou bien vous êtes devant une petite table sur le pont et vous vous tapez de l'essence de fenouil, alors je pense, vous allez croire que j'exagère, mais il faut pourtant bien que je vous l'avoue, j'étais trop modeste tout à l'heure, mais c'est pourtant vrai, je n'arrête pas de penser, je pense donc : En voilà un qui boit trop.

- On me l'a souvent reproché, dit Cidrolin.

- Votre fille, sans doute. Elle a épousé un ératépiste. Est-ce qu'elle est heureuse ?

- Je ne sais pas, je ne l'ai pas revue. Sauf de loin.

- Ça ne vous épate pas que je connaisse comme ça votre petite famille ?

- J'ai deux autres filles.

- On ne les voit pas souvent.

- De temps en temps.

L'assimilation de ce fait

[197] parut rendre le gardien songeur.

Cidrolin reprit:

- Et ma nouvelle gouvernante, comment la trouvezvous?

- Je n'ai fait que l'apercevoir. De loin. Alors j'ai pensé...

Le gardien s'était interrompu. interessante. Eu também o olho, e penso, pois eu penso, senhor, eu penso: Veja, aí está alguém que não tem grande coisa a fazer na vida. Quando estou vindo para cá, vejo-o na sua chata esticado na sua espreguiçadeira dormitando e penso, o senhor vai achar que quero insinuar que não paro de pensar, mas no entanto é verdade, eu penso certamente mais do que a média das pessoas, eu penso: Veja, aí está alguém que não tem grande coisa a fazer na existência. $\mathrm{Ou}$ então o senhor está diante de uma mesinha no convés e bebe essência de funcho, então eu penso, o senhor vai achar que exagero, mas no entanto é preciso que eu confesse, eu estava sendo muito modesto agora há pouco, mas no entanto é verdade, eu não paro de pensar, pois eu penso: Aí está alguém que bebe demais.

- Sempre me repreendem por isso, disse Cidrolin.

- Sua filha, provavelmente. Ela casou-se com um erriatepista. Ela é feliz?

- Não sei, não a vi mais. Só de longe.

- O senhor não se admira de eu conhecer assim sua pequena família?

- Tenho mais duas filhas.

- Não são vistas

frequentemente.

- De tempos em tempos.

A assimilação deste fato pareceu deixar o vigia pensativo.

Cidrolin retomou:

- E minha nova governanta, o que acha dela?

- Só a vi de relance. De longe. Então eu pensei...

O vigia interrompeu-se. 
Cidrolin insista :

- Ne craignez rien. Ditesmoi toute votre pensée.

Le gardien secoua la tête d'un air épuisé.

- J'ai pensé...

- Quoi donc?

- Ah! monsieur, si vous saviez comme c'est lourd de penser. De la façon dont je vous vois vivre, vous ne devez pas souffrir de ce tourment, mais moi, monsieur, je vous le répète, je ne cesse jamais de faire fonctionner ma matière grise, même quand je vais au sanitaire. Vous ne pouvez pas imaginer. C'est un monde !

- Et vous rêvez? demanda Cidrolin.

- Jamais, monsieur. Je ne pourrais pas. Il faut bien que je me repose.

- Moi je rêve beaucoup, dit Cidrolin. C'est très intéressant de rêver.

- Je ne sais pas. Je n'ai pas d'idées sur la question.

- Le rêve continu, par exemple. On se souvient d'un rêve et, la nuit suivante, on essaie de le continuer. Pour que ça fasse une histoire suivie.

- Monsieur, vous parlez à un sourd.

- J'ai vécu ainsi au temps de Saint Louis...

- Ah le fils à Blanche de Castille...

[198]

- ...de Louis XI...

- ...l'homme à la cage...

- ...de Louis XIII...

-...les trois mousquetaires...

-...de Louis XVI...

-...crac, le couperet...

- ...non, non, je n'en suis encore qu'aux premiers jours de l'Assemblée Constituante. Si je n'avais pas entrepris cette balade nocturne, j'aurais peut-être assisté au quatorze juillet.
Cidrolin insistiu:

- Não tenha medo. Diga-me tudo o que pensou.

O vigia balançou a cabeça com ar cansado.

- Eu pensei...

- O que?

- Ah! senhor, se soubesse como é duro pensar. Da forma como o vejo viver, o senhor não deve sofrer esse tormento, mas eu, senhor, eu repito, eu não paro nunca de fazer funcionar minha massa cinzenta, mesmo quando vou ao sanitário. $O$ senhor não pode imaginar. É demais!

- E o senhor sonha? perguntou Cidrolin.

- Nunca, senhor. Eu não poderia. Tenho que descansar.

- Eu sonho muito, disse Cidrolin. É muito interessante sonhar.

- Não sei. Não tenho nenhuma ideia sobre a questão.

- O sonho contínuo, por exemplo. A gente se lembra de um sonho e, na noite seguinte, tenta continuá-lo. Para que forme uma história contínua.

- Senhor, está falando a um surdo.

- Assim eu vivi no tempo de São Luís...

- Ah o filho de Branca de Castela...

- ...de Luís XI...

- ...o homem da gaiola...

- ...de Luís XIII...

- ...os três mosqueteiros...

- ...de Luís XVI...

- ...crac, a lâmina...

- ...não, não, ainda estou nos

primeiros dias da Assembléia Constituinte. Se não tivesse feito esse passeio noturno, talvez eu tivesse assistido ao quatorze de julho. 
- Monsieur, je n'entrave rien à vos propos.

- Vous ne voulez pas que je vous raconte mon dernier rêve ?

- Pardonnez-moi si je m'excuse, mais est-ce que ce n'est pas indécent de raconter ses rêves ?

- C'est ce que pense ma gouvernante. Elle pense, elle aussi.

- Oh monsieur, je n'empêche pas les autres, s'ils en sont capables.

$$
\begin{gathered}
\text { - Alors... ? ma } \\
\text { gouvernante... ? }
\end{gathered}
$$

- Puisque vous insistez, monsieur, j'ai pensé et cette pensée était une question, je ne sais si vous êtes au courant, monsieur, mais la pensée peut être interrogative, j'ai pensé : Où a-t-il bien pu aller la chercher, cette personne?

- Sur le trottoir qui menait de Bretagne en Zanzébie ou dans la république du Capricorne.

- Pays bien éloignés. Si je comprends bien...

- Vous m'avez compris.

- Vous commîtes l'une bonne action.

- Elle dure depuis près de vingt-quatre heures.

- Qui vivra verra.

Le gardien secoua les cendres de sa pipe sur le parquet. Il ajouta :

- Je n'ai pas trouvé tout seul cette expression, mais elle dit bien ce qu'elle veut dire.

Cidrolin regarda par la vitre.

- Il ne pleut plus, dit-il. Je vais rentrer chez moi. Merci de votre bon accueil.

- Il n'y a pas de quoi, répondit le gardien en bourrant une nouvelle pipe. Pardonnez-moi si je m'excuse, mais ce n'est peut-être pas la peine que je vous raccompagne.

- Pas la peine, dit Cidrolin
- Senhor, não estou sacando nada dessa conversa.

- O senhor não quer que eu conte meu último sonho?

- Perdoe-me de me desculpar, mas será que não é indecente contar seus sonhos?

- É o que pensa minha governanta. Ela também pensa.

- Oh senhor, não impeço os outros, se eles forem capazes.

governanta...?

Então...? minha

- Já que insiste, senhor, eu pensei e esse pensamento era uma pergunta, não sei se está a par, senhor, mas o pensamento pode ser interrogativo, eu pensei: Onde ele pode ter ido procurar essa pessoa?

- Na calçada que levava da Bretanha à Zanzébia ou à república do Capricórnio.

- Países bem distantes. Se estou entendendo...

- O senhor entendeu.

- O senhor cometeu uma boa ação.

- Ela dura cerca de vinte e quatro horas.

- Quem viver verá.

$\mathrm{O}$ vigia jogou as cinzas de seu cachimbo no chão. E acrescentou:

- Essa expressão não é de minha autoria, mas ela diz exatamente o que ela quer dizer.

Cidrolin olhou pela vidraça.

- Não está mais chovendo, disse ele. Vou voltar para casa. Obrigado por sua acolhida.

- Não há de quê, respondeu o vigia enchendo um novo cachimbo. Perdoe-me de me desculpar, mas talvez não seja necessário eu acompanhá-lo.

- Não precisa, disse 
qui s'était levé.

Sur le pas de la porte, il examina le bourbier. Il dit au gardien :

- Vos clients, eux, ils ont dû être bien saucés.

- Ils aiment ça, dit le gardien en mettant le feu au tabac qu'il avait logé dans sa pipe en racine de bruyère de Saint-Claude dans le Jura, au confluent du Tacon et de la Bienne, affluent de l'Ain.

- Vous croyez, dit Cidrolin distraitement.

- J'ai souvent pensé, et là j'espère, monsieur, que vous reconnaîtrez que je n'emploie pas le verbe penser à tort et à travers, j'ai souvent pensé, dis-je, que, s'ils n'aimaient pas les intempéries, dans un sens ou dans l'autre, orages ou canicules, averses ou sirocos, gels ou touffeurs, si donc, continuéje, ils n'aimaient pas ça, ils iraient pratiquer leur campigne dans les grottes que la nature semble avoir préparées pour cette activité puisqu'ils y trouveraient un abri où se maintient, hiver comme été, pour ne pas parler des saisons intermédiaires le printemps et l'automne, où, terminerai-je, se maintient une température sensiblement égale, ce dont avaient sagement profité nos ancêtres préhistoriques qui, comme chacun sait et vous-même, monsieur, ne

[200] l'ignorez pas non plus, qui, ajouterai-je, à titre de conclusion ultime, qui, donc, avaient fait des cavernes leur logis préféré.

- Tout le monde n'est pas d'accord sur ce point, dit Cidrolin paisiblement. Les spécialistes prétendent maintenant que les hommes préhistoriques ne furent pas spécialement des troglodytes.

- Vous êtes bien savant.

- Oh, j’ai lu ça dans les gazettes.
Cidrolin que tinha se levantado.

- Na soleira da porta, ele examinou o lodaçal. Ele disse ao vigia:

- Seus clientes devem estar bem ensopados.

- Eles gostam disso, disse o vigia pondo fogo no tabaco que havia alojado no seu cachimbo de raiz de urze de Saint-Claude no Jura, na confluência do Tacon e do Bienne, afluente do Ain.

- O senhor acha, disse Cidrolin distraidamente.

- Eu pensei muito, e espero, que o senhor reconheça que não emprego o verbo pensar a torto e a direito, eu pensei muito, estava dizendo, que, se eles não gostassem das intempéries, num sentido ou no outro, tempestades ou canículas, chuvaradas ou sirocos, gelo ou mormaço, se então, continuo eu, eles não gostassem disso, iriam praticar seu câmpingue nas grutas que a natureza parece ter preparado para essa atividade já que ali encontrariam um abrigo onde se mantém, no inverno como no verão, para não falar das estações intermediárias a primavera e o outono, em que, terminarei eu, se mantém uma temperatura sensivelmente igual, do que se aproveitaram sabiamente nossos ancestrais pré-históricos que, como todos sabem e o senhor também não ignora, que, acrescentaria eu, a título de conclusão final, que, pois, fizeram das cavernas sua morada preferida.

- Nem todo o mundo está de acordo sobre esse ponto, disse Cidrolin calmamente. Os especialistas afirmam agora que os homens pré-históricos não foram especialmente trogloditas.

- O senhor é muito culto.

- Oh, eu li isso nas revistas. 
- L'instruction! voyez ce que c'est, monsieur, que l'instruction. On apprend quelque chose à l'école, on se donne même du mal, beaucoup de mal, pour apprendre quelque chose à l'école, et puis vingt ans après, ou même avant, ce n'est plus ça, les choses ont changé, on ne sait plus rien, alors vraiment ce n'était pas la peine. Aussi je préfère penser qu'apprendre.

- Je crois que je vais rentrer, dit Cidrolin. ajouta :

En refermant la porte, il

- Et encore merci!

Dehors, il bâilla, puis frissonna.

- J'ai attrapé la crève, dit-il à mi-voix.

La porte de la cabane s'ouvrit. Le gardien cria :

- Pardon?

- Je vais me faire un grog, cria Cidrolin.

- Vous buvez trop! cria le gardien.

- Vos gueules! crièrent en diverses langues des troglodytes manqués, qui dans leur caravane, qui dans la tente, qui même dans un sac de couchage, ces derniers flottant doucement sur les mares qui s'étaient formées.

Cidrolin traversa péniblement le merdier qui séparait la cabane du gardien de la sortie. Lorsqu'il eut atteint le trottoir, il se mit à marcher d'un pas assez

[201] rapide, pas suffisamment pourtant pour ne pas subir une nouvelle averse. Arrivé devant l'Arche, il oublia de regarder si l'on avait souillé la clôture de graffiti. En s'étalant de temps à autre dans la boue, il récupéra la couverture et la bouteille de rome, abandonnées dans le buisson derrière lequel il s'était planqué, mais il laissa là le
- A instrução! veja o que é, senhor, a instrução. A gente aprende alguma coisa na escola, a gente se esforça para isso, se esforça muito, para aprender alguma coisa na escola, e depois vinte anos depois, ou mesmo antes, já não é mais isso, as coisas mudaram, a gente não sabe mais nada, então realmente não valeu a pena. Então eu prefiro pensar a aprender.

- Acho que vou pra casa, disse Cidrolin.

Ao fechar a porta, acrescentou:

- E mais uma vez obrigado!

Fora, ele bocejou, depois estremeceu.

- Peguei uma friagem, disse ele a meia voz.

A porta da cabana se abriu.

$\mathrm{O}$ vigia gritou:

- Como?

- Eu vou tomar um grog, gritou Cidrolin.

- O senhor bebe demais! gritou o vigia.

- Calem a boca! gritaram em diversas línguas os trogloditas frustrados, uns nos traillers, uns nas tendas, uns, talvez até mesmo, num saco de dormir, esses últimos flutuando suavemente nas poças que tinham se formado.

Cidrolin atravessou com dificuldade o lamaçal que separava a cabana do vigia da saída. Quando chegou à calçada, pôs-se a andar com um passo rápido, não suficientemente no entanto para não tomar outra pancada de chuva. Tendo chegado à Arca, esqueceu de olhar se haviam maculado a cerca com graffiti. Estendendo-se de tempos em tempos na lama, recuperou a coberta e a garrafa de rum, abandonados na moita atrás da qual tinha se escondido, mas deixou lá o cabo de vassoura. 
manche à balai.

Il frissonnait de plus en plus. Après avoir victorieusement traversé la planche passerelle, il avala un certain nombre de cachets de diverses couleurs en intercalant des gorgées de rome. Il se coucha. Dehors, l'aube s'annonçait, de médiocre qualité.

En revenant de dire sa messe, l'abbé Riphinte trouva le duc qui l'attendait.

- Nous déjeunons et nous partirons aussitôt après, dit le duc avec autorité.

L'abbé regarda le soleil déjà haut sur l'horizon, un soleil de juillet.

- Vous craignez la chaleur? lui dit le duc. Ne vous inquiétez pas : là où je vous emmène il fait frais. À table !

- Quel est le programme des réjouissances aujourd'hui? demande au passage Sthène à Pouscaillou qui fonçait vers le déjeuner.

- On promène l'abbé, répondit Pouscaillou qui disparut dans l'auberge.

- J'espère qu'on ne va pas me le coller sur le dos, dit Stèphe. Je n'ai pas envie de faire la conversation avec lui. Il est discutailleur comme pas un : il ne songe jamais qu'à vous mettre dans votre tort.

- Tu peux toujours le laisser tomber dans un fossé, dit Sthène.

[202] Stèfstu esténoci.

Un gâte-sauce, palefrenier en second, vint arracher près d'eux la mule de l'auberge, sellée. Dès qu'il fut parti, Sthène dit à Stèphe :

- Tu vois, à quoi bon te faire du mauvais sang à l'avance !

- Qu'est-ce qui te dit que cette mule n'est pas pour Pouscaillou ? Et moi j'écoperai du
Ele estremecia cada vez mais. Depois de ter vitoriosamente atravessado a passarela, engoliu um certo número de comprimidos de diversas cores intercalando-os com goladas de rum. Ele se deitou. Fora, a alvorada se anunciava, de qualidade medíocre.

Voltando de rezar a missa, o abade Rifinge encontrou o duque esperando-o.

- Nós almoçaremos e partiremos logo depois, disse o duque com autoridade.

O abade olhou o sol já alto sobre o horizonte, um sol de julho.

- O senhor tem medo do calor? disse-lhe o duque. Não se preocupe: lá onde vou levá-lo faz frio. À mesa!

- Qual o programa dos regozijos hoje? perguntou de passagem Stenes a Pouscaillou que corria para o almoço.

- Vamos levar o abade para passear, respondeu Pouscaillou que desapareceu dentro do albergue.

- Espero que não o coloquem nas minhas costas, disse Estêvão. Não tenho vontade de conversar com ele. Ele é discutidor como ninguém: só pensa em provar que você está errado.

- Você sempre pode deixálo cair num fosso, disse Stenes.

Estêvãossicalô stenestamém.

Um mau cozinheiro, também palafreneiro, veio amarrar perto deles a mula do albergue, selada. Assim que ele partiu Stenes disse a Estêvão:

- Está vendo, pra que ficar de mau humor antes da hora!

- Quem te garante que a mula não é para Pouscaillou? E eu vou apanhar o cura. 
curé.

- Tu me fends les sabots, tiens. Prends donc la vie comme elle vient. Tu auras toujours le temps de rouscailler.

- N'empèche que je ronge mon frein à l'idée d'être monté par un ecclésiastique. On a son honneur. Qu'est-ce que tu veux, tu me connais, je ne peux pas me refaire.

La mule les écoutait avec admiration; elle ne savait, elle, que quelques mots de limousin et n'aurait pas voulu se rendre ridicule devant d'aussi galants manipulateurs de la langue d'oil. Le déjeuner fut sans doute plutôt frugal, car, deux heures plus tard, à peine, le duc, le page et l'abbé enfourchèrent leurs montures et hop, les voilà partis.

À moins de deux lieues de là, ils mirent pied à terre en pleine campagne. Les chevaux et la mule furent confiés à Empoigne qui alla s'étendre sous un arbre.

- Il nous faut maintenant aller à pied, dit le duc.

- Qu'emportez-vous là ? demanda l'abbé.

- Une lanterne.

- En plein jour?

- Eh oui, il y a là un petit mystère.

L'abbé, contrarié, s'abstint de s'enquérir de l'usage éventuel de la corde que le duc prenait également avec lui.

Ils allèrent à travers champs, à travers près, à travers bois, à travers varennes, à travers brandes. L'abbé grommelait, peu disposé à goûter le spectacle de la nature, pestant contre Jean-Jacques Rousseau, les orties et les ronces, se tordant les pieds sur les caillous dont le nombre s'accroissait à chaque toise. Il fallut enfin gravir une pente assez roide et l'abbé
- Você me deixa nos cascos, ora. Aceite a vida como ela é. Você sempre vai ter tempo para reclamar.

- O que não impede que eu roa meu freio à ideia de ser montado por um eclesiástico. A gente tem sua honra. $\mathrm{O}$ que você quer, você me conhece, não posso me controlar.

A mula escutava-os com admiração; ela só sabia algumas palavras de limosino e não quis mostrar-se ridícula diante de tão galantes manipuladores da língua francesa. $\mathrm{O}$ almoço foi provavelmente frugal, pois, duas horas mais tarde apenas, o duque, o pajem e o abade montaram suas montarias e upa, partiram.

A menos de duas léguas de lá, apearam em pleno campo. Os cavalos e a mula foram confiados a Empoigne que foi se estender embaixo de uma árvore.

- Agora temos que ir a pé, disse o duque.

- O que o senhor está levando aí? perguntou o abade. - Uma lanterna.

- Em plena luz do dia?

- Ah sim, aí tem um certo mistério.

O abade, contrariado, absteve-se de perguntar sobre o uso eventual da corda que o duque também levava com ele.

Eles foram através de campos, através de pastos, através de bosques, através de matos, através de charnecas. $\mathrm{O}$ abade resmungava, pouco disposto a apreciar o espetáculo da natureza, praguejando contra Jean-Jacques Rousseau, as urtigas e os espinheiros, torcendo os pés sobre os pedregulhos cujo número crescia a cada toesa. Foi preciso 
Riphinte, essoufflé, rejoignit le duc devant une fente dans un rocher.

- Et maintenant l'abbé, dit le duc en contenant son rire avec peine, vous allez voir ce que vous allez voir.

- Ah monsieur le duc, dit Riphinte d'un ton aigre-doux, que voilà une promenade que je n'apprécie guère.

- Entrons, dit le duc.

lui.

L'abbé regarde autour de

- Là, dit le duc en désignant la fente.

Le duc commence à s'insérer dans le rocher.

L'abbé fait demi-tour, direction sa mule puis l'auberge du Soleil d'Or à Plazac.

- Holà, lui crie le duc, voulez-vous bien revenir!

L'abbé s'arrête. Il entend le duc rire, très fort. le duc.

- Auriez-vous peur ? lui crie

L'abbé se retourne et voit le duc à moitié entré dans la roche. Il trouve le spectacle plus ridicule que terrifiant. Il crie à son tour :

- Monsieur le duc, vous devriez plutôt tenir votre place aux États généraux, que faire le jacques [204] en Périgord.

Le duc rit de nouveau. L'abbé rectifie un point de son discours :

À l'Assemblée

Constituante, voulais-je dire.

Il fait de nouveau demitour, direction sa mule puis l'auberge du Soleil d'Or à Plazac ; ce que voyant, le duc s'extrait de son roc, pose la lanterne et court après l'abbé. Quoique lourdaud, il n'a pas de mal à le rattraper. Il le enfim subir um aclive muito abrupto e o abade Rifinge, sem fôlego, alcançou o duque diante de uma fenda num rochedo.

- E agora abade, disse o duque mal contendo o riso, o senhor vai ver o que o senhor vai ver.

- Ah senhor duque, disse Rifinge com um tom agridoce, está aí um passeio que não aprecio nem um pouco.

- Entremos, disse o duque.

$\mathrm{O}$ abade olha em volta.

- Lá, disse o duque apontando para a fenda.

$\mathrm{O}$ duque começa a se inserir no rochedo.

O abade faz meia-volta, direção de sua mula depois do albergue do Sol de Ouro em Plazac.

- Epa, grita-lhe o duque, queira voltar.

O abade para. Ele ouve o duque rir, muito alto.

- O senhor estaria com medo? grita-lhe o duque.

O abade volta-se e vê o duque enfiado pela metade na rocha. Ele acha o espetáculo mais ridículo do que aterrorizante. Ele grita por sua vez:

- Senhor duque, o senhor faria melhor tomando seu lugar nos Estados Gerais, do que fazendo-se de bobo no Périgord.

$\mathrm{O}$ duque ri de novo. $\mathrm{O}$ abade retifica um ponto de seu discurso:

$\mathrm{Na} \quad$ Assembléia

Constituinte, queria dizer.

Ele faz nova meia volta, direção de sua mula depois do albergue do Sol de Ouro em Plazac; vendo isso, o duque extraise de sua rocha, põe a lanterna no chão e corre atrás do abade. Embora gorducho, ele não tem 
saisit par le collet et le fond du pantalon et le ramène à son point de départ. Les voilà de nouveau devant la fente dans le rocher.

- Faire cela à un ecclésiastique! dit l'abbé tout essoufflé. Je ne suis pas près de vous le pardonner, monsieur le duc.

- Personne ne nous a vus, répliqua le duc calmement, et je ne le raconterai à personne. Allez, entrez!

- Vous ne voulez pas me tuer? s'écrie Riphinte.

Le duc se met à rire.

- Je n'y avais pas pensé, bredouilla l'abbé. C'est cela. Il veut me tuer! Il veut me tuer!

Bonhomme, le duc lui demande:

- Et pourquoi diable voudrais-je t'occire?

- Mais pour que je ne révèle point votre cache.

- Allons, allons, calmezvous, Riphinte. Il ne s'agit absolument pas de cela. Laissons pour le moment de côté toutes ces histoires contemporaines. N'y pensons plus. Riphinte, nous allons remonter vers le passé, nous allons même parler théologie. Suivezmoi !

Le duc commença de nouveau à s'insérer dans la fente.

- Serait-ce l'entrée de l'Enfer? dit l'abbé peu rassuré. La

[205] théologie moderne sait pourtant que l'Enfer n'est pas intraterrestre comme le croyaient nos ancêtres. La physique nioutonienne nous a permis de rejeter ces superstitions quelque peu matérialistes. Ce qui ne veut pas dire que l'Enfer n'existe pas, Dieu soit loué !

- Finissez votre sermon: dificuldade em alcançá-lo. Pega-o pelo colarinho e pelos fundos das calças e recoloca-o em seu ponto de partida. Ei-los de novo diante da fenda do rochedo.

- Fazer isso com um eclesiástico! disse o abade completamente sem fôlego. Não vou perdoá-lo tão fácil, senhor duque.

- Ninguém nos viu, replicou o duque calmamente, e eu não vou contar pra ninguém. Vamos, entre!

- O senhor quer me matar? exclama Rifinge.

$\mathrm{O}$ duque põe-se a rir.

- Eu não tinha pensado nisso, balbuciou o abade. É isso. Ele quer me matar! Ele quer me matar!

De bom humor, o duque pergunta-lhe:

- E por que diabos eu quereria matá-lo?

- Mas para que eu não revele seu esconderijo.

- Vamos, vamos, acalme-se, Rifinge. Não se trata absolutamente disso. No momento deixemos de lado todas essas histórias contemporâneas. Não pensemos mais nisso. Rifinge, nós vamos voltar ao passado, vamos até falar teologia. Siga-me!

O duque começou de novo a se inserir na fenda.

- Seria a entrada do Inferno? disse o abade pouco seguro. A teologia moderna sabe no entanto que o Inferno não é intraterrestre como acreditavam nossos ancestrais. A física niutoniana nos permitiu rejeitar essas superstições um pouco materialistas. O que não quer dizer que o Inferno não exista, Deus seja louvado!

- Acabe seu sermão: o 
vous n'y êtes pas du tout.

Il ne restait qu'un bras ducal à l'extérieur du rocher; il saisit Riphinte et l'entraîna à sa suite. Riphinte disparaît.

- Tenez cette corde, dit la voix du duc, et marchez sans crainte.

- Vous en avez de bonnes...

L'abbé saisit la corde et emboîte le pas au duc qui tient la lanterne à la main. Ils avancent en silence.

Dans le silence obscur, ils avancent.

Dans

l'obscurité

silencieuse, ils continuent d'avancer.

Sans cadence, ils avancent, la corde se balance et la lanterne aussi, c'est toujours le silence.

Ce n'est pas tout à fait le silence, car il y le bruit des pas, ce n'est pas tout à fait l'obscurité, car il $\mathrm{y}$ a cette petite lumière au bout du bras du conducteur.

Ils avancent en silence.

Soudain :

- Monsieur le duc...

- Ne craignez rien, l'abbé, vous voyez bien que je suis toujours là.

- Monsieur le duc, ne trouvez-vous pas que je suis fort courageux?

- Eh, Riphinte, les entrailles de la terre vous rendraient-elles [206] vaniteux ?

- Péché véniel, lorsque je le compare à la situation présente. Vous me conduisez peut-être vers l'Enfer ou vers la Mort, et je ne bronche pas. N'est-ce pas admirable ?

- Riphinte, ce n'est plus de la vanité, mais de l'orgueil. Péché mortel, ce coup-ci. Ça a mené très loin qui vous savez.

- Si vous reconnaissiez mes mérites, monsieur le duc, je senhor não está nem perto.

Só restava um braço ducal no exterior do rochedo; ele pegou Rifinge e puxou-o atrás de si. Rifinge desaparece.

- Segure essa corda, disse a voz do duque, e ande sem medo.

- É fácil falar...

O abade pega a corda e acerta o passo com o duque que segura a lanterna na mão. Avançam em silêncio.

Avançam no obscuro silêncio.

$\mathrm{Na}$ obscuridade silenciosa, continuam a avançar.

Sem mudança, o duo avança, a corda balança e a lanterna dança, continua o silêncio.

Não é exatamente silêncio, pois há o barulho dos passos, não é exatamente obscuridade, pois há essa pequena luz na ponta do braço do condutor.

Eles avançam em silêncio. De repente:

- Senhor duque...

- Não tenha medo, abade, o senhor pode ver que estou aqui.

- Senhor duque, o senhor não acha que sou mui corajoso?

- Ora Rifinge, as entranhas da terra estão tornando-o vaidoso?

- Pecado venial, quando comparado à situação presente. $\mathrm{O}$ senhor me conduz talvez ao Inferno ou à Morte, e eu não vacilo. Não é admirável?

- Rifinge, já não é mais vaidade, mas orgulho. Pecado mortal, desta vez. Isso levou muito longe o senhor sabe quem.

- Se o senhor reconhecesse meus méritos, senhor duque, eu 
n'aurais pas besoin d'insister.

- Nous verrons cela tout à l'heure, répliqua Joachim.

Cette phrase énigmatique fit taire Riphinte pendant quelques minutes. Le duc avance en silence, la corde se balance, l'abbé suit de confiance, la petite lumière aussi se balance, elle finit par intriguer l'abbé qui revisse la conversation :

- Il est vivace votre quinquet, monsieur le duc.

- Très.

- On dirait que la lumière qu'il donne est froide et perpétuelle.

- C'est ce qu'elle est.

- Vous raillez, monsieur le duc.

- En aucune façon.

- Sauf votre respect, je n'en crois rien.

- Regarde.

Le duc s'arrêta, se retourna, mit la lanterne sous le nez de l'abbé dont le visage demeura seul éclairé dans la ténèbre grottesque. L'abbé Riphinte avait des lèvres minces, un nez de grande taille, des yeux fort noirs, des sourcils très drus et un front ovin. Il regarda fort attentivement et n'y comprit rien. Comme il n'aimait pas être mis à quia, il risque l'hypothèse [207] suivante :

- Quelque invention moderne?

- Vous n'y êtes pas.

- Une invention de monsieur Lavoisier? de monsieur Volta ? de monsieur l'abbé Nollet?

- Je vous répète que vous n'y êtes pas.

Riphinte enrageait de ne pas résoudre cette énigme et regrettait d'avoir abordé ce sujet de conversation. Il fit une petite grimace et dit :

- Une amusette. não teria necessidade de insistir.

- Nós veremos isso daqui a

pouco, replicou Joaquim.

Essa frase enigmática fez calar Rifinge durante alguns minutos. Em silêncio, o duque avança, a corda balança, o abade segue com confiança a pequena luz que balança, ela acaba por intrigar o abade que reaviva a conversação: - É vivaz seu candeeiro, senhor duque.

- Muito.

- Dir-se-ia que a luz é fria e perpétua.

- É o que ela é.

- Está brincando, senhor duque.

- De forma alguma.

- Salvo por respeito ao senhor, não acredito nada nisso.

- Olhe.

O duque parou, voltou-se, pôs a lanterna embaixo do nariz do abade cujo rosto ficou sozinho iluminado na treva grutesca. O abade Rifinge tinha lábios finos, nariz de grande tamanho, olhos mui pretos, sobrancelhas muito apertadas e uma testa ovina. Ele olhou mui atentamente e não entendeu nada. Como não gostava de ficar sem palavras, arriscou a seguinte hipótese:

\section{moderna?}

Alguma invenção

- O senhor não está nem perto.

- Uma invenção do senhor Lavoisier? do senhor Volta? do senhor abade Nollet?

- Repito que o senhor não está nem perto.

Rifinge enraiveceu-se por não resolver esse enigma $\mathrm{e}$ arrependeu-se de ter abordado esse assunto. Ele riu com uma pequena careta e disse:

- Um brinquedinho. 
- Une amusette! s'exclama le duc d'Auge, mais c'est tout simplement la lumière philosophale, qui ne s'éteint jamais, secret ultime et don gracieux de Timoleo Timolei.

- Oh, celui-là...

L'abbé retira son visage de la zone éclairée pour le porter dans l'ombre et il entendit rire le duc, qui, ayant fait demi-tour, se remettait en marche. L'abbé décida qu'autant que faire se pourrait, il n'ouvrirait plus la bouche. Le rire finit par s'éteindre et la marche obscure continua.

Même les marches obscures ont une fin. Le duc dit :

- Nous y voilà.

Et il s'arrêta. L'abbé Riphinte fit de même.

- Où croyez-vous que nous soyons ? demanda le duc.

- Dans les ténèbres.

- Et qu'allons-nous voir?

- Pas grand'chose.

L'abbé Riphinte n'était pas de bonne humeur. Le duc n'y fit pas attention. Il continua son discours en ces termes solennels prononcés avec emphase :

[208] - Dans cette caverne, vécurent les préadamites.

L'abbé Riphinte, écœuré, ne fit aucun commentaire.

- Vous ne me croyez pas?

L'abbé Riphinte, écœuré, dédaigna de répondre.

Le duc approcha la lanterne de la paroi de la caverne et dit :

- Regardez!

L'abbé Riphinte, écœuré, jette un vague coup d'œil.

- Vous voyez? demande le duc.

- Oui, répond l'abbé à
Um brinquedinho! exclamou o duque de Auge, mas é simplesmente a luz filosofal, que nunca se apaga, último segredo e dom gracioso de Timoleu Timolei.

- Ah, aquele lá...

$\mathrm{O}$ abade retirou seu rosto da zona clareada para levá-lo para a sombra e ouviu o riso do duque, que, tendo feito meia-volta, punhase novamente em marcha. $\mathrm{O}$ abade decidiu que faria o possível para não abrir mais a boca. $\mathrm{O}$ riso acabou por apagar-se e a marcha obscura continuou.

Até mesmo as marchas obscuras têm um fim. O duque disse:

- Chegamos.

$\mathrm{E}$ ele parou. $\mathrm{O}$ abade Rifinge fez o mesmo.

- Onde você acha que estamos? pergunta o duque.

- Nas trevas.

- E o que vamos ver?

- Não grande coisa.

$\mathrm{O}$ abade Rifinge não estava de bom humor. $\mathrm{O}$ duque não deu atenção. Ele continuou seu discurso nestes termos solenes pronunciados com ênfase:

- Nesta caverna, viveram os preadamitas.

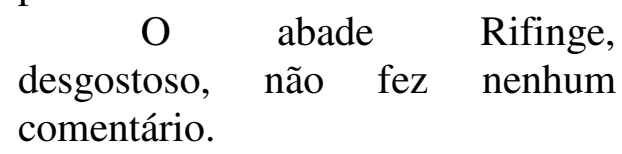

- O senhor não acredita em $\operatorname{mim}$ ?

O abade Rifinge, desgosto, não se dignou responder.

$\mathrm{O}$ duque aproximou a lanterna da parede da caverna e disse:

- Olhe!

O abade Rifinge, desgostoso, dá uma vaga olhadela.

- O senhor está vendo? pergunta o duque.

- Sim, responde o abade a 
contrecœur.

- Et que voyez-vous? contragosto.

- E o que o senhor está vendo? 
L'abbé Riphinte répondit, définitivement écœuré :

- Des dessins d'enfants.

- Bravo, l'abbé! les préadamites avaient la pureté des enfants, et, bien sûr, ils dessinaient comme des enfants. Je ne vous l'ai pas fait dire, l'abbé, mais vous avez apporté de l'eau à mon moulin. Les gens qui ont fait ces dessins, ces peintures - remarquez, il y a ici de la couleur -, ces gravures remarquez, il y a là des incisions dans le rocher -, ces gens ont vécu avant le péché originel, ils étaient comme ces enfants dont Jésus parle dans l'Évangile. Ce sont donc bien les préadamites les auteurs de ces dessins, preuve de leur existence. Ils vivaient dans ces cavernes où ils trouvaient abri contre les bouleversements qui agitaient la terre alors, elle aussi jeune.

Le duc approcha la lanterne $\mathrm{du}$ visage de Riphinte et lui demanda ce qu'il avait à répondre à cela.

- Monsieur le duc, dit l'abbé d'un ton ironique, je ne vous poserai qu'une seule question.

question.

Posez votre seule

- Si les préadamites vivaient dans cette caverne, comment

[210] faisaient-ils pour s'éclairer? Possédaient-ils déjà la lumière philosophale ou bien étaient-ils nyctalopes ?

- Ils avaient des yeux de chat, répondit le duc. Vous ne faites qu'apporter de l'eau à mon moulin. Comme ils ne possédaient pas la lumière philosophale, ils ne pouvaient donc avoir que des yeux de chat.

L'abbé, vexé d'avoir soufflé une réponse à l'objection qu'il croyait définitive, poursuivit
$\mathrm{O}$ abade Rifinge respondeu, definitivamente desgostoso:

- Desenhos de crianças.

- Parabéns, abade! os preadamitas tinham a pureza das crianças, e é lógico que desenhavam como crianças. Eu não o obriguei a falar, abade, mas o senhor puxou a brasa para minha sardinha. As pessoas que fizeram esses desenhos, essas pinturas note bem, aqui há cor -, essas gravuras - note bem, ali há incisões na rocha -, essas pessoas viveram antes do pecado original, elas eram como essas crianças de que Jesus fala no Evangelho. Logo, são mesmo os preadamitas os autores desses desenhos, prova de sua existência. Eles viviam nas cavernas onde encontravam abrigo contra o caos que agitava a terra então, jovem ela também.

$\mathrm{O}$ duque aproximou a lanterna do rosto de Rifinge e perguntou-lhe o que ele tinha a responder a isso.

- Senhor duque, disse o abade num tom irônico, vou lhe fazer somente uma única pergunta.

- Faça sua única pergunta.

- Se os preadamitas viviam nesta caverna, como faziam para clareá-la? Eles já possuíam a luz filosofal ou será que eram nictálopes?

- Eles tinham olhos de gato, respondeu o duque. O senhor só traz mais brasa para minha sardinha. Como não possuíam a luz filosofal, eles só podiam ter olhos de gato.

O abade, vexado por ter soprado uma resposta à objeção que acreditava definitiva, 
cependant :

- Et comment expliquezvous que personne n'en ait jamais parlé, et, en premier lieu, le Livre Sacré ?

- Je vous demande bien pardon, l'abbé. Et les géants dont parle la Genèse, chapitre six, verset quatre? Ah ah! je triomphe sur toute la ligne!

- Alors, selon vous, il y a des milliers et des milliers d'années, des géants aux yeux de chat se sont amusés à dessiner comme des enfants dans une caverne du Périgord?

- Vous raillez, l'abbé, mais êtes déconfit. D'ailleurs, il n'y a pas qu'une caverne, il y en a d'autres. Je vous les montrerai.

- Elles devaient être grandes, ces cavernes, pour contenir des géants.

- Voyez.

Le duc dirigea la lumière vers la voûte et la lumière se perdit dans le lointain vertical sans rencontrer cette voûte. Le duc promena cette lumière dans d'autres directions et l'abbé Riphinte put constater qu'il se trouvait dans une salle immense et, lui sembla-t-il, sans bornes et sans

[211] limites.

Il fut pris d'un frisson sacré.

- Hein, dit le duc, n'est-ce pas aussi beau que Saint-Sulpice ? Quant à ces dessins, vous les avez qualifiés un peu rapidement de dessins d'enfants. Regardez-moi ce mammut... cet aurochs... ce cheval... ce renne... Greuze ne peint pas mieux.

- Il faudrait s'entendre, dit Riphinte. Tout à l'heure vous prétendiez que vos géants étaient puérils et purs et maintenant les voilà aussi habiles qu'un académicien. prosseguiu, porém:

- E como o senhor explica que ninguém jamais tenha falado disso, e, em primeiro lugar, o Livro Sagrado?

- Peço-lhe que me perdoe, abade. $\mathrm{E}$ os gigantes de que fala $\mathrm{o}$ Gênesis, capítulo seis, versículo quatro? Ah ah! estou vencendo em todas as frentes!

- Então, segundo o senhor, há milhares e milhares de anos, os gigantes com olhos de gato divertiram-se desenhando como crianças numa caverna do Périgord?

- O senhor está caçoando, abade, mas está derrotado. Aliás, não há apenas uma caverna, há outras. Eu lhe mostrarei.

- Deviam ser grandes, essas cavernas, para conter gigantes.

- Veja.

$\mathrm{O}$ duque dirigiu a luz em direção ao teto e a luz perdeu-se na distância vertical sem encontrar esse teto. $\mathrm{O}$ duque passeou a luz em outras direções e o abade Rifinge pôde constatar que se encontrava numa sala imensa e, pareceu-lhe, sem fim e sem limites.

Ele foi tomado de um arrepio sagrado.

- Hein, disse o duque, não é tão belo quanto Saint-Sulpice? Quanto a esses desenhos, o senhor qualificou-os um pouco rapidamente de desenhos de criança. Olhe esse mamute... esse auroque... esse cavalo... essa rena... Greuze não pinta melhor.

- O senhor tem que se decidir, disse Rifinge. Agora mesmo afirmava que seus gigantes eram pueris e puros e agora ei-los tão hábeis quanto um acadêmico. 
- Si, dit le duc, les enfants ne sont plus aussi habiles que les académiciens, c'est à cause d'Adam, de sa côte, de sa pomme et de sa chute. Avant...

Un profond soupir évoqua la merveilleuse union préadamite de la pureté et de la dextérité. Le duc, promenant sa lanterne, continuait à montrer.

- Voyez... voyez... ces petits chevaus qui courent... ces rennes qui broutent... ces aurochs qui foncent... ces mammuts que l'on croirait entendre barrir.

- Il faut reconnaître que tout cela est fort curieux.

- Ah! s'écria le duc avec satisfaction, vous êtes un homme de bonne foi.

- Après tout, pourquoi n'y aurait-il pas eu des géants peintres aux yeux de chat du moment que vous m'accordez Adam et sa chute?

- Je ne vous accorde rien. C'était simple figure de style.

- Monsieur le duc, je me demande si vous, vous ne seriez pas de mauvaise foi.

- Vous avez reconnu l'existence de mes préadamites... - Pardon, pardon, j'ajoutais un si. Si vous m'accordiez...

- Pas de marchandage! Je ne vous accorde rien, l'abbé, et vous voilà devenu propréadamite. D'ailleurs je vais vous montrer d'autres preuves en d'autres antres. Venez!

Lorsqu'ils furent sortis de la grotte, l'abbé se frotta les yeux puis regarda le paysage et dit :

- Monsieur le duc, quand je vois ce ciel, ces arbres, ces herbes, ces caillous, et ces oiseaux qui volent, je me demande par quelle fantasmagorie je viens d'être halluciné. Je soupçonne fort votre
- Se as crianças não são mais tão hábeis quanto os acadêmicos, disse o duque, é por causa de Adão, da sua costela, da sua maçã e da sua queda. Antes...

Um profundo suspiro evocou a maravilhosa união preadamita da pureza e da destreza. O duque, passeando sua lanterna, continuava a mostrar.

- Veja... veja... esses cavallos que correm... essas renas que saltam... esses auroques que pastam... esses mamutes que a gente quase ouve barrir.

- Tenho que reconhecer que tudo isso é mui curioso.

- Ah! exclamou o duque com satisfação, o senhor é um homem de boa fé.

- Além de tudo, por que não poderia ter havido gigantes pintores com olhos de gato já que o senhor admite Adão e sua queda?

- Eu não admito nada. Foi uma simples figura de estilo.

- Senhor duque, eu me pergunto se o senhor não estaria de má fé.

- O senhor reconheceu a existência de meus preadamitas...

- Perdão, perdão, eu estava acrescentando um se. Se o senhor admitisse...

- Nada de negociação! Eu não admito nada, abade, e o senhor tornou-se pró-preadamita. Aliás, vou lhe mostrar outras provas em outros antros. Venha!

Quando saíram da gruta, o abade esfregou os olhos depois olhou a paisagem e disse:

- Senhor duque, quando vejo esse céu, essas árvores, essa grama, essas pedras, e esses pássaros voando, eu me pergunto por qual fantasmagoria acabo de ser alucinado. Estou mui 
lanterne d'être plus magique que philosophale. Vous permettez que je l'examine?

Le duc la lui tendit et l'abbé dut avouer qu'il n'y voyait rien de magique, mais peut-être quelque chose de philosophal.

- En route, dit le duc en reprenant sa lanterne.

Ils retrouvèrent Empoigne, la mule et les chevaux, et de Rouffillac se dirigèrent vers Tayac où ils restèrent coucher après avoir $\mathrm{vu}$ de nouvelles grottes. Le lendemain, ils poursuivirent leur chemin jusqu'à Montillac. Près de là, ils visitèrent ce que le duc qualifiait de chapelle Sixtine des préadamites. Ils rentrèrent souper à Plazac.

Ils y buvaient du vin frais, en attendant la garbure. L'abbé donnait tous les signes d'une réflexion active et, réprimant un sourire, ce qui lui faisait faire une drôle de grimace, le duc savourait en silence son triomphe. $\mathrm{Au}$ troisième verre de clairet, l'abbé Riphinte prit la parole et dit :

troublant.

- Tout cela est bien

- Et le trouble n' pas commencé, dit le duc d'Auge.

[213] Lorsque j'annoncerai ma découverte au monde, l'Église tremblera sur ses bases et le pape frémira de crainte. Lorsque le monde reconnaîtra ma découverte, l'Église s'écroulera et, pour gagner sa vie, le pape deviendra moutardier.

Seigneur, seigneur, murmura l'abbé Riphinte, où allons-nous ?

Le duc allait sans doute répondre à cette question lorsque Empoigne fit son apparition suivi desconfiado de que sua lanterna seja mais mágica do que filosofal. $\mathrm{O}$ senhor permite que eu a examine?

O duque estendeu-lhe a lanterna e o abade teve que confessar que não via nela nada de mágico, mas talvez alguma coisa de filosofal.

- Pé na estrada, disse o duque retomando sua lanterna. Eles encontraram Empoigne, a mula e os cavalos, e de Rouffillac dirigiram-se para Tayac onde pousaram depois de ter visto novas grutas. No dia seguinte, prosseguiram seu caminho até Montillac. Perto de lá, visitaram o que o duque qualificava de capela Sixtina dos preadamitas. Eles voltaram para cear em Plazac.

Beberam vinho fresco, enquanto esperavam a sopa. $\mathrm{O}$ abade dava todos os sinais de uma reflexão ativa e, reprimindo um sorriso, o que o fazia fazer uma careta engraçada, o duque saboreava em silêncio seu triunfo. No terceiro copo de clarete, o abade Rifinge tomou a palavra e disse:

perturbador.

Tudo isso é bem

- E a perturbação nem começou, disse o duque de Auge. Quando eu anunciar minha descoberta ao mundo, a Igreja tremerá nas suas bases e o papa se arrepiará de medo. Quando o mundo reconhecer minha descoberta, a Igreja desmoronará e, para ganhar a vida, o papa vai se tornar mostardeiro.

- Senhor, senhor, murmurou o abade Rifinge. Aonde vamos chegar?

O duque provavelmente ia responder a essa pergunta quando Empoigne fez sua aparição seguido 
d'un cavalier à pied mais en tenue idoine.

- Monsieur le duc! s'écria Empoigne, monsieur le...

- Qui t'a permis de m'interrompre? Je ne disais encore mot, mais j'allais commencer une phrase du plus grand intérêt pour l'abbé Riphinte en particulier et pour le monde ecclésiastique en général.

- Des nouvelles de Paris, monsieur le duc, continue Empoigne qui ne s'excuse pas.

- Eh! que me font les nouvelles de Paris! Les nouvelles intéressantes viendront maintenant d'ici. Et de moi-même.

- Voire, dit Empoigne insolemment. On a pris la Bastille.

- Qui ça, on ?

- Le peuple de Paris, répondit le cavalier à pied mais en tenue idoine. Les prisonniers sont libérés et $\mathrm{Sa}$ Majesté a rappelé monsieur Necker. Les couleurs de la France sont désormais le bleu, le blanc et le rouge.

Foutues nouvelles, murmura le duc. Personne ne va plus s'intéresser à mes préadamites.

- L’Église est sauvée! s'écria l'abbé en joignant les mains en signe de reconnaissance.

Ces deux dernières répliques parurent surprendre fort

[214] le cavalier à pied mais en tenue idoine. Il dit :

- Messieurs, bien que vos propos soient obscurs, je vois que vous êtes gens de qualité. Permettez-moi de me présenter: je suis le sire de Ciry.

- Ah mais, dit le duc, vous êtes mon gendre. Je ne vous reconnaissais pas. On se voit si peu. Vous prenez du ventre. Et ma de um cavaleiro a pé mas com roupas idôneas.

- Senhor duque! exclamou Empoigne, senhor...

- Quem lhe deu permissão para me interromper? Eu ainda não estava dizendo nada, mas ia começar uma frase do maior interesse para o abade Rifinge em particular e para o mundo eclesiástico em geral.

- Notícias de Paris, senhor duque, continua Empoigne sem se desculpar.

- Ei! que me interessam as notícias de Paris! As notícias interessantes agora virão daqui. $\mathrm{E}$ de mim mesmo.

Até parece, disse Empoigne insolentemente. Tomaram a Bastilha.

- Quem, tomaram?

- O povo de Paris, respondeu o cavaleiro a pé mas com roupas idôneas. Os prisioneiros foram libertados e Sua Majestade chamou Necker de volta. As cores da França a partir de agora são azul, branco e vermelho.

- Péssimas notícias, murmurou o duque. Ninguém vai mais se interessar pelos meus preadamitas.

- A Igreja está salva! exclamou o abade juntando as mãos em sinal de reconhecimento.

Essas duas últimas réplicas pareceram surpreender muito $\mathrm{o}$ cavaleiro a pé mas com roupas idôneas.

- Senhores, embora seus propósitos sejam obscuros, vejo que são gente de qualidade. Permitam que me apresente: sou o sir de Ciry.

- Ah, disse o duque, mas o senhor é meu genro. Eu não o estava reconhecendo. A gente se vê tão pouco. O senhor está criando 
fille Pigranelle, en a-t-elle pris souvent?

-Elle est morte stérile, répondit le sire de Ciry d'un air légèrement écœuré.

- La pauvre, dit le duc qui se tournant vers l'abbé Riphinte, ajouta: L'abbé, vous pourrez dire des prières pour elle, puisqu'elles vont être valables encore un certain temps.

Et revenant à Ciry :

- Au fait, pourquoi donc êtes-vous ici ? Me cherchiez-vous ?

- Nullement. J'émigre.

-
hirondelle?
- Je n'ai pas dit : je migre,
mais j'émigre. Je quitte la France aux nouveaux parapets. Ce qui vient de se passer ne me dit rien qui vaille et le peuple de Paris me semble prêt à montrer quelque férocité pour les aristocrates; sans parler des paysans qui commencent à brûler nos châteaux. Par des chemins détournés, je rejoins Bayonne où je m'embarquerai pour l'Angleterre.

- Pourquoi l'Angleterre?

- Pourquoi pas?

Le duc resta songeur; il finit par dire :

- Après tout, Ciry, ce n'est point une mauvaise idée que vous avez eue là. Quant à moi je me

[215] rendrai en Espagne où m'accueillera un ami très cher, le comte Altaviva y Altamira.

- Moi, dit l'abbé, je retourne auprès de ce bon peuple parisien qui vient de sauver l'Église sans le savoir, ce qui prouve bien qu'il y a là quelque miracle.

- Et toi, demanda le duc a Pouscaillou, m'accompagnes-tu ?

- Moi ? Je retourne auprès de ma maman. Je ne veux pas barriga. E minha filha Pigranela, criou barriga muitas vezes?

- Ela morreu estéril, respondeu o sir de Ciry com um ar ligeiramente desgostoso.

- Coitada, disse o duque que, voltando-se para o abade Rifinge, acrescentou: Abade, o senhor poderá dizer orações por ela, já que ainda vão ser válidas por algum tempo.

E voltando a Ciry:

- De fato, então por que o senhor está aqui? Estava me procurando?

- De forma alguma. Estou emigrando.

- O senhor seria uma andorinha?

- Eu não disse: migrando, mas: emigrando. Estou deixando a França de novos parapeitos. $\mathrm{O}$ que acaba de acontecer não me diz nada que valha e o povo de Paris me parece pronto a mostrar alguma ferocidade contra os aristocratas; sem falar dos camponeses que começam a queimar nossos castelos. Por caminhos tortuosos, estou indo para Bayonne onde embarcarei para a Inglaterra.

- Por que a Inglaterra?

- Por que não?

O duque ficou pensativo; ele acabou por dizer:

- No fim das contas, Ciry, não é uma má idéia que o senhor teve. Quanto a mim vou para a Espanha onde me acolherá um amigo muito querido, o conde Altaviva y Altamira.

- Eu, disse o abade, volto para perto desse bom povo parisiense que acaba de salvar a Igreja sem saber, o que prova que aí tem algum milagre.

- E você, perguntou o duque a Pouscaillou, me acompanha?

- Eu? Eu vou voltar para perto de minha mamãe. Não quero 
qu'on lui brûle son châtiau.

- Le benêt, s'exclama le duc, n'as-tu donc pas envie de voir des pays étrangers?

- Oh si, monsieur le duc.

- Alors, tu vois. Ciry, nous partons à l'aube tous les trois et nous laissons l'abbé à ses émeutiers. À propos, avez-vous des nouvelles de mon excellent ami Donatien ? A-t-il été libéré ?

On apportait la garbure. Tout en devisant des uns et des autres, ils soupèrent copieusement et, comme toutes ces émotions les avaient fatigués, hop, au lit.

$\mathrm{Au}$ petit matin, bien qu'ayant une forte répugnance pour cette opération abjecte, Cidrolin s'enfonça un thermomètre dans le derrière et, l'en ayant ensuite délicatement retiré, constata qu'il avait une fièvre quarte et carabinée ; il n'aurait d'ailleurs pas eu besoin de cette manœuvre pour découvrir son état, car il se sentait fort mal en point, mais, comme sans doute il serait fait appel à un homme de l'art, il craignait que celui-ci ne le grondât s'il ne pouvait le renseigner avec exactitude sur son déséquilibre thermique. Puis il attendit. Au bout d'un temps assez long qu'il évalua voisin d'une heure, Cidrolin eut envie de pisser. Toussant, [216] frissonnant, bouillant, il se leva; trébuchant, vacillant, chancelant, il sortit de sa cabine. Lalix l'aperçut qui se dirigeait vers les vécés.

Alors, cria-t-elle guillerettement, c'est à cette heurelà qu'on se lève? Le café vous attend!

Cidrolin ne répondit pas.

À son retour, lorsqu'elle l'invita de nouveau à la consommation du petit déjeuner, il que queimem o castelinho dela.

- Bobão, exclamou o duque, então você não tem vontade de ver países estrangeiros?

- Ah sim, senhor duque.

- Então, veja. Ciry, nós partimos ao amanhecer todos os três e deixamos o abade a seus revoltosos. A propósito, o senhor tem notícias de meu excelente amigo Donatien? Ele foi libertado?

Estavam trazendo a sopa. Falando de uns e de outros, eles cearam copiosamente e, como todas essas emoções tinham-nos deixado cansados, upa, para a cama.

De manhãzinha, apesar de ter uma forte repugnância por essa operação abjeta, Cidrolin se enfiou um termômetro no traseiro e, tendo-o em seguida retirado delicadamente de lá, constatou que estava com uma febre quartã e violenta; ele não teria precisado dessa manobra para descobrir seu estado, pois se sentia em mui mau estado, mas, como provavelmente chamariam um homem da arte, ele temia que este lhe desse uma bronca se ele não soubesse informar com exatidão sobre seu desequilíbrio térmico. Depois esperou. Após um tempo bem longo que avaliou perto de uma hora, Cidrolin teve vontade de mijar. Tossindo, tremendo, fervendo, ele se levantou; tropeçando, vacilando, cambaleando, ele saiu de sua cabina. Aalice percebeu-o dirigindo-se para o dabliucê. - E então, gritou ela alegremente, isso é hora de se levantar? O café está esperando!

Cidrolin não respondeu. $\mathrm{Na}$ volta, quando ela o convidou de novo à consumação do café da manhã, ele também não 
ne répondit pas non plus. Il réintégra sa cabine. Au bout d'une nouvelle heure à peu près, on vint frapper à sa porte.

Il dit d'entrer et Lalix exécuta cet ordre. elle.

- Ça ne va pas? demanda-t-

- Pas fort.

- C'est de ma faute, vous avez attrapé froid cette nuit.

- Voilà.

- Il a peut-être même plu.

- À verse.

- Vous auriez dû rentrer.

- Je suis rentré.

- Trop tard.

- Et je n'ai vu personne.

- J'aurais dû me taire.

- Vous en faites pas.

- Vous m'en voulez?

- Point.

- Alors, comme ça, ça ne va

pas?

- Pas fort.

- Je vais chercher un médecin.

- Des cachets ça suffirait peut-être. Un pharmacien vous donnerait des conseils judicieux.

Elle lui toucha le front.

- Qu'est-ce que vous tenez comme fièvre.

[217]

- J'en sais même la quantité : trente-neuf neuf.

- Je vais chercher un médecin.

Elle disparut aussitôt.

somnole.

Cidrolin frissonne et

Elle réapparut aussitôt. Le médecin demande la température.

Cidrolin dit que ça va chercher dans les trente-neuf neuf.

Le médecin écrit sur un bout de papier, puis il disparaît.

Lalix réapparaît. respondeu. Ele reintegrou sua cabina. No fim de uma nova hora mais ou menos, vieram bater à sua porta.

Ele disse para entrar e Aalice executou essa ordem.

- Não está bem? perguntou ela.

- Não muito.

- É culpa minha, você pegou frio essa noite.

- É.

- Talvez até tenha chovido.

- A cântaros.

- Você devia ter entrado.

- Eu entrei.

- Tarde demais.

- E não vi ninguém.

- Eu devia ter me calado.

- Não se preocupe.

- O senhor não está bravo comigo?

- De jeito nenhum.

- Então, não está bem?

- Não muito.

- Vou procurar um médico.

- Talvez uns comprimidos bastem. Um farmacêutico poderia dar bons conselhos.

Ela toca-lhe a testa.

- Quanta febre o senhor tem.

- Sei até a quantidade: trinta e nove e nove.

- Vou procurar um médico. seguida.

Ela desapareceu em cochila.

Cidrolin estremece e

Ela reapareceu em seguida. O médico pergunta a temperatura.

Cidrolin diz que está perto dos trinta e nove e nove.

O médico escreve num pedaço de papel, depois desaparece.

Aalice reaparece. 
médecines.

Cidrolin se tape des

Il ferme les yeux mais ne rêve pas.

Il boit des trucs chauds.

Dans le brouillard de l'infusion, il entend Lalix qui lui dit :

- Vous n'aviez pas dit à monsieur Albert que c'est une garde-malade qu'il vous fallait.

Elle rit.

Cidrolin fait un pâle sourire et ferme les yeux.

Le duc d'Auge, le sire de Ciry et le vicomte d'Empoigne, dit familièrement Pouscaillou, approchent de Bayonne.

Cidrolin ouvre les yeux de temps à autre.

De temps à autre il absorbe des médecines.

Il se sent encore comme tiède et mœlleux.

À ce propos, ce qui l'embête le plus, c'est d'aller aux vécés. Il s'y rend en trébuchant. Lalix veut le soutenir. Il refuse. Elle dit:

- Oh, on sait ce que c'est.

Cidrolin a honte sur le moment, ensuite, quand il est bien soulagé, il n'y pense plus.

$\mathrm{Au}$ fond ce n'et pas la mauvaise vie.

Il se demande comment Lalix se débrouille, si nouvellement

[218] arrivée sur cette péniche. Elle a l'air de se débrouiller, alors Cidrolin se rassure et ferme les yeux.

Il lui arrive de s'endormir.

À Bayonne, les trois compagnons se séparent. Le duc d'Auge et le vicomte d'Empoigne, familièrement nommé Pouscaillou, continuent leur chemin vers l'Espagne. Des contrebandiers les remédios.

Cidrolin engole uns

Ele fecha os olhos mas não sonha.

Ele bebe coisas quentes.

$\mathrm{Na}$ névoa da infusão, ele ouve Aalice que lhe diz:

- O senhor não tinha dito ao senhor Alberto que era de uma enfermeira que precisava.

Ela riu.

Cidrolin dá um pálido sorriso e fecha os olhos.

O duque de Auge, o sire de Ciry e o visconde de Empoigne, dito familiarmente Pouscaillou, aproximam-se de Bayonne.

Cidrolin abre os olhos de tempos em tempos.

De tempos em tempos ele absorve medicamentos.

Ele ainda se sente quente e mole.

Por falar nisso, o que o chateia mais, é ir ao dabliucê. Ele vai tropeçando. Aalice quer ajudálo. Ele recusa. Ela diz:

- Ora, a gente sabe o que é isso.

Cidrolin tem vergonha na hora, em seguida, quando está bem aliviado, não pensa mais no assunto.

No fundo não é tão mau.

Ele se pergunta como Aalice está se virando, tão recentemente chegada a essa chata. Ela parece se virar, então Cidrolin se acalma e fecha os olhos.

Acontece de ele adormecer.

Em Bayonne, os três companheiros se separam. O duque de Auge e o visconde de Empoigne, familiarmente chamado Pouscaillou, continuam seu caminho na direção da Espanha. 
aideront certainement à traverser la frontière.

Cidrolin se sent mieux. Par le hublot, entre un rayon de soleil. C'est agréable de savoir qu'il y a de bons médecins et de bonnes médecines. Lalix lui apporte un truc chaud à boire avec des cachets; ce ne sont pas les derniers, mais peut-être les antépénultièmes.

Lalix dit : mieux.

- Ça commence à aller

- Je crois.

Cidrolin est prudent dans ses pronostics.

Le mois d'octobre va vers sa fin. Tout le monde proclame :

exceptionnel !

- C'est un automne

Le thermomètre, enfoncé dans l'ombre de l'atmosphère, indique une température quasi estivale.

Cidrolin va s'étendre sur sa chaise longue au soleil.

Alors voilà qu'elles viennent prendre des nouvelles. Oh, elles sont bonnes maintenant, les nouvelles. Elles, les filles, regardent Lalix avec curiosité. Elles ne sont pas insolentes avec elle. Elles regardent aussi leur père avec curiosité.

- Y a encore des inscriptions sur votre clôture, dit Lucet.

- Qu'est-ce que tu as besoin de l'embêter, dit Sigismonde.

[219] - Vous voulez que j'aille nettoyer? propose Yoland.

- Tu vas salir ton costume tout neuf, dit Bertrande.

- Merci, dit Cidrolin, je m'en charge.

Lalix est allée chercher de quoi rafraîchir le gosier de ces messieurs-dames.
Contrabandistas certamente vão ajudá-los a atravessar a fronteira.

Cidrolin sente-se melhor. Pela escotilha, entra um raio de sol. É agradável saber que há bons médicos e bons medicamentos. Aalice lhe traz uma coisa quente para beber com uns comprimidos; não são os últimos, mas talvez os antepenúltimos.

Aalice diz:

melhorar.

- Está começando a

- Acho que sim.

Cidrolin é prudente nos seus prognósticos.

O mês de outubro está chegando ao fim. Todo o mundo proclama:

- É um outono excepcional!

O termômetro, enfiado na sombra da atmosfera, indica uma temperatura quase estival.

Cidrolin vai se estender em sua espreguiçadeira ao sol.

Então eis que elas vêm buscar notícias. Oh, agora são boas as notícias. Elas, as filhas, olham Aalice com curiosidade. Elas não são insolentes com ela. Elas olham também seu pai com curiosidade.

- Ainda tem inscrições na sua cerca, diz Lizeto.

- Por que você precisa chateá-lo, disse Sigismunda.

- O senhor quer que eu vá limpar? propõe Iolando.

- Você vai sujar seu terno novo, disse Orlanda.

- Obrigado, diz Cidrolin eu me encarrego disso.

Aalice foi buscar algo para refrescar a garganta desses senhores e senhoras. 
Bertrande dit à Cidrolin :

- Tu devrais lui acheter une tévé. Elle va s'emmerder toute seule avec toi. Surtout le soir.

- Tu ne peux pas savoir, dit Lucet à Bertrande. à Lucet.

- T'es bête, dit Sigismonde

- Il n'a peut-être pas tort, dit Yoland à Sigismonde.

- Vous n'allez pas laisser papa tranquille, dit Bertrande aux trois autres, et à Cidrolin : Croismoi, achète-lui une tévé.

Lalix revient avec les rafraîchissements, puis s'esbigne avec discrétion.

Bertrande apprécie :

- Elle est bien, cette petite.

- Elle a de la classe, dit

Lucet.

- Conard, dit Yoland, comme si tu t'y connaissais.

- Tu as fait un chopin, dit Sigismonde à Cidrolin.

- Maintenant qu'on est tranquillisés, dit Bertrande, on va pouvoir se retirer.

Ils restent encore un certain temps, pour finir les rafraîchissements. Ils en reviennent à la tévé. Bertrande insiste :

- Achètes-en une. Toimême, ça te distraira.

- Ça instruit même, dit Yoland.

[220] Ils ne partent pas si vite que ça parce qu'ils se sont mis à parler de la tévé.

Le lendemain, c'est Lamélie qui s'amène.

- Bertrande m'a dit que tu étais malade. Ça m'a l'air fini. Qui est-ce qui t'a soigné ?

D'un léger signe de tête Cidrolin désigne Lalix qui récure le pont.

- Elle est bien cette petite, dit Lamélie. Tu n'es pas mal
Orlanda diz a Cidrolin:

- Você deveria comprar-lhe uma tevê. Ela vai se chatear sozinha com você. Principalmente à noite.

- Você não pode saber, disse Lizeto a Orlanda.

- Você é besta, disse Sigismunda a Lizeto.

- Talvez ele tenha razão, diz Orlanda a Sigismunda.

- Vocês não vão deixar o papai tranquilo, diz Orlanda aos outros três, e a Cidrolin: Ouça-me, compre uma tevê pra ela.

Aalice retorna com os refrescos depois se esgueira discretamente.

Orlanda aprecia:

- É boa, essa moça.

- Ela tem classe, diz Lizeto.

- Babaca, diz Iolando, como se você entendesse do assunto.

- Você fez um bom negócio, diz Sigismunda a Cidrolin.

- Agora que estamos tranquilizados, disse Orlanda, vamos poder nos retirar.

Eles ficam ainda um certo tempo, para terminar os refrescos. Voltam à tevê. Orlanda insiste:

- Compre uma. Até você vai se distrair.

- Isso até instrui, disse Iolando.

Eles não vão embora tão depressa porque se puseram a falar da tevê.

No dia seguinte, é Aamélia que aparece.

- Orlanda me disse que você estava doente. Parece que já passou. Quem cuidou de você? Com um leve sinal de cabeça Cidrolin designa Aalice que está cuidando do convés.

- É boa, essa moça, disse Aamélia. Você se deu bem. 
tombé.

Cidrolin se compose une physionomie qui veut dire: oui, peut-être. Ensuite il utilise deux mots pour demander.

- Et toi ?

- Tu veux dire: qu'est-ce que je deviens, le mariage, tout ça ?

- Oui.

- Avec Boubou...

- Qui ?

- Mon mari. Il a eu huit jours de congé. On est allé en voyage.

- Où ?

- Dans le Périgord. Pas à cause des truffes, mais pour plus profond encore: les trous préhistoriques. On les a tous visités. Lascaux, Rouffignac, les Eyzies, Font-de-Gaume et le reste. Ils savaient vachement bien dessiner, les paléolithiques. Leurs chevaux, leurs mammouths, hein... comme ça! (geste).

- Des faux.

- Qu'est-ce que tu veux dire ?

- C'est tous des faux.

- Oh ! si c'était des vrais faux, ça se saurait.

- Moi je le sais.

- D'où tu sais ça ?

- Ah voilà.

- T'as rêvé ?

- C'est un type du dixhuitième siècle qui a peint tout ça. tout ça?

- Pourquoi il aurait peint

- Pour emmerder les curés.

- Tu rigoles, papa. Tu rêves. $\mathrm{Tu}$ ferais mieux de t'acheter une tévé, ça t'instruirait.

- Je sais.

- Maintenant que je suis tranquillisée, je vais me tirer.

Sur le quai, Lamélie fait des
Cidrolin faz uma fisionomia que quer dizer: sim, talvez. Em seguida ele utiliza duas palavras para perguntar:

- E você?

- Você quer dizer: como estou, o casamento, isso tudo? - Sim.

- Com Bubu...

- Quem?

- Meu marido. Ele teve oito dias de férias. Nós viajamos.

- Para onde?

- Para o Périgord. Não por causa das trufas, mas por coisas mais profundas ainda: os buracos pré-históricos. Visitamos todos. Lascaux, Rouffignac, Eyzies, Fontde-Gaume e o resto. Eles sabiam muitíssimo bem desenhar, os paleolíticos. Seus cavalos, seus mamutes, hein... assim! (gesto).

- Falsos.

- O que você quer dizer?

- São todos falsos.

- $\quad \mathrm{Ah} !$ se fossem verdadeiramente falsos, a gente saberia.

- Eu sei.

- Como você sabe?

- Sabendo.

- Você sonhou?

- Foi um sujeito do século dezoito quem pintou tudo isso. tudo isso?

- Por que ele teria pintado

- Para encher o saco dos curas.

Você está brincando, papai. Está sonhando. Você faria melhor em comprar uma tevê, ela te instruiria.

- Eu sei.

Agora, que estou tranquilizada, vou me retirar. No cais, Aamélia faz sinais, 
signes, non pour dire au revoir, mais parce qu'il y a des signes sur la clôture. Lalix l'a vue ; elle lâche le faubert et prend le pinceau et le pot de peinture.

Cidrolin s'étend sur sa chaise longue. Il regarde Lalix qui escalade le talus. Il ferme les yeux.

Il chevauche à côté de son excellent ami, le comte Altaviva y Altamira. Empoigne suit. Des contrebandiers rapaces et royalistes leur ont, à pris d'or, fait passer la frontière.

- Vous eûtes raison d'émigrer, Joachim, dit le comte dans cet excellent français que tout Européen cultivé parlait à l'époque. Voyez, si j'ose dire, cette nuit du quatre août, les aristocrates français n'arrêtent pas de faire des conneries.

- Je n'en disconviens point, dit le duc.

- En attendant que se dissipe cette agitation, à quoi passerez-vous votre temps, Joachim, maintenant que vous voilà en Espagne ? Le pays est austère et, en dehors des courses de taureaux, je ne vois guère de distractions pour vous, Joachim.

- Je peindrai.

- C'est là, en effet, un agréable amusement. Je n'y ai [222] jamais pensé pour moi-même. Et comment cette idée vous est-elle venue?

- En rêve.

- Dites-vous bien en rêve?

- Je dis bien : en rêve. Et dans ce rêve, Phélise, la plus jeune de mes filles, celle qui est idiote, revenait de Rome et me racontait qu'elle y avait vu la chapelle Sixtine et je me disais moi-même : et moi aussi je suis peintre.

- Et que peignez-vous, não para dizer adeus, mas porque há sinais na cerca. Aalice a viu; ela larga a vassoura e pega o pincel e a lata de tinta.

Cidrolin estende-se na espreguiçadeira. Ele olha Aalice escalar o barranco. Ele fecha os olhos.

Ele cavalga ao lado de seu excelente amigo, o conde Altaviva y Altamira. Empoigne acompanha. Contrabandistas rapaces e monarquistas ajudaram-nos, a preço de ouro, a passar a fronteira.

- Estáveis certo em emigrar, Joaquim, disse o conde naquele excelente francês que todo europeu culto falava na época. Vede, se posso dizer, essa noite de quatro de agosto, os aristocratas franceses não param de fazer besteiras.

- Eu não discordo, disse o duque.

- Enquanto espera que se dissipe essa agitação, como o senhor vai passar o tempo, Joaquim, agora que está na Espanha? O país é austero e, fora as corridas de touros, quase não vejo distrações para o senhor, Joaquim.

- Vou pintar.

- Realmente, é um divertimento agradável. Nunca pensei nisso para mim mesmo. E como o senhor teve essa idéia?

- Em sonho.

- O senhor quer dizer em sonho mesmo?

- Eu disse: em sonho. E nesse sonho, Feliza, a mais jovem de minhas filhas, a que é idiota, voltava de Roma e me contava que tinha visto a capela Sixtina e eu me dizia a mim mesmo: também sou pintor.

- E o que o senhor pinta, 
Joachim? Des bodegons? des fleurs? des batailles ?

- Des cavernes.

- Avec la tentation de saint Antoine ?

- Non! c'est sur les parois des grottes que je peins.

- Mais, Joachim, qui verra jamais vos œuvres?

- Les préhistoriens.

- Voilà un mot français que j'ignorais. Que veut-il dire?

- Je vous l'expliquerai plus tard. Dites-moi, ne connaîtriezvous pas quelque endroit de ce genre où je pourrais m'exercer ?

- J'ai justement cela sur mes terres, répondit le comte Altaviva y Altamira.
Joaquim? Bodegons? flores? Batalhas?

- Cavernas.

- Com a tentação de santo Antônio?

- Não! é nas paredes das grutas que eu pinto.

- Mas, Joaquim, quem vai ver suas obras?

- Os pré-historiadores.

- Está aí uma palavra francesa que eu ignorava. $O$ que quer dizer?

- Explicarei mais tarde. Diga-me, o senhor não conheceria algum lugar desse tipo onde eu poderia exercitar-me?

- Tenho isso justamente em minhas terras, respondeu o conde Altaviva y Altamira. 
Cidrolin guéri se réservait de nouveau les travaux de peinture.

[223]

Il donna le dernier coup de pinceau, puis fit deux pas en arrière afin d'avoir le recul nécessaire pour examiner son œuvre. De cet examen, il tira quelque satisfaction et c'est alors qu'il s'entendit héler. Il se retourna. Une houature tirant une roulotte s'était rangée le long $\mathrm{du}$ trottoir; un peu en arrière, en double position, une autre houature tirant un van s'était arrêtée. D'après les plaques minéralogiques, tout cela venait de la province. Le conducteur de la première houature passa la tête pour demander :

- Le camp de campigne pour les campeurs, je vous prie.

- Très simple. Tout droit, cinq cents mètres plus loin.

Cidrolin ajouta :

- Vous savez, à cette époque de l'année, ça doit être fermé. Merci.

- Je vais toujours aller voir.

L'autre rentra sa tête dans sa carapace et embraya.

Avant de démarrer, il cria pour Cidrolin : peintre!

- Et moi aussi, je suis

Cidrolin le regarda s'éloigner, suivi du van. Il attendit un petit quart d'heure puis une vingtaine de minutes, pour voir si par hasard, ayant trouvé fermé le camp de campigne pour les campeurs, la caravane ne ferait pas demi-tour. Au bout d'une heure, ne voyant rien venir, Cidrolin redescendit le talus et alla ranger pot de peiture et pinceau. Lalix épluchait des pommes de terre.
Cidrolin curado reservava de novo para si os trabalhos de pintura.

Ele deu a última pincelada, depois deu dois passos para trás a fim de ter o recuo necessário para examinar sua obra. Desse exame, tirou alguma satisfação e foi então que ouviu que o chamavam de longe. Ele se virou. Um otomóvil puxando um trailler estava parado ao longo da calçada; um pouco para trás, em fila dupla, um outro otomóvil puxando uma carreta tinha parado. Segundo as placas, tudo aquilo vinha do interior. $\mathrm{O}$ motorista do primeiro otomóvil pôs a cabeça pra fora para perguntar:

- O campo de câmpingue para campistas, por obséquio. - Muito simples. Direto, quinhentos metros mais adiante. Cidrolin acrescentou:

- O senhor sabe, nesta época do ano, deve estar fechado.

- Vou ver assim mesmo. Obrigado.

O outro pôs a cabeça para dentro da carapaça e engatou a marcha.

Antes de dar partida, gritou para Cidrolin:

- Eu também sou pintor!

Cidrolin olhou-o afastar-se, seguido pela carreta. Esperou um quarto de hora depois uns vinte minutos, para ver se por acaso, tendo encontrado fechado o campo de câmpingue para campistas, a caravana não faria meia-volta. Ao fim de uma hora, não vendo vir nada, Cidrolin desceu o barranco e foi guardar lata de tinta e pincel. Aalice descascava batatas. Cidrolin pergunta: 
Cidrolin demande :

- Y aura des frites?

- Non, du gratin dauphinois.

- J'aurais mieux aimé des frites.

- Y aura du gratin dauphinois.

- Bon, dit Cidrolin.

Il ajouta:

- Je vais faire un tour. Je vais jusqu'au camp de campigne pour les campeurs. Il y a encore des gens qui y arrivent.

- Ça doit être curieux.

- Peut vraiment pas y avoir des frites?

- Quel tyran. Y aura des frites ?

- Quelques-unes un peu molles et les autres comme des petits bouts de bois.

- Et pour moi, dit Lalix, des entre les deux.

- Peut-être serait-il possible de faire moitié gratin dauphinois et moitié pommes frites, les unes d'une façon, les autres d'une autre et une partie entre les deux.

Lalix ne répond pas.

- Bon, dit Cidrolin, je vais voir ce que ça devient à côté.

Le camp de campigne des campeurs est à peu près désert, mais il y subsiste encore une vague activité. Cidrolin n'aperçoit pas ce qu'il cherchait, mais il le découvre cent mètres plus loin. Les deux [225] houatures et les remorques sont arrêtées le long du trottoir; descendus sur le trottoir, deux hommes et deux femmes discutent. Cidrolin s'approche, il passe devant le petit groupe, le conducteur de la voiture de tête ne l'a pas reconnu, Cidrolin marche encore une cinquantaine de mètres, puis revient sur ses pas. À hauteur du groupe, il dit à celui qui l'avait questionné :

- C'est là (geste), vous
- Vai tê fritas?

- Não, gratinado à delfinesa.

- Eu preferia fritas.

delfinesa.

- Vai tê gratinado à

- Está bem, disse Cidrolin.

Ele acrescentou:

- Vou dar um passeio. Vou até o campo de câmpingue para campistas. Ainda tem gente chegando.

- Deve ser curioso.

- Num dá mesmo pra tê fritas?

- Que tirano. Será que vai tê fritas?

- Algumas um pouco moles e outras como pedaços de pau.

- E para mim, disse Aalice, entre as duas.

- Talvez fosse possível fazer metade gratinado à delfinesa $\mathrm{e}$ metade batatas fritas, umas de uma maneira, outras da outra e uma parte entre as duas.

Aalice não responde.

- Bom, disse Cidrolin, vou ver o que está acontecendo ao lado.

O campo de câmpingue para campistas está meio deserto, mas ainda subsiste lá uma vaga atividade. Cidrolin não avista o que estava procurando, mas descobre-o cem metros mais longe. Os dois zotomóvis e os reboques estão parados ao longo da calçada; na calçada, dois homens e duas mulheres discutem. Cidrolin aproxima-se, passa diante do pequeno grupo, o motorista do automóvel da frente não o reconheceu, Cidrolin anda ainda uns cinquenta metros, depois volta pelo mesmo caminho. À altura do grupo, ele diz ao que havia pedido informação:

- É lá (gesto), o senhor sabe. 
savez. Ça a encore l'air d'être ouvert.

- Monsieur, dit l'autre, je ne vous demande pas votre avis.

- Vous me l'avez demandé tout à l'heure, réplique Cidrolin, et je n'avais pas fini de vous le donner.

Sur ces mots, Cidrolin continue son chemin.

- Monsieur, lui crie-t-on.

Il s'arrête. L'autre le rejoint. Il dit:

- Ces imbéciles, ils ne veulent pas de nous à cause des chevaus. Pourquoi mes chevaus ne feraient-ils pas du campigne, eux aussi ?

Cidrolin ne répond pas.

L'autre dit :

- Vous ne trouvez pas?

Cidrolin dit : présentés.

- Nous n'avons pas été

- C 'est vrai.

Le caravanier tend la main et dit :

- Auge.

- Cidrolin, dit Cidrolin.

Ils se serrent la main. Auge ajoute:

- Comme vous voyez, je suis sans façons. Si vous êtes peintre en bâtiment, moi je suis duc.

- Je ne suis pas peintre en bâtiment, dit Cidrolin, je suis

[226] armateur. Je possède une péniche et un canot.

- Je ne voulais pas vous vexer, dit le duc. Il n'y a pas de sots métiers. Comme je vous en ai informé tout à l'heure, moi aussi j'ai été peintre, ce qui peut paraître curieux pour un duc, un duc qui a fait les croisades. J'étais même un spécialiste de la peinture pariétale. Un peu dans votre genre, si l'on veut.

- On veut, dit Cidrolin.
Parece que ainda está aberto.

- Senhor, disse o outro, não estou pedindo sua opinião.

- O senhor a tinha pedido há pouco, replica Cidrolin, e eu não tinha acabado de dá-la.

Com essas palavras, Cidrolin continua seu caminho.

- Senhor, gritam-lhe.

Ele para. O outro o alcança. Ele diz:

- Esses imbecis não nos querem por causa dos cavallos. Por que meus cavallos não poderiam fazer câmpingue, também?

Cidrolin não responde.

O outro diz:

- O senhor não acha?

Cidrolin diz:

- Ainda não fomos apresentados.

- É verdade.

$\mathrm{O}$ outro estende a mão e diz:

- Auge.

- Cidrolin, diz Cidrolin.

Eles apertam-se as mãos. Auge acrescenta:

- Como o senhor vê, não tenho cerimônia. Se o senhor é pintor de paredes, eu sou duque.

- Eu não sou pintor de paredes, diz Cidrolin, sou armador. Possuo uma chata e uma canoa.

- Não queria ofendê-lo, disse o duque. Não há profissão ruim. Como lhe informei há pouco, também fui pintor, o que pode parecer curioso para um duque, um duque que fez as cruzadas. Eu era mesmo um especialista em pintura mural. Um pouco no seu gênero, se podemos dizer assim.

- Podemos, disse Cidrolin. 
- Venez, je vais vous présenter à ma fille. Phélise, je te présente monsieur Cidrolin.

- Bê, bê, dit Phélise.

- Et voici mon entraîneur et ami Empoigne. Vicomte d'Empoigne.

- Cidrolin, dit Cidrolin.

- Et sa maman.

- Salut, dit la comtesse d'Empoigne.

- Je vous présenterai aux chevaus une autre fois, dit le duc. Bon, maintenant que la glace est brisée et que nous avons fait connaissance, non pas intime, mais cependant largement suffisante pour établir des contacts sur le plan social, contacts évidemment assez superficiels, mais qui sait? profitables et fructueux pour l'un comme pour les autres, dans on ne sait encore trop quel domaine, d'ailleurs, vous allez peut-être, monsieur Cidrolin qui semblez être $\mathrm{du}$ quartier, nous indiquer un autre endroit pas trop éloigné du centre de la ville, où mes chevaus, ma fille, Empoigne, sa maman et moi pourrions combiner les joies du campigne avec les plaisirs de la capitale.

Le duc fit un geste impératif pour empêcher Cidrolin de répondre sur-le-champ.

- En effet, continua-t-il, si je suis de haut lignage, je n'en suis

[227] pas moins provincial comme l'indique mon numéro minéralogique. Je suis un hobereau, gentilhomme-fermier même, et je préfère le grand air aux salles de bains avec vécés des hôtels urbains.

- C'est une opinion qui se défend, dit Cidrolin. Quant aux desiderata que vous exprimâtes, il y a quelques instants, je ne vois pas comment y satisfaire. Il y a bien des écuries dans le quartier, vous pourriez y mettre en pensions vos
- Venha, vou apresentá-lo a minha filha. Feliza, eu te apresento o senhor Cidrolin.

- Bé, bé, disse Feliza.

- E este é meu treinador de cavallos e amigo Empoigne, Visconde de Empoigne.

- Cidrolin, disse Cidrolin.

- E a mamãe dele.

- Olá, disse a condessa de Empoigne.

- Eu o apresentarei aos cavallos numa outra ocasião, disse o duque. Bom, agora que o gelo está quebrado e que nós nos conhecemos, não intimamente, mas no entanto mais do que o suficiente para estabelecer contatos no plano social, contatos evidentemente bastante superficiais, mas quem sabe? proveitosos e fecundos tanto para um como para os outros, não se sabe muito bem em que área, aliás, o senhor talvez possa, senhor Cidrolin que parece ser do bairro, nos indicar um outro lugar não demasiado longe do centro da cidade, onde meus cavallos, minha filha, Empoigne, a mamãe dele e eu possamos combinar as alegrias do câmpingue com os prazeres da capital.

$\mathrm{O}$ duque fez um gesto imperativo para impedir Cidrolin de responder de imediato.

- Com efeito, continuou ele, se sou de alta linhagem, não sou menos provinciano como indica a placa do meu automóvel. Sou um fidalguinho, cavalheiro-fazendeiro mesmo, e prefiro o ar livre aos banheiros com dabliucê dos hotéis urbanos.

- É uma opinião a se considerar, diz Cidrolin. Quando aos desiderata que exprimistes, há alguns instantes, não vejo como satisfazê-los. Há algumas estrebarias no bairro, poderíeis deixar seus cavalos numa delas. 
chevaux.

- Jamais, dit le duc.

- Comment donc avez-vous fait les autres fois?

- Il n'y a pas eu d'autres fois. Ce sont mes débuts dans le campigne.

encourageants.

Ils ne sont pas

- Monsieur Cidrolin que je connais encore peu, vous n'allez pas me démoraliser. D'ailleurs, ne craignez rien, je ne suis pas démoralisable.

- Vous conviendrez alors que vos débuts dans le campigne ne sont pas encourageants.

- Monsieur Cidrolin que je connais encore peu, seriez-vous un ratiocineur dans le genre de l'abbé Riphinte?

- L'abbé Riphinte, dit Cidrolin en fronçant les sourcils, l'abbé Riphinte... c'est un nom qui me dit quelque chose...

- Les gazettes ont rendu son nom célèbre, dit le duc. Il a passé la moitié de son temps sous terre.

- Ah, je vois, dit Cidrolin, le fameux préhistorien.

- Mon ancien chapelain, dit le duc.

- Fichtre, dit Cidrolin, vous avez les moyens de vous offrir un chapelain?

- Parfaitement, dit le duc. C'est moi qui l'ai congédié, pour [228] raisons d'athéisme. D'athéisme de ma part, bien entendu. Quoique luimême... enfin... revenons à la situation présente. Monsieur Cidrolin, voyons, où pourrais-je m'ébattre dans la nature à deux pas du centre de la ville?

- Je ne vois pas trop, dit Cidrolin. L'accès des squares n'est pas encore autorisé aux campeurs.

- Ah, fit le duc, où est le temps où chaque auberge avait son
- Jamais, disse o duque.

- Então como o senhor fez das outras vezes?

- Não houve outras vezes. É minha estreia no câmpingue.

- Não é muito encorajadora.

- Senhor Cidrolin que conheço ainda pouco, o senhor não vai me desanimar. Aliás, não tenha medo, eu não sou desanimável.

- O senhor há de convir então que sua estreia no câmpingue não é encorajadora.

- Senhor Cidrolin que conheço ainda pouco, o senhor seria um argumentador do gênero do abade Rifinge?

- Abade Rifinge, disse Cidrolin franzindo as sobrancelhas, abade Rifinge... é um nome que não me é estranho...

- As revistas tornaram seu nome célebre, disse o duque. Ele passou a metade de seu tempo embaixo da terra.

- Ah, já sei, disse Cidrolin, o famoso pré-historiador.

- Meu antigo capelão, disse o duque.

- Poxa, disse Cidrolin, o senhor tem condições de ter um capelão?

- Perfeitamente, disse o duque. Fui eu quem o despediu, por razões de ateísmo. De ateísmo de minha parte, bem entendido. Se bem que mesmo ele... enfim... voltemos à situação presente. Senhor Cidrolin, vejamos, onde poderia eu divertir-me na natureza a dois passos do centro da cidade?

- Não vejo onde, disse Cidrolin. $\mathrm{O}$ acesso às praças ainda não é autorizada aos campistas. - Ah, fez o duque, onde está o tempo em que cada albergue 
écurie. Les hôtels maintenant n'ont même pas de garage.

Cidrolin.

- Il y en a qui ont, dit

- Je n'avais pas tort, dit le duc, vous êtes un ratiocineur comme l'abbé Riphinte.

Cidrolin ne releva pas cette insolence et demande, si ce n'était pas indiscret, pourquoi le duc s'encombrait de ces deux chevaux. $\mathrm{Ne}$ seraient-ils pas mieux dans quelque pâturage normand ou berrichon?

- Ils aiment la ville, dit le duc. De temps à autre, ils éprouvent le besoin de reprendre contact avec la vie citadine! Ils n'ont pas vu la capitale depuis fort longtemps... Ils sont curieux de parcourir les nouveaux quartiers et d'admirer les curiosités, celles du moins qui sont dignes d'admiration.

- Tout cela ne me paraît pas très simple, dit Cidrolin.

- Je simplifierai, dit le duc. Et puisque vous êtes dans l'incapacité, monsieur Cidrolin, malgré votre bonne volonté évidente, de m'indiquer un camp de campigne pour chevaus campeurs, nous allons continuer notre chemin et nous installer quelque part dans ces bosquets que j'aperçois à l'horizon.

- C'est un lieu de promenade publique, dit Cidrolin.

[229] Gare à la contredanse.

- M'en fous, dit le duc. Adieu, monsieur. Et vous, en route.

Le duc s'installe au volant de la houature de tête ; Empoigne s'assoit à côté de lui. La comtesse conduit la seconde houature ; Phélise s'assoit à côté d'elle. Tout le monde part. Cidrolin aperçoit la tête des chevaus. Ils ont l'air de tinha sua estrebaria. Os hotéis agora não têm nem garagem.

Cidrolin.

- Há os que têm, disse

- Eu estava certo, disse o

duque, o senhor é um argumentador como o abade Rifinge.

Cidrolin não considerou essa insolência e pergunta, se não fosse indiscreto, por que o duque se preocupava com esses dois cavalos. Não ficariam eles melhor em alguma pastagem da Normandia ou do Berry?

- Eles gostam da cidade, disse o duque. De tempos em tempos, sentem a necessidade de retomar contato com a vida urbana! Eles não veem a capital há muito muito tempo... Estão curiosos por percorrer os novos bairros e por admirar as curiosidades, pelo menos aquelas que são dignas de admiração.

- Tudo isso não me parece muito simples, disse Cidrolin. - Vou simplificar, disse o duque. E já que o senhor é incapaz, senhor Cidrolin, apesar de sua evidente boa vontade, de me indicar um campo de câmpingue para cavallos campistas, nós vamos continuar nosso caminho e nos instalar em alguma parte desses bosques que estou avistando no horizonte.

- É um lugar de passeio público, disse Cidrolin. Cuidado com as multas.

- Tô nem aí, disse o duque. Adeus, senhor. E vocês, pé na estrada.

$\mathrm{O}$ duque se instala ao volante do otomóvil da frente; Empoigne senta-se ao lado dele. A condessa dirige o segundo otomóvil; Feliza senta-se ao lado dela. Todo o mundo parte. Cidrolin avista a cabeça dos cavallos. Eles 
chevaux.

Il rentre doucement chez lui. Arrivé devant sa porte, il regarde distraîtement l'immeuble qu'on finit d'achever; on travaille encore au toit et à la cave. De l'autre côté de la chaussée, quelqu'un salue Cidrolin, lequel adroitement traverse ladite sans se laisser renverser ni même accrocher par une houature.

- Vous allez pouvoir me donner un renseignement, dit Cidrolin.

- Je pense, dit le gardien, mais vous êtes peut-être étonné de me voir ici. On m'a proposé la loge de concierge. Je venais voir si ça me plaisait.

- Et ça vous plaît?

- Je pense. Vous m'avez comme voisin.

- Voici le renseignement que je voulais vous demander.

- Je vous écoute, dit le gardien.

- Il y a des gens qui ont été refoulés de votre terrain de campigne. jours.

- Ça ferme dans quelques

- Ce n'est pas cela. On n'a pas voulu d'eux parce qu'ils avaient deux chevaux.

- Des romanichels?

- Pas du tout. Un duc, une comtesse, un vicomte et une demoiselle simple d'esprit.

- Et deux chevaux.

- Et deux chevaux. Dans un

[230] van. Vous ne connaîtrez pas un autre terrain, à leur indiquer ? Pas trop loin du centre, parce que les deux chevaux n'ont pas vu la capitale depuis fort longtemps et ils sont curieux de parcourir les nouveaux quartiers pour y admirer les curiosités, celles du moins qui sont dignes d'admiration. parecem cavalos.

Ele volta para casa lentamente. Chegando diante de sua porta, olha distraidamente o prédio que acabam de terminar; ainda estão trabalhando no teto e no porão. Do outro lado da rua, alguém cumprimenta Cidrolin, o qual habilidosamente atravessa a dita rua sem se deixar atingir nem mesmo encostar por um otomóvil.

- O senhor vai poder me dar uma informação, disse Cidrolin.

- Eu penso, disse o vigia, mas o senhor talvez esteja espantado de me ver aqui. Ofereceram-me o apartamento do zelador. Eu vinha ver se me agradava.

E agrada?

- Eu penso. O senhor me tem como vizinho.

- Eis a informação que eu queria perguntar-lhe.

- Estou ouvindo, disse o vigia.

- Há algumas pessoas que foram rejeitadas na sua área de câmpingue.

- Vamos fechar em alguns dias.

- Não é isso. Não os quiseram porque eles tinham dois cavalos.

- Romanis?

- De forma alguma. Um duque, uma condessa, um visconde e uma senhorita pobre de espírito.

- E dois cavalos.

- E dois cavalos. Numa carreta. O senhor não conheceria uma outra área, para indicar-lhes? Não muito longe do centro, porque os dois cavalos não veem a capital há muito muito tempo e estão curiosos por percorrer os novos bairros para admirar as curiosidades, pelo menos aquelas que são dignas de admiração. 
- C'est un rêve ? demanda le gardien.

- Vous pensez? demanda Cidrolin.

- Ah, monsieur, dit le gardien en souriant, je vois que vous connaissez mon péché mignon. Eh oui ! Je pense. Lorsque je me lève, je pense. Lorsque je me couche, je pense. Entre-temps, je n'ai pas arrêté. Aussi vous pensez, si... vous voyez que j'attribue même ma petite manie aux autres... vous pensez si j'ai besoin de repos après toute une journée consacrée au malaxage de la matière grise de mon cerveau. Je la laisse alors reposer, je dors, je ne rêve pas. Quant à vos chevaux dans le van qui veulent visiter la capitale, je penserais, puisque vous me demandez votre avis, je penserais plutôt que vous avez rêvé.

- Alors vous ne connaissez pas un terrain de campigne qui les accueillerait?

- Vous rêvâtes.

- Pas trop loin du centre.

- Vous rêviez.

- Eux, le duc, les houatures et le reste.

- Vous rêvez.

- Les voilà, dit Cidrolin.

Le duc freina. Le gardien pâlit, fit deux pas en arrière et disparut.

- Il n'apprécie pas la méthode expérimentale, dit à mi[231] voix Cidrolin.

- Pardon ? dit un passant.

- Vous aviez raison! cria le

duc.

- Une autre fois, dit Cidrolin au passant qui s'évapora.

Cidrolin s'approcha de la portière.

- C'est plein d'argousins, ces bosquets, dit le duc. Je suis
- É um sonho? perguntou o vigia.

- O senhor pensa? perguntou Cidrolin.

- Ah, senhor, disse o vigia sorrindo, vejo que o senhor sabe do meu pequeno pecado. Ah sim! Eu penso. Quando me levanto, eu penso. Quando me deito, eu penso. No meio tempo, não paro. Assim pense o senhor, se... o senhor vê que até mesmo atribuo minha pequena mania aos outros... pense o senhor se eu preciso de repouso após um dia inteiro dedicado ao desgaste da matéria cinzenta do meu cérebro. Então deixo-a repousar, eu durmo, eu não sonho. Quanto a seus cavalos na carreta que querem visitar a capital, eu pensaria, já que o senhor me pede sua opinião, eu pensaria que o senhor esteve sonhando.

- Então o senhor não conhece uma área de câmpingue que os acolhesse?

- Sonhastes.

- Não muito longe do centro.

- Sonháveis.

- Eles, o duque, os zotomóvis e o resto.

- Estais sonhando. Cidrolin.

- Eles estão aí, disse

$\mathrm{O}$ duque freou. $\mathrm{O}$ vigia empalideceu, deu dois passos para trás e desapareceu.

- Ele não aprecia o método experimental, disse a meia voz Cidrolin.

- Como? disse um passante.

- O senhor tinha razão! gritou o duque.

- Outra vez, disse Cidrolin ao passante que se evaporou.

Cidrolin aproximou-se da porta do otomóvil.

- Estão cheios de policiais, esses bosques, disse o duque. Estou 
écœuré.

Il passa la tête et regarda l'immeuble.

- Vous habitez là ?

demanda-t-il.

- Non, en face, sur une péniche. Vous voulez prendre un verre?

- Ma foi...

- Vous avez une place làbas ; profitez-en... Et venez goûter mon essence de fenouil.

- Eh ! je ne dis pas non.

La caravane alla se garer un peu plus loin. Cidrolin traversa la chaussée avec prudence et habileté et attendit ses invités devant le portillon.

Ils descendirent le talus, Cidrolin menant la marche et répétant à plusieurs reprises :

- Faites attention de ne pas vous casser la figure.

Lorsqu'ils passèrent sur la planche passerelle au-dessus du bourbier, il changea de refrain :

- Faites attention de ne pas vous flanquer à l'eau.

La comtesse dit:

- De loin c'est coquet, mais de près c'est dégueulasse.

- L'eau paraît un peu sale, dit Cidrolin, mais elle n'est pas stagnante. On ne sent pas toujours deux fois les mêmes ordures. Avec un bâton je les pousse, elles s'éloignent, glissant au fil de l'eau.

[232] Entre la péniche et la rive, évidemment ça croupit et l'on sent parfois les mêmes.

- Les mêmes quoi ? demanda le duc.

Cidrolin.

Ordures, répondit

Puis :

- Vous cognez pas la tête. Ici c'est le carré, la salle de séjour si vous préférez.

comtesse. desgostoso.

Pôs a cabeça para fora e olhou o prédio.

- O senhor mora aí? perguntou.

- Não, em frente, numa chata. Quer tomar alguma coisa?

- Na verdade...

- Tem um lugar ali; aproveite... E venha saborear minha essência de funcho.

- Ah! não digo não.

A caravana foi estacionar um pouco mais longe. Cidrolin atravessou a rua com prudência e habilidade e esperou seus convidados diante do portão.

Eles desceram o barranco, Cidrolin puxando a fila e repetindo várias vezes:

machucar.

- Cuidado para não se

Quando eles passaram pela passarela sobre o lodaçal, ele mudou de refrão:

- Cuidado para não cair na água.

A condessa diz:

- De longe é bacana, mas de perto é nojento.

- A água parece um pouco suja, disse Cidrolin, mas não é estagnada. Não se cheira duas vezes o mesmo lixo. Com um pau eu o empurro, ele se afasta, deslizando na correnteza. Entre a chata e a margem, evidentemente amontoa um pouco e às vezes a gente cheira o mesmo.

perguntou o duque.

- O mesmo o que?

- Lixo, respondeu Cidrolin.

Depois:

- Não vão bater a cabeça. Aqui é o saguão, a sala de estar se o senhores preferirem. condessa.

- É simpática, disse a 
Cidrolin appela :

- Lalix.

Un personnage de sexe probablement féminin fit son apparition, vêtu d'un pantalon corsaire et d'un tricot à rayures horizontales bleues et blanches; coiffé d'une casquette d'enseigne de vaisseau, il tenait à la main un faubert.

- Salut, lui dit la comtesse.

Les autres ne lui dirent rien, sauf Cidrolin qui la pria de réapparaître assez vite avec des verres, une petite carafe d'eau plate et la bouteille d'essence de fenouil.

le duc.

- Quelle marque ? demanda Cidrolin.

- Cheval Blanc, répondit

Lorsque Lalix eut disparu, le duc commenta sa question en ces termes :

- Je préférerais naturellement celui que je distille avec le fenouil de mes terres d'après la recette de Timoleo Timolei...

- C'est un nom qui me dit quelque chose, murmura Cidrolin.

- Un illustre alchimiste. Illustre du moins pour ceux qui le connurent. On ne le cite guère dans les biographies.

- Vous le connûtes ?

- Fort bien. Je travaillais sous ses ordres. Je lui servais

[233] d'aide, tout duc que je sois. Vous voyez que je ne fais pas de manières, quand il le faut.

- Découvrîtes-vous la pierre philosophale? l'élixir de longue vie?

- Voulez-vous que je sois franc ? demanda le duc.

- Je le veux, répondit Cidrolin.

- Nous ne décrouvrîmes rien de tout cela, répondit le duc.
Cidrolin chamou:

- Aalice.

Uma personagem de sexo provavelmente feminino fez sua aparição, vestido com uma calça corsário e uma blusa com listras horizontais azuis e brancas; e com um boné com símbolo da marinha, tinha na mão uma vassoura.

- Olá, disse-lhe a condessa. Os outros não lhe disseram nada, exceto Cidrolin que pediu-lhe para reaparecer bem depressa com copos, uma jarrinha de água sem gás e a garrafa de essência de funcho.

- Que marca? perguntou o duque.

- Cavalo Branco, respondeu Cidrolin.

Quando Aalice desapareceu, o duque comentou sua questão nestes termos:

- Eu preferiria naturalmente a que destilo com o funcho de minhas terras segundo a receita de Timoleu Timolei...

- É um nome que não me é estranho, murmurou Cidrolin.

- Um ilustre alquimista. Ilustre pelo menos para os que o conheceram. Quase não é citado nas biografias.

- Vós o conhecestes?

- Mui bem. Eu trabalhava sob suas ordens. Eu lhe servia de ajudante, mesmo sendo duque. Veja que não faço cerimônia, quando é preciso.

- E descobrísteis a pedra filosofal? o elixir da longa vida?

- Quer que eu seja franco? perguntou o duque.

Quero, respondeu Cidrolin

- Nós não descobrimos nada disso, respondeu o duque. 
- Seulement l'essence de fenouil ? demanda Cidrolin.

- On va toujours se taper celle-là, dit la comtesse.

- Bê, bê, dit Phélise.

Lalix apportait adroitement un vaste plateau chargé.

Le service fait, elle s'assit, un verre à la main. Cidrolin dit aux autres :

fiancée.

- Je vous présente ma

Et à Lalix :

- Duc d'Auge... vicomte d'Empoigne... madame euh...

- Comtesse d'Empoigne, dit la comtesse d'Empoigne.

- Et mademoiselle...

- Madame... dit le duc. Madame de Malplaquet.

- Salut, dit Lalix.

- Bê, bê, dit Phélise.

- Eh bien, reprit le duc, elle n'est pas mauvaise, votre essence de fenouil.

- Pas méprisable du tout, dit Empoigne.

- Pas sale, dit sa maman.

Phélise n'eut pas à donner

[234] son appréciation, car elle ne buvait que de l'eau.

- Il faudrait faire boire les chevaus, dit le duc.

- J'y vais, dit Empoigne.

- Vous trouverez un seau sur le pont à bâbord, dit Lalix.

- Sthène et Stèphe doivent se demander ce qu'on devient, dit le duc.

- Vous les tenez toujours au courant de vos intentions? demanda Cidrolin.

- Ils préfèrent, répondit le duc.

- C'est un cirque ? demanda Lalix à Cidrolin.
- Só a essência de funcho? perguntou Cidrolin.

- De qualquer modo vamos tomar essa aqui, disse a condessa.

- Bé, bé, disse Feliza.

Aalice trazia habilmente uma grande bandeja cheia.

Feito o serviço, ela sentouse, um copo na mão. Cidrolin disse aos outros:

- Eu lhes apresento minha noiva.

E a Aalice:

- Duque de Auge... visconde de Empoigne... senhora ahn...

- Condessa de Empoigne, disse a condessa de Empoigne.

- E senhorita...

- Senhora... disse o duque.

Senhora de Malplaquet.

- Olá, disse Aalice.

- Bé, bé, disse Feliza.

- Então, retomou o duque, não é ruim, sua essência de funcho.

- Não desprezível de forma alguma, disse Empoigne.

- Nada mal, disse a mamãe dele.

Feliza não tinha apreciação a dar, pois ela só bebia água.

- É preciso dar de beber aos cavallos, disse o duque.

- Eu vou, disse Empoigne.

- O senhor vai encontrar um balde no convés a bombordo, disse Aalice.

- Stenes e Estêvão devem estar se perguntando o que está havendo com a gente, disse o duque.

- O senhor sempre os mantém a par de suas intenções? perguntou Cidrolin.

- Eles preferem, respondeu o duque.

- É um circo? perguntou Aalice a Cidrolin. 
- Je ne sais pas, répondit Cidrolin à Lalix. Tout au moins des campeurs. On a pas voulu d'eux sur le terrain à cause des chevaux.

- Pour le principe, demanda Lalix, ou bien c'est des canassons spéciaux?

- Ce sont des braves bêtes, dit le duc.

- Qu'est-ce qu'on fait maintenant qu'on a bu ? demanda la comtesse. On émigre?

Le duc ne répondit pas et regarda distraitement autour de lui ; puis, d'une voix terne, il dit :

- Cela doit être grand, une péniche.
- Não sei, respondeu Cidrolin a Aalice. No mínimo campistas. Não quiseram saber deles na área por causa dos cavalos.

- Por princípio, perguntou Aalice, ou são cavalos especialmente maus?

- São ótimos animais, disse o duque.

- O que a gente vai fazer agora que já bebemos? perguntou a condessa. Emigramos?

$\mathrm{O}$ duque não respondeu $\mathrm{e}$ olhou distraidamente a sua volta; depois, com uma voz terna, ele disse:

- Deve ser grande, uma chata. 
XVIII

Joachim d'Auge s'éveilla d'excellente humeur ; il avait dormi [235] d'un sommeil profond et sans rêves. Dès qu'il s'estima présentable, il monta sur le pont, aucun des autres passagers de la péniche n'était encore levé. Il alla pisser dans le fleuve et se réjouit en son cœur du bruit allègre du jet se brisant à la surface de l'eau. Sur l'autre rive des pêcheurs s'installaient. Des sportifs matinaux passèrent maniant l'aviron. Le duc se retourna; Sthène et Stèphe broutaient les rares friandises qui poussaient en haut du talus. Sur le quai les houatures passaient dru dans un roucoulement monotone.

Le duc mit pied à terre et alla retrouver les chevaux.

- Alors, mon beau Sthène, comment vous trouvez-vous ici ?

- Il faudrait être chèvre pour s'y plaire tout à fait.

- Vous vous y habituerez. Cela vous fera faire de l'exercice.

- On reste longtemps ici ?

- Je ne sais pas, dit le duc. Nous sommes peut-être arrivés.

- Stèphe et moi, nous aurions préféré un séjour plan. Stèphe.

- Un vrai pré plat, dit

- Et puis, ajouta Sthène, il n'y a pas grand'-chose à croûter.

- Pouscaillou va vous apporter du foin tout à l'heure.

- Quand? Il flemmarde, Pouscaillou. Vous devriez aller lui sonner les cloches.

- Patience, patience, mon beau Sthène. Laissons dormir les innocents.

- Soit, dit Sthène. Et vous, comment vous trouvez-vous à bord
XVIII

Joaquim de Auge acordou de excelente humor; ele tinha dormido um sono profundo e sem sonhos. Assim que se achou apresentável, subiu ao convés, nenhum dos outros passageiros da chata tinha se levantado ainda. Ele foi mijar no rio e alegrou seu coração com o barulho alegre do jato quebrando-se à superfície da água. Na outra margem alguns pescadores instalavam-se. Esportistas matinais passaram manejando o remo. $\mathrm{O}$ duque voltou-se; Stenes e Estêvão pastavam as raras guloseimas que cresciam no alto do barranco. No cais os zotomóvis passavam sem parar com um arrulho monótono.

$\mathrm{O}$ duque desceu à terra e foi ver os cavalos.

- E aí, meu belo Stenes, como estão se sentindo aqui?

- Tinha que ser cabra pra gostar disso.

- Vocês vão se acostumar. Com isso vocês farão exercício.

- Vamos ficar muito tempo aqui?

- Não sei, disse o duque. Talvez nós tenhamos chegado.

- Estêvão e eu, nós preferiríamos uma planura.

- Um vasto pasto plano, diz Estêvão.

- E depois, acrescentou Stenes, não há grande coisa pra saborear.

- Pouscaillou vai trazer-lhes feno daqui a pouco.

- Quando? Pouscaillou está fazendo corpo mole. $\mathrm{O}$ senhor deveria puxar-lhe as orelhas.

- Paciência, paciência, meu belo Stenes. Deixemos dormir os inocentes.

- Que seja, disse Stenes. E o senhor, como está se sentindo a 
de cette immobile nef?

- J'ai toujours rêvé d'habiter sur une péniche, répondit le duc. Je ne suis pas mécontent du tout.

- Je m'en réjouis pour vous, dit Sthène. Si seulement il y a vait un peu plus de foin et d'avoine...

- Patience, patience, mon bon Sthène.

Lalix apparut sur le pont.

- Café ? Thé ? Chocolat? Viandox? cria-t-elle au duc.

Le duc rappliqua.

- Du café bien noir, répondit-il, avec des toasts bien beurrés, de la confiture bien anglaise, des œufs sur le plat bien frits et une andouillette bien grillée. faim !

Tudieu, la navigation donne

Lalix disparut sans faire de commentaires.

Empoigne apparut sur le pont.

- Les chevaus attendent, lui dit aussitôt le duc, j'espère qu'il y a encore du foin et de l'avoine en réserve dans le van.

- Sinon, dit Empoigne en se frottant les yeux, j'irai en chercher à Inno. Monsieur le duc a bien dormi ?

- À merveille. J'avoue que je ne suis pas mécontent de notre point de chute.

- Et mon petit déjeuner? Où et quand vais-je y avoir droit ?

- Donne toujours à manger à Sthène et à Stèphe. Il doit bien rester de quoi les faire patienter.

Pouscaillou disparaît direction le van.

Madame d'Empoigne apparaît sur le pont.

- Dormîtes-vous bien, bordo desta nave imóvel?

- Sempre sonhei em morar

numa chata, respondeu o duque.

Não estou nem um pouco descontente.

- Fico contente pelo senhor, disse Stenes. Se pelo menos houvesse um pouco mais de feno e de aveia...

- Paciência, paciência, meu bom Stenes.

Aalice aparece no convés.

- Café? Chá? Chocolate? Fiambrada? gritou ela ao duque. $\mathrm{O}$ duque voltou rapidamente.

- Café bem preto, respondeu ele com torradas bem amanteigadas, geléia bem inglesa, ovos estrelados bem fritos e uma salsichinha bem grelhada.

fome!

Por Deus, a navegação dá

Aalice desapareceu sem fazer comentários.

Empoigne apareceu no convés.

- Os cavallos estão esperando, logo diz o duque, espero que haja ainda feno e aveia de reserva na carreta.

- Senão, disse Empoigne esfregando os olhos, vou buscar na Inno. O senhor duque dormiu bem?

Confesso que não estou nada descontente com o local em que viemos parar.

- E meu café da manhã?

Onde e quando vou ter direito a ele?

- Primeiro dê de comer a Stenes e a Estêvão. Ainda deve ter algo para acalmá-los.

Pouscaillou desaparece direção carreta.

A senhora Empoigne aparece no convés.

- Dormistes bem, maninha? 
sœurette? demanda le duc.

- Salut, lui répond la comtesse.

Phélise apparaît. Elle embrasse son papa.

- Bê, bê, dit-elle.

Lalix crie :

- C'est servi.

On rapplique dans le carré. On s'assied joyeusement. Empoigne a bientôt fait de rejoindre le peloton. Sur la table, le café bien chaud fume joyeusement. Il y a des toasts, des non-toasts, des confitures, des raviers de beurre.

- Il n'y a pas d'œufs sur le plat, remarque le duc.

- Il n'y a pas d'œufs sur le plat, affirme Lalix.

- Il n'y a pas d'andouillette, remarque le duc.

- Il n'y a pas d'andouillette, affirme Lalix. légèrement.

- Bien, bien, dit le duc

Il a déjà croqué sept toasts, y compris les matières grasses ou sucrées qu'il avait accumulées dessus.

- Monsieur Cidrolin n'est pas encore levé ? demanda le duc.

- Le voici, répond Cidrolin en s'attablant.

[238] - Je dormis fort bien, dit le duc. Je vous sais gré de votre hospitalité bien qu'elle soit sans andouillettes.

- Nous aviserons, dit Cidrolin. N'est-ce pas, Lalix ?

$$
\text { - Il n'y a pas }
$$

d'andouillettes, affirme Lalix. Ni d'œufs sur le plat.

- Et comment vont les chevaux ? demande Cidrolin.

- Ils trouvent le terrain plutôt en pente, répond le duc. Ils n'ont pas l'humeur caprine.

Bien qu'on ne l'y ait pas perguntou o duque. condessa.

- Olá, responde-lhe a

Feliza aparece. Ela beija seu papai.

- Bê, bê, diz ela.

Aalice grita:

- Está servido.

Acorrem ao saguão.

Sentam-se alegremente. Empoigne veio logo juntar-se ao pelotão. Sobre a mesa, o café bem quente fumega alegremente. Há torradas, não-torradas, geléias, pratinhos de manteiga.

- Não há ovos estrelados, observa o duque.

- Não há ovos estrelados, afirma Aalice.

- Não há salsichinhas, observa o duque.

- Não há salsichinhas, afirma Aalice.

- Bem, bem, disse o duque suavemente.

Ele já comeu sete torradas, incluindo as matérias graxas ou açucaradas que tinha acumulado em cima.

- O senhor Cidrolin ainda não se levantou? perguntou $\mathrm{o}$ duque.

- Ele está aqui, responde Cidrolin, pondo-se à mesa.

- Dormi mui bem, disse o duque. Sei que está contente de sua hospitalidade embora ela seja sem salsichinhas.

- Nós providenciaremos, disse Cidrolin. Não é Aalice?

- Não há salsichinhas, afirma Aalice. Nem ovos estrelados.

- E como vão os cavalos? pergunta Cidrolin.

- Estão achando o terreno inclinado demais, responde o duque. Eles não têm espírito caprino.

Ainda que não tenha sido 
invité, Pouscaillou prend la parole en ces termes :

- À propos...

- Quel propos ? demande le duc.

- À propos des chevaus. En rapportant le foin du van, j'ai vu qu'on avait écrit des injures sur la porte de monsieur Cidrolin.

- Elles me concernent? demanda le duc en fronçant les sourcils.

- Laissez, laissez, dit Cidrolin. C'est pour moi.

- On vous en veut? demanda le duc.

- C'est bien possible. Depuis que je suis installé ici, quelqu'un s'exerce aux graffiti sur le portillon et la clôture. Je les recouvre de peinture. L'autre s'acharne.

- Vous ne savez pas qui c'est ?

- Je n'en ai pas la moindre idée.

- Et vous n'avez jamais cherché à le pincer ?

- Une nuit, j'ai fait le guet. J'ai attrapé une bronchose virale aberrante, c'est tout ce que j'ai pincé.

- Empoigne! dit le duc d'une voix solennelle. Voilà un exploit pour nous autres

[239] chevaliers: nous débarrassons notre hôte, monsieur Cidrolin, de son graffitomane.

- Vraiment, dit Cidrolin. Vous êtes trop aimable...

- Nous le prenons en flagrant délit, continue le duc, et nous le pendons à un arbre du boulevard.

- C'est que... dit Cidrolin. C'est que... nous aurions des ennuis.

- Pourquoi donc?

- Des ennuis avec la police. convidado, Pouscaillou toma a palavra nestes termos:

- A propósito...

- Que propósito? pergunta o duque.

- A propósito dos cavallos. Quando lhes trazia o feno da carreta, vi que tinham escrito injúrias na porta do senhor Cidrolin.

- São sobre mim? perguntou o duque franzindo as sobrancelhas.

- Deixem, deixem, disse Cidrolin. É para mim.

- Alguém o odeia? perguntou o duque.

- É bem possível. Desde que estou instalado aqui, alguém exercita-se nos graffiti no portão e na cerca. Eu cubro de tinta. O outro insiste.

- O senhor não sabe quem

- Não faço a mínima idéia.

- E nunca tentou agarrá-lo?

- Uma noite, fiquei de sentinela. Peguei uma broncose viral aberrante, foi só o que agarrei.

- Empoigne! disse o duque com voz solene. Eis uma façanha para nós cavaleiros: vamos livrar nosso anfitrião, senhor Cidrolin, de seu grafitomaníaco.

- Realmente, disse Cidrolin. O senhor é muito amável.

- Nós o prendemos em flagrante delito, continua o duque, e o enforcamos numa árvore do bulevar.

- É que... disse Cidrolin. É que... teríamos problemas.

- Por que?

- Problemas com a polícia. 
- Comment, s'écria le duc. Vous n'avez pas le droit de haute et basse justice? Et n'êtes-vous pas maître après Dieu à bord de votre péniche?

- Oui, mais l'arbre du boulevard n'est pas sur ma péniche.

- Alors nous jetterons le délinquant à la flotte. Soigneusement ligoté.

- Je crains que ça aussi...

- Eh bien, nous nous contenterons de lui couper les oreilles.

- Non... non...

Alors simplement quelques coups de pied au cul ?

- Voilà... à la rigueur...

- Monsieur Cidrolin, ne comptez pas sur moi pour les coups de pied au cul. Jamais je n'userai la semelle de mes bottes sur le derrière d'un graffitomane. Ce serait déchoir.

- Monsieur le duc, monsieur Empoigne, je suis très touché par votre proposition, mais après tout, je me suis débrouillé comme ça jusqu'à ce jour et je peux continuer. C'est un article de mon budget : un pot de peinture par mois e, sans doute, un pinceau par an. Et puis cela me fait une distraction : sinon, que peindrais-je?

- Je connais encore quelques cavernes... dit le duc d'une voix rêveuse. Mais laissons cela...

Soudain il donna un violent coup de poing sur la table et gueula :

- Or çà, Empoigne! nous laisserions-nous amollir? Non certes! Malgré tout ce que peut raconter monsieur Cidrolin, ce soir nous capturons le graffitomane et qui vivra verra!

Foi d'Empoigne! capturons !

- Capturez! crie madame
- Como, exclamou o duque. O senhor não tem o direito de alta e baixa justiça? E não é senhor depois de Deus a bordo de sua chata?

- Sim, mas a árvore do bulevar não está na minha chata.

- Então nós jogaremos o delinquente no rio. Cuidadosamente amarrado.

- Temo que isso também...

- Bem, nós nos contentaremos em cortar-lhe as orelhas.

- Não... não...

- Então simplesmente alguns pontapés na bunda?

- Isso... a rigor...

- Senhor Cidrolin, não conte comigo para os pontapés na bunda. $\mathrm{Eu}$ jamais estragaria a sola de minhas botas no traseiro de um grafitomaníaco. Seria decair.

- Senhor duque, senhor Empoigne, estou muito tocado por sua proposta, mas a bem da verdade, estou me virando assim até hoje e posso continuar. É um item do meu orçamento: uma lata de tinta por mês, e, talvez, um pincel por ano. E depois isso pra mim é uma distração: senão, o que eu pintaria?

- Ainda conheço algumas cavernas... disse o duque com voz sonhadora. Mas deixemos pra lá...

De repente ele deu um soco violento na mesa e berrou:

- Ora essa, Empoigne! nós nos deixaríamos amolecer? Claro que não! Apesar de tudo o que possa contar o senhor Cidrolin, esta noite nós capturamos o grafitomaníaco e quem viver verá! capturemos!

- Palavra de Empoigne!

- Capturem! grita a senhora 
d'Empoigne.

- Bê, bê, dit Phélise.

Tout cela fait beaucoup de bruit.

- En attendant, dit Cidrolin, je vais donner quelques coups de pinceau.

Il sort suivi de Lalix. Lalix demande :

- Ils s'en vont quand?

- Nous n'avons rien convenu.

- Demain matin, je leur fais de l'andouillette et des œufs au plat?

Cidrolin prend le pot de peinture et le pinceau.

- Si ce n'est pas trop compliqué, répond Cidrolin. Nous devons nous montrer seigneuriaux.

Cidrolin s'engage sur la planche passerelle.

- Si nous sommes fiancés, dit Lalix, est-ce qu'on ne devrait pas se tutoyer?

- Se vouvoyer fait plus seigneurial.

Lalix retourne à ses occupations. Cidrolin passe devant Sthène et Stèphe. Il les regarde dans les yeux.

- Ce qu'ils ont l'air intelligent, dit-il à mi-voix. Il ne leur manque que la parole.

- Il ne nous manque rien du tout, dit Sthène. Merde, ajoute-t-il en frappant le sol de son sabot

[241] droit, Joachim m'avait pourtant bien recommandé de ne pas ouvrir la bouche.

Cidrolin se retrouve sur le trottoir. En chemin, il a renversé un peu de peinture.

- Étrange, dit-il à mi-voix, c'est vraiment étrange.

- Pardon?

C'est un passant qui s'arrête pour interroger Cidrolin.

- Étrange. Je disais
Empoigne.

- Bê, bê, diz Feliza.

Tudo isso faz muito barulho.

- Enquanto espero, disse Cidrolin, vou dar algumas pinceladas.

Ele sai seguido por Aalice. Aalice pergunta:

- Quando eles vão embora?

- Não combinamos nada.

- Amanhã de manhã, faço salsichinhas e ovos estrelados para eles?

Cidrolin pega a lata de tinta e o pincel.

- Se não for muito complicado, responde Cidrolin. Nós devemos mostrar-nos senhoriais.

Cidrolin dirige-se à passarela.

- Se nós somos noivos, disse Aalice, será que não devíamos nos chamar de você?

- Senhor e senhorita é mais senhorial.

Aalice volta a suas ocupações. Cidrolin passa diante de Stenes e Estêvão. Ele olha-os nos olhos.

- Como parecem inteligentes, diz a meia voz. Só faltam falar.

- Não falta absolutamente nada, disse Stenes. Merda, acrescenta ele pisando o solo com o casco direito, e Joaquim tinha me recomendado tanto para não abrir a boca.

Cidrolin encontra-se na calçada. No caminho, ele derrubou um pouco de tinta.

- Estranho, diz ele a meia voz, é muito estranho.

- Como?

É um passante que para para interrogar Cidrolin.

- Estranho. Eu dizia 
simplement : c'est vraiment étrange.

- Et qu'est-ce qui est vraiment étrange?

Cidrolin commence à badigeonner la porte.

- Ah voilà, répond-il.

- Monsieur! s'écrie le passant d'un air furieux, on ne pique pas comme ça la curiosité des gens : vous les intriguez et puis ensuite vous vous taisez. Non monsieur, cela ne se fait pas !

Il s'éloigne en faisant des moulinets avec les bras.

Cidrolin ne commente pas.

Puis il s'entend héler. C'est le concierge de l'immeuble pas tout à fait inachevé, pas tout à fait achevé. Il est debout devant sa porte, sur le trottoir d'en face. Cidrolin répond à son salut et continue son travail.

Puis ses hôtes font leur apparition. Ils discutent de leurs occupations. Empoigne doit acheter $\mathrm{du}$ foin et de l'avoine chez Inno, le duc visitera le Palais de l'Alchimie, les dames iront voir les couturiers. Ça, c'est pour la matinée. On déjeunera en ville dans un de-luxe. L'après-midi sera consacré à l'examen de diverses curiosités; une séance de cinéma est également prévue. Dîner dans un de-luxe ; pas le même que celui d'à midi. On ne rentrera pas très tard et [242] ensuite on capturera le graffitomane.

- Et les chevaux? demande Cidrolin. Ils ne vont pas se promener eux aussi ?

- Demain, répond le duc. Demain. Quand nous aurons capturé votre homme. Cidrolin.

- Quel rapport? demanda

- Aucun, répond le duc.

Il prend un air soucieux. simplesmente: é muito estranho.

- E o que é muito estranho?

Cidrolin começa a pincelar a porta.

- É isso aí, responde ele.

- Senhor! exclama o passante com ar furioso, não se aguça desse jeito a curiosidade dos outros: o senhor os intriga e depois se cala. Não senhor, isso não se faz!

Ele se afasta fazendo banana com os braços.

Cidrolin não comenta nada.

Depois ele ouve chamá-lo de longe. É o zelador do prédio não completamente inacabado, nem completamente acabado. Ele está em pé diante da porta, na calçada em frente. Cidrolin responde à sua saudação e continua seu trabalho.

Depois seus hóspedes fazem sua aparição. Eles discutem sobre suas ocupações. Empoigne tem que comprar feno e aveia na Inno, o duque visitará o Palácio da Alquimia, as damas irão ver os costureiros. Isso, pela manhã. Vão almoçar na cidade num de-luxo. A tarde será dedicada ao exame de diversas curiosidades; uma sessão de cinema também está prevista. Jantar num de-luxo; não o mesmo do almoço. Voltarão muito tarde e em seguida capturarão o grafitomaníaco.

- E os cavalos? pergunta Cidrolin. Não vão passear também?

- Amanhã, responde o duque. Amanhã. Quando tivermos capturado seu homem.

- E qual a relação? perguntou Cidrolin.

- Nenhuma, responde o duque.

Ele fica com uma expressão 
- C'est vrai, murmure-t-il. Pauvre Sthène, pauvre Stèphe. Ils voudraient admirer les beautés de la ville capitale, eux aussi. Deviendrais-je égoïste? Monsieur Cidrolin, j'en rougirais de honte. Vous avez bon cœur, monsieur Cidrolin. Vous avez raison, je ne laisserai pas deux amis se morfondre tandis que moi, je m'amuse. Empoigne, nous irons à cheval à Inno, vous les femmes prendrez votre houature. Empoigne, va chercher Sthène et Stèphe.

Mission accomplie, Sthène et Stèphe font la gueule.

- Mon bon Démo, dit le duc.

Sthène boude.

- Voyons, voyons, mon bon Démo, dit le duc. Je ne t'oubliais pas. Nous voulions échanger quelques mots avec monsieur Cidrolin. Il n'a jamais été question qu'on vous laisse là et que vous ne veniez pas admirer les beautés de la ville capitale avec nous. N'est-ce pas, monsieur Cidrolin?

De l'examen du visage de Cidrolin, il est facile d'inférer la situation cornicienne dans laquelle il se trouve; peut-on mentir à un cheval ? peut-on démentir un hôte ?

Cidrolin trouve une élégante solution. Il dit au duc :

- Vous vous adressez à lui comme s'il pouvait comprendre le langage des hommes. A-t-on jamais vu cela, un cheval qui parle? En rêve peut-être. $\mathrm{Ou}$ dans la mythologie.

Le duc ne trouva pas la solution élégante. Il dit :

- Qu'est-ce que ça peut vous foutre la façon dont je m'adresse à lui ? Tout ce que je vous demande, c'est la vérité ! À savoir que je ne t'oubliais pas, mon preocupada.

- É verdade, murmura ele. Coitado do Stenes, coitado do Estêvão. Eles gostariam de admirar as belezas da cidade capital, também. Estaria eu me tornando egoísta? Senhor Cidrolin, eu coraria de vergonha. O senhor tem bom coração, senhor Cidrolin. O senhor tem razão, não deixarei dois amigos se aborrecendo enquanto me divirto. Empoigne, nós iremos a cavalo até a Inno, vocês mulheres pegarão seu otomóvil. Empoigne, vá buscar Stenes e Estêvão.

Cumprida a missão, Stenes e Estêvão fazem cara feia.

- Meu bom Demós, diz o duque.

Stenes fica amuado.

- Vamos, vamos, meu bom Demós, diz o duque. Eu não estava esquecendo de você. Nós queríamos trocar algumas palavras com o senhor Cidrolin. Nunca pensamos em deixar vocês aí e em não levá-los para admirar as belezas da cidade capital conosco. Não é, senhor Cidrolin?

Pelo exame do rosto de Cidrolin, é fácil inferir a situação corneciniana em que se encontra; pode-se mentir a um cavalo? podese desmentir um hóspede?

Cidrolin encontra uma elegante solução. Ele diz ao duque:

- O senhor dirige-se a ele como se ele pudesse entender a linguagem dos homens. Já se viu isso, um cavalo que fala? Em sonho talvez. Ou na mitologia.

O duque não achou a solução elegante. Ele diz:

- O que o senhor tem a ver com a maneira com que me dirijo a ele? Tudo o que quero, é a verdade! A saber que eu não estava te esquecendo, meu bom Demós. 
bon Démo.

- Monsieur d'Auge, dit Cidrolin, écoutez donc ces enthymèmes pour ne pas dire ce sorite. Si ce cheval comprend le langage humain, il est donc fort intelligent. S'il est intelligent il a déjà deviné ce qu'il en est. D'autre part, s'il est intelligent, il est bon et, s'il est bon, il aura de l'indulgence pour une simple étourderie de votre part et cela ne saurait ternir votre amitié.

Et se tournant vers Sthène, Cidrolin ajouta :

- N'est-ce pas, Sthène ?

Sthène sourit, un peu tristement, et encensa.

- Brave Démo, dit le duc.

Il se met en selle, ainsi fait Empoigne et les voilà partis, les femmes dans la houature aussi, après avoir détaché la remorque, c'est Phélise qui s'est chargée de détacher la remorque. Cidrolin continue à peindre sa clôture. Le concierge a disparu. marché.

Puis c'est Lalix qui va au

- Alors, c'est bien entendu ? j'achète de l'andouillette ?

- Nous serons seigneuriaux, répond Cidrolin.

Lalix va au marché. Cidrolin achève sa peinture.

Après avoir rangé le pot et le pinceau, il va s'étendre dans le carré en attendant le déjeuner. Il y a

[244] de l'andouillette à déjeuner. Après le déjeuner, il va dans sa cabine faire une sieste. Il est quinze heures trente-deux minutes lorsqu'il dit à Lalix :

- J'ai fait une sieste presque sans rêves. Juste un petit, sans grand intérêt. Je le raconte?

- Non, répond Lalix.

- C'est un tout petit.

- Raison de plus. Et puis je
- Senhor de Auge, diz

Cidrolin, ouça então esses entimemas para não dizer esse sorites. Se esse cavalo entende a linguagem humana, então ele é mui inteligente. Se ele é inteligente, já adivinhou o que se passa. Por outro lado, se ele é inteligente, ele é bom e, se ele é bom, terá indulgência por uma simples distração de sua parte e isso não poderia empanar o brilho de sua amizade.

E virando-se para Stenes, Cidrolin acrescentou:

- Não é, Stenes?

Stenes sorriu, um pouco tristemente, e baixou a cabeça.

- Bravo Demós, disse o duque.

Ele se põe na sela, assim faz Empoigne e ei-los que partiram, as mulheres no otomóvil também, depois de ter desengatado o reboque, foi Feliza que se encarregou de desengatar $o$ reboque. Cidrolin continua a pintar a cerca. $O$ zelador desapareceu.

Depois é Aalice que vai ao mercado.

- Então, está bem entendido? compro salsichinhas? - Nós seremos senhoriais, responde Cidrolin.

Aalice vai ao mercado. Cidrolin termina sua pintura.

Depois de ter guardado a lata e o pincel, ele vai estender-se no saguão esperando o almoço. Há salsichinha no almoço. Depois do almoço, ele vai para sua cabina fazer uma sesta. São quinze horas e trinta e dois minutos quando ele diz a Aalice:

- Fiz uma sesta quase sem sonhos. Só um pequeno, sem grande interesse. Quer que o conte?

- Não, responde Aalice.

- É bem pequeno.

- Mais uma razão. E além 
vais au coiffeur.

Elle ne rentre que pour le dîner. Cidrolin a été voir ce qui se passait au camp de campigne pour les campeurs et il a pu constater que cette fois-ci c'est définitivement fermé. Il est rentré. À la nuit tombante, il a pris une perche, il a fait glisser vers le courant central les ordures accumulées dans le chenal entre la péniche et la rive. Ensuite, il a attendu le dîner.

Il y a de l'andouillette pour le dîner.

Après, Lalix allume une cigarette et va chercher un jeu de cartes enveloppé dans un tapis vert chipé dans un bistro. Elle fait des réussites, l'œil droit à moitié fermé à cause de la fumée qui monte du mégot qu'elle ne lâche pas. Elle éteint le mégot. La réussite n'est pas réussie. Lalix allume une autre cigarette et commence une autre réussite. Cidrolin la regarde opérer en silence. La seconde réussite n'est pas réussie. On recommence et ainsi de suite. Les mégots s'accumulent. Il est bientôt vingttrois heures sept minutes. À vingttrois heures sept minutes, les hôtes rentrent et s'installent dans le carré. Lalix termine sa réussite avant d'apporter le sirop de fenouil.

- Ils nous faut reprendre des forces pour la capture du graffitomane, dit gaiement le duc.

- Vous vous croyez vraiment obligé... dit Cidrolin.

façons. Nous faisons une pause et ensuite nous montons la garde.

- Je vous accompagne.

- Laissez, laissez. Avec Empoigne, nous viendrons à bout de cette tâche tout seuls.

do mais, vou no cabeleireiro.

Ela só volta para o jantar. Cidrolin foi ver o que se passava no campo de câmpingue para campistas e pôde constatar que desta vez estava definitivamente fechado. Ele voltou. À noitinha, ele pegou uma vara, empurrou para a corrente central o lixo acumulado no canal entre a chata e a margem. Em seguida, esperou o jantar.

Há salsichinha para o jantar.

Depois, Aalice acende um cigarro e vai buscar um jogo de cartas embrulhado num pano verde roubado de um boteco. Ela joga paciência, o olho direito meio fechado por causa da fumaça que sai da bituca que ela não tira da boca. Ela apaga a bituca. A paciência não dá certo. Aalice acende um outro cigarro e começa uma outra paciência. Cidrolin olhaa operar em silêncio. A segunda paciência não dá certo. Ela recomeça e assim vai. As bitucas acumulam-se. Logo são vinte e três horas e sete minutos. Às vinte e três horas e sete minutos, os hóspedes entram e se instalam no saguão. Aalice termina sua paciência antes de trazer o xarope de funcho.

- Precisamos recuperar as forças para a captura do grafitomaníaco, disse alegremente o duque.

- O senhor se sente realmente obrigado... diz Cidrolin.

- Ttt, $\mathrm{ttt}$, faz o duque. Nada de cerimônias. Nós fazemos uma pausa e em seguida montamos guarda.

- Eu os acompanho.

- Deixe, deixe. Com Empoigne, nós daremos conta da tarefa sozinhos. 
- Salut, dit la comtesse.

Elle veut dire par là qu'elle va se coucher.

- Bê, bê, dit Phélise.

Elle veut dire par là qu'elle va se coucher.

Effectivement, elles vont se coucher.

- Tout s'est bien passé ? demande Cidrolin au duc d'Auge qui n'a pas l'air disposé à monter déjà la faction.

- Quoi donc?

- Votre virée dans la capitale.

- Sthène et Stèphe sont enchantés.

- Et vous-même ? Et monsieur d'Empoigne?

- Il y a eu des moments difficiles, la capitale a bien changé.

- Cela faisait longtmps que vous n'étiez venu?

- Plus d'un siècle, répond tranquillement le duc.

Empoigne toussote.

- Je veux dire : très longtemps, reprend le duc. La circulation par exemple: nous avons eu des ennuis avec la circulation. Sthène et Stèphe n'étaient pas habitués à tout ce trafic. Les sergents de ville nous ont distribué des tas de petits prospectus dont je n'ai que faire.

Il les sortit de sa poche et les déchire en petits morceaux.

- C'est en visitant votre grande tour que tout faillit mal tourner, continua le duc. Sthène

[246] voulait monter jusqu'au troisième étage, il a dû se contenter du premier. Et encore pour qu'il aille au premier, ce fut toute une histoire. Heureusement qu'il y avait là des gens qui jouaient avec un appareil cinématographique, grâce à eux cela put s'arranger; du moment que c'était du
- Adeus, disse a condessa.

Ela quer dizer com isso que vai se deitar.

- Bê, bê, diz Feliza.

Ela quer dizer com isso que vai se deitar.

Efetivamente, elas vão se deitar.

- Foi tudo bem? pergunta Cidrolin ao duque de Auge que ainda não parece estar disposto a montar guarda.

- Tudo bem o que?

- Seu giro pela capital.

- Stenes e Estêvão ficaram encantados.

- E o senhor? E o senhor Empoigne?

- Houve momentos difíceis, a capital mudou muito.

- Fazia muito tempo que o senhor não vinha?

- Mais de um século, responde tranquilamente o duque. Empoigne dá uma tossidinha.

- Quero dizer: muito tempo, retoma o duque. $\mathrm{O}$ trânsito por exemplo: nós tivemos problemas com o trânsito. Stenes e Estêvão não estavam habituados a todo esse trânsito. Os guardas nos distribuíram montes de pequenos prospectos e não tenho o que fazer com eles.

Ele tirou-os do bolso e rasgou-os em pedacinhos.

- Foi quando visitamos sua grande torre que tudo quase foi por água abaixo, continuou o duque. Stenes queria subir até o terceiro andar, ele teve que se contentar com o primeiro. E ainda para que ele fosse até o primeiro, foi toda uma história. Felizmente havia lá algumas pessoas com um aparelho cinematográfico, graças a elas tudo pôde se arranjar, a partir do momento em que se tratava do 
cinématographe, tout devenait possible, mais, tout de même, Sthène a dû se contenter du premier.

- Et l'autre? demanda Cidrolin.

- L'autre quoi ?

- L'autre cheval.

- Stèphe ? Il n'a pas voulu monter. Il avait le vertige.

- Il serait peut-être temps que vous alliez faire le guet, dit Lalix.

- Encore un petit coup d'essence de fenouil et nous y courons, dit le duc conciliant. Cidrolin.

- Et le restaurant? demanda

- Comme ci comme ça, répondit le duc. Ils vous servent tout juste de quoi nourrir un oiseau souffrant et leur carte ne liste aucun des plats que j'aimais tant jadis et naguère, le pâté de rossignol au safran, la tarte de châtaignes à la graisse de campagnol, le chaudfroid d'ours à la graine de tournesol, tout cela arrosé d'alcool au bol.

Le duc finit son verre, puis énonça cette remarque :

- Ce qui me plaît dans l'essence de fenouil, c'est qu'il n'y a aucun autre mot qui rime avec. Avec fenouil.

- À moins qu'on ne change de genre, dit Lalix.

- On n'a pas le droit, répliqua le duc.

- Vous êtes aussi poète? demanda Cidrolin.

m'arrive de trousser la

chansonnette...

- C'est bien la première nouvelle, dit Empoigne.

Après être ainsi sorti de son mutisme respectueux, il alla valser à l'autre bout du carré en renversant des verres. Tandis qu'il cinematógrafo, tudo se tornava possível, mas, de qualquer modo, Stenes teve que se contentar com o primeiro.

- E o outro? perguntou Cidrolin.

- O outro o que?

- O outro cavalo.

- Estêvão? Ele não quis subir. Estava com vertigem.

- Talvez esteja na hora de os senhores montarem guarda, disse Aalice.

- Mais um golinho de essência de funcho e nós corremos para lá, disse o duque conciliador.

- E o restaurante? perguntou Cidrolin.

- Assim assim, respondeu o duque. Eles servem só o suficiente pra alimentar um passarinho moribundo e no cardápio não há nenhum dos pratos de que eu gostava tanto dantes e outrora, patê de rouxinol ao açafrão, torta de castanhas na gordura de musaranho, cozido frio de urso com semente de girassol, tudo isso regado de álcool e sem caruncho.

O duque acabou seu copo, depois enunciou esta observação:

- O que me agrada na essência de funcho, é que não há nenhuma outra palavra com que rime. Com funcho.

- A menos que fique carunchado, disse Aalice.

- Assim não vale, replicou o duque.

- O senhor é também poeta? perguntou Cidrolin.

- Ah, fez o duque, acontece de eu compor uma musiquinha... Empoigne.

- Isso é novidade, disse

Depois de ter saído assim de seu mutismo respeitoso, ele foi valsar do outro lado do saguão derrubando copos. Enquanto ele se 
se ramasse en se frottant la partie de la tête comprise entre l'oreille et la nuque, le duc termine sa phrase à l'intention de Cidrolin :

- ... mais je suis surtout peintre. Comme vous.

Puis il s'écrie:

- Au fait, j'y pense: si, d'une façon ou d'une autre, nous empêchons le graffiteur de recommencer, qu'aurez-vous à peindre ensuite? Vous allez vous sentir tout stupide et inoccupé.

J'aviserai.

- J'aviserai, dit Cidrolin.

- Eh bien! puisque le sort en est jeté, andiamo, comme disait Timoleo Timolei. Empoigne, tu m'as coupé la parole, mais je te pardonne. Suis-moi et nous montrerons à monsieur Cidrolin ce dont nous sommes capables. Tchao! toujours comme disait Timoleo Timolei.

Ils sortent.

- Vous attendez? demande Lalix. dit Cidrolin.

- Ce serait plus convenable,

Lalix éteint sa cigarette, réunit les cartes en un paquet qu'elle enveloppe dans le tapis vert. Elle se lève et dit :

- Qu'est-ce que c'est au fond que ces gens-là ? Il dit :

Cidrolin hausse les épaules.

- Cela ne nous regarde pas.

Lalix dit :

- C'est pas une réponse ça.

Ou plutôt si, ça nous regarde.

Cidrolin dit:

- J'ai parfois l'impression de les avoir déjà vus en rêve.

- Ça n'arrange rien. impression.

- Oh, ce n'est qu'une

- Je n'insiste pas. Les rêves, recompunha esfregando a parte da cabeça compreendida entre a orelha e a nuca, o duque termina sua frase dirigida a Cidrolin:

- ... mas sou principalmente pintor. Como o senhor.

Depois ele exclama:

- De fato, eu penso: se, de uma maneira ou de outra, nós impedirmos o grafiteiro de recomeçar, o que o senhor terá para pintar depois? O senhor vai se sentir totalmente estúpido e desocupado.

- Eu providenciarei, disse Cidrolin. Eu providenciarei.

- Bom! já que a sorte está lançada, andiamo, como dizia Timoleu Timolei. Empoigne, você me cortou a palavra, mas eu o perdôo. Siga-me e nós mostraremos ao senhor Cidrolin do que somos capazes. Tchao! ainda como dizia Timoleu Timolei.

Eles saem.

- O senhor vai esperá-los? pergunta Aalice.

- Seria mais conveniente, diz Cidrolin.

Aalice apaga seu cigarro, reúne as cartas em um maço que ela envolve no pano verde. Ela levanta-se e diz:

- No fundo o que é que é essa gente?

Cidrolin ergue os ombros. Ele diz:

- Não é da nossa conta.

Aalice diz:

- Isso não é resposta. Ou melhor sim, é da nossa conta.

Cidrolin diz:

- Às vezes tenho a impressão de já tê-los visto em sonho.

- Isso não resolve nada.

- Oh, é apenas uma impressão.

- Eu não vou insistir. Os 
moi...

Sur le pas de la porte, Lalix dit :

- Alors, vous restez là à les attendre ?

- Faut bien, répond Cidrolin.

Lalix est sortie.

Cidrolin étale de nouveau le tapis vert et prend le paquet de cartes. Il commence une réussite.

Lalix réapparaît.

- Et les chevaux ? dit elle. chevaux...

- Eh bien quoi, les

- Elles sont drôles, leurs histoires de chevaux.

- Encore plus drôles que vous ne pensez, Lalix. Un des deux chevaux parle. Je l'ai entendu.

raconte ?

- Et qu'est-ce qu'il

- Il a commencé par jurer, mais je ne me suis pas attardé pour l'écouter.

- Et ce n'était pas en rêve ?

- Oh, en rêve, les chevaux qui parlent, c'est tout à fait courant.

Lalix se rassoit. Elle dit :

- Je reste encore avec vous.

Elle prend les cartes et demande :

- On joue?

- C'est une bonne idée, dit Cidrolin calmement. Et ils jouèrent jusqu'à l'aube. sonhos, pra mim...

Na soleira da porta, Aalice diz:

- Então, o senhor vai ficar aí esperando?

Cidrolin.

- É preciso, responde

Aalice saiu.

Cidrolin estende de novo o pano verde e pega o maço de cartas. Ele começa uma paciência. Aalice reaparece.

- E os cavalos? diz ela.

- O que tem, os cavalos...

- São estranhas suas histórias de cavalos.

- Ainda mais estranhas do que a senhorita pensa, Aalice. Um dos cavalos fala. Eu ouvi.

- E o que ele conta?

- Ele começou por xingar, mas não parei para escutar.

- E não foi em sonho?

- Ora, em sonho, cavalos que falam, é completamente normal.

Aalice senta-se novamente. Ela diz:

- Vou ficar com o senhor. pergunta:

Ela pega as cartas e

- Vamos brincar?

- É uma boa idéia, diz Cidrolin calmamente. E eles brincaram até o amanhecer. 
XIX à gueuler.

À l'aube, dehors, ça se mit Lalix.

- Ils ont piqué le type, dit

Cidrolin ne dit rien.

Les gueulements se multiplièrent, auxquels s'adjoignirent insultes, injures et jurements probables.

- Y a du pétard au casino, dit Lalix.

Le chabanais se rapprocha ; finalement, la porte s'ouvrit. Un homme fut projeté sur la table, la débarrassant des cartes, tapis, verres, bouteille, cendrier. Le duc et Empoigne, cela fait, fermèrent soigneusement la lourde derrière eux. L'homme reprit son équilibre, mais s'assit aussitôt, y étant contraint et forcé par ses deux piégeurs.

- Et voilà, dit le duc avec satisfaction. On a bien travaillé.

- Je proteste, gueula l'homme piégé. C'est du rapt! de l'adulte-nappingne! À la rescousse! à l'aide! Il y a méprise ! atroce méprise. Je voulais surprendre ceux qui salissent votre clôture et ce sont ces individus qui me tombent dessus ! Ce sont peutêtre eux les coupables !

- Oh le vilain calomniateur! s'écria le duc et il lui fiche une beigne.

- Alerte! Infamie ! Récidive! Incorrection majeure!

[250] Écoutez-moi, monsieur, vous qui me connaissez...

Cidrolin dit au duc et à son lad-vicomte-acolyte :

- Asseyez-vous, je vous prie, nous allons écouter les explications de monsieur que je connais en effet.

Il s'adresse ensuite au concierge ex-gardien du camp de

\section{XIX}

Ao amanhecer, do lado de fora, começou uma gritaria.

- Eles pegaram o sujeito, disse Aalice.

Cidrolin não disse nada.

Os gritos se multiplicaram, aos quais se juntaram insultos, injúrias e prováveis blasfêmias.

- Tem um auê lá fora, disse Aalice.

O tumulto aproximou-se; finalmente, a porta abriu-se. Um homem foi projetado sobre a mesa, desembaraçando-a das cartas, pano verde, copos, garrafa, cinzeiro. Feito isso, o duque e Empoigne, fecharam cuidadosamente a porta atrás de si. $\mathrm{O}$ homem retomou o equilíbrio, mas sentou-se em seguida, seguro e forçado por seus dois caçadores.

- Aqui está, disse o duque com satisfação. Trabalhamos bem.

- Protesto, berrou o homem caçado. Isso é rapto! é adultnaping! socorro! acudam! Há um engano! Um engano atroz. Eu queria surpreender quem suja sua cerca e são esses indivíduos me caem em cima! Talvez sejam eles os culpados!

- Ah o vil caluniador! exclamou o duque e lhe dá uma bofetada.

- Alerta! Infâmia! Recidiva! Falta grave! Escute-me, senhor, o senhor que me conhece.

Cidrolin diz ao duque e a seu cavalariço-visconde-acólito:

- Sentem-se, por favor, vamos escutar as explicações do senhor que de fato eu conheço.

Em seguida, ele dirige-se ao zelador ex-vigia do campo de 
campigne pour campeurs :

- Monsieur, je vous connais en effet de vue, mais j'ignore votre nom.

- Louis - Antoine - Benoît

- Albert - Léopold - Antoine Nestor - Charles - Émile La Balance.

- C'est bien long, dit

Cidrolin.

- Pourquoi deux fois Antoine? demanda le duc.

- Une fois pour mon père et une fois pour mon grand-père. Quant à la longueur, on abrège habituellement en La Balance Bis.

- Vous n'auriez pas encore plus court? demande Cidrolin.

communément Labal.

m'appelle

- Eh bien, monsieur Labal, commença Cidrolin.

- Laissez tomber le Labal, ça fera plus court encore.

- Eh bien, monsieur...

- De quel droit m'interrogez-vous, monsieur Cidrolin ?

- Foutez-lui une beigne, dit le duc à mi-voix.

- Je n'ai aucun droit, dit Cidrolin, et vous avez le droit de ne pas répondre.

- Il va en profiter, remarque le duc en coulisse.

- Bon, dit Labal. Dans ces conditions je vous conterai mon [251] histoire.

- Ah, ah, une histoire, dit le duc en aparté.

lumineuse.

- Elle sera courte et

Labal reprit son soufle, prit son élan et prononça ces mots :

- Le nom que je porte, messieurs, m'a voué à un sort singulier. La balance, vous ne l'ignorez pas, est le symbole de la câmpingue para campistas:

- Senhor, de fato eu o conheço de vista, mas não sei seu nome.

- Antônio - Bento - Alberto - Leopoldo - Antônio - Nestor Carlos - Augusto A Balança.

- É bem comprido, disse Cidrolin.

- Por que duas vezes Antônio? perguntou o duque.

- Uma vez por meu pai e uma vez por meu avô. Quanto ao comprimento, normalmente se abrevia como A Balança Bis.

- O senhor não teria um um pouco mais curto? pergunta Cidrolin.

- Normalmente me chamam de Abal.

- Bem, senhor Abal, começou Cidrolin.

- Deixe o Abal pra lá, vai ficar mais curto ainda.

- Bem, senhor...

- Com que direito o senhor me interroga, senhor Cidrolin?

- Dê-lhe uma bofetada, disse o duque a meia voz.

- Não tenho nenhum direito, disse Cidrolin, e o senhor tem o direito de não responder.

- Ele vai se aproveitar disso, observa o duque para si mesmo.

- Bom, disse Abal. Nessas condições vou contar-lhes minha história.

- Ah, ah, uma história, disse o duque em off.

- Ela será curta e luminosa.

Abal retomou o fôlego, tomou impulso e pronunciou estas palavras:

- O nome que carrego, senhores, me dotou de um destino singular. A balança, os senhores não ignoram, é o símbolo da 
justice, et toute ma vie je me suis efforcé de la faire régner sur terre, dans la mesure de mes faibles forces bien entendu. Si la société m'a donné ce nom prédestinatoire, la nature m'a d'autre part pouvu d'une matière grise particulièrement active et, dès mon jeune âge, je me suis aperçu que la justice officielle n'était qu'un vain mot et je me promis de compenser par mes efforts personnels les défaillances des tribunaux réguliers. J'ai zigouillé comme ça trois à quatre cents personnes qui m'avaient paru insuffisamment châtiées ; si ce chiffre vous étonne, je dois vous avouer que je ne m'intéresse qu'aux cas graves et je ne connais qu'une seule rectification aux jugements erronés, la peine de mort. Rassurez-vous, je n'agis qu'après avoir longuement pensé au cas qui m'occupe. C'est là, messieurs, ce qui me différencie des juges ordinaires : je pense. Un lourd fardeau, messieurs, la pensée, un fardeau dont vous n'avez peutêtre pas à supporter la pesante présence, mais je ne m'attarderai pas sur ce sujet: je m'en suis entretenu l'autre soir avec monsieur Cidrolin. Quoi qu'il en soit, étant devenu pour des raisons qui ne vous regardent pas et qu'il serait trop long de vous expliquer, étant devenu, dis-je, gardien de nuit du camp de campeurs pour campigne, rentrant chez moi au petit jour, il m'arrivait de constater

[252] que l'on écrivait fréquemment des insultes sur la clôture d'un terrain devant la péniche à bord de laquelle vous êtes présentement, moi-même m'y trouvant bien contre ma volonté. La réitération du procédé me fit penser, et vous allez voir que lorsque je dis penser ce n'est pas là un vain mot que j'emploie, me fit penser, dis-je, que justiça, e toda a minha vida me esforcei para fazê-la reinar sobre a terra, na medida de minhas fracas forças bem entendido. $\mathrm{Se}$ a sociedade me deu esse nome predestinado, a natureza por outro lado me proveu de uma massa cinzenta particularmente ativa e, desde muito jovem, percebi que a justiça oficial não passava de uma palavra vã e prometi a mim mesmo compensar por esforços pessoais as falhas dos tribunais regulares. Assim, executei trezentas a quatrocentas pessoas que me pareceram insuficientemente castigadas; se os senhores se espantam com essa cifra, devo confessar que só me interesso pelos casos graves e que só conheço uma retificação para os julgamentos errados, a pena de morte. Fiquem tranquilos, eu só ajo depois de ter pensado longamente no caso que me ocupa. É isso, senhores, o que me diferencia dos juizes ordinários: eu penso. Um fardo pesado, senhores, o pensamento, um fardo cuja pesada presença talvez os senhores não tenham que suportar, mas não vou me alongar nesse assunto: já falei disso outra noite com o senhor Cidrolin. Seja como for, tendo-me tornado por razões que não lhes interessam e que seria muito demorado explicar, tendo-me tornado, dizia eu, vigia noturno do campo de campistas para câmpingue, ao voltar para casa de manhãzinha, me acontecia de constatar que frequentemente escreviam insultos na cerca de um terreno diante da chata a bordo da qual os senhores estão no momento, e onde me encontro eu mesmo muito contra minha vontade. A reiteração do procedimento me fez pensar, e os senhores vão ver que quando digo pensar não é uma palavra vã que 
l'auteur de ces inscriptions était peut-être un justicier dans mon genre et pour dire un concurrent. Cela me déplut. Si tout le monde se mettait à rendre la justice à sa façon, on n'en sortirait pas ; moi seul suis qualifié. Je me livrai donc à une petite enquête et appris vos déboires, monsieur Cidrolin, et l'injustice grave dont vous fûtes victime. Un innocent subissant deux années de préventive! La persécution dont vous étiez victime m'en parut d'autant plus amère. Voulant démasquer le salopard qui vous poursuivait de sa vindicte injustifiée, je me fis engager comme concierge dans l'immeuble que l'on a construit de l'autre côté du quai. Je fais le guet chaque nuit, mais n'avais rien découvert. Tout à l'heure, j'aperçus deux silhouettes, suspectes. Ils étaient deux, je n'étais qu'un. Je me rendis cependant avec courage sur les lieux de leurs agissements sans doute délictueux. Ce fut le premier échec de ma carrière, puisque me voici entre vos mains. Quant à mon innocence, pour ce qui est des graffiti, elle me paraît amplement prouvée par le fait que je ne suis ni n'étais porteur d'un quelconque moyen d'écriture, de peinture ou de gravure.

Il se tut et l'on entendit alors le calme ronflement du duc d'Auge qui, dès le début de ce pallas, s'était endormi.

Cidrolin se gratta la tête. Il vit qu'Empoigne, lui, ne faisait que

[253] somnoler et lui demanda s'il était vrai que leur capture n'était porteur d'aucun instrument d'écriture, de peinture ou de gravure.

Empoigne, ouvrant à peine les yeux, répondit :

- L'homme a dit vrai. estou usando, me fez pensar, dizia eu, que o autor dessas inscrições era talvez um justiceiro do meu tipo e por assim dizer um concorrente. Isso não me agradou. Se todo o mundo se pusesse a fazer justiça a sua maneira, isso não teria fim; só eu sou qualificado. Dediquei-me então a uma pequena investigação e soube de seus infortúnios, senhor Cidrolin, e da grave injustiça de que o senhor foi vítima. Um inocente passando dois anos na preventiva! A perseguição de que o senhor era vítima me pareceu ainda mais amarga. Querendo desmascarar o covarde que o perseguia com sua vindita injustificada, eu me empreguei como zelador no prédio que construíram do outro lado do cais. Fico de sentinela toda noite, mas não tinha descoberto nada. Há pouco, percebi duas silhuetas, suspeitas. Eram dois, eu era só um. Dirigi-me no entanto com coragem ao lugar de seus atos provavelmente delituosos. Foi o primeiro fracasso de minha carreira, já que estou aqui em suas mãos. Quanto a minha inocência, no que se refere aos graffiti, ela me parece amplamente provada pelo fato de que não sou nem era portador de nenhum meio de escrita, de pintura ou de gravura.

Ele calou-se e ouviu-se então o calmo ronco do duque de Auge que, desde o início desse palavrório, tinha adormecido.

Cidrolin coçou a cabeça. Ele viu que Empoigne também estava cochilando e perguntou-lhe se era verdade que seu prisioneiro não era portador de nenhum instrumento de escrita, de pintura ou de gravura.

Empoigne, mal abrindo os olhos, respondeu:

- O homem disse a verdade. 

innocent, conclut Cidrolin.

- C'est vite dit.

- Mademoiselle n'est pas

d'accord? demanda Labal insolemment.

- Non, répondit Lalix. Tout ce que vous avez raconté prouve par a plus b que c'est vous le justicier à la con, le judex à la manque, le monte-cristo de papa, le zorro de grand-mère, le robin des bois pourris, le rancunier gribouilleur, l'insulteur des murailles, le maniaque du barbouillage, enfin quoi l'emmerdeur patenté anticidrolinique.

- Mademoiselle, dit Labal avec calme, permettez-moi de vous dire que vous raisonnez comme un manche, ne voyez pas plus loin que le bout de votre nez et utilisez de travers votre matière grise. Réfléchissez un instant; je ne me servirai pas du mot penser qui vous effraierait peut-être, je vous demande seulement de réfléchir. Pas comme un miroir, bien entendu, ce qui serait des plus superficiel bien que je n'ignore pas que les jeunes demoiselles sont plus habituées à...

- Tu le laisses continuer? dit Lalix à Cidrolin. À ta place, je lui casserais la gueule. Si le duc ne dormait pas, il aurait fait taire ce con depuis longtemps.

- Mais il dort, dit Labal. Je reprends : réfléchissez, mademoiselle. Vous aurais-je raconté ma vie, exemplaire d'ailleurs, si j'étais le responsable de cette persécution? C'est absurde! Persuadez-vous bien, [254] mademoiselle, que je suis cidrolinophile cent pour cent.

Lalix ne répond pas.

- Monsieur Labal, dit
- Então o acusado é inocente, concluiu Cidrolin.

- Está indo depressa demais.

- A senhorita não concorda? perguntou Abal insolentemente.

- Não, respondeu Aalice. Tudo o que o senhor contou prova por a mais $b$ que o senhor é um justiceiro ridículo, um judas imbecil, um montecristo do papai, um zorro da vovó, um robin dos bosques podres, um rancoroso rabiscador, um insultante das muralhas, um maníaco dos garranchos, enfim um pentelho patenteado anticidrolínico.

- Senhorita, disse Abal com calma, permita-me dizer-lhe que a senhorita raciocina como um jegue, não enxerga um palmo diante do nariz e utiliza muito mal sua massa cinzenta. Reflita um instante; eu não me serviria da palavra pensar que talvez a amedrontasse. Peço somente para refletir. Não como um espelho, bem entendido, o que seria muito superficial embora eu não ignore que as mocinhas são mais habituadas a...

- Você o deixa continuar? diz Aalice a Cidrolin. Em seu lugar, eu lhe quebraria a cara. Se o duque não estivesse dormindo, ele teria feito esse babaca calar há muito tempo.

- Mas ele está dormindo, diz Abal. Eu continuo: reflita, senhorita. Eu lhes teria contado minha vida, por sinal exemplar, se eu fosse o responsável por essa perseguição? É absurdo! Convença-se, senhorita, de que sou cem por cento cidrolinófilo.

Aalice não responde.

- Senhor Abal, diz Cidrolin, 
Cidrolin, vous voulez bien excuser mes hôtes ; ils ont cru bien faire.

- Je serai superbe et généreux, dit Labal. Je passe l'éponge.

- C'est ce qu'on verra, dit Lalix.

- Salut, dit la comtesse en entrant dans le carré.

- Bê, bê, dit Phélise.

- Vous permettez que je me retire? dit Labal.

Il s'esquive.

- Le petit déjeuner n'est pas prêt ? demande la maman d'Empoigne.

Elle demande ça d'ailleurs d'une façon très aimable. Lalix n'a pas de quoi se vexer. L'autre ajoute :

- Qui était ce monsieur? Celui qu' on voulait attraper? Cidrolin.

- Il y avait erreur, dit

La comtesse s'abstint de tout commentaire pour ne pas troubler le sommeil de son fils qui s'était à son tour endormi ; mais tous eurent l'œil grand ouvert lorsque l'odeur des andouillettes grillées apportées par Lalix pénètre dans leurs narines.

- Agréable réveil, s'écria le duc. Succulente apparition! Noble récompense pour les chevaliers que nous sommes ! Et notre coquin? où donc est-il? Je crois comprendre, monsieur Cidrolin, que, malgré vos bonnes paroles, vous l'avez flanqué dans le fleuve lesté de quelques lingots de plomb.

- Non, dit Cidrolin. Je l'ai laissé partir.

- On m'y reprendra, dit le duc indigné, à commettre une bonne action!

- Elle était mauvaise, dit Cidrolin avec calme. Cet homme n'avait rien à voir avec les queira desculpar meus hóspedes; eles pensavam agir corretamente.

- Serei soberbo e generoso, diz Abal. Eu passo a borracha.

- É o que veremos, diz Aalice.

- Olá, diz a condessa entrando no saguão.

- Bé, bé, diz Feliza.

- Você permite que eu me retire? diz Abal.

Ele se esquiva.

- O café da manhã não está pronto? pergunta a mamãe de Empoigne.

Aliás, ela faz essa pergunta de uma maneira muito amável. Aalice não tem do que se vexar. A outra acrescenta:

- Quem era esse senhor? O que queriam pegar?

Cidrolin.

- Houve um engano, diz

A condessa se absteve de qualquer comentário para não perturbar o sono de seu filho que por sua vez também dormia; mas todos ficaram de olhos bem abertos quando o odor das salsichinhas grelhadas trazidas por Aalice penetra suas narinas.

- Agradável despertar, exclamou o duque. Suculenta aparição! Nobre recompensa para os cavaleiros que somos! E o nosso canalha? onde está ele? Penso compreender, senhor Cidrolin, que, apesar de suas boas palavras, o senhor jogou-o no rio lastreado com alguns lingotes de chumbo.

- Não, disse Cidrolin. Eu o deixei partir.

- Nunca mais me pegam cometendo uma boa ação, disse o duque indignado.

- Ela era má, disse Cidrolin com calma. Aquele homem não tinha nada a ver com as inscrições 
inscriptions injurieuses. dit Lalix.

- Cidrolin s'est laissé avoir,

- Je n'en doute pas, dit le duc, et puis, après tout, je m'en moque. Je vous laisse à votre peinture, monsieur! Je vous laisse à votre peinture !

Cependant Cidrolin n'eut pas à repeindre la clôture de toute la journée et, comme la veille, de toute la journée il ne vit pas ses hôtes. Ils ne rentrèrent qu'après dîner. Cidrolin jouait aux cartes avec Lalix. Lalix fumait en jouant aux cartes.

Le duc et Empoigne s'assirent à côté d'eux et se servirent de l'essence de fenouil. La comtesse et Phélise étaient allées directement à leur cabine.

- Tout s'est bien passé ? demanda Cidrolin poliment.

- Et vous-même? demanda le duc avec entrain. La barbouille ?

- Aujourd-hui, néant.

- Eh bien, nous, nous avons donné dans l'architecture. Pour faire plaisir à sa maman (geste), nous visitâmes tous les terriers à curés de la capitale; et cela ne manque pas.

- Seriez-vous anticlérical, monsieur le duc? demanda Cidrolin.

- Véhémentement! Mais ne me donnez donc pas du monsieur le duc. Maintenant que nous nous connaissons, appelez-moi tout simplement Joachim.

Et pourquoi vous appellerais-je Joachim? prénom.

- Parce que c'est mon

- C'est aussi le mien, dit Cidrolin. Je ne me vois pas m'appelant sous les espèces d'un autre ! injuriosas.

- Cidrolin se deixou enganar, disse Aalice.

- Não tenho dúvida, disse o duque, e depois, estou pouco ligando. $\mathrm{Eu}$ o deixo com sua pintura, senhor! Eu o deixo com sua pintura!

Entretanto Cidrolin não teve que pintar a cerca o dia inteiro e, como na véspera, o dia inteiro ele não viu seus hóspedes. Eles só voltaram depois do jantar. Cidrolin jogava cartas com Aalice. Aalice fumava enquanto jogava cartas.

$\mathrm{O}$ duque e Empoigne sentaram-se ao lado deles e se serviram de essência de funcho. A condessa e Feliza foram diretamente para sua cabina.

- Foi tudo bem? perguntou Cidrolin polidamente.

- E com o senhor? perguntou o duque com vivacidade. Os garranchos?

- Hoje, nada.

- Bem, nós nos dedicamos à arquitetura. Para agradar a mamãe dele (gesto), nós visitamos todas as tocas de curas da capital; e não são poucas.

- O senhor seria anticlerical, senhor duque? perguntou Cidrolin.

- Veementemente! Mas não me chame de senhor duque. Agora que nós nos conhecemos, me chame simplesmente de Joaquim?

- E por que eu o chamaria de Joaquim?

- Porque é o meu nome.

- É também o meu, disse Cidrolin. Eu não me vejo me chamando sob a forma de um outro!

- Forma de outro é o senhor, 
même, répliqua le duc avec bonhomie. Puisque nous sommes tous deux des Joachim, appelezmoi donc Olinde, c'est mon second prénom.

- À moi aussi.

- J'en ai cinq autres : Anastase Cré...

- ...pínien Hon...

- ...orat Irénée Mé...

- ...déric.

- Dans ce cas, s'écria le duc d'une humeur particulièrement excellente, revenons à notre point de départ ; appelez-moi Jo et moi je vous appellerai Cid. dit Cidrolin.

- J'aimerais mieux Cidrolin,

- Cidrolin soit, puisque Cidrolin voulez, mais alors je te tutoie.

d'inconvénients.

$$
\text { - Je n'y vois pas }
$$

- Et tu me tutoies, ajouta le duc en s'envoyant une grande lampée d'essence de fenouil.

- C'est ça, je vous tutoie.

- Eh bien, Cidrolin, reprit le duc sur un ton de voix très élevé, tummplupeu ce matin lorsque l'aube tomba sur l'évasion de notre captif. C'était bien la peine, me disais-je, que je me gèle le train arrière durante toute une nuit pour rendre service à mon hôte et que ledit hôte se conduise ensuite comme une sensitive vergogneuse et perplexe; mais comme me l'a fait remarquer Sthène, après tout, tu connais la question mieux que moi et tu dois avoir de bonnes raisons pour relâcher ce personnage, dont la tête continue à ne pas me revenir. Si j'étais à ta place, je n'aimerais pas l'avoir dans mon voisinage. Là-dessus bonsoir.

Sur cette brusque replicou o duque com bom humor. Já que nós dois somos Joaquim, me chame então de Olindo, é o meu segundo nome.

- Meu também.

- Tenho mais cinco:

Anastácio Qui...

- ... rino. Um...

- ...berto, Irineu, Me...

- ... derico.

- Nesse caso, exclamou o duque com um humor particularmente excelente, voltemos a nosso ponto de partida; me chame de Jo e eu vou chamá-lo de Cid.

- Eu preferiria Cidrolin, diz Cidrolin.

- Cidrolin seja, já que Cidrolin quer, mas então vou chamá-lo de você.

- Não vejo inconvenientes.

- E você também me chama de você, acrescentou o duque tomando um grande gole de essência de funcho.

- Está bem, vou chamá-lo de você.

- Bem, Cidrolin, retomou o duque num tom de voz muito elevado, cê num mi agradô essa manhã quando a alvorada iluminou a evasão de nosso prisioneiro. Valeu a pena, me dizia eu, ter-me gelado o traseiro durante a noite inteira para prestar serviço a meu anfitrião e o dito anfitrião portar-se em seguida como uma sensitiva vergonhosa e perplexa; mas como Stenes me fez observar, apesar de tudo, você conhece a questão melhor que eu e deve ter boas razões para libertar essa personagem, cuja cara não consigo engolir. Se eu estivesse em seu lugar, não gostaria de tê-lo na vizinhança. Sendo assim, boa noite. Com essa brusca conclusão, 
conclusion, il se leva, ce que fit également Empoigne; mais Lalix intervint :

- Qui est ce monsieur Sthène qui vous fait cette remarque à son sujet? (geste en direction de Cidrolin).

- Ce n'est pas un monsieur, c'est un cheval, répondit Joachim.

- Et il fait des remarques ?

- A ce propos, continua Joachim sans tenir compte de cette question, j'ai fait, moi aussi, une remarque. J'ai découvert qu'avec leur tiercé, les Français étaient devenus alchimistes.

Ni Lalix, ni Cidrolin ne bronchèrent ; encore moins Empoigne.

- Oui, conclut le duc, ils espèrent tous faire de l'or avec des chevaus. Cette fois-ci, bonsoir ! aussitôt.

Il disparut, puis réapparut

- Ma réflexion vous a paru sans doute singulière. Je reconnais en effet qu'elle venait comme des chevaus sur la soupe.

Il disparut de nouveau et l'on entendit son rire s'éloigner puis s'éteindre.

- Restez donc encore un peu avec nous, dit Lalix à Empoigne qui avait tardé à disparaître également.

- Je ne peux. Je dois aider le duc à retirer ses bottes.

- Il ne porte pas de bottes.

- Il porte des bottes morales. des bottes?

- Vos chevaux portent aussi

- Morales ? Certainement.

Un long glapissement se fit entendre.

- Vous l'entendez? dit Empoigne. Il va me gronder.

Il s'empressa de disparaître. ele levantou-se, o que fez também Empoigne; mas Aalice interveio:

- Quem é esse senhor Stenes que lhe fez essa observação a propósito dele? (gesto na direção de Cidrolin).

- Não é um senhor, é um cavallo, respondeu Joaquim.

- E ele faz observações?

- A propósito disso, continuou Joaquim sem levar em conta essa pergunta, também fiz uma observação. Descobri que com suas corridas de cavallos, os franceses tornaram-se alquimistas.

Nem Aalice, nem Cidrolin entenderam; Empoigne menos ainda.

- Sim, concluiu o duque, todos eles esperam fazer ouro com os cavallos. Desta vez, boa noite!

Ele desapareceu, logo depois reapareceu.

$$
\begin{aligned}
& - \text { Minha reflexão } \\
& \text { provavelmente lhes pareceu } \\
& \text { singular. Reconheço que ela veio } \\
& \text { realmente como um caballo na } \\
& \text { sopa. }
\end{aligned}
$$

Ele desapareceu de novo e ouviram seu riso afastar-se e depois apagar-se.

- Fique um pouco mais conosco, diz Aalice a Empoigne que demorou a desaparecer também.

- Não posso. Tenho que ajudar o duque a retirar as botas.

- Ele não usa botas.

- Ele usa botas morais.

- Seus cavalos também

usam botas?

- Morais? Certamente. Um longo ganido

fez-se ouvir.

- Estão ouvindo? disse Empoigne. Vou levar uma bronca. Ele apressou-se em desaparecer.

- Sendo assim, disse Aalice, 
aussi je vais aller retirer mes bottes morales.

- Je reste encore un peu, dit Cidrolin.

Seul, il fait une réussite. Puis il éteint.

Pendant des minutes d'affilée, on n'entend plus que les houatures noctambules chapechuter sur le boulevard.

Puis il y a des clameurs, des cris, des jurements peut-être. La porte du carré s'ouvre, la lumière se fait. Labal projette dans la pièce l'homme qu'il vient de surprendre en train de couvrir la clôture d'outrageants graffiti. L'homme s'assoit, reprend sa respiration, se sert un verre d'essence de fenouil. Lalix accourt, elle s'est levée, elle a mis une robe de chambre. Les autres passagers de la péniche, eux, dorment profondément. Ils dorment toujours profondément depuis qu'ils ne rêvent plus ou guère.

Lalix accourue voit Cidrolin qui se sert un verre d'essence de fenouil. Labal s'est assis, il a l'air tout grave et ne dit rien. poser.

Lalix ne sait quelle question

Cidrolin boit son verre d'essence de fenouil; il dit au concierge :

- J'espère que vous n'avez pas attrapé froid en m'attendant. Vous avez droit à un verre d'essence de fenouil.

Il dit à Lalix en souriant faiblement :

- Monsieur est un fin limier.

Lalix s'assoit.

- Ce que je me demande, dit Labal, c'est ce que vous allez faire maintenant. Je sais bien que cela ne me regarde pas, mais, puisque j'ai une responsabilité majeure dans les événements récents, vous comprendrez que je puisse me [259] poser une telle question et même também vou retirar minhas botas morais.

- Eu vou ficar mais um pouco, disse Cidrolin.

Sozinho, ele joga uma paciência. Depois apaga a luz. Durante uns minutos consecutivos, só se ouvem os zotomóvis noctâmbulos passar chiando no bulevar.

Depois surgem clamores, gritos, talvez blasfêmias. A porta do saguão se abre, faz-se a luz. Abal projeta no aposento o homem que acaba de surpreender cobrindo a cerca com graffiti ultrajantes. O homem senta-se, retoma o fôlego, serve-se de um copo de essência de funcho. Aalice acorre, ela levantouse, ela pôs um roupão. Os outros passageiros da chata dormem profundamente. Eles sempre dormem profundamente desde que não sonham mais ou quase.

Aalice acorrida vê Cidrolin se servindo de um copo de essência de funcho. Abal sentou-se, ele tem um ar muito grave e não diz nada.

Aalice não sabe que pergunta fazer.

Cidrolin bebe seu copo de essência de funcho; ele diz ao zelador:

- Espero que o senhor não tenha pego um resfriado me esperando. $\mathrm{O}$ senhor tem direito a um copo de essência de funcho.

Ele diz a Aalice sorrindo fracamente.

- Esse senhor é um Sherlok.

Aalice senta-se.

- O que me pergunto, diz Abal, é o que o senhor vai fazer agora. Sei que não tenho nada com isso, mas, já que tenho uma responsabilidade maior nos acontecimentos recentes, o senhor vai entender que eu possa me fazer tal pergunta e até mesmo lhe fazer 
vous la poser également.

Comme Cidrolin ne répond pas, Labal continua :

- Après tout, vous pourriez

continuer comme par le passé.

Il ajoute :

- Je ne vous aurai pas à l'œil, allez. Maintenant que ma mission est accomplie, je vais donner ma démission de concierge et je quitterai le quartier pour de nouvelles aventures.

Il se tourne vers Lalix et conclut :

- Je ne veux aucun mal à monsieur Cidrolin, mais après le petit incident d'hier, il était naturel que j'aie cherché à faire reconnaître mon innocence pleine et entière. Monsieur Cidrolin peut encore s'estimer heureux que je ne l'ai pas zigouillé pour s'être ainsi moqué du monde et de moi-même. Merci pour l'essence de fenouil, je n'en bois jamais. Vous permettez maintenant que je me tire?

- On vous y invite même, dit Lalix.

Il sort en fermant soigneusement la porte du carré derrière lui.

- Je vais me recoucher, dit Lalix.

- C'est ça, dit Cidrolin. Bonne fin de nuit.

Lalix sort en fermant soigneusement la porte du carré derrière elle. Lorsque, au petit jour, le duc vient voir si, par hasard, le petit déjeuner ne serait pas en train de se préparer, il trouve Cidrolin, assis, qui somnole devant son verre.

- Holà ! cria le duc. Déjà levé ou pas couché ? La fiancée dort encore ? Y a-t-il toujours de l'andouillette dans le frigidaire ? Le temps est à la pluie.

Empoigne apparaît. igualmente essa pergunta.

Como Cidrolin não

responde, Abal continuou:

- Afinal, o senhor poderia

continuar como no passado.

Ele acrescenta:

- Não vou ficar de olho. Agora que minha missão está cumprida, vou pedir demissão do cargo de zelador e deixarei o bairro em busca de novas aventuras. conclui:

Ele vira-se para Aalice e

- Não quero mal ao senhor Cidrolin, mas depois do pequeno incidente de ontem, era natural que eu tenha procurado fazer reconhecer minha inocência geral e irrestrita. O senhor Cidrolin pode ainda se dar por feliz que eu não o tenha executado por ter zombado assim de todo o mundo e de mim mesmo. Obrigado pela essência de funcho, nunca bebo isso. Os senhores me permitem que me retire agora?

- Nós o convidamos a fazêlo, diz Aalice.

Ele sai fechando cuidadosamente a porta do saguão atrás de si.

- Vou voltar para a cama, diz Aalice.

- Está bem, diz Cidrolin. Bom fim de noite.

Aalice sai fechando cuidadosamente a porta do saguão atrás de si. Quando, de manhãzinha, o duque vem ver se, por acaso, o café da manhã não estaria sendo preparado, encontra Cidrolin, sentado, cochilando diante do copo.

- Olá! gritou o duque. Já em pé ou ainda não deitado? A noiva ainda está dormindo? Ainda tem salsichinha na geladeira? O tempo está para chuva.

Empoigne aparece. 
- Prépare donc le petit déjeuner, lui dit le duc. J'ai [260] grand'faim.

- Et les chevaus, monsieur le duc ?

- C'est vrai.

Empoigne va s'occuper des chevaux. Le duc s'assoit en face de Cidrolin.

- Il faut donc que j'attende le lever de la fiancée. Que vais-je absorber d'ici là ? Pas de l'essence de fenouil tout de même. À cette heure-ci. D'autant plus que je ne la trouve pas fameuse, bien que ce soit du Cheval Blanc. Elle ne vaut pas celle que je prépare selon la recette de mon alchimiste, Timoleo Timolei. Encore un rapport entre cheval et alchimie. La chevalchimie. Est-ce un bon mot ? Je me le demande. J'avais accoutumé d'en faire de meilleurs naguère... jadis... autrefois...

Il bâilla.

- Tudieu, Cid! tu n'es pas bavard ce matin!

- J'ai une nouvelle à vous apprendre.

- On ne se tutoie plus?

- à t'apprendre.

- J'écoute.

- Le concierge d'en face a mis la main sur le type qui maculait la clôture.

- Sur le vrai ?

- Sur le vrai.

Le duc rit très fort et longtemps avant de dire :

- Alors, il t'a pincé ?

- Eh oui.

- Quelle importance!

- Cela pourrait bien en

avoir.

- Il ne t'empêchera tout de même pas de peindre et repeindre si cela te chante.

- Ce n'est pas lui qui me donne souci.
- Prepare nosso café da manhã, disse-lhe o duque. Estou com muita fome.

- E os cavallos, senhor duque?

- É mesmo.

Empoigne vai cuidar dos cavalos. O duque senta-se diante de Cidrolin.

- Vou ter que esperar o despertar da noiva. O que vou absorver até lá? Essência de funcho não, de jeito nenhum. Não a esta hora. Ainda mais que não a acho tão boa assim, apesar de ser Cavalo Branco. Ela não chega aos pés da que preparo segundo a receita de meu alquimista, Timoleu Timolei. Mais uma relação entre cavalo e alquimia. A cavalquimia. É um bom trocadilho? Eu me pergunto. $\mathrm{Eu}$ costumava fazer melhores outrora... dantes... antigamente...

Ele bocejou.

- Por Deus, Cid! você não está nada falante esta manhã!

- Tenho uma novidade para contar ao senhor. de você?

- Não nos chamamos mais

- ... para contar a você.

- Estou ouvindo.

- O zelador da frente pôs as mãos no sujeito que maculava a cerca.

- No verdadeiro?

- No verdadeiro.

$\mathrm{O}$ duque ri muito alto e por muito tempo antes de dizer:

- Então ele pegou você?

- Sim.

- Não tem importância!

- Poderia ter.

- De qualquer forma, ele não vai impedi-lo de pintar e repintar se isso lhe agrada.

- Não é ele que me preocupa. 
- Elle ne se lève donc pas, ce matin, dit le duc.

[261]

- Je ne sais pas, dit Cidrolin.

- Puisque c'est comme ça, dit le duc, je vais promener les chevaus et nous irons prendre le petit déjeuner en ville. À la Sirène Torte par exemple. Tu diras aux deux mouquères de nous $y$ rejoindre.

Je n'y manquerai pas, dit Cidrolin.

Le duc sortit en claquant distraitement la porte du carré derrière lui.
- Então ela não vai se levantar, essa manhã, disse o duque.

- Não sei, disse Cidrolin.

- Já que é assim, disse o duque, vou levar os cavallos passear e vamos tomar o café da manhã na cidade. No Sereia Torta por exemplo. Diga às duas mulheres para nos encontrarem lá.

- Direi sem falta, disse Cidrolin.

O duque saiu batendo distraidamente a porta do saguão atrás de si. 
Cidrolin fit un peu le ménage dans le carré, puis il sortit [262] sur le pont. La comtesse et Phélise rappliquaient pour consommer de l'andouillette ; conformément aux instructions du duc, elles furent invitées à se diriger vers la Sirène Torte, et donc obtempérèrent. Elles étaient déjà parties depuis seize minutes, lorsque apparut Lalix. Elle tenait sa valise à la main.

- Adieu, dit-elle.

Elle posa sa valise et tendit la main à Cidrolin.

Celui-ci dut en conclure qu'elle s'en allait, puis éprouver le besoin d'exprimer cette découverte, car il dit :

- Vous partez?

- Comme vous voyez.

- Vous avez des raisons sérieuses pour partir?

- Je n'aime pas les tordus.

- Pour qui dites-vous ça ?

- Je m'étais attachée à vous. Je croyais qu'on vous persécutait.

Elle se mit à pleurer.

- Là, là, dit Cidrolin. Vous m'en voulez?

- Voui, répondit-elle en reniflant. Vous vous êtes moqué de [263] moi.

- Je ne me suis moqué de personne. Simplement je m'étais trouvé une occupation. Une distraction dans la vie sans plus.

- Faut être timbré pour faire des choses pareilles.

- Cela valait bien mieux que d'aller au bistro.

- Et puis vous buvez trop.

- Suis-je jamais ivre?

- Vous devez être imbibé
Cidrolin deu uma arrumadinha no saguão, depois saiu para o convés. A condessa e Feliza acorriam para consumir salsichinhas; de acordo com as instruções do duque, elas foram convidadas a se dirigirem à Sereia Torta, e então obtemperaram. Elas já tinham partido havia dezesseis minutos, quando apareceu Aalice. Ela segurava uma valise na mão. - Adeus, disse ela.

Ela pousou a valise e estendeu a mão a Cidrolin.

Este teve que concluir que ela ia embora, depois sentir a necessidade de exprimir essa descoberta, pois disse:

- A senhorita está partindo?

vendo.

- Como o senhor está

- A senhorita tem sérias razões para partir?

- Não gosto de desajustados. falando?

- De quem a senhorita está

- Eu tinha me ligado ao senhor. Pensava que o senhor estava sendo perseguido.

Ela se pôs a chorar.

- Tá, tá, disse Cidrolin. A senhorita está zangada comigo?

- Shim, respondeu ela fungando. $\mathrm{O}$ senhor zombou de mim.

- Não zombei de ninguém. Simplesmente estava arranjando uma ocupação. Uma distração na vida só isso.

- Tem que sê doido pra fazê uma coisa dessas.

- Era melhor do que ir para o botequim.

- E, além disso, o senhor bebe demais.

- Alguma vez fico bêbado?

- O senhor deve estar 
d'essence de fenouil quand vous allez gribouiller vos trucs. S'insulter soi-même ! pourquoi pas montrer votre derrière pendant que vous y êtes?

- Ce n'est pas du tout mon genre, dit Cidrolin. Et puis là, je crois que vous confondez.

- Confondre quoi et quoi ? Vous allez pas vous mettre à discutailler.

Elle se mit de nouveau à pleurer.

- Là, là, dit Cidrolin. Je serai très malheureux si je vous ai fait de la peine.

- Il est bien temps de dire ça.

Elle tamponna l'humidité qui coulait sur ses joues, puis se moucha énergiquement.

- Je m'en vais, ajouta-t-elle.

Elle souleva sa valise.

- Qu'est-ce que vous allez faire? demanda Cidrolin. Retourner voir monsieur Albert? chercher du travail ? rentrer chez vous?

- Qu'est-ce que ça peut vous faire puisque je sors de votre vie !

Ce qu'elle venait de dire la fit tant sangloter qu'elle dut poser de nouveau sa valise.

- Puisque ça vous fait tant pleurer, dit Cidrolin, n'en sortez [264] pas.

- Si c'est tout ce que vous trouvez à me dire...

Elle ravala ses pleurs, reprit sa valise en main, dit adieu et partit d'un pas ferme. Cidrolin la regarda monter le talus, pousser le portillon de la clôture. Elle s'éloignait.

Au bistro du coin du pont, elle s'arrêta pour boire un café. À la terrasse, des couples faisaient la ventouse et se palpaient avant embebido de essência de funcho quando vai rabiscar suas baboseiras. Insultar a si mesmo! por que não mostrar seu traseiro enquanto está lá?

- Isso não faz o meu gênero, disse Cidrolin. E aí, acho que a senhorita está confundindo.

- Confundindo o que com o que? O senhor não vai se pôr a discutir.

Ela se pôs de novo a chorar.

- Tá, tá, disse Cidrolin. Ficarei muito infeliz se eu tiver lhe causado sofrimento.

- Já era tempo de dizer isso.

Ela enxugou a umidade que escorria no seu rosto, depois assoou o nariz energicamente.

- Vou-me embora, acrescentou ela.

Ela pegou a valise.

- O que é que a senhorita vai fazer? perguntou Cidrolin. Voltar a ver o senhor Alberto? procurar trabalho? voltar para casa?

- O que é que lhe interessa já que estou saindo de sua vida!

O que acabava de dizer a fez soluçar tanto que ela teve que pousar de novo a valise.

- Já que isso a faz chorar tanto, disse Cidrolin, não saia.

- Se isso é tudo o que o senhor tem para me dizer...

Ela engoliu suas lágrimas, retomou a valise nas mãos, disse adeus e partiu com passo decidido. Cidrolin olhou-a subir o barranco, empurrar o portão da cerca. Ela afastava-se.

No bar da esquina da ponte, ela parou para tomar um café. No terraço, casais se faziam de ventosa e apalpavam-se antes de ir para o 
d'aller à leur travail. Ce spectacle incita Lalix à laisser couler quelques nouvelles larmes qu'elle essuie discrètement. À l'intérieur, des alchimistes préparent leur tiercé, avec des pinces et des crayons. Parmi eux figurait le justicier. Lalix s'empressa de boire son café et de repartir.

À la gare où elle avait rencontré monsieur Albert, elle mit sa valise à la consigne et alla prendre un second café pour considérer un tantinet soit peu sa situation présente. Elle s'était assise à la terrasse d'une brasserie, une grande avec des tas de consommateurs et des tas de garçons et même plusieurs maîtres d'hôtel. Sur le trottoir passaient des tas de passants ; sur la chaussée, roulaient des tas de houatures. Il y avait un marchand de journaux qui criait bien fort, et il y avait une dame-alchimiste qui agitait une petite sonnette pour essayer de vendre des billets de loterie.

Lalix demeura là, stupide, hébétée, pendant une bonne heure, c'est-à-dire environ une heure quatre minutes ; puis, brusquement, la voilà qui paie, prend un bus, descend et pénètre dans le bar Biture, un bar qui se donne l'air de ressembler à tous les autres. Elle s'assoit. La salle est vide: ni clients, ni patron. Une trappe ouverte semble signifier que ce

[265] dernier s'occupe dans sa cave, mais à quoi ? Profitant de la solitude, Lalix pleure doucement.

Soudain apparaît au niveau $\mathrm{du}$ plancher une casquette micourte mi-longue en drap mœlleux à quadrillage noir et blanc. Lalix se tamponne les mirettes et le tarin d'un mouchoir déjà tout humide tandis que s'élève lentement audessus du sol le couvre-chef compendieusement sus-décrit. Une trabalho. Esse espetáculo incitou Aalice a deixar escorrer algumas novas lágrimas que ela enxuga discretamente. No interior, dois alquimistas preparam suas apostas para o páreo do dia, com pinças e lápis. Entre eles estava o justiceiro. Aalice apressou-se em tomar seu café e partir.

$\mathrm{Na}$ estação em que tinha encontrado o senhor Alberto, ela pôs a valise no depósito de bagagens e foi tomar um segundo café para considerar um tantinho que fosse a sua situação presente. Ela tinha se sentado no terraço de uma lanchonete, uma grande com montes de consumidores e montes de garçons e até vários maîtres d'hôtel. Na calçada passavam montes de passantes; na rua, rodavam montes de otomóvis. Havia um vendedor de jornais que gritava bem alto, e havia uma dama-alquimista que agitava uma sineta para tentar vender bilhetes de loteria.

Aalice ficou lá, estúpida, abobada, durante uma boa hora, isto é cerca de uma hora e quatro minutos; depois, bruscamente, eis que ela paga, toma um ônibus, desce e penetra no bar Bitúrico, um bar que se dá ares de parecer com todos os outros. Ela senta-se. O salão está vazio: nem clientes, nem dono. Um alçapão aberto parece significar que este último está ocupado no porão, mas com que? Aproveitando a solidão, Aalice chora suavemente.

De repente aparece ao nível do assoalho um gorro meio-curto meio-longo de tecido mole de xadrez preto e branco. Aalice enxuga os olhos e o nariz com um lenço já completamente úmido enquanto lentamente eleva-se por sobre o solo o gorro compendiosamente descrito acima. 
tête suit, puis le reste, des épaules à la semelle des pantoufles, des pantoufles mi-courtes mi-longues en drap mœlleux à quadrillage noir et blanc. Lorsque le tout a fermé la trappe, il pivote de trente-sept degrés, ce qui fait alors apercevoir une jeunesse qui, d'un air vague, regarde dans une glace le reflet d'une reproduction de l'Hercule mourant de Samuel-Finlay-Breese Morse.

- Vous désirez quoi? demande le patron. Ici on ne sert pas les dames seules. Qu'est-ce que vous croyez?

- J'attends monsieur Albert, répond Lalix d'une voix soumise.

- Albert, quel monsieur Albert? Vous croyez que je connais tous mes clients par leur nom?

Il jette un coup d'œil circulaire pour indiquer la vastitude de la chose, vastitude à inférer de la constatation du désert ambiant. Lalix insiste :

- Vous voyez bien qui je veux dire. Monsieur Albert, voyons, monsieur Albert. Je ne lui veux pas de mal. J'ai besoin de lui parler. Je vais l'attendre.

Onésiphore soulève sa casquette et se gratte le sinciput avec une telle énergie que les maxillaires finissent par bouger et laissent passer, par leur

[266] entr'ouverture, les mots suivants :

- Eh bien monsieur Albert, si c'est lui que vous cherchez, il est en tôle.

- Pas vrai!

- J'ai l'air d'un menteur?

Il replace son couvre-chef sur sa tête d'un air menaçant.

- C'est bien ma veine, murmure Lalix.

- Des monsieur Albert t'en
Segue-se uma cabeça, depois o resto, dos ombros até a sola das pantufas, pantufas meio-curtas meio-longas de tecido mole de xadrez preto e branco. Quando o todo fechou o alçapão, gira trinta e sete graus, o que então $\mathrm{o} f \mathrm{fez}$ perceber uma guria que, com um ar vago, olha num espelho o reflexo de uma reprodução da Morte de Hércules de Samuel-Finlay-Breese Morse.

- O que a senhorita deseja? pergunta $\mathrm{o}$ dono. Aqui não servimos mulheres sozinhas. O que é que está pensando?

- Estou esperando o senhor Alberto, responde Aalice, com uma voz submissa.

- Alberto, que senhor Alberto? A senhorita acha que conheço todos os meus clientes pelo nome?

Ele lança um olhar circular para indicar a vastidão da coisa, vastidão a inferir pela constatação do deserto ambiente. Aalice insiste:

- O senhor bem sabe quem eu quero dizer. $\mathrm{O}$ senhor Alberto, oras, o senhor Alberto. Eu não o quero mal. Preciso falar com ele. Vou esperá-lo.

Onesíforo levanta o gorro e coça o sincipúcio com uma tal energia que os maxilares acabam por se mexer e deixam passar pela sua entreabertura, as seguintes palavras:

- Bom, o senhor Alberto, se é ele que a senhorita está procurando, está no xadrez.

- Não acredito!

mentiroso?

- Eu tenho cara de

Ele recoloca o gorro na cabeça com um ar ameaçador.

- Estou com sorte mesmo, murmura Aalice.

- Se é isso o que procura, cê 
trouveras des charibotées si c'est ça que tu cherches.

- J'avais confiance en lui.

Elle va se mettre encore une fois à pleurer. Onésiphore prend les devants.

- Barre-toi, barre-toi, qu'il dit. Tu ne le reverras plus avant longtemps ton monsieur Albert. Pas avant longtemps. Alors barretoi... barre-toi...

L'air tragique, Lalix se lève et sort en fermant soigneusement la porte derrière elle tandis que le patron s'effondre en pleurs derrière son comptoir.

Lalix va son chemin, un chemin qui n'en est pas un puisqu'il ne mêne nulle part, on n'est pas en forêt pourtant, mais Lalix marche au hasard, c'est tout juste si le vent ne l'emporte, car il y a du vent, on est en novembre, il pleut même, et Lalix continue son chemin, sous la pluie, mais il finit par lansquiner trop fort, alors Lalix s'arrête sous un porche et sur son visage dégoulinent des gouttes d'eau de pluie ou des larmes.

- Eh bien, dit la comtesse, vous vous êtes fait saucer.

- Bê, bê, dit Phélise.

Lalix les regarde, hébétée.

- Ça ne va pas? demande la comtesse. Vous nous reluquez d'un air comme si qu'on vous avait

[267] vendu des zaricos qui veulent pas cuire. Holà ! est-ce que vous nous reconnaissez ?

- Bonjour, madame, dit Lalix d'une façon peu compromettante.

- Salut, dit la comtesse.

- Bê, bê, dit Phélise.

- On s'est mises à l'abri, dit la comtesse, dès que ça flotte un peu moins, on fonce vers la houature qu'est là-bas (geste) au coin de la rue. On vous emmène? vai encontrar senhores Albertos aos montes.

- Eu tinha confiança nele. Ela vai se pôr a chorar mais uma vez. Onesíforo toma a dianteira.

- Cai fora, cai fora, disse ele. Cê não vai mais rever o seu senhor Alberto por muito tempo. Por muito tempo. Então cai fora... cai fora...

Com ar trágico, Aalice levanta-se e sai fechando cuidadosamente a porta atrás de si enquanto que o dono se desfaz em lágrimas atrás do balcão.

Aalice toma seu caminho, um que não é caminho já que não leva a parte alguma, no entanto não está numa floresta, mas Aalice anda ao acaso, é por pouco que o vento não a leva, pois há vento, estamos em novembro, está até chovendo, e Aalice continua seu caminho, embaixo de chuva, mas a chuva acaba por apertar muito, então Aalice para embaixo de uma marquise e em seu rosto pingam gotas de água de chuva ou de lágrimas.

- Bem, disse a condessa, a senhorita se ensopou toda.

- Bé, bé, disse Feliza.

Aalice olha-as, abobada.

- Algo não vai bem? pergunta a condessa. A senhorita está nos olhando atravessado como se nós lhe tivéssemos vendido fejão que não quer cozinhá. Olá! está nos reconhecendo?

- Bom dia, senhora, disse Aalice de um modo pouco comprometedor.

- Olá, disse a condessa.

- Bé, bé, disse Feliza.

- A gente se abrigou aqui, disse a condessa, assim que chover um pouco menos, vamos para o otomóvil que está ali (gesto) na esquina. A gente leva você? A 
On retrouve Jojo et Pousspousse pour déjeuner. Vous déjeunez avec nous? On va dans un de-luxe super, c'est pas trois étoiles qu'il faut pour le cataloguer, c'est toute une constellation, autant vous dire qu'on ne s'ennuiera pas devant les assiettes, n'est-ce pas Phélise ?

- Bê, bê, répond Phélise en montrant un bout de langue baveuse.

- Il pleut moins, dit la comtesse. On y va?

- Non, merci, madame, murmure Lalix.

- Allez, pas d'histoires !

Elle entraîne Lalix et

Phélise trotte derrière.

- Mais si vous restez déjeuner avec nous, qui est-ce qui va lui faire la tambouille? demande le duc lorsqu'ils se sont retrouvés au de-luxe superconstellation.

- Je ne la lui ferai jamais plus, dit Lalix. Plus moi. Jamais plus. Je m'en vais. C'est fini entre nous.

Elle se mit à sangloter de façon lamentable.

- Ah non, non et non! s'écria le duc, vous n'allez pas nous gâcher notre déjeuner !

- Racontez-nous ce qui vous arrive, murmura Pouscaillou audacieusement.

- J'aime pas les cinglés, dit Lalix à travers ses larmes.

[268] -Vous parlez pour qui ? demanda le duc.

- Cidrolin, répondit Lalix en babotant. C'est lui qui...

- On sait, on sait, dit le duc avec agacement. Et puis après ?

Lalix.

- C'est pas normal, dit

Cette réponse fit sourire le duc qui continua le dialogue en ces gente encontra Jojo e Pouspous para almoçar. A senhorita almoça conosco? Nós vamos a um de-luxo super, três estrelas só não bastam para catalogá-lo, é preciso uma constelação inteira, o que quer dizer que a gente não vai se aborrecer diante dos pratos, não é Feliza?

- Bé, bé, responde Feliza mostrando uma ponta de língua babenta.

- Está chovendo menos, disse a condessa. Vamos?

- Não, obrigada, senhora, murmura Aalice.

- Vamos, deixe de histórias!

Ela arrasta Aalice e Feliza trota atrás.

- Mas se a senhorita fica para almoçar conosco, quem é que vai preparar o rango pra ele? pergunta o duque quando eles se encontraram no de-luxo superconstelação.

- Não vou prepará-lo nunca mais, disse Aalice. Não eu. Nunca mais. Eu vou embora. Está tudo acabado entre nós.

Ela pôs-se a soluçar de maneira lamentável.

- Ah não, não e não! exclamou o duque, a senhorita não vai estragar nosso almoço!

- Conte-nos o que está acontecendo, murmurou Pouscaillou audaciosamente.

- Não gosto de anormais, disse Aalice através das lágrimas.

- A senhorita está falando de quem? perguntou o duque.

- Cidrolin, respondeu Aalice gaguejando. Era ele que...

- Nós sabemos, nós sabemos, disse o duque com irritação. E daí?

- Não é normal, disse Aalice.

Essa resposta fez sorrir o duque que continuou o diálogo 
termes :

- Vous avez un faible pour lui ?

- J'avais.

- Vous l'aimez, quoi.

- Voui, je l'aimais.

- Est-ce que c'était normal ?

Lalix, surprise, se tut.

Le duc continua :

- Et je parie que vous

l'aimez toujours.

Lalix ne répondit pas.

- C'est pas vrai?

- Si.

- Et ça, est-ce que c'est normal ?

Lalix ne répliquait rien.

- Vous voyez, dit le duc. Rien n'est normal.

Il ajouta :

- Allons! vous rentrerez après le déjeuner pour retrouver votre Cidrolin. Promis ?

Lalix murmura :

- Voui.

Le duc se tourna vers la comtesse pour lui dire :

- Vous voyez. Ce n'est pas plus difficile que ça.

Il frappa dans ses mains et clama :

- Et nous commencerons par de l'andouille, maître d'hôtel, nous continuerons par de l'andouillette, maître d'hôtel, et nous terminerons par de douillettes

[269] friandises, maître d'hôtel. Voilà ce qu'on appelle un repas bien enchaîné. Et foin du caviar et autres moscoviteries! Et champagne !

Ils se régalèrent donc d'andouille, d'andouillettes et de douillettes friandises, mais Lalix avait hâte de retourner sur la péniche. Après le café, elle se tira discrètement tandis que le duc s'offrait une neuvième bouteille de nestes termos:

- A senhorita tem um fraco por ele?

- Tinha.

- A senhorita o ama, isso $\operatorname{sim}$.

- Shim, eu o amava.

- Será que isso era normal?

Aalice, surpresa, calou-se.

$\mathrm{O}$ duque continuou:

- E aposto que a senhorita ainda o ama.

Aalice não respondeu.

- Não é verdade?

- Sim.

- E isso, será que é normal?

Aalice não replicava nada.

- A senhorita está vendo, disse o duque. Nada é normal.

Ele acrescentou:

- Vamos! a senhorita vai voltar pra casa depois do almoço para encontrar o seu Cidrolin. Promete?

Aalice murmurou:

- Shim.

$\mathrm{O}$ duque voltou-se para a condessa para dizer-lhe:

- A senhora está vendo. Não é assim tão difícil.

Ele bateu palmas e clamou:

- E nós começaremos com salsichinhas aperitivo, maître d'hôtel, continuaremos com salsicha, maître d'hôtel, e terminaremos com salsichão, maître d'hôtel. Eis o que se pode chamar uma refeição bem encadeada. E abaixo o caviar e outras moscoviterias! E champanhe!

Eles se regalaram então com salsichinha aperitivo, com salsicha e com salsichão, mas Aalice tinha pressa de voltar para a chata. Depois do café, ela retirou-se discretamente enquanto o duque pedia a nona garrafa de 
champagne.

Les deux chevaux étaient attachés dehors, à un panneau d'interdiction de stationner. Des passants les voyant se transformaient en curieux pendant quelques instants, puis retournaient à leur nature propre. Un petit groupe de sergents de ville discutaient vaguement. Tout cela n'arrivait pas à former un attroupement. Lalix ne s'attarda pas, car elle connaissait à peine Sthène et Stèphe. S'étant payé un taxi, elle se fit déposer devant le bistro au coin du quai pour $\mathrm{y}$ acheter des cigarettes. Quelques couples y faisaient consciencieusement la ventouse, tandis que des alchimistes attendaient qu'un petit appareil les instuisît sur le bien-fondé de leurs distillations.

Lalix sortit du tabac et s'engagea sur le quai-boulevard et de loin aperçut un grand attroupement, et, se rapprochant, distingua des cars de police et des voitures de pompiers.

- Merde, dit-elle à mi-voix. Qu'est-ce qui a encore bien pu arriver?

Un immeuble en construction s'est écroulé, répondit un passant qui venait en sens inverse. Il était inhabité, naturellement, puisqu'il était toujours en construction. Il n'y avait que le gardien. On est en train de le retirer des décombres. Mon

[270] discours vous intéresse-t-il ? Lalix. - Moyennement, répondit - Vous êtes bien difficile, répliqua le passant qui s'éloigne écœuré.

Le boulevard est bloqué.

- J'habite là, dit Lalix. Sur la péniche.

On la laisse passer. champanhe.

Os dois cavalos estavam amarrados do lado de fora, numa placa de proibido estacionar. Vendo-os os passantes transformavam-se em curiosos durante alguns instantes, depois retornavam a sua própria natureza. Um pequeno grupo de guardas de trânsito discutia vagamente. Tudo isso não chegava a formar uma aglomeração. Aalice não se demorou, pois ela mal conhecia Stenes e Estêvão. Tendo tomado um táxi, ela desceu na frente do bar da esquina do cais para comprar cigarros. Alguns casais faziam ventosa conscienciosamente, enquanto que alguns alquimistas esperavam que um aparelhinho os informasse sobre o sucesso de suas destilações.

Lalix saiu do bar e dirigiuse ao cais-bulevar e de longe percebeu uma grande aglomeração, e, aproximando-se, distinguiu viaturas de polícia e carros de bombeiros.

- Que merda, disse ela a meia voz. O que mais pode ter acontecido?

- Um prédio em construção desabou, respondeu um passante que vinha em sentido inverso. Não era habitado, naturalmente, já que ainda estava em construção. Só estava o zelador. Estão tentando retirá-lo dos escombros. Minha história lhe interessa?

Aalice.

- Mais ou menos, respondeu

- A senhorita é bem difícil, replicou o passante que se afasta furioso.

O bulevar está bloqueado.

- Eu moro lá, diz Aalice. Na chata.

Deixam-na passar. 
Elle cherche Cidrolin. Il n'y a pas de Cidrolin sur la péniche. Elle s'assoit dans le carré, allume une cigarette, déplie le tapis vert, commence une réussite. Cidrolin, lui, est sur le quai parmi les curieux. D'autres travaillent: on déblaie la chaussée, on essaie de désencombrer le concierge, on filme pour les actualités et la tévé. Comme la nuit s'annonce, des militaires amènent des projecteurs. C'est vraiment très chouette, mais les projecteurs seront inutiles. On extrait enfin quelque chose de dessous les débris, le cadavre de La Balance en très mauvais état. On le fait disparaître aussi discrètement que rapidement. La chaussée est dégagée, la circulation des houatures recommence, les curieux vont regarder ailleurs, les passants de nouveau passent : toujours rares, ils sont maintenant nocturnes. Et les sergents de ville, les pompiers, les militaires s'éloignent dans la nuit.

Devant le portillon de la clôture, Cidrolin voit s'effacer peu à peu toute cette activité faitdiverse. En se retournant, il s'aperçut qu'il y avait de la lumière à bord de la péniche.

- Tiens, dit-il à mi-voix, mes hôtes seraient-ils rentrés ?

Aucun passant ne lui répondit.

Il descendit le talus, frnchit la planche passerelle et entra dans le carré. Lalix écrasa son mégot [271] dans le cendrier déjà plein et lui sourit.

- Ça marche, cette réussite? demanda Cidrolin en s'asseyant en face d'elle.

Lalix ne répondit pas; elle retourna une nouvelle carte, puis une autre, et soudain elle se tapa le front de la pointe des doigts et s'écria :
Ela procura Cidrolin. Nada de Cidrolin na chata. Ela senta-se no saguão, acende um cigarro, desdobra o pano verde, começa uma paciência. Cidrolin está no cais entre os curiosos. Outros trabalham: desobstruem a rua, tentam desenterrar o zelador, filmam para as atualidades e a tevê. Como a noite se anuncia, militares trazem holofotes. É bem legal, mas os holofotes vão ser inúteis. Extraem finalmente alguma coisa de debaixo dos escombros, o cadáver de A Balança em péssimo estado. Fazem-no desaparecer tão discreta quanto rapidamente. A rua é desimpedida, o trânsito dos zotomóvis recomeça, os curiosos vão olhar em outro lugar, os passantes passam novamente: sempre raros, agora eles são noturnos. E os guardas de trânsito, os bombeiros, os militares afastamse na noite.

Diante do portão da cerca, Cidrolin vê apagar-se pouco a pouco essa atividade policialesca. Voltando-se, ele nota que há luz a bordo da chata.

- Poxa, diz ele a meia voz, meus hóspedes já teriam voltado? Nenhum passante respondeu.

Ele desceu o barranco, atravessou a passarela e entrou no saguão. Aalice esmagou sua bituca no cinzeiro já cheio e lhe sorriu.

- Vai bem essa paciência? perguntou Cidrolin sentando-se na frente dela.

Aalice não respondeu; ela virou uma nova carta, depois outra, e de repente bateu na testa com a ponta dos dedos e gritou: 
- Ma valoche! J'ai oublié ma valoche à la consigne !

- Je vais aller vous la chercher. À quelle gare ?

- Vous en faites pas. J'irai demain matin.

- C'est comme vous voulez.

Après un petit silence, Lalix reprit :

- Il s'en est passé des choses pendant mon absence.

- Oh, pas tellement. L'immeuble en face est tombé sur la tête du concierge. Judex ?

- Et qu'est-ce qu'est devenu

- Il est mort.

- Et vous? Les travaux de peinture?

- Je suis en chômage.

- Ça fait tout de même des choses qui se sont passées pendant mon absence.

Après un petit silence, Cidrolin reprit :

- Pauvre type.

- Qui ça ?

- Le concierge.

- Pourquoi pauvre type? Un emmerdeur et un assassin.

- Il est tout de même mort.

- Évidemment, il n'y a pas de quoi rire, mais on se passera bien de lui. Nous n'y sommes pour rien.

Elle prit une cigarette et l'alluma. Elle ajouta:

- À moins que...

[272] reprit :

Après un petit silence, elle

- Ça ne devait pas être de la si mauvaise construction, cet immeuble. Il n'a pas dû s'effondrer tout seul. Non?

Après un petit silence, Cidrolin répondit :

- Je suis peintre, je ne suis pas architecte.
- Minha maleta! Esqueci minha maleta no depósito de bagagens!

- Vou buscar. Em que estação?

- Não se preocupe. Vou amanhã de manhã.

- Como quiser.

Depois de um pequeno silêncio, Aalice retomou:

- Aconteceram coisas durante minha ausência.

- Ah, nem tanto. O prédio em frente caiu na cabeça do zelador.

- E o que aconteceu com o judas?

- Morreu.

- E o senhor? Os trabalhos de pintura?

- Estou desempregado.

- É mais uma coisa que aconteceu durante minha ausência.

Depois de um pequeno silêncio, Cidrolin retomou:

- Pobre coitado.

- Quem?

- O zelador.

- Por que pobre coitado? Um pentelho e um assassino.

- De todo jeito, ele está morto.

- Evidentemente, não há razão para rir, mas a gente vai passar bem sem ele. Nós não temos nada com isso.

Ela pegou um cigarro e acendeu-o. Ela acrescentou:

- A menos que...

Depois de um pequeno silêncio, ela retomou:

- Não devia ser uma construção tão ruim, esse prédio. Não deve ter desmoronado sozinho. Não?

Depois de um pequeno silêncio, Cidrolin respondeu:

- Eu sou pintor, não sou arquiteto. 
Il sourit gravement et conclut :

- Vraiment: nous n'y sommes pour rien.

Lalix écrasa dans le cendrier sa cigarette à peine commencée et dit :

- Je vais aller faire le dîner.

- Il reste encore des andouillettes dans le frigidaire, dit Cidrolin, mais je n'ai pas eu le courage d'aller acheter du pain. Voulez-vous que j'y aille?

- Pas la peine. On s'en passera.

Lalix se lève, range les cartes et le tapis ; lorsqu'elle est sur le pas de la porte, Cidrolin propose : cinéma?

- Après le dîner, on ira au

En rentrant, ils trouvèrent les chevaux sur le pont de la péniche et leurs hôtes dans le carré. Cidrolin va voir ce qu'ils deviennent.

- Il nous arrive un pépin, s'écria le duc avec entrain. Le van a été ratatiné dans l'effondrement ! Un énorme parpaing lui est tombé dessus. Vous ne pourriez pas abriter Sthène et Stèphe dans la cale? dit Cidrolin.

- On pourrait arranger ça,

- Ce n'est pas tout, continua le duc avec le même entrain. Quelques mœllons ont également abîmé ma houature : on peut la dire complètement et totalement inutilisable. Comme celle de la mère Empoigne est tombée en panne cet après-midi, je me

[273] demande comment nous allons rentrer.

- Vous aviez l'intention de rentrer? demanda Cidrolin.

- Quant à eux, ajouta le duc en négligeant cette question, ils ont
Ele sorriu gravemente $\mathrm{e}$ concluiu:

- Realmente: não temos nada com isso.

Aalice esmagou no cinzeiro seu cigarro nem bem começado e disse:

- Vou fazer o jantar.

- Ainda tem salsichinhas na geladeira, disse Cidrolin, mas não tive ânimo para ir comprar pão. Quer que eu vá?

Não vale a pena. Passaremos sem.

Aalice levanta-se, guarda as cartas e o pano; quando ela está passando pela porta, Cidrolin propõe: ao cinema?

- Depois do jantar, vamos

$\mathrm{Na}$ volta, eles encontraram os cavalos no convés da chata e seus hóspedes no saguão. Cidrolin vai ver o que aconteceu com eles.

- Estamos com um pepino, exclamou o duque com vivacidade. A carreta foi esmagada no desmoronamento! Um enorme bloco tombou-lhe em cima. O senhor não poderia abrigar Stenes e Estêvão no porão?

- Poderíamos arranjar isso, disse Cidrolin.

- Não é só isso, continuou o duque com a mesma vivacidade. Alguns pedaços de concreto também estragaram meu otomóvil: pode-se dizer que foi perda total. Como o da mamãe Empoigne enguiçou esta tarde, eu me pergunto como vamos voltar para casa.

- Os senhores tinham intenção de voltar? perguntou Cidrolin.

- Quanto a eles, acrescentou

o duque negligenciando essa 
bousillé leur vélo.

- Un tandem à moteur, dit l'abbé Riphinte.

En comptant bien, Cidrolin s'aperçut que, de quatre, ses hôtes étaient devenus six.

- Un excellent véhicule, dit Monseigneur Biroton.

- On ne fait pas mieux, dit l'abbé Riphinte.

- Une marque italienne, dit Monseigneur Biroton.

- Nous l'avons acheté à

Trente, dit l'abbé Riphinte.

- Oui, dit le duc. Ils reviennent du Concile.

- Nous y avons soutenu quelques thèses sur le monothéisme des peuples préhistoriques, dit Monseigneur Biroton.

- Leurs peintures pariétales en sont une preuve évidente, dit l'abbé Riphinte.

- Et votre fiancée? demanda le duc à Cidrolin en coupant la parole aux ecclésiastiques. Elle n'est pas là ?

- Si, si, dit Cidrolin. Elle était fatiguée. Elle est allée se coucher.

- Je comprends ça, dit le duc. Les émotions.

- C'est ça, dit Cidrolin qui s'empressa d'ajouter: Je vais aller m'occuper de vos bêtes.

Et il sortit.

Ayant dégagé l'ouverture de la cale, il prit la position du penseur debout et s'y maintient si longtemps qu'il finit par entendre une voix lui dire:

- Vous n'avez qu'à mettre une planche assez large, on se laissera glisser.

Cidrolin se retourna; les deux chevaux le regardaient et personne d'autre.

- Et pour remonter ? demanda-t-il. Comment ferez- pergunta, acabaram com a bicicleta.

- Um tandem motorizado, disse o abade Rifinge.

Contando bem, Cidrolin percebeu que de quatro, seus hóspedes tinham-se tornado seis.

- Um excelente veículo, disse Monsenhor Biroton.

- Não se fazem melhores, disse o abade Rifinge.

- Uma marca italiana, disse Monsenhor Biroton.

- Nós o compramos em Trento, disse o abade Rifinge.

- Sim, disse o duque. Estão voltando do Concílio.

- Nós defendemos lá algumas teses sobre o monoteísmo dos povos pré-históricos, disse Monsenhor Biroton.

- Suas pinturas parietais são uma prova evidente disso, disse o abade Rifinge.

- E a sua noiva? perguntou o duque a Cidrolin cortando a palavra dos eclesiásticos. Ela não está?

- Sim, sim, disse Cidrolin. Ela estava cansada. Foi se deitar.

- Entendo, disse o duque. As emoções.

- É isso aí, disse Cidrolin que se apressou a acrescentar: Vou cuidar de seus animais.

E ele saiu.

Tendo liberado a abertura do porão, ele tomou a posição do pensador em pé e se mantém assim por tanto tempo que acaba por ouvir uma voz dizer-lhe:

- O senhor só tem que pôr uma tábua larga o suficiente, nós deslizaremos.

Cidrolin voltou-se; os dois cavalos o olhavam e mais ninguém.

- E depois para subir? perguntou ele. Como vão fazer? 
vous ?

- Ah, pour ça, il faudra un palan et une sous-ventriere, répondit Sthène. Et une certaine quantité de force, dont l'unité de mesure portera désormais mon nom en cela mille fois supérieur à celui de Newton.

- Une fois là-dedans, vous risquez d'y rester.

- Vous vous débrouillerez. Pour le moment nous n'avons pas envie de passer la nuit dehors, surtout s'il se met à pleuvoir. N'est-ce pas Stèphe?

Comme Cidrolin ne bougeait pas, Sthène reprit la parole en ces termes:

- Il se fait tard. En cherchant bien, vous devez trouver ça, une planche assez large. Celle qui sert de passerelle, par exemple.

Cidrolin fit comme Sthène lui avait dit.

Une fois les chevaux à l'abri, il alla se coucher.
- Ah, para isso, vai ser necessário um guindaste e uma sobrecilha, respondeu Stenes. E uma certa quantidade de força, cuja unidade de medida daqui pra frente levará meu nome nisso mil vezes superior ao de Newton.

- Uma vez lá dentro, vocês correm o risco de ficar lá.

- O senhor vai se virar. Para o momento, não estamos com vontade de passar a noite ao relento, principalmente se começa a chover. Não é Estêvão?

Como Cidrolin não se mexia, Stenes retomou a palavra nestes termos:

- Já se faz tarde. Procurando bem, o senhor deve encontrar uma tábua suficientemente larga. A que serve de passarela, por exemplo. Cidrolin fez como Stenes tinha-lhe dito.

Uma vez os cavalos abrigados, ele foi se deitar. 
Lorsque Cidrolin sortit sur le pont le lendemain matin, il [275] aperçut le duc qui coupait les amarres avec un couteau de cuisine, cependant qu'Empoigne et les ecclésiastiques, à l'aide de perches, éloignaient péniblement la péniche du rivage.

- On peut savoir ce que vous êtes en train de faire? demanda Cidrolin poliment.

- Je rentre chez moi, répondit le duc.

Comme Cidrolin s'apprêtait à poser quelques questions complémentaires, le duc lui dit avec autorité :

tard.

- On parlera de cela plus

Cidrolin, se grattant la tête, se dirigea vers la cuisine où il trouva Lalix en train de faire griller des andouillettes.

- Alors, dit-elle, on va voyager?

- Il paraît.

Ils ne se dirent rien de plus. Cidrolin, ensuite, pénétra dans le carré. Il trouva là plusieurs dames ou demoiselles qui attendaient en silence le petit déjeuner. Retournant sur le pont, il s'aperçut que ses hôtes ne cessaient de se multiplier. Le duc donnait des ordres, interpellant de nouveaux venus. Le dernier câble avait été

[276] sectionné, la péniche s'éloignait de la rive. Cidrolin fit demi-tour et se dirigea de nouveau vers la cuisine. Les autres ne lui portaient aucune attention. Il prit Lalix par le bras et l'entraîna sur le pont.

Doucement la péniche remontait le cours du fleuve. Le duc s'était mis à la barre et semblait prendre un grand plaisir à cette occupation. Il aperçut
Quando Cidrolin saiu para o convés na manhã seguinte, percebeu o duque cortando as amarras com uma faca de cozinha, enquanto Empoigne e os eclesiásticos, com a ajuda de varas, afastavam com dificuldade a chata da margem.

- Pode-se saber o que o senhor está fazendo? perguntou Cidrolin polidamente.

- Estou voltando para casa, respondeu o duque.

Como Cidrolin se preparava

para fazer algumas perguntas complementares, o duque disse-lhe com autoridade:

- Falaremos disso mais

tarde.

Cidrolin, coçando a cabeça, dirigiu-se para a cozinha onde encontrou Aalice assando salsichinhas.

- Então, disse ela, vamos viajar?

- Parece que sim.

Não disseram mais nada. Cidrolin, em seguida, penetrou no saguão. Encontrou ali muitas senhoras ou senhoritas que esperavam em silêncio o café da manhã. Voltando para o convés, percebeu que seus hóspedes não paravam de se multiplicar. O duque dava ordens, interpelando recém chegados. O último cabo tinha sido seccionado, a chata afastava-se da margem. Cidrolin fez meia volta e dirigiu-se novamente para a cozinha. Os outros não prestavam nenhuma atenção nele. Ele tomou Aalice pelo braço e trouxe-a para o convés.

Suavemente a chata subia o curso do rio. $\mathrm{O}$ duque havia tomado o timão e parecia ter um grande prazer nessa ocupação. Ele notou Cidrolin e Aalice que 
Cidrolin et Lalix qui descendaient dans le canot et le détachaient; ils eurent bientôt rejoint la rive et disparurent.

C'est alors qu'il se mit à pleuvoir. Il plut pendant des jours et des jours. Il y avait tant de brouillard qu'on ne pouvait savoir si la péniche avançait, reculait, ou demeurait immobile. Elle finit par échouer au sommet d'un donjon. Les passagers y prirent pied, Sthène et Stèphe non sans mal ; ils étaient, les pauvres, bien maigres et bien las. L'eau s'était retirée dans ses lits et réceptacles habituels et le soleil était déjà haut sur l'horizon, lorsque le lendemain s'éveilla le duc. Il s'approcha des créneaux pour considérer, un tantinet soit peu, la situation historique. Une couche de vase couvrait encore la terre, mais, ici et là, s'épanouissaient déjà de petites fleurs bleues. desciam para a canoa e a desamarravam; eles logo alcançaram a margem e desapareceram.

Foi então que começou a chover. Choveu durante dias e dias. Havia tanta névoa que não se podia saber se a chata avançava, voltava ou permanecia imóvel. Ela acabou por encalhar no alto de um torreão. Os passageiros desceram, Stenes e Estêvão não sem dificuldade; eles estavam, os coitados, bem magros e bem cansados. A água tinha-se retirado para seus leitos e receptáculos habituais e o sol já estava alto no horizonte, quando no dia seguinte o duque despertou. Ele aproximou-se das ameias para considerar, um tantinho que fosse, a situação histórica. Uma camada de lama ainda cobria a terra, mas, aqui e ali, já desabrochavam pequenas flores azuis. 